\title{
2010 Remediation Effectiveness Report for the U.S. Department of Energy Oak Ridge Reservation, Oak Ridge, Tennessee
}

\section{Data and Evaluations}

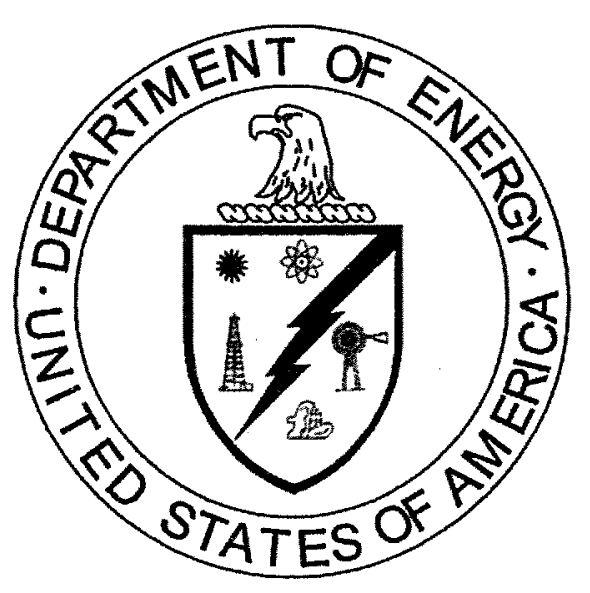

This document is approved for public release per review by:

\begin{tabular}{lc} 
A. F. McBride & $08 / 24 / 10$ \\
\hline $\begin{array}{l}\text { BJC ETTP Classification \& } \\
\text { Information Control Office }\end{array}$ & Date
\end{tabular}




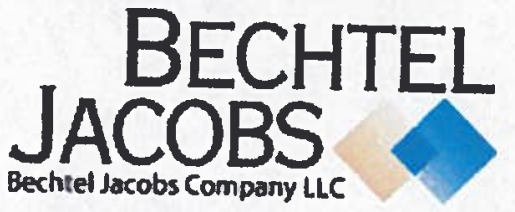

DOE Contract No. DE-AC05-98OR22700

Job No. 23900

WRRP-2010-0024

September 16, 2010

Mr. John R. Eschenberg

Contracting Officer's Representative

for Bechtel Jacobs Company LLC

U.S. Department of Energy

Post Office Box 2001

Oak Ridge, Tennessee 37831

Dear Mr. Eschenberg:

DE-AC05-980R22700: H-4 Clause, "Government Furnished Services and Items (GFS\&I" Request for Post-Record of Decision (ROD) Comprehensive Environmental Response, the U.S. Department of Energy Oak Ridgents: 2010 Remediation Effectiveness Report for 2437\&D2), GFS\&I No. 11-B-152

Enclosed are 20 copies of the 2010 Remediation Effectiveness Report and the associated comment resolution forms for your use and for transmittal to the U.S. Environmental Protection Agency and the Tennessee Department of Environment and Conservation (jointly the regulators) for their final review and approval. Also enclosed, are two compact disks containing electronic copies of the documents.

This document incorporates comments received from the regulators during review of the D1 version. In accordance with the approval cycle protocol for primary documents, approval should be received from the regulators by October 20, 2010.

Questions or comments should be addressed to Lynn Sims at (865) 241-1158.

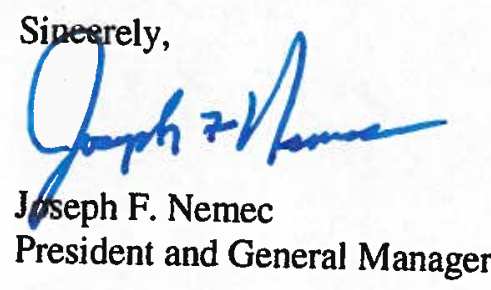

JFN:LS:rsw 
Mr. John R. Eschenberg

September 16, 2010

WRRP-2010-0024

Page 2 $\begin{array}{ll}\text { Enclosures: } & 2010 \text { Remediation Effectiveness Report for the U.S. Department of Energy Oak Ridge } \\ & \text { Reservation, Oak Ridge, Tennessee (DOE/OR/01-2437\&D2) }\end{array}$

c: $\quad$ R. James

G. Eidam

C. R. Johnson

D. Pendry

R. W. Thompson

R. J. Tosetti

c/enc: D. G. Adler, DOE-ORO

S. Brown, w/1

R. Butler, w/2

J. Darby, DOE-ORO

S. B. Garland, w/l

C. Hill, w/1

T. L. James, w/1

S. B. Jones, $w / 1$

R. H. Ketelle, w/1

H. L. Haase, w/1

J. W. Kubarewicz, w/1

M. J. Peterson, w/1

T. Poole, w/1

T. L. Salamacha, w/1

L. M. Sims, w/1

J. R. Walker, ELVADO/w1

R. S. Williams, w/1

File-ORO Mail Room

File-EMEF DMC (WRRP)-RC, w/1 


\title{
2010 Remediation Effectiveness Report for the U.S. Department of Energy \\ Oak Ridge Reservation, Oak Ridge, Tennessee \\ Data and Evaluations
}

Date Issued-September 2010

\author{
Prepared by the \\ Water Resources Restoration Program \\ Bechtel Jacobs Company LLC
}

Prepared for the U. S. Department of Energy Office of Environmental Management

BECHTEL JACOBS COMPANY LLC managing the

Environmental Management Activities at the

East Tennessee Technology Park

Y-12 National Security Complex Oak Ridge National Laboratory

under contract DE-AC05-98OR22700

for the

U. S. DEPARTMENT OF ENERGY 
This page intentionally left blank. 


\section{CONTENTS}

FIGURES.

vii

TABLES

$x i$

ACRONYMS

$x v$

ACKNOWLEDGEMENTS

xix

EXECUTIVE SUMMARY

$\mathbf{x x i}$

1. INTRODUCTION 1-1

1.1 OBJECTIVE OF THE ANNUAL REMEDIATION EFFECTIVENESS REPORT ............... 1-1

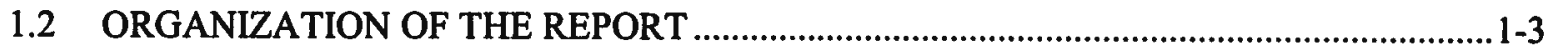

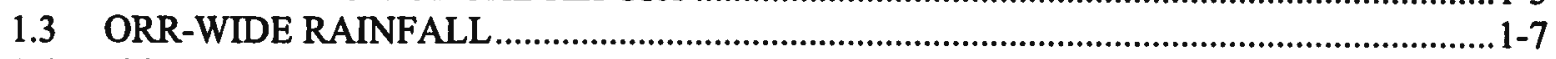

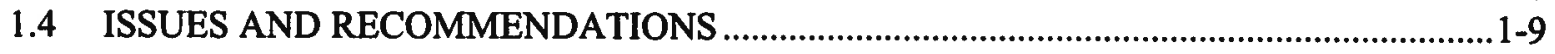

2. CERCLA ACTIONS IN BETHEL VALLEY WATERSHED .....................................................

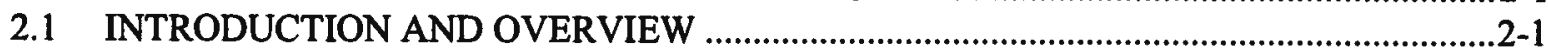

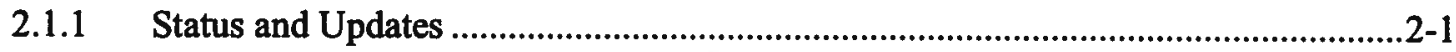

2.2 RECORD OF DECISION FOR INTERIM ACTIONS FOR THE BETHEL VALLEY

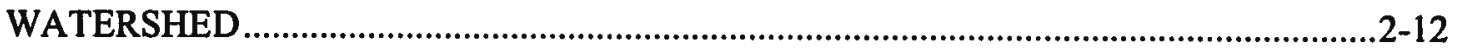

2.2.1 Performance Goals and Monitoring Objectives ...............................................2-15

2.2.2 Evaluation of Performance Monitoring Data ....................................................2-15

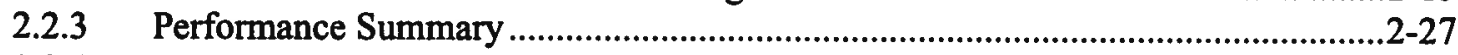

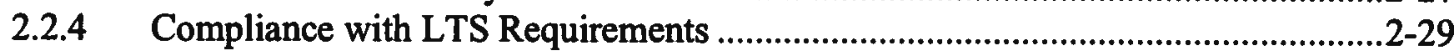

2.3 COMPLETED SINGLE ACTIONS IN BETHEL VALLEY WITH MONITORING

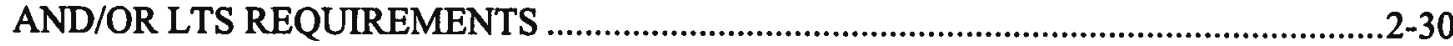

2.3.1 Waste Area Grouping (WAG) 1 Corehole 8 Removal Action (Plume

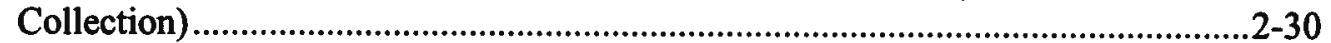

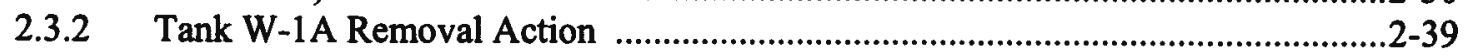

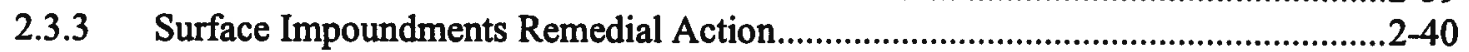

2.3.4 Metal Recovery Facility Removal Action ...........................................................2-41

2.4 BETHEL VALLEY MONITORING CHANGES AND RECOMMENDATIONS..............2-42

3. CERCLA ACTIONS IN MELTON VALLEY WATERSHED .................................................. 3-1

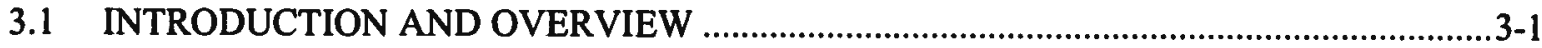

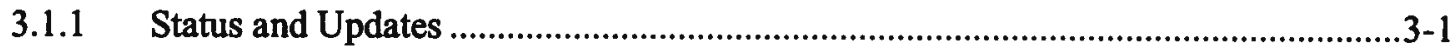

3.2 RECORD OF DECISION FOR INTERIM ACTIONS IN MELTON VALLEY

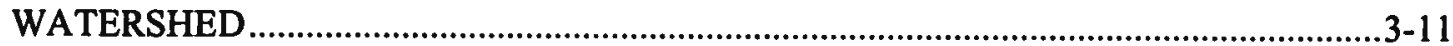

3.2.1 Performance Goals and Monitoring Objectives .................................................... 3-11

3.2.2 Evaluation of Performance Monitoring Data .......................................................

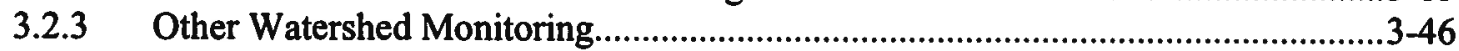

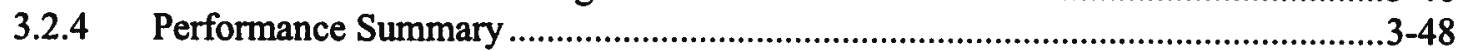

3.2.5 Compliance with MV ROD LTS Requirements .................................................3-49

3.3 COMPLETED SINGLE ACTIONS IN MELTON VALLEY WITH MONITORING

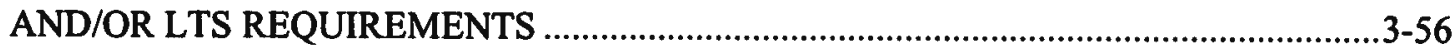

3.3.1 White Oak Creek Embayment Sediment Retention Structure.................................3-56

3.3.2 WAG 13 Cesium Plots Interim Remedial Action ................................................. $3-57$

3.3.3 MSRE D\&D Uranium Deposit Removal ..........................................................3-58

3.4 MELTON VALLEY MONITORING CHANGES AND RECOMMENDATIONS .............3-59 
4. CERCLA ACTIONS IN BEAR CREEK VALLEY WATERSHED .........................................

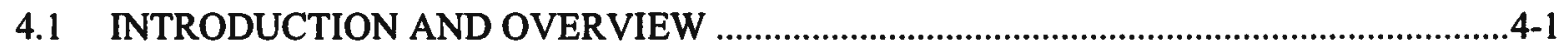

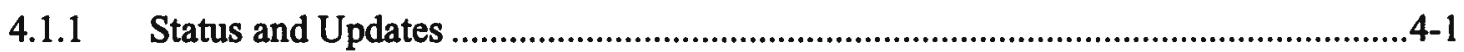

4.2 BEAR CREEK VALLEY PHASE I RECORD OF DECISION ......................................4-9

4.2.1 Performance Goals and Monitoring Objectives .......................................................4-9

4.2.2 Evaluation of Performance Monitoring Data ..................................................4-12

4.2.3 Compliance with BCV LTS Requirements ..........................................................4-41

4.2.4 BCV ROD Performance Summary .....................................................................4-41

4.3 COMPLETED SINGLE ACTIONS IN BEAR CREEK VALLEY WITH

MONITORING AND/OR LTS REQUIREMENTS...................................................4-43

4.3.1 BCV OU2 Remedial Action............................................................................4-43

4.4 BEAR CREEK VALLEY MONITORING CHANGES AND

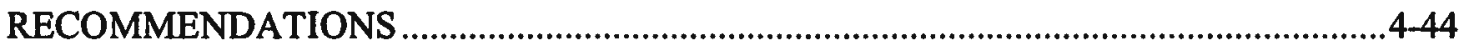

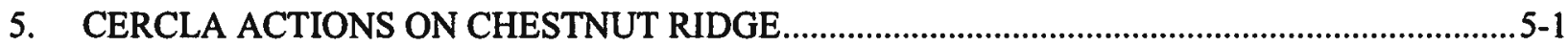

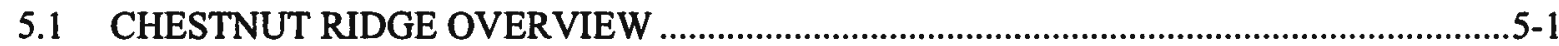

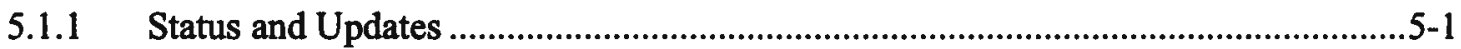

5.2 UNITED NUCLEAR CORPORATION SITE REMEDIAL ACTION .............................5-4

5.2.1 Performance Goals and Monitoring Objectives ...................................................5-4

5.2.2 Evaluation of Performance Monitoring Data - FY 2009 ......................................5-4

5.2.3 Performance Summary .................................................................................5.

5.2.4 Compliance with LTS Requirements .........................................................5-8

5.2.5 Monitoring Changes and Recommendations for the UNC .....................................5-9

5.3 KERR HOLLOW QUARRY REMEDIAL ACTION ................................................5-10

5.3.1 Performance Goals and Monitoring Objectives ...................................................5-10

5.3.2 Evaluation of Performance Monitoring Data - FY 2009 ....................................... 5-10

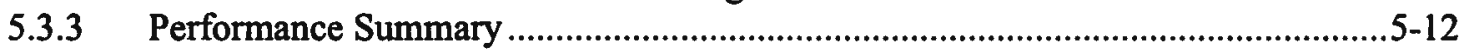

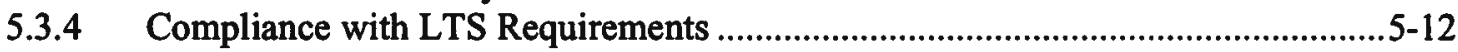

5.3.5 Monitoring Changes and Recommendations for KHQ .....................................5-12

5.4 FILLED COAL ASH POND/UPPER MCCOY BRANCH REMEDIAL ACTION............. $5-13$

5.4.1 Performance Goals and Monitoring Objectives ................................................5-13

5.4.2 Evaluation of Performance Monitoring Data - FY 2009 ......................................5-13

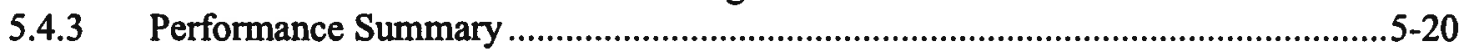

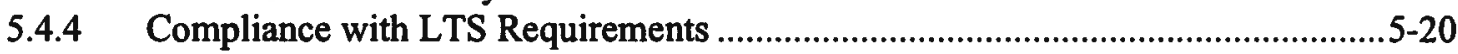

5.4.5 Monitoring Changes and Recommendations for FCAP .....................................5-20

5.5 CHESTNUT RIDGE MONITORING CHANGES AND RECOMMENDATIONS............5-21

6. CERCLA ACTIONS IN UPPER EAST FORK POPLAR CREEK WATHERSHED .....................6-1

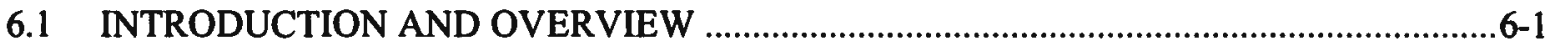

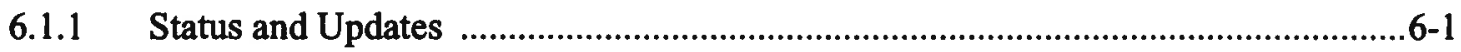

6.2 PHASE I INTERIM SOURCE CONTROL ACTIONS IN THE UEFPC

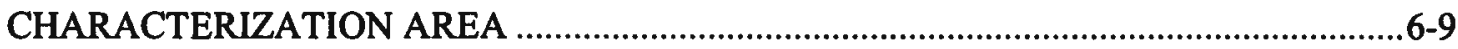

6.2.1 Performance Goals and Monitoring Objectives .......................................................6-9

6.2.2 Evaluation of Performance Monitoring Data - FY 2009 ......................................6-9

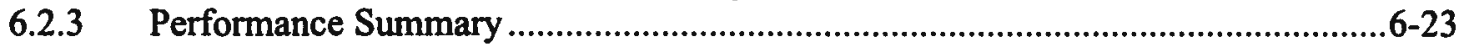

6.2.4 Compliance with LTS Requirements ..........................................................6-23

6.3 COMPLETED SINGLE PROJECT ACTIONS IN UEFPC WATERSHED WITH

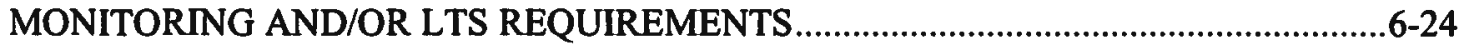

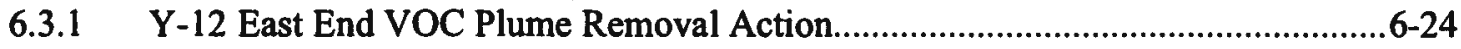

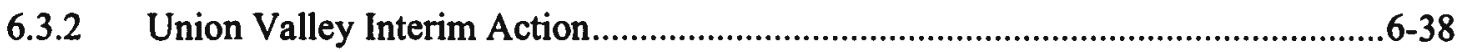


6.4 UPPER EAST FORK POPLAR CREEK MONITORING CHANGES AND

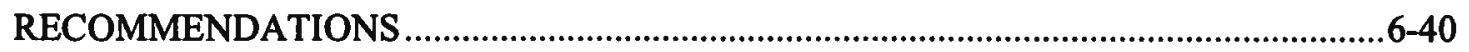

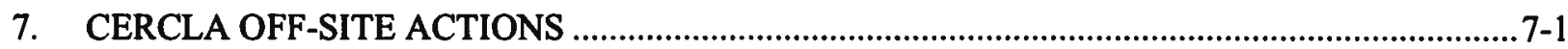

7.1 INTRODUCTION AND OVERVIEW ……………...............................................

7.1.1 Status and Updates .............................................................................................

7.2 LOWER EAST FORK POPLAR CREEK REMEDIAL ACTION ………..............................7-3

7.2.1 Performance Goals and Monitoring Objectives ........................................................7-3

7.2.2 Evaluation of Performance Monitoring Data - FY 2009 ...........................................7-3

7.2.3 Performance Summary .........................................................................................

7.2.4 Compliance with LTS Requirements ..............................................................

7.2.5 Monitoring Changes and Recommendations for LEFPC..........................................7-11

7.3 CLINCH RIVER/POPLAR CREEK ……………….....................................................7-12

7.3.1 Performance Goals and Monitoring Objectives ....................................................

7.3.2 Evaluation of Performance Data - FY 2009 ………...............................................

7.3.3 Performance Summary .........................................................................................7-16

7.3.4 Compliance with LTS Requirements .....................................................................

7.3.5 Monitoring Changes and Recommendations for CR/PC........................................7-19

7.4 LOWER WATTS BAR RESERVOIR …………….................................................

7.4.1 Performance Goals and Monitoring Objectives ......................................................7-20

7.4.2 Evaluation of Performance Monitoring Data - FY 2009 .......................................7-21

7.4.3 Performance Summary .........................................................................................

7.4.4 Compliance with LTS Requirements ...............................................................7-21

7.4.5 Monitoring Changes and Recommendations for LWBR ......................................7-22

7.5 OFFSITE -SITE MONITORING CHANGES AND RECOMMENDATIONS …………......7-23

8. CERCLA ACTIONS AT EAST TENNESSEE TECHNOLOGY PARK ………………….............. 8-1

$8.1 \quad$ INTRODUCTION AND OVERVIEW ......................................................................

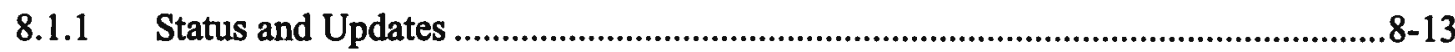

8.2 ZONE 1 SELECTED CONTAMINATION AREAS INTERIM REMOVAL ACTION RECORD OF DECISION....................................................................................

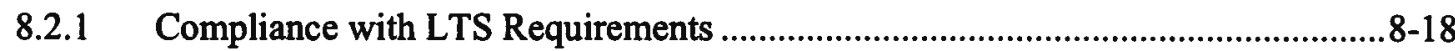

8.3 ZONE 2 SOIL, BURIED WASTE, AND SUBSURFACE STRUCTURE REMOVAL ACTIONS RECORD OF DECISION ………………………........................................

8.3.1 Performance Goals and Monitoring Objectives ………………………………......8-28

8.3.2 Evaluation of Performance Monitoring Data - FY 2009 ........................................8-28

8.3.3 Compliance with LTS Requirements ...............................................................8-31

8.4 COMPLETED SINGLE ACTIONS AT ETTP WITH MONITORING AND/OR LTS

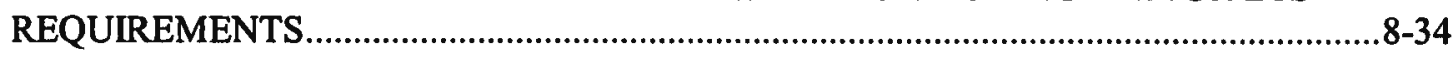

8.4.1 K-1407-B/C Ponds Remedial Action .................................................................8-34

8.4.2 K-901-A and K-1007-P1 Ponds ....................................................................8-38

8.4.3 K-1070-C/D G-Pit and Concrete Pad Remedial Action...........................................8-46

8.4.4 K-1070-A Burial Ground Remedial Action ...........................................................8-48

8.4.5 Mitchell Branch Chromium Reduction .............................................................8-50

8.5 COMPLETED DEMOLITION PROJECTS WITH ACCESS CONTROLS AND LTS

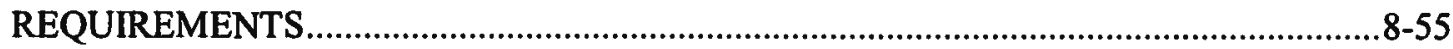

8.5.1 Compliance with LTS Requirements .............................................................8-56

8.6 OTHER WATERSHED MONITORING AT EAST TENNESSEE TECHNOLOGY

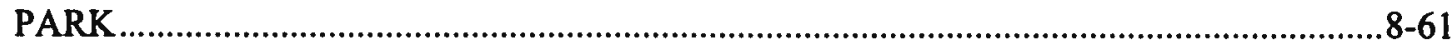

8.6.1 Major Site Contaminant Plumes...........................................................................8-61

8.6.2 Exit Pathway Monitoring ……………………………….......................................8-61 


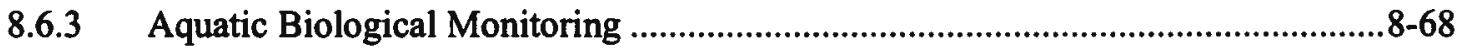

8.6.4 Monitoring Summary …......................................................................................... 8-71

8.7 EAST TENNESSEE TECHNOLOGY PARK MONITORING CHANGES AND RECOMMENDATIONS

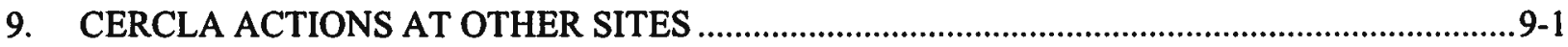

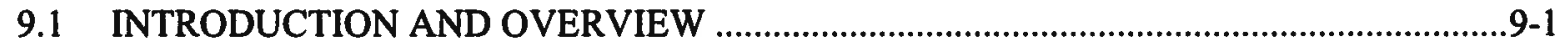

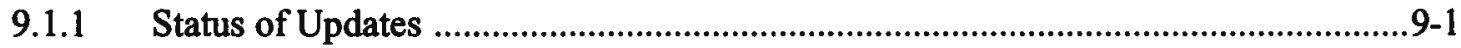

9.2 WHITE WING SCRAP YARD (WAG 11) SURFACE DEBRIS REMEDIAL ACTION ....

9.2.1 Compliance with LTS Requirements ....................................................................

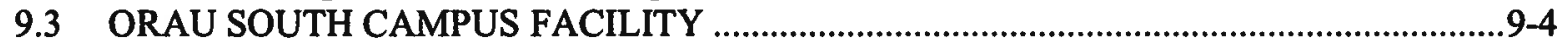

9.3.1 Performance Goals and Monitoring Objectives ....................................................9-4

9.3.2 Evaluation of Performance Monitoring Data - FY 2009 .....................................9-4

9.3.3 Compliance with LTS Requirements ................................................................9-4

9.3.4 Monitoring Changes and Recommendation for ORAU SCF ....................................9-6

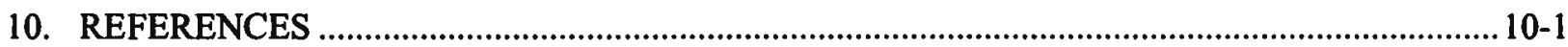

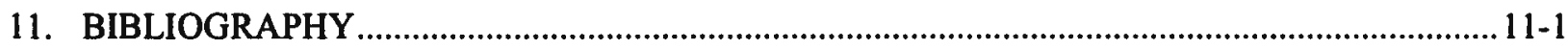

APPENDIX-A: CERTIFICATION OF LAND USE CONTROL IMPLEMENTATION FY 2009

APPENDIX -B: MELTON VALLEY GROUNDWATER DATA …................................................ B-1 


\section{FIGURES}

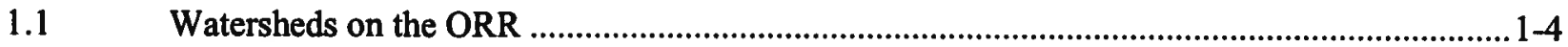

1.2 Lower Watts Bar, Clinch River/Poplar Creek, and Lower East Fork Operational Units .......... 1-5

1.3

1.4

2.1

2.2

2.3

2.4

2.5

2.6

2.7

2.8

2.9

FY 2009 monthly average rainfall from six rain gauges on the ORR

Mean annual rainfall from six rain gauges on the ORR, 2001-2009 .................................... 1-9

Bethel Valley Watershed site map.....................................................................................2-3

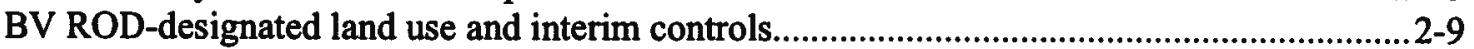

CERCLA surface water monitoring locations in ORNL main plant area. ..............................2-13

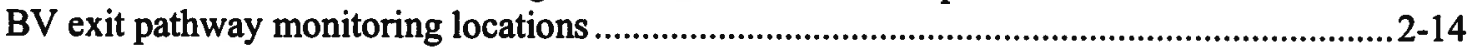

Mercury concentration history at 7500 Bridge and WOC-105 monitoring locations.................2-17

Annual average concentrations of ${ }^{137} \mathrm{Cs},{ }^{90} \mathrm{Sr}$, and tritium at 7500 Bridge ............................2-20

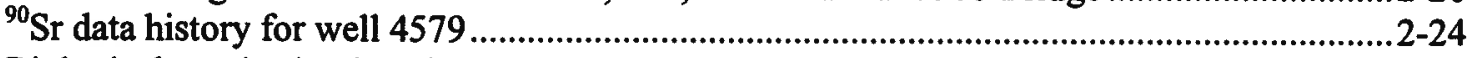

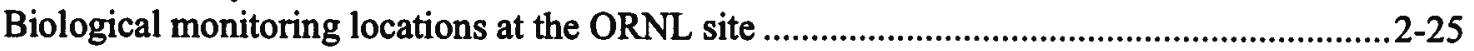

Mean concentrations of mercury $(\mu \mathrm{g} / \mathrm{g}, \pm \mathrm{SE}, \mathrm{N}=6)$ in muscle tissue of sunfish and

bass from WOC (WCK 2.9 and WCK 3.9) and White Oak Lake (WCK 1.5), 1998-

2009

2.10 Mean PCB concentrations $(\mu \mathrm{g} / \mathrm{g}, \pm \mathrm{SE}, \mathrm{N}=6)$ in fish fillet collected from the WOC

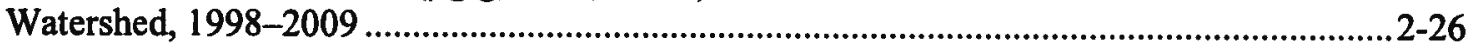

2.11 Species richness (number of species) in samples of the fish community in upper WOC

(WCK 3.9) and reference streams, Brushy Fork kilometer (BFK) and Mill Branch

kilometer (MBK), 1985-2009

2.12 Mean $(n=3)$ taxonomic richness of the pollution-intolerant taxa for the benthic macroinvertebrate community at sites in upper WOC and Walker Branch, April

sampling periods, 1987-2008.

Location and features of the Corehole 8 Plume...

Conceptual block diagram of the Corehole Plume .............................................................2-32

2.14

Contaminant concentrations in well 4411 and Corehole 8 Zone 2.

${ }^{90} \mathrm{Sr}$ and alpha activity concentration in collected Corehole 8 Plume groundwater.....................2-35

2.16

2.17

2.18

3.1

3.2

3.3

3.4

3.5

3.6

3.7

Corehole 8 Plume groundwater collector annual intercepted ${ }^{90} \mathrm{Sr}$ flux and rainfall.

$2-36$

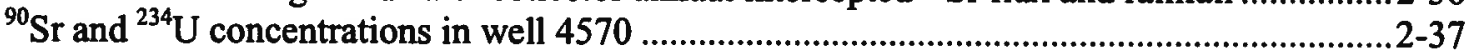

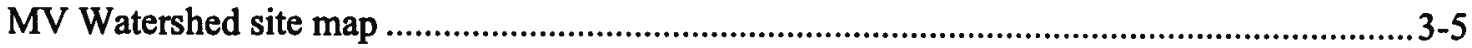

MV ROD-designated land use and interim controls............................................................... 3-7

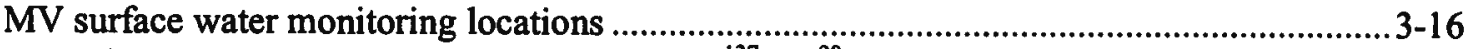

Annual average surface water concentration of ${ }^{137} \mathrm{Cs}$, ${ }^{90} \mathrm{Sr}$, and tritium at WOD....................3-22

Annual radionuclide fluxes at WOD and annual rainfall at ORNL ...................................3-23

Summary of groundwater level monitoring results for FY 2009 ..........................................3-27

Examples of groundwater level fluctuations upslope (outside) and inside the SWSA 4

Upgradient Diversion Trench .................................................................................................. 3-29

3.8 Examples of groundwater level responses in shallow wells inside the SWSA 4

hydrologically isolated areas FY 2007 through FY 2009................................................3-30

3.9 Hydrograph for wells 4127 and 0850 for FY 2007 through FY 2009 ...............................3-31

3.10 Hydrograph of wells 1071 and 4558 in SWSA 4 for FY 2007 through FY 2009 ..................3-33

3.11 Hydrograph of wells 0958 in SWSA 4 and 4547 and 4548 at the downgradient

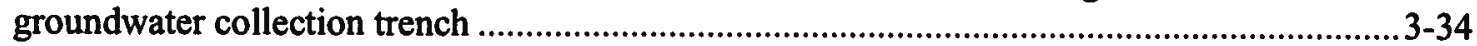

3.12 Locations of wells monitored in the vicinity of the Seepage Pits and Trenches .....................3-36

3.13 WOD groundwater tritium and ${ }^{90} \mathrm{Sr}$ concentration histories...............................................3-39

3.14 Locations of MV Exit Pathway deep groundwater monitoring wells...................................3-40

3.15 Locations of exit pathway sampling zones.......................................................................

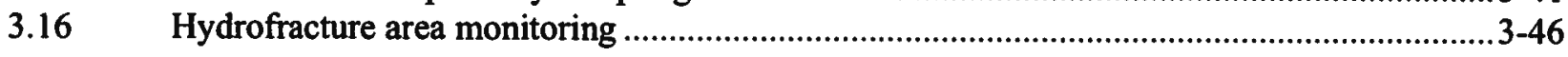


3.17 Species richness (number of species) in samples of the fish community in MV (WCK and MEK) and reference streams, Brushy Fork (BFK) and Mill Branch (MBK), 19852009

3.18 Mean $(n=3)$ taxonomic richness of the pollution-intolerant taxa for the benthic macroinvertebrates communities in lower WOC (WCK 2.3), lower Melton Branch (MEK 0.6), and reference sites in upper WOC (WCK 6.8) and Mill Branch (MBK 1.6), April sampling periods, 1987-2009.

Average annual uranium isotope and nitrate concentrations at BCK 9.2 and annual rainfall.

4.14 Mean nickel concentrations in stoneroller minnows at three sites in Bear Creek and a reference site (HCK 20.6), 1994-2009....

4.15 Mean cadmium concentrations in stoneroller minnows at three sites in Bear Creek and a reference site (HCK 20.6), 1994-2009

4.16 Mean uranium concentrations in stoneroller minnows at three sites in Bear Creek and a reference site (HCK 20.6), 1994-2009.

4.17 Mean PCB concentrations in stoneroller minnows at three sites in Bear Creek and a reference site (HCK 20.6), 1994-2009.

4.18 Species richness (number of species) in samples of the fish community in Bear Creek (BCK), NT-3, and reference streams, BFK, MBK, and Pinhook Branch (PHK), 1984 2009

4.19 Mean $(n=3)$ taxonomic richness of the pollution-intolerant taxa for the benthic macroinvertebrate community at sites in Bear Creek, NT-3, and range of mean values among reference streams (two sites in Gum Hollow Branch and one site in Mill Branch), October 1996-April 2009.

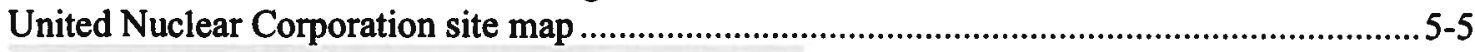

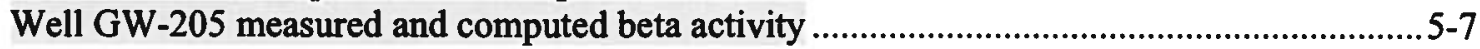

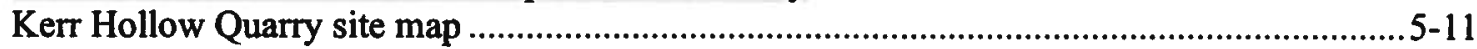

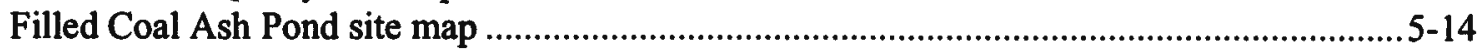

Historic data at MCK 2.0 and MCK 2.05 between FY 1998 and FY 2009.........................5-16

Mean concentrations of selenium and arsenic in fillets of largemouth bass from Rogers

Quarry.

5.8 Mean concentrations of mercury in fillets of largemouth bass from Rogers Quarry 
5.10 Mean $(n=3)$ taxonomic richness of the pollution-intolerant taxa for the benthic macroinvertebrate community at sites in McCoy Branch, and range of mean values among reference streams (First Creek, Fifth Creek, Gum Hollow Branch, Mill Branch,

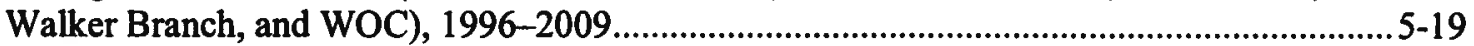

Species richness (number of species) in samples of the fish community in East Fork Poplar Creek (EFK) and a reference stream, Brushy Fork (BFK), 1985-2009.

6.10 Mean $(n=5 ; n=4$ after 2006) taxonomic richness of the pollution-intolerant taxa for the benthic macroinvertebrate community at sites in EFPC and Brushy Fork, April sampling periods, 1986-2009.

Mercury export from the headwaters (Y-12 plant) and rest of the watershed during a

7.8 Average PCB concentrations in channel catfish from CR/PC and LWBR sites, 1986- 


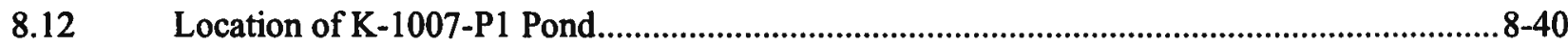

8.13 Mean concentrations of PCBs in largemouth bass fillets from K-1007-P1 Pond, 19932009, representing baseline trends prior to the non-TC RmA .................................................8-42

8.14 Mean concentrations of PCBs in largemouth bass from K-901-A, 1993-2009 .................... 8-43

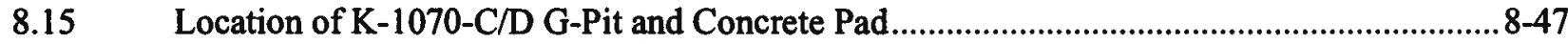

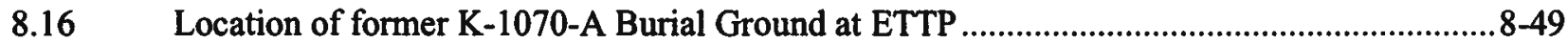

8.17 Location of chromium releases to Mitchell Branch..............................................................8-51

8.18 Mitchell Branch (MIK 0.79) chromium concentrations, FY 2007-2009.............................8-52

8.19 K-1420 Pad Storm Water Runoff Sample Results................................................................ 8-59

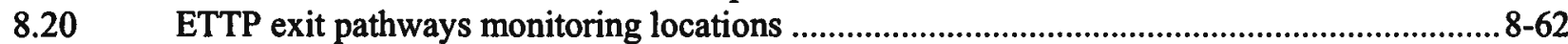

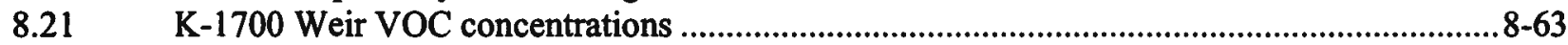

8.22 VOC concentrations in groundwater at K-1064 Peninsula area ...........................................8 8-64

8.23 Chromium concentrations in groundwater in the K-31/K-33 area. .....................................8 8-65

8.24 Detected VOC concentrations in groundwater exit pathway wells near K-27 and K-29 ........8-66

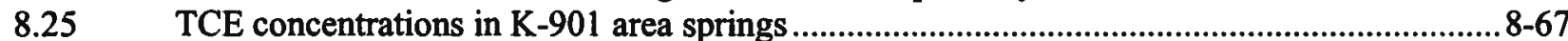

8.26 History of measured alpha and beta activity in the K-770 area........................................8-68

8.27 Mean PCB concentrations in redbreast sunfish from Mitchell Branch, 1993-2009 ...............8-69

8.28 Species richness (number of species) in spring samples of the fish community in Mitchell Branch (MIK) and a range of reference streams (Ref. High-Low), 1986 to 2009

8.29 Mean $(n=3)$ taxonomic richness of the pollution-intolerant taxa for the benthic macroinvertebrate community at sites in Mitchell Branch at the ETTP, April sampling periods, 1996-2009

9.1 Location of White Wing Scrap Yard (WAG 11) ................................................................. 9-3

9.2 South Campus Facility monitoring locations and contaminated groundwater area..................9-5

9.3 VOC concentrations in wells GW-841 and GW-842 at SCF .............................................9-6 


\section{TABLES}

1.12010 summary of technical issues, recommendations, and follow-up actions............................ 1-10

1.2 Summary of closed-out technical issues, recommendations, and follow-up actions.................... 1-13

1.3 Summary of unresolved technical issues, recommendations, and follow-up actions from the FYR .

1.4 Summary of completed technical issues, recommendations, and follow-up actions from the FYR

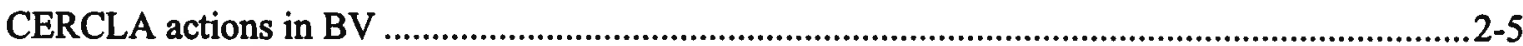

2.2 LTS requirements for CERCLA actions in BV Watershed ........................................................ 2-7

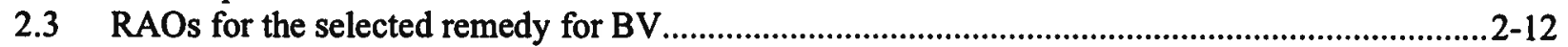

2.4 CERCLA monitoring requirements and performance standards for BV Watershed....................2-16

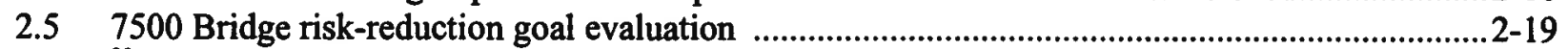

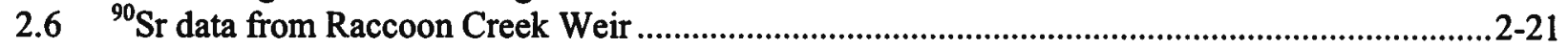

2.7 Detected groundwater constituents in Well 4579 that have exceeded criteria ...............................2-22

2.8 First Creek ${ }^{90}$ Sr fluxes pre-action and in FY 2009 ...............................................................2-32

$2.9{ }^{90} \mathrm{Sr}$ flux changes at First Creek Weir, 1993-2009 ..............................................................2 2-33

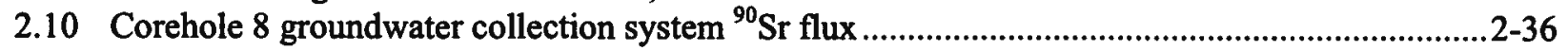

2.11 Summary of BV Watershed technical issues and recommendations......................................2-42

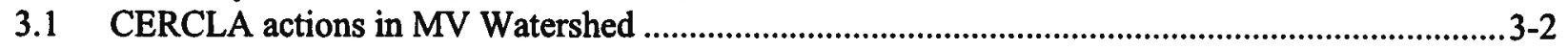

3.2 LTS requirements for CERCLA actions in MV Watershed .........................................................9

3.3 RAO for the MV Watershed selected remedy, ORNL, Oak Ridge, Tennessee ...........................3-11

3.4 Performance measures for major actions in the Melton Valley Watershed, ORNL, Oak

Ridge, Tennessee.

3.5 Surface water remediation levels for the Melton Valley Watershed, ORNL, Oak Ridge,

Tennessee

3.6 Residential risk-based surface water remediation concentrations for the Melton Valley

Watershed, ORNL, Oak Ridge, Tennessee .

3.7 Recreational risk-based surface water remediation concentrations for the Melton Valley

Watershed, ORNL, Oak Ridge, Tennessee .

3.8 Summary of FY 2009 radiological contaminant levels at surface water IPs in MV ...................3-21

3.9 Average annual radionuclide concentrations at tributary surface water monitoring locations

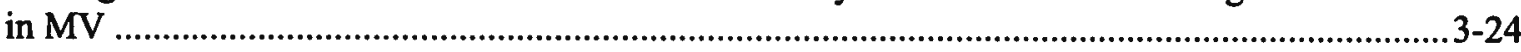

3.10 Summary of radiological groundwater contaminants detected at Seepage Trenches 5 and 7 .......3-37

3.11 Summary of FY 2009 groundwater analyses from MV exit pathway wells ...............................3-43

3.12 Summary of MV Watershed technical issues and recommendations.........................................3-59

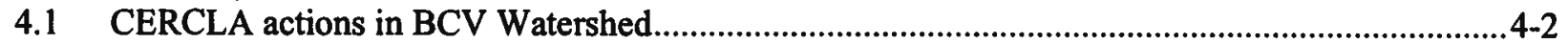

4.2 LTS requirements for CERCLA actions in BCV Watershed .................................................. 4-5

4.3 Groundwater and surface water goals, Bear Creek Valley Y-12 Plant, Oak Ridge,

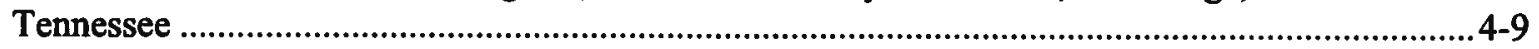

4.4 Site-specific goals for remedial actions at the S-3 Site Pathway 3 and the BY/BY ...................4-10

4.5 Expected outcome of the selected remedy, Bear Creek Valley, Y-12 Plant, Oak Ridge, Tennessee .

4.6 BCV Watershed CERCLA performance monitoring ............................................................4-13

4.7 Historic average concentration of uranium isotopes and nitrate at the IP (BCK 9.2) ................4-17

4.8 Uranium flux at flow-paced monitoring locations in BCV ..................................................4-18

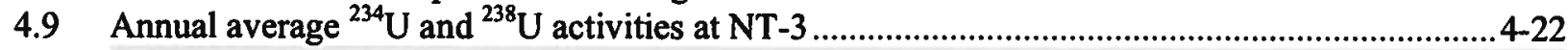

4.10 Nitrate concentrations measured in wells GW-712, GW-713, and GW-714 .............................4-27

4.11 Summary of transect physical habitat metrics for NT-3, August 25, 2009 .............................. 4-36 
4.12 Vegetation metrics. The percent ground and canopy cover, plant species diversity, the amount of riparian overhang, and planted tree/shrub survival and condition for each monitored transect at the NT-3 restoration site, August 25, 2009.

4.13 Summary of transect physical habitat metrics for Bear Creek Weir, August 25, 2009

4.14 Vegetation metrics. The percent ground and canopy cover, plant species diversity, and the amount of riparian overhang for each monitored plot at the Bear Creek restoration site and the upstream reference location, August 25, 2009

4.15 Summary of BCV Watershed technical issues and recommendations ......................................4-44

5.1 CERCLA actions on ChR

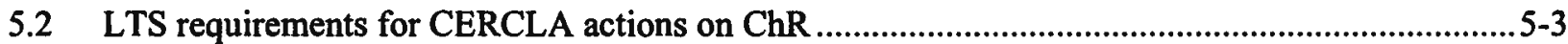

5.3 Analytical results for performance indicator constituents at the UNC Site, FY 2009...................5-6

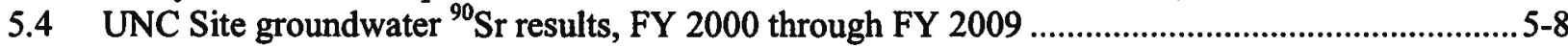

5.5 Summary of FCAP pre-remediation monitoring results, 1996...................................................5-15

5.6 Summary of FY 2009 post-remediation data from MCK 2.05 and MCK 2.0

5.7 Summary of technical issues and recommendations .................................................................

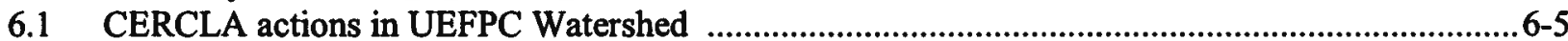

6.2 LTS requirements for CERCLA actions in UEFPC Watershed ................................................6-7

6.3 Performance measures for Phase I Interim Source Control Actions in the UEFPC

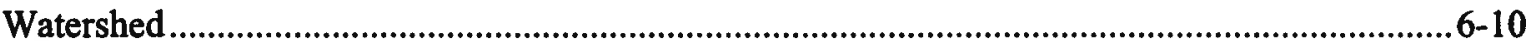

6.4 Annual uranium and mercury fluxes and average concentrations at Station 17 .........................6-14

6.5 Selected FY 2009 data for Y-12 EEVOC Plume performance ...............................................6-32

6.6 Selected Y-12 EEVOC Plume treatment system performance data, FY 2009 ............................6-34

6.7 Estimated mass removals for key EEVOC Plume constituents since inception of treatment

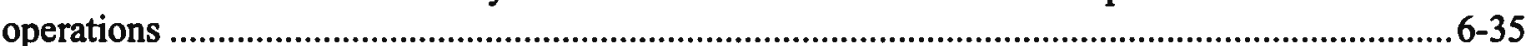

6.8 Summary of Y-12 EEVOC Plume groundwater treatment system performance results,

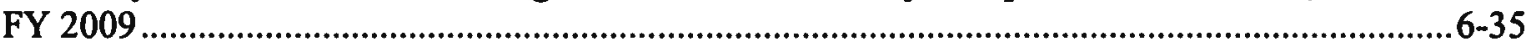

6.9 Summary of UEFPC Watershed technical issues and recommendations ..................................6-40

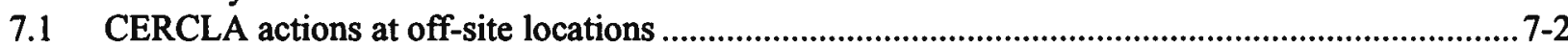

7.2 LTS requirements for CERCLA actions at off-site locations....................................................

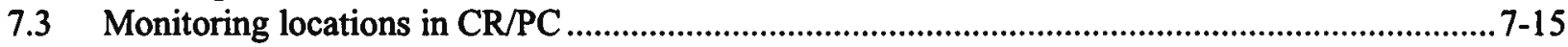

7.4 Mean concentrations ( $\mathrm{N}=6$ fish, \pm standard error) of total PCBs (Aroclor- $1248+1254$

+1260 ), total mercury, and ${ }^{137} \mathrm{Cs}$ in fish muscle fillet from off-site locations in FY 2009............ 7-17

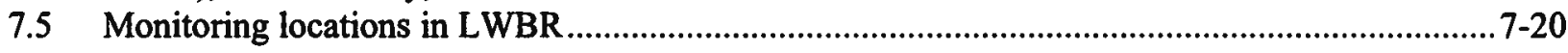

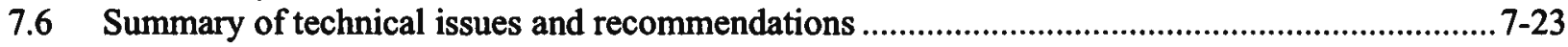

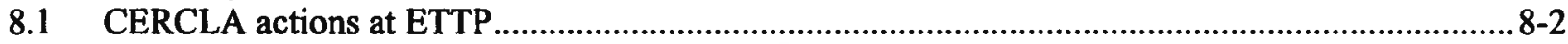

8.2 LTS requirements for CERCLA actions at ETTP ......................................................................

8.3 LTS requirements for K-770 Scrap Removal Project facilities associated with remaining

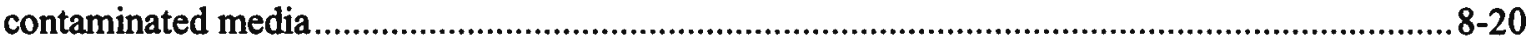

8.4 Summary of radiological monitoring for K-770 Scrap Removal Project....................................8-23

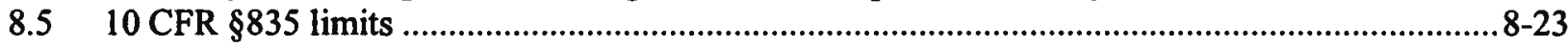

8.6 Summary of storm drain and surface water monitoring for K-770 Scrap Removal Project.......... 8-24

8.7 Total PCB (Aroclors 1248, 1254, and 1260) concentrations in fish from the K-1007-P1 Holding Pond, K-720 Slough, and K-901-A Holding Pond, 2009 ........................................8-44

8.8 FY 2009 performance monitoring results for reduction of hexavalent chromium releases

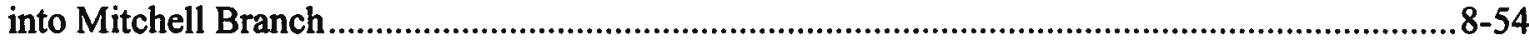

8.9 LTS requirements for D\&D facilities associated with remaining contaminated media ...............8-55

8.10 Summary of radiological monitoring information for ETTP D\&D sites....................................8-57

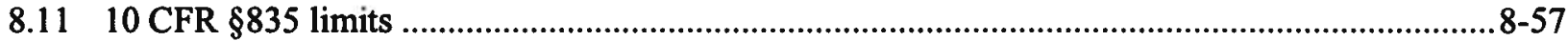

8.12 Summary of storm drain and surface water monitoring information ...................................... 8-58

8.13 K-1420 Slab Storm Water Runoff Performance Monitoring .......................................................8-59

8.14 VOCs detected in groundwater in the Mitchell Branch Exit Pathway ........................................ 8-64 


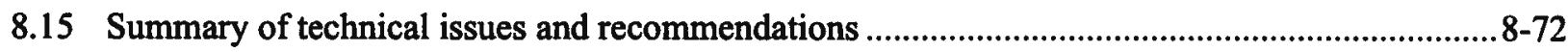

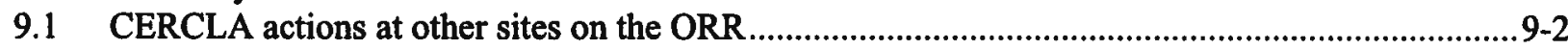

9.2 LTS requirements for CERCLA actions at other sites on the ORR ........................................9-2

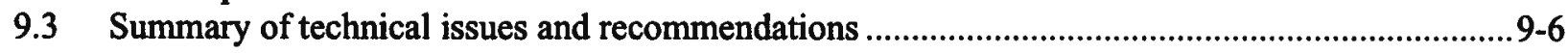


This page intentionally left blank. 


\section{ACRONYMS}

\begin{tabular}{|c|c|}
\hline $\mathrm{ACB}$ & auxiliary charcoal bed \\
\hline ALARA & as low as reasonably achievable \\
\hline $\mathrm{AM}$ & Action Memorandum \\
\hline $\mathrm{AOC}$ & area of contamination \\
\hline ARAR & applicable or relevant and appropriate requirements \\
\hline ARRA & American Recovery and Reinvestment Act \\
\hline AWQC & ambient water quality criteria \\
\hline BCBG & Bear Creek Burial Ground \\
\hline BCK & Bear Creek kilometer \\
\hline $\mathrm{BCV}$ & Bear Creek Valley \\
\hline BFK & Brushy Fork kilometer \\
\hline bgs & below ground surface \\
\hline BJC & Bechtel Jacobs Company LLC \\
\hline BMAP & Biological Monitoring and Abatement Program \\
\hline BMP & best management practice \\
\hline BORCE & Black Oak Ridge Conservation Easement \\
\hline BOS-LABS & Balance of Sites Laboratories \\
\hline BSWTS & Big Spring Water Treatment System \\
\hline BV & Bethel Valley \\
\hline B\&W & Babcock \& Wilcox Y-12 \\
\hline BYBY & Boneyard/Burnyard \\
\hline $\mathrm{CA}$ & Characterization Area \\
\hline CERCLA & Comprehensive Environmental Response, Compensation, and Liability Act of 1980 \\
\hline CFR & Code of Federal Regulations \\
\hline CMTS & Central Mercury Treatment System \\
\hline $\mathrm{COC}$ & contaminant of concern \\
\hline $\mathrm{COE}$ & Corp of Engineers (U.S. Army) \\
\hline ChR & Chestnut Ridge \\
\hline CR & Clinch River \\
\hline CRK & Clinch River kilometer \\
\hline CRM & Clinch River mile \\
\hline $\mathrm{CR} / \mathrm{PC}$ & Clinch River/Poplar Creek \\
\hline CROET & Community Reuse Organization of East Tennessee \\
\hline CVOC & chlorinated volatile organic compound \\
\hline CY & calendar year \\
\hline D\&D & decontamination and decommissioning \\
\hline DARA & Disposal Area Remedial Action \\
\hline DCA & dichloroethane \\
\hline DCG & derived concentration guidelines \\
\hline DMC & Document Management Center \\
\hline DNAPL & dense non-aqueous-phase liquid \\
\hline DOE & U.S. Department of Energy \\
\hline DSWM & Division of Solid Waste Management \\
\hline DVS & Dynamic Verification Strategy \\
\hline EDE & effective dose equivalent \\
\hline $\mathrm{EE} / \mathrm{CA}$ & Engineering Evaluation/Cost Analysis \\
\hline EEMTS & East End Mercury Treatment System \\
\hline EEVOC & East End Volatile Organic Compound \\
\hline
\end{tabular}




\begin{tabular}{|c|c|}
\hline EFK & East Fork kilometer \\
\hline EFPC & East Fork Poplar Creek \\
\hline ELCR & excess lifetime cancer risk \\
\hline EM & Environmental Management \\
\hline EMWMF & Environmental Management Waste Management Facility \\
\hline EPA & U. S. Environmental Protection Agency \\
\hline EPP & excavation/penetration permit \\
\hline ESD & Explanation of Significant Difference \\
\hline ETTP & East Tennessee Technology Park \\
\hline $\mathbf{E U}$ & exposure unit \\
\hline FCA & fixed contamination area \\
\hline FCAP & Filled Coal Ash Pond \\
\hline FFA & Federal Facility Agreement \\
\hline FFS & Focused Feasibility Study \\
\hline FIR & federal controlled industrial/research \\
\hline FIT & Facility Inspection and Training Manual \\
\hline FLUTe & Flexible Liner Underground Technologies, LLC \\
\hline FS & feasibility study \\
\hline FSD & Fuel Salt Disposition \\
\hline FUSRAP & Formerly Utilized Sites Remedial Action Program \\
\hline FY & fiscal year \\
\hline FYR & Five-Year Review \\
\hline GHK & Gum Hollow kilometer \\
\hline HCK & Hinds Creek kilometer \\
\hline HF & hydrofluoric acid \\
\hline HFIR & High Flux Isotope Reactor \\
\hline HI & hazard index \\
\hline HTF & Hillcut Test Facility \\
\hline ICMA & Interim Corrective Measure Areas \\
\hline IP & integration point \\
\hline IROD & Interim Record of Decision \\
\hline ISG & in situ grouting \\
\hline $\mathrm{KHQ}$ & Kerr Hollow Quarry \\
\hline LEFPC & Lower East Fork Poplar Creek \\
\hline LLLW & liquid low-level waste \\
\hline LTS & long-term stewardship \\
\hline LUC & land use control \\
\hline LUCAP & Land Use Control Assurance Plan \\
\hline LUCIP & Land Use Control Implementation Plan \\
\hline LWB & Lower Watts Bar \\
\hline LWBR & Lower Watts Bar Reservoir \\
\hline MBK & Mill Branch kilometer \\
\hline MCK & McCoy Branch kilometer \\
\hline MCL & maximum contaminant level \\
\hline MEK & Melton Branch kilometer \\
\hline MIK & Mitchell Branch kilometer \\
\hline MRF & Metal Recovery Facility \\
\hline MSRE & Molten Salt Reactor Experiment \\
\hline MV & Melton Valley \\
\hline NFA & No Further Action \\
\hline NNSA & National Nuclear Security Administration \\
\hline
\end{tabular}




\begin{tabular}{|c|c|}
\hline NPDES & National Pollutant Discharge Elimination System \\
\hline NSC & Non-Significant Change \\
\hline NT-3 & North Tributary 3 \\
\hline NTF & North Tank Farm \\
\hline OLFSCP & Oil Landfarm Soil Containment Pad \\
\hline ORAU & Oak Ridge Associated Universities \\
\hline OREIS & Oak Ridge Environmental Information System \\
\hline ORNL & Oak Ridge National Laboratory \\
\hline ORO & Oak Ridge Operations \\
\hline ORR & Oak Ridge Reservation \\
\hline OU & operable unit \\
\hline $\mathrm{PC}$ & Poplar Creek \\
\hline PCB & polychlorinated biphenyl \\
\hline PCCR & Phased Construction Completion Report \\
\hline PCE & tetrachloroethene \\
\hline PCM & Poplar Creek mile \\
\hline PCR & Post-Construction Report \\
\hline PDCC & Project Document Control Center \\
\hline PHK & Pinhook Branch Kilometer \\
\hline PIDAS & Perimeter Intrusion Detection and Assessment System \\
\hline PP & Proposed Plan \\
\hline PPA & property protection area \\
\hline PRG & Preliminary Remediation Goal \\
\hline psig & pounds per square inch gauge \\
\hline PUF & Predominantly Uncontaminated Facilities \\
\hline PWTC & Process Waste Treatment Complex \\
\hline QAPP & Quality Assurance Program Plan \\
\hline RA & remedial action \\
\hline RAO & remedial action objective \\
\hline RAR & Remedial Action Report \\
\hline RAWP & Remedial Action Work Plan \\
\hline RBC & risk-based concentrations \\
\hline RCRA & Resource Conservation and Recovery Act of 1976 \\
\hline RDR & Remedial Design Report \\
\hline RER & Remediation Effectiveness Report \\
\hline RI & remedial investigation \\
\hline RI/FS & Remedial Investigation/Feasibility Study \\
\hline RL & remediation level \\
\hline RMA & Radioactive Materials Areas \\
\hline RmAR & Removal Action Report \\
\hline ROD & Record of Decision \\
\hline RPP & Radiation Protection Plan \\
\hline SAP & Sampling and Analysis Plan \\
\hline S\&M & surveillance and maintenance \\
\hline SCF & South Campus Facility \\
\hline SDWA & Safe Drinking Water Act of 1974 \\
\hline SIOU & Surface Impoundments Operable Unit \\
\hline SNS & Spallation Neutron Source \\
\hline SRS & Sediment Retention Structure \\
\hline SWPPP & Storm Water Pollution Prevention Program \\
\hline SWSA & Solid Waste Storage Area \\
\hline
\end{tabular}

xvii 


\begin{tabular}{ll} 
TC RmA & time-critical removal action \\
TDEC & Tennessee Department of Environment and Conservation \\
T1 & Thallium \\
TEF & Toxicity Equivalency Factor \\
TMDL & Total Maximum Daily Load \\
TRM & Tennessee River mile \\
TRU & transuranic \\
TTEQ & Total Toxicity Equivalency Quotient \\
TVA & Tennessee Valley Authority \\
TWRA & Tennessee Wildlife Resources Agency \\
UEFPC & Upper East Fork Poplar Creek \\
UNC & United Nuclear Corporation \\
VOC & volatile organic compound \\
WAC & waste acceptance criteria \\
WAG & Waste Area Grouping \\
WBIWG & Watts Bar Interagency Working Group \\
WCK & White Oak Creek kilometer \\
WEMA & West End Mercury Area \\
WOC & White Oak Creek \\
WOCC & Waste Operations Control Center \\
WOCE & White Oak Creek Embayment \\
WOD & White Oak Dam \\
WOL & White Oak Lake \\
WQC & Water Quality Criteria \\
WRRP & Water Resources Restoration Program \\
WWSY & White Wing Scrap Yard \\
Y-12 & Y-12 National Security Complex \\
ZVI & zero valent iron \\
\hline
\end{tabular}




\section{ACKNOWLEDGEMENTS}

Primary tasks of the U.S. Department of Energy Oak Ridge Operations (DOE-ORO) are contracted to various entities (public and non-profit companies, as well as educational institutions). Bechtel Jacobs Company LLC (BJC) conducts environmental cleanup and long-term stewardship (LTS) at sites with Comprehensive Environmental Response, Compensation, and Liability Act of 1980 as the primary regulatory authority on the Oak Ridge Reservation (ORR) and impacted sites off the reservation (e.g., Lower East Fork Poplar Creek). BJC's Water Resources Restoration Program (WRRP) implements a comprehensive, integrated environmental monitoring program for the ORR and prepares the annual Remediation Effectiveness Report (RER). B\&W Y-12 operates the Y-12 National Security Complex, which manages the production and refurbishment of nuclear weapon components for the DOE and the National Nuclear Security Administration. A partnership between the University of Tennessee and Battelle, UT-Battelle, manages and operates the Oak Ridge National Laboratory (ORNL) for the DOE.

The BJC WRRP gratefully acknowledges the contributions and efforts of many organizations and individuals on the ORR for providing support in preparation of the 2009 RER. Particular thanks are due to the Ecological Assessment Group of the Environmental Sciences Division (UT-Battelle) at the ORNL for providing field support, biological data, and technical interpretations included in the biological monitoring sections of this report. Where applicable, ORR monitoring data collected by other programs were used to augment the WRRP sampling results. Considerable thanks are due to UT-Battelle's Environmental Protection and Waste Services Division; B\&W Y-12's Environment, Safety and Health Organization and Groundwater Protection programs; BJC's Environmental Compliance and Protection Organization (East Tennessee Technology Park) for providing National Pollution Discharge Elimination System Clean Water Act data; and BJC's Radiation Protection Organization for providing radiological surveillance data for sites with residual contamination. LTS information used in the RER is collected and compiled in conjunction with the BJC Surveillance and Maintenance programs. The Tennessee Valley Authority generously provided historical sampling results that were used to construct some graphs depicting off-site data. A sincere note of thanks is due to Commodore Advanced Sciences Inc. sampling and support personnel for their diligent efforts in completing much of the field work for the WRRP monitoring program. 
This page intentionally left blank. 


\section{EXECUTIVE SUMMARY}

Under the requirements of the Oak Ridge Reservation (ORR) Federal Facility Agreement (FFA) established between the U.S. Department of Energy (DOE), the U.S. Environmental Protection Agency, (EPA) and the Tennessee Department of Environment and Conservation (TDEC) in 1992, all environmental restoration activities on the ORR are performed in accordance with the Comprehensive Environmental Response, Compensation, and Liability Act of 1980 (CERCLA). Since the 1990s, the environmental restoration activities have experienced a gradual shift from characterization to remediation. As this has occurred, it has been determined that the assessment of the individual and cumulative performance of all ORR CERCLA remedial actions (RAs) is most effectively tracked in a single document. The Remediation Effectiveness Report (RER) is an FFA document intended to collate all ORR CERCLA decision requirements, compare pre- and post-remediation conditions at CERCLA sites, and present the results of any required post-decision remediation effectiveness monitoring. First issued in 1997, the RER has been reissued annually to update the performance histories of completed actions and to add descriptions of new CERCLA actions.

Monitoring information used in the 2010 RER to assess remedy performance was collected and/or compiled by DOE's Water Resources Restoration Program (WRRP). Only data used to assess performance of completed actions are provided. In addition to collecting CERCLA performance assessment data, the WRRP also collects baseline data to be used to gauge the effectiveness of future actions once implemented. These baseline data are maintained in the Oak Ridge Environmental Information System and will be reported in future RERs, as necessary, once the respective actions are completed. However, when insufficient data exist to assess the impact of the RAs, e.g., when the RA was only recently completed, a preliminary evaluation is made of early indicators of effectiveness at the watershed scale, such as contaminant trends at surface water integration points (IPs).

Long-term stewardship (LTS) information used in this report is collected, compiled, and tracked by the WRRP in conjunction with the Bechtel Jacobs Company LLC (BJC) Surveillance and Maintenance (S\&M) program, the BJC Radiation Protection Organization at East Tennessee Technology Park (ETTP), and the ETTP Environmental Compliance Program. Additionally, documentation verifying the implementation of administrative land use controls (LUCs) [i.e., property record restrictions, property record notices, zoning notices, and excavation/penetration permit (EPP) program] is also obtained from many sources throughout the fiscal year (FY), including County Register of Deeds offices for property record restrictions and property record notices, City Planning Commission for zoning notices, and BJC project engineers for EPP program verification. Copies of this documentation are obtained by the WRRP and maintained with the project RER files.

\section{REPORT ORGANIZATION}

New in 2010 are updated maps in applicable watersheds that identify the status of actions. The implementation of the large watershed-scale Records of Decision (RODs), in some instances, can take multiple years to complete. While the RODs are not complete until all actions are implemented, incomplete RODs with selected completed actions usually affect the ROD's watershed goals. Therefore, in this RER, select watershed maps contain completed actions, actions not implemented, and actions which are in progress (e.g., Figure 4.1 "CERCLA Actions in BCV Watershed").

The 2010 RER is issued and is identified as the 2010 RER: Data and Evaluations. The 2007 RER, a compendium of the details and background on all CERCLA decisions made as of September 30, 2006, will be updated every five years in the ORR CERCLA Five-Year Review (FYR). You may request a copy 
at the DOE Information Center, 475 Oak Ridge Turnpike, Oak Ridge, Tennessee. The 2006 RER FYR can also be accessed online under the document request link at:

$<$ http://www.oakridge.doe.Gov/external/Home/PublicActivities/DOEInformationCenter/tabid/126/Default.aspx>.

The annual RER contains the required monitoring data evaluation and effectiveness assessment for the completed CERCLA remediation activities, as well as the compliance assessment with LTS requirements (i.e., engineering and LUCs). This greatly streamlines the RER document process and focuses the annual review on the sampling data gathered and results at those sites where the work has been completed.

Within the 2010 RER, a chapter is devoted to each of the ORR administrative watersheds, as well as a chapter each to Chestnut Ridge, ETTP, and a single chapter to all off-site actions. Each chapter of the 2010 RER identifies single actions and, if applicable, watershed-scale ROD actions with on-going monitoring and/or LTS activities. The remedial action objectives and performance monitoring criteria are provided, followed by an evaluation of the monitoring results with a comparison to stated performance metrics. When insufficient data exist to assess the impact of the RAs, e.g., when the RA was only recently completed or not all RAs prescribed by the watershed ROD have yet to be implemented, a preliminary evaluation is made of early indicators of effectiveness at the watershed scale, such as contaminant trends at surface water IPs. Each chapter concludes with any technical issues and/or recommendations for monitoring changes.

\section{REMEDLATION EFFECTIVENESS SUMMARY}

Highlights of the effectiveness of completed RAs are provided below. Issues and recommendations identified since the $2006 \mathrm{RER} / \mathrm{FYR}$ including current year evaluations of performance monitoring data are summarized in Chap. 1 of this 2010 RER. A more detailed discussion of the issue(s) resulting from the 2010 RER evaluations is provided in the appropriate chapter.

\section{Bethel Valley (BV)}

In FY 2009, BV monitoring results showed a continued significant decrease in mercury concentrations in White Oak Creek (WOC) following implementation of a maintenance action at Bldg. 4501, and an increase in the average ${ }^{90} \mathrm{Sr}$ concentration at 7500 Bridge. The maintenance action of routing mercurycontaminated groundwater collected in building basement sumps at Bldg. 4501 to treatment at the Process Waste Treatment Complex (PWTC) continued to reduce mercury concentrations in WOC. During FY 2009, the mercury concentrations at the 7500 Bridge were below the TDEC ambient water quality criteria (AWQC) value except on one sampling occasion at 7500 Bridge in June 2009. On that date, a high mercury concentration $(383 \mathrm{ng} / \mathrm{L})$ was detected. Investigation into the elevated concentration revealed the PWTC effluent had elevated mercury concentrations. In spite of the elevated June concentration, a statistical comparison of mercury concentration in surface water at 7500 Bridge confirms that the post-diversion stream concentrations are significantly lower than the pre-diversion concentrations.

During FY 2009, the ${ }^{90} \mathrm{Sr}$ reduction goal was not attained for the Corehole 8 Plume collection system due to an increase in ${ }^{90} \mathrm{Sr}$ discharges to First Creek from the Corehole 8 Plume. The cause of increased plume discharge is related to leaks in the Oak Ridge National Laboratory (ORNL) potable and fire water system as well as operational problems with the plume collection system. Strontium-90 and ${ }^{234} U$ concentrations measured in groundwater at well 4411 and Corehole 8 Zone 2 rose sharply during FY 2009. Such increases in plume concentrations were disproportionate to the above average rainfall measured across the ORR. Near the end of FY 2009, it became apparent that potable and firewater utility system leaks were the probable cause of the dramatic increases in contaminant concentrations near the source and within the plume. Water line leaks to the north and upslope from the North Tank Farm apparently fed water into the 
plume source area which mobilized additional contaminants from the source area into the plume. Mechanical problems with the plume collection system also impaired plume capture during FY 2009.

Tritium concentrations in surface water in WOC in BV have increased as a result of collection and transfer of former groundwater discharges from Melton Valley (MV) to the wastewater treatment system in BV. This condition is a result of the MV RA. Concentrations in surface water throughout WOC are below the DOE derived concentration guide and below remedy human health risk goals.

Recommended responses for the performance of the Corehole 8 Plume collection system include two actions: 1) identification and repair of fire water utility system leaks in the vicinity of the contaminant source areas and plumes which cause contaminant releases and overwhelm collection systems, and 2) conduct an engineering evaluation of the existing Corehole 8 Plume collection system and refurbish as needed to ensure proper operation.

The technical issue/recommendation associated with ungauged ${ }^{90} \mathrm{Sr}$ flux was carried forward from the 2006 FYR. Additional sampling will occur during FY 2010 to determine if excess ungauged ${ }^{90} \mathrm{Sr}$ impacts BV ROD goals as summarized in Table 1.1.

\section{Melton Valley (MV)}

Radiological goals for ${ }^{137} \mathrm{Cs},{ }^{90} \mathrm{Sr}$, and tritium, which are the principal surface water contaminants in $\mathrm{MV}$, were met at White Oak Dam and at other monitoring locations throughout the valley. The total fluxes of ${ }^{137} \mathrm{Cs},{ }^{90} \mathrm{Sr}$, and ${ }^{3} \mathrm{H}$ remained low and comparable to the FY 2007 and FY 2008 values even though the annual rainfall across the ORR and at the ORNL site was well above the long-term average.

Groundwater level monitoring of the hydrologic isolation areas in MV showed that performance criteria were met at 37 of 43 locations. Five of the wells that did not attain their performance target in FY 2009 did so based on a response to groundwater level controls outside the hydrologically isolated area. The sixth well is located adjacent to the downgradient groundwater collection trench in Solid Waste Storage Area 4, which receives infiltration of groundwater from outside the hydrologically isolated area. FY 2009 was a good test of the groundwater level controls in MV since it was the first year since remedy completion with above average rainfall.

Groundwater contaminant concentrations around the shallow land burial sites are generally decreasing or stable compared to concentrations measured before completion of the MV remedy.

Groundwater monitoring of the deep groundwater exit pathway continues to show a broad area that exhibits high $\mathrm{pH}$, fluoride, and dissolved solids. Some of the dissolved constituents, such as chloride and sulfate, are predominantly naturally occurring. Alpha activity was detected at more than the $15 \mathrm{pCi} / \mathrm{L}$ drinking water standard in six sampling zones from deep groundwater that also shows natural brine chemistry influences that may bias the alpha activity measurement. Strontium-90 was detected in three sampled zones at activities less than $50 \%$ of the drinking water standard.

An issue carried forward from the 2008 RER is the elevated alpha and beta activity results for some zones in the MV exit pathway wells. In FY 2009, a new project to install offsite groundwater monitoring wells west of the Clinch River was started as a result of these elevated activity levels. Issues/recommendations carried forward from the 2009 RER are summarized in Table 1.1. 


\section{Bear Creek Valley}

During FY 2009, surface water monitoring at the IP (BCK 9.2) showed that the ROD goal of $\leq 34 \mathrm{~kg} / \mathrm{yr}$ of uranium was not attained. The measured uranium flux at the IP was $148 \mathrm{~kg}$. About $31 \%$ of the FY 2009 uranium flux is attributed to surface water discharged from the S-3 Ponds plume as measured at BCK 12.34 and about $41 \%$ of the FY 2009 uranium flux originated in the Bear Creek Burial Grounds and discharged to Bear Creek via North Tributary (NT-8). Other contributors to the total uranium flux include deeper groundwater flows in the S-3 plume that discharge to Bear Creek via springs SS-4 and SS-5 and diffuse bed seepage, as well as smaller contributions from NT-3, NT-5, and NT-7. During FY 2009, the risk level associated with uranium at the IP remained about twice the ROD goal.

During FY 2009, the average nitrate concentration measured at BCK 12.34 near the S-3 Pond source area was less than the industrial risk-based screening criteria (RBC) for nitrate. The RBC for nitrate in an industrial land use scenario is $160 \mathrm{mg} / \mathrm{L}$. During FY 2009, the average nitrate concentration was $33 \mathrm{mg} / \mathrm{L}$ based on 52 weekly grab sample results. None of the samples exceeded the $160 \mathrm{mg} / \mathrm{L} \mathrm{RBC}$.

Groundwater monitoring during FY 2009 showed that groundwater contaminant trends in monitored areas are relatively stable and changes from FY 2008 levels are minor.

No new technical issues were identified in Bear Creek Valley from an evaluation of FY 2009 data. The issue of ungauged uranium flux into Bear Creek continues to be carried forward into the 2009 RER. Uranium concentrations at BCK 9.2 continue to increase; however, increasing uranium trends are not observed at gauged monitoring stations so that the increasing uranium flux into Bear Creek is from ungauged sources. DOE recommends re-instatement of flow-paced monitoring at NT-3 and NT-5 and creation of an additional flux monitoring station downstream of SS-4 but upstream of NT-7 to attempt to determine inputs directly to the stream channel from karst discharges. Issues/recommendations carried forward from the 2009 RER are summarized in Table 1.1.

Based on the substantial improvement of the NT-3 stream restoration at the Boneyard/Burnyard site, DOE recommended the annual stream channel stability monitoring be discontinued and be replaced with annual erosion control monitoring inspection to be performed during the Y-12 National Security Complex (Y-12) S\&M inspections. Concurrence of DOE's recommendation was received by EPA and TDEC. While the channel stability monitoring has been discontinued, the riparian, fish and macroinvertebrate monitoring will continue at this time and be reevaluated at the FYR.

\section{Chestnut Ridge}

Filled Coal Ash Pond (FCAP) - The monitoring results since the RA indicate that the remedy is successfully lowering the concentration of contaminants of concern (COCs) in surface water as it exits the constructed wetland. Arsenic concentrations, however, exceed the AWQC in both the upgradient and downgradient locations at the FCAP wetland. Biological communities in McCoy Branch have improved over time, but still remain impacted relative to uncontaminated reference streams.

Kerr Hollow Quarry (KHQ) - Results of statistical evaluations of 2009 groundwater analytical data for KHQ do not indicate a contaminant release for the uppermost aquifer and do not warrant any response action, as specified in the post-closure permit that governs the site. 
United Nuclear Corporation (UNC) - Elevated gross beta activity continues to be observed in downgradient well GW-205 at the UNC site, suggesting a potential contaminant release from the site. The gross beta activity does not appear to be caused by ${ }^{90} \mathrm{Sr}$, but does track closely to ${ }^{40} \mathrm{~K}$. A downgradient spring, added to the monitoring network in FY 2008 to assess the potential impacts of the UNC groundwater seepage on surface water quality, exhibits data consistent with results from other downgradient monitoring wells at the site that do not detect any COCs above an action limit.

This issue regarding the elevated gross beta activity downgradient of the UNC site was identified in the 2008 RER and is carried forward. The gross beta in sample results from the UNC area will continue to be trended in future RERs. Completed or resolved issues at Chestnut Ridge are summarized in Table 1.2.

\section{Upper East Fork Poplar Creek (UEFPC)}

Surface water contaminant discharge conditions in UEFPC during FY 2009 reflected the increased rainfall during FY 2009 relative to FY 2006 through FY 2008. During FY 2009, mercury discharges measured at the West End Mercury Area IP (Outfall 200A6) and at the watershed IP (Station 17) using flow-paced sampling were about 3.5 and $3.9 \mathrm{~kg}$, respectively. The $3.9 \mathrm{~kg}$ watershed discharge of mercury reflects the affect of above average rainfall during FY 2009. The Big Spring Water Treatment System (BSWTS) was fully operational during FY 2009 with no significant downtime or operational problems. The average effluent concentration for BSWTS was $0.025 \mu \mathrm{g} / \mathrm{L}$, which is less than the performance standard of $0.2 \mu \mathrm{g} / \mathrm{L}$.

Aquatic biological monitoring shows that mercury concentrations in fish tissue at EFK 23.4 remain consistent with levels measured in previous years near the watershed IP, although surface water mercury concentrations have decreased significantly as a result of BSWTS operation. Polychlorinated biphenyls (PCBs) concentrations in fish tissue remained much lower than the peak levels observed in the mid-1990s. The number of fish and benthic communities in the upper reaches of UEFPC (EFK 23.4) remain below the reference communities in nearby streams; however, the number of fish species in reaches further downstream (EFK 13.8) has improved to the point of exceeding the reference communities.

The performance of the groundwater pump-and-treat system of the East End Volatile Organic Compound Plume is measured by evaluating reductions in volatile organic compounds (VOC) concentrations downgradient of the extraction well, GW-845. FY 2009 data indicate that the groundwater pump and treatment system has effectively withdrawn contaminant mass from the permeable limestone downgradient in Union Valley, thereby meeting the performance criteria of the action memorandum (AM). Increasing uranium isotopic levels in the influent and effluent streams indicate that groundwater contaminants from the Former Oil Skimmer Basin and other groundwater source areas to the west are being pulled into the extraction well zone of influence. Monitoring will continue to determine if levels continue to rise which could indicate the need, as identified in the AM, to modify the treatment train to capture uranium in addition to treating the VOCs.

No new technical issues or recommendations are added for UEFPC. Issues carried forward from previous RERs include elevated mercury fish tissue concentrations within East Fork Poplar Creek (EFPC) even though mercury surface water concentrations have decreased. The recommendation included a working team (which has started and is ongoing) to develop a conceptual model. Also since mercury concentrations at Station 17 are still above the $200 \mathrm{ppt}$ goal, monitoring continues and concentrations are anticipated to decrease with the implementation of mercury source control actions. Technical issues/recommendations carried forward from previous years' performance data evaluations for the UEFPC watershed are summarized in Table 1.1. 


\section{CERCLA Off-Site Actions}

Monitoring in Lower East Fork Poplar Creek (LEFPC) at Station 17 is conducted to measure the concentration and mass flux of mercury that is discharged from the UEFPC watershed. During FY 2009, the flow-paced continuous monitoring detected an average concentration of $273 \mathrm{ng} / \mathrm{L}$ and a mass flux of about $3.9 \mathrm{~kg}$ mercury. Analytical results obtained from grab samples collected on a 4-days per week basis detected an average mercury concentration of about $310 \mathrm{ng} / \mathrm{L}$. Although surface water mercury concentrations and fluxes have declined over recent years since BSWTS started operations, the levels of mercury in fish tissue in the LEFPC have remained elevated.

Performance monitoring of the Clinch River and Poplar Creek continues to indicate a downward trend in fish PCB concentrations since the late 1980s. PCB levels are at or below fish advisory levels in channel catfish in most recent years. However, very large fish, e.g., striped bass, are substantially higher. Mercury concentrations in fish at monitored sites continue to indicate the influence of mercury sources from EFPC, with the highest levels in fish in Poplar Creek and lower levels with distance downstream. Overall, the performance monitoring has been successful in addressing the ROD goal of evaluating changes in fish contaminant levels and how those levels compare to fish advisory limits.

Performance monitoring results from Lower Watts Bar Reservoir obtained during FY 2009 continue to indicate that mercury and PCB levels in fish are below commonly-used fish advisory levels.

Evaluations of current performance monitoring data did not identify any issues that warrant specific recommendations for any of the Off-site actions during the FY.

\section{$\underline{\text { ETTP }}$}

Removal of soil and debris from the K-1070-C/D Burial Grounds in 1999 has reduced the concentration of VOCs in groundwater downgradient of the removal area. An evaluation of VOC concentrations in wells UNW-064, UNW-114, and TMW-011 over the past several years indicates that generally VOC concentrations in groundwater have declined and remain relatively stable with fluctuations related to climatic cycles.

The RA for the K-1007-P1 Holding Pond was initiated in FY 2009 and included draining the pond, killing undesirable fish, recontouring approximately one quarter of the pond bottom to create a suitable environment for aquatic vegetation, and the planting of aquatic vegetation. Operational monitoring is scheduled to begin in FY 2010.

During FY 2009, monitoring results for the principal surface water and groundwater locations at ETTP indicate that contaminant levels are generally stable to decreasing in most instances. The hexavalent chromium collection system and treatment functioned as planned and protected surface water quality in Mitchell Branch. Contaminants detected during previous years in exit pathway groundwater near the K-1007-P1 weir were not detected in FY 2009. Low concentrations of PCE and TCE greater than the maximum contaminant level (MCL) was detected in a bedrock well in the exit pathway at the mouth of Mitchell Branch. These contaminants have been detected previously but were not present during recent drought years. Most of the groundwater plumes monitoring results indicate stable contaminant levels compared to recent years.

The northern section of ETTP Zone 1 was identified as the Black Oak Ridge Conservation Easement in March 2005 and is to be utilized for recreational use including hiking, bicycling, and select controlled deer hunts. This is different than the end use identified in the Zone 1 ROD which states the area is unrestricted industrial with no recreational use designated. DOE acknowledges the discrepancy in the end 
use. Technical issues/recommendations carried forward from previous years' performance data evaluations are summarized in Table 1.1.

An additional issue that is carried forward from the 2009 RER is the discontinuing of monitoring from the $\mathrm{K}-1420$ slab, this is currently being reviewed by the ETTP Core Team.

\section{Oak Ridge Associated Universities (ORAU) South Campus Facility (SCF)}

VOCs in groundwater at the SCF have exhibited a long-term decreasing concentration history, consistent with a monitored natural attenuation remedy.

Evaluations of current performance monitoring data for the ORAU SCF did not identify any technical issues/recommendations. 


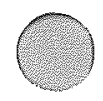

0

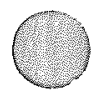




\section{INTRODUCTION}

\subsection{OBJECTIVE OF THE ANNUAL REMEDIATION EFFECTIVENESS REPORT}

The objective of the annual Remediation Effectiveness Report (RER) is to assess and document effectiveness, or progress toward a stated goal, of each completed remedy performed in accordance with the Comprehensive Environmental Response, Compensation, and Liability Act of 1980 (CERCLA) on and around the U. S. Department of Energy (DOE) Oak Ridge Reservation (ORR). As part of this assessment, compliance with long-term stewardship (LTS) requirements (e.g., engineering and land use controls [LUCs]) of CERCLA decisions is also evaluated.

Various CERCLA instruments are used to document remedial decisions on the ORR. Typically, either a Record of Decision (ROD) for a remedial action (RA) or Action Memorandum (AM) for a removal action defines the selected remedy for a site. These instruments serve as the statutory decision guiding the performance of site remediation activities and may also specify monitoring and LTS requirements. However, because most decision documents generally lack monitoring specifics, additional details are typically found in post-ROD documents, such as remedial action work plans (RAWPs), post-construction reports (PCRs), remedial action reports (RARs), removal action reports (RmARs), phased-construction completion reports (PCCRs) or ROD monitoring plans.

Monitoring information used in the 2010 RER to assess performance of completed CERCLA actions was compiled under DOE's Water Resources Restoration Program (WRRP). The WRRP was established to implement a comprehensive, integrated environmental monitoring and assessment program for the DOE ORR and to minimize duplication of field, analytical, and reporting efforts. Groundwater, surface water, sediment, and biota are monitored and evaluated as part of this assessment program. In addition to collecting CERCLA performance assessment data, the WRRP also collects baseline data to be used to gauge the effectiveness of future actions once implemented. All data used in the RER are collected in accordance with the annual WRRP Sampling and Analysis Plan (SAP), Quality Assurance Project Plan for the WRRP (BJC 2009), and are maintained in the Oak Ridge Environmental Information System (OREIS). Baseline data will be reported in future RERs, as required, once the respective actions are completed.

Select biological monitoring data collected by the WRRP provide a usable measure of overall improvements in aquatic conditions. However, these data are not intended to imply any conclusions regarding the current status of ecological risk. The risk to ecological receptors will be evaluated in future studies, such as Remedial Investigations (RIs), and addressed by final decisions for each of the watersheds or Operable Units (OUs).

When remediation is complete, selected sites will require some level of LTS to ensure protection of human health and the environment from the remaining hazards, or residual contamination. LTS ensures that remediation remains effective for an extended, or possibly indefinite, period of time until residual hazards are reduced sufficiently to permit unrestricted use and unlimited access (DOE 2003a). LTS is designed to:

- Prevent the residual hazard from migrating to the receptor (generally through engineering controls), and

- Prevent the receptor from encountering the residual hazard (generally through LUCs). 
Engineering controls include actions to stabilize and/or physically contain or isolate waste, contamination, or other residual hazards. Engineered controls include in situ stabilization; capping of residual contamination; groundwater extraction and treatment systems; and vaults, repositories, or engineered landfills designed to isolate waste or materials.

LUCs are legal and other non-engineering measures intended to prevent the public from coming into contact with contamination left in place. LUCs include administrative controls such as property record restrictions, property record notices, zoning notices, and excavation/penetration permit (EPP) programs, as well as physical controls, such as state advisories/postings, fences, signs, and surveillance patrols.

LTS encompasses both engineering controls and LUCs. The RER evaluates the performance of engineering controls and LUCs that are required by CERCLA documents (e.g., RODs, AMs, RAWPs, Removal Action Work Plans, PCCRs, RARs, RmARs) to protect human health and the environment. The definitions encompassing LTS have evolved over time and earlier decision documents used the term "institutional controls" loosely instead of LUCs and engineering controls. This term "institutional controls" is used throughout the RER when using citations directly from these earlier decision documents.

LTS information used in this report was collected and/or compiled by the WRRP in conjunction with the Bechtel Jacobs Company LLC (BJC) Surveillance and Maintenance (S\&M) programs and the BJC Radiation Protection Organization at East Tennessee Technology Park (ETTP). Site-specific inspections to assess the condition of engineering controls, as well as physical LUCs (i.e., access controls, signs, and security patrols), are performed by BJC S\&M programs at Y-12 National Security Complex (Y-12), Oak Ridge National Laboratory (ORNL), and ETTP, in accordance with site-specific S\&M plans. Inspection checksheets are completed for each location and tied to any needed maintenance request forms. This documentation is maintained by the Project Document Control Center (PDCC) for each site and ultimately filed in the BJC Document Management Center (DMC). The WRRP routinely obtains copies of these checksheets to monitor the effectiveness of the remedy throughout the fiscal year (FY) and uses this information to summarize the status of compliance with the LTS requirements annually in the RER. LTS requirements at ETTP also include radiological surveys, Contamination Area postings, storm drain sampling, and surface water monitoring for areas with remaining contamination. Radiological monitoring information is maintained by the BJC Radiation Protection Organization in the ETTP Compliance Survey Database, and a summary of the survey results are provided annually to the WRRP for incorporation into the RER. Storm drain sampling and surface water monitoring is performed by the ETTP Environmental Compliance Program.

Documentation verifying the implementation of administrative LUCs (i.e., property record restrictions, property record notices, zoning notices, and EPP programs) is also obtained from many sources throughout the FY, including County Register of Deeds offices for property record restrictions and property record notices, City Planning Commission for zoning notices, and BJC project engineers for EPP program verification. Copies of this documentation are obtained by the WRRP and maintained with the project RER files.

Select LUCs, for Melton Valley (MV) only, require an annual certification. The RER contains, in Appendix A, the Certification of Land Use Controls FY 2009 (for MV). The Land Use Control Assurance Plan (LUCAP) requires that the Manager, DOE Oak Ridge Operations (ORO), annually verify in the RER that Land Use Controls Implementation Plans (LUCIPs) are being implemented on the ORR. 


\subsection{ORGANIZATION OF THE REPORT}

New in 2010 are updated maps in applicable watersheds that identify the status of actions. The implementation of the large watershed-scale RODs, in some instances, can take multiple years to complete. While the RODs are not complete until all actions are implemented, incomplete RODs with selected completed actions usually affect the ROD's watershed goals. Therefore, in this RER, select watershed maps include different symbols completed actions, actions not implemented, and actions which are in progress (e.g., Figure 4.1 "CERCLA Actions in BCV Watershed").

The format of the RER is streamlined to facilitate annual reviews and to focus on data evaluations to assess performance of completed actions and compliance with LTS requirements. The 2007 RER (DOE 2007a) is a compendium of all CERCLA decisions finalized through September 30, 2006. It contains a concise description of each RA in the context of a conceptual contaminant fate and transport model for each watershed, and summarizes the goals of the remedy. Section 1.4 of the 2007 RER provides the physical context with which to better understand the CERCLA decision and activities to date, including a summary of the contaminant source areas and surface water, groundwater, and biological resources. The 2007 RER also includes CERCLA decisions that include future actions and any ongoing actions. This compendium summarizes all monitoring, LTS, and applicable LUC requirements for each CERCLA decision, as well as the associated metrics against which performance is measured.

The 2010 RER provides the current status and updates to completed CERCLA actions on the ORR, as well as the technical evaluation of effectiveness for each remedy that includes monitoring and/or LTS requirements. For each of these actions, the 2010 RER provides: (1) a summary of performance goals and objectives; (2) specific monitoring locations and parameters that fulfill the requirements contained in the respective decision document(s); and (3) a comparison of monitoring results to stated goals or metrics to evaluate the performance of the remedy. Based on this evaluation, changes and recommendations to the monitoring program may be proposed, as appropriate. Actions that do not have LTS or monitoring requirements or have been terminated or superseded by watershed-scale actions are not discussed in the 2010 RER. Lastly, Appendix A provides the applicable compliance certification for the approved MV LUCs.

Figure 1.1 shows the boundaries of the administrative watersheds on the ORR, and Figure 1.2 depicts the boundaries of the impacted watersheds adjacent to the ORR. Within the $2010 \mathrm{RER}$, a chapter is devoted to each of the watersheds, as well as a chapter each to Chestnut Ridge (ChR), ETTP, and a single chapter to all off-site actions. Rather than forming a single defined hydrologic watershed, ChR and the ETTP comprise several individual sub-watersheds, but are treated as a single unit for planning and administrative purposes (Figure 1.1). Each chapter identifies completed single actions and, as applicable, completed watershed-scale ROD actions with ongoing monitoring and/or LTS activities. The remedial action objective (RAO) and performance monitoring criteria are provided, followed by an evaluation of the monitoring results with a comparison to stated performance metrics. When insufficient data exist to assess the impact of the RA(s), e.g., when the RA was only recently completed or not all RAs prescribed by the watershed ROD have yet to be implemented, a preliminary evaluation is made of early indicators of effectiveness at the watershed scale, such as contaminant trends at surface water integration points (IPs).

Figure 1.1 also shows areas of known groundwater contamination in each of the ORR administrative watersheds. No final groundwater decisions have been made on the ORR to date, although several groundwater RAs have been undertaken. Progress toward groundwater remediation has been challenging on the ORR because of the hydrogeologic complexity of fractured rock and karst systems, as well as the recalcitrant nature of some groundwater contaminants. During the 1990s, DOE attempted several passive groundwater RAs using in situ media to capture or degrade contaminants. None of these 


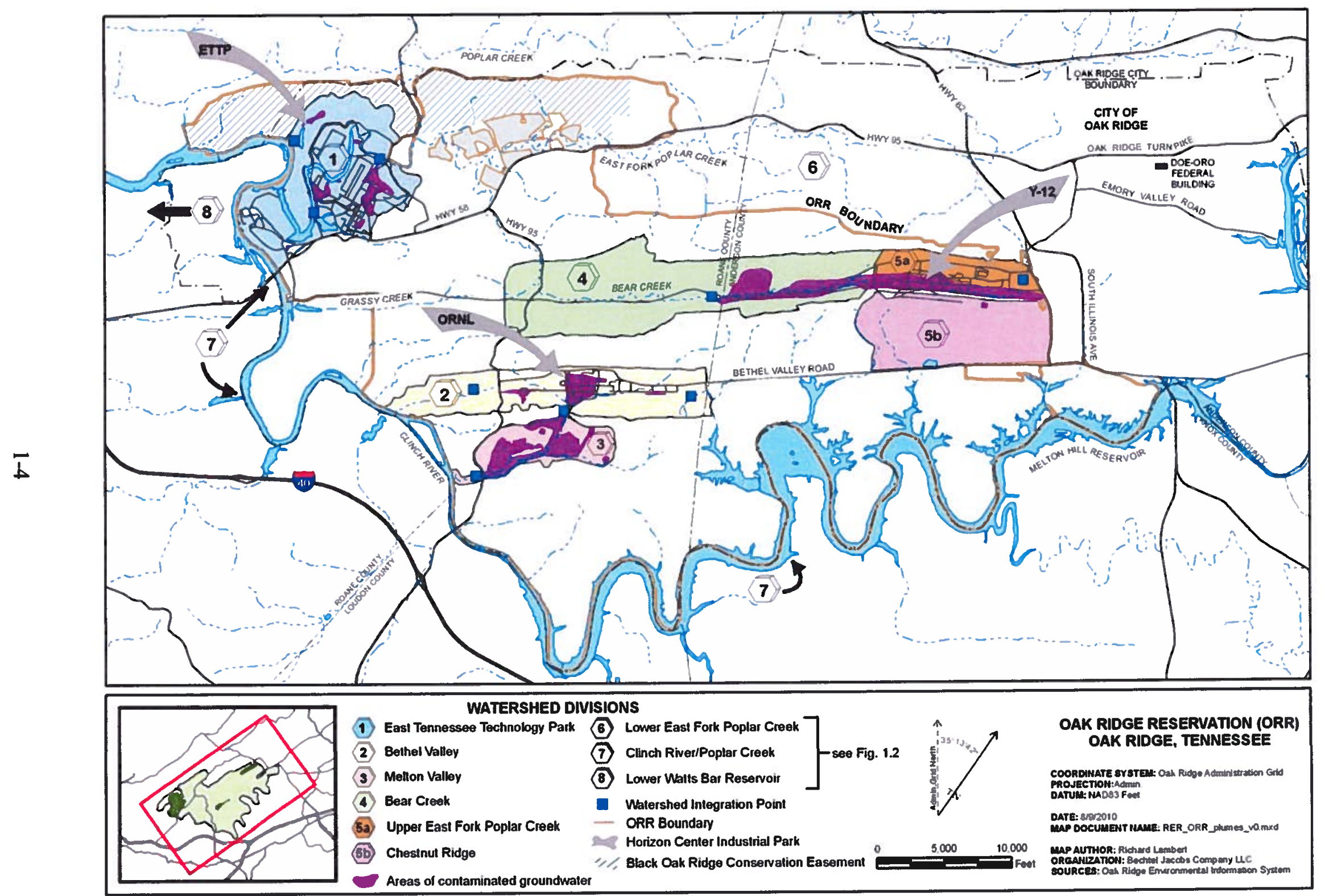

Figure 1.1. Watersheds on the ORR. 


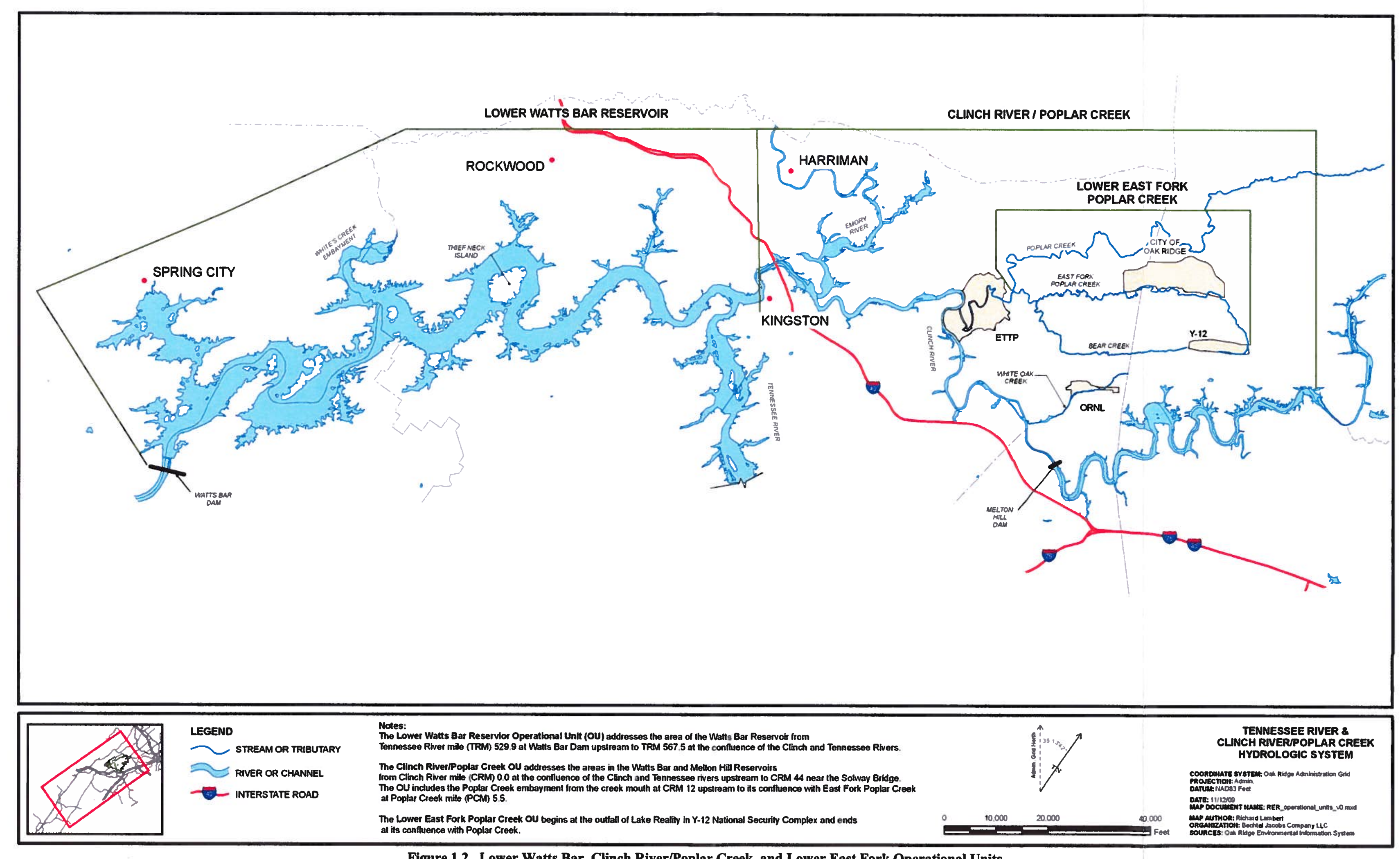

Figure 1.2. Lower Watts Bar, Clinch River/Poplar Creek, and Lower East Fork Operational Units. 
This page intentionally left blank. 
projects met with long-term success and all were terminated under agreements with the Federal Facility Agreement (FFA) parties. Actions on the ORR that have been successful at prevention of the spread of groundwater contamination have included containment pump-and-treat systems and aggressive hydrologic isolation of wastes left in place. Containment pump and treat systems are successful at prevention of offsite plume migration at the $\mathrm{Y}-12$ east-end volatile organic compound (VOC) plume in UEFPC and at the hexavalent chromium plume at ETTP. Such systems do require periodic maintenance and potential modification, as is the case at the Core Hole 8 plume in Bethel Valley (BV). In MV at ORNL, aggressive hydrologic isolation and in situ solidification by grouting of wastes left in place is successful in halting formation of contaminated leachate which feeds groundwater contaminant plumes. Dense non-aqueous phase liquids (DNAPLs) containing chlorinated VOCs in fractured bedrock are known to exist at the ETTP site and in Bear Creek Valley (BCV) and may be present in other areas of the ORR. Such contaminant problems are extremely difficult and in some instances have been determined to be technically impracticable to remediate. DOE is currently conducting groundwater treatability studies at two chlorinated VOC sites on the ORR - one at ETTP and one at ORNL - to evaluate the feasibility of remediating these contaminants in the ORR groundwater setting. The current ORR FFA remediation strategy and sequencing of actions places final groundwater decisions and RAs several years into the future.

The order of presentation within the 2010 RER is as follows:

- Chap. 2-BV Watershed

- Chap. 3-MV Watershed

- Chap. 4-BCV Watershed

- Chap. 5-ChR

- Chap. 6-Upper East Fork Poplar Creek (UEFPC), including Union Valley

- Chap. 7-Off-Site Actions, including Lower East Fork Poplar Creek (LEFPC), Clinch River/Poplar Creek (CR/PC), and Lower Watts Bar Reservoir (LWBR)

- Chap. 8-ETTP

- Chap. 9-Other Sites

Chapter 10 provides a list of references used in the preparation of this report. Chapter 11 includes a bibliography of the relevant documentation for actions initiated, in progress, or completed under CERCLA for each watershed that were used to prepare the initial tables of each chapter (e.g., Table 2.1, Table 3.1, Table 4.1, etc.). Appendix A provides the required DOE certification that relevant LUCIP requirements were implemented in accordance with the LUCAP (DOE, EPA, and TDEC 1999). Appendix B of this report includes graphical presentations of data that support discussions of MV performance assessments in Chap. 3.

\subsection{ORR-WIDE RAINFALL}

The quantity, duration, and intensity of rainfall affect contaminant concentrations in groundwater and surface water across the ORR. Because of this, general rainfall trends for FY 2009 are summarized in this section to provide a general context for the remainder of this report. 
Details of rainfall distribution within FY 2009 are illustrated in Figure 1.3. Mean monthly rainfall values for FY 2009 for the ORR vary from 2 inches/month to more than 8 inches/month. During FY 2009, the greatest monthly rainfall occurred in December 2008 and the lowest monthly rainfall occurred during October 2008. Rainfall occurred frequently during FY 2009, with relatively dry conditions during October and February. Rainfall amounts recorded during the summer months were sustained and typical August and September dry conditions were not observed.

Total rainfall on the ORR during FY 2009 measured over 62 inches based on a composite of six raingauge stations located throughout the reservation (Figure 1.4). The total rainfall during FY 2009 was significantly greater than the long-term mean for the ORR of 54 inches/year, signaling the end of the multiyear drought reported in recent RERs.

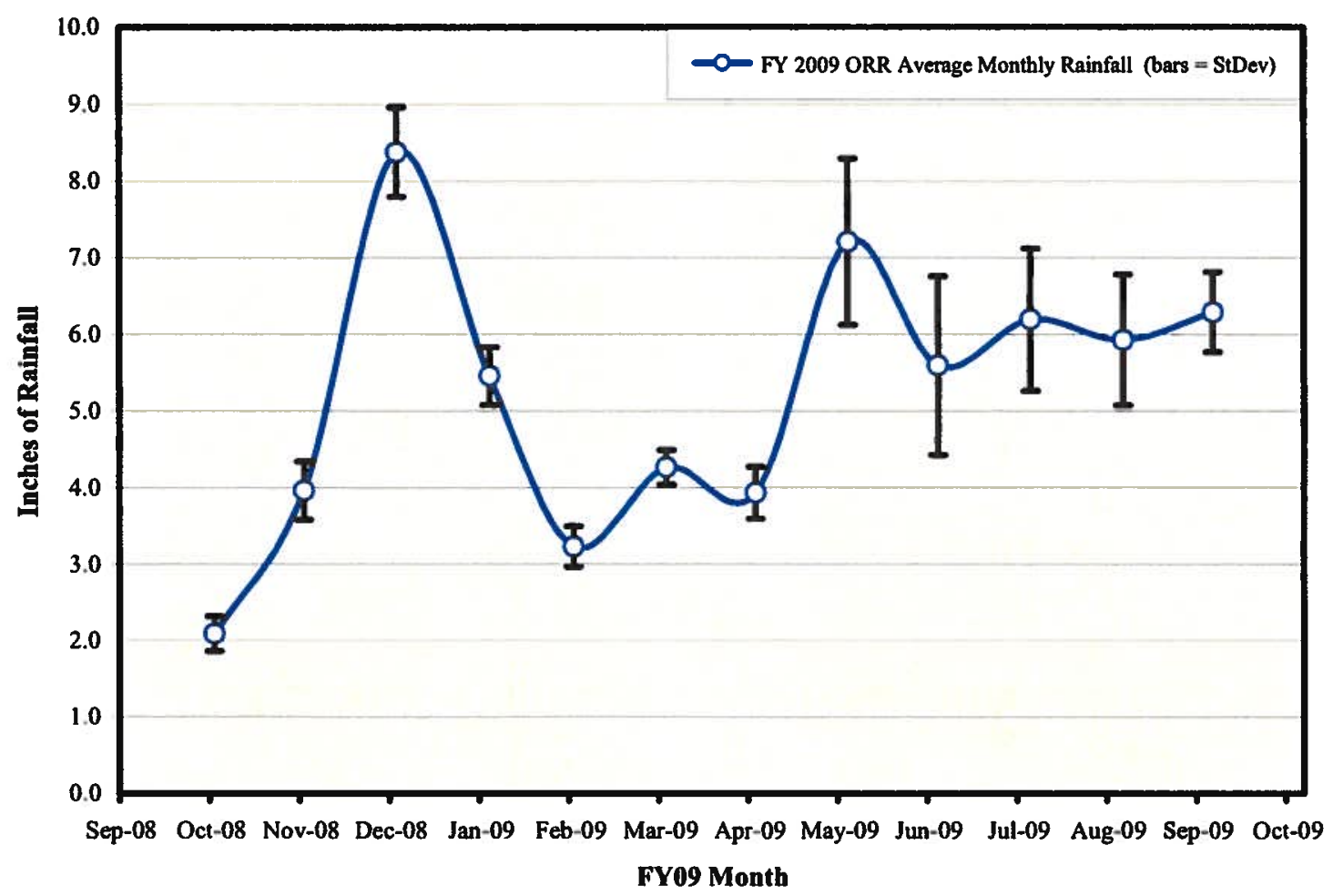

Figure 1.3. FY 2009 monthly average rainfall from six rain gauges on the ORR. 


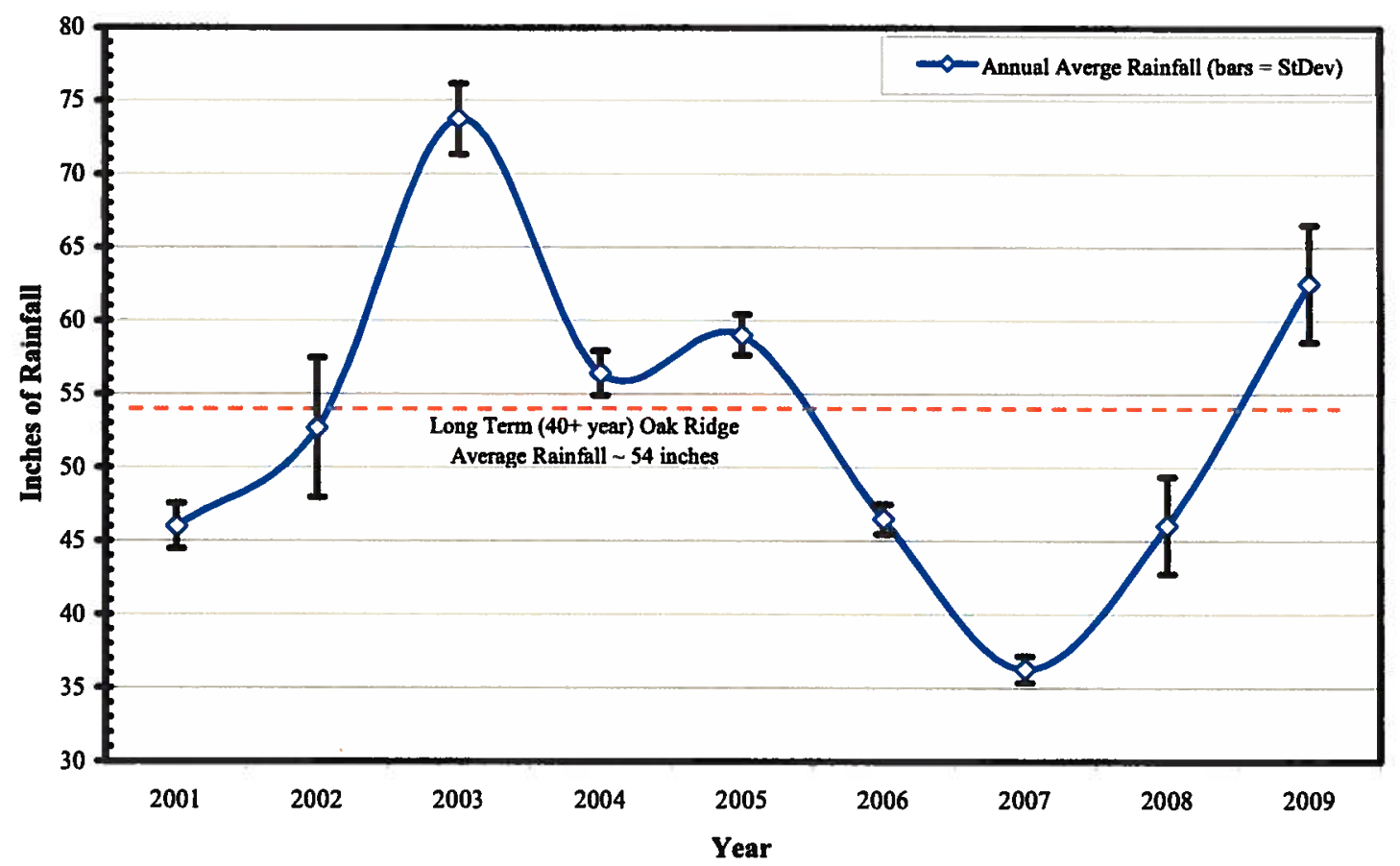

Figure 1.4. Mean annual rainfall from six rain gauges on the ORR, 2001-2009.

\subsection{ISSUES AND RECOMMENDATIONS}

Table 1.1 summarizes issues identified through evaluation of performance monitoring data and provides recommendations, as appropriate. To track issues through their resolution, the table includes a compilation of: (1) the issues identified in subsequent chapters of this $2010 \mathrm{RER}$, and (2) unresolved issues carried forward from a previous RER. Table 1.2 identifies those issues that are closed out in the 2010 RER and will no longer be tracked in future RERs or Five Year Reviews (FYRs). Table 1.3 includes open issues relevant only to the 2006 FYR that are provided a status as of December 2009. Some of these issues are duplicated in Table 1.1. Table 1.4 identifies FYR issues that are completed.

An issue that is carried forward from a previous years' RER is only discussed in the respective chapter of the text if FY 2009 monitoring data clarifies, modifies, or otherwise impacts the issue in any way. For example, because many of the issues currently included in Table 1.1 require completion of future actions within the watershed, those particular issues will remain in the table for tracking purposes, but generally will not be discussed in any detail in the respective chapter. 
Table 1.1. 2010 summary of technical issues, recommendations, and follow-up actions

(New issues identified in this RER are in bold and blue text.)

\begin{tabular}{|c|c|c|c|}
\hline \multirow{2}{*}{ Issue $^{\mathrm{a}}$} & \multirow{2}{*}{$\begin{array}{c}\text { Action/ } \\
\text { Recommendation }\end{array}$} & $\begin{array}{c}\text { Responsible } \\
\text { parties }\end{array}$ & \multirow{2}{*}{$\begin{array}{l}\text { Target } \\
\text { response } \\
\text { date }\end{array}$} \\
\hline & & Primary/Support & \\
\hline \multicolumn{4}{|c|}{ Melton (MV) } \\
\hline $\begin{array}{l}\text { Monitoring results for some zones in } \\
\text { the MV exit pathway wells yield } \\
\text { elevated alpha and beta activity results } \\
\text { that are apparently the result of } \\
\text { elevated suspended and/or dissolved } \\
\text { solids. These results raise concern } \\
\text { over possible migration of } \\
\text { contamination across the DOE } \\
\text { property boundary in western MV. } \\
\text { (2008 RER) }\end{array}$ & $\begin{array}{l}\text { 1. During FY 2009, groundwater monitoring in the exit pathway continued and a } \\
\text { project was defined and started to install offsite groundwater monitoring wells } \\
\text { west of the Clinch River. Additionally, DOE provided utility water to residents } \\
\text { in the Jones Road area. }\end{array}$ & $\begin{array}{l}\text { DOE/ } \\
\text { EPA \& TDEC }\end{array}$ & FY 2010 \\
\hline \multicolumn{4}{|c|}{ Bethel Valley (BV) } \\
\hline $\begin{array}{l}\text { Corehole } 8 \text { Plume collection system } \\
\text { performance does not meet RmAR } \\
\text { performance goals. (2010 RER) }\end{array}$ & $\begin{array}{l}\text { 1. The recommended responses to the problems include: 1) identification and } \\
\text { repair of potable water leaks in the vicinity of the contaminant source } \\
\text { areas and plumes which cause contaminant releases and overwhelm } \\
\text { collection systems, and 2) conduct an engineering evaluation of the } \\
\text { existing Corehole } 8 \text { Plume collection system and refurbish, as needed, to } \\
\text { ensure proper operation. }\end{array}$ & $\begin{array}{l}\text { DOE/ } \\
\text { EPA \& TDEC }\end{array}$ & $\begin{array}{l}\text { To be addressed by } \\
\text { the ORNL Core } \\
\text { Team. }\end{array}$ \\
\hline $\begin{array}{l}\text { 2. The }{ }^{90} \mathrm{Sr} \text { contamination from non- } \\
\text { point sources has become the } \\
\text { dominant contributor to }{ }^{90} \mathrm{Sr} \text { flux at } \\
\text { the } 7500 \text { Bridge location. SWSA } 3 \\
\text { may also be contributing to increased } \\
\text { flux seen at Raccoon Creek. } \\
(2006 \mathrm{FYR})^{2}\end{array}$ & $\begin{array}{l}\text { 2. During FY 2009, non-point }{ }^{90} \mathrm{Sr} \text { sources comprised less than } 20 \% \text { of the } \\
0.33 \mathrm{Ci} \text { measured at } 7500 \text { Bridge compared to the } 35 \% \text { comprised by } \\
\text { Corehole } 8 \text { Plume discharges to First Creek. Sampling will occur during } \\
\text { FY } 2010 \text { to determine if excess ungauged }{ }^{90} \mathrm{Sr} \text { impacts BV ROD goals. }\end{array}$ & $\begin{array}{l}\text { DOE/ } \\
\text { EPA \& TDEC }\end{array}$ & $\begin{array}{l}\text { BV ROD, refer to } \\
\text { the FFA Appendix E } \\
\text { and Appendix J for } \\
\text { planned } \\
\text { implementation } \\
\text { schedules. }\end{array}$ \\
\hline \multicolumn{4}{|c|}{ Upper East Fork Poplar Creek (UEFPC) } \\
\hline $\begin{array}{l}\text { 1. Mercury concentrations in fish within } \\
\text { the EFPC system remain elevated, } \\
\text { despite decreasing concentrations in } \\
\text { aqueous mercury levels. (2007 RER) }\end{array}$ & $\begin{array}{l}\text { 1. A team consisting of DOE EM, NNSA, and Office of Science has been } \\
\text { working together to develop a conceptual model(s) for mercury fate and } \\
\text { transport relevant to methyl mercury concentrations in the EFPC ecosystem. } \\
\text { The effort is being coordinated with the UEFPC Core Team. }\end{array}$ & \begin{tabular}{|l} 
DOE/ \\
EPA \& TDEC
\end{tabular} & $\begin{array}{l}\text { Summary of results } \\
\text { included in } 2010 \\
\text { RER. }\end{array}$ \\
\hline
\end{tabular}


Table 1.1. 2010 summary of technical issues, recommendations, and follow-up actions (cont.)

(New issues identified in this RER are in bold and blue text.)

\begin{tabular}{|c|c|c|c|}
\hline \multirow[t]{2}{*}{ Issue $^{\mathrm{a}}$} & \multirow{2}{*}{$\begin{array}{c}\text { Action/ } \\
\text { Recommendation }\end{array}$} & $\begin{array}{c}\text { Responsible } \\
\text { parties }\end{array}$ & \multirow{2}{*}{$\begin{array}{c}\text { Target } \\
\text { response } \\
\text { date }\end{array}$} \\
\hline & & Primary/Support & \\
\hline \multicolumn{4}{|c|}{ Upper East Fork Poplar Creek (UEFPC) - cont } \\
\hline $\begin{array}{l}\text { 2. FY } 2005 \text { pre-action } \mathrm{Hg} \\
\text { concentrations at Station } 17 \text { are above } \\
\text { the } 200 \text {-ppt performance goal. Hg } \\
\text { concentrations in fish in UEFPC have } \\
\text { yet to respond to commensurate } \\
\text { reductions of Hg from historical } \\
\text { RMPE actions. Biota monitoring in } \\
\text { UEFPC shows impaired diversity and } \\
\text { density of pollution-intolerant } \\
\text { species. (2006 FYR) }\end{array}$ & $\begin{array}{l}\text { 2. Remedial measures required by the UEFPC Phase I ROD are expected to reduce } \\
\text { Hg concentrations at Station } 17 \text {, as well as in fish in UEFPC (see UEFPC } \\
\text { Action/Recommendation } \# 1 \text { above). These measures include Hg source removal } \\
\text { and surface water treatment. The BSWTS was fully operational during FY 2009 } \\
\text { and a corresponding decrease in Hg flux from pre-action levels was observed at } \\
\text { Station } 17 \text {. Also, FY } 2009 \mathrm{Hg} \text { levels in LEFPC fish remain above federal } \\
\text { AWQC, but are less than peak levels observed in } 2001-2002 \text {. It is anticipated } \\
\text { that implementation of the Hg-source removal actions will result in a similar } \\
\text { decrease in flux at the IP. }\end{array}$ & $\begin{array}{l}\text { DOE/ } \\
\text { EPA \& TDEC }\end{array}$ & $\begin{array}{l}\text { UEFPC Phase I } \\
\text { ROD, refer to the } \\
\text { FFA Appendix E } \\
\text { and Appendix J for } \\
\text { planned } \\
\text { implementation } \\
\text { schedules. }\end{array}$ \\
\hline \multicolumn{4}{|c|}{ Bear Creek Valley (BCV) } \\
\hline $\begin{array}{l}\text { 1. Monitoring results for Zone } 1 \text { of } \\
\text { BCV exhibit trace-to-low } \\
\text { contaminant concentrations in } \\
\text { groundwater, thereby } \\
\text { compromising the Phase I ROD } \\
\text { goal to maintain clean groundwater } \\
\text { acceptable for unrestricted use. }\end{array}$ & $\begin{array}{l}\text { 1. The contaminant concentrations have remained low and are observed } \\
\text { intermittently at various monitoring locations. In FY 2009, concentrations } \\
\text { continued to trend downward or were not observed at all. The } \\
\text { intermittent plume in the Maynardville Limestone will continue to be } \\
\text { monitored during FY 2011. }\end{array}$ & $\begin{array}{l}\text { DOE/ } \\
\text { EPA \& TDEC }\end{array}$ & $\begin{array}{l}\text { To be addressed by } \\
\text { the BCV Core } \\
\text { Team. }\end{array}$ \\
\hline $\begin{array}{l}\text { 2. Results for BCK } 9.2 \text { show an increase } \\
\text { in the proportion of ungauged uranium } \\
\text { flux beginning in FY } 2002 \text {. } \\
\text { Increasing uranium trends are not } \\
\text { observed at gauged monitoring } \\
\text { stations, or in principal groundwater } \\
\text { exit points contributing to Bear Creek } \\
\text { surface flow. (2006 FYR) }\end{array}$ & $\begin{array}{l}\text { 2. Uranium flux mass balance in the Bear Creek watershed is complicated by the } \\
\text { karst groundwater system. During FY 2009, approximately } 29 \mathrm{~kg} \text { of the total } \\
148 \mathrm{~kg} \text { were attributed to ungauged sources. DOE recommends re-instatement } \\
\text { of flow-paced monitoring at NT-3 and NT-5 and creation of an additional flux } \\
\text { monitoring station downstream of SS-4 but upstream of NT-7 to attempt to } \\
\text { determine inputs directly to the stream channel from karst discharges. }\end{array}$ & $\begin{array}{l}\text { DOE/ } \\
\text { EPA \& TDEC }\end{array}$ & $\begin{array}{l}\text { BCV Phase I \& II } \\
\text { RODs, BCV } \\
\text { Groundwater ROD; } \\
\text { refer to FFA } \\
\text { Appendix E and J } \\
\text { for planned } \\
\text { implementation } \\
\text { schedule. }\end{array}$ \\
\hline $\begin{array}{l}\text { 3. In addition to surface water } \\
\text { monitoring at the BYBY, the PCCR } \\
\text { (DOE 2003d) specifies five years of } \\
\text { riparian vegetation monitoring of the } \\
\text { restored NT-3 channel. (2008 RER) }\end{array}$ & $\begin{array}{l}\text { 3. DOE completed the fifth year of vegetation riparian monitoring at BYBY } \\
\text { during FY 2008. Results are reported in the } 2009 \text { RER. DOE recommends that } \\
\text { riparian monitoring, fish and macroinvertebrate monitoring continue until the } \\
\text { FYR. }\end{array}$ & $\begin{array}{l}\text { DOE/ } \\
\text { EPA \& TDEC }\end{array}$ & 2011 FYR \\
\hline
\end{tabular}


Table 1.1. 2010 summary of technical issues, recommendations, and follow-up actions (cont.)

(New issues identified in this RER are in bold and blue text.)

\section{East Tennessee Technology Park (ETTP)}

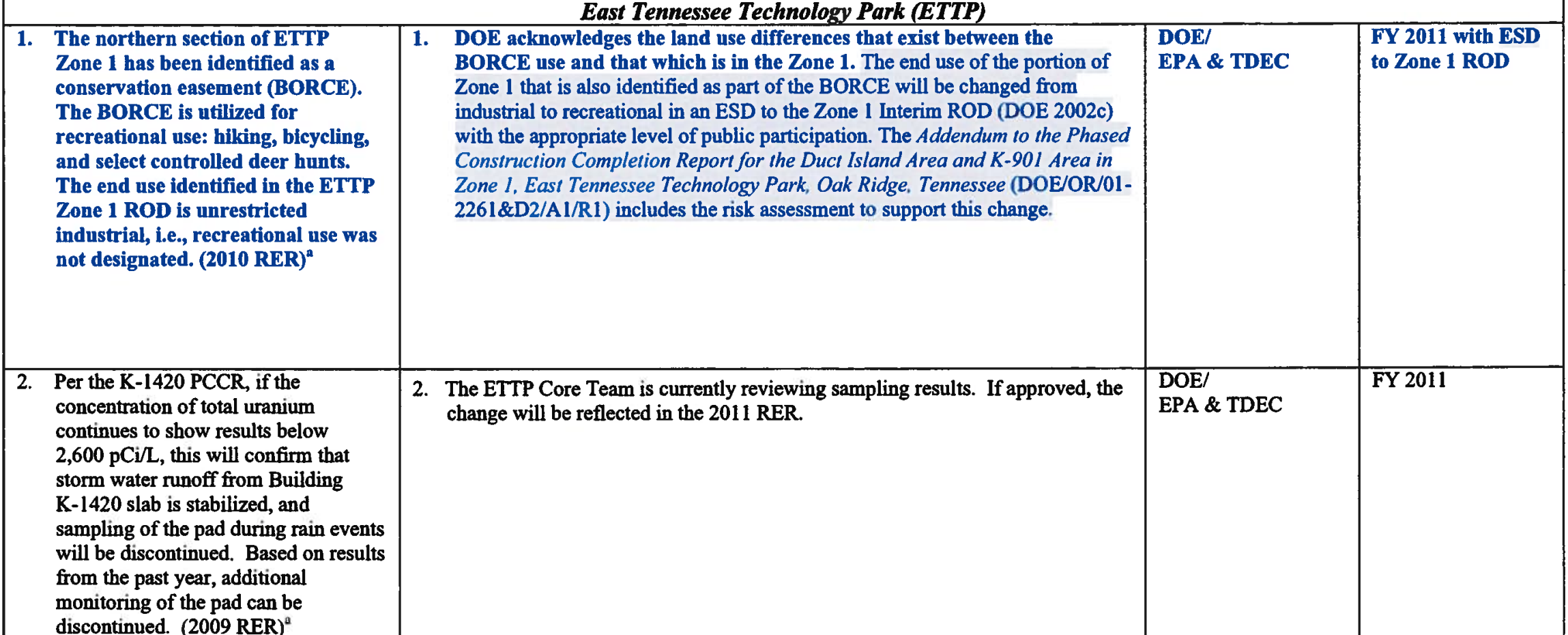

${ }^{\text {a }}$ The year of the RER or the FYR in which the issue originated is provided in parentheses, e.g., (2008 RER).

AWQC $=$ ambient water quality criteria

BCK = Bear Creek kilometer

BORCE = Black Oak Ridge Conversation Easement

BSWTS $=$ Big Spring Water Treatment System

EFPC $=$ East Fork Poplar Creek

EM - Environmental Management

EPA = Environmental Protection Agency

ESD $=$ Explanation of Significant Difference
NNSA = National Nuclear Security Administration

NT $=$ North Tributary

RMPE = Reduction of Mercury in Plant Effluents

SWSA $=$ Solid Waste Storage Area

TDEC $=$ Tennessee Department of Environment and Conservation 
Table 1.2. Summary of closed-out technical issues, recommendations, and follow-up actions

\begin{tabular}{|c|c|c|c|}
\hline \multirow{2}{*}{ Issue $^{\mathrm{a}}$} & \multirow{2}{*}{$\begin{array}{c}\text { Action/ } \\
\text { Recommendation }\end{array}$} & $\begin{array}{c}\text { Responsible } \\
\text { parties }\end{array}$ & \multirow{2}{*}{$\begin{array}{l}\text { Target } \\
\text { response } \\
\text { date }\end{array}$} \\
\hline & & Primary/Support & \\
\hline \multicolumn{4}{|c|}{ Bear Creek Valley } \\
\hline $\begin{array}{l}\text { 1. In addition to surface water } \\
\text { monitoring at the BYBY, the PCCR } \\
\text { (DOE 2003d) specifies five years of } \\
\text { (a) stream channel stability and } \\
\text { (b) riparian vegetation monitoring of } \\
\text { the restored NT-3 channel. (2008 } \\
\text { RER) }\end{array}$ & $\begin{array}{l}\text { 1. DOE completed the fifth year of (a) stream channel stability monitoring and } \\
\text { (b) vegetation riparian monitoring at BYBY during FY 2008. Results are } \\
\text { reported in the } 2009 \text { RER. DOE recommended that the annual stream channel } \\
\text { stability monitoring be discontinued and an erosion control inspection be } \\
\text { performed annually. Concurrence was received by the regulators. In addition, } \\
\text { DOE recommends that riparian monitoring, fish and macroinvertebrate } \\
\text { monitoring continue until the FYR. }\end{array}$ & $\begin{array}{l}\text { DOE/ } \\
\text { EPA \& TDEC }\end{array}$ & $\begin{array}{l}\text { FY } 2009 \\
\text { Completed }\end{array}$ \\
\hline $\begin{array}{l}\text { 2. Multiple large-scale construction } \\
\text { activities have occurred in the eastem } \\
\text { portion of the water shed (e.g., } \\
\text { EMWMF and the capping at BYBY). } \\
\text { This has resulted in large-scale } \\
\text { clearing of mature woodland-forested } \\
\text { areas, extensive cut-and-fill } \\
\text { construction, complete diversion of } \\
\text { NT-4, and regarding most of the NT-3 } \\
\text { drainage basin. This may have altered } \\
\text { runoff and infiltration patterns and } \\
\text { evapotranspiration rates. Additionally, } \\
\text { uranium flux attributable to NT-7 and } \\
\text { NT-8 has not been quantified since the } \\
\text { RU. (2006 FYR) } \\
\end{array}$ & $\begin{array}{l}\text { 2. Uranium flux mass balance in the Bear Creek watershed is complicated by the } \\
\text { karst groundwater system. Additionally, uranium flux monitoring during } \\
\text { FY } 2008 \text { quantified the western BCBG contribution to Bear Creek and was } \\
\text { demonstrated to be a large fraction of the total flux. }\end{array}$ & $\begin{array}{l}\text { DOE/ } \\
\text { EPA \& TDEC }\end{array}$ & $\begin{array}{l}\text { FY } 2009 \\
\text { Completed }\end{array}$ \\
\hline \multicolumn{4}{|c|}{ Melton Valley } \\
\hline $\begin{array}{l}\text { 1. The groundwater level fluctuation } \\
\text { metric for hydrologic isolation } \\
\text { effectiveness evaluation is applicable } \\
\text { only in cases where wells do not } \\
\text { extend into bedrock beneath buried } \\
\text { waste units. (2008 RER) }\end{array}$ & $\begin{array}{l}\text { 1. The groundwater level fluctuation metric for hydrologic isolation was discussed } \\
\text { in the MV Core Team Meeting on September } 18,2008 \text {. The ROD definition of } \\
\text { the metric (i.e., } 75 \% \text { reduction of water level fluctuation in the buried waste } \\
\text { elevation zone; see Table } 3.4 \text { of this RER) is only relevant when the water level } \\
\text { is fluctuating within the buried waste itself. It is not relevant when the water } \\
\text { level is well below the buried waste. A revised discussion and graphic were } \\
\text { presented in the } 2009 \text { RER (Sect. 3.2.2.2.2 and Figure 3.6). }\end{array}$ & $\begin{array}{l}\text { DOE/ } \\
\text { EPA \& TDEC }\end{array}$ & $\begin{array}{l}\text { FY } 2009 \\
\text { Completed }\end{array}$ \\
\hline
\end{tabular}


Table 1.2. Summary of closed-out technical issues, recommendations, and follow-up actions (cont.)

\begin{tabular}{|c|c|c|c|}
\hline \multirow{2}{*}{ Issue } & \multirow{2}{*}{$\begin{array}{c}\text { Action/ } \\
\text { Recommendation }\end{array}$} & $\begin{array}{c}\text { Responsible } \\
\text { parties }\end{array}$ & \multirow{2}{*}{$\begin{array}{c}\text { Target } \\
\text { response } \\
\text { date }\end{array}$} \\
\hline & & Primary/Support & \\
\hline \multicolumn{4}{|c|}{ Chestnut Ridge } \\
\hline $\begin{array}{l}\text { 1. Elevated } \mathrm{pH} \text {, gross beta activity, and } \\
\text { intermittent }{ }^{0} \mathrm{Sr} \text { concentrations } \\
\text { observed in downgradient monitoring } \\
\text { well GW-205 at the UNC site suggest } \\
\text { a potential contaminant release from } \\
\text { the site. (2007 RER) }\end{array}$ & $\begin{array}{l}\text { 1. The issue was discussed by the UEFPC Core Team in FY 2007. The UEFPC } \\
\text { Core Team agreed to continue monitoring in existing wells, but added a } \\
\text { downgradient spring to assess the potential impacts of UNC groundwater } \\
\text { seepage on surface water quality. Spring (UNC SW-1) was added to WRRP } \\
\text { FY } 2008 \text { SAP. Results are reported in the } 2009 \text { and } 2010 \text { RERs and are } \\
\text { consistent with other site monitoring data. Gross beta will continue to be } \\
\text { trended in future RERs. }\end{array}$ & $\begin{array}{l}\text { DOE/ } \\
\text { EPA \& TDEC }\end{array}$ & $\begin{array}{l}\text { FY } 2009 \\
\text { Completed }\end{array}$ \\
\hline
\end{tabular}

" The year of the RER or the FYR in which the issue originated is provided in parentheses, e.g., (2008 RER).

$B C B G=$ Bear Creek Burial Ground

BYBY $=$ Boneyard/Burnyard

EMWMF = Environmental Management Waste Management Facility

EPA = Environmental Protection Agency

NT $=$ North Tributary

TDEC = Tennessee Department of Environment and Conservation

UNC = United Nuclear Corporation 
Table 1.3. Summary of unresolved technical issues, recommendations, and follow-up actions from the FYR

\begin{tabular}{|c|c|c|c|c|c|c|c|}
\hline \multirow[b]{2}{*}{ Issue } & \multicolumn{2}{|c|}{$\begin{array}{c}\text { Affects } \\
\text { protectiveness } \\
\text { Y/N } \\
\end{array}$} & \multirow{2}{*}{$\begin{array}{l}\text { Recommendation/ } \\
\text { follow-up action }\end{array}$} & \multicolumn{2}{|c|}{$\begin{array}{c}\text { Responsible } \\
\text { parties }\end{array}$} & \multirow{2}{*}{$\begin{array}{c}\text { Target } \\
\text { response } \\
\text { date }\end{array}$} & \multirow{2}{*}{$\begin{array}{c}\text { December } \\
2009 \\
\text { status } \\
\end{array}$} \\
\hline & Current & Future & & Primary & Support & & \\
\hline \multicolumn{8}{|c|}{ Lower Watts Bar Reservoir (LWBR) } \\
\hline $\begin{array}{l}\text { 1. The RI/FS/ROD process evaluated } \\
\text { mercury fish ingestion risk using } \\
\text { the toxicity factor for mercuric } \\
\text { chloride. The current risk } \\
\text { assessment practice is to use the } \\
\text { toxicity factor for methyl mercury. } \\
\text { The cesium slope factor bas } \\
\text { changed since the time of the } \\
\text { RU/FS/ROD. }\end{array}$ & $\mathbf{N}$ & $\mathbf{N}$ & $\begin{array}{l}\text { 1. There is no required immediate action } \\
\text { since the State of Tennessee fish advisories } \\
\text { address fish ingestion. Exposure to cesium } \\
\text { is controlled by the WBIWG process. New } \\
\text { toxicity factors do not impact } \\
\text { protectiveness of the action. }\end{array}$ & $\overline{\mathrm{DOE}}$ & TDEC & Ongoing & To be evaluated in $2011 \mathrm{FYR}$. \\
\hline \multicolumn{8}{|c|}{ Clinch River/Poplar Creek (CR/PC) } \\
\hline $\begin{array}{l}\text { The RI/FS/ROD process evaluated } \\
\text { mercury fish ingestion risk using the } \\
\text { toxicity factor for mercuric chloride. } \\
\text { The current risk assessment practice } \\
\text { is to use the toxicity factor for } \\
\text { methyl mercury. The cesium slope } \\
\text { factor has changed since the time of } \\
\text { the RI/FS/ROD. }\end{array}$ & $\mathbf{N}$ & $\mathbf{N}$ & $\begin{array}{l}\text { 1. There is no required immediate action } \\
\text { since the State of Tennessee fish advisories } \\
\text { address fish ingestion. Exposure to cesium } \\
\text { is controlled by the WBIWG process. New } \\
\text { toxicity factors do not impact } \\
\text { protectiveness of the action. }\end{array}$ & DOE & TDEC & Ongoing & To be evaluated in 2011 FYR. \\
\hline \multicolumn{8}{|c|}{ Melton Valley (MV) } \\
\hline $\begin{array}{l}\text { 1. There has been a change in some } \\
\text { toxicity factors for radionuclides } \\
\text { since the Interim ROD was } \\
\text { approved. }\end{array}$ & $\mathbf{N}$ & $\bar{Y}$ & $\begin{array}{l}\text { T. Toxicity factors and final cleanup goals } \\
\text { will be evaluated as part of the } 2011 \text { FYR } \\
\text { and the Final ROD for MV. }\end{array}$ & $\overline{\mathrm{DOE}}$ & $\begin{array}{l}\text { EPA } \\
\text { TDEC }\end{array}$ & $\begin{array}{l}\text { MV Final } \\
\text { ROD, refer } \\
\text { to FFA } \\
\text { Appendix J } \\
\text { for current } \\
\text { testimated } \\
\text { date. } \\
\end{array}$ & $\begin{array}{l}\text { To be evaluated in the } 2011 \text { FYR. } \\
\text { The Final ROD schedule is in the } \\
\text { FFA Appendix C. }\end{array}$ \\
\hline \multicolumn{8}{|c|}{ Bethel Valley } \\
\hline $\begin{array}{l}\text { 1. The }{ }^{90} \text { Sr contamination from non- } \\
\text { point sources has become the } \\
\text { dominant contributor to }{ }^{90} \mathrm{Sr} \text { flux at } \\
\text { the } 7500 \text { Bridge location. SWSA } 3 \\
\text { may also be contributing to } \\
\text { increased flux seen at Raccoon } \\
\text { Creek. }\end{array}$ & $\mathbf{N}$ & $\mathbf{Y}$ & $\begin{array}{l}\text { 1. During FY } 2009 \text {, non-point }{ }^{90} \mathrm{Sr} \text { sources } \\
\text { comprised less than } 20 \% \text { of the } 0.33 \mathrm{Ci} \\
\text { measured at } 7500 \text { Bridge compared to the } \\
35 \% \text { comprised by Corehole } 8 \text { Plume } \\
\text { discharges to First Creek. Sampling will } \\
\text { occur during FY } 2010 \text { to determine if } \\
\text { excess ungauged }{ }^{90} \mathrm{Sr} \text { impacts BV ROD } \\
\text { goals. }\end{array}$ & $\overline{\mathrm{DOE}}$ & $\begin{array}{l}\text { EPA/ } \\
\text { TDEC }\end{array}$ & $\begin{array}{l}\text { BV ROD, } \\
\text { refer to } \\
\text { FFA } \\
\text { Appendices } \\
\text { E and J for } \\
\text { planned } \\
\text { implemen- } \\
\text { tation } \\
\text { schedules. }\end{array}$ & $\begin{array}{l}\text { Refer to FFA Appendices } \\
\text { schedules. }\end{array}$ \\
\hline
\end{tabular}


Table 1.3. Summary of unresolved technical issues, recommendations, and follow-up actions from the FYR (cont.)

\begin{tabular}{|c|c|c|c|c|c|c|c|}
\hline \multirow[b]{2}{*}{ Issue } & \multicolumn{2}{|c|}{$\begin{array}{l}\text { Affects } \\
\text { protectiveness } \\
\text { Y/N } \\
\end{array}$} & \multirow{2}{*}{$\begin{array}{c}\text { Recommendation/ } \\
\text { follow-up action }\end{array}$} & \multicolumn{2}{|c|}{$\begin{array}{c}\text { Responsible } \\
\text { parties }\end{array}$} & \multirow{2}{*}{$\begin{array}{c}\text { Target } \\
\text { response } \\
\text { date }\end{array}$} & \multirow{2}{*}{$\begin{array}{c}\text { December } \\
2009 \\
\text { status } \\
\end{array}$} \\
\hline & Current & Future & & Primary & Support & & \\
\hline \multicolumn{8}{|c|}{ Upper East Fork Poplar Creek } \\
\hline $\begin{array}{l}\text { 1. FY } 2005 \text { pre-action } \mathrm{Hg} \\
\text { concentrations at Station } 17 \text { are } \\
\text { above the } 200 \text {-ppt performance } \\
\text { goal. } \mathrm{Hg} \text { concentrations in fish in } \\
\text { UEFPC have yet to respond to } \\
\text { commensurate reductions of } \\
\text { mercury from historical RMPE } \\
\text { actions. Biota monitoring in } \\
\text { UEFPC shows continued diversity } \\
\text { and density of pollution-intolerant } \\
\text { species. }\end{array}$ & $\bar{Y}$ & $\bar{Y}$ & $\begin{array}{l}\text { 1. Remedial measures required by the } \\
\text { UEFPC Phase I ROD are expected to } \\
\text { reduce Hg concentrations at Station 17, as } \\
\text { well as in fish in UEFPC. These measures } \\
\text { include Hg source removal and surface } \\
\text { water treatment. The BSWTS was fully } \\
\text { operational during FY } 2009 \text { and a } \\
\text { corresponding decrease in } \mathrm{Hg} \text { flux was } \\
\text { observed at Station } 17 \text {. Also, FY } 2009 \mathrm{Hg} \\
\text { levels in LEFPC fish remain above federal } \\
\text { AWQC, but are less than peak levels } \\
\text { observed in } 2001-2002 \text {. It is anticipated } \\
\text { that implementation of the Hg-source } \\
\text { removal actions will result in a decrease in } \\
\text { flux at the IP. }\end{array}$ & DOE & $\begin{array}{c}\text { EPA/ } \\
\text { TDEC }\end{array}$ & $\begin{array}{c}\text { UEFPC } \\
\text { Phase I } \\
\text { ROD, refer } \\
\text { to FFA } \\
\text { Appendices } \\
\text { E and J for } \\
\text { planned } \\
\text { implemen- } \\
\text { tation } \\
\text { schedules. }\end{array}$ & $\begin{array}{l}\text { UEFPC Phase I ROD, refer to the } \\
\text { FFA Appendix E and Appendix J } \\
\text { for planned implementation } \\
\text { schedules. }\end{array}$ \\
\hline \multicolumn{8}{|c|}{ Bear Creek Valley } \\
\hline $\begin{array}{l}\text { 1. Flux results for BCK } 9.2 \text { show an } \\
\text { increase in the proportion of } \\
\text { ungauged uranium flux beginning in } \\
\text { FY } 2002 \text {. Increasing uranium trends } \\
\text { are not observed at gauged } \\
\text { monitoring stations, or in principal } \\
\text { groundwater exit points contributing } \\
\text { to Bear Creek surface flow. }\end{array}$ & $\overline{\mathbf{N}}$ & $\mathbf{N}$ & $\begin{array}{l}\text { 1. Uranium flux mass balance in the Bear } \\
\text { Creek watershed is complicated by the } \\
\text { karst groundwater system. During } \\
\text { FY } 2009 \text { approximately } 43 \mathrm{~kg} \text { of the total } \\
148 \mathrm{~kg} \text { were attributed to ungauged } \\
\text { sources. DOE recommends re-instatement } \\
\text { of flow-paced monitoring at NT-3 and } \\
\text { NT-5 and creation of an additional flux } \\
\text { monitoring station downstream of SS-4 but } \\
\text { upstream of NT-7 to attempt to determine } \\
\text { inputs directly to the stream channel from } \\
\text { karst discharges. }\end{array}$ & DOE & $\begin{array}{l}\text { EPA } \\
\text { TDEC }\end{array}$ & $\begin{array}{l}\text { BCV Phase } \\
\text { I \& II } \\
\text { RODs, } \\
\text { BCV } \\
\text { Ground- } \\
\text { water ROD; } \\
\text { refer to } \\
\text { FFA } \\
\text { Appendix E } \\
\text { and J for } \\
\text { planned } \\
\text { implemen- } \\
\text { tation } \\
\text { schedules. }\end{array}$ & $\begin{array}{l}\text { Identified as a BCV issue in } \\
\text { Table 1.1. Target response date } \\
\text { BCV Phase I and II RODs, BCV } \\
\text { Groundwater ROD; refer to FFA } \\
\text { Appendix E and J for planned } \\
\text { implementation schedule. }\end{array}$ \\
\hline
\end{tabular}

AWQC = ambient water quality criteria $\mathrm{BCK}=$ Bear Creek kilometer

BSWTS = Big Stream Treatment System

EPA = U.S. Environmental Protection Agency

FS = Feasibility Study
NT = North Tributary

RMPE = Reduction of Mercury in Plant Effluents

SWSA $=$ Solid Waste Storage Area

TDEC $=$ Tennessee Department of Environment and Conservation

WBIWG = Watts Bar Interagency Working Group 
Table 1.4. Summary of completed technical issues, recommendations, and follow-up actions from the FYR

\begin{tabular}{|c|c|c|c|c|c|c|c|}
\hline \multirow[b]{2}{*}{ Issue } & \multicolumn{2}{|c|}{$\begin{array}{c}\text { Affects } \\
\text { protectiveness } \\
\text { Y/N } \\
\end{array}$} & \multirow{2}{*}{$\begin{array}{l}\text { Recommendation/ } \\
\text { follow-up action }\end{array}$} & \multicolumn{2}{|c|}{$\begin{array}{c}\text { Responsible } \\
\text { parties }\end{array}$} & \multirow{2}{*}{$\begin{array}{c}\text { Target } \\
\text { response } \\
\text { date }\end{array}$} & \multirow{2}{*}{$\begin{array}{c}\text { December } \\
2009 \\
\text { status } \\
\end{array}$} \\
\hline & Current & Future & & Primary & Support & & \\
\hline \multicolumn{8}{|c|}{ Lower Watts Bar Reservoir (LWBR) } \\
\hline $\begin{array}{l}\text { 1. Some fish advisory signs are } \\
\text { damaged. }\end{array}$ & $\mathbf{N}$ & $\mathbf{N}$ & $\begin{array}{l}\text { I. In the August 20, 2008 FFA meeting it was } \\
\text { agreed that DOE will notify the State of } \\
\text { these conditions and that the State has an } \\
\text { active program to address these conditions. }\end{array}$ & TDEC & DOE & Ongoing & $\begin{array}{l}\text { Action completed. FFA Meeting } \\
\text { Minutes, August 20, } 2008 \text {. }\end{array}$ \\
\hline \multicolumn{8}{|c|}{ Clinch River/Poplar Creek (CR/PC) } \\
\hline $\begin{array}{l}\text { 1. Some fish advisory signs are } \\
\text { damaged. }\end{array}$ & $\mathbf{N}$ & $\mathbf{N}$ & $\begin{array}{l}\text { 1. In the August 20, 2008 FFA meeting, it } \\
\text { was agreed that DOE will notify the State } \\
\text { of these conditions and that the State has } \\
\text { an active program to address these } \\
\text { conditions. }\end{array}$ & $\overline{\mathrm{DOE}}$ & TDEC & Ongoing & $\begin{array}{l}\text { Action completed. FFA Meeting } \\
\text { Minutes, August 20, } 2008 \text {. }\end{array}$ \\
\hline \multicolumn{8}{|c|}{ Upper East Fork Poplar Creek } \\
\hline $\begin{array}{l}\text { 1. Pre-action data do not definitively } \\
\text { indicate whether there is a net gain } \\
\text { or loss of Hg mass between source } \\
\text { areas in the western portion of } \\
\text { Y-12 and OF-200A6. Substantial } \\
\text { fluctuations in Hg mass balance } \\
\text { (flux) have been observed the past } \\
\text { three years. }\end{array}$ & $\mathbf{N}$ & $\overline{\mathbf{N}}$ & $\begin{array}{l}\text { 1. The monitoring methods for mercury for } \\
\text { the Phase I ROD have been reviewed with } \\
\text { the UEFPC Core Team. A letter (per FFA } \\
\text { Appendix 1-12) was sent to EPA VTDEC } \\
\text { asking for approval of the modified } \\
\text { monitoring program in August 2006, and } \\
\text { approval was granted in October 2006 and } \\
\text { is being implemented. }\end{array}$ & $\mathrm{DOE}$ & $\begin{array}{l}\text { EPA/ } \\
\text { TDEC }\end{array}$ & $\begin{array}{l}\text { Letter per } \\
\text { FFA } \\
\text { Appendix } \\
\text { I-12, } \\
\text { October } \\
2006 .\end{array}$ & Completed. \\
\hline $\begin{array}{l}\text { 2. Access to OF-169 is no longer } \\
\text { available due to changes in the } \\
\text { Y-12 security boundary. } \\
\text { Alternative sampling locations } \\
\text { were evaluated, but a single } \\
\text { suitable alternate was not } \\
\text { identified. }\end{array}$ & $\mathbf{N}$ & $\mathrm{N}$ & $\begin{array}{l}\text { 2. The monitoring methods for mercury for } \\
\text { the Phase I ROD were reviewed with the } \\
\text { UEFPC Core Team and a letter (per FFA } \\
\text { Appendix I-12) was sent to EPA/TDEC in } \\
\text { August 2006 asking for approval to change } \\
\text { the four WEMA outfalls listed in the ROD } \\
\text { to OF-200A6. Regulator approval was } \\
\text { granted in October } 2006 \text { and is being } \\
\text { implemented. Upon completion of Phase I } \\
\text { actions, the feasibility of resuming } \\
\text { monitoring at OF-169, or locating a } \\
\text { suitable alternative station, should be } \\
\text { evaluated. }\end{array}$ & DOE & $\begin{array}{l}\text { EPA/ } \\
\text { TDEC }\end{array}$ & $\begin{array}{l}\text { Letter per } \\
\text { FFA } \\
\text { Appendix } \\
\text { I-12, } \\
\text { October } \\
2006 .\end{array}$ & Completed. \\
\hline
\end{tabular}


Table 1.4. Summary of completed technical issues, recommendations, and follow-up actions from the FYR (cont.)

\begin{tabular}{|c|c|c|c|c|c|c|c|}
\hline \multirow[b]{2}{*}{ Issue } & \multicolumn{2}{|c|}{$\begin{array}{l}\text { Affects } \\
\text { protectiveness } \\
\text { Y/N }\end{array}$} & \multirow{2}{*}{$\begin{array}{l}\text { Recommendation/ } \\
\text { follow-up action }\end{array}$} & \multicolumn{2}{|c|}{$\begin{array}{c}\text { Responsible } \\
\text { parties }\end{array}$} & \multirow{2}{*}{$\begin{array}{c}\text { Target } \\
\text { response } \\
\text { date }\end{array}$} & \multirow{2}{*}{$\begin{array}{l}\text { December } \\
2009 \\
\text { status }\end{array}$} \\
\hline & Current & Future & & Primary & Support & & \\
\hline \multicolumn{8}{|c|}{ Bear Creek Valley } \\
\hline $\begin{array}{l}\text { 1. Performance monitoring for the } \\
\text { BYBY action has shown that } \\
\text { annual uranium flux has remained } \\
\text { below the goal of } 4.3 \mathrm{~kg} / \text { year for } \\
\text { two consecutive years. }\end{array}$ & $\overline{\mathbf{N}}$ & $\mathbf{N}$ & $\begin{array}{l}\text { 1. This issue was discussed with EPA/TDEC } \\
\text { representatives in the fall of } 2006 \text {. A letter } \\
\text { (per FFA Appendix I-12) was sent to } \\
\text { EPA/TDEC asking for approval of } \\
\text { monitoring changes in December } 2006 \text {. } \\
\text { Approval granted in April } 2007 \text {. }\end{array}$ & $\overrightarrow{\mathrm{DOE}}$ & $\begin{array}{l}\text { EPA/ } \\
\text { TDEC }\end{array}$ & $\begin{array}{l}\text { Letter per } \\
\text { FFA } \\
\text { Appendix } \\
\text { I-12, } \\
\text { December } \\
2006 .\end{array}$ & Action completed. \\
\hline $\begin{array}{l}\text { 2. Multiple large-scale construction } \\
\text { activities bave occurred in the } \\
\text { eastern portion of the watershed } \\
\text { (e.g., EMWMF, capping actions at } \\
\text { BYBY, and SNS construction). } \\
\text { This has resulted in large-scale } \\
\text { clearing of mature woodland- } \\
\text { forested areas, extensive cut-and- } \\
\text { fill construction, complete } \\
\text { diversion of NT-4, and regrading } \\
\text { most of the NT-3 drainage basin. } \\
\text { This may have altered runoff and } \\
\text { infiltration patterns and } \\
\text { evapotranspiration rates. } \\
\text { Additionally, uranium flux } \\
\text { attributable to NT-7 and NT-8 has } \\
\text { not been quantified since the RI. }\end{array}$ & $\mathbf{N}$ & $\mathrm{Y}$ & $\begin{array}{l}\text { 2. See response to Issue 2. Similar response } \\
\text { and actions needed. }\end{array}$ & DOE & $\begin{array}{l}\text { EPA } \\
\text { TDEC }\end{array}$ & $\begin{array}{c}\text { Final BCV } \\
\text { Ground- } \\
\text { water ROD; } \\
\text { refer to } \\
\text { FFA } \\
\text { Appendices } \\
\text { E and J for } \\
\text { planned } \\
\text { implemen- } \\
\text { tation } \\
\text { schedule. }\end{array}$ & Closed out. \\
\hline
\end{tabular}

BYBY = Boneyard/Burnyard

EMWMF = Environmental Management Waste Management Facility

EPA $=$ U.S. Environmental Protection Agency

$\mathrm{NT}=$ North Tributary
SNS $=$ Spallation Neutron Source

TDEC = Tennessee Department of Environment and Conservation

WEMA $=$ West End Mercury Area 


\section{CERCLA ACTIONS IN BETHEL VALLEY WATERSHED}

\subsection{INTRODUCTION AND OVERVIEW}

The BV Watershed contains most of the ORNL active facilities and a considerable fraction of the CERCLA facilities and contaminated sites at ORNL. Figure 2.1 shows the location of key CERCLA sites and actions in the watershed. Single actions (i.e., major actions completed as stand-alone projects) in BV include remediation of dozens of liquid low-level waste (LLLW) tanks including steel and gunite tanks, remediation of the four former process wastewater ponds that constituted the Surface Impoundments Operable Unit (SIOU), installation and operation of the Corehole 8 plume containment system, and partial completion of contaminated soil excavation in the North Tank Farm (NTF) related to the Corehole 8 plume source near Tank W-1A. In 2002, the Record of Decision for Interim Actions at Bethel Valley, Oak Ridge, Tennessee (DOE 2002a) was signed. This ROD specifies RAs for CERCLA facilities and establishes protectiveness and cleanup levels for the watershed. RAs specified by the BV ROD have not yet been completed. However, in FY 2009, planning started to remediate tank W-1A, Solid Waste Storage Area (SWSA) 3, and decontamination and decommissioning (D\&D) approximately 180 facilities in BV (See Sect. 2.1.1).

This section provides an update to CERCLA activities in BV prior to and during FY 2009, includes discussion of the watershed RAO and performance metrics, and evaluates performance of stand-alone CERCLA actions for which monitoring and performance metrics were stipulated in decision documents. Table 2.1 summarizes the CERCLA actions completed in BV. Table 2.2 provides a summary of LTS requirements, and Figure 2.2 shows BV ROD-designated land use and interim controls.

For a complete discussion of background information and performance metrics for each remedy, a compendium is provided in Chap. 2 of Vol. 1 of the FY 2007 RER (DOE 2007a). This information will be updated in the annual RER and republished every fifth year at the time of the CERCLA FYR.

\subsubsection{Status and Updates}

The BV ROD defined RAs for soil and sediment and included three different tasks: (1) capping at two large waste sites, SWSA 1 and the SWSA 3 area; (2) soil removal actions that vary in size from limited extent to large areas; and (3) removal of stream sediments from seven stream-reach exposure units. The RAWP (DOE 2009a) was submitted to the regulators in FY 2008 and addresses soil and sediment RAs and characterization activities in BV, as set forth in the BV ROD. In addition to defining the scope of remediation work to be performed and describing the methods of accomplishment to be used to execute the work, the RAWP also addresses the ROD requirement to develop a statistically-based soil characterization strategy to acquire additional data to verify, following RAs, that the BV ROD RAO requirements are met. At the end of FY 2009, the D4 version of the RAWP was still pending approval.

In December 2007, an action specified in the BV ROD to reduce mercury-contaminated groundwater discharging to White Oak Creek (WOC) was partially completed by the UT-Battelle as a maintenance action. This action consisted of re-routing mercury-contaminated basement sump water at Bldg. 4501 to the treatment system at the Process Waste Treatment Complex (PWTC). An ion exchange treatment system to remove mercury from the contaminated wastewater prior to treatment at the PWTC installed in FY 2009 started operation in October 2009. The action is complete and documentation will be placed in the CERCLA Administrative Record (Post Decision File). Monitoring to measure the effectiveness of the Bldg. 4501 sump water re-route action is discussed in Sect. 2.2.2.1.2. 
This page is intentionally left blank. 


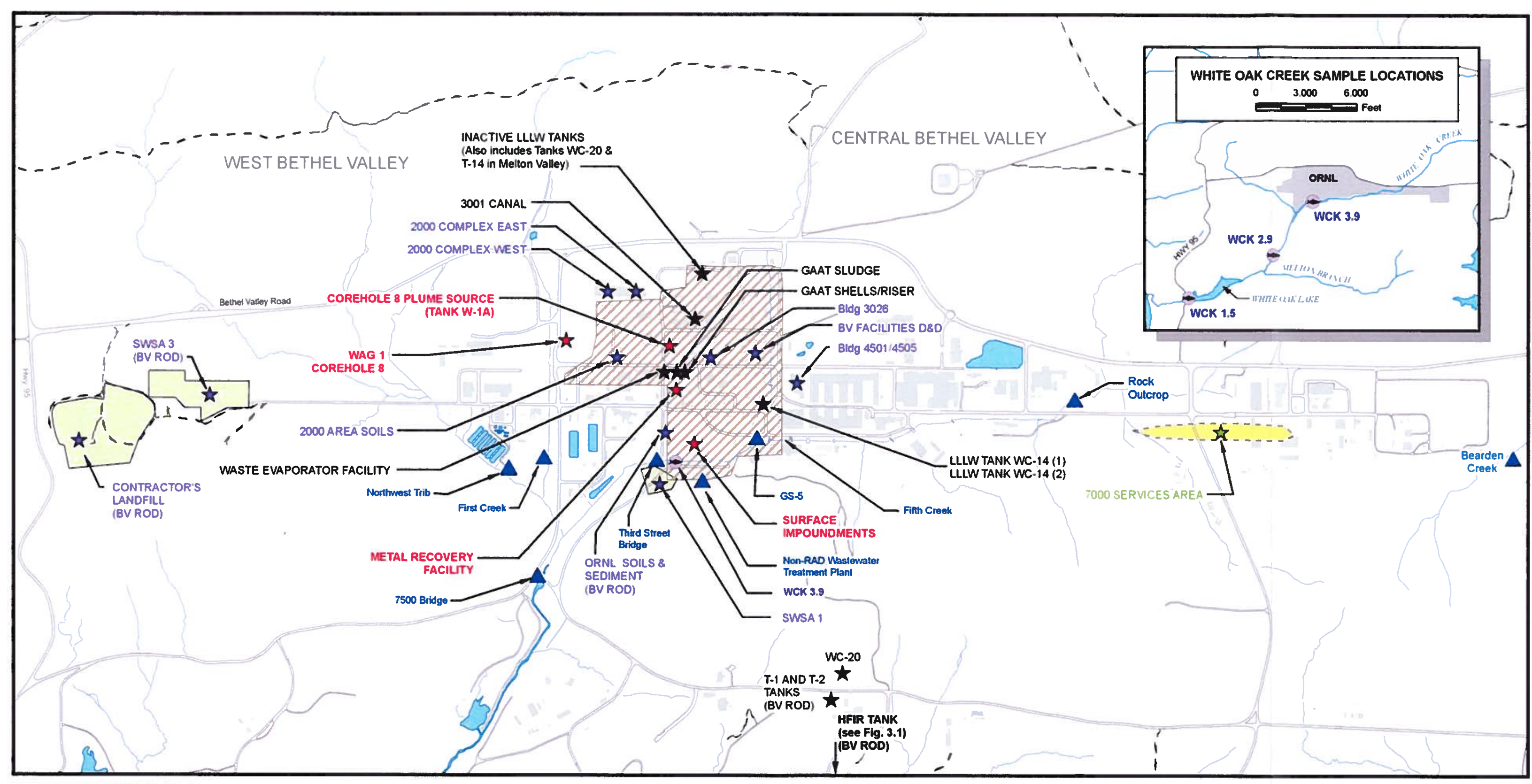

\# Completed Action. monitoring and/or LTS required
$\star$ Completed Action, no monitoring or LTS required

Figure 2.1. Bethel Valley Watershed site map. 
This page intentionally left blank. 
Table 2.1. CERCLA actions in BV

\begin{tabular}{|c|c|c|c|c|}
\hline CERCLA action & $\begin{array}{c}\text { Decision document, date signed } \\
(\mathrm{mm} / \mathrm{dd} / \mathrm{yy})\end{array}$ & Action/Document status ${ }^{a}$ & $\begin{array}{l}\text { Monitoring/ } \\
\text { LTS } \\
\text { required }\end{array}$ & $\begin{array}{c}\text { RER } \\
\text { section }\end{array}$ \\
\hline \multicolumn{5}{|c|}{ Watershed-scale actions } \\
\hline BV Interim Actions & $\begin{array}{l}\text { ROD (DOE/OR/01-1862\&D4): 05/2/02 } \\
\text { NSC (05/2/04) } \\
\text { NSC (12/3/04) } \\
\text { NSC (submitted 09/10/09) }\end{array}$ & $\begin{array}{l}\text { Actions complete. } \\
\text { - PCCR for the Tanks T-1, T-2, and HFIR (DOE/OR/01- } \\
\text { 2238\&D1) 11/16/05. } \\
\text { Actions in progress } \\
\text { - RDR/RAWP for ORNL soils and sediments (DOE/OR/01- } \\
\text { 2378\&D4) pending approval. }\end{array}$ & $\begin{array}{l}\text { Yes/Yes } \\
\text { No/Noc }\end{array}$ & $\begin{array}{c}2.2 \\
2.2 .4\end{array}$ \\
\hline \multicolumn{5}{|c|}{ Single-project actions } \\
\hline $\begin{array}{l}\text { WAG I Corehole } 8 \\
\text { Removal Action (Plume } \\
\text { Collection) }\end{array}$ & $\begin{array}{l}\text { AM (DOE/OR/02-1317\&D2): 11/10/94 } \\
\text { Addendum AM (Letter): 04/22/98 } \\
\text { Addendum AM (DOE/OR/01-1831\&D2): } \\
\text { 09/30/99 }\end{array}$ & $\begin{array}{l}\text { RmAR (DOE/OR/01-1380\&D1) approved 09/11/95. } \\
\text { - Phase I Operations Report (DOE/OR/01-1832\&D1) } \\
\text { - Phase II Operations Report (DOE/OR/01-1882\&D1) } \\
\text { approved 06/21/00. }\end{array}$ & Yes/No & 2.3 .1 \\
\hline $\begin{array}{l}\text { Bldg. } 3001 \text { Canal } \\
\text { Removal Action }\end{array}$ & $\mathrm{AM}$ (DOE/OR/02-1533\&D2): 11/18/96 & RmAR (DOE/OR/01-1599\&D2) approved 08/22/97. & $\mathrm{No} / \mathrm{No}^{\mathrm{d}}$ & - \\
\hline SIOU RA & ROD (DOE/OR/02-1630\&D2): 09/25/97 & $\begin{array}{l}\text { - RAR for Impoundments A (DOE/OR/01-2086\&D2) } \\
\text { approved 05/17/04. } \\
\text { - RAR for Impoundments C and D (DOE/OR/01-1784\&D2) } \\
\text { approved 04/19/99. }\end{array}$ & No/Yes & 2.3 .3 \\
\hline MRF RA & AM (DOE/OR/01-1843\&D2): 03/3/00 & $\begin{array}{l}\mathrm{RmAR}[(\mathrm{DOE} / \mathrm{OR} / 01-2000 \& \mathrm{D} 2 / \mathrm{R} 1) \text { approved with the } \\
\text { acceptance of the Completion Letter (waste disposition) } \\
06 / 18 / 08] \text {. }\end{array}$ & No/Yes & 2.3.4 \\
\hline $\begin{array}{l}\text { WAG } 1 \text { Tank WC-14 TC } \\
\text { RmA (1) Liquid removal }\end{array}$ & $\mathrm{AM}$ (DOE/OR/02-1322\&D2): 02/16/95 & RmAR (DOE/OR/01-1397\&D1) approved 08/21/95. & $\begin{array}{l}\text { Discontinued/ } \\
\text { No }\end{array}$ & -- \\
\hline $\begin{array}{l}\text { WAG } 1 \text { Tank WC-14 TC } \\
\text { RmA (2) Sludge removal }\end{array}$ & AM (DOE/OR/02-1598\&D2): 09/3/97 & RmAR (DOE/OR/01-1738\&D2) approved 12/15/98. & No/No & -- \\
\hline $\begin{array}{l}\text { Waste Evaporator } \\
\text { Facility Removal Action }\end{array}$ & AM (DOE/OR/02-1381\&D2): 07/28/95 & RmAR (DOE/OR/01-1460\&D1) approved 12/12/96. & No/No & - \\
\hline $\begin{array}{l}\text { GAAT OU Interim } \\
\text { Removal Action }\end{array}$ & ROD (DOE/OR/02-1591\&D3): 09/2/97 & RAR (DOE/OR-01-1955\&D1) approved 10/2/01. & No/No & - \\
\hline
\end{tabular}


Table 2.1. CERCLA actions in BV (cont.)

\begin{tabular}{|c|c|c|c|}
\hline CERCLA action & $\begin{array}{l}\text { Decision document, date signed } \\
(\mathrm{mm} / \mathrm{dd} / \mathbf{y y})\end{array}$ & $\begin{array}{c}\text { Monitoring/ } \\
\text { LTS } \\
\text { required } \\
\end{array}$ & $\begin{array}{c}\text { RER } \\
\text { section }\end{array}$ \\
\hline $\begin{array}{l}\text { Inactive LLLW Tanks } \\
\text { Removal Action }\end{array}$ & $\begin{array}{l}\text { AM (DOE/OR/01-1813\&D1): 05/26/99 } \\
\text { AM Addendum (DOE/OR/01-1833\&D2): } \\
\text { 09/30/99 }\end{array}$ & No/No & - \\
\hline $\begin{array}{l}\text { GAAT Stabilization } \\
\text { Removal Action } \\
\text { (Shells/Risers) }\end{array}$ & RmAR (DOE/OR/01-2010\&D1) approved 08/21/02. & No/No & -- \\
\hline \multicolumn{4}{|c|}{ Single-project action; pending additional action } \\
\hline $\begin{array}{l}\text { Corehole } 8 \text { Plume } \\
\text { Source (Tank W-1A) } \\
\text { Removal Action } \\
\end{array}$ & $\begin{array}{l}\text { AM (DOE/OR/01-1749\&D1): 09/18/98 RmAR (DOE/OR/01-1969\&D1) issued August 2001. } \\
\text { Amended in } 1999\end{array}$ & No/Yes & 2.3 .2 \\
\hline \multicolumn{4}{|c|}{ ORNL decontamination and demolition projects } \\
\hline $\begin{array}{l}\text { Non-Reactor Facilities } \\
\text { D\&D }\end{array}$ & $\begin{array}{l}\text { TC AM (DOE/OR/01-2412\&D1): 09/30/09 } \\
\text { TC AM (DOE/OR/01-2407\&D1): 04/09/09 }\end{array}$ & & \\
\hline $\begin{array}{l}\text { BV Isotopes Facilities } \\
\text { D\&D }\end{array}$ & $\begin{array}{l}\text { TC AM (DOE/OR/01-2402\&D1): 03/24/09 } \\
\text { TC AM (DOE/OR/01-2402\&D2) submitted } \\
\text { 03/30/09 }\end{array}$ & & \\
\hline
\end{tabular}
03/30/09

${ }^{a}$ Detailed information of the status of ongoing actions is from Appendix E of the FFA and is available at $<$ http://www.bechteljacobs.com/ettp-ffa-appendices.html>.

bIn December 2007, an action to reduce mercury-contaminated groundwater discharging to WOC from the basement sump at Bldg. 4501 was started by UT-Battelle as a maintenance action. When the action is completed, documentation will be placed in the CERCLA Administrative Record.

${ }^{c}$ The PCCR for the T-1 T-2 and HFIR Tank states that the above-ground areas of these sites are subject to routine maintenance and radiological surveys. However, this requirement was superseded by the MV RAR which omits any LTS requirements for these sites. The long-term stewardship of these sites is no longer reported in the RER. The T-1 and T-2 Tanks are located on the BV Watershed map (Figure 2.1) and HFIR Tank is located on the MV Watershed map (Figure 3.1).

The RmAR for the Bldg. 3001 Canal required monthly inspections of the grout and paint for one year only. The monthly checks were conducted through 2006 and are no longer reported in the RER.

${ }^{\mathrm{C}}$ In FY 2009, planning began for the removal of Tank W-1A and the excavation of remaining transuranic soils.
HFIR = High Flux Isotope Reactor
GAAT $=$ Gunite and Associated Tanks
NSC $=$ Non-Significant Change
TC RmA = time-critical removal action
WAG $=$ Waste Area Grouping
MRF $=$ Metal Recovery Facility
WAG $=$ Waste Area Grouping 
Table 2.2. LTS requirements for CERCLA actions in BV Watershed

\begin{tabular}{|c|c|c|c|c|}
\hline \multirow[b]{2}{*}{ Site/Project } & \multicolumn{2}{|c|}{ LTS requirements } & \multirow[b]{2}{*}{ Status } & \multirow[b]{2}{*}{ RER section } \\
\hline & LUCs & Engineering controls & & \\
\hline \multicolumn{5}{|c|}{ Watershed-scale actions } \\
\hline $\begin{array}{l}\text { ROD for Interim Actions in } \\
\mathrm{BV}^{\mathrm{a}}\end{array}$ & \begin{tabular}{|l} 
Watershed LUCs \\
Administrative: \\
- land use and \\
groundwater deed \\
restrictions \\
- property record \\
notices \\
- zoning notices \\
- permits program \\
Physical: \\
- access controls \\
- signs \\
- security patrols \\
\end{tabular} & - Maintain caps & $\begin{array}{l}\text { LUCs in place } \\
\text { Physical LUCs } \\
\text { in place. } \\
\text { - Administrative } \\
\text { LUCs required } \\
\text { at completion } \\
\text { of actions. } \\
\text { - Engineering } \\
\text { controls } \\
\text { remain } \\
\text { protective. }\end{array}$ & 2.2 .4 \\
\hline \multicolumn{5}{|c|}{ Completed single project actions } \\
\hline $\begin{array}{l}\text { WAG } 1 \text { Corehole } 8 \text { Removal } \\
\text { Action (Plume Collection) }{ }^{\mathrm{b}}\end{array}$ & None specified & & NA & 2.3 .1 \\
\hline SIOU RA & $\begin{array}{l}\text { Maintain existing } \\
\text { EPP program } \\
\end{array}$ & & - LUCs in place. & 2.3.3.1 \\
\hline MRF Removal Action & - Signs & - Maintain gravel cover & $\begin{array}{l}\text { LUCs in place. } \\
\text { Engineering } \\
\text { controls } \\
\text { remain } \\
\text { protective. }\end{array}$ & 2.3 .4 .1 \\
\hline \multicolumn{5}{|c|}{ Completed single project actions-pending additional action } \\
\hline $\begin{array}{l}\text { Corehole } 8 \text { Plume Source (Tank } \\
\text { W-1A) Removal Action }\end{array}$ & - Signs & - Maintain backfill & $\begin{array}{l}\text { LUCs in place. } \\
\text { - Engineering } \\
\text { controls } \\
\text { remain } \\
\text { protective. } \\
\end{array}$ & 2.3 .2 .1 \\
\hline
\end{tabular}

${ }^{a}$ Actions requiring LTS have not been implemented.

${ }^{b}$ Extraction system is maintained.

$\mathrm{MRF}=$ Metal Recovery Facility

NA $=$ not applicable

WAG $=$ Waste Area Grouping 
This page intentionally left blank. 


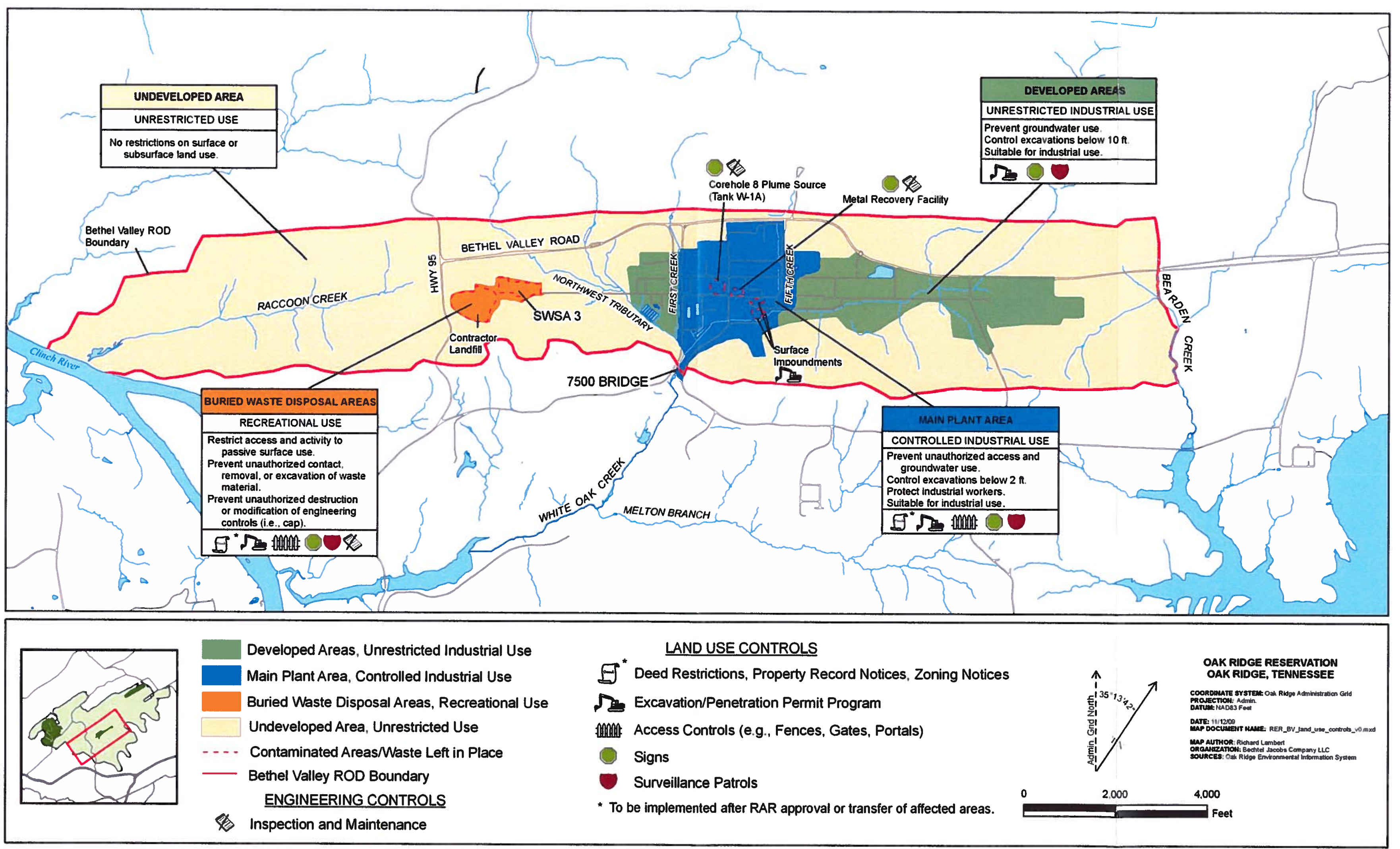

Figure 2.2. BV ROD-designated land use and interim controls. 
This page intentionally left blank. 
In FY 2009, planning began for the remediation of Tank W-1A. Remediation includes excavating, packaging, and transporting waste for disposal; removing, size-reducing, containerizing, and transporting the concrete pad and tank supports and tank shell to the Nevada Test Site; and performing soil sampling and characterization along a Tank W-1A feed pipeline to delineate the extent, type, and concentration of contamination for excavation. The engineering will take place in early FY 2010. The field work is expected to begin in early FY 2011 with project completion scheduled for the end of FY 2011.

In FY 2009, DOE prepared a Remedial Design Report (RDR)/RAWP that presents the design for hydrologic isolation of buried waste at the Bethel Valley Burial Grounds. The RDR/RAWP addresses remediation of two former waste sites that are sources of contaminant release: SWSA 1 in Central Bethel Valley and SWSA 3 in West Bethel Valley, as well as contaminated areas in the vicinity of SWSA 1 and SWSA 3. The Bethel Valley Burial Grounds remediation will hydologically isolate SWSAs 1 and 3 and remove and dispose of associated "hot spot" soil contamination. Resolution of regulator comments to finalize the RDR/RAWP is in progress. Project completion is planned for 2011.

In FY 2009, DOE prepared a RDR/RAWP for D\&D of non-reactor facilities and legacy material removal in the BV watershed (DOE 2009b). The RDR/RAWP addresses D\&D of approximately 180 facilities including near-term projects funded by the American Recovery and Reinvestment Act (ARRA) that are planned for completion in 2011, and other (non-ARRA funded) facility D\&D and legacy material removal scope planned for implementation over a $20+$ year period. Key work components described in the RDR/RAWP are site preparation, removal of legacy material, building D\&D to slab or grade level, waste management, site restoration, and demolition. At the end of FY 2009, regulator comments were being incorporated to finalize the RDR/RAWP. Remediation of building slabs and soils, D\&D of reactor facilities, and other RAs identified in the BV ROD will be addressed in separate CERCLA documents.

Demolition was initiated in FY 2009 on one of the highest hazard excess facilities at ORNL, the Facility 3026 C\&D Radioisotope Development Laboratory. A roof failure in 2007 damaged the fire suppression sprinkler system, requiring it to be deactivated. DOE determined that the resulting risks from this deactivation warranted implementing a Time-Critical AM (DOE 2009c) to remove the Facility 3026 C\&D wooden structure. The activities required to prepare for final demolition of the wooden superstructure were initiated and are now approximately $75 \%$ complete. At the end of FY 2009, final preparations were in progress to begin the shipment and disposal of asbestos-containing debris at the Environmental Management Waste Management Facility (EMWMF). The Time-Critical AM (DOE 2009c) for Facility 3026 C\&D Wooden Superstructure was approved in May 2009 and demolition is expected to be completed in early FY 2010. A follow on project is planned to be initiated later in FY 2010 to demolish the remaining Facility 3026 hot cell structures. Any required follow-on monitoring will be addressed in the RmAR.

Also in FY 2009, planning was under way for the demolition of the 2000 Complex at ORNL. The Time-Critical AM for the 2000 Complex Facilities Demolition (DOE 2009d) was submitted in September 2009. Demolition of the 2000 Complex East buildings and Complex West facilities are expected to be completed in the spring and late fall of 2010, respectively. Demolition of the 2000 Complex West facilities is expected to be completed in the late fall of 2010. Additionally, the Time-Critical AM for buildings 3074 \& 3136, and the 3020 Stack (DOE 2009e) was submitted in April 2009. This removal action includes the dismantlement of buildings 3074 and 3136 to allow for the dismantlement of the 3020 Stack. 


\subsection{RECORD OF DECISION FOR INTERIM ACTIONS FOR THE BETHEL VALLEY WATERSHED}

The ROD for Interim Actions in BV (DOE 2002a) was approved by the three FFA parties on May 2, 2002. Under this decision, a combination of RAs, including containment, stabilization, removal, treatment, monitoring, and LUCs, will be implemented to address inactive units, accessible sources of contamination, and contaminated media to the extent practicable. The scope includes contaminated buildings and other facilities designated for D\&D, buried waste, underground LLLW tanks, accessible underground process and LLLW transfer pipelines, accessible contaminated surface and subsurface soil, contaminated sediment and surface water, contaminated groundwater, and groundwater monitoring wells and piezometers no longer needed for monitoring. The scope does not include active facilities (e.g., Bldg. 4500N) and infrastructure at ORNL that have ongoing missions, nor does it include contaminated media or sources that are considered inaccessible due to the presence of the active facilities and infrastructure. Also, a final groundwater decision is not within the scope of the ROD. The participating federal and state agencies desire to complete source control actions, monitor their effectiveness, and collect limited additional characterization data. Figure 2.1 shows the BV area, locations of completed CERCLA actions, and elements of the BV remedy. Areas of groundwater contamination in the Central BV area are shown on Figure 2.3 and areas of contaminated groundwater in West BV and the Raccoon Creek headwaters are shown on Figure 2.4.

RAOs for the selected remedy are presented in Table 2.3. RAOs were developed separately for the Central and East BV and the West BV and Raccoon Creek areas. This was done because contamination in West BV/Raccoon Creek is limited to discrete areas (i.e., SWSA 3, the Contractor's Landfill, the Closed Scrap Metal Area, and a few small areas of potential surface soil contamination), while the Central/East BV area contains widespread contamination resulting from its use as a nuclear research laboratory. Thus, land use options that were considered in the feasibility study (FS) for the West BV/Raccoon Creek area were different from those considered for the Central/East BV area. Additional information concerning the RAOs for the ROD for Interim Actions in BV are included in Chap. 2 of Vol. 1 of the FY 2007 RER (DOE 2007a).

Table 2.3. RAOs for the selected remedy for BV

\begin{tabular}{ll}
\hline \multicolumn{1}{c}{ Issue } & \multicolumn{1}{c}{ Protection goals } \\
\hline Future land use & $\begin{array}{l}\text { Protect human health for: (1) controlled industrial use in ORNL's main plant } \\
\text { area, (2) unrestricted industrial use in the remainder of the ORNL developed } \\
\text { areas, (3) recreational use of SWSA } 3 \text { and the Contractor's Landfill, and }\end{array}$ \\
(4) unrestricted use in the undeveloped areas, all to a risk level of $1 \times 10^{-4}$ \\
Protection of surface water bodies & $\begin{array}{l}\text { Achieve AWQC for designated stream uses in all waters of the state } \\
\text { Achieve at least } 45 \% \text { risk reduction at the } 7500 \text { Bridge } \\
\text { Maintain surface water and achieve sediment recreational risk-based limits to a } \\
\text { goal of } 1 \times 10^{-4}\end{array}$ \\
Groundwater protection & $\begin{array}{l}\text { Minimize further impacts to groundwater } \\
\text { Prevent groundwater from causing surface water exceedances in all waters of } \\
\text { the state } \\
\text { Prointain protection for area populations of terrestrial organisms; protect } \\
\text { reach-level populations of aquatic organisms }\end{array}$ \\
\hline
\end{tabular}

$A W Q C=$ ambient water quality criteria 


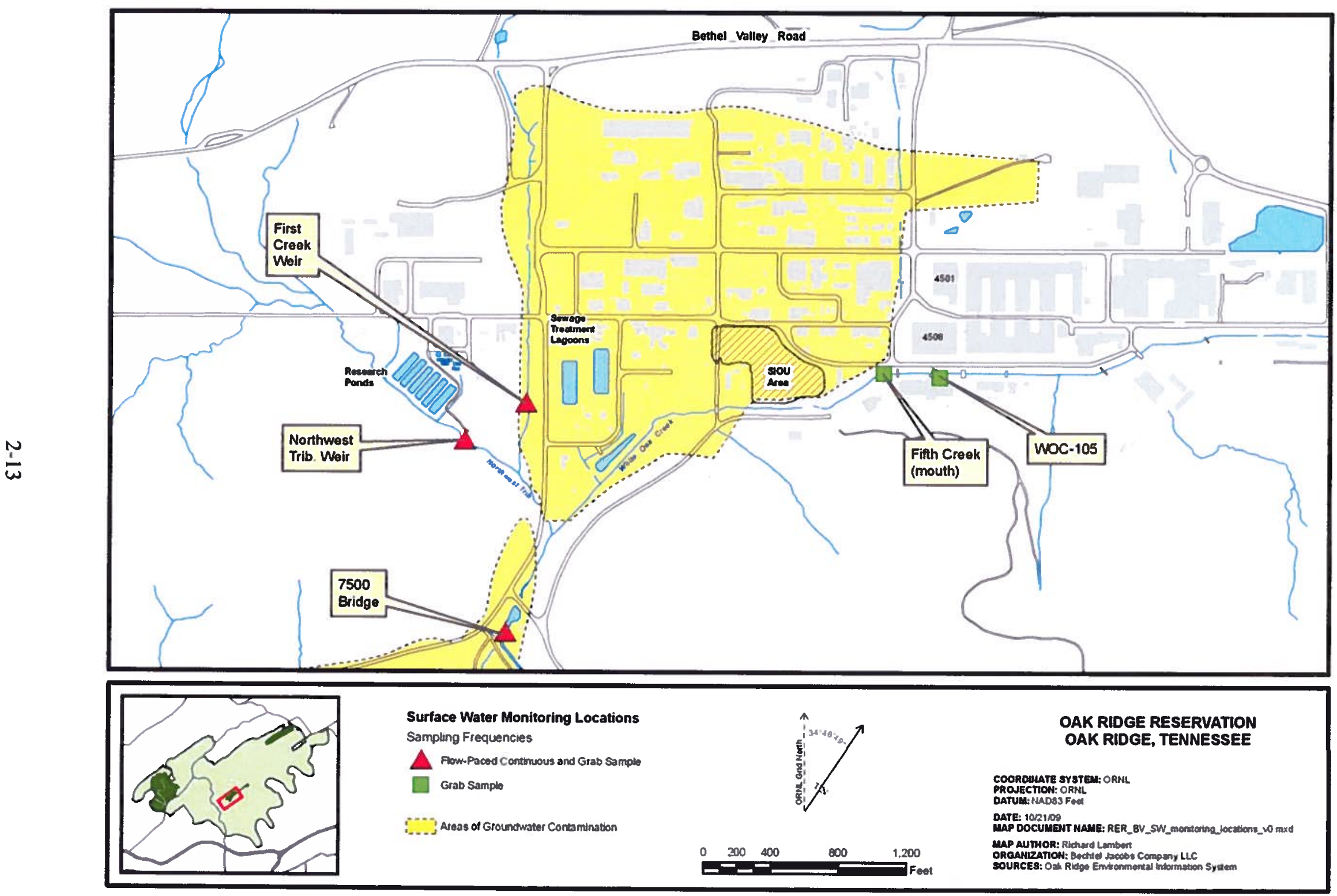

Figure 2.3. CERCLA surface water monitoring locations in ORNL main plant area. 


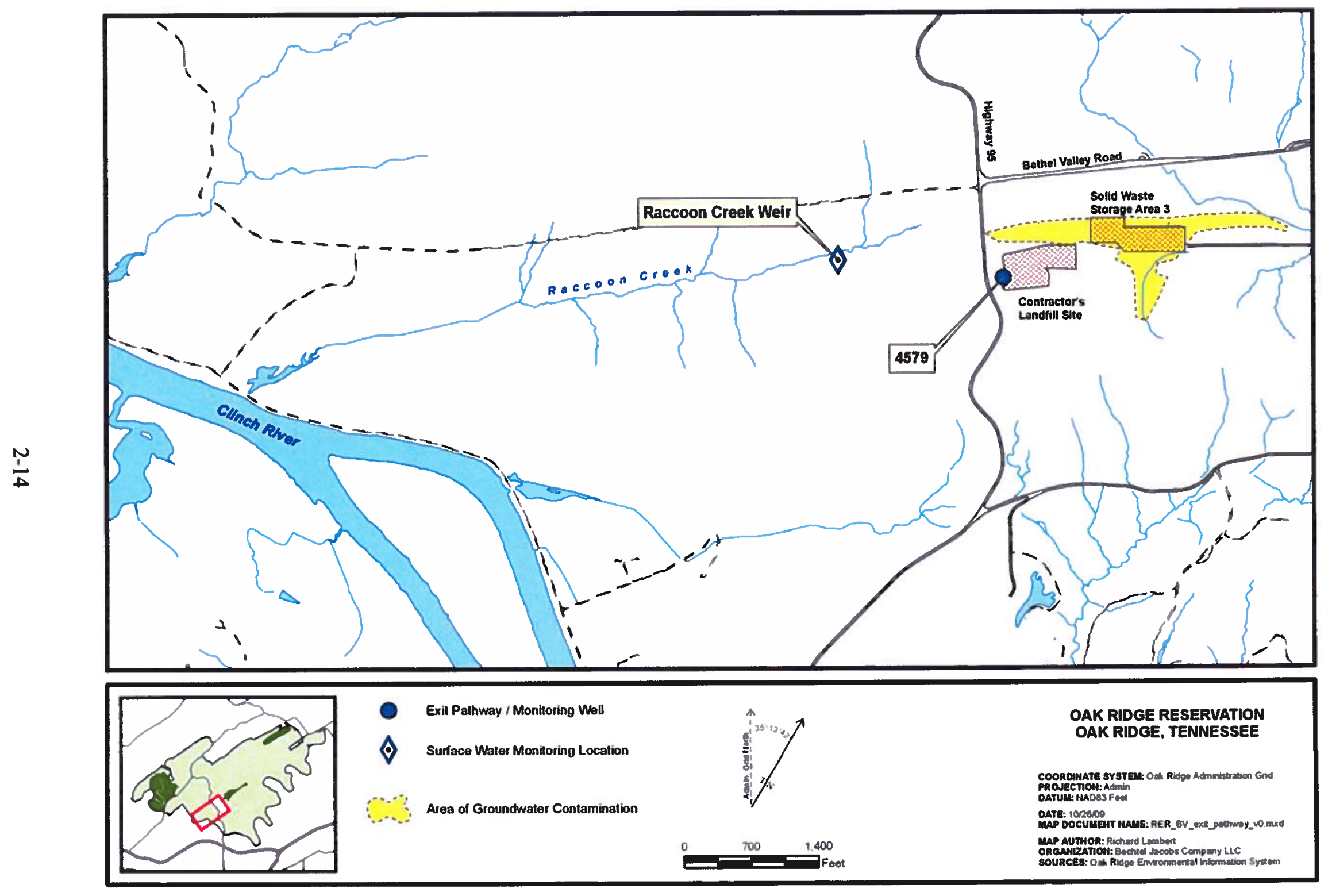

Figure 2.4. BV exit pathway monitoring locations. 


\subsubsection{Performance Goals and Monitoring Objectives}

RAOs for surface water include attainment of a 45\% risk reduction from baseline levels of 1994 at the 7500 Bridge and attainment of ambient water quality criteria (AWQC) for designated stream uses. Principal contaminants of concern (COCs) identified for risk reduction at the 7500 Bridge include ${ }^{90} \mathrm{Sr}$ and ${ }^{137} \mathrm{Cs}$. In addition, the ROD specifies the attainment and maintenance of water quality and sediment contaminant levels of $1 \times 10^{-4}$ for a hypothetical recreational use scenario. The RAO for groundwater is to prevent further degradation of water quality by remediation of soils that contribute to groundwater contamination above a $1 \times 10^{-4}$ risk level for a hypothetical industrial use scenario, to protect surface water by continued collection and treatment of groundwater that causes surface water exceedances, and to reduce surface water risk from contaminated groundwater discharge. The ROD also includes the requirements to monitor groundwater exit pathway wells and to monitor groundwater in the vicinity of contaminant source control areas to measure effectiveness of contaminant source control actions.

An investigation of subsurface soil and groundwater contamination was conducted in FY 2004-2005 [the $B V$ Groundwater Engineering Study (DOE 2005b)] that provided information concerning soil RA to protect groundwater consistent with the RAO and to further delineate groundwater contamination in portions of BV. The groundwater engineering study included installation of a multizone well located in western BV to sample groundwater between the SWSA 3 area and the headwaters of Raccoon Creek. Until major RAs are completed in BV, little change in surface water or groundwater contaminant conditions is expected to occur. Surface water, groundwater, and biological monitoring in BV continue to be conducted to document conditions and trends relevant to the BV RAOs.

\subsubsection{Evaluation of Performance Monitoring Data}

This section presents the results of environmental monitoring that is conducted to evaluate performance of CERCLA RAs, to evaluate long-term trends, to determine compliance with other regulations, or as a best management practice.

\subsubsection{Surface Water Monitoring Data}

\subsection{Surface Water Quality Metrics and Monitoring Requirements}

Table 2.4. summarizes monitoring requirements and performance standards that are used to measure progress toward meeting RAOs of the BV ROD.

\subsection{Surface Water Monitoring Results}

Surface water monitoring in BV includes both continuous, flow-paced monitoring at key locations and routine collection of grab samples. Figure 2.3 shows the locations of CERCLA surface water monitoring sites in Central BV. The Raccoon Creek monitoring location is shown in Figure 2.4.

\section{BUILDING 4501 MERCURY CONTAMINATED SUMP DISCHARGES}

In December 2007, the first RA specified in the BV ROD was partially completed as a maintenance action. Prior to the action, mercury-contaminated groundwater collected in building basement sumps at Bldg. 4501 was discharged to WOC via storm drain Outfall 211. The maintenance action consisted of rerouting of mercury-contaminated basement sump water at Bldg. 4501 to treatment at the PWTC. In October 2009, installation of a ion exchange system for the collected groundwater to remove particle- 
Table 2.4. CERCLA monitoring requirements and performance standards for BV Watershed ${ }^{\text {a,b }}$

\begin{tabular}{|c|c|c|c|c|}
\hline Media & $\begin{array}{c}\text { Monitoring } \\
\text { location }\end{array}$ & Schedule & Parameters & Performance standard \\
\hline \multirow[t]{13}{*}{ Surface water } & \multirow[t]{4}{*}{7500 Bridge weir } & $\begin{array}{l}\text { Continuous flow-proportional monthly } \\
\text { composite sample }\end{array}$ & ${ }^{90} \mathrm{Sr},{ }^{3} \mathrm{H}$, gamma ${ }^{\mathrm{c}}$ (flux) & \multirow{13}{*}{$\begin{array}{c}\text { Achieve } 45 \% \text { risk reduction from } \\
1994 \text { levels at } 7500 \text { Bridge (based } \\
\text { on combined risk from }{ }^{90} \mathrm{Sr} \text { and } \\
{ }_{137} \mathrm{Cs} \text { ); achieve AWQC for all } \\
\text { designated stream uses in all } \\
\text { waters of the state. }\end{array}$} \\
\hline & & Semiannual grab sample & $\begin{array}{l}\text { Metals (including } \mathrm{Hg} \text { ), gross alpha, } \\
\text { gross beta, gamma, }{ }^{90} \mathrm{Sr},{ }^{3} \mathrm{H}\end{array}$ & \\
\hline & & Annual grab sample (year prior to FYR) & AWQC & \\
\hline & & Monthly grab sample & $\mathrm{Hg}$ & \\
\hline & \multirow[t]{3}{*}{ First Creek weir } & $\begin{array}{l}\text { Continuous flow-proportional monthly } \\
\text { composite sample }\end{array}$ & gross alpha, gamma, ${ }^{90} \mathrm{Sr}$ (flux) & \\
\hline & & Semiannual grab sample & $\begin{array}{l}\text { gross alpha, gross beta, gamma, } \\
{ }^{90} \mathrm{Sr},{ }^{3} \mathrm{H}\end{array}$ & \\
\hline & & Annual grab sample (year prior to FYR) & AWQC & \\
\hline & \multirow[t]{3}{*}{ NWT weir } & $\begin{array}{l}\text { Continuous flow-proportional monthly } \\
\text { composite sample }\end{array}$ & gamma, ${ }^{90} \mathrm{Sr},{ }^{3} \mathrm{H}$ (flux) & \\
\hline & & Semiannual grab sample & $\begin{array}{l}\text { Metals, gross alpha, gross beta, } \\
\text { gamma }\end{array}$ & \\
\hline & & Annual grab sample (year prior to FYR) & AWQC & \\
\hline & \multirow[t]{3}{*}{$\begin{array}{l}\text { Raccoon Creek } \\
\text { weir }\end{array}$} & $\begin{array}{l}\text { Continuous flow-proportional monthly } \\
\text { composite sample }\end{array}$ & ${ }^{90} \mathrm{Sr},{ }^{3} \mathrm{H}$ (flux) & \\
\hline & & Semiannual grab sample & $\begin{array}{l}\text { Metals, gross alpha, gross beta, } \\
\text { gamma }\end{array}$ & \\
\hline & & Annual grab sample (year prior to FYR) & AWQC & \\
\hline Groundwater & $\begin{array}{l}4579-1,4579-2, \\
\text { and 4579-3 (west } \\
\text { BV/Raccoon } \\
\text { Creek area) }\end{array}$ & Semiannual ${ }^{d}$ grab samples & gross alpha, gross beta, ${ }^{90} \mathrm{Sr}$ & $\begin{array}{l}\text { Exit pathway monitoring to } \\
\text { determine if contaminants are } \\
\text { leaving known contaminated areas. }\end{array}$ \\
\hline
\end{tabular}

This table represents current requirements for monitoring included in the ROD for Interim Actions for the BV Watershed, post-decision primary documents, or any subsequent addenda that have received concurrence/approval from the U.S. Environmental Protection Agency and Tennessee Department of Environment and Conservation.

To date, actions implemented as part of the BV Interim Actions ROD include re-routing of collected mercury-contaminated groundwater from Bldg. 4501 basement sumps, tank/sludge stabilization (T-1, T-2, and High Flux Isotope Reactor tanks), and the BV Groundwater Engineering Study. Additional monitoring requirements will be developed and approved during the remedial design process.

${ }^{1} \mathrm{Gamma}$ scan provides ${ }^{137} \mathrm{Cs},{ }^{60} \mathrm{Co}$, and ${ }^{40} \mathrm{~K}$ activity.

SPer the BV Groundwater Engineering Study Report, semiannual grab samples in each monitoring zone were recommended for two years (starting in FY 2006), which provided a total of six baseline values. If analytical results are consistent, monitoring will be reduced to high-and low-base sampling every three years. If those results are consistent for a period of nine years (through FY 2016), monitoring will be reduced to high- and low-base sampling every five years. Monitoring at this frequency will continue until a statistically valid decreasing concentration trend is clearly demonstrated. Note monitoring has not been reduced due to presence of contamination. 
associated mercury and dissolved mercury from the wastewater stream prior to its treatment at the PWTC was completed. This system installation includes a pre-filter and ion exchange and is located in the basement of Bldg. 4501. It serves to pre-treat the sump water which is then routed to the PWTC for final treatment and discharge.

Mercury monitoring is conducted at several surface water sampling locations in BV and two locations are key to measuring the effectiveness of the Bldg. 4501 sump water re-route. These locations include the watershed IP surface water sampling location at the 7500 Bridge and an instream sampling location (WOC-105) that is located downstream of the Outfall 211 storm drain (Figure 2.3). Figure 2.5 shows the mercury concentration history for these two locations. As shown on Figure 2.5, there has been only one measured exceedance of the Tennessee Department of Environment and Conservation (TDEC) AWQC for total $\mathrm{Hg}$ at 7500 Bridge and none at WOC-105 since the contaminated sump water was routed to the PWTC.

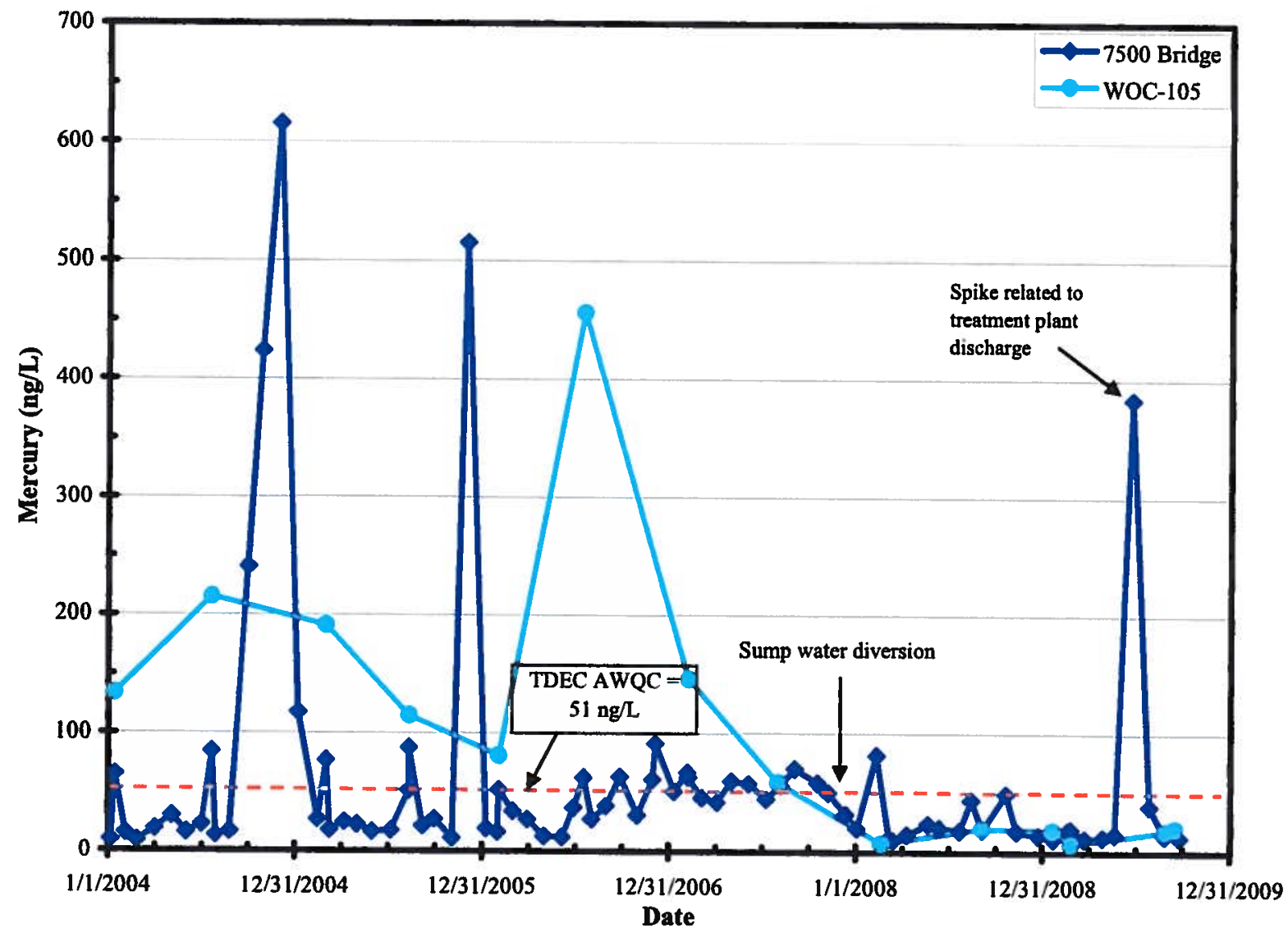

Figure 2.5. Mercury concentration history at 7500 Bridge and WOC-105 monitoring locations.

During FY 2009, the mercury concentrations at WOC-105 and 7500 Bridge were normally below the TDEC AWQC value (single) except on one sampling occasion at 7500 Bridge in June 2009. On that date, a high mercury concentration $(383 \mathrm{ng} / \mathrm{L})$ was detected. Upon receipt of this result, the ORNL Environmental Compliance organization was consulted regarding possible information that would help identify the source of the mercury. Plant effluent monitoring data from the same week had detected an elevated mercury concentration in the treatment plant effluent. Follow-up investigation within the treatment complex did not reveal the source or cause of the discharge. 
Statistical comparison of mercury concentration in surface water at 7500 Bridge confirms that the postdiversion stream concentrations are significantly lower than the pre-diversion concentrations. The high mercury concentration detected in June was excluded from the statistical comparison since it originated from a known discharge point not co-located with the 4501 source. An equivalent number of sequential samples collected before and after the diversion of 4501 basement sump water were included in the analysis. Both the Student's $t$ test and the Wilcoxon-Mann-Whitney methods confirmed that the reduction is statistically significant.

\section{RADIOLOGICAL DISCHARGES}

Historic and ongoing discharges of ${ }^{90} \mathrm{Sr}$ and ${ }^{137} \mathrm{Cs}$ in surface water in the central part of BV are principal COCs that directly impact the condition of the watershed and are performance metrics for the BV ROD. Tritium discharges in surface water in BV originate primarily from sources outside the BV CERCLA area of contamination (AOC) - from groundwater collected in MV and transferred to the PWTC via the groundwater collection and treatment system, and wastewaters generated by Office of Science facilities [High Flux Isotope Reactor (HFIR) and Spallation Neutron Source (SNS)] that are discharged via the PWTC and sanitary sewage systems.

Figure 2.3 shows locations in the ORNL main plant area in BV where contaminant concentrations and flows are measured to estimate the discharge fluxes from various contributing areas or outfalls. Strontium-90 is the principal radiological COC in surface water in BV because it is a fairly widely distributed contaminant in buried waste, in contaminated soils related to LLLW pipeline leaks, and in groundwater. Cesium-137 is a significant surface water contaminant in WOC and its sources include discharges from the PWTC effluent and contaminated soils on the WOC floodplain from the former SIOU area downstream to 7500 Bridge Weir.

While ROD actions that will directly address several known source areas of ${ }^{90} \mathrm{Sr}$ and ${ }^{137} \mathrm{Cs}$ have not yet been completed, ongoing measurement of these contaminants is conducted to track baseline discharge conditions. As summarized in Sect. 2.2, surface water goals include $45 \%$ reduction of risk levels associated with COCs at the 7500 Bridge monitoring station compared to FY 1994 levels.

Table 2.5 includes the average annual ${ }^{90} \mathrm{Sr}$ and ${ }^{137} \mathrm{Cs}$ concentrations calculated from the flow-paced composite samples collected at the 7500 Bridge for FY 1994 and FY 2001 through FY 2009. Also included are the concentration goals for ${ }^{90} \mathrm{Sr}$ and ${ }^{137} \mathrm{Cs}$ based on the $45 \%$ risk-reduction requirement. As shown in Table 2.5, ${ }^{90} \mathrm{Sr}$ concentrations exceeded the risk-based goal in 1994, 2004, 2005, and 2009, while ${ }^{137} \mathrm{Cs}$ concentrations exceeded the goal in each year except 2006 through 2009 . The elevated ${ }^{90} \mathrm{Sr}$ concentrations of 2004 and 2005 have been noted in previous RERs and were the consequence of prolonged above normal rainfall patterns. Higher than average rainfall during 2009 compounded with problems associated with the Corehole 8 system (Sect. 2.3.1) are responsible for the increase in ${ }^{90} \mathrm{Sr}$ during 2009. Figure 2.6 shows the annual average concentrations and the average plus one standard deviation concentration of ${ }^{137} \mathrm{Cs}$, ${ }^{90} \mathrm{Sr}$, and tritium at the 7500 Bridge. The risk-based goals calculated based on the $45 \%$ reduction of ${ }^{137} \mathrm{Cs}$ and ${ }^{90} \mathrm{Sr}$ stipulated in the ROD are also shown. 
Table 2.5. 7500 Bridge risk-reduction goal evaluation

\begin{tabular}{|c|c|c|}
\hline Year & $\begin{array}{c}\text { Average }{ }^{90} \mathrm{Sr} \\
(\text { Goal }=37 \mathrm{pCi} / \mathrm{L})^{\mathrm{b}}\end{array}$ & $\begin{array}{c}\text { Average }{ }^{137} \mathrm{Cs} \\
(\text { Goal }=33 \mathrm{pCi} / \mathrm{L})^{b}\end{array}$ \\
\hline $1994^{\mathrm{a}}$ & 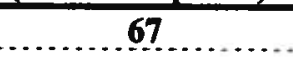 & 59 \\
\hline 2001 & 37 & 219 \\
\hline 2002 & 37 & 116 \\
\hline 2003 & 37 & 41 \\
\hline 2004 & 78 & 47 \\
\hline 2005 & 70 & 78 \\
\hline 2006 & 35 & 33 \\
\hline 2007 & 27 & 17 \\
\hline 2008 & 27 & $<6$ \\
\hline 2009 & 40 & 12 \\
\hline
\end{tabular}

Bold values indicate years during which annual average concentration exceeded the ROD risk goal.

"BV ROD baseline year.

${ }^{b} \mathrm{Goal}=45 \%$ reduction in average concentrations measured during baseline year.

Tritium concentrations in surface water in the BV portion of WOC have increased as a result of collection and transfer of former groundwater discharges from MV to the wastewater treatment system in BV. This activity is conducted as a condition of the MV RA. However, tritium concentrations in surface water throughout WOC are still below the DOE derived concentration guide and below remedy human health risk goals.

\section{WESTERN EXIT PATHWAY}

Surface water monitoring is conducted at the western end of BV to determine if contaminants discharge to Raccoon Creek and the Clinch River via a western exit pathway. Figure 2.4 shows locations where BV exit pathway sampling is conducted. Contaminated groundwater originates from SWSA 3 seeps to the headwaters of Raccoon Creek, a short distance to the west of Tennessee Highway 95. Planning for the remediation of SWSA 3 was started in FY 2009. This seepage pathway was discovered in the early 1980s and monitoring has been conducted at the Raccoon Creek Weir intermittently since the 1990s. The principal contaminant detected in the Raccoon Creek headwaters is ${ }^{90} \mathrm{Sr}$. The annual flux of ${ }^{90} \mathrm{Sr}$ discharging via Raccoon Creek has been measured since 1999 with the exception of FY 2005, 2006, and part of 2007 when problems with flow measurements at the site prevented the ability to estimate flux.

Table 2.6 summarizes average ${ }^{90} \mathrm{Sr}$ concentration data from continuous flow samples collected at the Raccoon Creek Weir and estimated flux for periods when reliable station flow data were available. The ${ }^{90} \mathrm{Sr}$ concentrations at the weir have historically fluctuated inversely to the amount of flow at the station because the seepage pathway from the source is in bedrock and groundwater seepage constitutes a higher proportion of baseflow during dry seasons than it does during wet seasons. During above-normal rainfall periods, such as those experienced in 2003 and 2004, the flux of ${ }^{90} \mathrm{Sr}$ discharged via Raccoon Creek increases. Historically, during 1998, the highest ${ }^{90} \mathrm{Sr}$ concentrations measured at Raccoon Creek were nearly $100 \mathrm{pCi} / \mathrm{L}$. 

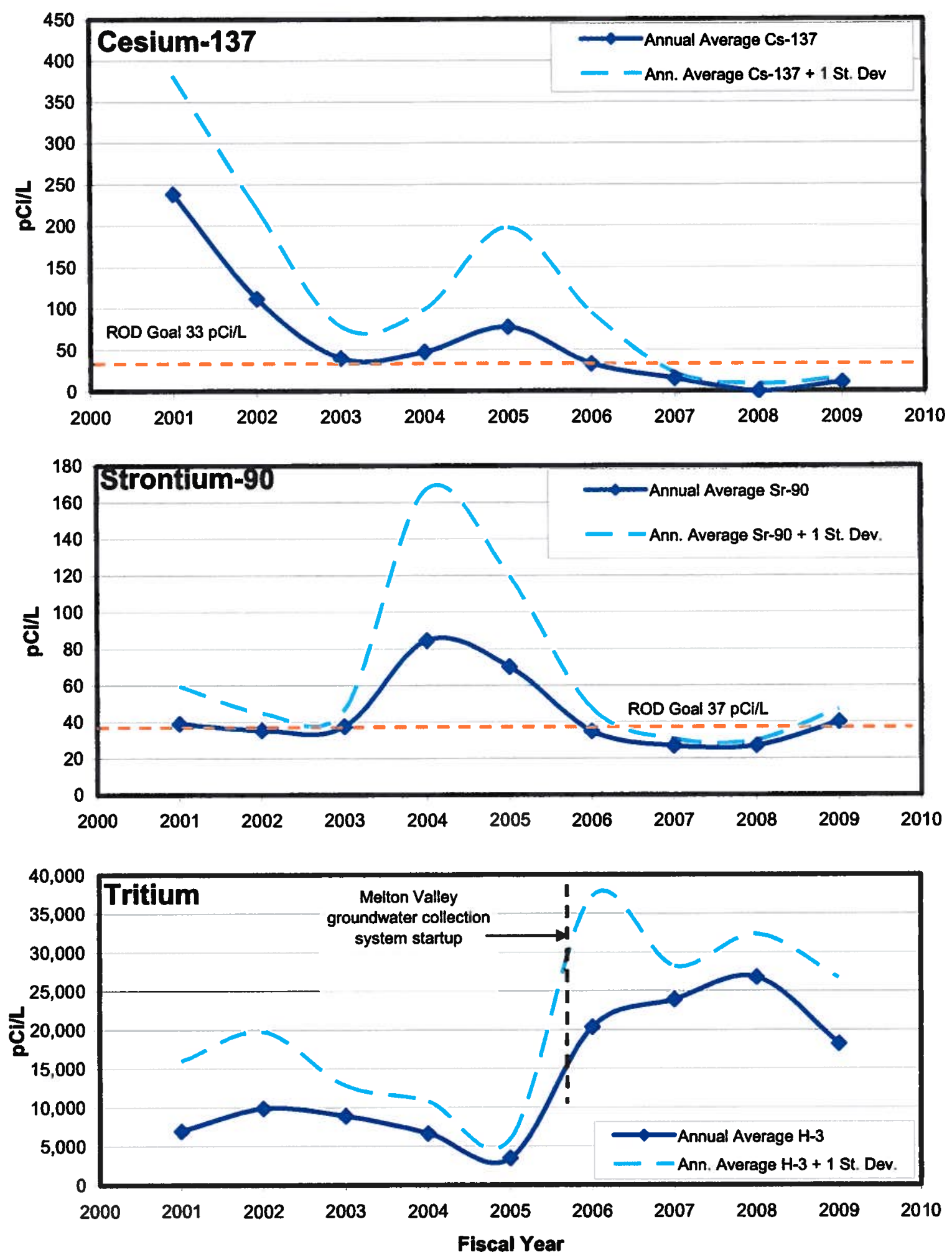

Figure 2.6. Annual average concentrations of ${ }^{137} \mathrm{Cs}$, ${ }^{90} \mathrm{Sr}$, and tritium at 7500 Bridge. 
Table 2.6. ${ }^{90} \mathrm{Sr}$ data from Raccoon Creek Weir

\begin{tabular}{lccc}
\hline \multirow{2}{*}{ Year } & Flow volume & \multicolumn{2}{c}{${ }^{90}$ Sr } \\
\cline { 4 - 5 } & $(\mathbf{L})$ & $\begin{array}{c}\text { Result } \\
\text { (pCi/L) }\end{array}$ & $\begin{array}{c}\text { Flux } \\
(\mathbf{C i})\end{array}$ \\
\hline FY 1999 Total & $244,698,985$ & & $4.40 \mathrm{E}-04^{\mathrm{a}}$ \\
\hline FY 2001 (11 months) & $315,555,053$ & $6.7^{\mathrm{b}}$ & $6.10 \mathrm{E}-04$ \\
FY 2002 Total & $318,825,472$ & $8.7^{\mathrm{b}}$ & $9.35 \mathrm{E}-04$ \\
FY 2003 Total & $380,747,035$ & $5.9^{\mathrm{b}}$ & $1.07 \mathrm{E}-03$ \\
FY 2004 Total & $254,073,296$ & $9.6^{\mathrm{b}}$ & $1.68 \mathrm{E}-03$ \\
FY 2005 & $\mathrm{NA}^{\mathrm{c}}$ & $16.8^{\mathrm{b}}$ & -- \\
FY 2006 & $\mathrm{NA}^{\mathrm{c}}$ & $29.3^{\mathrm{b}}$ & -- \\
FY 2007 (Feb. - Jul.) & $86,992,200^{\mathrm{d}}$ & $14.5^{\mathrm{d}}$ & $3.9 \mathrm{E}-04^{\mathrm{d}}$ \\
FY 2008 & $117,209,419$ & 15.5 & $6.4 \mathrm{E}-04$ \\
FY 2009 & $235,559,024$ & 7.6 & $6.2 \mathrm{E}-04$ \\
\hline
\end{tabular}

${ }^{2}$ Flux for FY 1999 was reported at $0.37 \mathrm{mCi}$ in the 2000 Remediation Effectiveness Report (DOE 2000e). The flux was subsequently recalculated to include "nondetected" concentrations omitted from the original calculation.

${ }^{b}$ Concentration value represents average concentration for all monthly flow composite samples at the station.

${ }^{\text {c } T h e ~ F Y ~} 2005$ and 2006 flow and flux data are not reported as the data have been deemed unusable due to problems associated with the weir.

dStation was returned to full operation at end of January 2007. Reported flows and fluxes are calculated for the months when flow was present after station maintenance.

NA $=$ not applicable

\subsubsection{Groundwater Monitoring Data}

Groundwater monitoring is conducted at the western end of BV to determine if contaminants discharge to Raccoon Creek and the Clinch River via a western exit pathway. Figure 2.4 shows locations where BV exit pathway sampling is conducted. During the BV Groundwater Engineering Study in 2005, a multizone monitoring well (well 4579) was constructed near Highway 95 to determine if contaminated groundwater from SWSA 3 seeps downward and may flow to the Clinch River beneath the known seep that discharges to Raccoon Creek.

\subsection{Groundwater Quality Metrics and Monitoring Requirements}

Based upon the RAO of unrestricted land use in the area surrounding SWSA 3 and the closed Contractors Landfill and in the Raccoon Creek area (Figure 2.2), drinking water maximum contaminant levels (MCLs) are considered appropriate criteria for screening of groundwater monitoring results.

\subsection{Groundwater Monitoring Results}

Well 4579 contains a Westbay ${ }^{\oplus u}$ multizone sampling system with three separate sampling zones at depths of nominally $152-172,80-90$, and $35-45 \mathrm{ft}$ below ground surface (bgs). Groundwater at well 4579 is analyzed for field parameters ( $\mathrm{pH}$, temperature, dissolved oxygen, conductivity, and redox potential), anions, metals, and radionuclides. Groundwater contaminants measured in the exit pathway groundwater that have exceeded a drinking water criterion include fluoride, $\mathrm{pH}$, and ${ }^{90} \mathrm{Sr}$, as shown in Table 2.7. Well 4579 was constructed in February 2005 and sampling was initiated in April of that year. The sampling

\footnotetext{
${ }^{6}$ Reference herein to any specific commercial product, process, or service by trade name, trademark, manufacturer, or otherwise, does not necessarily constitute or imply its endorsement, recommendation, or favoring by the United States Government or any agency thereof or its contractors or subcontractors.
} 
Table 2.7. Detected groundwater constituents in Well 4579 that have exceeded criteria

\begin{tabular}{|c|c|c|c|c|c|c|c|c|c|c|c|c|c|c|}
\hline $\begin{array}{c}\text { Sample } \\
\text { Zone* }\end{array}$ & Constituent & Units & Criterion & Apr-05 & May-05 & $\begin{array}{c}\mathrm{Jan} / \mathrm{Feb} \\
-06\end{array}$ & Jul-06 & Jan-07 & Mar-07 & Jul-07 & Jan-08 & Jul-08 & Jan-09 & Jul-09 \\
\hline $4579-01$ & Arsenic & $\mathrm{ug} / \mathrm{L}$ & 10 & 15.8 & 18.3 & - & - & - & - & - & 7.4 & 7.2 & $5 \mathrm{U}$ & $5 \mathrm{U}$ \\
\hline 4579-01 & Fluoride & $\mathrm{mg} / \mathrm{L}$ & $2^{a}-4^{b}$ & 6.2 & 8.1 & - & - & - & - & - & 8.2 & 12 & 10.1 & 2.05 \\
\hline $4579-01$ & $\mathrm{pH}^{\mathrm{a}}$ & units & $6.5-8.5$ & 10.54 & 10.39 & 10.16 & 10.13 & 9.9 & 9.72 & 9.83 & 10.2 & 9.84 & 8.98 & 9.21 \\
\hline $4579-01$ & ${ }^{90} \mathrm{Sr}$ & $\mathrm{pCi} / \mathrm{L}$ & $8^{c}$ & $<1.57$ & $<1.67$ & $<1.18$ & 1.96 & - & $<1.37$ & $<1.89$ & $<1.5$ & 2.53 & $2.05 \mathrm{U}$ & 49.9 \\
\hline 4579-02 & Fluoride & $\mathrm{mg} / \mathrm{L}$ & $2^{a}-4^{b}$ & 2.7 & 2.6 & - & - & - & - & - & $3.5 / 3$ & $\begin{array}{c}5.2 \prime \\
5.1\end{array}$ & 2.2 & 2.25 \\
\hline 4579-02 & $\mathrm{pH}^{\mathrm{a}}$ & Units & $6.5-8.5$ & 11.87 & 11.53 & 10.25 & 9.79 & 9.78 & - & 9.93 & 10.16 & 9.81 & 9.55 & 9.66 \\
\hline $4579-02^{d}$ & ${ }^{90} \mathrm{Sr}$ & $\mathrm{pCi} / \mathrm{L}$ & $8^{c}$ & $<1.02$ & $<1.79$ & $\begin{array}{c}1.07 \mathrm{~J} / \\
4.79\end{array}$ & $\begin{array}{c}2.08 \mathrm{~J} / \\
9.08\end{array}$ & $\begin{array}{c}13.9 / \\
76.9\end{array}$ & - & $\begin{array}{c}<2.04 / \\
<2.03\end{array}$ & $\begin{array}{l}<2.39 / \\
<2.46\end{array}$ & $\begin{array}{l}<1.63 / \\
<1.58\end{array}$ & $\begin{array}{c}1.59 \mathrm{U} / \\
2.15\end{array}$ & $\begin{array}{c}9.91 / \\
177\end{array}$ \\
\hline $4579-03$ & Fluoride & $\mathrm{mg} / \mathrm{L}$ & $2^{a}-4^{b}$ & 0.75 & 0.33 & - & - & - & - & - & 0.32 & 0.71 & 0.4 & 0.1 \\
\hline $4579-03$ & $\mathrm{pH}^{\mathrm{a}}$ & Units & $6.5-8.5$ & 7.4 & 7.63 & 8.06 & 7.66 & 7.8 & - & 8.41 & 7.73 & 8.08 & 7.12 & 6.96 \\
\hline $4579-03$ & ${ }^{90} \mathrm{Sr}$ & $\mathrm{pCi} / \mathrm{L}$ & $8^{c}$ & 1.37 & 2.47 & $0.9 \mathrm{~J}$ & 3.69 & 36.4 & & 2.55 & 2.36 & 3.71 & 4.23 & 6.25 \\
\hline
\end{tabular}

${ }^{a}$ Constituent or level is an EPA secondary drinking water criterion.

N Constituent or level is an EPA primary drinking water criterion.

${ }^{1} 8 \mathrm{pCi} / \mathrm{L}$ of ${ }^{90} \mathrm{Sr}$ is the activity level equivalent to an exposure of $4 \mathrm{mrem} / \mathrm{yr}$, which is the MCL for beta particle and photon activity for residential use of the water.

'Duplicate samples analyzed. Results of both samples separated by "\%."

Bold values indicate concentration exceeds criterion.

" - " = parameter not analyzed.

EPA = U.S. Environmental Protection Agency

$\mathrm{J}=$ estimated value

*4579-01 sample interval 152-172 $\mathrm{ft}$ bgs

4579-02 sample interval 80-90 ft bgs

4579-03 sample interval 35-45 ft bgs 
history shows that $\mathrm{pH}$ is consistently high in the deepest and intermediate zones but is near neutral in the shallowest zone. The elevated fluoride concentrations are associated with the elevated $\mathrm{pH}$ condition and are observed in the deep and intermediate zones. Initial samples collected during spring of 2005 from the deepest zone contained arsenic at concentrations above the MCL; however, levels in FY 2008 and 2009 were below the MCL. Strontium-90 has been detected in all three sampling zones and has been measured at levels greater than effective dose equivalent $(\mathrm{EDE})$ of $8 \mathrm{pCi} / \mathrm{L}$, the activity level equivalent to $4 \mathrm{mrem} / \mathrm{yr}$, the beta particle and photon radioactivity MCL for drinking water, on at least one occasion in all three zones. Higher than average rainfall during FY 2009 may be the cause of ${ }^{90} \mathrm{Sr}$ concentration spikes observed in the deep and intermediate zones.

Figure 2.7 provides the ${ }^{90} \mathrm{Sr}$ monitoring data from well 4579 through FY 2009. The highest concentrations measured to date were observed in the intermediate and deeper zones during the summer of 2009. Comparison of the FY 2009 groundwater ${ }^{90} \mathrm{Sr}$ concentrations in well 4579 to the $7.6 \mathrm{pCi} / \mathrm{L}$ average concentration measured at the Raccoon Creek Weir (Table 2.6) suggests that additional seepage pathways carry ${ }^{90} \mathrm{Sr}$ from SWSA 3 to the Raccoon Creek headwater. Monitoring of well 4579 will continue on a semiannual basis. Planning for the SWSA 3 RA was started in FY 2009.

\subsubsection{Other Watershed Monitoring}

\subsection{Aquatic Biological Monitoring in WOC}

Biomonitoring data are available for several locations in BV, including a location in WOC near the watershed's exit point. This information is useful in evaluating watershed trends and the effectiveness of watershed-scale decisions defined in the ROD for Interim Actions in BV (Figure 2.8). Biological monitoring data for the WOC watershed includes: (1) contaminant accumulation in fish; (2) fish community survey; and (3) benthic macroinvertebrate surveys. Fish bioaccumulation results from all of WOC, including stream sections downstream of the Melton Branch confluence, are presented in this chapter (Figure 2.9 and Figure 2.10).

In WOC, mercury and polychlorinated biphenyl (PCB) concentrations in fish are at or near human health risk thresholds. U.S. Environmental Protection Agency [EPA] fish-based AWQC for mercury is $0.3 \mu \mathrm{g} / \mathrm{g}$, and the TDEC issues fish advisories for mercury at that limit. PCB advisories are issued in the State of Tennessee when levels are in the $0.8-1.0 \mu \mathrm{g} / \mathrm{g}$ range. Mercury concentrations in fish collected in the WOC [White Oak Creek kilometer (WCK) 2.9, WCK 1.5] in 2009 remained within historical ranges (Figure 2.9), and have yet to respond to decreases in aqueous mercury concentrations as a result of the 4501 re-route. Mercury concentrations in redbreast sunfish at WCK 3.9 (a site collected for the first time in 2007) averaged $0.38 \mu \mathrm{g} / \mathrm{g}$.

Mean PCB concentrations in redbreast sunfish samples from the WOC watershed also remained within historical ranges (Figure 2.10). Redbreast samples from WCK 3.9 averaged $0.30 \pm 0.08 \mu \mathrm{g} / \mathrm{g}$, an apparent decrease at this site compared to 2008. Mean PCB values for redbreast at WCK 3.9 in 2009 were lower than the mean PCBs observed one kilometer downstream $(0.43 \mu \mathrm{g} / \mathrm{g})$ and at WCK $1.5(0.64 \mu \mathrm{g} / \mathrm{g})$ for bluegill. Largemouth bass PCB concentrations were about 5-fold higher than bluegill at WCK 1.5 , consistent with expectations of PCB accumulation in the larger and fattier species (Figure 2.10). The steady increase in White Oak Lake (WOL) fish PCB concentrations (i.e., at WCK 1.5) since 2003 may indicate changing prey patterns in the lake (e.g., a change to shad prey that are relatively high in PCBs). There is no known source of increasing PCBs further upstream in the watershed.

Fish and benthic communities are degraded relative to reference sites, although improvements have occurred since the mid-1980s. The fish communities in WOC have been fairly stable in terms of overall numbers of species in recent samples, with numbers of fish species being well below the Brushy Fork 

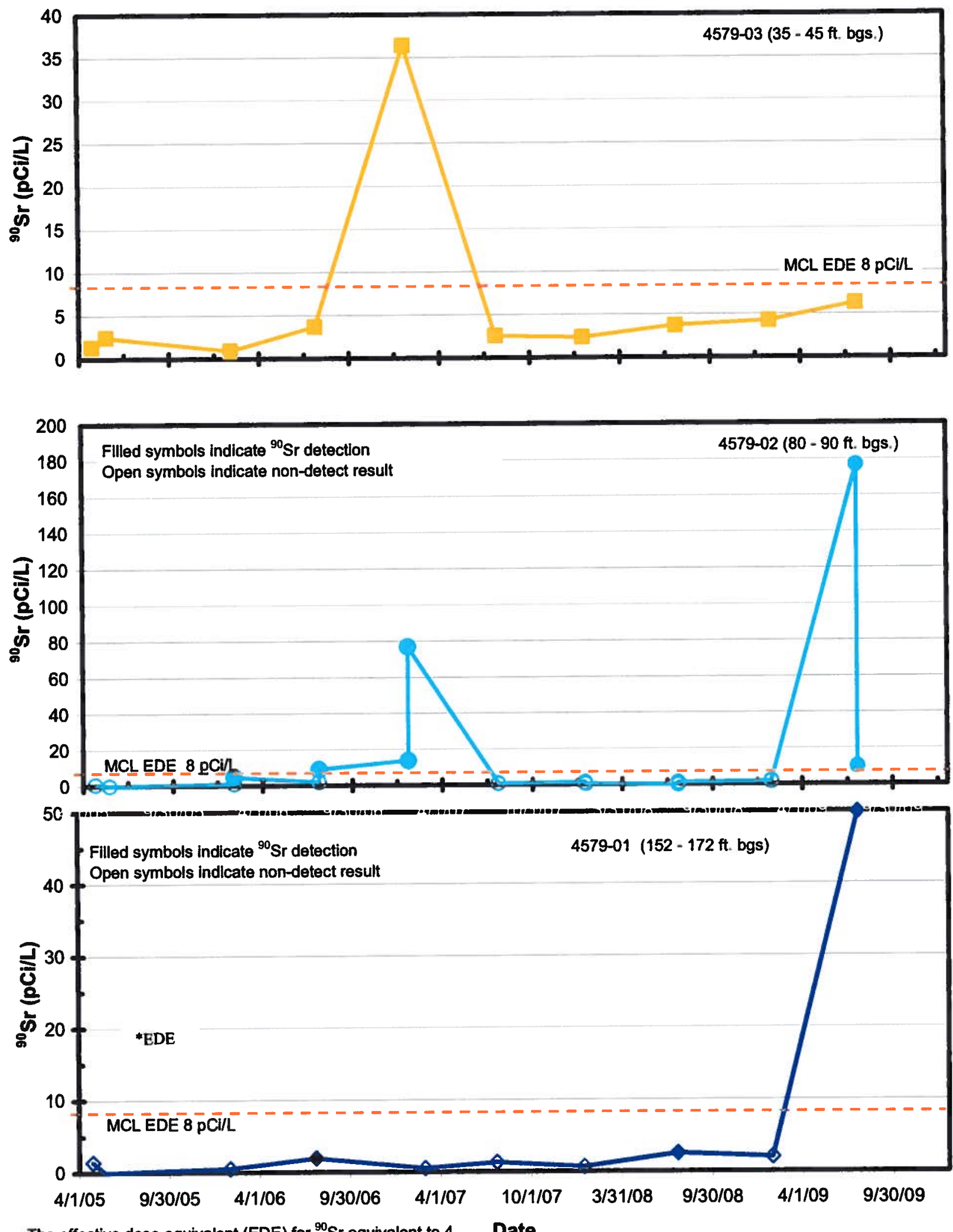

The effective dose equivalent (EDE) for ${ }^{90} \mathrm{Sr}$ equivalent to 4 Date mrem/yr beta activity MCL. is $8 \mathrm{pCi} / \mathrm{L}$

Figure 2.7. ${ }^{90} \mathrm{Sr}$ data history for well 4579. 


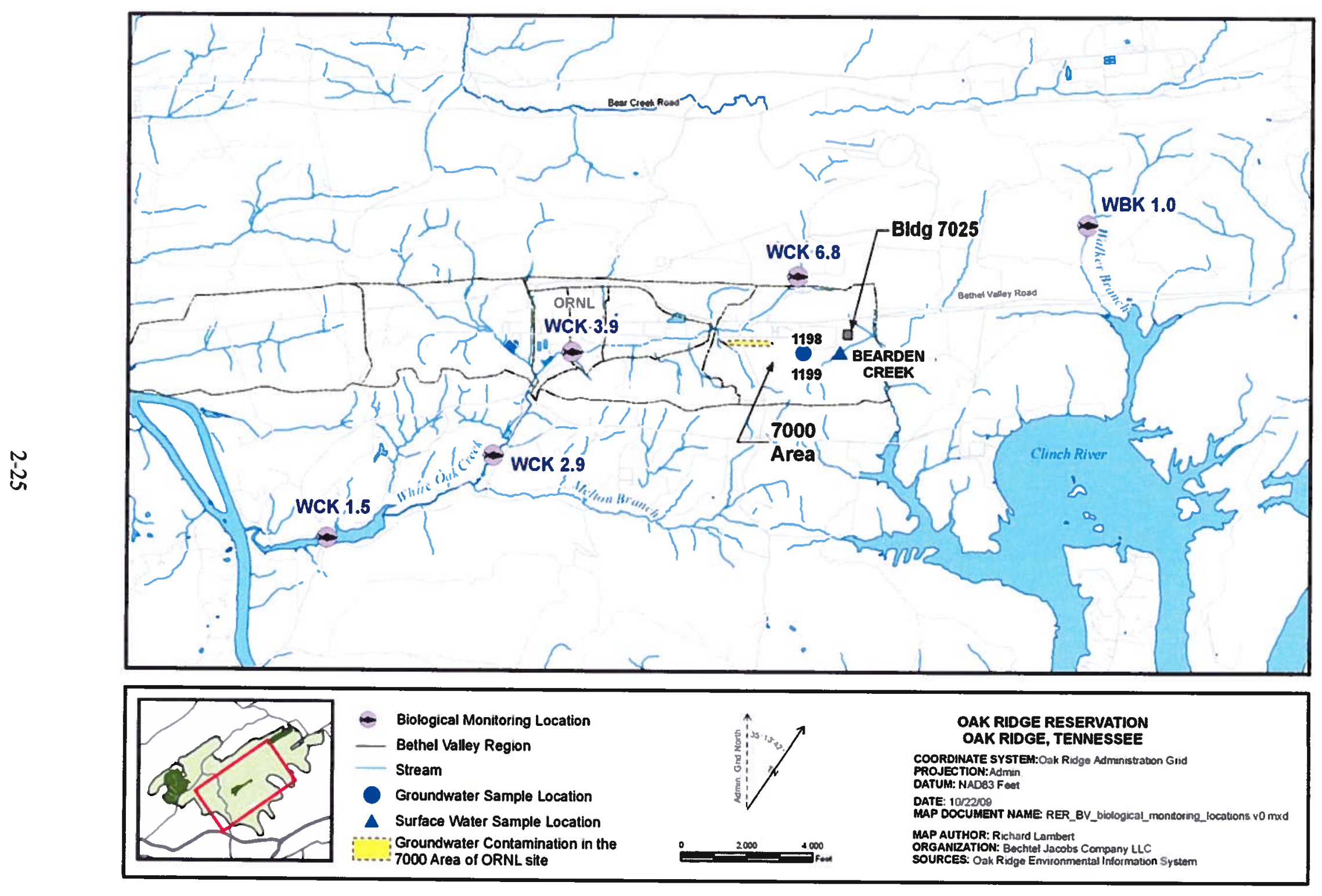

Figure 2.8. Biological monitoring locations at the ORNL site. 


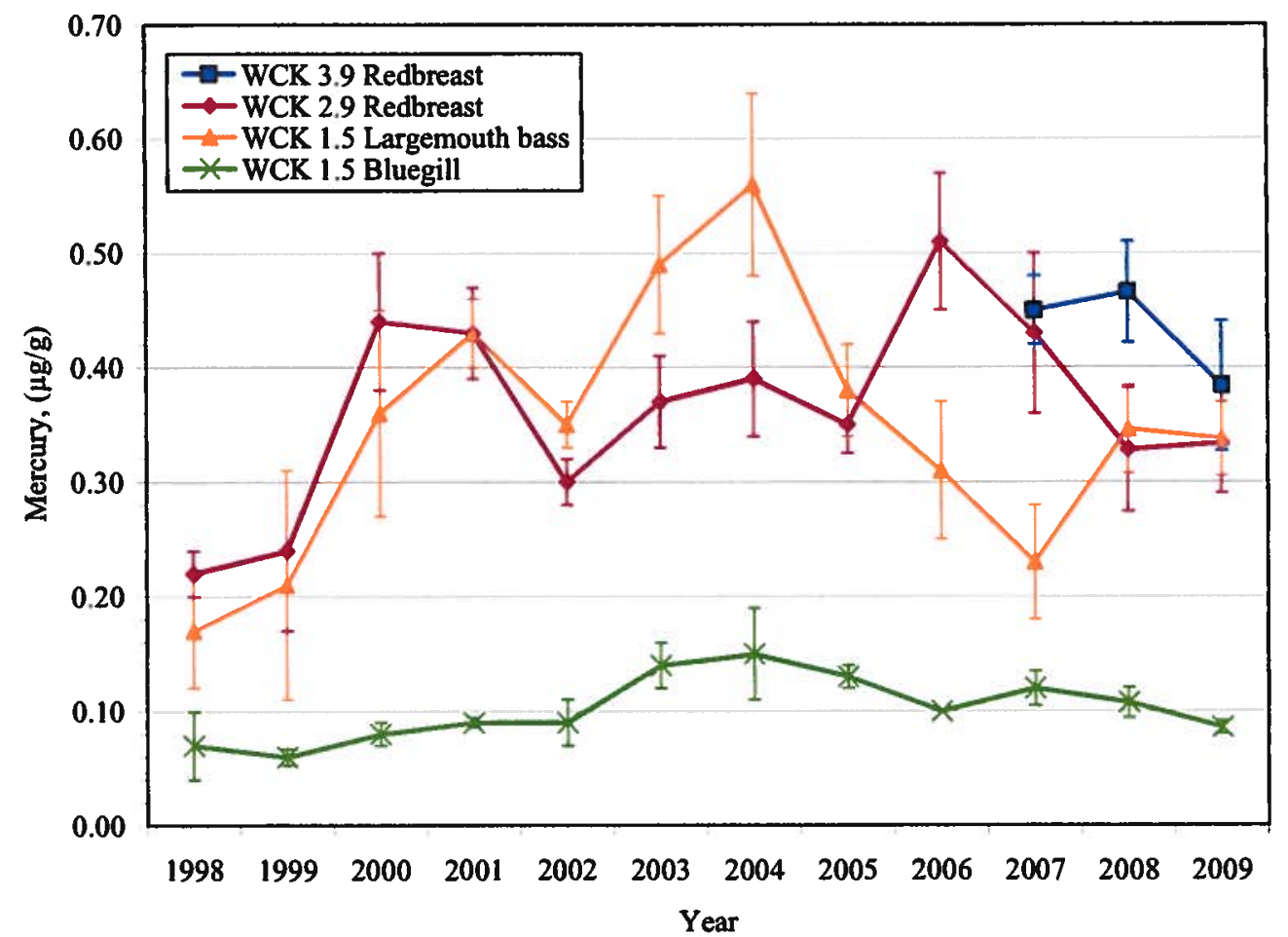

Figure 2.9. Mean concentrations of mercury $(\mu \mathrm{g} / \mathrm{g}, \pm \mathrm{SE}, \mathrm{N}=6)$ in muscle tissue of sunfish and bass from WOC (WCK 2.9 and WCK 3.9) and WOL (WCK 1.5), 1998-2009.

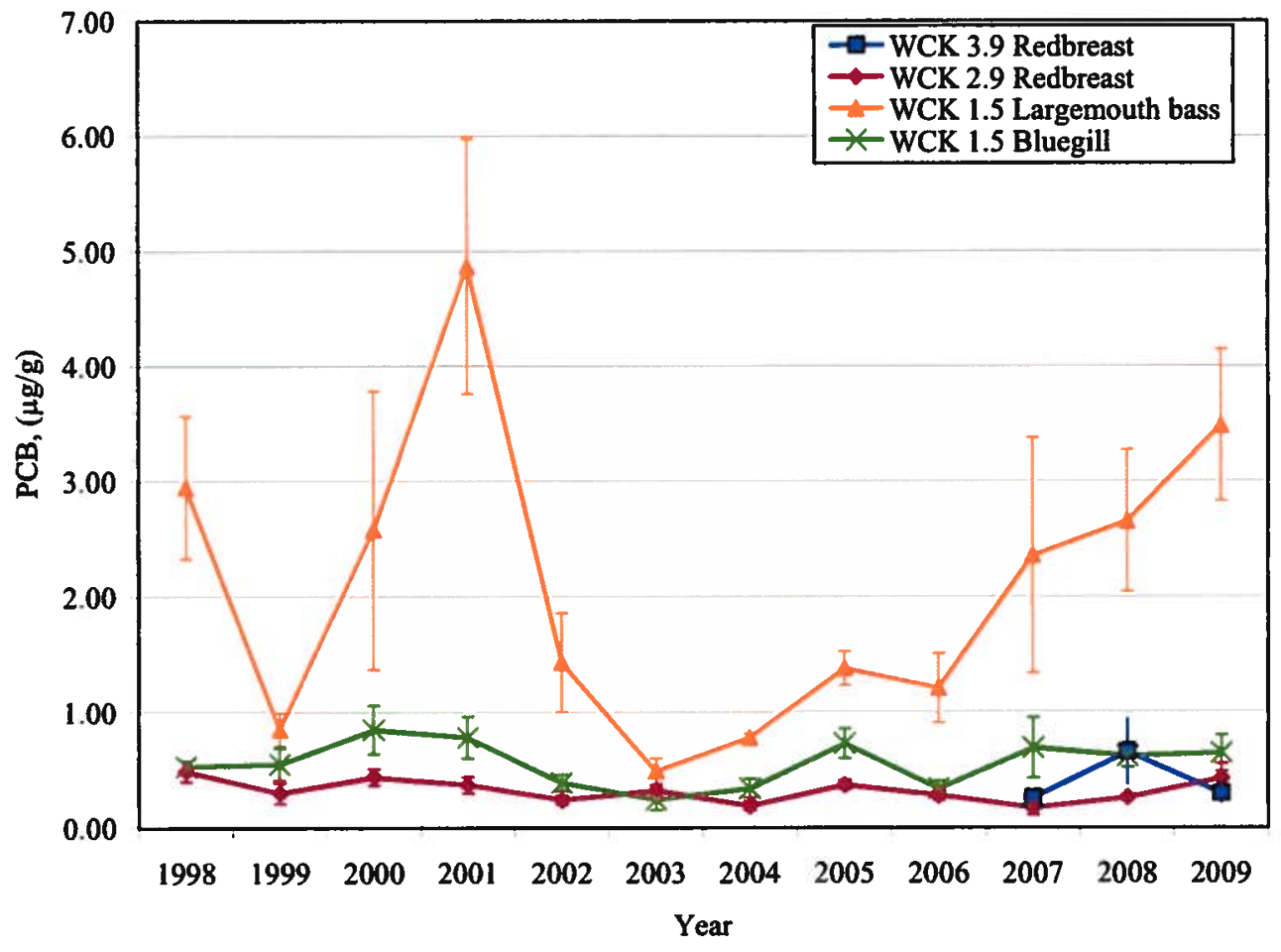

Figure 2.10. Mean PCB concentrations $(\mu \mathrm{g} / \mathrm{g}, \pm \mathrm{SE}, \mathrm{N}=6)$ in fish fillet collected from the WOC Watershed, 1998-2009. 
reference site, but similar or above the number of fish found at the Mill Branch reference site (Figure 2.11). There was no major change in the benthic macroinvertebrate community just downstream of most major effluent discharges from ORNL in 2008 (Figure 2.12). Although these results indicate thatecological conditions in WOC remain degraded, they also show that the moderate recovery experienced by the macroinvertebrate community after 1996 has persisted.

\subsection{Bearden Creek (7000 area)}

Surface water is sampled in a tributary of Bearden Creek at the eastern end of BV to evaluate contaminant discharges to surface water eastward from the 7000 Services Area. The principal contaminant source that affects this area is the former tritium handling facility at Bldg. 7025 (Figure 2.8). Tritium has been detected in groundwater and surface water in the area, as described below. The 7000 Services Area is also the site of a VOC plume in groundwater (Figure 2.8) that migrates westward from its source.

Surface water monitoring has been conducted in the Bearden Creek tributary near the ORNL 7000 Services Area since the mid-1990s. Parameters included in analytical suites have varied over the monitoring history and have included metals, VOCs, and radionuclides. Metals, VOCs, and gross alpha and beta activity have not exceeded drinking water criteria with the exception of aluminum, which may be related to suspended solids as indicated by elevated turbidity levels in field measurements. Of 23 results obtained since the mid-1990s, 12 contained detectable concentrations of tritium. During 1998 and 1999, two samples were reported to contain tritium at concentrations greater than the drinking water limit; however, these results are considered suspect because of possible laboratory problems. During the period 2000 through 2005, 7 of 10 samples analyzed contained detectable tritium at concentrations ranging from $417 \mathrm{pCi} / \mathrm{L}$ to $949 \mathrm{pCi} / \mathrm{L}$, and it should be noted that all results were less than $5 \%$ of the drinking water EDE limit of $20,000 \mathrm{pCi} / \mathrm{L}$. During FY 2009, the Bearden Creek headwater location was sampled in September following strong storms. Tritium was not detected in that sample.

Groundwater monitoring data from wells 1198 and 1199 that are located southwest of the 7025 facility exhibited detectable tritium concentrations in 1997. Both wells showed an increase in tritium from values less than $600 \mathrm{pCi} / \mathrm{L}$ (which may have been below lab detection levels) to concentrations of around 5,000 to $6,000 \mathrm{pCi} / \mathrm{L}$. Tritium concentrations in these wells have decreased steadily since its appearance in 1997. Site investigations conducted by the Office of Science for a new facility to be constructed near the Bearden Creek exit pathway (and to the northeast of the 7025 facility) encountered tritium in groundwater in the area. All lab results on groundwater samples in the area were less than the drinking water EDE limit.

\subsubsection{Performance Summary}

In FY 2009, BV monitoring results showed a continued significant decrease in mercury concentrations in WOC following implementation of a maintenance action at Bldg. 4501, and an increase in the average ${ }^{90} \mathrm{Sr}$ concentration at 7500 Bridge. The maintenance action that caused the mercury reduction was a reroute of basement foundation sump water from discharge to a storm drain to pretreatment and to the PWTC. In October 2009 installation of a pre-filter and ion exchange water treatment system was completed. This system is located in the basement of Bldg. 4501 and it serves to pre-treat the sump water which is then routed to the PWTC for final treatment and discharge. The mercury concentrations measured at the 7500 Bridge only exceeded the TDEC AWQC of $51 \mathrm{ng} / \mathrm{L}$ (the most stringent of the applicable AWQC for WOC) in one of the 12 monthly grab samples. Two samples were collected from WOC near the former mercury discharge outfall and neither result exceeded the AWQC criterion. Most other monitoring results were consistent with ongoing trends. 


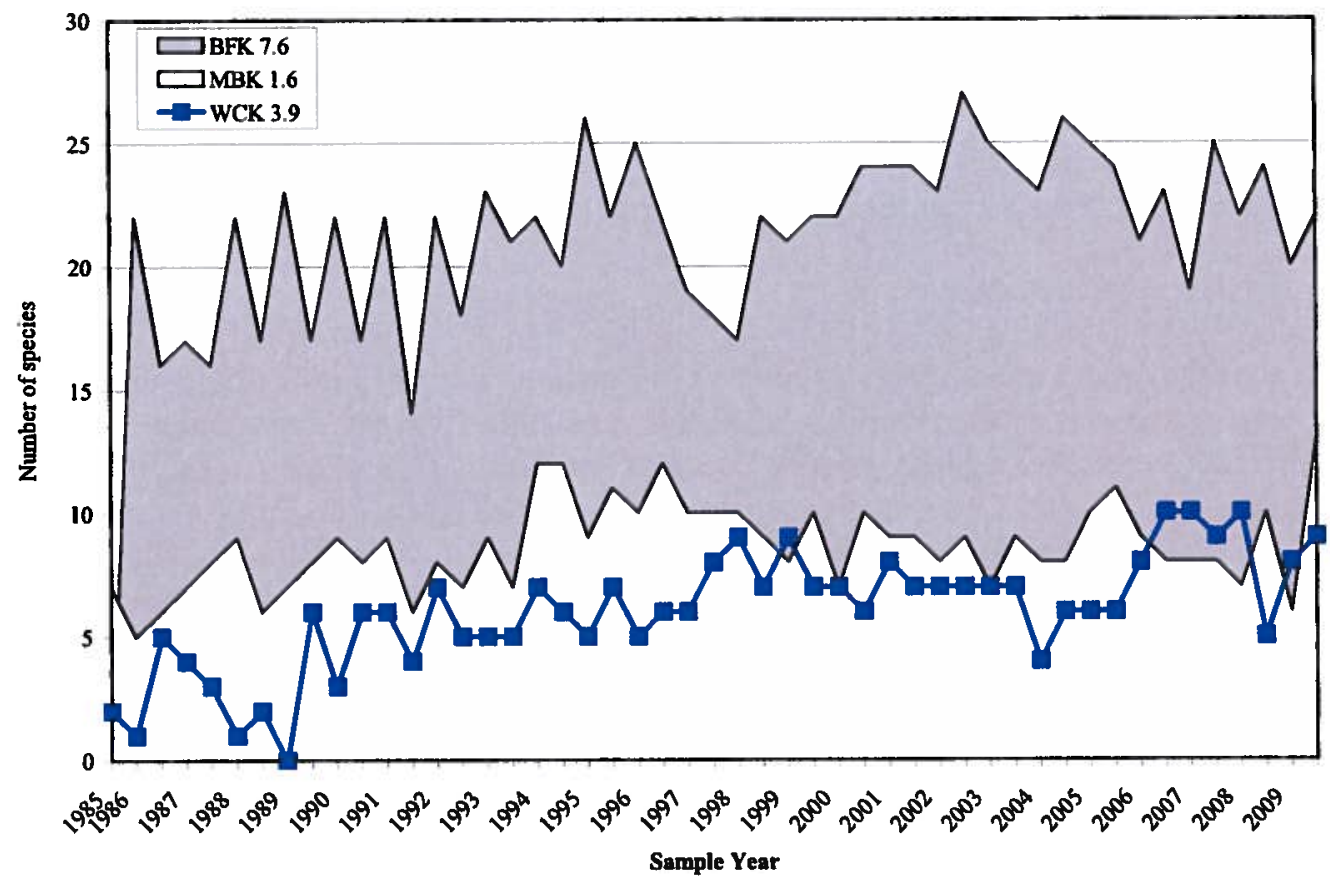

Figure 2.11. Species richness (number of species) in samples of the fish community in upper WOC (WCK 3.9) and reference streams, Brushy Fork kilometer (BFK) and Mill Branch kilometer (MBK), 1985-2009.

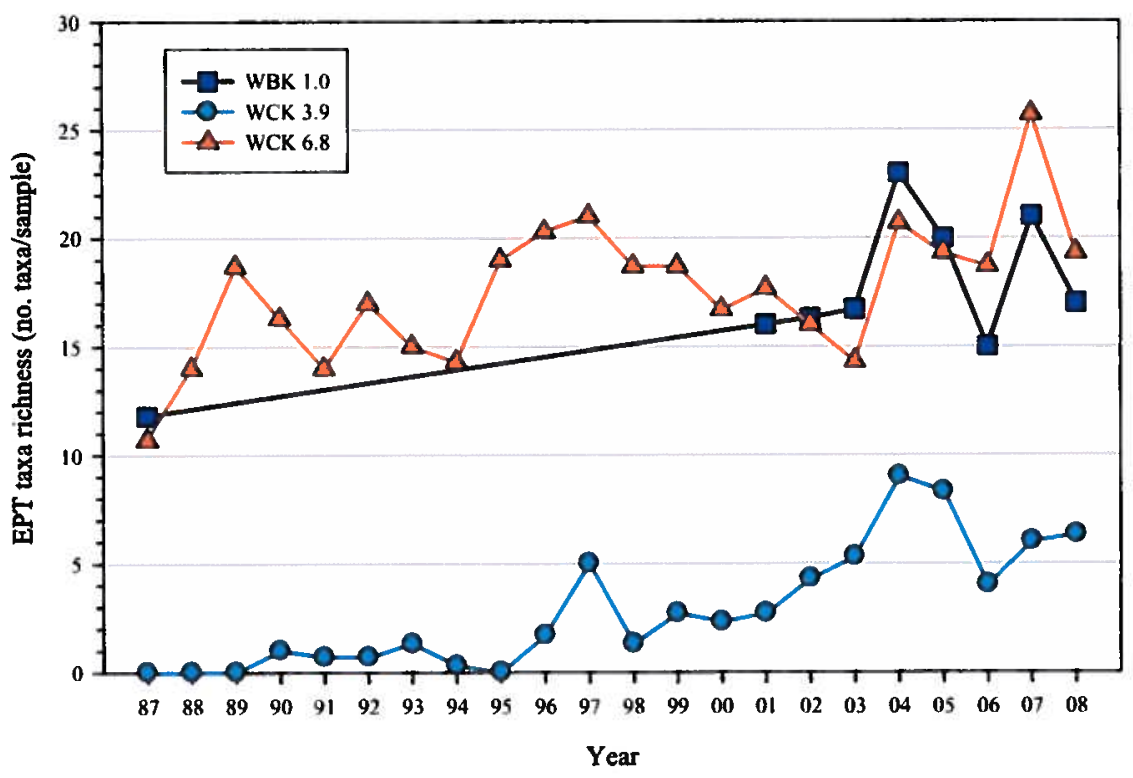

Figure 2.12. Mean $(n=3)$ taxonomic richness of the pollution-intolerant taxa for the benthic macroinvertebrate community at sites in upper WOC and Walker Branch, April sampling periods, 1987-2008. a,b

${ }^{\text {a WBK }}=$ Walker Branch kilometer. EPT $=$ Ephemeroptera, Plecoptera, and Trichoptera, or mayflies, caddisflies, and stoneflies. bSamples collected in 2009 have not yet been processed. Data were not available for Walker Branch from 1988-2000. 
During FY 2009, the risk reduction goals for ${ }^{137} \mathrm{Cs}$ was attained at the BV watershed IP (7500 Bridge). However, during FY 2009, the ${ }^{90} \mathrm{Sr}$ reduction goal was not attained because of an increase in ${ }^{90} \mathrm{Sr}$ discharges to First Creek from the Corehole 8 Plume. Increased plume discharges are results of leaks in the ORNL potable and fire water system, as well as operational problems with the plume collection system. This issue is discussed in Sect. 2.3 and was identified as an issue in Sect. 2.4.

Reduction of ${ }^{90} \mathrm{Sr}$ discharges from BV is an ongoing problem and is an issue carried forward (identified in Sect. 2.4) from previous remedy evaluations. DOE has implemented increased surface water monitoring to identify sources of ${ }^{90} \mathrm{Sr}$ discharge into WOC and its tributaries. To date, the releases identified during periods of increased ${ }^{90} \mathrm{Sr}$ discharge have been related to infrastructure operations that cause groundwater collection systems to underperform.

\subsubsection{Compliance with LTS Requirements}

\subsubsection{Requirements}

The ROD requires implementation of LUCs to protect against unacceptable exposures to contamination during the RAs, as well as after completion of all RAs in BV. During RAs, interim LUCs are being imposed and will remain until permanent LUCs are established in future remedial decisions for this area. Because the final groundwater decision is being deferred, groundwater use restrictions in contaminated areas will be required regardless of land use. Other objectives of the LUCs are as follows:

- Controlled industrial area: Restrict excavations or penetrations deeper than $0.6 \mathrm{~m}(2 \mathrm{ft})$ and prevent uses of the land more intrusive than industrial use above $0.6 \mathrm{~m}(2 \mathrm{ft})$.

- Unrestricted industrial area: No restrictions on excavations or penetrations shallower than $3 \mathrm{~m}(10 \mathrm{ft})$ and prevent uses of the land more intrusive than industrial use deeper than $3 \mathrm{~m}(10 \mathrm{ft})$.

- Recreational area (as applied to the SWSA 3 burial ground and the Contractor's Landfill): Restrict recreational activity to passive surface use of disposal areas; prevent unauthorized contact, removal, or excavation of waste material; prevent unauthorized destruction or modification of engineered controls; and preclude use of the areas for additional future waste disposals or alternate uses inconsistent with the management of currently disposed waste.

No RAs requiring LTS specified by the ROD have yet been completed in BV.

\subsubsection{Status of Requirements for FY 2009}

Interim LUCs were maintained for the specified land use areas identified in the BV ROD. Signs were maintained to control access, and surveillance patrols conducted as part of routine S\&M inspections were effective in preventing access by unauthorized personnel. The EPP program functioned according to established procedures and plans for the site. 

AND/OR LTS REQUIREMENTS

\subsubsection{Waste Area Grouping (WAG) 1 Corehole 8 Removal Action (Plume Collection)}

In 1991, CERCLA characterization efforts identified a plume of ${ }^{90} \mathrm{Sr}$-contaminated groundwater, referred to since that time as the Corehole 8 Plume (Figure 2.13). Note that the Corehole 8 Plume Source (Tank W-1A) is addressed as a separate action and included in Sect. 2.3.2. A removal site evaluation performed in 1994 concluded that contaminated groundwater seeping into the ORNL storm drain system was being discharged into First Creek at storm drain Outfall 342. First Creek is a tributary to WOC and ultimately to the Clinch River. Further investigation showed that contaminated groundwater entered the storm water collection system by in-leakage to three catch basins in the western part of ORNL.

Figure 2.14 is a conceptual block diagram of the Corehole 8 Plume that shows the plume confined within a dipping limestone bed that is approximately $10 \mathrm{ft}$ thick. Contaminants seep into the weathered limestone bed beneath the NTF in the vicinity of Tank W-1A. Groundwater seepage within the dipping bed carries contamination downward and westward, as shown by the seepage arrows in Figure 2.14. The flow rises to discharge into the base of the soil profile near the western edge of the ORNL Central Campus near First Street, where the plume collection system was installed during implementation of the removal action. Contaminant concentrations are attenuated along the seepage pathway with approximately 100 -fold reduction in concentration measured between well 4411 (near the source area) and at well 0812 and in the collection system at the western end of the plume.

The AM for the project was approved in November 1994 (DOE 1994a). Installation of a groundwater collection and transmission system began in December. Water collected in the two porous sumps is pumped into the Corehole 8 sump and then on to a process waste system manhole in the NTF. Startup of the system occurred on March 31, 1995. Collected groundwater is piped to the ORNL PWTC for treatment and is discharged through an existing National Pollutant Discharge Elimination System (NPDES) outfall (X12).

In October 1997, monitoring of surface water in First Creek identified elevated levels of ${ }^{90} \mathrm{Sr}$ and ${ }^{234} \mathrm{U}$ known to be caused by the Corehole 8 Plume. Additional sampling conducted in December 1997 identified two unlined storm drain manholes as the point of entry for the contamination. In March 1998, an additional groundwater interceptor trench was installed that connects to one of the Corehole 8 Plume collection sumps.

In September 1999, an addendum to the AM (DOE 1999a) authorized additional groundwater extraction and treatment actions expected to enhance the effectiveness of the original removal action. The additional actions involved pumping contaminated groundwater out of well 4411 and discharging it into the PWTC for further treatment. Well 4411 is located downgradient and down-dip from Tank W-1A and intersects a thin limestone bedrock layer determined to be the preferential flow pathway for the Corehole 8 Plume.

\subsubsection{Performance Goals and Monitoring Objectives}

The AM (DOE 1994a) estimated that the plume collection system would intercept between 20 and $50 \%$ of the Corehole 8 Plume water prior to its entering First Creek. Evaluation of the ${ }^{90} \mathrm{Sr}$ flux measured at First Creek monitoring station is used as the performance metric for remedy effectiveness evaluation. 


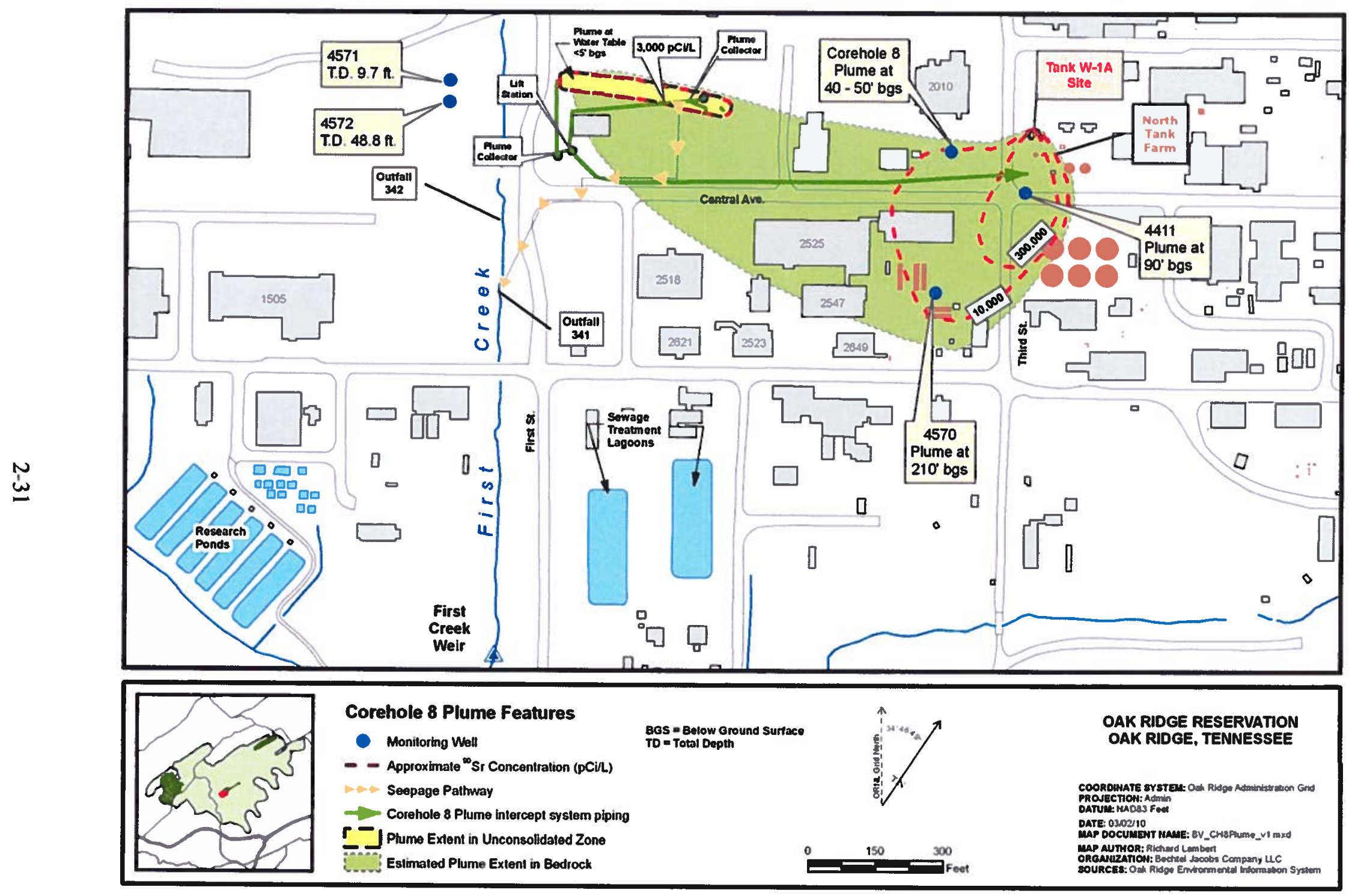

Figure 2.13. Location and features of the Corehole 8 Plume. 


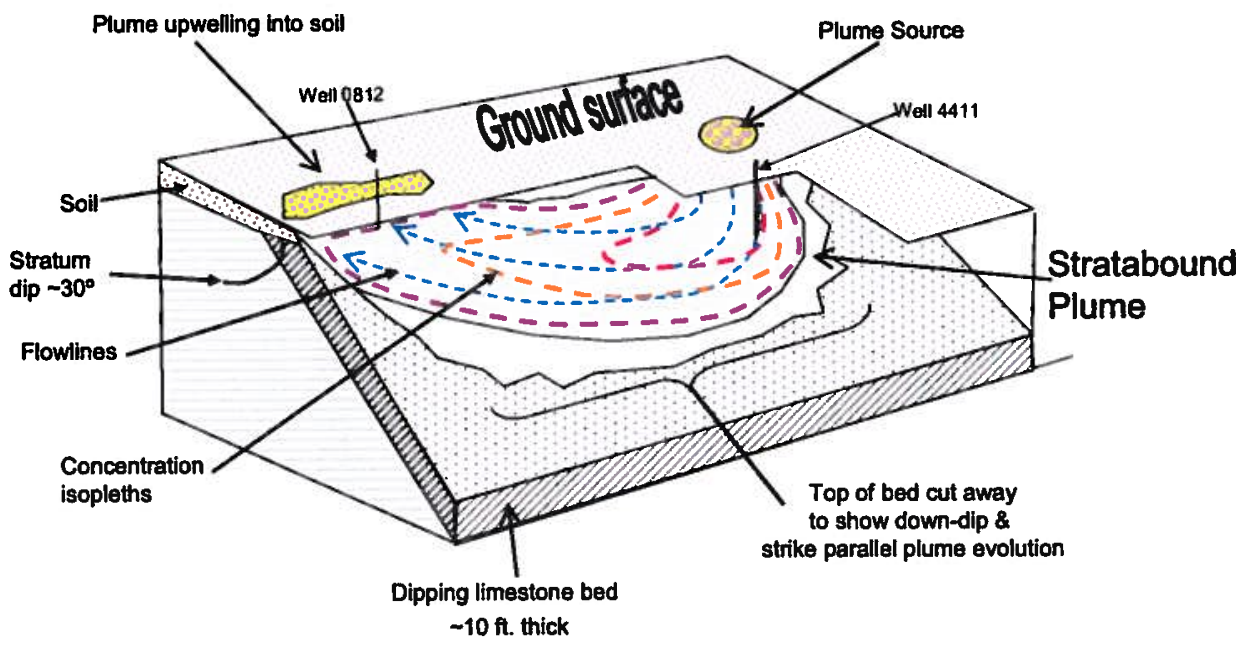

Figure 2.14. Conceptual block diagram of the Corehole 8 Plume.

\subsubsection{Evaluation of Performance Monitoring Data}

During FY 2009, the Corehole 8 Plume interceptor system did not achieve the performance goal for reduction of ${ }^{90} \mathrm{Sr}$ discharge to First Creek. The reasons for not attaining the performance goal are mechanical problems with the plume capture pumping system compounded by leaks in the potable and firewater utility systems in several locations.

First Creek is the receiving surface water body for discharge of contaminated groundwater in the Corehole 8 Plume. Continuous flow-paced monitoring of First Creek has been ongoing since before the Corehole 8 Plume removal action was conducted. Table 2.8 includes the FY 2009 monthly flow volumes, ${ }^{90} \mathrm{Sr}$ concentrations, and ${ }^{90} \mathrm{Sr}$ fluxes, as well as similar data from 1994 prior to the removal action. The flux of ${ }^{90} \mathrm{Sr}$ measured in First Creek in FY 2009 was approximately $87.1 \%$ of the flux measured during calendar year (CY) 1994 prior to startup of the Corehole 8 groundwater collection system. Table 2.9 shows the history of ${ }^{90} \mathrm{Sr}$ fluxes and flux reduction factors in First Creek from FY 1993 through 2009.

Table 2.8. First Creek ${ }^{90}$ Sr fluxes pre-action and in FY 2009

\begin{tabular}{|c|c|c|c|c|c|c|c|}
\hline \multirow[b]{2}{*}{ Month } & \multicolumn{3}{|c|}{ CY 1994 (pre-action) } & \multirow[b]{2}{*}{ Month } & \multicolumn{3}{|c|}{ FY 2009} \\
\hline & $\begin{array}{c}{ }^{90} \mathrm{Sr} \\
(\mathrm{pCi} / \mathrm{L})\end{array}$ & $\begin{array}{c}\text { Flow } \\
\text { volume } \\
\text { (iters) }\end{array}$ & $\begin{array}{c}{ }^{90} \mathrm{Sr} \text { flux } \\
\text { (Ci) }\end{array}$ & & $\begin{array}{c}{ }^{90} \mathrm{Sr} \\
(\mathrm{pCl} / \mathrm{L})\end{array}$ & $\begin{array}{c}\text { Flow volume } \\
\text { (liters) }\end{array}$ & $\begin{array}{c}{ }^{90} \mathrm{Sr} \text { flux } \\
\text { (Ci) }\end{array}$ \\
\hline January 1994 & 124.4 & $102,893,891$ & 0.0128 & October 2008 & 104 & $16,825,565$ & 0.0017 \\
\hline February 1994 & 95.6 & $126,569,038$ & 0.0121 & November 2008 & 77 & $17,853,278$ & 0.0014 \\
\hline March 1994 & 89.2 & $228,699,552$ & 0.0204 & December 2008 & 72.5 & $113,999,054$ & 0.0083 \\
\hline April 1994 & 105.4 & $166,982,922$ & 0.0176 & January 2009 & 56.8 & $96,548,746$ & 0.0055 \\
\hline May 1994 & 236.5 & $41,437,632$ & 0.0098 & February 2009 & 106 & $74,144,290$ & 0.0079 \\
\hline June 1994 & 297.3 & $32,963,337$ & 0.0098 & March 2009 & 74.1 & $79,600,752$ & 0.0059 \\
\hline July 1994 & 324.4 & $25,585,697$ & 0.0083 & April 2009 & 191 & $116,097,163$ & 0.0222 \\
\hline August 1994 & 378.4 & $30,919,662$ & 0.0117 & May 2009 & 207 & $86,283,374$ & 0.0179 \\
\hline September 1994 & 364.9 & $26,586,673$ & 0.0097 & June 2009 & 399 & $40,661,035$ & 0.0162 \\
\hline October 1994 & 133.6 & $24,700,599$ & 0.0033 & July 2009 & 205 & $36,458,021$ & 0.0075 \\
\hline November 1994 & 260.9 & $37,178,996$ & 0.0097 & August 2009 & 159 & $72,634,709$ & 0.0115 \\
\hline December 1994 & 179.8 & $66,740,823$ & 0.012 & September 2009 & 195 & $68,718,918$ & 0.0134 \\
\hline Total & & $911,258,822$ & 0.137 & Total & & $819,824,905$ & 0.1193 \\
\hline
\end{tabular}


Table 2.9. ${ }^{90} \mathrm{Sr}$ flux changes at First Creek Weir, 1993-2009

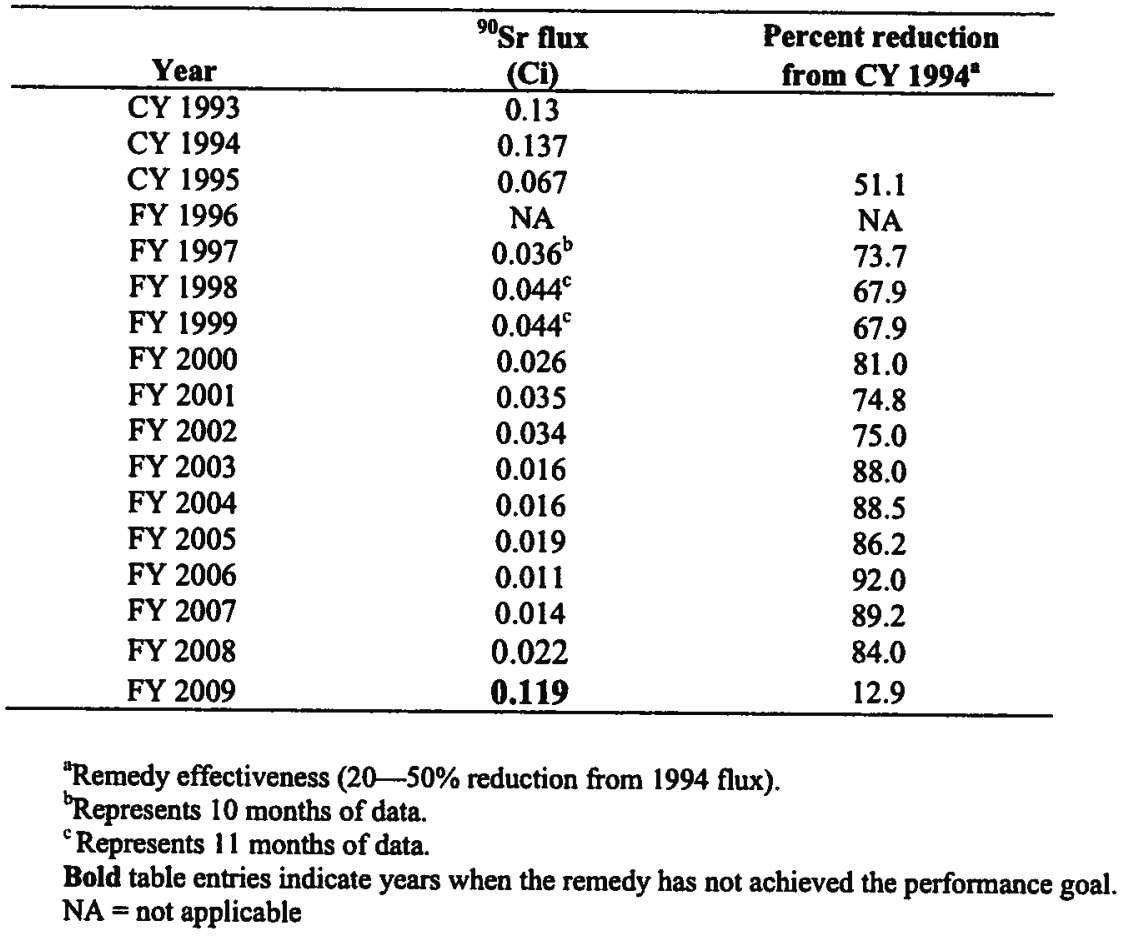

Performance evaluation data summarized above show that the WAG 1 Corehole 8 Removal Action effectively reduced contaminant discharge to First Creek through FY 2008, but that performance deteriorated in FY 2009.

Figure 2.15 shows the historical ${ }^{90} \mathrm{Sr}$ and ${ }^{234} \mathrm{U}$ concentrations measured in groundwater at well 4411 and Corehole 8 Zone 2 . Well 4411 is a plume extraction well that intersects the plume at a depth of approximately $90 \mathrm{ft}$ bgs in a location approximately $120 \mathrm{ft}$ south of Tank W-1A, where leakage from a broken LLLW pipeline created the plume source. Samples from well 4411 are taken at the wellhead and represent contaminant concentrations in extracted groundwater that is being pumped to the PWTC for treatment. Corehole 8 is a $50 \mathrm{ft}$ deep well in which a Westbay ${ }^{\circledR}$ multizone sampling system was installed to allow sampling of discrete intervals in the well. Zone 2 is the second zone from the bottom of the well and its sampling interval spans the depth of 41.2-43.2 ft bgs. During well installation and initial sampling, this zone was found to produce the highest concentrations of contaminants in the well and for that reason it has become the focal point for ongoing monitoring at that location. Data presented in Figure 2.15 show that during FY 2009 at Corehole $8,{ }^{90} \mathrm{Sr}$ concentrations rose sharply from levels near $20,000 \mathrm{pCi} / \mathrm{L}$ to more than $50,000 \mathrm{pCi} / \mathrm{L}$. Activity levels of ${ }^{234} \mathrm{U}$ also rose dramatically during $\mathrm{FY} 2009$ and reached the highest levels measured at that well. Strontium-90 and ${ }^{234} \mathrm{U}$ data for well 4411 showed a similar behavior with large increases in ${ }^{234} U$ activity levels during FY 2009. Such increases in plume concentrations were disproportionate to the above average rainfall measured across the ORR. Near the end of FY 2009, it became apparent that potable and firewater utility system leaks were the probable cause of the dramatic increases in contaminant concentrations near the source and within the plume. Detection of chlorine in groundwater at the NTF and within the plume indicate that water line leaks to the north and upslope from the NTF apparently fed water into the plume source area which mobilized additional contaminants from the source area into the plume. 

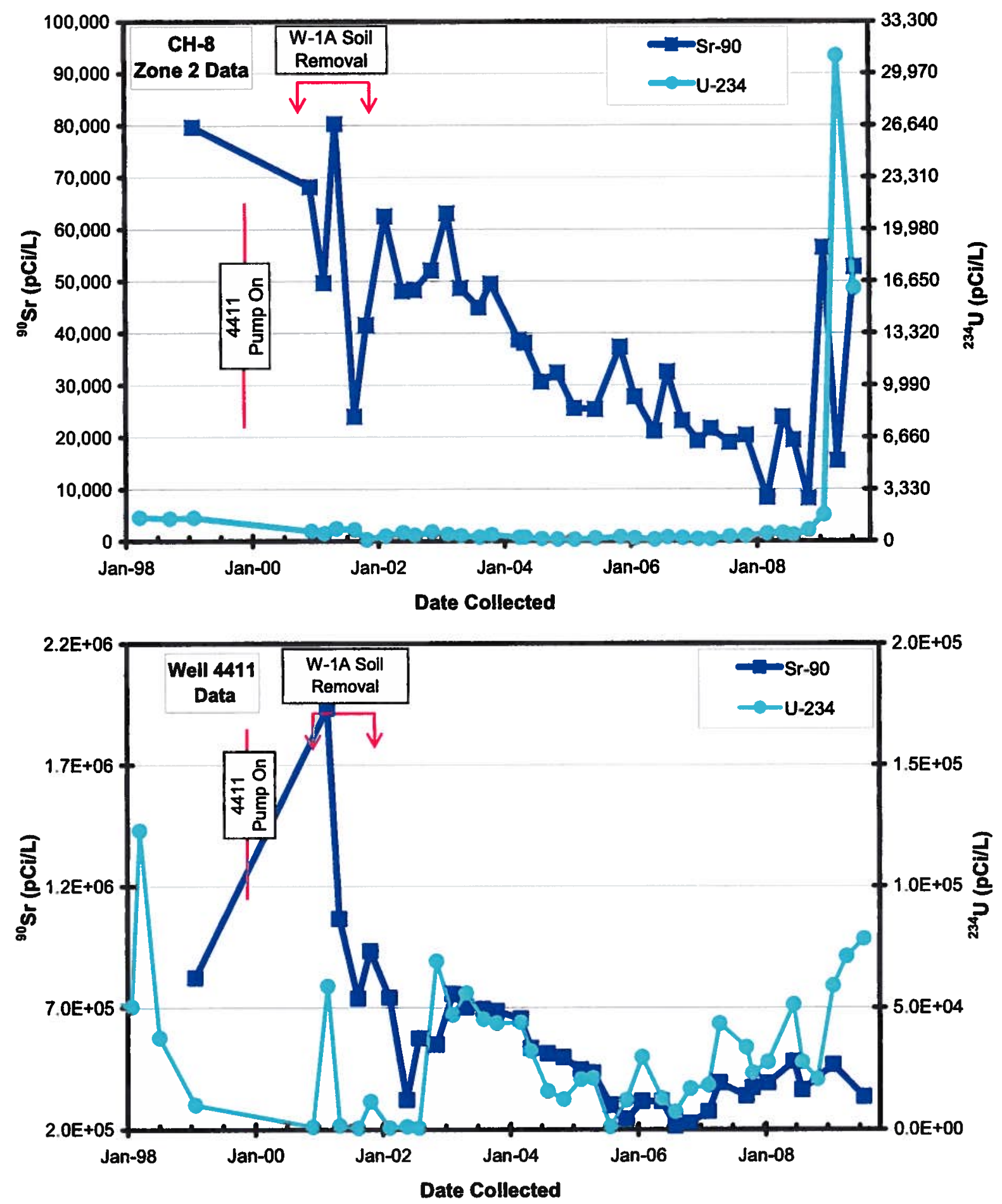

Figure 2.15. Contaminant concentrations in well 4411 and Corehole 8 Zone 2. 
Figure 2.16 shows the Corehole 8 groundwater collection sump ${ }^{90} \mathrm{Sr}$ and alpha activity concentration data from system startup in 1995 through FY 2009. Notations on the figure show approximate dates when extraction of contaminated groundwater via well 4411 started, as well as the approximate dates during which contaminated soil was excavated from the NTF. The data demonstrate that both actions had visible benefits in reducing contaminant concentrations in the plume collection system that is located in the western end of the plume. Table 2.10 includes Corehole 8 collection system monthly and annual total flow volumes collected and ${ }^{90} \mathrm{Sr}$ flux captured and sent to the PWTC for FY 1997 and FY 2009. Figure 2.17 shows the annual flux of ${ }^{90} \mathrm{Sr}$ collected by the Corehole 8 groundwater collection system along with total annual rainfall measured at the ORNL site. The long-term average annual rainfall for Oak Ridge is approximately 54 inches per year. As shown on Figure 2.17, FY 2003-FY 2005 were years of above average rainfall. FY 2003 was an especially unusual year in that the annual rainfall was approximately $35 \%$ above the long-term average. Although mass of ${ }^{90} \mathrm{Sr}$ captured in the plume collection system increased during FY 2009, the system's ability to control the plume, as it had during previous periods of above-average rainfall, was overwhelmed by added water volume from potable and/or fire water leaks.

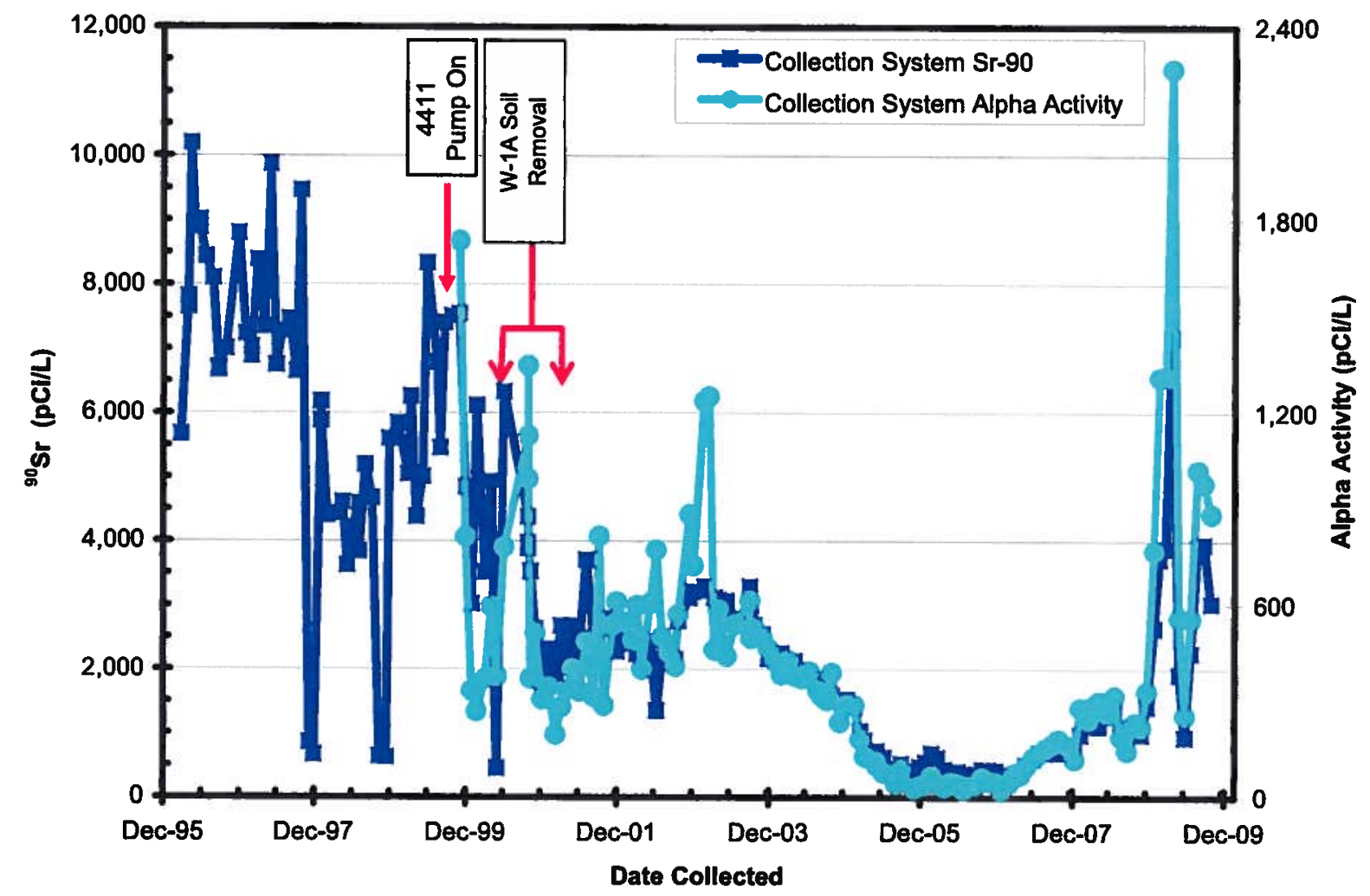

Figure 2.16. ${ }^{90} \mathrm{Sr}$ and alpha activity concentration in collected Corehole 8 Plume groundwater. 
Table 2.10. Corehole 8 groundwater collection system ${ }^{90} \mathrm{Sr}$ flux

\begin{tabular}{|c|c|c|c|c|c|c|c|}
\hline \multirow[b]{2}{*}{ Month } & \multicolumn{3}{|c|}{ FY 1997} & \multirow[b]{2}{*}{ Month } & \multicolumn{3}{|c|}{ FY 2009} \\
\hline & ${ }^{{ }^{90} \mathrm{Sr}}$ & $\begin{array}{c}\text { Flow } \\
\text { volume } \\
\text { (liters) }\end{array}$ & $\begin{array}{l}{ }^{90} \text { Sr flux } \\
\text { (Ci) }\end{array}$ & & $\begin{array}{c}{ }^{90} \mathrm{Sr} \\
(\mathrm{pCi} / \mathrm{L})\end{array}$ & $\begin{array}{l}\text { Flow volume } \\
\text { (liters) }\end{array}$ & $\begin{array}{l}{ }^{90} \mathrm{Sr} \text { flux } \\
\text { (Ci) }\end{array}$ \\
\hline $\begin{array}{l}\text { October } 1996 \\
\text { November } 1996\end{array}$ & $\begin{array}{l}8700 \\
8800\end{array}$ & $\begin{array}{c}933,000 \\
1,845,000\end{array}$ & $\begin{array}{l}0.0081 \\
0.0162\end{array}$ & $\begin{array}{l}\text { October } 2008 \\
\text { November } 2008\end{array}$ & $\begin{array}{l}988 \\
1420\end{array}$ & $\begin{array}{l}3,334,579 \\
3,285,245\end{array}$ & $\begin{array}{l}0.003 \\
0.005\end{array}$ \\
\hline December 1996 & 7230 & $2,595,000$ & 0.0188 & December 2008 & 2640 & $5,352,264$ & 0.014 \\
\hline January 1997 & 6890 & $1,711,000$ & 0.0118 & January 2009 & 3730 & $4,778,064$ & 0.018 \\
\hline February 1997 & 8390 & $1,858,000$ & 0.0156 & February 2009 & 3890 & $3,641,674$ & 0.014 \\
\hline March 1997 & 7350 & $2,162,000$ & 0.0159 & March 2009 & 7180 & $2,611,714$ & 0.019 \\
\hline April 1997 & 9870 & $1,946,000$ & 0.0192 & April 2009 & 1920 & $2,786,702$ & 0.005 \\
\hline May 1997 & 6750 & $1,697,000$ & 0.0115 & May 2009 & 947 & $2,453,933$ & 0.002 \\
\hline June 1997 & 7280 & $2,631,000$ & 0.0192 & June 2009 & 2260 & $2,626,589$ & 0.006 \\
\hline July 1997 & 7463 & $1,705,000$ & 0.0127 & July 2009 & 3910 & $4,269,917$ & 0.017 \\
\hline August 1997 & 6647 & $1,131,000$ & 0.0075 & August 2009 & 3950 & $3,480,192$ & 0.014 \\
\hline September 1997 & 9465 & 953,000 & 0.009 & September 2009 & 3030 & $3,514,264$ & 0.011 \\
\hline Total & & $21,167,000$ & 0.1655 & Total & & $42,135,136$ & 0.128 \\
\hline
\end{tabular}

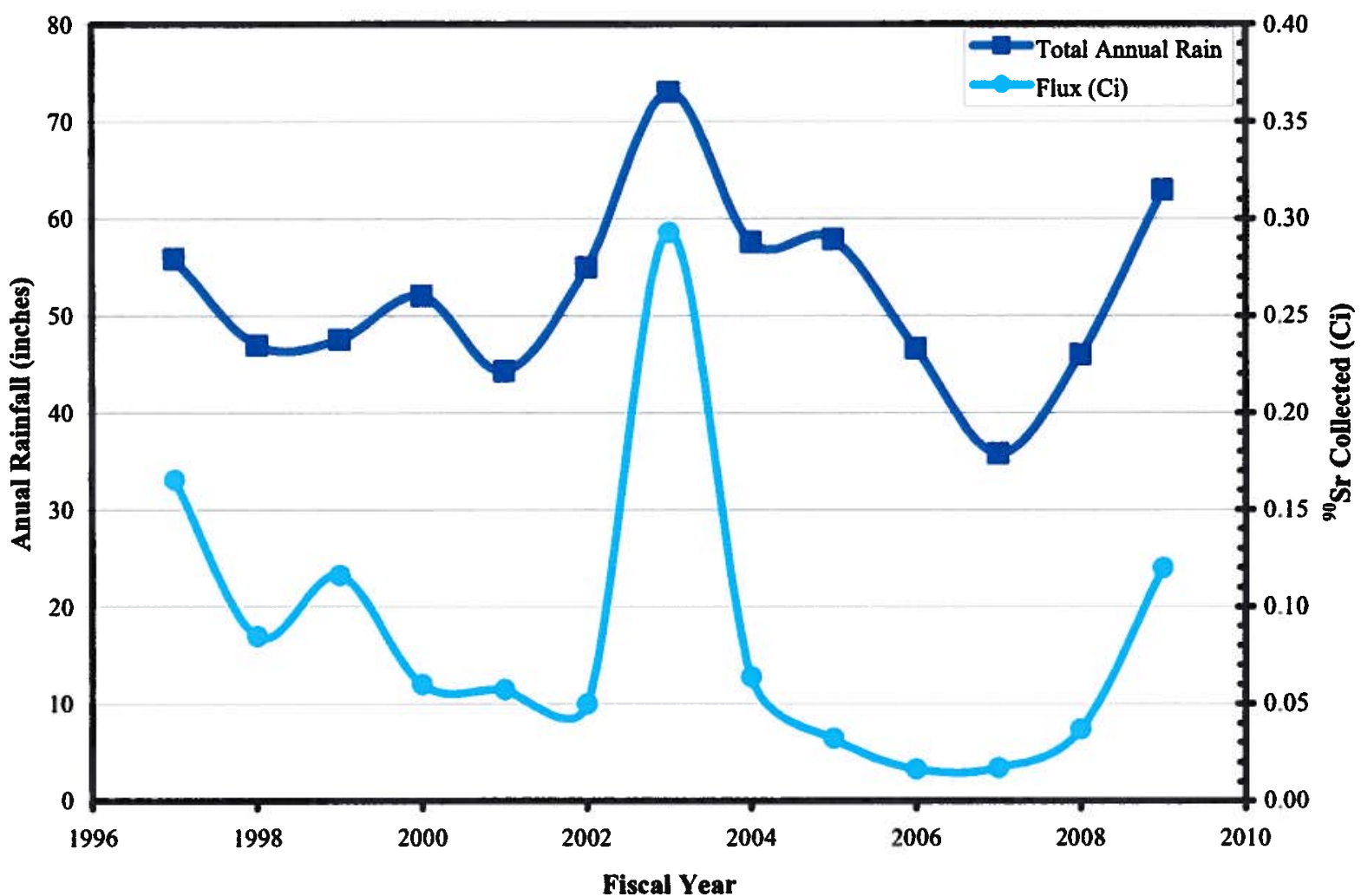

Figure 2.17. Corehole 8 Plume groundwater collector annual intercepted ${ }^{90} \mathrm{Sr}$ flux and rainfall.

Figure 2.18 shows ${ }^{90} \mathrm{Sr}$ and ${ }^{234} \mathrm{U}$ concentrations measured at well 4570 (see Figure 2.13) since its installation as part of the BV Groundwater Engineering Study. Contaminant concentrations have generally declined since the beginning of monitoring this well. However, during FY 2009, the concentrations of ${ }^{90} \mathrm{Sr}$ and ${ }^{234} \mathrm{U}$ continued a gradual increasing trend that started between summer 2007 
and winter of 2008. This trend may be related to the onset of potable water influx into the plume source area. Wells 4571 and 4572 are also monitored to evaluate the potential extension of the plume west of First Creek. Strontium-90 was not detected in well 4571 (9.7 ft deep) or well 4572 (48.8 ft deep) in either of two sampling events during FY 2009. Strontium-90 has not been detected in either well since the start of monitoring in 2005.

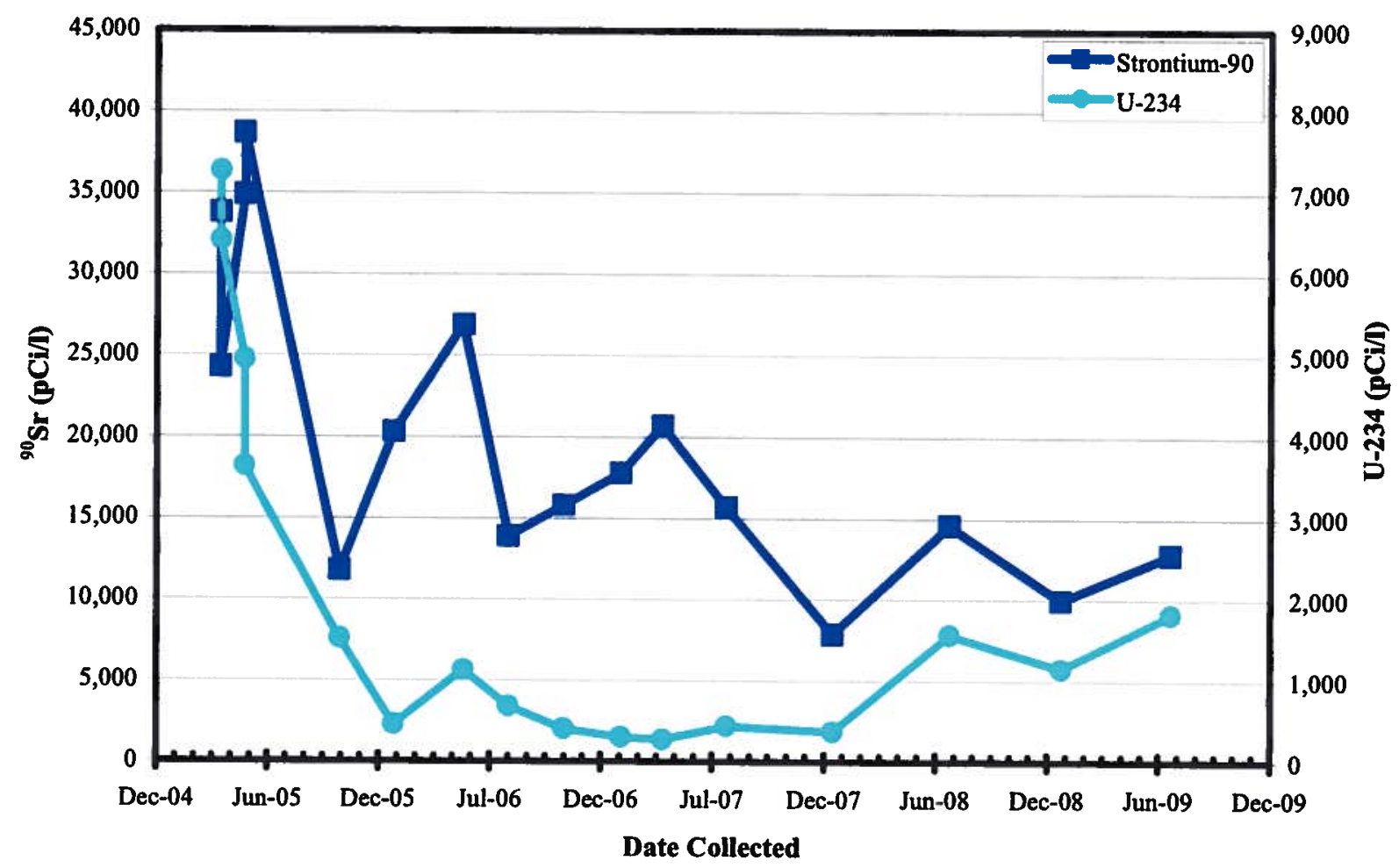

Figure 2.18. ${ }^{90} \mathrm{Sr}$ and ${ }^{234} \mathrm{U}$ concentrations in well 4570.

\subsubsection{Performance Summary}

The Corehole 8 Plume collection system did not meet its performance goal during FY 2009.

During FY 2009, a major increase in contaminant mass transport occurred in the Corehole 8 Plume. Leaks in the ORNL potable and firewater utility systems appear to be mobilizing contaminants from the source area at Tank W-1A. The increased source release translated throughout the plume and, although the collection system did capture a large mass of the contaminant, a relatively large amount of contamination discharged to First Creek via plume infiltration into storm drains to Outfall 341. Mechanical problems with the plume collection system also impaired plume capture during FY 2009.

The problems with the Corehole 8 Plume collection system are identified as an issue and included in Sect. 2.4. The recommended responses to the problems are: 1) identification and repair of fire water utility system leaks in the vicinity of the contaminant source areas and plumes which cause contaminant releases and overwhelm collection systems, and 2) conduct an engineering evaluation of the existing Corehole 8 Plume collection system and refurbish, as needed, to ensure proper operation. 


\subsubsection{Compliance with LTS Requirements}

\subsection{Requirements}

LTS requirements are not specified in the decision document pertaining to this site.

\subsection{Status of Requirements for FY 2009}

Although no LTS requirements are specified, the groundwater collection system underwent monthly inspections in FY 2009 by the ORNL S\&M Program as a Best Management Practice to monitor the condition of the system and note any extended downtimes ( $>1$ day) or major operational problems. Operational checks of the pumping and treatment system were conducted by EnergySolutions, routine maintenance was performed as required, and the system was monitored by the BJC Waste Operations Control Center (WOCC) via the automated alarm for pump malfunctions. Additionally, the ORNL site was subject to access controls (badge required to pass through security checkpoints), and "Contamination Area" signs were clearly in place.

Operational problems this year have included continuous malfunctions with the pumps at Lift Station \#2 and Lift Station \#3. The pump at Lift Station \#3 was replaced in June, but continued to have problems. Additionally, solenoid switches for valves from Lift Station \#2 and Lift Station \#3 located in Lift Station \#1 did not function properly. The system was continuously in and out of high alarm mode. The pump at Lift Station \#2 was replaced at the end of FY 2009. 


\subsubsection{Tank W-1A Removal Action}

Location of the Corehole 8 Plume Source (Tank W-1A) Removal Action is shown on Figure 2.1. The scope of this action included removal of contaminated soils, along with associated piping, valve pits, and appurtenances within the area of excavation; backfilling; and site restoration. Some soils and the tank have been left in place due to potential transuranic (TRU) waste that would require special handling and disposition. The tank interior was cleaned; however, excavation of the contaminated soil from around the tank and tank removal require completion, which is scheduled for FY 2010 through FY 2011. This site has only LTS requirements. A review of compliance with these requirements is included in Sect. 2.3.2.1. Background information on this remedy and performance standards are provided in Chap. 2 of Vol. 1 of the 2007 RER (DOE 2007a).

No surface water or groundwater monitoring is required to verify the effectiveness of the removal action; however, the Corehole 8 Plume groundwater recovery and monitoring continue at well 4411 and the Corehole 8 sump (Sect. 2.3.1).

\subsubsection{Compliance with LTS Requirements}

\subsection{Requirements}

LTS requirements specified in the RmAR (DOE 2002b) include S\&M activities to be performed routinely to ensure that the clean backfill is not undergoing excessive subsidence or erosion. The RmAR also requires that the area be posted as "Soil Contamination Area-Contact Radiation Protection before disturbing surfaces." In its current condition, the area does not require fencing to protect personnel.

\subsection{Status of Requirements for FY 2009}

The site underwent an annual inspection in FY 2009 by the ORNL S\&M Program to monitor the condition of the backfill to note excessive subsidence or erosion. Site access controls, general housekeeping, and condition of the signs were also inspected. No maintenance was required. 


\subsubsection{Surface Impoundments Remedial Action}

The location of the SIOU RA is shown on Figure 2.1. The scope of this action involved the removal of contaminated water, sediment, and the upper 0.1 to $0.2 \mathrm{ft}$ of subimpoundment soil (clay) and was implemented in two phases. The first phase involved contaminated water and sediment removal and backfilling of impoundments $\mathrm{C}$ and $\mathrm{D}$, which were small, lined impoundments. The second phase involved removal and treatment of discrete batches of contaminated sediment and backfilling of impoundments A and B, which were larger, unlined impoundments. Upon completion of the RA, all four impoundments were covered with gravel and asphalt and are currently used as parking areas. This site has only LTS requirements. A review of compliance with these LTS requirements is included in Sect. 2.3.3.1. Background information on this remedy and performance standards are provided in Chap. 2 of Vol. 1 of the 2007 RER (DOE 2007a).

No post-action performance monitoring of groundwater or surface water was specified in the decision documents.

\subsubsection{Compliance with LTS Requirements}

\subsection{Requirements}

The RAR (DOE 2003b) states that no institutional controls are needed at the site. However, it does state that institutional controls that limit excavation will remain in place for potential residual subsurface contamination around the site.

\subsection{Status of Requirements for FY 2009}

The site underwent an annual inspection in FY 2009 by the ORNL S\&M Program to check for evidence of unauthorized excavation/penetration without a valid permit. No unacceptable activity was noted.

In addition, both primary workgroups of this area, UT-Battelle and BJC, have an EPP program with procedures that do not allow for unauthorized excavations/penetrations in this area. 


\subsubsection{Metal Recovery Facility Removal Action}

Location of the Metal Recovery Facility (MRF) Removal Action is shown on Figure 2.1. The scope of this action included removal of surface structures to slab, leaving in place the concrete floor slab, foundation, and other subsurface structures. The floor slab area was sealed and the slab and surrounding yard areas were covered with a minimum two inches of gravel. Final disposition of the slab and subsurface structures has been deferred to the BV ROD. This site has only LTS requirements. A review of compliance with these LTS requirements is included in Sect. 2.3.4.1. Background information on this remedy and performance standards are provided in Chap. 2 of Vol. 1 of the 2007 RER (DOE 2007a).

No surface water or groundwater monitoring is required to verify the effectiveness of the removal action.

\subsubsection{Compliance with LTS Requirements}

\subsection{Requirements}

LTS requirements specified in the RmAR (DOE 2003c) include S\&M activities to ensure that the gravel cover is not grossly disturbed in a manner that might expose subsurface contamination. In the event that the gravel cover is disturbed, the minimum two inches gravel protective cover over the epoxy barrier coating will be restored. The RmAR also requires that the site be posted as an underground contamination area.

\subsection{Status of Requirements for FY 2009}

The site underwent an annual inspection in FY 2009 performed by the ORNL S\&M Program to monitor the condition of the gravel cover and ensure that the signs denoting that the area has underground contamination are present and visible and firmly in place. No maintenance was required. 


\subsection{BETHEL VALLEY MONITORING CHANGES AND RECOMMENDATIONS}

Table 2.11 summarizes recommendations for the BV Watershed and carries forward the issue of ungauged flux in BV from the 2006 RER/CERCLA FYR (DOE 2007b) for tracking purposes until final resolution.

In FY 2009, the Corehole 8 Plume collection system did not meet RmAR goals (Sect. 2.3.1.2). It is recommended that ORNL's water leaks are diligently repaired and an evaluation of the Corehole 8 system is completed. The recommendations are included in Table 2.11 .

During FY 2009, ungauged ${ }^{90} \mathrm{Sr}$ flux comprised $20 \%$ of the total flux measured at the 7500 Bridge weir. As discussed in prior years' RERs, causes of the variability of ungauged ${ }^{90} \mathrm{Sr}$ contributions to WOC are under continuing investigation (see Sect. 2.2.2.1.2). A collection of remedial measures required by the BV ROD is ultimately expected to reduce ${ }^{90} \mathrm{Sr}$ releases into the watershed. Until such measures have been completed, baseline monitoring will continue during FY 2010 to more precisely locate specific contributors to the ungauged ${ }^{90} \mathrm{Sr}$ flux in WOC. No changes to monitoring in BV are recommended at this time.

Table 2.11. Summary of BV Watershed technical issues and recommendations

\begin{tabular}{|c|c|}
\hline Issue $^{\mathbf{a}}$ & $\begin{array}{c}\text { Action/ } \\
\text { Recommendation }\end{array}$ \\
\hline $\begin{array}{l}\text { 2010 Current Issue: } \\
\text { 1. Corehole } 8 \text { Plume collection system } \\
\text { performance does not meet RmAR } \\
\text { performance goals. (2010 RER) }\end{array}$ & $\begin{array}{l}\text { 1. The recommended responses to the problems include: 1) identification and } \\
\text { repair of potable water leaks in the vicinity of the contaminant source areas } \\
\text { and plumes which cause contaminant releases and overwhelm collection } \\
\text { systems, and 2) conduct an engineering evaluation of the existing Corehole } 8 \\
\text { Plume collection system and refurbish, as needed, to ensure proper } \\
\text { operation. }\end{array}$ \\
\hline $\begin{array}{l}\text { Issue Carried Forward: } \\
\text { 1. The }{ }^{90} \mathrm{Sr} \text { contamination from non- } \\
\text { point sources has become the } \\
\text { dominant contributor to }{ }^{90} \mathrm{Sr} \text { flux at } \\
\text { the } 7500 \text { Bridge location. SWSA } 3 \\
\text { may also be contributing to } \\
\text { increased flux seen at Raccoon } \\
\text { Creek. }(2006 \mathrm{FYR})^{\mathrm{b}}\end{array}$ & $\begin{array}{l}\text { 1. During FY } 2009 \text {, non-point }{ }^{90} \text { Sr sources comprised less than } 20 \% \text { of the } \\
0.33 \text { Ci measured at } 7500 \text { Bridge compared to the } 35 \% \text { comprised by } \\
\text { Corehole } 8 \text { Plume discharges to First Creek. Sampling will occur during } \\
\text { FY } 2010 \text { to determine if excess ungauged }{ }^{90} \text { Sr impacts BV ROD goals. }\end{array}$ \\
\hline
\end{tabular}

${ }^{a}$ An issue identified as a "Current lssue" indicates an issue identified during evaluation of current FY 2009 data for inclusion in the 2010 RER.

'The year in which the issue originated is provided in parentheses, e.g., (2006 FYR). 


\section{CERCLA ACTIONS IN MELTON VALLEY WATERSHED}

\subsection{INTRODUCTION AND OVERVIEW}

This chapter provides an update of the effectiveness of ongoing and completed CERCLA actions in MV Watershed during FY 2009. Table 3.1 lists CERCLA actions within the watershed and Figure 3.1 shows the locations of those actions. Only sites that have performance monitoring and LTS requirements, as noted in Table 3.1, are included in the performance evaluations provided herein. In subsequent sections, performance goals and objectives, monitoring results, and an assessment of the effectiveness of each completed action are presented. RAOs that form the basis for the interim RAs conducted as part of the MV ROD are based on future land uses outlined on Figure 3.2. These future land uses require certain restrictions regarding site access and allowable activities within the area as summarized in the LTS requirements.

A summary of LTS requirements is provided in Table 3.2, and a review of compliance with these requirements is included in Sect. 3.2.5, Sect. 3.3.1.1, Sect. 3.3.2.1, and Sect. 3.3.3.1.

For background information on each remedy and performance standards, a compendium of all CERCLA decisions in the watershed within the context of a contaminant release conceptual model is provided in Chap. 3 of Vol. 1 of the 2007 RER (DOE 2007a). This information will be updated in the annual RER and republished every fifth year at the time of the CERCLA FYR.

\subsubsection{Status and Updates}

The PCCR (DOE 2008h) documenting the completion of the Fuel Salt Disposition (FSD) project conducted at the Molten Salt Reactor Experiment (MSRE) facility was approved in October 2008. This FSD action included the sequential processing of each of the three MSRE drain tanks to: (1) melt and chemically treat the salts, (2) fluorinate the salt to remove uranium, (3) trap the uranium on cold traps and transfer the uranium to chemical traps $(\mathrm{NaF})$, and (4) ship the uranium loaded traps to ORNL Bldg. 3019A for storage. Per agreement with the three parties to the FFA, the ROD requirements relative to the MSRE uranium were considered completed when the uranium was delivered to Bldg. 3019A. The ROD commitment to transfer the residual TRU salts to shielded canisters and interim storage at the ORNL SWSA 5 has been delayed and will be addressed in the MSRE RAR. No monitoring or LTS activities are required by the PCCR.

In FY 2009, planning began on the installation of a series of offsite monitoring wells. The wells are located west of the Clinch River and MV. The purpose for offsite well installation is to evaluate potential groundwater communication beneath the Clinch River between DOE land and an area of offsite groundwater use. The wells will be arranged in clusters with four wells per cluster, up to four clusters are possible, pending negotiation of access agreements. The target monitoring zone elevation ranges are $200-$ $250 \mathrm{ft} \mathrm{msl}, 400-450 \mathrm{ft} \mathrm{msl}, 600-650 \mathrm{ft} \mathrm{msl}$, and 720 to $750 \mathrm{ft} \mathrm{msl}$. Drilling is scheduled to begin in FY 2010.

Errata to the MV RAR (DOE 2007g) were submitted on two occasions during FY 2009. In June 2009 the first set was approved and replaced Chap. 7 of the RAR, Land Use Controls, with changes to the sign locations and access controls along with changes to the requirements for State Advisory Postings. Specifically, the locations of signs changed to support current site conditions. Access control locations specified in the MV RAR were also modified. Access control locations are now located with the proposed sign locations. This includes eliminating several interior locations in which gates remain open 
Table 3.1 CERCLA actions in MV Watershed

\begin{tabular}{|c|c|c|c|c|}
\hline CERCLA action & $\begin{array}{l}\text { Decision document, date signed } \\
(\mathrm{mm} / \mathrm{dd} / \mathrm{yy})\end{array}$ & Action/Document status ${ }^{a}$ & $\begin{array}{c}\text { Monitoring/ } \\
\text { LTS } \\
\text { required }\end{array}$ & $\begin{array}{c}\text { RER } \\
\text { section }\end{array}$ \\
\hline \multicolumn{5}{|c|}{ Watershed-scale actions } \\
\hline \multirow[t]{13}{*}{ MV Interim Actions } & ROD (DOE/OR/01-1826\&D3): 09/21/00 & $\begin{array}{l}\text { RAR (DOE/OR/01-2343\&D1) 09/5/07 } \\
\text { (DOE/OR/01-2343\&D1/A1) 06/25/09 } \\
\text { (DOE/OR/01-2343\&D1/A2) submitted } \\
\text { 08/5/09, pending approval }\end{array}$ & Yes/Yes & 3.2 \\
\hline & ROD (DOE/OR/01-2170\&D1): 09/7/04 & PCCRs approved: & & \\
\hline & $\begin{array}{l}\text { Amendment to change remediation approach } \\
\text { for Trenches } 5 \& 7 \text { to ISG. }\end{array}$ & $\begin{array}{l}\text { Hydrofracture Well Plugging \& Abandonment } \\
\text { (DOE/OR/01-2138\&D1) 07/14/06 }\end{array}$ & & \\
\hline & & $\begin{array}{l}\text { New Hydrofracture Facility D\&D } \\
\text { (DOEOR/01-2306\&D1) 07/31/06 }\end{array}$ & & \\
\hline & $\begin{array}{l}\text { ESD (DOE/OR/01-2040\&D2): 03/12/04 } \\
\text { Add Tumulus } 1 \text { and } 2 \text { and the Intermediate }\end{array}$ & $\begin{array}{l}\text { Trenches } 5 \text { and } 7 \text { and HRE Fuel Wells In Situ } \\
\text { Grouting (DOE/OR/01-2302\&D1) 08/14/06 }\end{array}$ & & \\
\hline & $\begin{array}{l}\text { Waste Management Facility to the scope of } \\
\text { the Interim ROD. }\end{array}$ & $\begin{array}{l}\text { Hydrologic Isolation at SWSA } 6 \\
\text { (DOE/OR/01-2285\&D1) 09/6/06 }\end{array}$ & & \\
\hline & $\begin{array}{l}\text { ESD (DOE/OR/01-2165\&D1): 09/7/04 } \\
\text { Modify requirements for } 11 \text { waste units. }\end{array}$ & $\begin{array}{l}\text { SWSA } 4 \text { and Intermediate Holding Pond } \\
\text { (DOE/OR/01-2300\&D1) 09/11/06 }\end{array}$ & & \\
\hline & & $\begin{array}{l}\text { Old Hydrofracture Facility D\&D } \\
\text { (DOE/OR/01-2014\&D2) 09/26/06 }\end{array}$ & & \\
\hline & $\begin{array}{l}\text { ESD (DOE/OR/01-2249\&D1): 09/13/05 } \\
\text { Remove seven facilities from MSRE D\&D. }\end{array}$ & $\begin{array}{l}\text { Hydrologic Isolation at Seepage Pits and Trenches } \\
\text { (DOE/OR/01-2310\&D1) 10/2/06 }\end{array}$ & & \\
\hline & & Soils and Sediments (DOE/OR/01-2315\&D1) 10/2/06 & & \\
\hline & $\begin{array}{l}\text { ESD: DOE/OR/01-2333\&D1): } 12 / 27 / 06 \\
\text { Remove five STTs from D\&D scope. }\end{array}$ & $\begin{array}{l}\text { HRE Ancillary Facilities D\&D } \\
\text { (DOE/OR/01-2307\&D1) 10/4/06 }\end{array}$ & & \\
\hline & LUCIP (DOE/OR/01-1977\&D6): 05/24/06 & $\begin{array}{l}7841 \text { Equipment Storage Area and 7802F Storage Shed } \\
\text { D\&D (DOE/OR/01-2323\&D1) 10/5/06 }\end{array}$ & & \\
\hline & & $\begin{array}{l}\text { Hydrologic Isolation at SWSA } 5 \\
\text { (DOE/OR/01-2286\&D1) } 11 / 6 / 06\end{array}$ & & \\
\hline \multicolumn{5}{|c|}{ Single-project actions } \\
\hline WOCE & AM (Letter): $11 / 9 / 90$ & RmAR (ORNL/ER/Sub/91-KA931/4) approved 09/30/92. & No/Yes & 3.3.1 \\
\hline WAG 13 Cesium Plots & IROD (DOE/OR/01-1059\&D4): 10/6/92 & $\begin{array}{l}\text { RAR Postclosure report (DOE/OR/01-1218\&D2) } \\
\text { approved 8/25/94. }\end{array}$ & No/Yes & 3.3 .2 \\
\hline
\end{tabular}


Table 3.1. CERCLA actions in MV Watershed (cont.)

\begin{tabular}{|c|c|c|c|c|}
\hline CERCLA action & $\begin{array}{l}\text { Decision document, date signed } \\
(\mathbf{m m} / \mathbf{d d} / \mathbf{y y})\end{array}$ & Action/Document status ${ }^{a}$ & $\begin{array}{l}\text { Monitoring/ } \\
\text { LTS } \\
\text { required } \\
\end{array}$ & $\begin{array}{c}\text { RER } \\
\text { section }\end{array}$ \\
\hline WAG 5 Seep C & AM (DOE/OR/02-1235\&D2): 03/30/94 & $\begin{array}{l}\text { RmAR Postclosure Report (DOE/OR/01-1334\&D2) } \\
\text { approved 06/22/95. } \\
\text { System shutdown prior to capping. }\end{array}$ & Discontinued & - \\
\hline WAG 5 Seep $D^{b}$ & AM (DOE/OR/02-1283\&D2): 07/26/94 & $\begin{array}{l}\text { RmAR Postclosure Report (DOE/OR/01-1334\&D2) } \\
\text { approved 06/22/95. } \\
\text { Collection of contaminated groundwater ongoing. }\end{array}$ & Superseded & -- \\
\hline WAG 4 Seep Control & $\mathrm{AM}$ (DOE/OR/02-1440\&D2): 02/12//96 & RmAR (DOE/OR/01-1544\&D2) approved 03/5/98. & Discontinued & -- \\
\hline $\begin{array}{l}\text { MSRE D\&D Reactive } \\
\text { Gas }\end{array}$ & AM (Letter): 06/12/95 & RmAR (DOE/OR/01-1623\&D2) approved 02/12/98. & No/No & -- \\
\hline $\begin{array}{l}\text { MSRE D\&D Uranium } \\
\text { Deposit Removal }\end{array}$ & AM (DOE/OR/02-1488\&D2): 08/6/96 & RmAR (DOE/OR/01-1918\&D2) approved 12/18/01. & No/Yes & 3.3 .3 \\
\hline OHF Tank Sludges & AM (DOE/OR/02-1487\&D2): 09/12/96 & RmAR (DOE/OR/01-1759\&D1) approved 12/15/98. & No/No & - \\
\hline \multirow{2}{*}{$\begin{array}{l}\text { OHF Tanks and } \\
\text { Impoundment }\end{array}$} & AM (DOE/OR/01-1751\&D3): 05/14/99 & \multirow[t]{2}{*}{ RmAR (DOE/OR/01-1908\&D2) approved 05/11/2001. } & \multirow[t]{2}{*}{ Discontinued } & \multirow[t]{2}{*}{--} \\
\hline & $\begin{array}{l}\text { AM Addendum (DOE/OR/01-1866\&D2): } \\
03 / 31 / 00\end{array}$ & & & \\
\hline \multirow[t]{2}{*}{$\begin{array}{l}\text { MSRE D\&D Fuel Salt } \\
\text { Removal }\end{array}$} & ROD (DOE/OR/02-1671\&D2): 07/7/98 & \multirow[t]{2}{*}{$\begin{array}{l}\text { PCCR [DOE/OR/01-2256\&D1 (removal and transfer of } \\
\text { uranium from the MSRE Facility)] 10/10/08. }\end{array}$} & \multirow[t]{2}{*}{ No/No } & \multirow[t]{2}{*}{--} \\
\hline & $\begin{array}{l}\text { ESD (DOE/OR/01-2088\&D2) approved: } 01 / 19 / 07 \\
\text { Delete requirement to convert MRSE }{ }^{233} U \text { to an } \\
\text { oxide. }\end{array}$ & & & \\
\hline
\end{tabular}

${ }^{a}$ Detailed information on the status of actions is from Appendix $E$ of the FFA. The most up-to-date status of schedule information is available at $<$ http://www.bechteljacobs.com/ettp ffa appendices.shtml>.

${ }^{b}$ The Seep D treatment system was dismantled during MV ROD RAs. The groundwater collection sump was incorporated into the MV ROD groundwater collection system.

ESD $=$ Explanation of Significant Difference

HRE $=$ Homogeneous Reactor Experiment

IROD = Interim Record of Decision

ISG $=$ in situ grouting

$\mathrm{OHF}=$ Old Hydrofracture Facility

STT $=$ Shielded Transfer Tanks

$\mathrm{TBD}=$ to be determined

WOCE $=$ White Oak Creek Embayment 
This page intentionally left blank. 

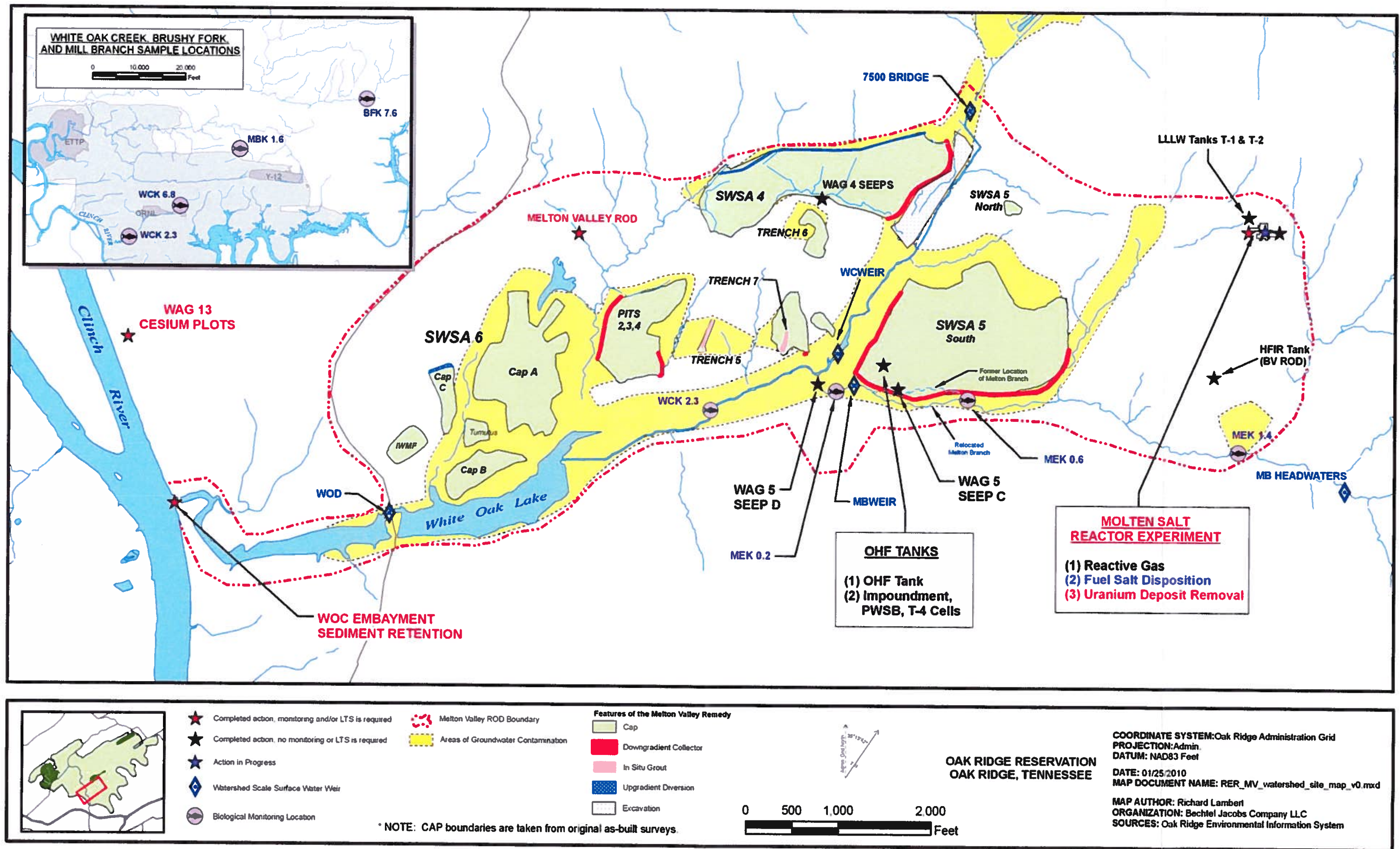

Figure 3.1 MV Watershed site map. 
This page intentionally left blank. 

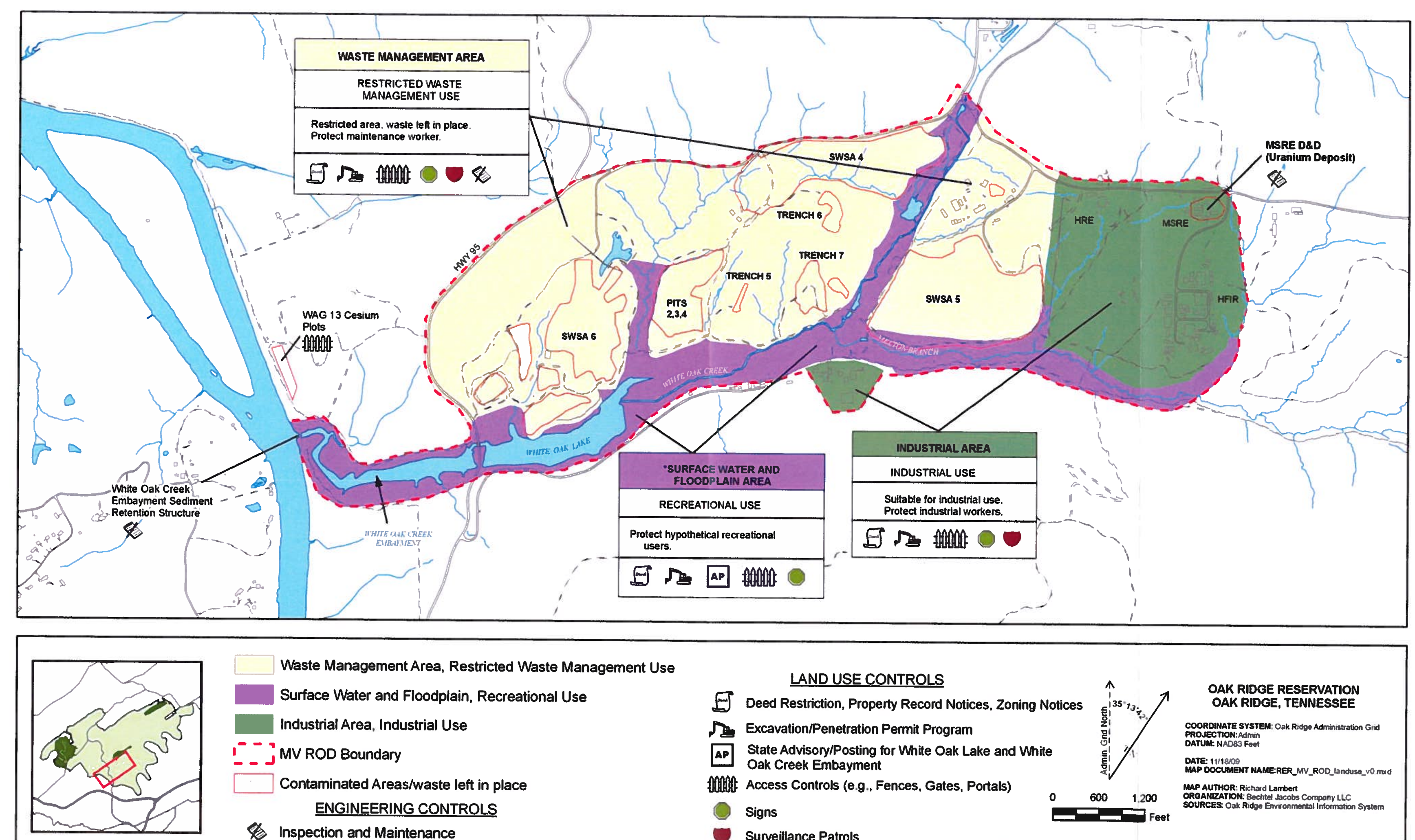

Waste Management Area, Restricted Waste Management Use

Surface Water and Floodplain, Recreational Use

Industrial Area, Industrial Use

- . J MV ROD Boundary

Contaminated Areas/waste left in place

ENGINEERING CONTROLS

Inspection and Maintenance

\section{LAND USE CONTROLS}

E Deed Restriction, Property Record Notices, Zoning Notices

T. Excavation/Penetration Permit Program

AP. State Advisory/Posting for White Oak Lake and White

Access Controls (e.g., Fences, Gates, Portals)

Signs

$\checkmark$ Surveillance Patrols 
This page intentionally left blank. 
Table 3.2. LTS requirements for CERCLA actions in MV Watershed

\begin{tabular}{|c|c|c|c|c|}
\hline \multirow[b]{2}{*}{ Site/Project } & \multicolumn{2}{|c|}{ LTS Requirements } & \multirow[b]{2}{*}{ Status } & \multirow{2}{*}{$\begin{array}{c}\mathbf{R E R} \\
\text { section }\end{array}$} \\
\hline & LUCs & Engineering controls & & \\
\hline \multicolumn{5}{|c|}{ Watershed-scale actions } \\
\hline $\begin{array}{l}\text { ROD for Interim Actions } \\
\text { for the MV Watershed } \\
\text { - SWSA } 4 \text { and IHP } \\
\text { PCCR } \\
\text { - SWSA } 5 \text { PCCR } \\
\text { - SWSA } 6 \text { PCCR } \\
\text { - Seepage Pits and } \\
\text { Trenches PCCR } \\
\text { - Trenches } 5 \text { and } 7 \text { PCCR } \\
\text { - Soils and Sediments } \\
\text { PCCR } \\
\text { - Hydrofracture Well } \\
\text { P\&A PCCR } \\
\text { - NHF D\&D PCCR } \\
\text { - OHF D\&D PCCR } \\
\text { - HRE Ancillary } \\
\text { Facilities D\&D PCCR } \\
\text { - 7841 Equipment } \\
\text { Storage Area and 7802F } \\
\text { Storage Shed D\&D } \\
\text { PCCR }\end{array}$ & $\begin{array}{l}\text { Watershed LUCs } \\
\text { Administrative: } \\
\text { - land use and groundwater } \\
\text { deed restrictions } \\
\text { - property record notices } \\
\text { - zoning notices } \\
\text { - permits program } \\
\text { Physical: } \\
\text { " state advisory / postings } \\
\text { - access controls } \\
\text { - signs } \\
\text { - security patrols }\end{array}$ & $\begin{array}{l}\text { Hydrologic Isolation } \\
\text { Projects }{ }^{\mathrm{a}} \text { PCCRs specific: } \\
\text { - Maintain caps }\end{array}$ & $\begin{array}{l}\text { Watershed LUCs } \\
\text { implemented under } \\
\text { LUCIP: } \\
\text { - Physical LUCs in place. } \\
\text { - Administrative LUCs in } \\
\text { place. } \\
\text { - RCRA required notices } \\
\text { complete. } \\
\text { Hydrologic Isolation } \\
\text { Projects }{ }^{\mathrm{g}, \mathrm{b}} \text { PCCRs } \\
\text { specific: } \\
\text { - Engineering controls } \\
\text { remain protective. }\end{array}$ & 3.2 .5 \\
\hline \multicolumn{5}{|c|}{ Completed single project actions } \\
\hline $\begin{array}{l}\text { White Oak Creek } \\
\text { Embayment Sediment } \\
\text { Retention Structure }\end{array}$ & & $\begin{array}{l}\text { - Inspection and } \\
\text { maintenance of SRS }\end{array}$ & $\begin{array}{l}\text { - Engineering controls } \\
\text { remain protective. }\end{array}$ & 3.3 .1 .1 \\
\hline $\begin{array}{l}\text { WAG } 13 \text { Cesium Plots } \\
\text { Interim Remedial Action }\end{array}$ & $\begin{array}{l}\text { Long-term S\&M of the } \\
\text { fenced enclosure }\end{array}$ & & - LUCs in place. & 3.3 .2 .1 \\
\hline $\begin{array}{l}\text { MSRE D\&D (Uranium } \\
\text { Deposit) Removal Action }\end{array}$ & & - Ongoing S\&M & $\begin{array}{l}\text { Engineering controls } \\
\text { remain protective. }\end{array}$ & 3.3 .3 .1 \\
\hline
\end{tabular}

"Hydrologic Isolation Projects include SWSA 4, SWSA 5, SWSA 6, and Seepage Pits and Trenches area.

'Zoning Notices will be filed with the City Planning Commission if/when areas are to be transferred out of DOE federal control

HRE = Homogeneous Reactor Experiment

IHP = Intermediate Holding Pond

NHF $=$ New Hydrofracture Facility

$\mathrm{OHF}=$ Old Hydrofracture Facility

P\&A = plugging and abandonment

RCRA = Resource Conservation and Recovery Act of 1976

SRS $=$ Sediment Retention Structure

continuously, and adding locations at White Oak Dam (WOD). In addition to these changes, errata also included changes to the State Advisory Postings, specifically, changes to reflect that the DOE will continue to place appropriate signs at the WOL and the WOC to provide notice to resource users of contamination and risks associated with uses. These changes do not prevent future postings of these waters by the State. This change does allow DOE to fully meet the intent of this requirement. The second erratum was submitted to the regulators in August 2009. These changes better represent how the City of Oak Ridge is prepared to handle zoning information provided by the DOE for land on the ORR. The City had informed DOE that they will not record, maintain, or consider zoning changes until transference of 
the Reservation property to a non-Federal entity, which would then be added to the City tax rolls. Until that time, they will maintain the current zoning of the Reservation as federal-controlled industrial/research (FIR) areas. 


\subsection{RECORD OF DECISION FOR INTERIM ACTIONS IN MELTON VALLEY WATERSHED}

This section presents the remediation goals, performance metrics, and progress toward achieving the goals in the MV Watershed. Annual performance measurements obtained during FY 2009 are presented along with historic monitoring results.

\subsubsection{Performance Goals and Monitoring Objectives}

The MV ROD specified surface water quality, surface water risk goals, and groundwater controls to be achieved within specified periods after completion of the RAs. The ROD also included specific performance objectives that would be used as the metrics to evaluate the effectiveness of the remediation. These goals and metrics are presented below. The evaluation of performance during FY 2009 is presented in Sect. 3.2.2.

The MV ROD stipulated a RAO for MV based on the industrial use area (east of SWSA 5), the Waste Management Area, the Surface Water and Floodplain Area, and for human receptors and ecological populations (Table 3.3). Highlighted portions of the RAO are supported by ongoing monitoring and are discussed in detail in subsequent sections for this RER.

Table 3.3. RAO for the MVWatershed selected remedy, ORNL, Oak Ridge, Tennessee

\begin{tabular}{|c|c|}
\hline Area/receptor & Goal \\
\hline $\begin{array}{l}\text { Waste management area } \\
\text { (includes SWSA 4, 5, and } \\
6 \text { and Seepage Pits and } \\
\text { Trenches) }\end{array}$ & $\begin{array}{l}\text { - Manage waste disposal sites as a restricted waste management area } \\
\text { - Protect maintenance workers } \\
\text { - Meet AWQC in surface water in a reasonable amount of time } \\
\text { - Mitigate further impact to groundwater }\end{array}$ \\
\hline $\begin{array}{l}\text { Industrial use area } \\
\text { (generally the area east } \\
\text { of SWSA 5) }\end{array}$ & $\begin{array}{l}\text { - Manage areas generally east of SWSA } 5 \text { as an industrial area } \\
\text { - Protect industrial workers } \\
\text { - Meet AWQC in surface water in a reasonable amount of time } \\
\text { - Mitigate further impact to groundwater }\end{array}$ \\
\hline $\begin{array}{l}\text { Surface water and } \\
\text { floodplain area }\end{array}$ & $\begin{array}{l}\text { - Achieve numeric and narrative AWQC for waters of the state in a reasonable } \\
\text { amount of time } \\
\text { - Remediate contaminated floodplain soils to } 2500 \mu R / h o u r^{b} \\
\text { - Protect an off-site resident user of surface water at the confluence of White Oak } \\
\text { Creek with the Clinch River from contaminant sources in Melton Valley } \\
\text { - Make progress toward meeting Clinch River's stream use classification as a } \\
\text { drinking water source at confluence of White Oak Creek with the Clinch River }\end{array}$ \\
\hline Human receptors & $\begin{array}{l}\text { - Protect maintenance workers, industrial workers, and off-site resident users of } \\
\text { surface water (at the confluence of White Oak Creek with the Clinch River) to a } \\
10^{-4} \text { to } 10^{6} \text { excess lifetime cancer risk and an HI of l } \\
\text { - Protect hypothetical recreational users of waters of the state }{ }^{c}\end{array}$ \\
\hline Ecological receptors & - Protect ecological populations ${ }^{d}$ \\
\hline
\end{tabular}

"Source: MV ROD Table 1.1.

${ }^{b}$ A future CERCLA decision will be prepared to determine whether additional actions are required for floodplain soll $<2500 \mu R /$ hour. 
Table 3.3. RAO for the MV Watershed selected remedy, ORNL, Oak Ridge, Tennessee (cont.)

'This remedy addresses water quality but does not fully address fish consumption or sediment/floodplain soil contact or exposure under the recreational scenario. This remedy protects the hypothetical recreational user through a combination of remedial actions including land use controls. A future CERCLA decision will be prepared to assess whether any additional actions are required. Additional data collection and evaluation will be conducted as part of this remedy to further assess the status of ecological receptors in these areas. Results of this ecological monitoring and any additional actions, as necessary, will be included in a future remedial decision.

${ }^{d} T h e$ selected remedy enhances overall protection of valleywide ecological populations and subbasin-level populations over a majority of the valley. However, portions of the valley that are not addressed by the selected remedy may pose potential unacceptable risks to ecological receptors.

HI = hazard index

The MV ROD included specific performance objectives and performance measures that form the basis of remediation effectiveness monitoring. These performance objectives provide a quantitative basis to evaluate the effectiveness of hydrologic isolation at limiting contaminant releases from buried waste by monitoring groundwater fluctuation within hydrologic isolation areas. Additionally, the performance measure for surface water quality is to achieve the AWQC numeric and narrative goals related to contaminant discharges originating from MV areas within two years after completion of RAs. Table 3.4 includes the ROD performance objectives and performance measures for those elements of the remedy that specified post-remediation monitoring. Also, included in Table 3.4 are goal attainment dates and references to sections in this RER where the annual status of performance for each metric are discussed.

During the design process for in situ grouting (ISG) of Liquid Waste Seepage Trenches 5 and 7, a groundwater quality monitoring plan was prepared and implemented to monitor 13 wells in the vicinity of those two units for water quality evaluation. Results of that sampling and analyses are included in Sect. 3.2.2.2.3.

Groundwater emanating from capped waste areas is collected by downgradient interceptor trenches at SWSA 5; along the eastern edge of SWSA 4; southeast of Trench 7; along the eastern and western sides of Pits 2, 3, and 4; and at Seep D. The system includes some 30+ pumps that are operated based on automated level controls in the groundwater collection areas. The collected groundwater is all routed to an equalization tank located at SWSA 4 before transfer to the ORNL PWTC in BV. Water at the equalization tank is sampled to verify that the wastewater meets the facility waste acceptance criteria (WAC). 
Table 3.4. Performance measures for major actions in the Melton Valley Watershed, ORNL, Oak Ridge, Tennessee

\begin{tabular}{|c|c|c|}
\hline $\begin{array}{l}\text { Unit typel } \\
\text { unit names } \\
\text { project scope }\end{array}$ & Performance objectives & $\begin{array}{l}\text { Performance measure, } \\
\text { Attainment schedule and RER section }\end{array}$ \\
\hline $\begin{array}{l}\text { SWSA } 4 \\
\text { - } \text { SWSA } 4 \\
\text { Liquid Seepage Pit } 1 \& \\
\text { Secondary Media } \\
\text { - Inactive Waste Transfer Lines } \\
\text { @ Lagoon Rd. } \\
\text { - Pilot Pits Area } \\
\text { - Shallow Well P\&A }\end{array}$ & $\begin{array}{l}\text { - Contain disposed \& contaminated } \\
\text { materials } \\
\text { Meet RAO for the waste management use } \\
\text { area [soil] }\end{array}$ & $\begin{array}{l}\text { Prevent releases from SWSA } 4 \text { from } \\
\text { causing AWQC exceedances in waters of } \\
\text { the state within } 2 \text { years after SWSA } 4 \\
\text { construction is complete (Fall 2008). }{ }^{c} \\
\text { [See Sect. 3.2.2.1.3] } \\
\text { Reduce SWSA } 4 \text { contaminant releases to } \\
\text { surface water by approximately } 80 \% \text { to } \\
\text { meet computed } 1 X 10^{-4} \text { total residential } \\
\text { risk at the confluence of White Oak } \\
\text { Creek with Clinch River in } \sim 10 \text { years } \\
\text { after all ROD actions are complete } \\
\text { (2016). [See Sect. 3.2.2.1] } \\
\text { Reduce groundwater through flow in } \\
\text { buried waste units by }>75 \% \text { as measured } \\
\text { by }>75 \% \text { decrease in water level } \\
\text { fluctuations in selected monitoring } \\
\text { locations inside the contained area [See } \\
\text { Sect. 3.2.2.2] }\end{array}$ \\
\hline $\begin{array}{l}\text { SWSA } 5 \text { South } \\
\text { - SWSA } 5 \text { South } \\
\text { - Stabilized OHF Pond and } \\
\text { Tanks } \\
\text { - Stabilized subsurface OHF } \\
\text { facilities } \\
\text { Contaminated soils at OHF } \\
\text { site } \\
\text { - Shallow Well P\&A }\end{array}$ & $\begin{array}{l}\text { - } \quad \text { Contain disposed materials } \\
\text { Meet } R A O \text { for the waste management use } \\
\text { area [soil] }\end{array}$ & $\begin{array}{l}\text { Prevent releases from SW } 5 \text { South from } \\
\text { causing AWQC exceedances in waters of } \\
\text { the state in Melton Branch, Lower HRE } \\
\text { Tributary, and SWSA } 5 \text { DI within } 2 \text { years } \\
\text { after SWSA } 5 \text { South construction is } \\
\text { complete (Fall 2008). }{ }^{c} \text { [See Sect. } \\
3.2 .2 .1 .3 \text { ] } \\
\text { Reduce SWSA } 5 \text { contaminant releases to } \\
\text { surface water by approximately } 80 \% \text { to } \\
\text { meet computed I X } 10^{-4} \text { total residential } \\
\text { risk at the confluence of White Oak } \\
\text { Creek with Clinch River in } \sim 10 \text { years } \\
\text { after all ROD actions are complete } \\
\text { (2016). [See Sect. } 3.2 .2 .1] \\
\text { Reduce groundwater throughflow in } \\
\text { buried waste units by }>75 \% \text { as measured } \\
\text { by }>75 \% \text { decrease in water level } \\
\text { fluctuations in selected monitoring } \\
\text { locations inside the contained area [See } \\
\text { Sect. 3.2.2.2] }\end{array}$ \\
\hline - SWSA 5 North 4 trenches & $\begin{array}{l}\text { - Contain disposed materials } \\
\text { - Meet RAO for the waste management use } \\
\text { area [soil] }\end{array}$ & $\begin{array}{l}\text { - Verify that groundwater does not contact } \\
\text { the buried waste through water level } \\
\text { monitoring in and adjacent to the } \\
\text { trenches after capping. [See Sect. } \\
3.2 .2 .2 \text { ] }\end{array}$ \\
\hline $\begin{array}{l}\text { SWSA } 6 \\
\text { - SWSA } 6 \\
\text { - Shallow Well P\&A }\end{array}$ & $\begin{array}{l}\text { - Contain disposed materials } \\
\text { - Meet RAO for the waste management } \\
\text { area [soil] }\end{array}$ & $\begin{array}{l}\text { Prevent releases from SWSA } 6 \text { from } \\
\text { causing AWQC exceedances in waters of } \\
\text { the state within } 2 \text { years after SWSA } 6 \\
\text { construction is complete (Fall 2008). } \\
\text { [See Sect. 3.2.2.1.3] } \\
\text { Comply with RCRA postclosure } \\
\text { requirements for designated RCRA areas } \\
\text { (Ongoing). [See Sect. 3.2.2.2.3] }\end{array}$ \\
\hline
\end{tabular}


Table 3.4. Performance measures for major actions in the Melton Valley Watershed, ORNL, Oak Ridge, Tennessee" (cont.)

\begin{tabular}{|c|c|c|}
\hline $\begin{array}{l}\text { Unit typel } \\
\text { unit names } \\
\text { project scope }\end{array}$ & Performance objectives & $\begin{array}{l}\text { Performance measure, } \\
\text { Attainment schedule and RER section }\end{array}$ \\
\hline & & $\begin{array}{l}\text { Reduce groundwater throughflow in } \\
\text { buried waste units by }>75 \% \text { as } \\
\text { measured by }>75 \% \text { decrease in water } \\
\text { level fluctuations in selected monitoring } \\
\text { locations inside the contained area. } \\
\text { [See Sect. } 3.2 .2 .2 \text { ] }\end{array}$ \\
\hline $\begin{array}{l}\text { Pits 2, 3, and } 4 \text { and Trench } 6 \\
\text { - Liquid seepage pits } \\
\text { - Inactive waste pipelines } \\
\text { - Shallow well P\&A }\end{array}$ & $\begin{array}{l}\text { - Contain disposed materials } \\
\text { - Meet } R A O \text { for the waste management use } \\
\text { area [soil] }\end{array}$ & $\begin{array}{l}\text { Prevent releases from Liquid Waste } \\
\text { Seepage Pits 2, 3, and 4, and Trench } 6 \\
\text { from causing AWQC exceedances in } \\
\text { waters of the state within } 2 \text { years after } \\
\text { construction is complete (Fall 2008). } \\
\text { [See Sect. 3.2.2.1.3] } \\
\text { Reduce groundwater throughflow in the } \\
\text { contained area by >75\% as measured by } \\
>75 \% \text { decrease in water level } \\
\text { fluctuations in selected monitoring } \\
\text { locations inside the contained area [See } \\
\text { Sect. 3.2.2.2] }\end{array}$ \\
\hline $\begin{array}{l}\text { Trenches } 5 \text { and } 7 \\
\text { - Liquid seepage trenches } \\
\text { - Inactive waste pipelines } \\
\text { - Shallow well P\&A }\end{array}$ & $\begin{array}{l}\text { - Immobilize disposed materials. } \\
\text { Meet RAO for the waste management use } \\
\text { area [soil] }\end{array}$ & $\begin{array}{l}\text { Prevent releases from Seepage Trenches } \\
5 \text { and } 7 \text { from causing AWQC } \\
\text { exceedances in waters of the state within } \\
2 \text { years after ISV is complete (Fall } \\
2008 \text { ). }{ }^{C} \text { [See Sect. } 3.2 .2 .1 .3 \text { ] } \\
\text { Vitrify any additional contaminated soils } \\
\text { that cause contamination of groundwater } \\
\text { leading to surface water exceedances. }\end{array}$ \\
\hline Surface water quality & $\begin{array}{l}\text { - Meet TDEC numeric AWQC and } \\
\text { narrative (risk-based) water quality } \\
\text { criteria in all waters of the state for } \\
\text { specified uses. } \\
\text { - Meet risk levels for hypothetical } \\
\text { recreational water use (contact and } \\
\text { consumption under the recreational } \\
\text { exposure scenaria) }\end{array}$ & $\begin{array}{l}\text { - Achieve numeric AWQC and narrative } \\
\text { (risk-based) water quality criteria in } \\
\text { waters of the state within } 2 \text { years after } \\
\text { completion of all actions that are part of } \\
\text { the selected remedy. Meet recreation use } \\
\text { criteria for water contact and } \\
\text { consumption, excluding fish consumption } \\
\text { (Fall 2008). [See Sect. } 3.2 .2 .1 .3 \text { ] } \\
\text { Reduce contaminant releases to meet } \\
\text { water quality conditions that would allow } \\
\text { hypothetical residential use (risk level of } \\
\text { lX } 10-{ }^{4} \text { for water only - no fish } \\
\text { consumption or sediment contact } \\
\text { scenarios) at confluence with the Clinch } \\
\text { River in } \sim 10 \text { years after completion of all } \\
\text { ROD actions. Reductions in }{ }^{90} \text { Sr and } \\
\text { tritium of } 75-80 \% \text { are required. [See } \\
\text { Sect. 3.2.2.1] }\end{array}$ \\
\hline
\end{tabular}

"Source: MV ROD Table 2.17. NOTE: Non-italicized text within table is referencing sections in the current document.

${ }^{h}$ To meet a target post-remediation risk level of $I \times 10^{-t}$ for surface water under the residential scenario at the mouth of White Oak Creek an $80 \%$ reduction of risk from the sum of individual contaminants from combined sources in Melton Valley is required. This calculation includes anticipated reductions in surface water contaminant risk that originate in Bethel Valley. Reduction of releases from individual source areas in Melton Valley as a result of remedial actions may vary somewhat. For all remediated areas, post-construction surveillance and maintenance monitoring will be implemented, which includes inspection of cap integrity, proper functioning and maintenance of surface water and groundwater flow control features, and conformance with land use control requirements.

'Indicates date goal is to be attained by.

HRE = Homogeneous Reactor Experiment $\mathrm{OHF}=$ Old Hydrofracture Facility
$P \& A=$ plugging and abandonment RCRA = Resource Conservation and Recovery Act of 1976 


\subsubsection{Evaluation of Performance Monitoring Data}

\subsubsection{Surface Water Monitoring Data}

This section presents the results of remedy effectiveness evaluation surface water monitoring in MV. Section 3.2.2.1.1 summarizes the remediation goals for surface water. Section 3.2.2.1.2 presents information concerning major radionuclide concentrations and fluxes at the surface water IP monitoring stations. Section 3.2.2.1.3 presents data obtained at the tributary sampling locations.

\subsection{Surface Water Quality Goals and Monitoring Requirements}

Surface water goals include protection of the Clinch River to meet its stream use classification (e.g., as a domestic water supply), and to achieve AWQC in on-site waters of the state. The ROD included specific surface water remediation levels (RLs), as outlined in Table 3.5. Locations where surface water monitoring occurs to evaluate the remedy performance are shown on Figure 3.3. The following excerpts from the MV ROD (Sect. 2.11.7.3.1 Remediation Levels for Surface Water) include the specific concentration goals for the principal surface water COCs in MV.

Table 3.5. Surface water remediation levels for the Melton Valley Watershed ORNL, Oak Ridge, Tennessee

\begin{tabular}{|c|c|c|c|}
\hline \multirow{2}{*}{$\begin{array}{l}\text { Melton Valley } \\
\text { watershed }\end{array}$} & \multicolumn{2}{|c|}{ Goal: $A W Q C$ in waters of the state } & \multirow[b]{2}{*}{$\begin{array}{l}\text { Residential } \\
\text { risk }\end{array}$} \\
\hline & Numeric AWQC & $\begin{array}{l}\text { Narrative AWQC/ } \\
\text { recreational risk }\end{array}$ & \\
\hline Receptor & $\begin{array}{l}\text { Hypothetical recreational } \\
\text { user; fish and aquatic life }\end{array}$ & Hypothetical recreational user & $\begin{array}{l}\text { Hypothetical off-site } \\
\text { resident }\end{array}$ \\
\hline Areas affected & All waters of the state & All waters of the state & $\begin{array}{l}\text { Confluence of White Oak } \\
\text { Creek with Clinch River }\end{array}$ \\
\hline $\begin{array}{l}\text { Anticipated } \\
\text { compliance locations }\end{array}$ & See Figure 3.3 of RER & See Figure 3.3 of RER & $\begin{array}{l}\text { Confluence of White Oak } \\
\text { Creek with Clinch River }\end{array}$ \\
\hline Remediation level & $\begin{array}{l}\text { Levels established in Rules } \\
\text { of the TDEC Chapter } 1200 \text { - } \\
4-3-.03\end{array}$ & See Table 3.7 of RER & See Table 3.4 of RER \\
\hline Exposure scenarios & $\begin{array}{l}\text { N/A (numeric criteria } \\
\text { tabulated in regulation; no } \\
\text { separate calculation using } \\
\text { exposure scenarios needed) }\end{array}$ & $\begin{array}{l}\text { Hypothetical recreational } \\
\text { swimming for White Oak Lake } \\
\text { and White Oak Creek } \\
\text { Embayment; recreational } \\
\text { wading for White Oak Creek. } \\
\text { Melton Branch, and other } \\
\text { waters of the state. The } \\
\text { exposure scenarios do not take } \\
\text { into account fish ingestion and } \\
\text { sediment contact }\end{array}$ & $\begin{array}{l}\text { Hypothetical residential } \\
\text { (i.e., general household } \\
\text { use) }\end{array}$ \\
\hline
\end{tabular}

aSource: MV ROD Table 2.18. NOTE: Non-italicized text within table is referencing figures and tables in the current document $N / A=$ not applicable 


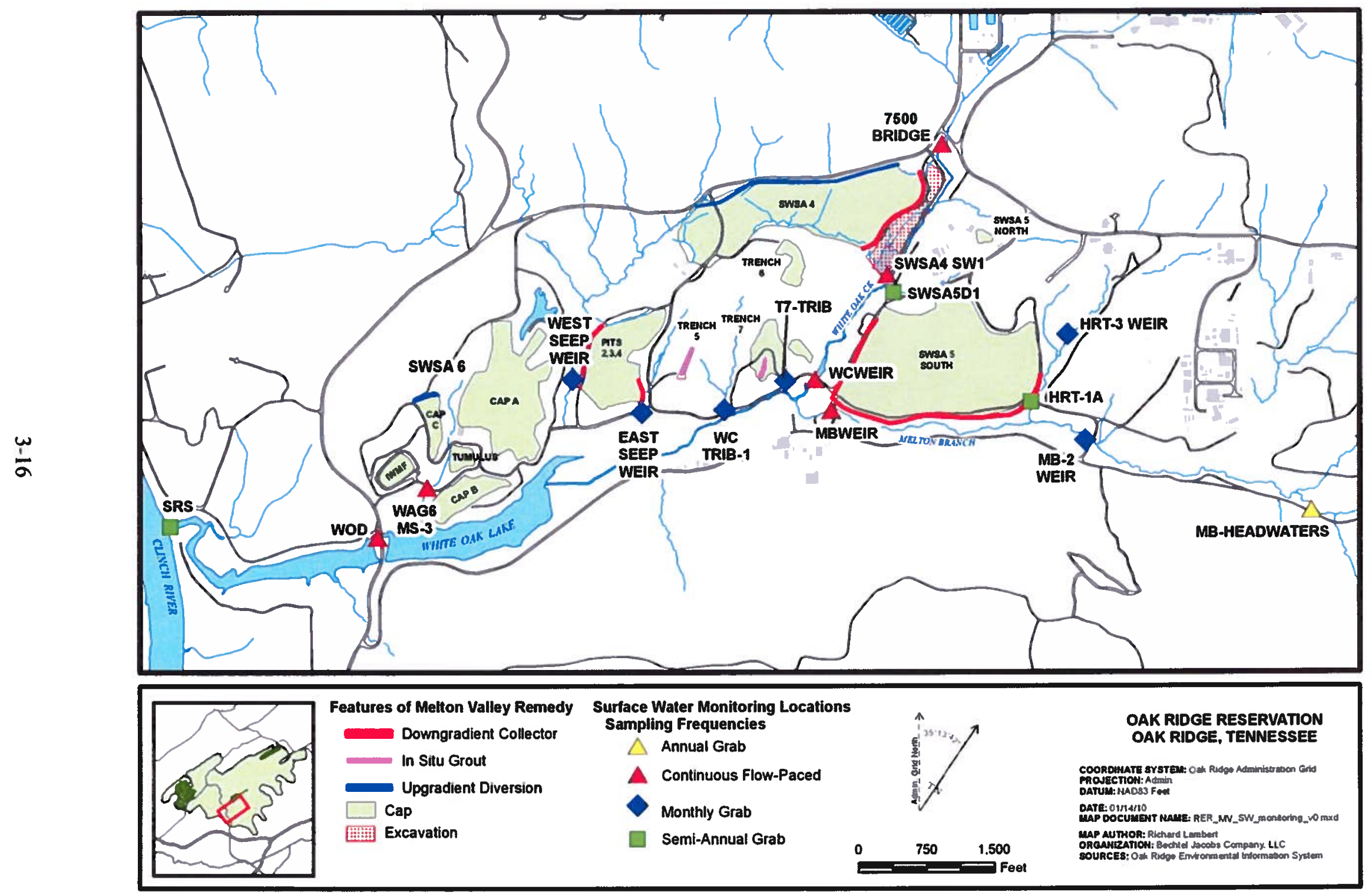

Figure 3.3. MV surface water monitoring locations. 


\section{Protect Clinch River to meet its stream use classification}

This goal protects Clinch River as a domestic water supply [i.e., meets Safe Drinking Water Act of 1974 (SDWA) MCLs"] from contaminated surface water coming from MV. This goal provides residential riskbased limits for surface water at the confluence of WOC with Clinch River. This goal will be met within ten years from completion of actions in MV and BV. Remediation levels at the confluence of WOC with Clinch River will achieve an annual average excess lifetime cancer risk (ELCR) less than $1 \times 10^{-4}$ and an hazard index (HI) less than one for a residential exposure scenario (i.e., general household use). Samples to demonstrate compliance with these RLs may be taken from the White Oak Creek Embayment (WOCE) and/or WOD. Table 3.6 lists the RLs for the contaminants contributing to residential risk at WOD.

Table 3.6. Residential risk-based surface water remediation concentrations for the Melton Valley Watershed, ORNL, Oak Ridge, Tennessee

\begin{tabular}{|c|c|c|c|c|}
\hline $\begin{array}{c}\text { Contaminants at } \\
\text { White Oak Dam }\end{array}$ & Units & $\begin{array}{c}\text { Reference } \\
\text { concentration }\end{array}$ & $\begin{array}{c}\text { Minimum } \\
\text { detection limit }\end{array}$ & $\begin{array}{c}\text { Concentrations based on a } \\
\text { residential scenarioe } \\
\text { (for White Oak Creek } \\
\text { Embayment and Wor White Oak } \\
\text { Dam) }\end{array}$ \\
\hline Arsenic & $m g / L$ & $N D$ & 0.003 & 0.0056 \\
\hline Chloroform & $m g / L$ & $N D$ & 0.001 & 0.021 \\
\hline l,2-dichloroethane & $m g / L$ & $N D$ & 0.001 & 0.016 \\
\hline PCBs & $m g / L$ & $N D$ & 0.001 & 0.011 \\
\hline Cesium- $137+D$ & $p C i / L$ & 40 & 10.0 & 150 \\
\hline Cobalt-60 & $p C i / L$ & $N D$ & 10.0 & 250 \\
\hline Strontium-90+D & $p C i / L$ & $N D$ & 2.0 & 85 \\
\hline Tritium & $p C i / L$ & 1626 & 300 & 58,000 \\
\hline
\end{tabular}

Note: The remediation levels are calculated at $1 \times 10^{-4}$ ELCR or HI of 1 using standard risk assessment protocols for a general household use scenario. These values apply to single contaminants only. To account for the total risk from multiple contaminants, sum of ratios calculations may be applied to all contaminants that are present above background. Actual remediation concentrations when multiple contaminants are present will therefore likely be lower than the single contaminant concentrations listed in the table. Concentrations for other contaminants not listed in the table will be determined as necessary and in a manner similar to that followed above.

"Source: MV ROD Table 2.20.

${ }^{b}$ Bervllium was identified as a COC in the FS but was not included here because EPA has since revised its position on the carcinogenicity of beryllium (see MV ROD Table 2.5). Also, some of these contaminants have SDWA MCLs. The selected remedy will make progress toward protecting Clinch River as a drinking water source (i.e., meet SDWA MCLs).

"Reference concentrations equal twice the arithmetic mean of the background; these concentrations were used for surface water analyte screening in the $M V$ watershed risk assessment.

"The minimum detection limits are based on existing regulatory methodology and current laboratory instrument capabilities.

${ }^{c}$ The residential scenario assumes a 70-kg adult receptor, an exposure frequency of 350 davs/year, an exposure duration of 30 years, an ingestion rate of $2 \mathrm{~L} / d a y$, and a skin surface area (for dermal exposure) of $1.94 \mathrm{~m}^{2}$.

$\mathrm{D}=$ daughter products

$\mathrm{ND}=$ not detected or analyzed

\footnotetext{
"MCLs refer to the Safe Water Drinking Act of 1974 maximum contaminant levels for drinking water.
} 


\section{Achieve AWOC in waters of the state}

White Oak Creek and Melton Branch (MB) are classified for Fish and Aquatic Life, Recreation, and Livestock Watering and Wildlife uses, but not for Domestic or Industrial Water Supply or Irrigation. All other named and unnamed surface waters in the watershed are also classified for Irrigation by default under the Rules of the TDEC Chapter 1200-4-4. Numeric AWQC and narrative criteria for the protection of human health (based on ELCR of $1 \times 10^{-4}$ and HI less than 1 for recreational exposure scenario) and aquatic organisms will be met for site-related contaminants in all waters of the state in $M V$ in $\sim 10$ years from completion of source actions in $M V$. Numeric AWQC exists for selected compounds under the Recreation and Fish and Aquatic Life Classifications. Consistent with EPA guidance, compliance with numeric AWQC for Recreation and Fish and Aquatic Life Classifications is sufficiently stringent to ensure protection of other uses for which there are narrative, but not numeric, criteria (i.e., Irrigation or Livestock Watering and Wildlife). A recreational risk scenario considered representative of the surface water classifications is used to calculate cumulative risk from measured concentrations of surface water contaminants or conversely to derive allowable concentrations from risk-based limits.

\section{AWOC in Waters of the State-Numeric AWOC}

The numeric AWQC for (1) Fish and Aquatic life and (2) Recreation (organisms only) apply to waters of the state in MV and are tabulated in Rules of the TDEC Chapter 1200-4-3-.03 for most of the COCs. Compliance will be based on statistically valid data assessments, and take into account frequency of detection and data trends. The sampling locations for the selected remedy will be finalized in a postROD sampling plan. The locations are generally at the downstream end of individual reaches but upstream of any confluence with other major streams. Samples taken from such locations would essentially integrate contamination entering the reach from any sources upstream of the sampling location.

\section{AWOC in Waters of the State-Narrative Criteria}

In accordance with EPA guidance, the CERCLA risk assessment process is used to address the narrative criteria for waters of the state. A recreational risk scenario considered representative of the surface water classifications is used to calculate cumulative risk from measured concentrations of surface water contaminants or conversely to derive allowable concentrations from risk-based limits. However, DOE does not reasonably foresee actual recreational use of $M V$ surface water in the future.

Waters of the state containing COCs that do not have numeric AWQC will achieve an annual average ELCR less than $1 \times 10^{-4}$ and an HI less than 1 for a recreational exposure scenario. This goal applies only to surface water and only to those contaminants of concern that do not have numeric AWQC, such as radionuclides. The numeric AWQC for individual contaminants is generally equivalent to risk levels ranging up to $10^{-5}$. The annual average risk goal of $1 \times 10^{-4}$ meets the intent of the $A W Q C$ because when multiple contaminants are present in the surface water, as is likely, their individual risk levels would be roughly equivalent to the $A W Q C$-equivalent risk of $10^{5}$. A lower risk goal could routinely require individual contaminant risks to be below the AWQC-equivalent risk of $10^{-5}$.

Under this ROD, the recreational scenario is defined as a swimming scenario for the impounded water bodies, such as White Oak Lake and the WOCE, and a wading scenario for streams such as WOC and $M B$. Since contaminated sediments are left in place under the remedy in this ROD, the swimming or wading scenarios do not include external exposure to or contact with sediment. Also, the scenarios do not include fish consumption because some contaminants in fish may be linked to contaminated 
sediments. Table 3.7 [sic] lists the remediation levels for the recreational surface water COCs identified in the FS. The sampling locations for the selected remedy will be finalized in a post-ROD sampling plan.

Table 3.7. Recreational risk-based surface water remediation concentrations for the Melton Valley Watershed, ORNL, Oak Ridge, Tennessee

\begin{tabular}{|c|c|c|c|c|c|}
\hline $\begin{array}{c}\text { COCs identified in } \\
\text { the FS }\end{array}$ & Units & $\begin{array}{c}\text { Reference } \\
\text { Concentration }^{c}\end{array}$ & $\begin{array}{c}\text { Minimum } \\
\text { Detection } \\
\text { Limit }^{\prime}\end{array}$ & $\begin{array}{l}\text { Concentrations } \\
\text { based on a } \\
\text { recreational } \\
\text { swimming } \\
\text { scenario } \\
\text { (for White Oak } \\
\text { Lake and White } \\
\text { Oak Creek } \\
\text { Embayment) }\end{array}$ & $\begin{array}{c}\text { Concentrations } \\
\text { based on a } \\
\text { recreational } \\
\text { wading scenariof } \\
\text { (for White Oak } \\
\text { Creek, Melton } \\
\text { Branch, and other } \\
\text { waters of the state) }\end{array}$ \\
\hline Arsenic & $m g / L$ & $N D$ & 0.003 & $N A^{g}$ & $N A^{g}$ \\
\hline Tetrachloroethylene & $m g / L$ & $N D$ & 0.001 & $N A^{g}$ & $N A^{g}$ \\
\hline Vinyl chloride & $m g / L$ & $N D$ & 0.001 & $N A^{g}$ & $N A^{g}$ \\
\hline Cesium-137+D & $p C i / L$ & 40 & 10.0 & $4.69 E+04$ & $2.37 E+05$ \\
\hline Cobalt -60 & $p C i / L$ & $N D$ & 10.0 & $7.84 E+04$ & $3.92 E+05$ \\
\hline Radium $-228+D$ & $p C i / L$ & $N D$ & 0.5 & $5.97 E+03$ & $2.99 E+04$ \\
\hline Strontium-90+D & $p C i / L$ & $N D$ & 2.0 & $2.65 E+04$ & $1.33 E+05$ \\
\hline Tritium & $p C i / L$ & 1,626 & 300 & $2.07 E+07$ & $1.04 E+08$ \\
\hline Uranium-234 & $p C i / L$ & $N D$ & 0.5 & $3.34 E+04$ & $1.67 E+05$ \\
\hline
\end{tabular}

Note: The remediation levels are calculated at 1 X $10^{4}$ ELCR or HI of 1 using standard risk assessment protocols for a swimming or wading scenario. These values apply to single contaminants only. To account for the total risk from multiple contaminants, sum of ratios calculations may be applied to all contaminants that are present above background. Actual remediation concentrations when multiple contaminants are present will therefore likely be lower than the single contaminant concentrations listed in the table. Concentrations for other site-related contaminants not listed in the table will be determined as necessary and in a manner similar to that followed above.

"Source: MV ROD Table 2.19.

${ }^{b}$ Beryllium was identified as a COC in the FS but was not included here because EPA has since revised its position on the carcinogenicity of beryllitum (see MV ROD Table 2.5).

${ }^{c}$ Reference concentrations equal twice the arithmetic mean of the background; these concentrations were used for surface water analyte screening in the $M V$ watershed risk assessment.

"The minimum detection limits are based on existing regulatory methodology and current laboratory instrument capabilities.

'The recreational swimming scenario assumes a 70-kg adult receptor, an exposure frequency of 45 hours/year, an exposure duration of 30 years, an ingestion rate of $0.05 \mathrm{~L} / \mathrm{hour}$, and a skin surface area (for dermal exposure) of $1.94 \mathrm{~m}^{2}$.

${ }^{f}$ The recreational wading scenario assumes a 70-kg adult receptor, an exposure frequency of $45 \mathrm{hrs} / \mathrm{yr}$, an exposure duration of 30 years, an ingestion rate of $0.01 \mathrm{~L} /$ hour, and a skin surface area (for dermal exposure) of $0.632 \mathrm{~m}^{2}$. for them.

${ }^{8}$ Risk-based concentrations to meet the narrative criteria were not derived for these COCs since numeric AWQC exists

$\mathrm{D}=$ daughter products

NA $=$ not applicable

$\mathrm{ND}=$ not detected or analyzed 


\subsection{IP Monitoring Results}

This section provides an evaluation of the surface water quality data collected at surface water IPs on WOC and Melton Branch during FY 2009 compared to the MV ROD (DOE 2000a) goals and performance metrics. Surface water monitoring locations are shown on Figure 3.3.

The principal IP surface water monitoring station in MV is at WOD where WOC discharges from WOL. Continuous, flow-paced sampling is conducted at WOD to provide an ongoing record of radiological discharges from the watershed. The monitoring includes measurement of radionuclide concentrations on samples that integrate the water collected during each month and the flow volume passing through the monitoring station. Similar monitoring is conducted at three upstream IP surface water monitoring stations in MV - the WOC Weir (WCWEIR), the Melton Branch Weir (MBWEIR), and at the 7500 BRIDGE.

Table 3.8 includes the concentrations of ${ }^{137} \mathrm{Cs},{ }^{90} \mathrm{Sr}$, and ${ }^{3} \mathrm{H}$ from the monthly flow-paced composite samples obtained at main stem IPs including 7500 BRIDGE, WCWEIR, MBWEIR, and WOD.

Comparison of ${ }^{137} \mathrm{Cs},{ }^{90} \mathrm{Sr}$, and ${ }^{3} \mathrm{H}$ concentrations measured at WOD (Table 3.8) with the ROD goal (Table 3.6) is the basis for remedy effectiveness evaluation for protection of the Clinch River.

Figure 3.4 shows the annual average and average plus one standard deviation concentrations of ${ }^{137} \mathrm{Cs}$, ${ }^{90} \mathrm{Sr}$, and tritium at WOD for FY 2001 through FY 2009. Total annual rainfall at the ORNL site is provided to enable long-term comparison of contaminant concentration response to rainfall. ROD goals for these three contaminants for protection of the Clinch River as a public water supply are also shown. The monthly flow-paced sampling provides continuous sampling of surface water at each sample station, thus providing a reliable measure of the time-averaged contaminant concentration. During FY 2009, all flow-paced composite sample results from samples collected at WOD were below the risk-based concentration goals.

Comparison of ${ }^{137} \mathrm{Cs},{ }^{90} \mathrm{Sr}$, and ${ }^{3} \mathrm{H}$ concentrations (Table 3.8) measured at 7500 Bridge, WCWEIR, and MBWEIR, which are upstream integration monitoring locations, with the ROD goal for a recreational scenario (Table 3.7) indicates that all results for FY 2009 are well below the risk-based goals for these constituents. Additional information concerning CERCLA contaminant monitoring at the 7500 Bridge is presented in Chap. 2, as applicable to BV ROD goals.

Figure 3.5 shows the annual radionuclide flux measured at WOD and the ORNL site total annual rainfall from FY 2001 through FY 2009. During FY 2009, the ORNL site rainfall was much greater than the long-term average of 54 inches. The total fluxes of ${ }^{137} \mathrm{Cs},{ }^{90} \mathrm{Sr}$, and ${ }^{3} \mathrm{H}$ remained low and comparable to the FY 2007 and FY 2008 values even though the annual rainfall across the ORR and at the ORNL site was well above the long-term average. 
Table 3.8. Summary of FY 2009 radiological contaminant levels at surface water IPs in MV

\begin{tabular}{|c|c|c|c|c|c|c|c|c|c|c|c|c|}
\hline \multirow[b]{2}{*}{$\begin{array}{c}\text { Monthly FPC } \\
\text { date }\end{array}$} & \multicolumn{3}{|c|}{7500 BRIDGE } & \multicolumn{3}{|c|}{ WCWEIR } & \multicolumn{3}{|c|}{ MBWEIR } & \multicolumn{3}{|c|}{ WOD } \\
\hline & ${ }^{90} \mathrm{Sr}$ & ${ }^{3} \mathrm{H}$ & ${ }^{137} \mathrm{Cs}$ & ${ }^{90} \mathrm{Sr}$ & ${ }^{3} \mathrm{H}$ & ${ }^{137} \mathrm{Cs}$ & ${ }^{90} \mathrm{Sr}$ & ${ }^{3} \mathrm{H}$ & ${ }^{137} \mathrm{Cs}$ & ${ }^{90} \mathrm{Sr}$ & ${ }^{3} \mathbf{H}$ & ${ }^{137} \mathrm{Cs}$ \\
\hline 29-Oct-08 & 28 & 37,700 & 17.5 & 35 & 48,000 & 4.8 & 24 & 7,800 & $5.1(\mathrm{U})$ & 48 & 30,000 & 22 \\
\hline 26-Nov-08 & 27 & 27,000 & 14 & 29 & 34,000 & 7.6 & 36 & 13,000 & $6(U)$ & 40 & 31,000 & 26 \\
\hline 31-Dec-08 & 36 & 14,900 & $5.88(\mathrm{U})$ & 51 & 19,000 & 5.0 & 71 & 11,000 & $5.7(\mathrm{U})$ & 55 & 21,000 & 18 \\
\hline 28-Jan-09 & 43 & 14,700 & 11.8 & 42 & 32,000 & 10.1 & 46 & 8,000 & $5.1(\mathrm{U})$ & 52 & 19,000 & 23 \\
\hline 25-Feb-09 & 39 & 17,000 & 14 & 29 & 10,000 & 11.1 & 31 & 7,600 & $5.8(U)$ & 39 & 18,000 & 24 \\
\hline 25-Mar-09 & 35 & 12,000 & 21.2 & 44 & 16,000 & 4.8 & 39 & 6,400 & $4.6(U)$ & 55 & 18,000 & 27 \\
\hline 29-Apr-09 & 50 & 11,000 & 6.3 & 61 & 8,400 & 10.0 & 41 & 5,000 & $5.3(\mathrm{U})$ & 55 & 8,600 & 22 \\
\hline 27-May-09 & 44 & 7,200 & 13 & 59 & 11,000 & 11.4 & 55 & 5,000 & $0.6(\mathrm{U})$ & 72 & 6,100 & 16 \\
\hline 24-Jun-09 & 50 & 14,000 & 7.2 & 64 & 19,000 & 5.9 & 36 & 9,900 & $2.4(\mathrm{U})$ & 73 & 20,000 & 18 \\
\hline 29-Jul-09 & 47 & 25,000 & 6 & 57 & 22,000 & 8.5 & 45 & 8,900 & $-0.6(U)$ & 61 & 17,000 & 25 \\
\hline 26-Aug-09 & 38 & 23,000 & 13 & 48 & 17,000 & 21.8 & 45 & 5,600 & 4 & 57 & 17,000 & 59 \\
\hline 30-Sep-09 & 37 & 15,000 & 7.9 & 55 & 48,000 & 4.8 & 44 & 9,000 & $4.7(\mathrm{U})$ & 63 & 21,000 & 34 \\
\hline $\begin{array}{l}\text { Average } \\
\text { concentration } \\
\text { (pCi/L) }\end{array}$ & 40 & 18,000 & 12 & 48 & 22,000 & 15 & 43 & 8,100 & $<4$ & 56 & 19,000 & 26 \\
\hline
\end{tabular}

Concentration values are $\mathrm{pCi} / \mathrm{L}$.

$\mathrm{U}=$ reported concentration was below the minimum detectable activity - analyte was not detected.

MV ROD radiological contaminant concentration goals for ${ }^{137} \mathrm{Cs},{ }^{90} \mathrm{Sr}$, and ${ }^{3} \mathrm{H}$ are met at all IP locations. 

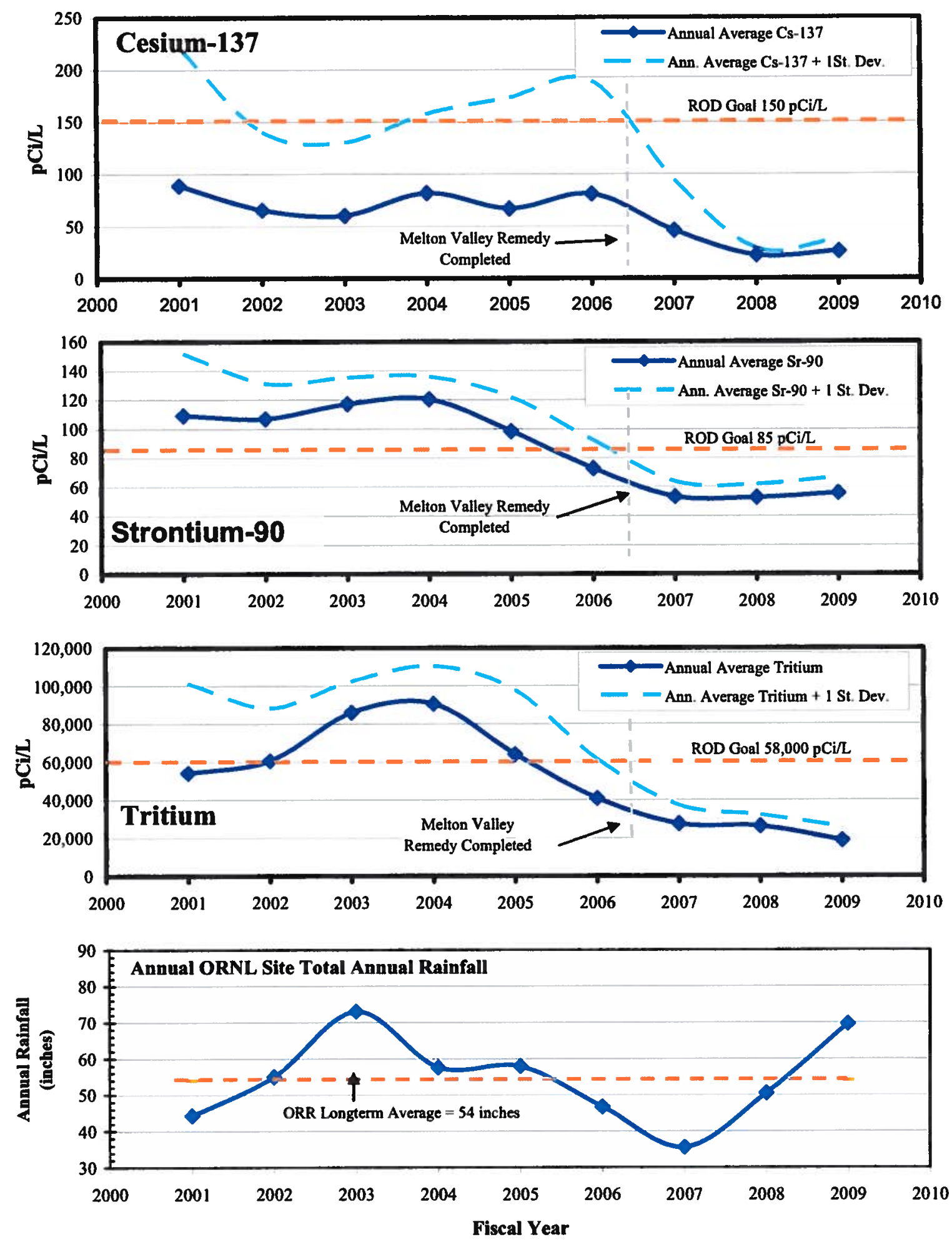

Figure 3.4. Annual average surface water concentrations of ${ }^{137} \mathrm{Cs},{ }^{90} \mathrm{Sr}$, and tritium at WOD. 

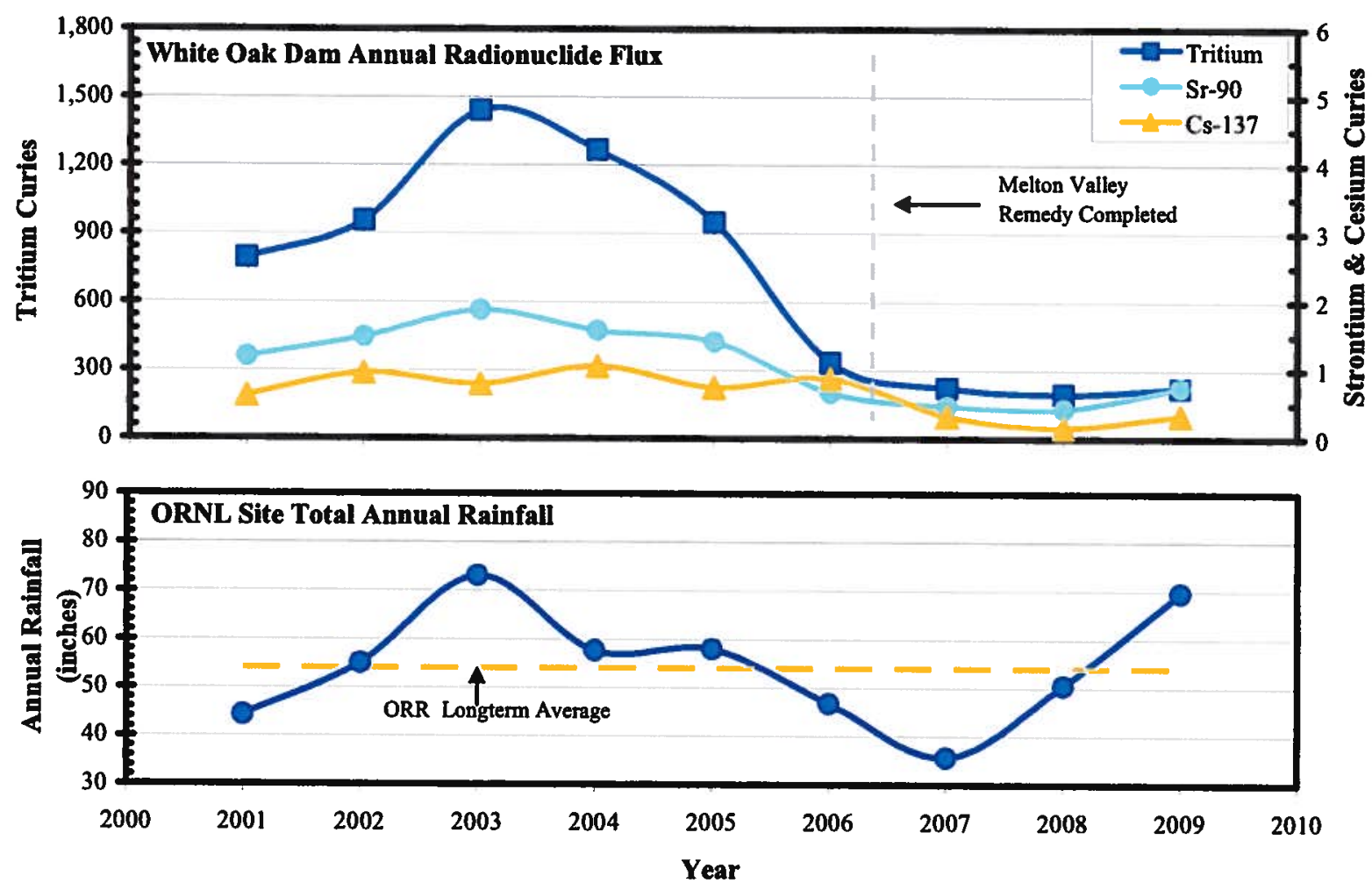

Figure 3.5. Annual radionuclide fluxes at WOD and annual rainfall at ORNL.

\subsection{Tributary Surface Water Monitoring Results}

Tributary monitoring locations are sampled to evaluate the effect of RAs on water quality in tributaries to WOC and Melton Branch. Tributary sample locations are shown on Figure 3.3 and samples are obtained by the grab method except at WAG6 MS-3 and SWSA4 SW1 where flow-paced sampling is performed. Radiological RLs for surface water in the MV tributaries are presented in Table 3.7. Table 3.9 includes annual average and standard deviations of the principal radiological COCs in surface water for the tributary sampling locations.

All results are well below the ROD recreational goals for surface water and, therefore, trend graphs are not included in this RER. Examination of the annual average concentration values at most locations indicates that in most areas principal radiological contaminant levels are decreasing. 
Table 3.9. Average annual radionuclide concentrations at tributary surface water monitoring locations in MV

\begin{tabular}{|c|c|c|c|c|c|c|c|c|c|c|c|c|c|c|c|c|c|c|c|}
\hline \multirow{2}{*}{ Location } & \multirow[t]{2}{*}{ Year } & \multicolumn{3}{|c|}{ Alpha activity } & \multicolumn{3}{|c|}{ Beta activity } & \multicolumn{3}{|c|}{ Cobalt-60 } & \multicolumn{3}{|c|}{ Strontium-90 } & \multicolumn{3}{|c|}{ Tritium } & \multicolumn{3}{|c|}{ U-233/234 } \\
\hline & & $\mathbf{N}$ & Avg. & StD. & $\mathbf{N}$ & Avg & StD. & $\mathbf{N}$ & Avg. & StD. & $\mathbf{N}$ & Avg & StD. & $\mathbf{N}$ & Avg. & Sț. & $\mathbf{N}$ & Avg. & StD. \\
\hline \multirow{6}{*}{$\begin{array}{l}\text { EAST } \\
\text { SEEP } \\
\text { WEIR }\end{array}$} & 2004 & 12 & 280 & 170 & 12 & 230 & 110 & 12 & 18 & 7.2 & 12 & 5 & 0.7 & 12 & 7,100 & 2,500 & 12 & 146 & 96 \\
\hline & 2005 & 12 & 110 & 65 & 12 & 160 & 40 & 12 & 12 & 4.1 & 12 & 5.3 & 1 & 12 & 5,400 & 2,100 & 12 & 69 & 24 \\
\hline & 2006 & 13 & 44 & 28 & 11 & 190 & 69 & 13 & 9.9 & 3.9 & 13 & 6.6 & 2.8 & 13 & 6,200 & 2,800 & 11 & 35 & 28 \\
\hline & 2007 & 10 & 18 & 6 & 10 & 120 & 40 & 10 & 5.4 & 2.5 & 10 & 41 & 103 & 10 & 4,400 & 1,600 & 9 & 16 & 4.5 \\
\hline & 2008 & 7 & 19 & 15 & 7 & 180 & 73 & 1 & 11 & & 7 & 3.7 & 0.6 & 7 & 3,400 & 2,100 & 7 & 13 & 7 \\
\hline & 2009 & 11 & 16 & 12 & 11 & 130 & 42 & 11 & $\mathrm{ND}$ & & 11 & 4.3 & 2.4 & 11 & 3,100 & 1,900 & 11 & 16 & 11 \\
\hline \multirow{4}{*}{ HRT-1A } & 2006 & 2 & 3.67 & 1.63 & & & & 2 & ND & & 2 & 145 & 82 & 2 & 1360 & 1080 & 2 & 0.87 & 0.59 \\
\hline & 2007 & 2 & ND & & 2 & 288 & 84.9 & 2 & ND & & 2 & 131 & 36 & 2 & $<666$ & 473 & 2 & 0.41 & 0.19 \\
\hline & 2008 & 2 & ND & & 2 & 198 & 103 & 2 & ND & & 2 & 91.3 & 51.9 & 2 & $<384$ & 37.5 & 2 & $<0.8$ & \\
\hline & 2009 & 2 & ND & & 2 & 248 & 8.5 & 2 & $\mathrm{ND}$ & & 2 & 124 & 7.8 & 2 & 596 & 74 & 2 & $<0.3$ & \\
\hline \multirow{10}{*}{$\begin{array}{l}\text { HRT-3 } \\
\text { WEIR }\end{array}$} & 2000 & 12 & 7.29 & 8.5 & 12 & 461 & 75 & 12 & ND & & 12 & 200 & 36.3 & 12 & 1658 & 3684 & & & \\
\hline & 2001 & 12 & 20 & 39.2 & 12 & 382 & 165 & 12 & ND & & 12 & 184 & 50 & 12 & 164 & 448 & & & \\
\hline & 2002 & 12 & 5.32 & 4.6 & 12 & 385 & 160 & 12 & $\mathrm{ND}$ & & 12 & 137 & 57 & 12 & 454 & 1160 & & & \\
\hline & 2003 & 13 & 5.2 & 14.4 & 13 & 519 & 121 & 13 & $\mathrm{ND}$ & & 13 & 207 & 52 & 13 & 269 & 237 & & & \\
\hline & 2004 & 14 & 3.94 & 2.3 & 14 & 658 & 253 & 14 & ND & & 14 & 293 & 132 & 14 & 311 & 156 & & & \\
\hline & 2005 & 12 & 11.15 & 24.3 & 12 & 584 & 225 & 12 & ND & & 12 & 248 & 89 & 12 & 1180 & 3630 & & & \\
\hline & 2006 & 13 & 2.17 & 1.5 & 12 & 317 & 151 & 13 & ND & & 13 & 144 & 65 & 13 & $<293$ & 49 & & & \\
\hline & 2007 & & & & 13 & 254 & 158 & 13 & $\mathrm{ND}$ & & 13 & 114 & 73 & 13 & ND & & & & \\
\hline & 2008 & 12 & $<3.16$ & 2.02 & 12 & 220 & 117 & 12 & $\mathrm{ND}$ & & 12 & 187 & 274 & 12 & $<379$ & 122 & & & \\
\hline & 2009 & 12 & ND & & 12 & 283 & 128 & 12 & $\mathrm{ND}$ & & 12 & 140 & 63 & 12 & $<358$ & & & & \\
\hline \multirow{9}{*}{$\begin{array}{l}\text { MB-2 } \\
\text { WEIR }\end{array}$} & 2001 & 2 & ND & & & & & & & & & & & & & & & & \\
\hline & 2002 & 12 & $<2.55$ & 1.55 & & & & 12 & ND & & 12 & $<1.81$ & & 12 & 4254 & 4970 & & & \\
\hline & 2003 & 1 & ND & & & & & 1 & $\mathrm{ND}$ & & 1 & 2.11 & & 1 & 2848 & & & & \\
\hline & 2004 & & & & & & & & & & & & & & & & & & \\
\hline & 2005 & & & & & & & 12 & $<5.4$ & & 13 & 3.3 & 0.98 & 12 & 719 & 261 & & & \\
\hline & 2006 & 1 & 6.11 & & & & & 13 & ND & & 13 & 15.4 & 35.9 & 13 & 651 & 263 & & & \\
\hline & 2007 & 3 & ND & & 12 & $<16$ & 23 & 13 & $\mathrm{ND}$ & & 13 & $<2.23$ & 1.2 & 12 & $<407$ & 113 & & & \\
\hline & 2008 & 12 & $<2.4$ & 1.1 & 12 & 9.2 & 4.9 & 12 & ND & & 12 & $<2.2$ & 0.57 & 12 & $<247$ & 69 & & & \\
\hline & 2009 & 12 & $<2.2$ & & 12 & 8.5 & 3.3 & 12 & ND & & 12 & $<2.4$ & 0.69 & 12 & $<990$ & 1,900 & & & \\
\hline \multirow{5}{*}{$\begin{array}{l}\text { MB- } \\
\text { HEAD- } \\
\text { WATERS }\end{array}$} & 2002 & 1 & 1.02 & & 1 & 1.36 & & 1 & $\mathrm{ND}$ & & 1 & 14.34 & & 1 & 383 & & & & \\
\hline & 2003 & 1 & ND & & & & & 1 & $\mathrm{ND}$ & & 1 & ND & & 1 & 361 & & & & \\
\hline & 2004 & 2 & $<2.31$ & 0.3 & 2 & 3.66 & 0.40 & 2 & ND & & 2 & $<0.94$ & 0.3 & 2 & 272 & 128 & & & \\
\hline & 2005 & 2 & ND & & 2 & $\mathrm{ND}$ & & 2 & $\begin{array}{c}<4.1 \\
8\end{array}$ & 1.94 & 2 & ND & & 2 & ND & & & & \\
\hline & $\begin{array}{l}2006 \\
2007 \\
\end{array}$ & 2 & $\begin{array}{c}<1.35 \\
\text { dry }\end{array}$ & 0.39 & 2 & $\begin{array}{c}3.35 \\
\text { dry }\end{array}$ & 1.56 & 2 & $\begin{array}{l}\text { ND } \\
\text { dry }\end{array}$ & & & $\begin{array}{c}<1.27 \\
\text { dry }\end{array}$ & 0.18 & 2 & $\begin{array}{l}365 \\
\text { dry }\end{array}$ & 116 & & & \\
\hline
\end{tabular}


Table 3.9. Average annual radionuclide concentrations at tributary surface water monitoring locations in MV (cont.)

\begin{tabular}{|c|c|c|c|c|c|c|c|c|c|c|c|c|c|c|c|c|c|c|c|}
\hline \multirow{2}{*}{$\frac{\text { Location }}{\mathrm{MB}-}$} & \multirow[t]{2}{*}{ Year } & \multicolumn{3}{|c|}{ Alpha activity } & \multicolumn{3}{|c|}{ Beta activity } & \multicolumn{3}{|c|}{ Cobalt-60 } & \multicolumn{3}{|c|}{ Strontium-90 } & \multicolumn{3}{|c|}{ Tritium } & \multicolumn{3}{|c|}{ U-233/234 } \\
\hline & & $\mathbf{N}$ & Avg & StD & $\mathbf{N}$ & Avg & StD & $\mathbf{N}$ & Avg & StD & $\mathbf{N}$ & Avg. & StD & $\mathbf{N}$ & Avg & StD & $\mathbf{N}$ & Avg & StD \\
\hline HEAD- & 2008 & 1 & $<0.41$ & & 1 & 2.7 & & 1 & $\mathrm{ND}$ & & 1 & 1.48 & & 1 & ND & & & & \\
\hline WATERS & 2009 & 1 & $\mathrm{ND}$ & & 1 & 5.4 & & $i$ & $\begin{array}{l}\mathrm{ND} \\
<6.1\end{array}$ & & 1 & ND & & 1 & ND & & & & \\
\hline \multirow{5}{*}{$\begin{array}{l}\text { SWSA4 } \\
\text { SW1 }^{2}\end{array}$} & 2006 & 7 & 3.83 & 2.08 & 7 & 515 & 337 & 7 & 6 & 1.22 & 7 & 222 & 163 & 7 & 36,000 & 38,800 & & & \\
\hline & 2007 & 6 & 3.85 & 2.32 & 6 & 454 & 186 & 6 & ND & & 6 & 204 & 97 & 6 & 11,200 & 5,580 & & & \\
\hline & 2008 & 11 & $<3.73$ & 0.69 & 11 & 396 & 168 & 11 & ND & & 11 & 181 & 82 & 11 & 6,130 & 5,900 & 2 & 1.01 & 0.26 \\
\hline & 2009 & 13 & $<2.9$ & & 13 & 269 & 95 & 13 & ND & & 13 & 123 & 46 & 13 & 4,700 & 3,300 & 2 & ND & \\
\hline & 2004 & 11 & 197 & 68 & 11 & 150 & 46 & & & & 11 & 24 & 5 & 11 & 166,800 & 62,900 & & & \\
\hline \multirow{7}{*}{$\begin{array}{l}\text { SWSA5 } \\
\text { D-1 }\end{array}$} & 2005 & 11 & 250 & 114 & 11 & 179 & 82 & & & & 11 & 26 & 7 & 11 & 81,100 & 32,200 & & & \\
\hline & 2006 & 10 & 97 & 59 & 9 & 74 & 43 & & & & 10 & 12 & 5 & 10 & 40,900 & 50,400 & & & \\
\hline & 2007 & 9 & 36 & 12 & 9 & 46 & 61 & & & & 9 & 8 & 4 & 9 & 11,800 & 6,800 & 1 & 14.9 & \\
\hline & 2008 & 8 & 56 & 23 & 8 & 40 & 23 & & & & 8 & 9 & 3 & 8 & 11,400 & 11,300 & 8 & 27 & 13 \\
\hline & 2009 & 13 & 38 & 17 & 13 & 32 & 11 & 11 & $\mathrm{ND}$ & & 13 & 8 & 2 & 13 & 10,700 & 12,900 & 13 & 22 & 10 \\
\hline & 2002 & 12 & 27 & 24 & 12 & 714 & 309 & & & & 12 & 224 & 103 & 12 & 977,600 & 695,800 & & & \\
\hline & 2003 & 12 & 10 & 12 & 12 & 829 & 247 & & & & 12 & 253 & 84 & 12 & 693,900 & 271,300 & & & \\
\hline \multirow{8}{*}{$\begin{array}{l}\text { WAG6 } \\
\text { MS-3 }^{2}\end{array}$} & 2004 & 12 & 6.3 & 4.3 & 12 & 883 & 200 & & & & 12 & 338 & 67 & 12 & 905,500 & 355,500 & & & \\
\hline & 2005 & 12 & 14 & 13 & 12 & 841 & 193 & & & & 12 & 299 & 659 & 12 & 613,400 & 349,600 & & & \\
\hline & 2006 & 10 & 24 & 57 & 9 & 550 & 167 & & & & 12 & 211 & 81 & 10 & 338,600 & 147,000 & & & \\
\hline & 2007 & 9 & 4.1 & 1.7 & 9 & 402 & 48 & & & & 10 & 166 & 19 & 10 & 292,900 & 95,600 & & & \\
\hline & 2008 & & & & 12 & 290 & 67 & & & & 12 & 113 & 33 & 12 & 162,000 & 78,400 & & & \\
\hline & 2009 & 13 & ND & & 13 & 230 & 57 & 13 & ND & & 13 & 115 & 31 & 13 & 100,000 & 35,000 & & & \\
\hline & 2001 & 12 & 281 & 252 & 12 & 428 & 133 & 12 & 4.4 & 5.4 & 12 & 153 & 43 & 12 & 12,300 & 3,600 & & & \\
\hline & 2002 & 13 & 363 & 322 & 13 & 457 & 140 & 13 & 5.1 & 5.6 & 13 & 116 & 36 & 13 & 10,600 & 3,800 & & & \\
\hline \multirow{7}{*}{$\begin{array}{l}\text { WEST } \\
\text { SEEP } \\
\text { WEIR }\end{array}$} & 2003 & 13 & 159 & 150 & 13 & 312 & 121 & 13 & 2.5 & 3.1 & 13 & 101 & 33 & 13 & 20,200 & 45,100 & & & \\
\hline & 2004 & 12 & 85 & 82 & 12 & 176 & 120 & & & & 12 & 68 & 33 & 12 & 16,900 & 29,000 & & & \\
\hline & 2005 & 12 & 112 & 124 & 12 & 132 & 87 & & & & 12 & 33 & 13 & 12 & 7,500 & 4,800 & & & \\
\hline & 2006 & 14 & 107 & 83 & 12 & 122 & 57 & 14 & 1.7 & 1.6 & 14 & 38 & 12 & 14 & 12,200 & 4,000 & & & \\
\hline & 2007 & 13 & 41 & 25 & 13 & 82 & 45 & 13 & $\mathrm{ND}$ & & 13 & 29 & 7 & 13 & 10,200 & 4,200 & & & \\
\hline & 2008 & 13 & 37 & 28 & 13 & 82 & 37 & 13 & $\mathrm{ND}$ & & 13 & 30 & 12 & & 12,300 & 8,100 & & & \\
\hline & 2009 & 14 & 32 & 30 & 14 & 61 & 17 & 14 & $\mathrm{ND}$ & & 14 & 25 & 7 & 14 & 8,000 & 5,000 & & & \\
\hline
\end{tabular}

Flow-paced continuous sample result. All other results are based on grab samples

$<=$ One or more sample during the year reported ND values. Average and standard deviations based on average of detected results and detection limits for ND results. Avg $=$ average

$\mathrm{N}=$ number of samples

$\mathrm{ND}=$ not detected

$\mathrm{StD}=$ standard deviation 


\subsubsection{Groundwater Monitoring Data}

\subsection{Groundwater Quality Goals and Monitoring Requirements}

The MV ROD RAO for groundwater is to mitigate further impact to groundwater in the waste management and industrial land use areas (Table 3.3). Mitigation of further groundwater impacts from the MV CERCLA units was a goal of hydrologic isolation of buried waste, ISG of Liquid Waste Seepage Trenches 5 and 7, and excavation of contaminated soils and pond sediment per the ROD. The performance metric for hydrologic isolation effectiveness is based on reduction of groundwater contact with principal threat source materials in shallow land waste burial units (Table 3.4). Groundwater level control in hydrologic isolation areas is discussed in Sect. 3.2.2.2.2.

The ROD stipulates that groundwater be monitored in the exit pathway along the western edge of the valley, in the vicinity of the hydrofracture waste injection sites, and in the vicinity of contaminant source control areas. Monitoring of groundwater at SWSA 6 is conducted under the requirements of the SWSA 6 Post-Closure Permit Application [pending approval by TDEC-Division of Solid Waste Management (DSWM)]. Data obtained from the SWSA 6 Resource Conservation and Recovery Act of 1976 (RCRA) monitoring is used to evaluate the post-remediation groundwater quality conditions at the site perimeter. Monitoring results obtained to date in these areas are discussed in Sect. 3.2.2.2.3.

\subsection{Groundwater Level Control in Hydrologic Isolation Units}

Minimization of surface water infiltration and groundwater inflows into buried waste to reduce contaminant releases is key to the concept of hydrologic isolation. Prior to remediation, groundwater levels were observed to rise into waste burial trenches in many areas of MV. In some areas waste trenches were known to completely fill with water during winter months. Contact of this water with buried waste materials was the source of contaminated leachate that subsequently seeped downward and laterally to adjacent seeps, springs, and streams.

The MV remedy utilizes multilayer caps to prevent vertical infiltration of rainwater into buried waste or other hydrologic isolation units, as well, as upgradient storm flow interceptor trenches, where necessary, to prevent shallow subsurface seepage from entering the areas laterally. Downgradient seepage collection trenches were constructed in several locations along downgradient perimeters of buried waste units. Seepage that is pumped from these trenches is piped to the ORNL PWTC for treatment prior to discharge.

The MV ROD included the performance goal of reducing groundwater level fluctuations within hydrologically isolated areas by $>75 \%$ from preconstruction fluctuation ranges (Table 3.4). The performance goal of attaining a $>75 \%$ reduction in groundwater level fluctuations created a design requirement to minimize, as much as possible, the contact of groundwater with buried waste to reduce the contaminated leachate formation process. As such, the fluctuation range is most relevant in cases where groundwater levels rise into the waste burial elevation zone. Groundwater level fluctuations at elevations below the contaminant sources have less importance to the overall remedy effectiveness. During the remedial design of each hydrologic isolation area, wells were selected for monitoring post-remediation groundwater level fluctuations. Existing baseline fluctuation ranges were evaluated for the wells and target post-remediation groundwater elevations were determined to indicate that groundwater levels had dropped to below the $75 \%$ fluctuation range elevation.

Figure 3.6 shows the locations where groundwater level monitoring is conducted to evaluate hydrologic isolation performance. Symbol shape and color indicate locations where the maximum observed groundwater elevation attains (is lower than) or exceeds (is greater than) the target groundwater level specified in the ROD. General observations concerning the nature of groundwater level fluctuations in the 

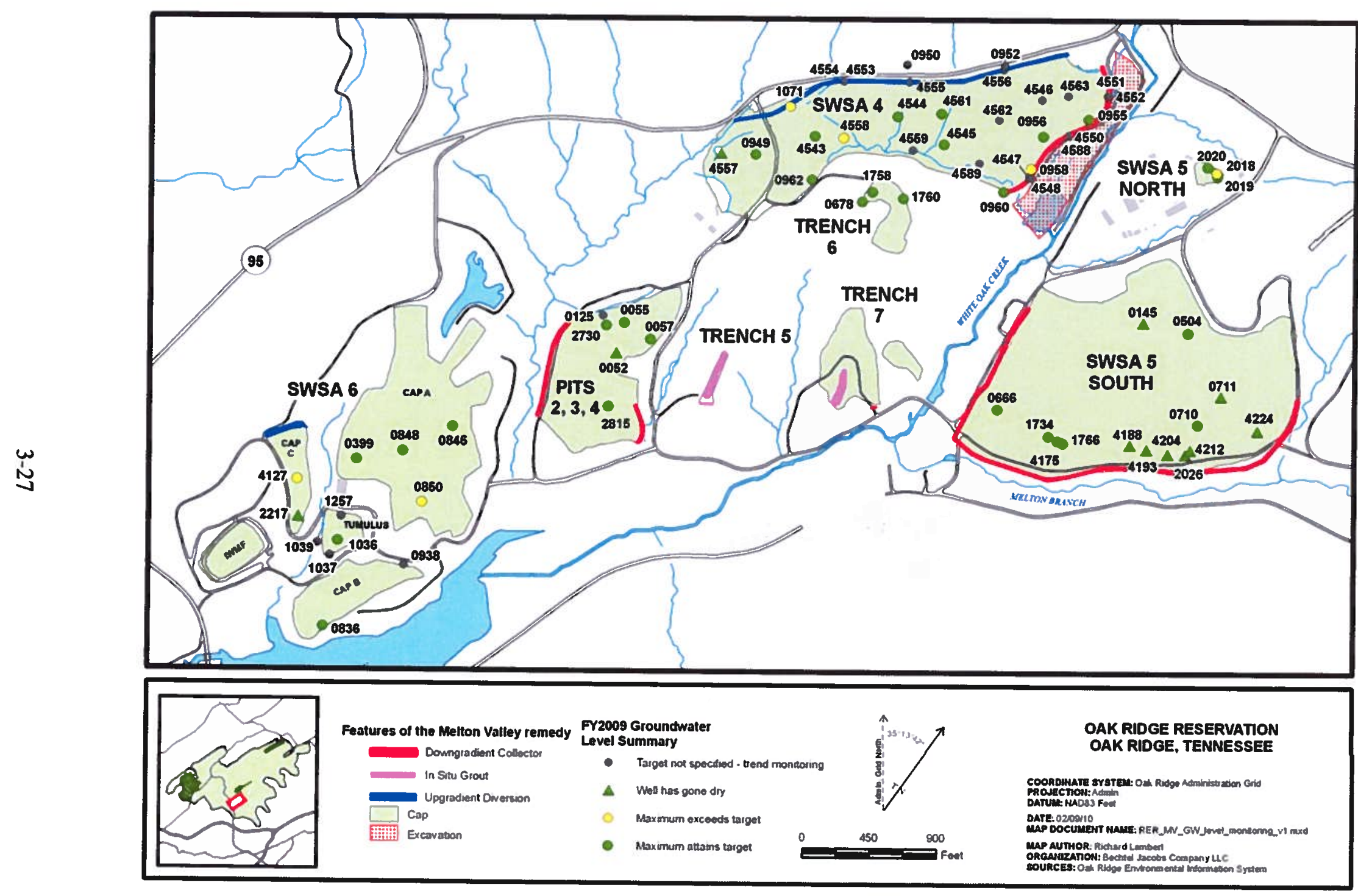

Figure 3.6. Summary of groundwater level monitoring results for FY 2009. 
hydrologically isolated areas and specific discussions regarding wells that have not attained their target elevations are included in this section. Appendix B contains a tabular summary of groundwater level monitoring results along with well hydrographs showing groundwater level responses during FY 2007 through FY 2009.

During FY 2009, groundwater level fluctuation observed in the MV monitoring behavior was very similar to that observed in FY 2008. Groundwater level response characteristics may be categorized in several groups. Water level responses observed in shallow wells outside hydrologically isolated areas respond quickly to rainfall events and may undergo large short-term and annual fluctuation ranges (Figure 3.7). Wells located inside hydrologically isolated areas show very subdued water level fluctuations compared to wells outside caps or may exhibit continuing water level decline as seepage drains the area (Figures 3.7 and 3.8).

Some shallow wells inside the hydrologically isolated areas have gone dry as a result of area capping and water level decline. Some shallow wells inside hydrologically isolated areas exhibit continuing water level declines as gradual drainage of groundwater toward collector trenches or adjacent surface water bodies occurs (Figure 3.8). Bedrock wells are observed to respond to head changes from areas outside hydrologic isolation structures which can cause target groundwater level exceedances. This condition is observed at SWSA 6.

During FY 2009, the maximum measured groundwater elevation in six wells inside hydrologically isolated areas exceeded the design target groundwater elevation in comparison to the three wells that exceeded target elevations in FY 2008 (Figure 3.6). As in FY 2008, two of the wells that exceeded the target elevation in FY 2009 are in SWSA 6, as discussed below. Three wells within the SWSA 4 hydrologically isolated area exceeded target elevations. During FY 2009, one well at SWSA 5 North (well 2018) exceeded its target elevation by $0.07 \mathrm{ft}$. The reasons for these wells not attaining the design target elevations are related to the well construction characteristics, location with respect to preremediation topography, or location near a downgradient trench.

Well 4127 in western SWSA 6 is a bedrock well that extends more than $20 \mathrm{ft}$ below waste burial trench floor elevations in the adjacent capped area. Groundwater elevation is measured monthly and the hydrograph for well 4127 is shown in Figure 3.9. This well monitors groundwater level fluctuation beneath a fairly narrow cap that lies between two surface water drainages. The groundwater elevation measured in well 4127 shows a strong seasonal fluctuation signature and wet season levels are similar to the ground surface elevations in the adjacent ravines where wet-weather streams exist. The groundwater levels measured in well 4127 are probably controlled by the shallow groundwater levels in areas adjacent to the cap. A well (2217) further downslope beneath the same cap monitors groundwater levels in a shallow waste burial trench and that well was dry during all measurements during FY 2009, as it was throughout FY 2008, indicating that the cap is preventing trench flooding. 

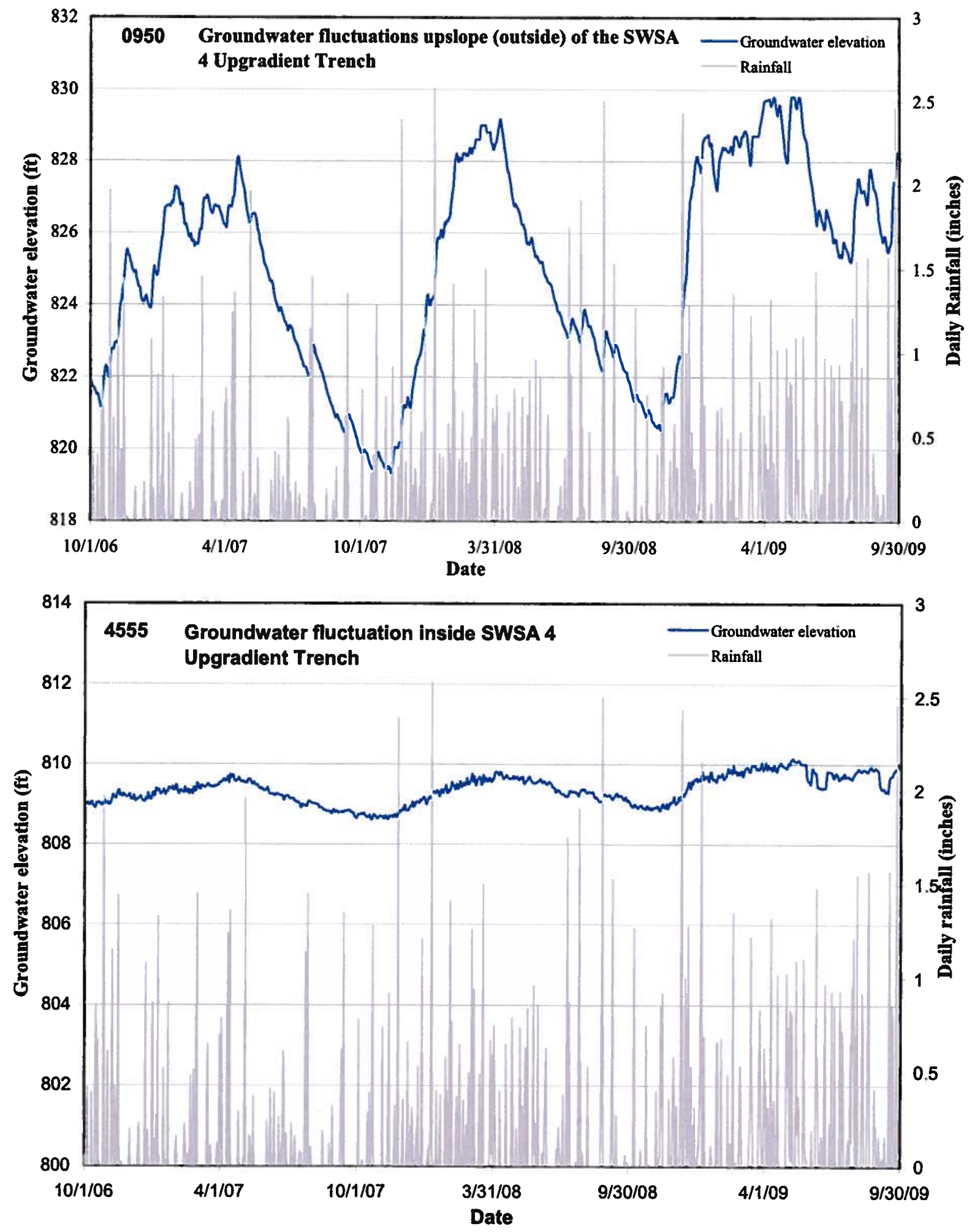

Figure 3.7. Examples of groundwater level fluctuations upslope (outside) and inside the SWSA 4 Upgradient Diversion Trench. 

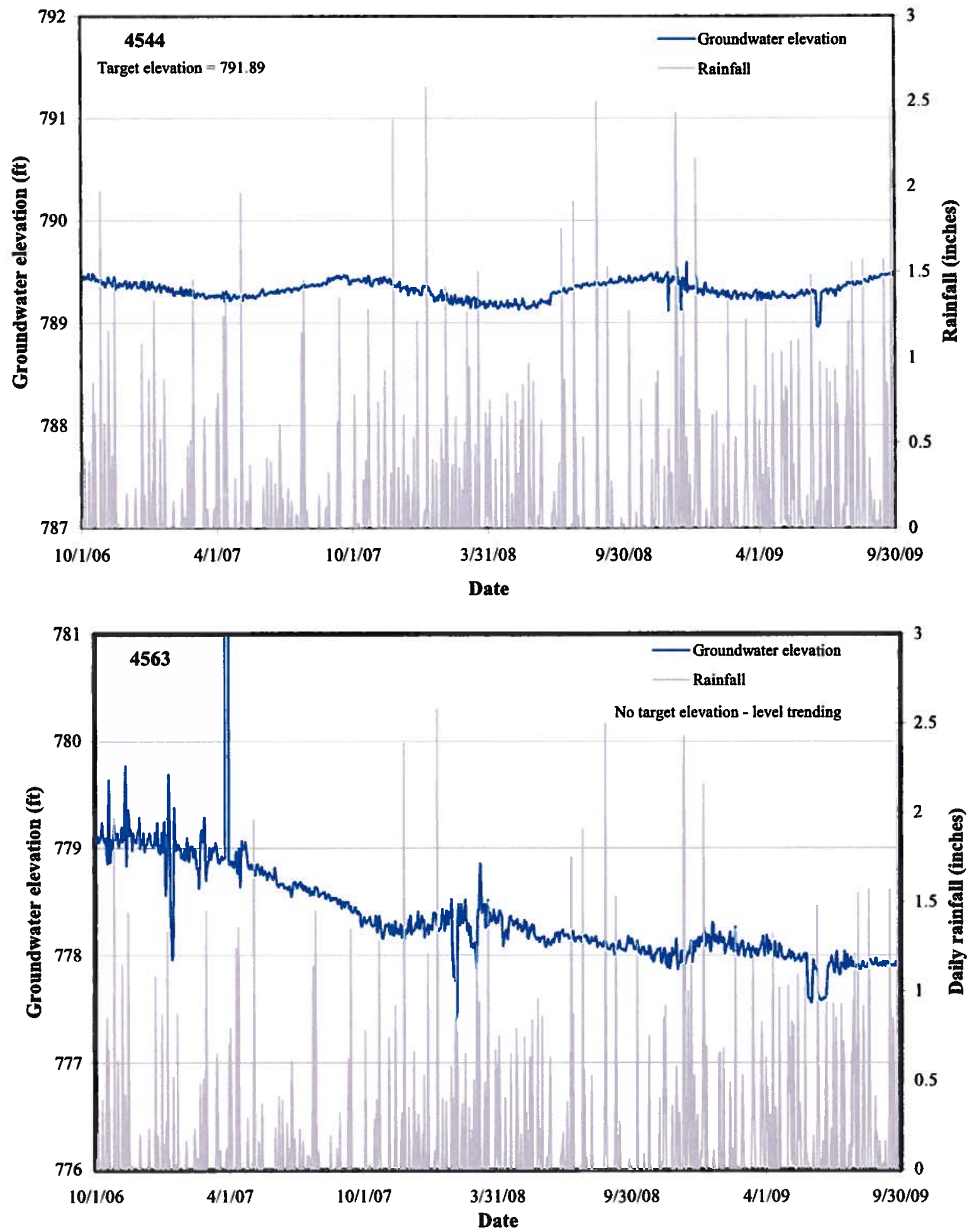

Figure 3.8. Examples of groundwater level responses in shallow wells inside the SWSA 4 hydrologically isolated areas FY 2007 through FY 2009. 

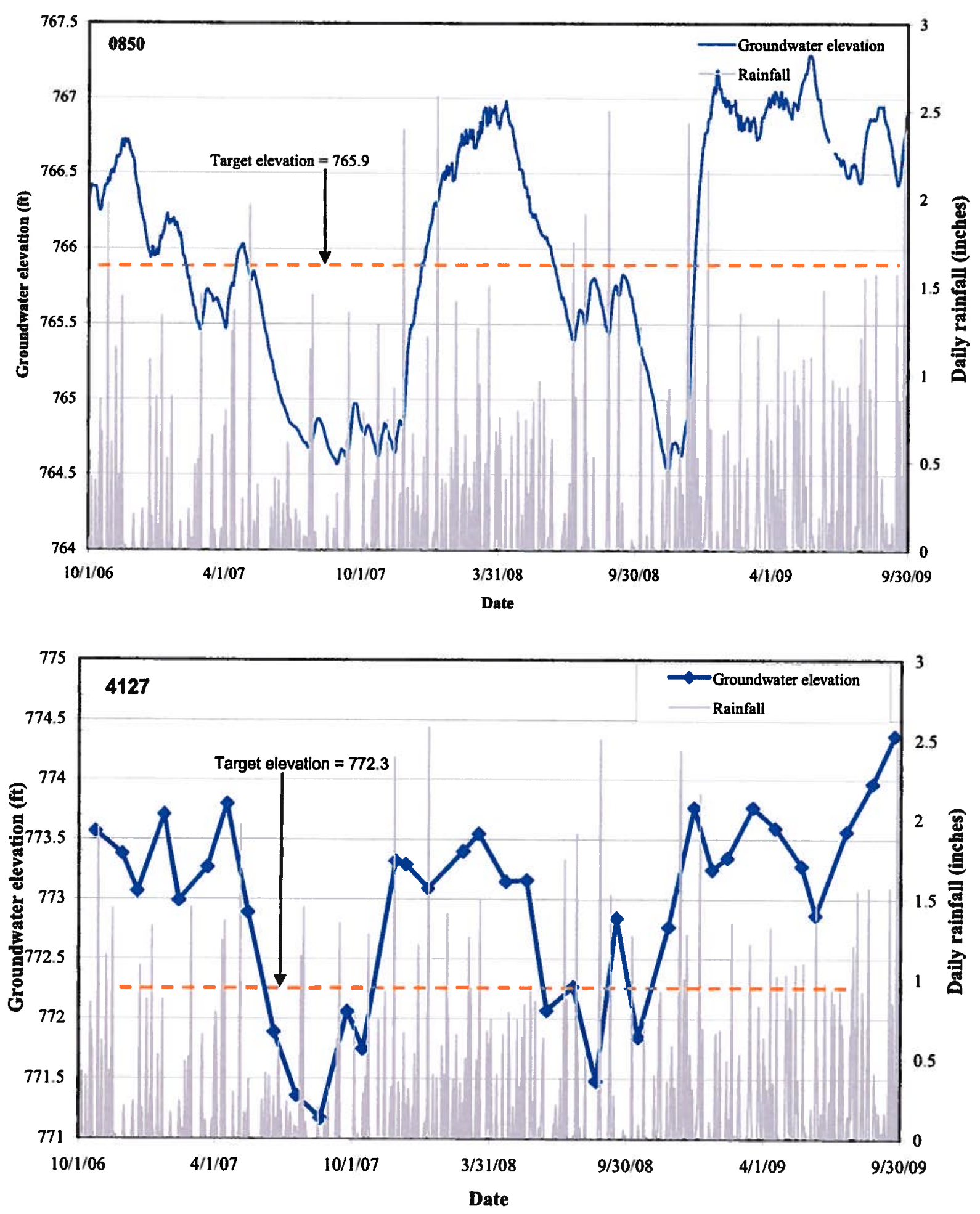

Figure 3.9. Hydrograph for wells 4127 and 0850 for FY 2007 through FY 2009. 
Well 0850 is located in the central portion of SWSA 6 in a former ravine area. The well extends approximately $13 \mathrm{ft}$ below the estimated floor elevations of nearby waste burial trenches beneath the adjacent capped area. Water level monitoring data indicate that during the wet season the groundwater level in the well rises above the target groundwater elevation. The hydrograph response for well 0850 (Figure 3.9) shows a muted response to rainfall events and a strong seasonal fluctuation signature suggesting that the well is responding to groundwater level variations caused by recharge to areas outside the capped area. Water quality data from well 0838 , which is located downgradient from well 0850 , was reviewed to determine if contaminant levels from that portion of SWSA 6 are adversely affected by the groundwater levels near well 0850 . VOCs are not detected at well 0838 , nor are alpha and beta activity. Tritium is detected in well $\mathbf{0 8 3 8}$, as it was in surface water from the area prior to remediation, and since FY 2004 the tritium concentrations have decreased from more than $200,000 \mathrm{pCi} / \mathrm{L}$ to about $5,000 \mathrm{pCi} / \mathrm{L}$. This decrease in tritium concentration in this area is a continuation of tritium concentration reduction observed since about FY 2003 and suggests that the groundwater levels observed at well 0850 are not causing mobilization of contaminants from the area.

Three wells in SWSA 4 did not attain their target elevations in FY 2009 - wells 1071 and 4558 in the western part of the burial ground, and well 0958 located near the SWSA 4 downgradient trench. Wells 1071 and 4558 are both located near a former surface water drainage feature that crossed SWSA 4 from northwest to southeast. This area formerly carried runoff from an upslope area of about 16.5 acres. During construction of the SWSA 4 Upgradient Diversion Trench, a clay plug was constructed in conjunction with the installation of the SWSA 4 Upgradient Diversion Trench to prevent continued seepage into the hydrologically isolated burial ground. The well 1071 hydrograph (Figure 3.10) shows that there is water level fluctuation within a range of approximately $0.7 \mathrm{ft}$ and the August 2009 level exceeded the target elevation by $0.14 \mathrm{ft}$. At well 4558 , further downslope and also in the former drainage area, groundwater levels continue to fluctuate within a range of about $0.36 \mathrm{ft}$, with an average elevation of 789.79 which is about $0.67 \mathrm{ft}$ higher than the target elevation for the area. This behavior is presumed to be caused by a small amount of groundwater seepage that originates from the slope of Haw Ridge to the north of the Upgradient Diversion Trench. The groundwater level behavior of other wells within the former SWSA 4 tributary area to the east and downgradient of wells 1071 and 4558 do not indicate that a large amount of water is moving through the former surface drainage features because their water levels are stable or continuing to decrease gradually. Based on the above average rainfall during FY 2009, DOE recommends continued monitoring of water levels to determine the trend.

The third well in SWSA 4 that did not meet its target groundwater level during FY 2009 was well 0958, which is located near the downgradient groundwater collection trench inside the hydrologically isolated area. Figure 3.11 includes a hydrograph of well 0958 which is located approximately $20 \mathrm{ft}$ west of the downgradient groundwater collection trench, inside the hydrologically isolated area. Well 4547 measures the groundwater level within the downgradient trench and well 4548 measures groundwater level to the east of the downgradient trench in the Intermediate Holding Pond area. Figure 3.11 shows that under normal conditions the groundwater level in the downgradient trench is depressed to the design level of about $758 \mathrm{ft} \mathrm{msl}$. Intense rainfall causes water levels outside the hydrologically isolated area (in the Intermediate Holding Pond) to rise, which can cause water to flow into the downgradient trench more rapidly than the pumping system can remove. This condition is observed to occur for periods of 3 to 4 days, after which the storm runoff subsides and the downgradient trench pumps draw the trench groundwater levels back down to about $758 \mathrm{ft}$ msl. As shown on Figure 3.11 , ten storm events during FY 2009 caused the SWSA 4 downgradient trench to fill. Nine of the ten events occurred between midDecember 2008 and mid-May 2009 and one event occurred in late September. During FY 2008, this condition occurred five times between December 2007 and March 2008. The higher incidence of SWSA 5 downgradient trench inundation during FY 2009 is a result of the above average rainfall. Similar conditions are not observed at the other downgradient collection trenches in MV because a different 

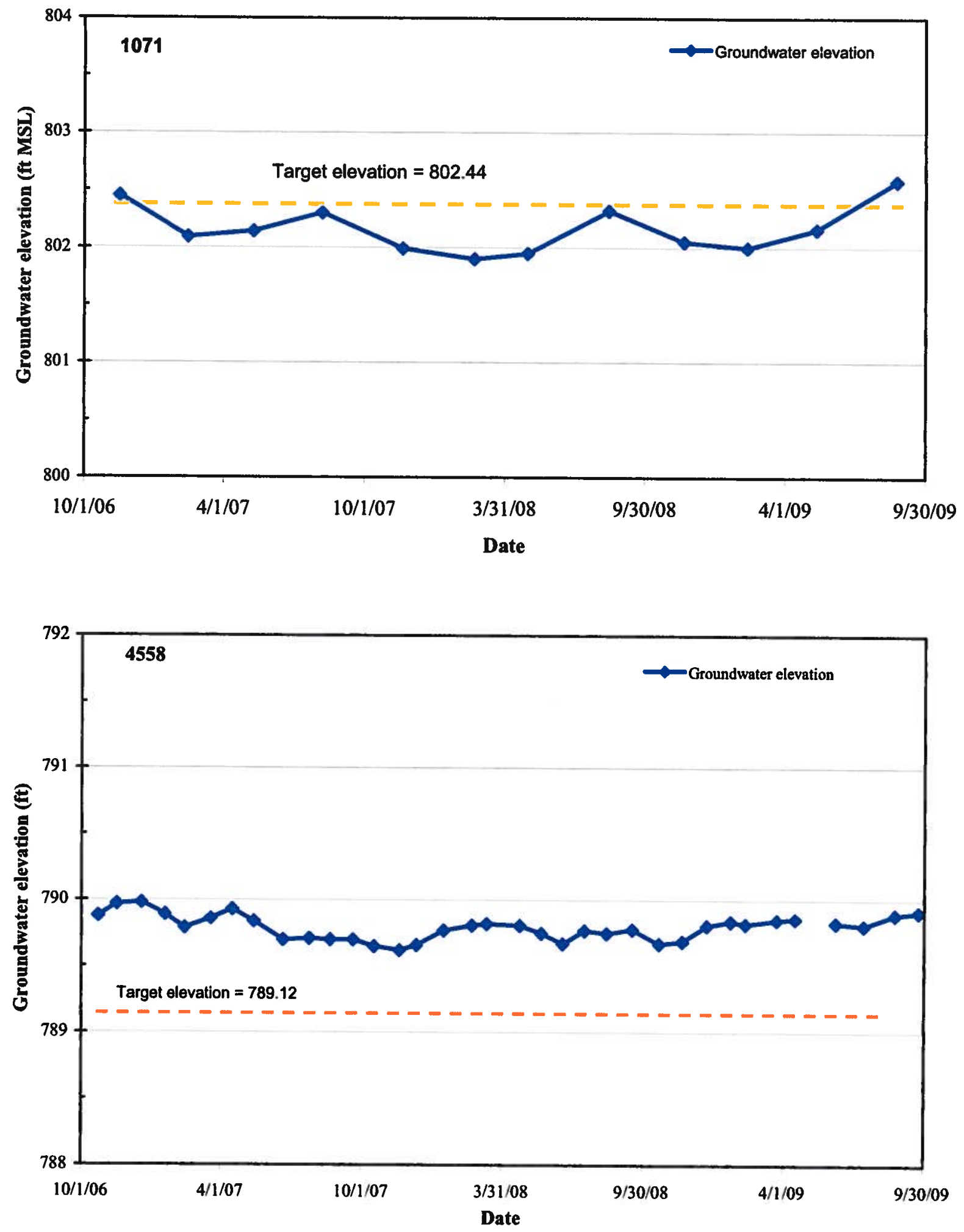

Figure 3.10. Hydrographs of wells 1071 and 4558 in SWSA 4 for FY 2007 through FY 2009. 

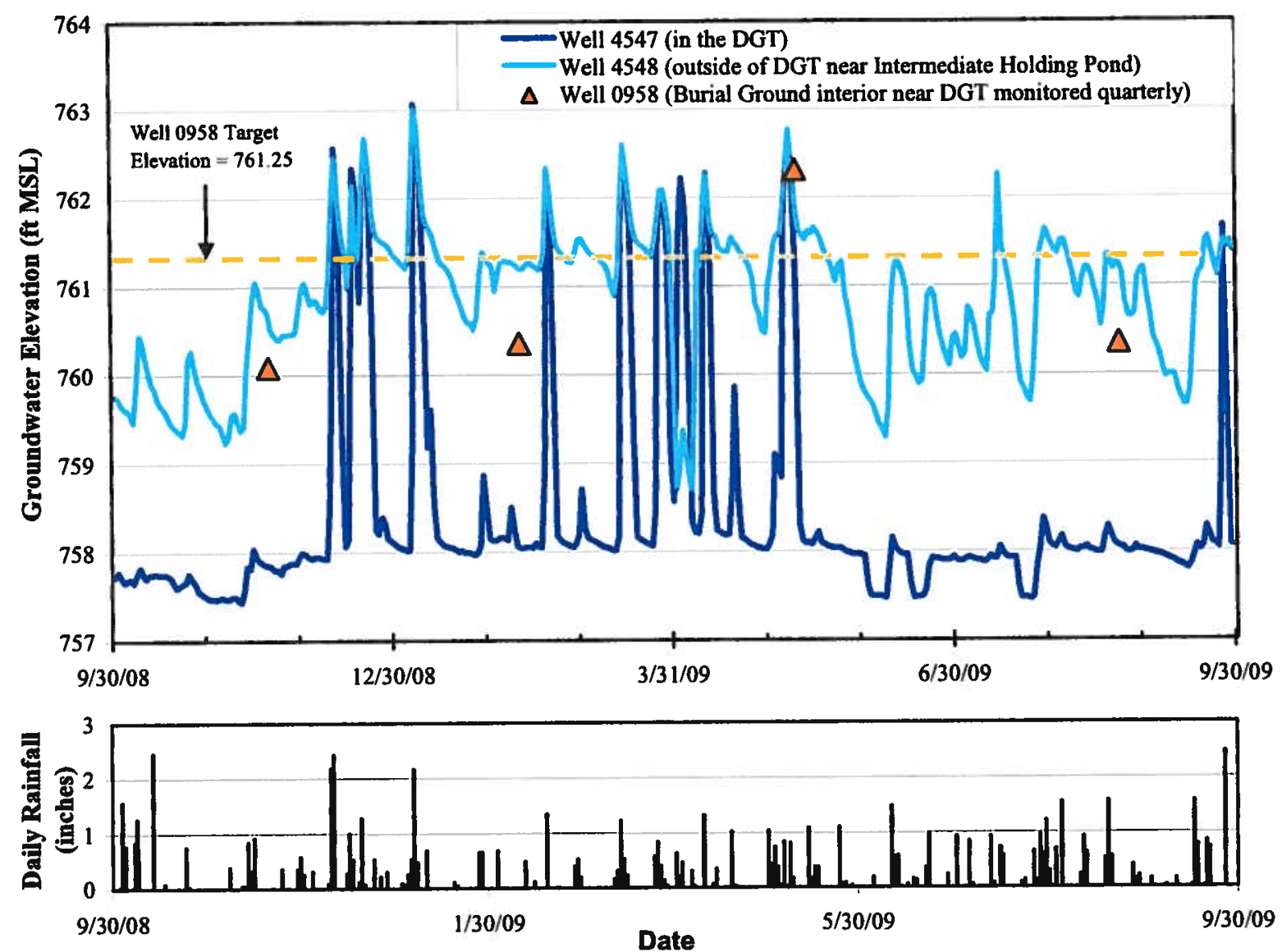

Figure 3.11. Hydrographs of wells 0958 in SWSA 4 and 4547 and 4548 at the downgradient groundwater collection trench.

design was used that prevents groundwater in-leakage from outside the collection trench. Winter months are the season during which most groundwater recharge occurs because the dormant vegetation cannot lower soil moisture levels through evapotranspiration.

\subsection{Groundwater Quality}

Groundwater monitoring is conducted for CERCLA remediation effectiveness evaluation in MV Exit Pathway wells, near the Seepage Pits and Trenches, and around the Tumulus low-level solid waste disposal facility in SWSA 6. Additionally, groundwater monitoring is conducted at SWSA 6 in compliance with the SWSA 6 proposed RCRA permit requirements and results are reported annually to the TDEC DSWM and are summarized in this section.

\section{Seepage Pits and Trenches Area Groundwater Quality}

Groundwater monitoring is conducted in wells located around the perimeter of the Seepage Pits and trenches area (formerly referred to as WAG 7), as well as in the immediate proximity to LLLW Seepage Trenches 5 and 7. 
Figure 3.12 shows the locations of wells that are monitored at the Pits and Trenches area. Table 3.10 includes a summary of radiological contaminants detected in the area. Principal radiological groundwater contaminants detected at Trenches 5 and 7 include ${ }^{14} \mathrm{C},{ }^{60} \mathrm{Co},{ }^{90} \mathrm{Sr},{ }^{99} \mathrm{Tc},{ }^{3} \mathrm{H},{ }^{232} \mathrm{U},{ }^{234} \mathrm{U}$, and ${ }^{238} \mathrm{U}$. Carbon-14 was a constituent of the LLLW disposed in the seepage trenches, and because the chemical treatment used to immobilize strontium and cesium had little affect on carbon, this contaminant is detected in most wells near these trenches. The highest levels of groundwater contamination in the Seepage Pits and Trenches area occur in the immediate vicinity of Trenches 5 and 7. Groundwater contaminant concentrations in wells near Trenches 5 and 7 are generally decreasing compared to concentrations measured during FY 2005 and 2006.

Table 3.10 provides the FY 2009 levels of radiological contaminants present in the groundwater compared to risk-based criteria of $1 \times 10^{-4}$ levels for industrial and residential exposure scenario concentrations. Concentration trend direction for the pre-remediation through FY 2009 data is also indicated in Table 3.10 for radionuclides that exceed their target level. The $1 \times 10^{-4}$ risk level was selected as a screen since that level is commonly used as the upper bound of a target risk range. Appendix B includes a summary table of the industrial and residential risk-equivalent radionuclide concentrations, as well as trend graphs for wells with elevated radionuclide concentrations.

In general, groundwater contaminant concentrations in the Seepage Pits and Trenches area have decreased since levels measured prior to RA. Contaminant levels in wells at the perimeter of the Pits and Trenches area have decreased since the MV remedy was completed. Several shallow wells have become dry since they lie within areas that were hydrologically isolated. Contaminant levels in some wells near Trenches 5 and 7 continue to decline while others have apparently reached relatively stable concentrations and tend to fluctuate somewhat with seasonal changes. A few contaminants near the seepage trenches exhibit gradual increases. Overall, groundwater contaminant levels are lower since remedy completion.

\section{SWSA 6 Groundwater Monitoring Results}

The RCRA monitoring program samples 10 wells around the perimeter of SWSA 6 (Figure 3.12). Well 0846 is the designated upgradient well. The principal detected RCRA contaminants are VOCs, carbon tetrachloride and its degradation product chloroform, and TCE and its degradation products cis1,2-DCE and 1,2-DCA. These constituents are detected regularly in wells 0841 and 0842 , located on the eastern boundary of SWSA 6 . RCRA monitoring data indicate that the concentrations of regulated hazardous constituents in groundwater at SWSA 6 are generally stable to gradually decreasing. CERCLA radiological monitoring of groundwater is also conducted in these wells. The principal and most mobile radionuclide detected in groundwater at SWSA 6 is tritium. The highest tritium concentrations in the RCRA well network are measured in wells 0842,0843 , and 0844 along the eastern site boundary. Tritium concentration trends are generally decreasing, although tritium in well 0844 continues to follow a longterm increasing trend. Trend graphs of the contaminants noted above are included in Appendix B.

Tritium is also monitored in groundwater around the Tumulus low-level solid waste disposal facility where historic discharges from containerized waste created a groundwater tritium plume. Six wells (Figure 3.12) at the Tumulus are sampled to measure the groundwater tritium trends. Trend plots for tritium in these wells are included in Appendix B. Wells 1036 and 1039 exhibit the highest tritium levels and both have shown significant declines in tritium concentration subsequent to the 2006 remedy completion. Well 1258 has exhibited an increase in tritium concentration following area capping, possibly as a result of seepage pattern changes beneath the hydrogically isolated area. 


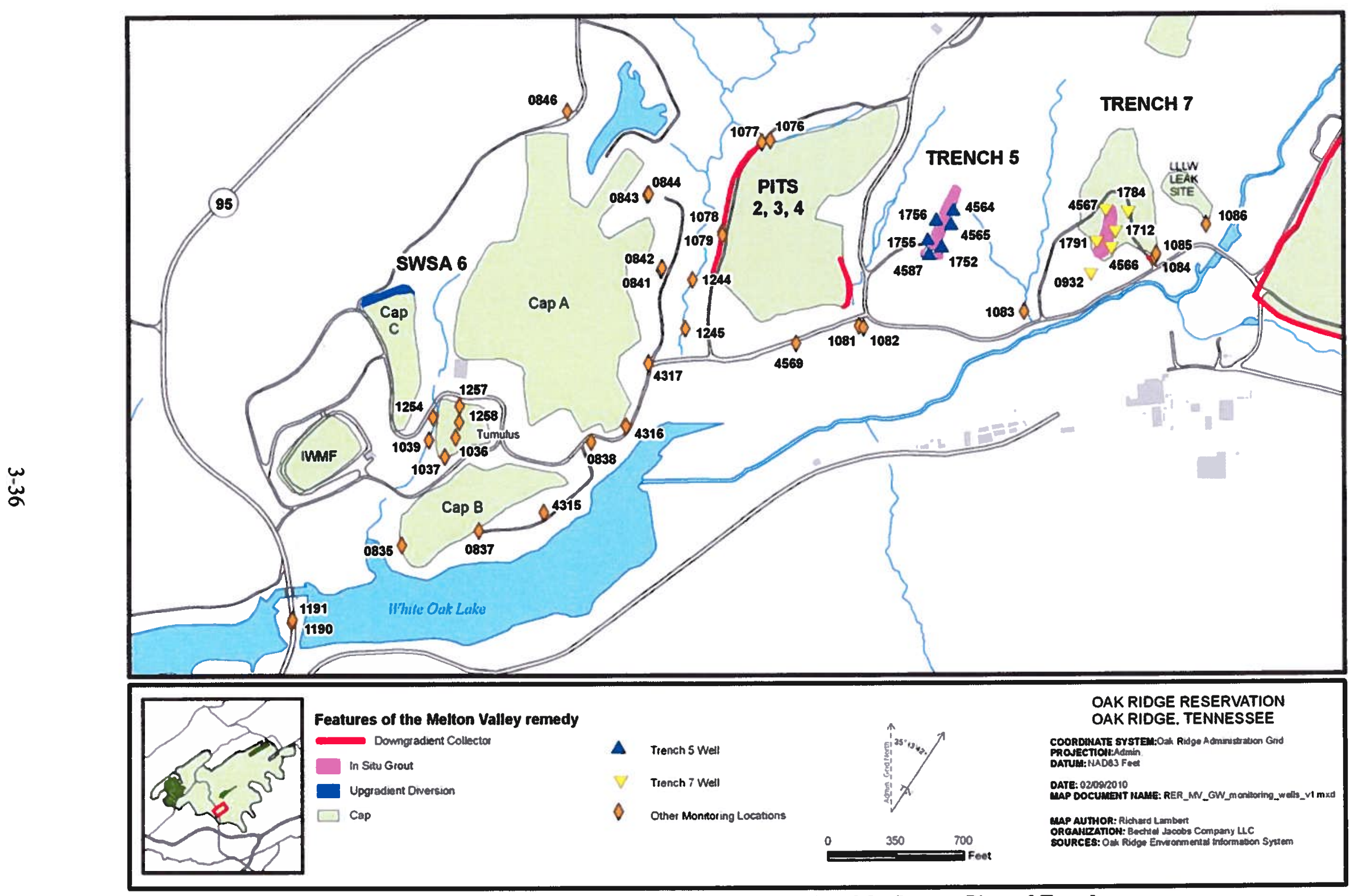

Figure 3.12. Locations of wells monitored in the vicinity of the Seepage Pits and Trenches. 
Table 3.10. Summary of radiological groundwater contaminants detected at Seepage Trenches 5 and 7

\begin{tabular}{|c|c|c|c|c|c|c|c|c|c|c|}
\hline Well & Alpha & ${ }^{14} \mathrm{C}$ & ${ }^{60} \mathrm{Co}$ & ${ }^{\sqrt[3]{H}}$ & ${ }^{90} \mathrm{Sr}$ & ${ }^{99} \mathrm{Tc}$ & ${ }^{232} U$ & ${ }^{234} \mathbf{U}$ & ${ }^{235} \mathbf{U}$ & ${ }^{238} U$ \\
\hline 0932 & ND & ND & $\mathrm{ND}$ & $<\mathrm{MCL}$ & ND & $\mathrm{ND}$ & $\mathrm{ND}$ & $<\mathrm{I}<\mathrm{R} \leftrightarrow$ & ND & ND \\
\hline 0935 & ND & $>$ I $>$ R $\downarrow$ & ND & $<\mathrm{I}>\mathrm{R} \downarrow$ & $\mathrm{ND}$ & $\mathrm{ND}$ & $\mathrm{ND}$ & $\mathrm{ND}$ & ND & ND \\
\hline 1076 & $<\mathrm{MCL}$ & ND & $\mathrm{ND}$ & $<\mathrm{MCL}$ & $<\mathrm{I}<\mathbf{R} \downarrow$ & $<\mathrm{MCL}$ & ND & $<\mathrm{I}<\mathbf{R} \downarrow$ & ND & ND \\
\hline 1077 & $\mathrm{ND}$ & ND & ND & ND & ND & ND & ND & ND & ND & - \\
\hline $1078^{a}$ & -- & -- & -- & -- & - & - & - & - & - & -- \\
\hline 1079 & $\leftrightarrow$ & $>$ I $>$ R $\leftrightarrow$ & ND & $>\mathrm{I}>\mathrm{R} \downarrow$ & ND & $<\mathrm{MCL}$ & ND & $>\mathrm{I}>\mathrm{R} \downarrow$ & $<\mathrm{I}<\mathrm{R} \leftrightarrow$ & $<\mathbf{I}<\mathbf{R} \downarrow$ \\
\hline 1081 & ND & ND & ND & ND & ND & ND & ND & ND & ND & $<\mathrm{I}<\mathrm{R} \leftrightarrow$ \\
\hline 1082 & ND & ND & ND & $<\mathrm{MCL}$ & $<\mathrm{MCL}$ & $<\mathrm{MCL}$ & ND & $<\mathrm{I}<\mathrm{R} \leftrightarrow$ & ND & ND \\
\hline 1083 & ND & ND & ND & $<\mathrm{MCL}$ & $\mathrm{ND}$ & $<\mathrm{MCL}$ & $\mathrm{ND}$ & $<\mathrm{I}<\mathrm{R} \leftrightarrow$ & ND & ND \\
\hline 1084 & $<\mathrm{MCL}$ & $>\mathrm{I}>\mathrm{R} \downarrow$ & ND & $<\mathrm{MCL}$ & ND & $<\mathrm{MCL}$ & ND & ND & ND & $<\mathrm{I}<\mathrm{R} \leftrightarrow$ \\
\hline 1085 & $\mathrm{ND}$ & ND & ND & ND & ND & ND & $\mathrm{ND}$ & ND & ND & ND \\
\hline $1086^{\mathrm{a}}$ & $\cdots$ & - & -- & - & - & - & - & - & -- & - \\
\hline 1244 & $<\mathrm{MCL}$ & $>\mathrm{I}>\mathrm{R} \downarrow$ & ND & $<\mathrm{MCL}$ & ND & $<\mathrm{MCL}$ & ND & $<\mathrm{I}<\mathrm{R} \downarrow$ & ND & ND \\
\hline 1245 & ND & ND & ND & $\mathrm{ND}$ & ND & $\mathrm{ND}$ & ND & $<\mathrm{I}<\mathrm{R} \leftrightarrow$ & ND & ND \\
\hline 1712 & $\downarrow$ & $>$ I $>$ R $\leftrightarrow$ & $<\mathrm{I}<\mathrm{R} \downarrow$ & $<\mathrm{MCL} \uparrow$ & $<\mathbf{I}<\mathbf{R} \uparrow$ & $<\mathrm{MCL} \uparrow$ & ND & $<\mathbf{I}<\mathbf{R} \downarrow$ & $<\mathrm{I}<\mathrm{R} \downarrow$ & $<\mathrm{I}<\mathrm{R} \downarrow$ \\
\hline 1752 & $\downarrow$ & $>$ I > R $\downarrow$ & $<\mathrm{I}>\mathrm{R} \downarrow$ & $<\mathrm{MCL}$ & $<\mathrm{MCL}$ & $>\mathrm{I}>\mathrm{R} \downarrow$ & $>$ I $>$ R $\leftrightarrow$ & $>\mathrm{I}>\mathrm{R} \leftrightarrow$ & $<\mathrm{I}<\mathrm{R} \leftrightarrow$ & $<1<\mathrm{R} \leftrightarrow$ \\
\hline 1755 & $\leftrightarrow$ & $>\mathrm{I}>\mathrm{R} \downarrow$ & $>\mathrm{I}>\mathrm{R} \downarrow$ & $<\mathrm{MCL}$ & $<\mathrm{I}<\mathrm{R} \downarrow$ & $<\mathrm{I}>\mathrm{R} \downarrow$ & $>\mathrm{I}>\mathrm{R} \uparrow$ & $>\mathrm{I}>\mathrm{R} \uparrow$ & $<\mathrm{I}<\mathrm{R} \leftrightarrow$ & $<\mathrm{I}>\mathrm{R} \uparrow$ \\
\hline 1756 & $\downarrow$ & $>$ I $>$ R $\downarrow$ & $<\mathrm{I}<\mathrm{R} \downarrow$ & $<\mathrm{MCL}$ & $<\mathrm{MCL}$ & $<\mathrm{I}<\mathrm{R} \downarrow$ & $<\mathrm{l}>\mathrm{R} \leftrightarrow$ & $>\mathrm{I}>\mathrm{R} \downarrow$ & $<\mathrm{I}<\mathrm{R} \leftrightarrow$ & $<\mathrm{I}<\mathrm{R} \downarrow$ \\
\hline 1784 & $\sim \mathrm{MCL}$ & $>\mathrm{I}>\mathrm{R} \leftrightarrow$ & ND & $<\mathrm{MCL}$ & $<\mathrm{I}<\mathrm{R} \downarrow$ & $<\mathrm{MCL}$ & ND & $<\mathrm{I}<\mathrm{R} \leftrightarrow$ & ND & $<\mathrm{I}<\mathrm{R} \leftrightarrow$ \\
\hline 1791 & $>\mathrm{MCL}$ & $>\mathrm{I}>\mathrm{R} \downarrow$ & $<\mathrm{I}>\mathrm{R} \downarrow$ & $<\mathrm{MCL}$ & ND & $>\mathrm{I}>\mathrm{R} \uparrow$ & ND & ND & ND & $\mathrm{ND}$ \\
\hline 4564 & $\downarrow$ & $>\mathrm{I}>\mathrm{R} \downarrow$ & $<\mathrm{I}<\mathrm{R} \leftrightarrow$ & $<\mathrm{MCL}$ & ND & $<\mathrm{MCL}$ & ND & $<\mathrm{I}<\mathrm{R} \leftrightarrow$ & $<\mathbf{I}<\mathbf{R} \downarrow$ & $<\mathrm{I}<\mathrm{R} \downarrow$ \\
\hline 4565 & $\downarrow$ & $>\mathrm{I}>\mathrm{R} \downarrow$ & $<\mathrm{I}<\mathrm{R} \downarrow$ & $<\mathrm{I}<\mathrm{R} \leftrightarrow$ & ND & $<\mathrm{I}<\mathrm{R} \downarrow$ & $\mathrm{ND}$ & $<\mathrm{I}<\mathrm{R} \leftrightarrow$ & ND & $<\mathrm{I}<\mathrm{R}$ \\
\hline 4566 & $\sim \mathrm{MCL} \leftrightarrow$ & $>$ I > R $\downarrow$ & $>\mathrm{I}>\mathrm{R} \downarrow$ & $<\mathrm{MCL}$ & ND & $<\mathbf{I}<\mathbf{R} \uparrow$ & ND & $<\mathrm{I}<\mathrm{R} \leftrightarrow$ & ND & $<\mathbf{I}<\mathbf{R} \uparrow$ \\
\hline $4567^{\mathrm{a}}$ & - & - & - & - & -- & -- & - & -- & - & -- \\
\hline 4569 & ND & ND & ND & $<\mathrm{MCL}$ & ND & ND & ND & ND & ND & ND \\
\hline 4587 & $\uparrow$ & $>\mathrm{I}>\mathrm{R} \uparrow$ & $<\mathrm{I}<\mathrm{R} \downarrow$ & $<\mathrm{MCL}$ & ND & $<\mathrm{I}>\mathrm{R} \leftrightarrow$ & $<\mathrm{I}<\mathrm{R} \leftrightarrow$ & $<\mathrm{I}<\mathrm{R} \leftrightarrow$ & $<\mathrm{I}<\mathrm{R} \leftrightarrow$ & $<\mathrm{I}<\mathrm{R} \leftrightarrow$ \\
\hline
\end{tabular}

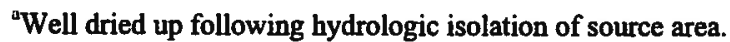

$I=$ industrial scenario $1 \times 10^{-4}$ risk-based concentration

$R=$ residential scenario $1 \times 10^{-4}$ risk-based concentration

$\downarrow=$ pre-remedy vs. post-remedy concentration trend downward

$\uparrow=$ pre-remedy vs. post-remedy concentration trend upward

$\overleftrightarrow{\mathrm{ND}}=$ trend indeterminate

${ }^{3} \mathrm{H} \mathrm{MCL}$ EDE $=20,000 \mathrm{pCi} / \mathrm{L},{ }^{99} \mathrm{Tc} \mathrm{MCL}$ EDE $=900 \mathrm{pCi} / \mathrm{L}$, and ${ }^{90} \mathrm{Sr} \mathrm{MCL}$ EDE $=8 \mathrm{pCi} / \mathrm{L}$ are individual EDEs to the 4 mrem/yr MCL for beta particle and photon activity. 
The reduction in tritium discharges from the Tumulus is a significant component of the decrease in tritium measured in surface water at WAG6 MS3 which is located nearby. The reader is referred back to Sect. 3.2.2.1.3 and Table 3.9 where the surface water data for this location is presented.

\section{Melton Valley Exit Pathway and Hydrofracture Area Groundwater Quality Results}

Exit pathway groundwater monitoring includes monitoring of wells 1190 and 1191 that are located on WOD (Figure 3.12) and monitor groundwater seepage beneath the dam, as well as monitoring of deep groundwater between the Clinch River and the western edge of SWSA 6.

Wells 1190 and 1191 are about 47 and $26 \mathrm{ft}$ deep, respectively, and are located near the centerline of WOD. Well 1190 is constructed to monitor groundwater in bedrock at an elevation $708-718 \mathrm{ft}$ msl, which is approximately equivalent to the bed of the Clinch River located about 2,500 $\mathrm{ft}$ to the west. Well 1191 samples water from the interface between the bedrock surface and the sediment/soil fill beneath the dam at elevations from $724-743 \mathrm{ft} \mathrm{msl}$, which is approximately equivalent to elevations of the WOC embayment and the channel of the Clinch River. Tritium and ${ }^{90} \mathrm{Sr}$ are the principal contaminants detected in these wells and Figure 3.13 shows the concentration histories from about 1990 through FY 2009. Contaminant levels are greater in the bedrock well (1190) than in the shallow well and both contaminants continue a long-term decline in concentrations. During FY $2009,{ }^{90} \mathrm{Sr}$ levels were below detection limits $(0.9 \mathrm{pCi} / \mathrm{L})$ in well 1190.

As part of the MV ROD (DOE 2000a), six groundwater monitoring wells were installed in the western end of MV to serve as sentinel wells to detect site-related contaminants that may seep toward the Clinch River. These six deep, multizone monitoring wells were constructed in a line extending from the toe of Haw Ridge southward to the south side of the WOCE near WOD. Locations of these wells are shown on Figure 3.14.

In MV, relatively fresh groundwater extends to depths of approximately $300 \mathrm{ft}$ bgs. Beneath the fresh water zone, groundwater contains elevated sodium chloride and sulfate that are components of the naturally occurring ancient waters contained in the bedrock. At depths greater than about $500 \mathrm{ft}$ in MV, the groundwater is saline brine that contains extremely high concentrations of chloride, sulfate, sodium, and calcium. This deep groundwater is non-potable because of natural salinity and wells constructed in the bedrock at such depths produce very little water. The exit pathway wells were designed and installed to sample groundwater above the brine zone.

Each well was drilled to a depth of $500 \mathrm{ft}$ and was tested to determine the locations of water-bearing fractures that could be instrumented for sampling. Based on the results of testing, a total of 37 sampling zones were created by installation of Westbay ${ }^{\circledR}$ multizone sampling systems. Subsequent to installation, each zone was purged in preparation for sampling. Over FY 2005 and 2006, baseline samples were collected and analyzed to evaluate the stabilization of groundwater quality in the sampled wells.

Figure 3.15 provides a cross-sectional view of the location, depth of sample zones, and indicates zones sampled during FY 2009. Sampling was conducted consistent with the requirements of the MV RAR. Field measurements included pH, specific conductance, and redox. Samples were analyzed for major anions (fluoride, chloride, sulfate), metals (including major dissolved cations, minor and trace metals), radiological constituents (alpha and beta activity, measurable radionuclides using gamma spectroscopy, tritium, and uranium in selected samples), and VOCs. Many of the lab analyses of samples from the exit pathway wells yielded non-detected results and the following discussion focuses on results of general chemistry (anions and metals), radionuclides, and VOCs. 

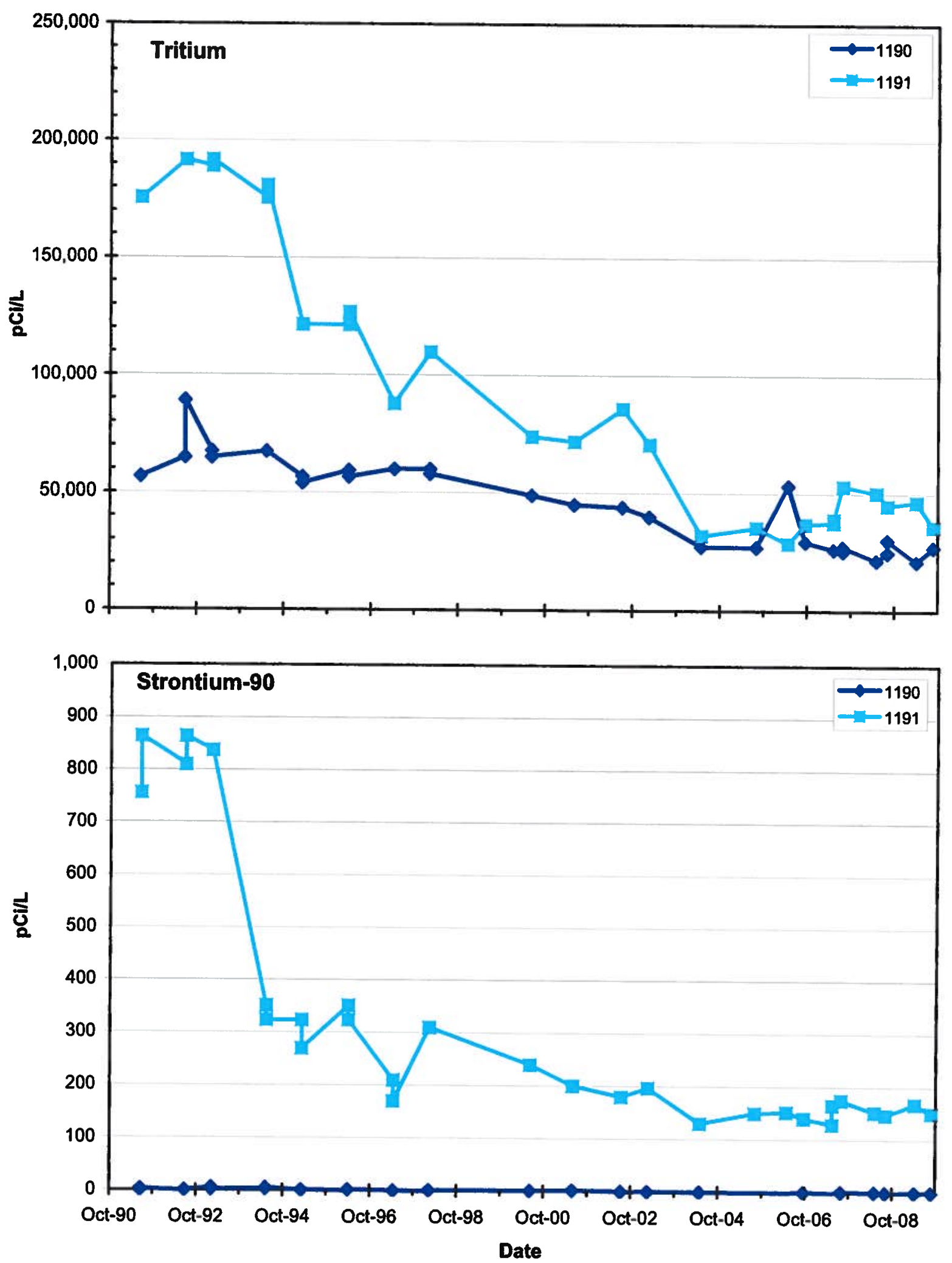

Figure 3.13. WOD groundwater tritium and ${ }^{90} \mathrm{Sr}$ concentration histories. 

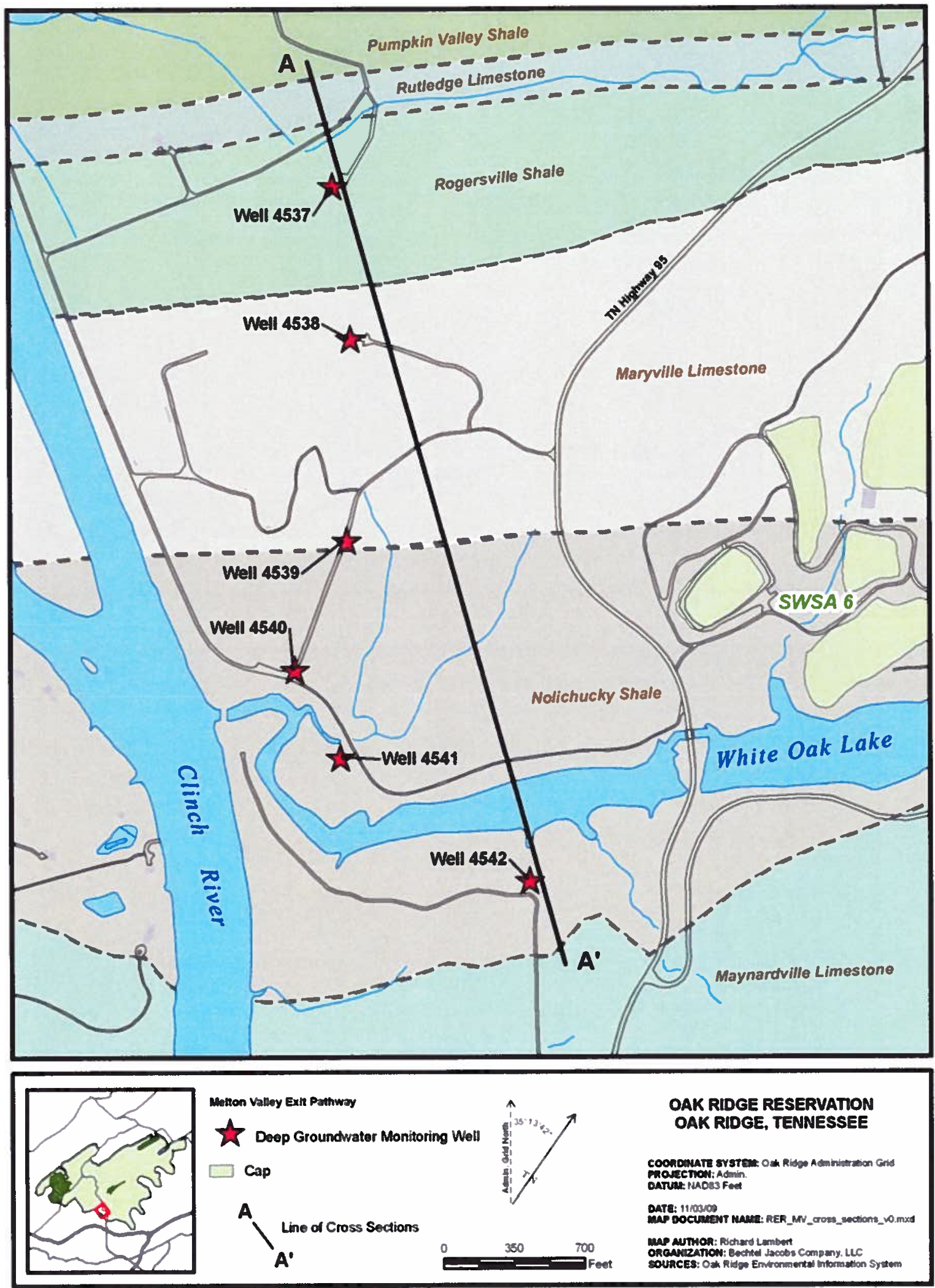

Figure 3.14. Locations of MV Exit Pathway deep groundwater monitoring wells. 


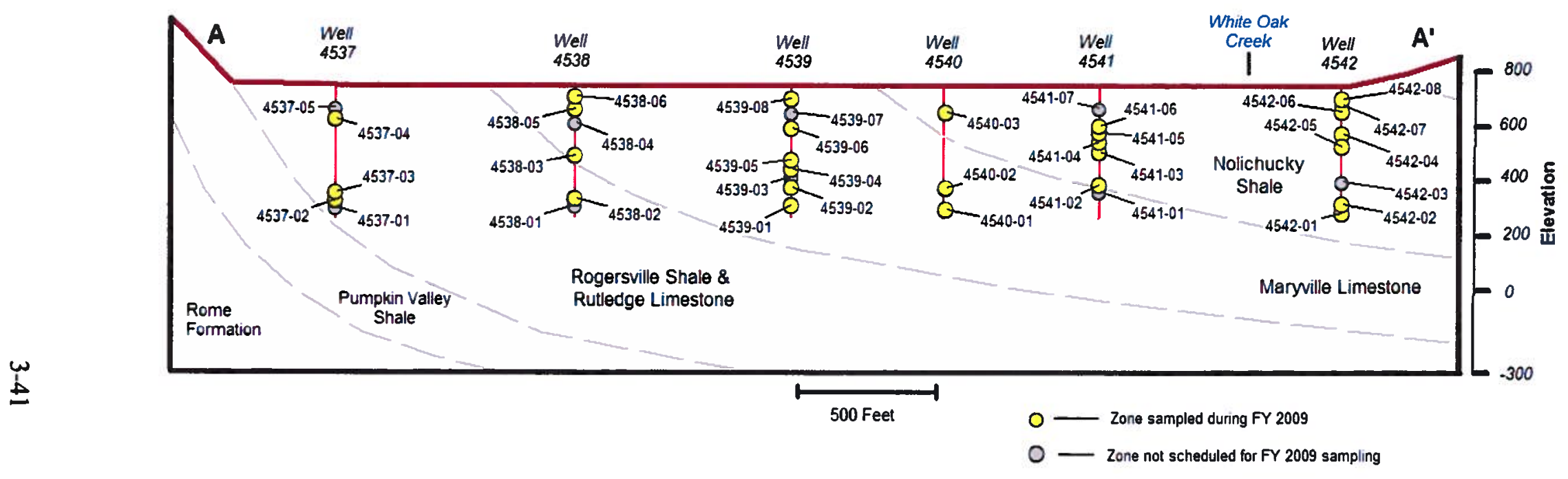

Figure 3.15. Locations of exit pathway sampling zones. 
Table 3.11 summarizes the results of analyses for samples collected during FY 2009 and compares results to the SDWA primary and secondary drinking water standards. Results are the maximum concentrations detected for cases in which more than one lab analysis was conducted for a specific parameter from one sample zone for a particular sample event. Total dissolved solids in many of the sampled zones were greater than the secondary drinking water standard screening value and are attributable to naturally occurring chloride, sulfate, calcium, and sodium. Water $\mathrm{pH}$ in many of the zones is elevated. As was observed during baseline monitoring, many of the sample zones continue to produce water with significant turbidity and measurable suspended solids that apparently contribute significantly to the measured concentrations of aluminum, iron, and manganese. Samples for metals analysis have historically been acid-preserved in the field without filtration to remove solids which can allow dissolution of fine-grained and colloidal oxy-hydroxides of aluminum, iron, and manganese and can dissolve metals adsorbed to clay particles. During FY 2009, samples for metals analysis were collected in duplicate and one aliquot was field filtered prior to acid preservation. Screening results included in Table 3.11 are from the field filtered aliquot and represent dissolved or colloidal metals. Chloride and sulfate in some of the sampled zones were greater than the secondary drinking water standards. Chloride and sulfate originate from natural bedrock minerals and native geologic brines. Fluoride was detected at concentrations greater than the secondary drinking water standard but less than primary standard in four zones and exceeded the primary standard in 11 sampled zones. The likely origin of fluoride in the wells is not yet known but may be associated with natural mineral dissolution. Barium was detected at concentrations greater than the drinking water reference concentrations in four zones. Lead was detected in one sample zone at approximately $10 \%$ of the drinking water standard. Nine samples showed the presence of lead at estimated concentrations less than $1 \mu \mathrm{g} / \mathrm{L}$.

During FY $2009,{ }^{90} \mathrm{Sr}$ was analyzed on 19 samples. Strontium-90 was detected in samples from three of the zones as indicated in Table 3.11 and all detected values were less than one-half the $8 \mathrm{pCi} / \mathrm{L}$ drinking water standard equivalent level. In six of the sampled zones, the radiological screening parameter for alpha activity exceeded the drinking water standard. Uranium isotopes were analyzed in eleven of the sample zones during FY 2009 to evaluate the possible contribution of uranium to some of the alpha activity levels. The results for uranium isotopes indicated that ${ }^{234} \mathrm{U}$ was detected in three sample zones 4538-02, 4539-04, and 4541-04 with activities ranging from 1.46 to $8.67 \mathrm{pCi} / \mathrm{L}$. Uranium was detected in zone 4538-02 at a concentration less than $1 \mathrm{pCi} / \mathrm{L}$. The uranium detected in these wells is below a $1.2 \mathrm{E}-5$ risk level for ${ }^{234} \mathrm{U}$ and below a $1 \mathrm{E}-6$ risk level for ${ }^{238} \mathrm{U}$ assuming a residential groundwater use. None of the samples contained detectable ${ }^{137} \mathrm{Cs}$ or ${ }^{60} \mathrm{Co}$. Of 27 samples analyzed for tritium, a radionuclide that is common in several of the MV waste disposal areas, the sample from 4541-03 contained tritium at an activity of $847 \mathrm{pCi} / \mathrm{L}$, which is about $4 \%$ of the drinking water standard. The drinking water standard screening concentration for tritium is $20,000 \mathrm{pCi} / \mathrm{L}$.

During FY 2009, the results of VOC analyses did not detect PCE, TCE, or their transformation products. Chloroform was estimated to be present in the sample from $4542-01$ at $1.1 \mathrm{~J} \mu \mathrm{g} / \mathrm{L}$, and at $0.66 \mu \mathrm{g} / \mathrm{L}$ in the sample from 4540-03. Chloromethane was reported at estimated concentrations $<1 \mu \mathrm{g} / \mathrm{L}$ in three sample zones. Acetone was also reported from nine sample zones. Although not indicated in lab data qualifiers, these compounds are common lab solvents and may be lab artifacts. Low concentrations of petroleum hydrocarbons including benzene (indicated in five samples) and toluene (indicated in three samples) were present as they have been in previous years. These petroleum hydrocarbons may be of natural origins based on occurrences of petroleum crude oil noted in other parts of the ORNL site.

In addition to the parameters discussed previously, samples were analyzed for metals. Arsenic was detected at $13.3 \mu \mathrm{g} / \mathrm{L}$ (slightly greater than the $10 \mu \mathrm{g} / \mathrm{L}$ drinking water standard) in zone $4540-01$. Antimony, beryllium, cadmium, chromium, copper, selenium, and thallium were not detected at concentrations greater than their respective drinking water standard screening levels. 
Table 3.11. Summary of FY 2009 groundwater analyses from MV exit pathway wells

\begin{tabular}{|c|c|c|c|c|c|c|c|c|c|c|c|c|c|c|c|c|}
\hline $\begin{array}{l}\text { Sample } \\
\text { zone }\end{array}$ & $\begin{array}{c}\text { Spec. } \\
\text { cond. } \\
(\mu S / c m)\end{array}$ & $\begin{array}{c}\text { TDS }^{\mathbf{b}} \\
(\mathbf{5 0 0} \\
\mathbf{m g} / \mathbf{L})\end{array}$ & $\begin{array}{l}\text { pH } \\
(6.6- \\
\left.8.5^{2}\right)\end{array}$ & $\begin{array}{l}\text { Redox } \\
\text { (mV) }\end{array}$ & $\begin{array}{l}\text { Turbidity } \\
\text { (NTU) }\end{array}$ & $\begin{array}{c}\text { Alpha } \\
\text { activity } \\
\left(15^{\mathbf{b}}\right. \\
\text { pCi/L) }\end{array}$ & $\begin{array}{c}\text { Beta } \\
\text { activity } \\
\text { (pCi/L) }\end{array}$ & $\begin{array}{c}{ }^{90} \mathbf{S r} \\
\left(8^{d}\right. \\
p C i / L)\end{array}$ & $\begin{array}{c}\mathrm{Al} \\
\left(0.2^{\mathrm{a}}\right. \\
\mathrm{mg} / \mathrm{L})\end{array}$ & $\begin{array}{l}\mathrm{Ba}\left(2^{\mathrm{b}}\right. \\
\mathrm{mg} / \mathrm{L})\end{array}$ & $\begin{array}{c}\mathrm{Fe} \\
\left(0.3^{\mathrm{a}}\right. \\
\mathrm{mg} / \mathrm{L})\end{array}$ & $\begin{array}{c}\mathbf{P b} \\
(\mathbf{1 5} \\
\mathbf{u g} / \mathbf{L})\end{array}$ & $\begin{array}{c}\mathbf{M n} \\
\left(50^{\mathbf{a}}\right. \\
\text { ug/L) }\end{array}$ & $\begin{array}{c}\mathbf{C l} \\
\left(250^{\mathrm{a}}\right. \\
\mathrm{mg} / \mathrm{L})\end{array}$ & $\begin{array}{c}F\left(2^{a},\right. \\
4^{b} \\
m g / L)\end{array}$ & $\begin{array}{c}\mathrm{SO}_{4} \\
\left(250^{\mathrm{a}}\right. \\
\mathrm{mg} / \mathrm{L})\end{array}$ \\
\hline $4537-02$ & 673 & 720 & 7.25 & -5 & 9 & $3.53 \mathrm{~J}$ & 5.53 & $2.4 \mathrm{~J}$ & 0.084 & 0.033 & 0.69 & $<1.1$ & 31 & 6.4 & 0.35 & 360 \\
\hline 4537-03 & 657 & 560 & 7.55 & 87 & 8 & $<2.94$ & 5.2 & $<2.14$ & $<0.0056$ & 0.028 & 0.026 & $<1.1$ & 27 & 3.6 & 0.33 & 230 \\
\hline $4537-04$ & 3,657 & $\mathbf{2 , 0 0 0}$ & 8.42 & 35 & 3 & 26.4 & 17.9 & $\mathrm{NA}$ & $<0.015$ & 0.0189 & 0.035 & $0.55 \mathrm{~J}$ & 27 & 13.5 & 2.14 & 844 \\
\hline 4538-02 & 3,646 & 1,970 & 8.84 & -4 & $>1,000$ & $53 \mathrm{~J}$ & 17.1 & $<0.99$ & $0.019 \mathrm{~J}$ & 0.013 & $<0.033$ & $<0.5$ & 5.1 & 257 & 2.46 & 463 \\
\hline $4538-03$ & 5,870 & 4,100 & 8.06 & 90 & 27 & 3.11 & $<20.6$ & $<1.5$ & $<0.0056$ & 0.026 & 0.071 & $<1.1$ & 22 & 1,100 & 2.2 & 1,500 \\
\hline 4538-05 & 1,626 & 880 & 8.98 & -97 & 6 & 2.76 & 5.67 & $\mathrm{NA}$ & $<0.0056$ & 0.014 & 0.029 & $<1.1$ & $<0.097$ & 87 & 4.1 & 160 \\
\hline $4538-06$ & 720 & 371 & 8.12 & -33 & 44 & 6.66 & $<3.88$ & NA & $<0.015$ & 0.249 & $0.056 \mathrm{~J}$ & $<0.5$ & 24.2 & 14.7 & 0.467 & 3.58 \\
\hline $4539-01$ & 19,306 & 14,000 & 7.46 & 159 & 7 & 2.7 & 32 & $<1.93$ & $<0.0056$ & 8.1 & 0.0043 & $<1.1$ & 160 & $\mathbf{9 , 5 0 0}$ & $<0.43$ & $<4.6$ \\
\hline 4539-02 & 1,561 & 1,200 & 8.8 & -122 & 81 & 5.16 & 6.78 & $<1.45$ & $<0.0056$ & 0.15 & 0.027 & $<1.1$ & 0.75 & 96 & 4.8 & 4.1 \\
\hline 4539-04 & 1,540 & 1,100 & 8.89 & -72 & 15 & 2.82 & 5.47 & $<1.46$ & 0.043 & 0.14 & $<0.0013$ & $<1.1$ & $<0.097$ & 47 & 5.2 & 7.8 \\
\hline 4539-05 & 1,282 & 980 & 8.79 & -20 & 15 & 1.93 & $<3.97$ & NA & 0.036 & 0.13 & $<0.0013$ & $<1.1$ & $<0.097$ & 5.1 & 11 & 19 \\
\hline $4539-06$ & 1,187 & 559 & 9.2 & -20 & 2 & 2.28 & $<2.95$ & NA & $<0.015$ & 0.057 & $<0.033$ & $0.7 \mathrm{~J}$ & $2.15 \mathrm{~J}$ & 1.61 & 5.25 & 16 \\
\hline 4539-08 & 339 & 230 & 8.29 & -13 & 10 & $<1.76$ & $<2.96$ & $<1.63$ & $<0.0056$ & 0.22 & 0.016 & 1.6 & $<0.097$ & 1.9 & 0.6 & 11 \\
\hline $4540-01$ & 30,687 & 16,200 & 7.3 & -82 & 6 & $31.6 \mathrm{~J}$ & 41.8 & 1.82 & 0.055 & 16.2 & 2 & $<0.5$ & 120 & $\mathbf{8 , 7 2 0}$ & 1.32 & 3.92 \\
\hline $4540-02$ & 2,766 & 2,170 & 8.44 & 53 & $>1,000$ & 10.1 & 19.8 & 2.37 & 0.037 & 0.217 & $<0.033$ & $0.67 \mathrm{~J}$ & $1.96 \mathrm{~J}$ & 210 & 5.18 & 1.62 \\
\hline $4540-03$ & 1,339 & 645 & 9.34 & -97 & 53 & $<3.79$ & $<2.54$ & $<0.782$ & 0.03 & 0.036 & $<0.033$ & $0.6 \mathrm{~J}$ & $<1$ & 2.64 & 6.01 & 4.37 \\
\hline 4541-02 & 3,635 & 1,900 & 8.15 & -25 & 1 & $<5.19$ & $<7.01$ & $<1.59$ & $<0.0056$ & 0.34 & $<0.0013$ & $<1.1$ & $<0.097$ & 720 & 4 & $<1$ \\
\hline $4541-03$ & 1,504 & 878 & 9.02 & 36 & 12 & 5.1 & 6.66 & NA & $0.0527 \mathrm{~J}$ & 0.0477 & $<0.033$ & $0.64 \mathrm{~J}$ & $1.06 \mathrm{~J}$ & 30.7 & 5.9 & 44.2 \\
\hline 4541-04 & 1,367 & 732 & 9.34 & -66 & 26 & $<4.84$ & 5.61 & $<0.916$ & $0.07 \mathrm{~J}$ & 0.0306 & $0.062 \mathrm{~J}$ & $0.71 \mathrm{~J}$ & $1.2 \mathrm{~J}$ & 18.1 & 2.57 & 33.2 \\
\hline $4541-05$ & 1,327 & 855 & 9.17 & -89 & 26 & $27.1 \mathrm{~J}$ & 4.87 & $<0.899$ & $0.217 \mathrm{~J}$ & 0.0406 & $<0.033$ & $0.657 \mathrm{~J}$ & $<1$ & 69.9 & 1.62 & 17.8 \\
\hline 4541-06 & 1,153 & 840 & 9.38 & -69 & 31 & 13.4 & 8.5 & $<0.9$ & $0.111 \mathrm{~J}$ & 0.0289 & $0.039 \mathrm{~J}$ & $0.676 \mathrm{~J}$ & $<1$ & 12.3 & 1.09 & 16 \\
\hline $4542-01$ & 22,626 & 14,000 & 7.47 & 112 & 17 & 17.8 & $<41.1$ & $<2.7$ & $<0.0056$ & 6 & 0.003 & $<1.1$ & 85 & 9,900 & $<0.43$ & $<4.6$ \\
\hline $4542-02$ & 39,380 & 20,700 & 7.13 & 73 & 9 & $20.8 \mathrm{~J}$ & $<13.9$ & $<0.971$ & $<0.015$ & 14.5 & $1.5 \mathrm{~J}$ & $0.582 \mathrm{~J}$ & 226 & 11,600 & $<3.3$ & $<10$ \\
\hline $4542-04$ & 1,875 & 1,060 & 8.69 & 46 & 11 & $7.22 \mathrm{~J}$ & $<3.35$ & $<0.856$ & 11.1 & 0.178 & 2.96 & $<0.5$ & 8.12 & 90.1 & 8.86 & 55.6 \\
\hline $4542-05$ & 1,128 & 890 & 8.86 & -103 & 9 & 2.9 & 7.48 & $<1.45$ & 0.098 & 0.037 & 0.038 & $<1.1$ & $<0.097$ & 20 & 6.9 & 45 \\
\hline $4542-06$ & 1,224 & 536 & 8.77 & -131 & 6 & $<4.38$ & $<2.98$ & NA & $<0.015$ & 0.0278 & $<0.033$ & $<0.5$ & $1.1 \mathrm{~J}$ & 4.05 & 0.916 & 2.86 \\
\hline $4542-08$ & 597 & 380 & 7.47 & -13 & 4 & 2.09 & 4.97 & NA & $<0.0056$ & 0.57 & $<0.0013$ & $<1.1$ & 9.2 & 1.9 & 0.17 & 8.1 \\
\hline
\end{tabular}

${ }^{\mathrm{a}}$ Reference concentration is a secondary drinking water standard.

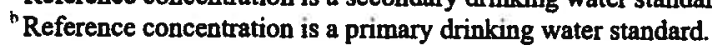


Table 3.11. Summary of FY 2008 groundwater analyses from MV exit pathway wells (cont.)

'Reference concentration is a primary drinking water standard action level applicable to a public water supply.

${ }^{d}$ Reference concentration is the regulatory annual average concentration equivalent to a $4 \mathrm{mrem} / \mathrm{yr}$ beta exposure.

Reporting units are shown in parentheses. Where drinking water standard exists for comparison, it is included with the units. Bold font entries exceed screening comparison with reference concentration.

$<=$ analyte not detected at detection limit

$\mathbf{J}=$ estimated value

NA $=$ not analyzed

Sp. cond. $=$ specific conductance

Std. unit $=$ standard unit used for $\mathrm{pH}$ measurement

Redox $=$ oxidation/reduction potential

$\mathrm{mV}=$ millivolts

NTU $=$ nephelometric turbidity units

TSS - total suspended solids

TDS $=$ total dissolved solids 


\section{Exit Pathway Summary}

Groundwater analyses conducted on samples from the picket wells since their construction in 2004 have resulted in a number of radionuclides being detected periodically. Alpha activity, beta activity, ${ }^{90} \mathrm{Sr}$, tritium, and uranium isotopes have been detected at some time in one or more sampling zones. Alpha and beta activity are indicator parameters that may indicate the presence of individual radionuclides. Both alpha and beta analyses can be adversely affected by the presence of high suspended and/or dissolved solids in water samples and some of the MV groundwater analyses have noted these problems that have resulted in erroneously high results. Alpha and beta analyses have been conducted on all water samples collected from all $36 \mathrm{MV}$ picket well sampling zones. A total of 327 alpha activity analyses have been conducted to date with 73 unqualified detections and 42 results that exceeded the $15 \mathrm{pCi} / \mathrm{L}$ drinking water standard. In many instances the maximum detected result occurred relatively early in the sampling history with subsequent decreases, sometimes to non-detect levels. A total of 281 beta activity analyses have been conducted to date with 121 unqualified detections with 44 greater than the $50 \mathrm{pCi} / \mathrm{L}$ screening level. Similar to the alpha activity results, the maximum observed beta activity results were observed early in the monitoring history.

Based on the observation of elevated beta activity in some sample zones, ${ }^{90} \mathrm{Sr}$ has been sampled in 21 of the MV picket well zones. A total of $65^{90} \mathrm{Sr}$ analyses have been conducted to date with 7 qualified results suggesting a possible presence, 9 unqualified results, and 4 results that have exceeded the $8 \mathrm{pCi} / \mathrm{L}$ drinking water equivalent activity level. As noted in previous RERs, only one sample zone (4537-02) consistently contains detectable ${ }^{90} \mathrm{Sr}$. The maximum measured concentration in that zone was observed in 2004 and subsequent concentrations have been less than $8 \mathrm{pCi} / \mathrm{L}$. Since tritium is the most environmentally mobile radionuclide in $\mathrm{MV}$, it has been analysed on all samples collected in the MV picket wells. A total of 238 tritium analyses have been conducted with qualified results on 34 samples suggesting a possible presence, and 4 unqualified detections, of which the maximum result was $590 \mathrm{pCi} / \mathrm{L}$ which is about $3 \%$ of the drinking water EDE level for tritium.

Uranium isotopic analyses have been conducted on samples from $14 \mathrm{MV}$ picket well sampling zones to determine the uranium contribution to the alpha activity. Uranium-234 is the most frequently detected uranium isotope, and like the other individual radionuclides, its detection history tends to be sporadic. Uranium 234 analyses has been conducted on 33 samples with 10 qualified results suggesting possible presence and 10 unqualified results. One sampling zone (4540-02) has had a high (5 out of 6 samples) frequency of detection.

A worst-case risk evaluation was made for the detected uranium results. This scenario assumes for adults, 30 years of drinking 2 liters of the sampled water per day (for children the exposure scenario is 1 liter/day for 6 years). The worst-case assumption was that the maximum detected or estimated uranium isotope concentration was present continuously at the tap of a residential water user. Uranium-234 is the predominant isotope detected and the worst-case individual sample result to date would result in a $1.2 \mathrm{E}-5$ ELCR and the average risk from the maximum per well results is about 3.3E-6. Data obtained to date indicate uranium is not chronically present at the levels assumed in the worst-case evaluation.

Continued monitoring of the exit pathway wells will be conducted consistent with the approach presented in the MV RAR (DOE 2007g).

Figure 3.16 shows the location of hydrofracture waste disposal sites and deep groundwater monitoring wells included in the MV Monitoring Plan. The hydrofracture waste disposal areas lie slightly more than one mile to the east of the Clinch River. Figure 3.16 shows the approximate extent of grout sheets based on monitoring conducted during the disposal operations. The extent of known ${ }^{90} \mathrm{Sr}$ contamination in the 
connate brine within the Pumpkin Valley Shale is also shown. Sampling of the hydrofracture area wells will be conducted prior to the CERCLA FYR.

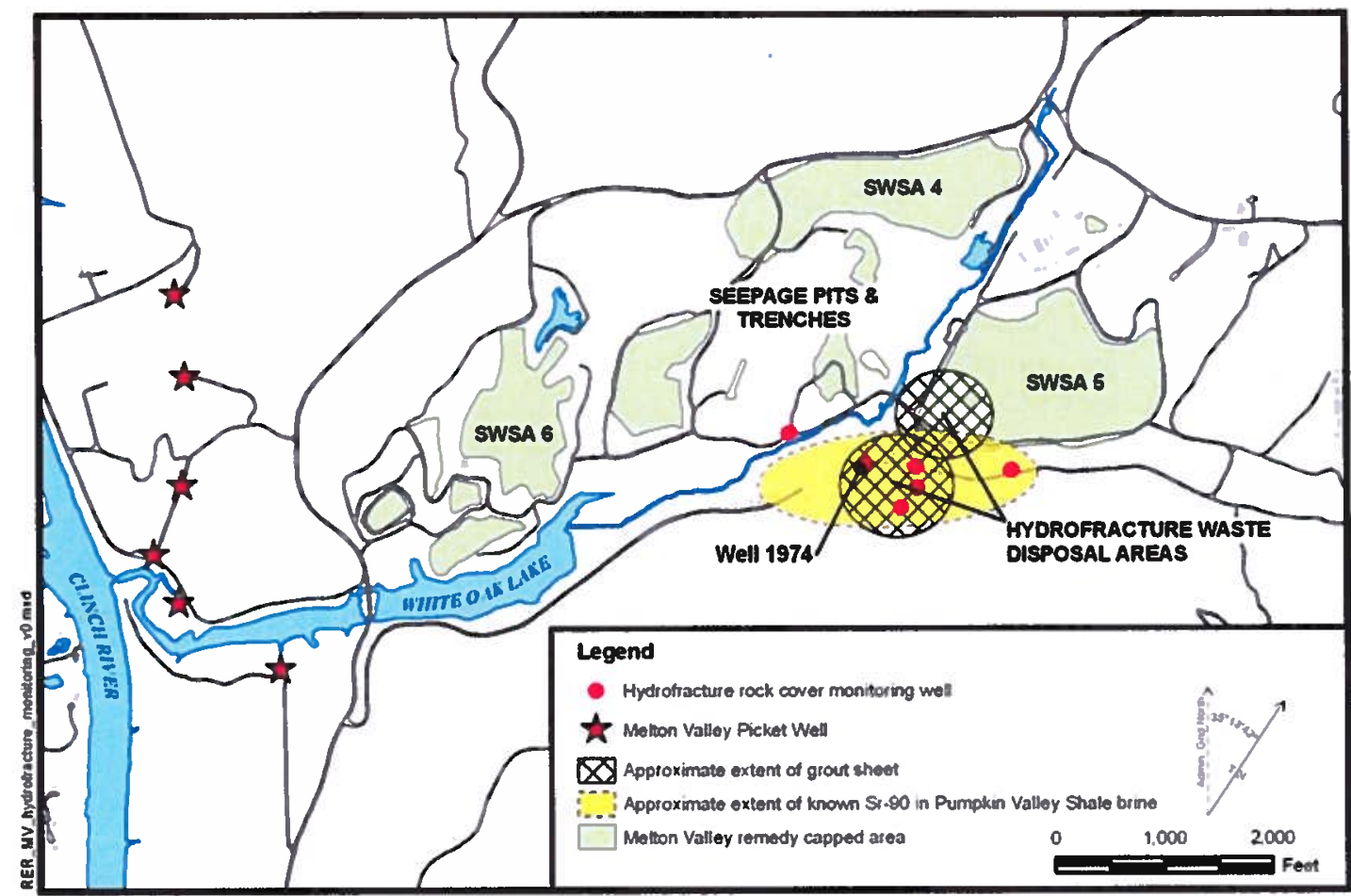

Figure 3.16. Hydrofracture area monitoring.

\subsection{PWTC WAC Compliance for Collected Groundwater}

Groundwater collected in the downgradient seepage interceptor systems at Seepage Pits and Trenches, SWSA 4, and SWSA 5 is pumped to the equalization tank located at SWSA 4 prior to being pumped via pipeline to the PWTC in BV for treatment. Samples of the collected groundwater are obtained monthly at the equalization tank and analyses include metals, radionuclides, and VOCs. WAC for the PWTC have been developed for radionuclides and metals. The only constituent detected near or above the PWTC WAC was tritium. The PWTC WAC for tritium is $2 \times 10^{+6} \mathrm{pCi} / \mathrm{L}$ and the average and maximum tritium concentrations measured in FY 2009 in the collected groundwater were about $1.7 \times 10^{+6}$ and $4.4 \times 10^{+6}$, respectively, which are both about one-half the values measured during FY 2008. During FY 2009, three of the monthly samples contained tritium at concentrations greater than the WAC compared to six FY 2008 samples collected that contained tritium above the WAC level. Although the maximum tritium concentrations in the collected groundwater were greater than the WAC, the PWTC discharge was compliant with the required discharge limit for tritium in all of the continuous, flow-paced samples collected and analyzed at the point of discharge.

\subsubsection{Other Watershed Monitoring}

\subsubsection{Aquatic Biological Monitoring}

The monitoring of fish and benthic macroinvertebrate communities provides a useful measure of watershed trends and whether watershed ROD goals of achieving narrative AWQC and protecting ecological populations are met. Aquatic biological monitoring locations used to gauge the conditions of 
the MV Watershed, as well as their reference sites, are shown on Figure 3.1. As is the case for most watershed units, biological monitoring data in Melton Branch include: (1) contaminant accumulation in fish, (2) fish community surveys, and (3) benthic macroinvertebrate surveys. In addition to Melton Branch, fish and benthic macroinvertebrate monitoring results include a site in WOC just downstream of the Melton Branch confluence (Figure 3.1).

Redbreast sunfish were collected in 2009 from lower Melton Branch [Melton Branch kilometer (MEK) $0.2]$ and analyzed for mercury, PCBs, metals, and ${ }^{137} \mathrm{Cs}$. Mean $( \pm \mathrm{SE})$ mercury concentration in these fish $(0.06 \pm 0.005 \mu \mathrm{g} / \mathrm{g})$ was typical of reference site concentrations in this species, while PCBs averaged 0.10 \pm 0.02 in the six redbreast sunfish analyzed. As expected, all metals (As, $\mathrm{Se}, \mathrm{Sb}, \mathrm{Be}, \mathrm{Cd}, \mathrm{Cr}, \mathrm{Cu}, \mathrm{Pb}, \mathrm{Ni}$, $\mathrm{Ag}$, and $\mathrm{Tl}$ ) were below detection limits or at levels observed previously in fish from the Hinds Creek reference site. Zinc, with an average of $13 \mathrm{mg} / \mathrm{kg}$, was slightly higher than observed in recent years, as well as in previous monitoring at MEK 0.2 and reference sunfish (Ashwood 1993). Cesium-137 was not detected in sunfish samples from MEK 0.2 .

The monitoring results for Melton Branch and WOC below the Melton Branch confluence continue to indicate slight to moderate impacts to fish and benthic communities relative to uncontaminated sites, but most stream sites are much improved relative to their ecological status in the mid-1980s. The fish communities in Melton Branch have been fairly stable in terms of overall numbers of species in recent samples (Figure 3.17), but both the larger site in WOC (WCK 2.3) and the smaller sites in Melton Branch (MEK 0.6 and 1.4) have species richness values below that of comparable reference fish communities (Brushy Fork Creek and Mill Branch, respectively). Some improvement in number of species has occurred at the downstream sites as a result of a fish introduction program. Two darter species are now commonly found at MEK 0.6 and at WCK 2.3 three introduced fish species are common. The apparent success of these introduced sensitive species is additional evidence that the watershed has improved since the 1980 s.

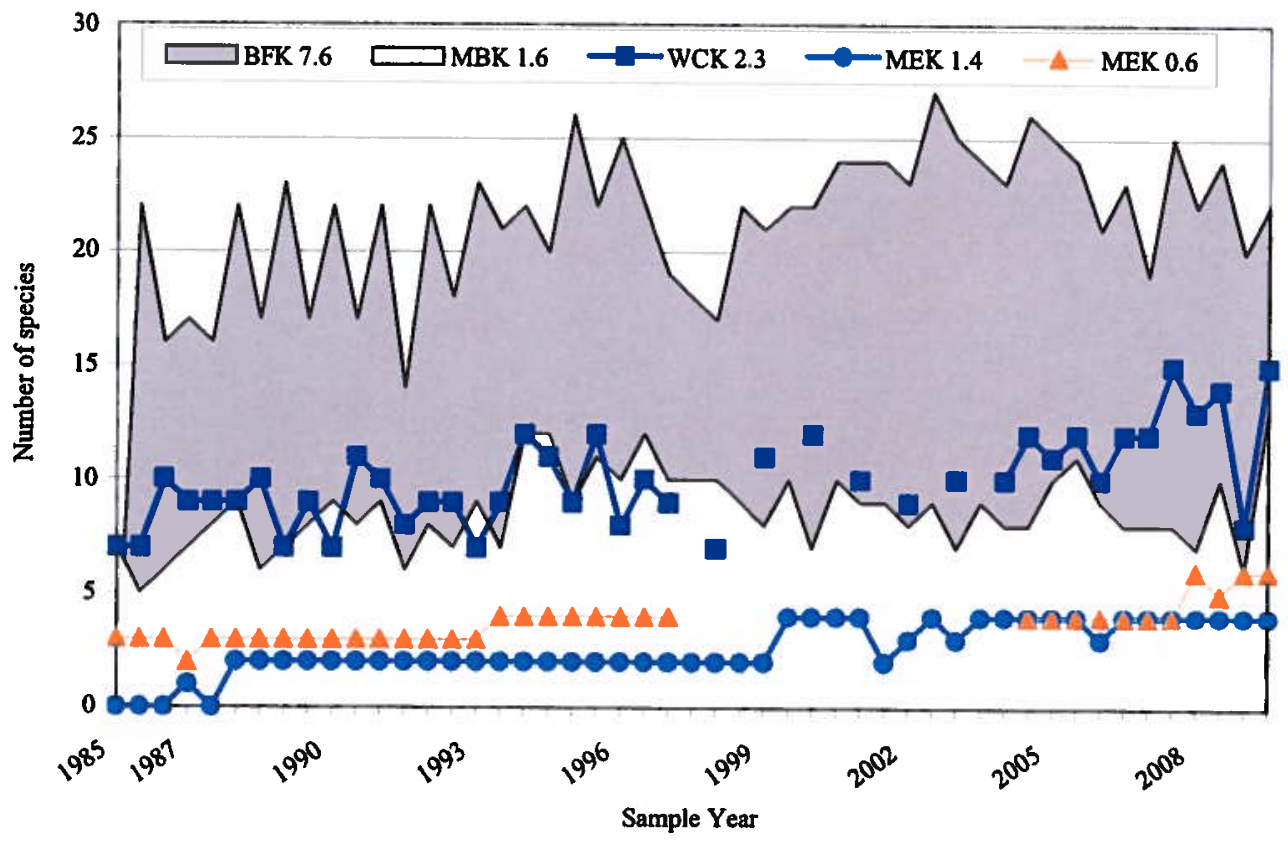

Figure 3.17. Species richness (number of species) in samples of the fish community in MV (WCK and MEK) and reference streams, Brushy Fork (BFK) and Mill Branch (MBK), 1985-2009".

${ }^{a}$ Reduction of sampling frequency at WCK 2.3 from biannual to annual between 1998 and 2005 is indicated by the discontinuation of the line for this period. 
Relative to reference (MBK 1.6) and near-reference (WCK 6.8) conditions, long-term trends for the benthic macroinvertebrate community in lower WOC (WCK 2.3) indicate that degraded conditions persist, although no major change occurred from 2007 to 2008 (Figure 3.18). Although moderately fewer pollution-intolerant taxa were present in 2008 than in 2007, similar trends were also observed at MBK 1.6 and WCK 6.8 during the same time period, suggesting the change was related to a general phenomenon (e.g., recent rain storm or just natural temporal variation). The number of pollution intolerant macroinvertebrate taxa in lower Melton Branch (MEK 0.6) and nearby reference sites has been comparable since 2006, suggesting that, based only on this metric, the condition of the invertebrate community is similar to what is typical in nearby reference streams (Figure 3.18).

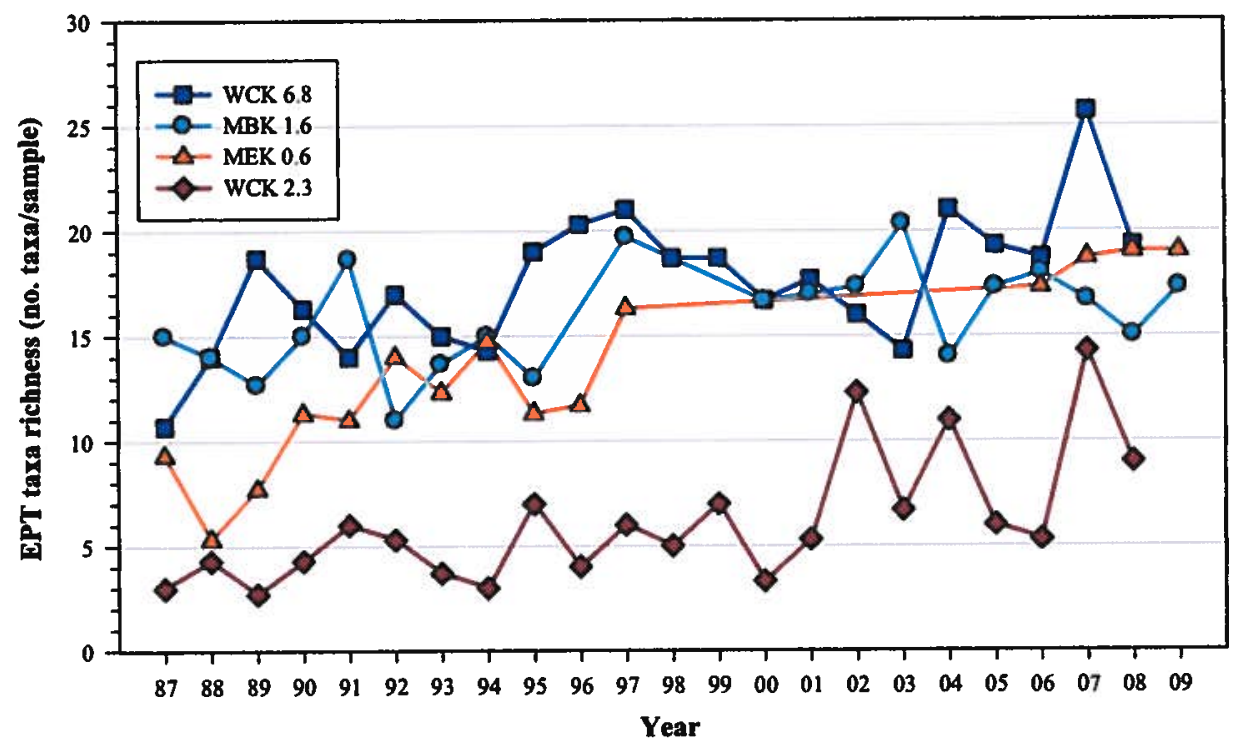

Figure 3.18. Mean $(n=3)$ taxonomic richness of the pollution-intolerant taxa for the benthic macroinvertebrates communities in lower WOC (WCK 2.3), lower Melton Branch (MEK 0.6), and reference sites in upper WOC (WCK 6.8) and Mill Branch (MBK 1.6), April sampling periods, 1987-2009.

\subsubsection{Performance Summary}

Radiological goals for ${ }^{137} \mathrm{Cs},{ }^{90} \mathrm{Sr}$, and tritium, which are the principal surface water contaminants in $\mathrm{MV}$, were met at WOD. Concentration trends for these contaminants were stable or decreasing during FY 2009. It was a good test year for the post-remediation surface water concentration responses because it is the first year since remedy completion with above average rainfall. Principal contaminant concentrations at tributary and mainstem monitoring locations remained compliant with ROD goals. Although minor increases in the three principal COCs were observed during FY 2009, the contaminant fluxes from MV remained low relative to the responses observed during wet years prior to remediation.

Groundwater level monitoring of the hydrologic isolation areas in MV showed that performance criteria were met at 37 of 43 locations. FY 2009 was a good test of the groundwater level controls in MV because it was the first year since remedy completion with above average rainfall.

Groundwater contaminant concentrations around the shallow land burial sites are generally decreasing or stable compared to concentrations measured before completion of the MV remedy. 
Groundwater monitoring of the deep groundwater exit pathway continues to show a broad area that exhibits high $\mathrm{pH}$, fluoride, and dissolved solids. Some of the dissolved constituents, such as chloride and sulfate, are of predominantly natural origin. Alpha activity was detected at more than the $15 \mathrm{pCi} / \mathrm{L}$ drinking water standard in six sampling zones. Uranium isotopes have been detected as the principal alpha-emitting constituents. Risk levels associated with the measured uranium levels are low. Strontium90 was detected in three sampled zones at activities less than 50\% of the drinking water EDE level.

\subsubsection{Compliance with MV ROD LTS Requirements}

\subsubsection{Requirements}

The ROD requires implementation of LUCs to protect against unacceptable exposures to contamination during the RAs, as well as after completion of all RAs in MV (see Table 3.2). During RAs, interim LUCs were imposed and will remain until permanent LUCs are established in future remedial decisions for this area. The LUC objectives stated in the ROD are as follows:

1. Industrial area: prevent unauthorized access to or use of groundwater; control excavations or penetrations below prescribed contamination cleanup depths; prevent unauthorized access; and preclude uses of the area that are inconsistent with LUCs.

2. Waste management area: prevent unauthorized access to or use of groundwater; prevent unauthorized contact, removal, or excavation of source material; prevent unauthorized access; and preclude alternate uses of the area (e.g., additional waste disposal or development).

3. Surface water and floodplain area: prevent unauthorized access to surface water, sediment, floodplain soils, or underlying groundwater; prevent fish consumption; and preclude uses of the media that are inconsistent with planned LUCs.

The implementation and maintenance of these LUC objectives identified in the ROD are specified in the MV LUCIP (DOE 2006b), which was approved in May 2006, and revised through errata to the MV RAR in 2009 (DOE 2009o and DOE 2009p). Because of the similarity in interim LUC objectives among the three remediation areas (i.e., industrial, waste management. and surface water/floodplain) identified in the ROD, most of the LUCs specified in the LUCIP apply generally throughout the watershed. The LUCs are defined as follows:

1. DOE land notation (property record restrictions) on land use and groundwater use in areas where waste is left in place.

2. Property record notices to provide records about existence and location of areas where wastes are left in place.

3. Zoning notices to provide notice to the city of Oak Ridge of existence and locations where wastes are left in place.

4. EPP program.

5. State advisories/postings (e.g., no fishing or contact advisories at WOL and WOCE).

6. Access controls (fences, gates, portals).

7. Signs at designated locations throughout the valley, to provide warning to prevent unauthorized access.

8. Surveillance patrols. 
These LUCs can be grouped into administrative controls (land use and groundwater deed restrictions, property record notices, zoning notices, permits program) and physical controls (state advisories/postings, access controls, signs, and security patrols), as provided in Table 3.2.

The MV LUCIP also states that, as individual remediation projects are undertaken within the MV Watershed, project-specific LUCs, if any, will be identified in the project construction completion report. None of the MV PCCRs contain project-specific LUCs.

The hydrologic isolation projects PCCRs require engineering controls be maintained at the 13 separate waste caps in MV. Details of the S\&M of the engineering controls at the caps are addressed in the S\&M Plan (DOE 2007h) that is attached to the RAR. This plan covers the S\&M required by all RAs performed in MV; however, only the hydrologic isolation caps constructed at SWSA 5, SWSA 4, Seepage Pits and Trenches, and SWSA 6 require long-term maintenance. No other RA performed in MV required longterm S\&M after completion of the construction activities. Inspections of the engineering controls and maintenance began immediately upon closure and were implemented in accordance with the ORNL Facility Inspection and Training (FIT) Manual (BJC 2006).

The requirements of the MV LUCIP are presented in a tabular summary in Appendix A, along with the required certification.

\subsubsection{Status of Requirements for FY 2009}

Appendix A of the RER contains the Certification of Land Use Controls for FY 2009. The LUCAP requires that the Manager, DOE ORO, annually verify in the RER that LUCIPs are being implemented on the ORR. Below are summaries of the implementation verification and status of all eight LUCs specified in the LUCIP and in Table A.1 (Appendix A).

\section{DOE Land Notation (Property Record Restrictions)}

The ROD requires that deed restrictions (e.g., land and groundwater use) be drafted and implemented by DOE for all waste management areas and other areas where hazardous substances are left in place to restrict use of property by imposing limitations and prohibiting uses of groundwater. The land notation is to be recorded by DOE in accordance with state law at the County Register's of Deeds office upon completion of RAs and/or transfer of affected areas.

The LUCIP states that the DOE Realty Officer will file the Land Notation in the applicable county records and that it is to include a survey plat executed by a registered land surveyor and will depict the relevant restricted areas subject to LUCs, including contamination/waste disposal areas. The LUCIP requires that a DOE official (or its contractor) verify annually that the information is properly recorded at the County Register of Deeds office in the event of a records search.

The DOE Realty office filed the MV Land Notation with the Roane County Register's of Deeds office on August 21, 2008. It is titled, "Notation on Ownership Record for Notification of Closure of Melton Valley Burial Grounds," and was filed as an Environmental Notation in Books 1290, Pages 727-748. The Notation includes the principal contaminants left in place and restrictions on the property, including EPP program and access controls (i.e., postings/signs). Survey plats for each of the waste units were attached to the Notation and delineated property that will be restricted in its future use. For FY 2009, the WRRP verified this information had been properly filed electronically at the Roane County Register's of Deeds office. 


\section{Property Record Notices}

The ROD requires that a deed notice/RCRA postclosure notice be recorded by DOE for all waste management areas and other areas where hazardous substances are left in place to provide notice to anyone searching records about the existence and location of a hazardous waste landfill(s). This deed notice is to be recorded by DOE in accordance with state law at the County Register's of Deeds office upon completion of RAs and/or transfer of affected areas.

The LUCIP calls this LUC a Property Record Notice and states that DOE Environmental Management (EM) will prepare a property record notice that will include the purpose of the notice, a brief summary of the main COCs, a listing of the LUCs and LUC objectives, available maps and figures, an explanation of DOE's assumptions of future use of the property and the LUC and an ORR program contact. The applicable LUC information, including the available figures and maps identified, will be posted on the DOE EM web home page, a hardcopy of the property record notice placed at the publicly accessible DOE Information Center, and added to the Appendix A of the LUCIP. At the completion of the ROD remediation activities, this property record notice will be replaced within the DOE EM web page and the DOE Information Center by the above DOE Realty Officer-prepared land notation and survey plat described in the previous section. Both the DOE Realty Officer-prepared land notice and survey plat will also be filed by the DOE Realty Officer in the Register's of Deeds records of the pertinent county. The LUCIP requires that a DOE official (or its contractor) verify annually that the information is properly recorded at the County Register's of Deeds office in the event of a records search.

The DOE Realty office placed the MV Property Record Notice, officially titled, "Notice of Land Use Restrictions in Melton Valley Area Department of Energy - Oak Ridge Reservation," in the Roane County News (December 10, 2007), Oak Ridger (December 11, 2007), Knoxville News Sentinel (December 11, 2007), Loudon County News Herald (December 13, 2007), and the Oak Ridge Observer (December 13, 2007). This same notice was also placed on the EM website and filed at the DOE Information Center. The notice includes the predominant COCs; future use limitations of the areas within MV; lists the LUCs including signs, surveillance patrols, and the EPP program; and additional contact information. A figure depicting the three land use zones was also included. For FY 2009, the WRRP verified this information had been posted electronically on the EM web site and that the hard copy had been placed at the DOE Information Center. In addition to the MV Property Record Notice, the DOE Land Notation and survey plat were also filed on the DOE EM web page and at the DOE Information Center. The WRRP also verified that the DOE Land Notation was properly recorded at the Roane County Register's of Deeds office (see previous section).

\section{Zoning Notices}

In FY 2009, requirements for Zoning Notices were changed through an erratum that replaced Chap. 7 (LUCs) of the RAR (DOE 2009p), and were added to Appendix A of the LUCIP. These changes represent how the City of Oak Ridge is to handle zoning information provided by the DOE for land on the ORR. The RAR now states that the ORR, including the MV-wide area, is currently zoned as a FIR area with the City Planning Commission. Zoning notice, use limitations information, and boundary survey plat will be filed with the City Planning Commission if/when areas are to be transferred out of DOE federal control. RCRA Subtitle C hazardous waste landfill(s) Property Record notice(s) will be filed according to TDEC Chapter 1200-1-11.05 and/or 1200-1-11.06 with the City Planning Commission. This replaces the requirement from the LUCIP that DOE EM will file a zoning notice with the City Planning Commission upon completion of all ROD remediation activities.

The ROD requires that a zoning notice be recorded by DOE for all waste management areas and other areas where hazardous substances are left in place to provide notice to the city about the existence and 
location of a hazardous waste landfill(s) for zoning/planning purposes. A survey plat of SWSA 6 Interim Corrective Measure Areas/Hillcut Test Facility (ICMAs/HTF) is to be filed by DOE with the City Planning Commission.

The LUCIP states that DOE EM will submit to the City Planning Commission a survey plat (at least four copies) indicating the location and dimensions of landfill cells or other disposal units (i.e., the SWSA 6 ICMAs and the HTF) with respect to permanently surveyed benchmarks as well as a record of the type, location, and quantity of hazardous wastes disposed to the best of DOE's knowledge based upon any kept records. This zoning notice information is similar to the property record notices discussed above. The LUCIP requires that a DOE official (or its contractor) verify annually that the information is properly maintained and assessable at the City Planning Commission.

\section{Excavation/Penetration Permit Program}

The ROD requires that an EPP program be in place throughout the MV remediation areas (i.e., Waste Management Area Industrial Area, and Surface Water and Floodplain Area) to provide notice to the worker/developer (i.e., permit requestor) on the extent of contamination and to prohibit or limit excavation/penetration activity, as appropriate. The LUCIP requires a DOE official (or its contractor) to verify no less than annually the functioning of the permit program against existing procedures.

Verification was provided by the BJC MV Project Engineer stating that the EPP program was functioning during FY 2009 in accordance with existing procedures listed in Appendix B of the MV LUCIP and also in accordance with the BJC MV EPP procedure OR-1010, Excavation/Penetration Permit for ORNL Site. Excavations conducted by the UT-Battelle when operating as the prime workgroup were performed in accordance with the UT-Battelle procedure titled Initiating and Issuing an Excavation or Penetration Permit, which requires the BJC MV Project Engineer signature on every excavation permit before work can begin. The UT-Battelle ORNL excavation permit form (ORNL-211) also requires that the BJC MV Project Environmental Compliance Lead review the area to determine if any CERCLA LUCIPs are established, and if so, specify the relevant details. In FY 2009, there were no UT-Battelle excavation permits requested for MV remediation areas.

Excavations conducted by BJC at MV were performed in accordance with BJC procedure OR-1010, which requires that a BJC ORNL EPP Log be maintained and that all EPPs for the ORNL be entered into the $\log$ and maintained by one person. The procedure also requires that an Environmental Compliance Review Form (BJCF-147b) be completed by MV Environmental Compliance for all excavations and that Environmental Compliance review existing information sources to determine if the area is covered by a LUCIP to ensure that the activity will not unknowingly violate CERCLA LUCs. In FY 2009, there were no BJC excavation permits requested for MV remediation areas.

\section{State Advisories/Postings}

The LUCIP states that advisories established by the TDEC Division of Water Pollution Control that provide notice to potential resource users of contamination and prohibit fishing/swimming in WOCE and WOL on signs and in the fishing regulations published by the Tennessee Wildlife Resources Agency (TWRA) will be effective immediately upon LUCIP approval. Although adequate warning signs have been established and maintained by the DOE on the WOL and WOCE, current state advisories and published fishing regulations do not address the WOL and WOCE. Changes made through the FY 2009 erratum to the RAR, state that DOE will continue to place appropriate signs at the WOL and WOCE. These changes do not prevent future postings of these waters by the State, but allow DOE to fully meet the intent of this requirement. 
Per the LUCIP, the purpose of the advisories/postings is to provide the public with important warnings that seek to limit/restrict incompatible uses and prevent unsafe exposure to contaminants. There are DOE established signs posted along the WOL dam access areas at HWY 95 and at the access gate and on fencing along WOCE that state, "Warning, No Fishing, No Water Contact, Area Contaminated."

These signs have been added to the MV Access Controls and Signs map in the RAR through an erratum that replaced Chap. 7 (LUCs) of the RAR (DOE 2009o). The changes incorporated the additional signs around the WOL and WOCE at six of the twenty major access points in MV to provide notice to potential resource users of contamination and prohibit fishing/contact. These changes allow DOE to meet the intent of the State Advisories/Postings requirements with the continued placement of appropriate signs at WOL and WOCE to prevent the unauthorized use of these waters.

The LUCIP also requires that a DOE official (or its contractor) verify the information in the fishing regulations with a TWRA official to ensure that fishing regulations accurately describe impacted streams. TWRA receives guidance from the TDEC on publishing these advisories in their annual fishing regulations. Currently, there are no TDEC-established advisories on WOL and WOCE because the DOE ORR property does not afford public access and, therefore, no information has been published in the TWRA fishing regulations for these areas.

\section{Access Controls}

The ROD requires that access controls (e.g., fences, gates, portals) be maintained by DOE throughout MV remediation areas to control and restrict access to workers and the public to prevent unauthorized uses. A map depicting the location of access controls that are necessary to ensure protectiveness of the remedy is included in the RAR. In FY 2008, this map was revised through an erratum that replaced Chap. 7 (LUCs) of the RAR (DOE 2009o). The revision increased the number of access control locations from 16 to 20 to better cover WOD while also removing interior MV access control locations that are no longer necessary.

The LUCIP states that any selected access controls will be monitored and maintained by DOE and its contractors as part of its S\&M program indefinitely or for as long as needed. The LUCIP requires that a DOE official (or its contractor) conduct a field survey no less than annually of all controls to assess their condition and ensure fences are erect or intact and gates/portals are functioning properly. In addition to routine site inspections conducted by the BJC MV S\&M Program according to the FIT manual of all remediated areas in MV, a field survey was conducted by the WRRP and the BJC MV S\&M facility manager to verify access controls designated in the revised RAR (with proposed errata sheets incorporated) were in place, in good condition and functioning properly. All major access points as identified in the pending revised RAR (e.g., portals, exterior gates) remain guarded or locked at all times, and interior gates are selectively locked. Specifically, access is restricted by the DOE ORR perimeter fence and security portals at the east and west ends of BV Road. There also is a locked gate at the junction of the haul road and the MV Access Road. Perimeter roads around MV have gates that allow access for maintenance activities.

\section{Signs}

The ROD requires that signs be maintained by DOE at select locations throughout MV to provide notice or warning to prevent unauthorized access. A map depicting the location of the signs that apply to the MV Watershed is included in the RAR (DOE 2009o). This map was revised through an erratum that replaced Chap. 7 (LUCs) of the RAR. The revision increased the number of sign locations from 13 to 20 to better cover WOD while also removing interior MV sign locations that are no longer necessary. In addition to location changes, wording of the signs was updated to more appropriately represent the current site conditions and restrictions. This revision allows DOE to meet the intent of the State Advisories/Postings 
requirements with the continued placement of appropriate signs at WOL and WOCE to prevent the unauthorized use of these waters.

The LUCIP requires that, within six months of approval of the LUCIP, signs will be in place at designated locations throughout MV Watershed near major access points to provide notice or warning to prevent unauthorized access. Any signs that are LUCs will be monitored and maintained, until the concentration of hazardous substances in the environmental media are at such levels to allow for unrestricted use and exposure or as long as needed. The LUCIP requires that a DOE official (or its contractor) conduct a field survey no less than annually of all signs to assess their condition and ensure they remain erect, intact, and legible. In addition to routine site inspections conducted by the BJC MV S\&M Program according to the FIT manual of all remediated areas in MV, a field survey was conducted by the WRRP and the BJC MV S\&M facility manager to verify signs designated in the pending revised RAR were in place, in good condition and legible. All signs as identified in the revised RAR (e.g., prevent unauthorized access, prohibit fishing/swimming) were in place and meeting their intended purpose. Specifically, 20 signs were in place around the MV Watershed and at the WOL and WOCE to provide notice of contamination or warning to prevent unauthorized access. There were also six additional signs posted at locations around WOL and WOCE and on the Sediment Retention Structure (SRS) to provide notice to potential resource users of contamination and prohibit fishing/swimming.

\section{Surveillance Patrols}

The LUCIP requires that surveillance patrols of selected areas in MV be effective immediately upon LUCIP approval and conducted no less frequently than once a quarter as part of the routine S\&M site inspections that are required for units/areas. The LUCIP requires a DOE official (or its contractors) to verify no less than annually against approved procedures/plans that routine patrols are conducted to ensure that incompatible uses have not occurred for units/areas requiring land use restrictions. In FY 2009, surveillance patrols were performed by the BJC ORNL S\&M Program as part of routine S\&M site inspections. The BJC ORNL S\&M Program developed the FIT manual to initiate routine S\&M inspections as a means to monitor, maintain and enforce the LUC compliance requirements of the MV LUCIP. Inspections of the capped areas within MV were performed on a quarterly basis. In addition, UT-Battelle security personnel also perform required daily patrols of various areas within MV.

In addition to implementing the physical LUCs (i.e., access controls, signs, surveillance patrols) as detailed above, the BJC MV S\&M Program also performed inspections of the MV hydrologic isolation areas to inspect each of the engineering controls listed below as applicable at each site:

- Vegetative cover on compacted fill or isolation cap,

- Compacted fill cover or isolation cap outslopes,

- Rock buttress outslopes,

- Surface drainage features,

- Monitoring wells (including well interior conditions),

- Weirs at surface water monitoring locations,

- Groundwater (leachate) collection equipment,

- Gas vents,

- Wetlands,

- Melton Branch relocation area, and

- Cover/cap maintenance roads, fences, gates, and signs.

The RAR states that for the first two years after installation of a hydrologic isolation cap, an engineer familiar with the cap design shall inspect each cap and associated features quarterly and after any 
precipitation that is greater than or equal to a five-year, 24-hour storm event (4.1 inches in a 24-hour period). After a minimum two-year period or until the hydrologic isolation cap and surface drainage features remain stable, the inspection schedule will revert to twice per year and after any precipitation that is greater than or equal to a 25 -year, 24-hour storm event (5.5 inches in a 24-hour period).

In FY 2009, engineering controls were inspected quarterly by the MV S\&M Program according to the ORNL FIT Manual at the following sites:

- SWSA 4,

- SWSA 5 North 4-Trench Area,

- SWSA 5 South,

- SWSA 6 Capped Area - CAP A,

- SWSA 6 Capped Area - CAP B,

- SWSA 6 Capped Area - CAP C,

- SWSA 6 Capped Area - CAP D,

- SWSA 6 Capped Area - CAP E,

- SWSA 6 Capped Area - HTF,

- Pits 2, 3, and 4,

- Trench 5,

- Trench 6 and Trench 6 Leak Sites,

- Trench 7 and Trench 7 Leak Sites Cap, and

- Trench 7 East Leak Site.

Minor maintenance included fixing areas of erosion at SWSA 4 and SWSA 5 South, fixing a loose gas vent at SWSA 6 Cap B, adding a culvert to a gravel road outside the SWSA 5 South burial ground, and mowing all caps a minimum of once during the year. 


\subsection{COMPLETED SINGLE ACTIONS IN MELTON VALLEY WITH MONITORING AND/OR LTS REQUIREMENTS}

\subsubsection{White Oak Creek Embayment Sediment Retention Structure}

Location of the WOC SRS is shown on Figure 3.1. The scope of this action involved the construction of a sediment retention structure, referred to as the SRS, at the mouth of WOC to contain the sediments in lower WOCE and minimize transport off-site to the Clinch River and Watts Bar Reservoir. The SRS uses rip-rap-filled wire gabions to slow water movement, preventing scour of sediment out of the embayment during changes in WOC flow and fluctuation of Watts Bar Reservoir levels. This site has only LTS requirements (Table 3.2). A review of compliance with these LTS requirements is included in Sect. 3.3.1.1. Background information on this remedy and performance standards are provided in Chap. 3 of Vol. 1 of the 2007 RER (DOE 2007a).

No surface water or groundwater monitoring is required to verify the effectiveness of the removal action.

\subsubsection{Compliance with LTS Requirements}

\subsection{Requirements}

LTS requirements for this action include inspection and maintenance of the SRS.

\subsection{Status of Requirements for FY 2009}

The site was inspected monthly in FY 2009 by the ORNL S\&M Program to check the fence and gate to ensure they were preventing access, inspect the condition of the warning signs, determine if excessive debris or vegetation had built up on the SRS, and identify any evidence that there had been any movement or shift of the embayment structure. No maintenance was required. 


\subsubsection{WAG 13 Cesium Plots Interim Remedial Action}

Location of the WAG 13 Cesium Plots Interim RA is shown on Figure 3.1. The scope of this action involved excavation of contaminated soil from the plots, placement of a permeable liner in each excavated plot and backfill with clean, compacted fill material and topsoil layer. This site has only LTS requirements (Table 3.2). A review of compliance with these LTS requirements is included in Sect. 3.3.2.1. Background information on this remedy and performance standards are provided in Chap. 3 of Vol. 1 of the 2007 RER (DOE 2007a).

No surface water or groundwater monitoring is required to verify the effectiveness of the removal action.

\subsubsection{Compliance with LTS Requirements}

\subsection{Requirements}

LTS requirements specified in the completion documents for this site includes long-term S\&M of the fenced enclosure.

\subsection{Status of Requirements for FY 2009}

The site underwent monthly inspections in FY 2009 conducted by the ORNL S\&M Program to verify that all gates to the site were closed and locked, the fence was not damaged, vegetation within the fenced area was cut, vegetation growth along fence line was acceptable, radiological postings were in place, point-ofcontact signs were in place, and the site was clear of unauthorized materials. Minor maintenance was required to repair damaged barbed wire along a portion of the fence. 


\subsubsection{MSRE D\&D Uranium Deposit Removal}

Location of the MSRE D\&D Uranium Deposit Removal is shown on Figure 3.1. The scope of this action involved the break up and removal of nongranular uranium-laden charcoal and vacuuming of the remaining loose charcoal and chips from the auxiliary charcoal bed (ACB) to ensure that less than a critical mass remains. This site has only LTS requirements (Table 3.2). A review of compliance with these LTS requirements is included in Sect.3.3.3.1. Background information on this remedy and performance standards are provided in Chap. 3 of Vol. 1 of the 2007 RER (DOE 2007a).

No surface water or groundwater monitoring is required to verify the effectiveness of the removal action.

\subsubsection{Compliance with LTS Requirements}

\subsection{Requirements}

LTS requirements specified in the RmAR (DOE 2001a) include S\&M activities for the interim storage of the collector canister holding the uranium-laden charcoal removed from the ACB, specifically, periodic pressure measurements (daily checks of the pressure gauge and hourly recorder data) and venting of the canister, as necessary, to maintain a pressure of less than 50 psig.

\subsection{Status of Requirements for FY 2009}

Inspections were conducted daily of the uranium-laden charcoal canister, in accordance with MSRE procedures. These inspections included periodic pressure measurements and periodic venting of the canister to reduce pressure when needed. No maintenance was required during FY 2009. 


\subsection{MELTON VALLEY MONITORING CHANGES AND RECOMMENDATIONS}

Table 3.12 provides a summary of technical issues and recommendations for the MV Watershed. Evaluation of FY 2009 monitoring data did not reveal any new issues beyond those identified from previous years' data evaluations which carried forward for tracking purposes. In addition, issues that have been completed or resolved are listed in the summary table one final time and will no longer be included in future RERs.

Table 3.12. Summary of MV Watershed technical issues and recommendations

\begin{tabular}{|c|c|}
\hline Issue $^{a}$ & $\begin{array}{c}\text { Action/ } \\
\text { Recommendation }\end{array}$ \\
\hline $\begin{array}{l}\text { 2010 Current Issue: } \\
\text { None. }\end{array}$ & \\
\hline $\begin{array}{l}\text { Issues Carried Forward: } \\
\text { 1. Monitoring results for some zones in } \\
\text { the MV exit pathway wells yield } \\
\text { elevated alpha and beta activity } \\
\text { results that are apparently the result of } \\
\text { elevated suspended and/or dissolved } \\
\text { solids. These results raise concern } \\
\text { over possible migration of } \\
\text { contamination across the DOE } \\
\text { property boundary in western MV. } \\
(2008 \text { RER })^{b}\end{array}$ & $\begin{array}{l}\text { 1. During FY } 2009 \text {, groundwater monitoring in the exit pathway continued and a } \\
\text { project was defined and started to install offsite groundwater monitoring wells } \\
\text { west of the Clinch River. Additionally, DOE provided utility water to residents } \\
\text { in the Jones Road area. }\end{array}$ \\
\hline $\begin{array}{l}\text { Completed/Resolved Issues: } \\
\text { 1. The groundwater level fluctuation } \\
\text { metric for hydrologic isolation } \\
\text { effectiveness evaluation is applicable } \\
\text { only in cases where wells do not } \\
\text { extend into bedrock beneath buried } \\
\text { waste units. }(2008 \mathrm{RER})^{\mathrm{b}}\end{array}$ & $\begin{array}{l}\text { The groundwater level fluctuation metric for hydrologic isolation was } \\
\text { discussed in the MV Core Team Meeting on September 18, 2008. The ROD } \\
\text { definition of the metric (i.e., } 75 \% \text { reduction of water level fluctuation in the } \\
\text { buried waste elevation zone; see Table } 3.4 \text { of this RER) is only relevant when } \\
\text { the water level is fluctuating within the buried waste itself. It is not relevant } \\
\text { when the water level is well below the buried waste. A revised discussion and } \\
\text { graphic were presented in the } 2009 \text { RER (Sect. 3.2.2.2.2 and Figure 3.6). }\end{array}$ \\
\hline
\end{tabular}

"Issues are identified in the table as an "ISSUE CARRIED FORWARD" to indicate that the issue is carried forward from a previous year's RER so as to track the issue through resolution. Any additional discussion will occur at the appropriate CERCLA Core Team level. Issues identified in the table as "Completed/Resolved Issues" indicate that the issue has been resolved and will not be tracked in subsequent RERs.

${ }^{b}$ The year of the RER or the FYR in which the issue originated is provided in parentheses, e.g., (2008 RER). 
This page intentionally left blank. 


\section{CERCLA ACTIONS IN BEAR CREEK VALLEY WATERSHED}

\subsection{INTRODUCTION AND OVERVIEW}

This chapter provides an update to CERCLA activities ongoing and completed in BCV Watershed. Only sites that have performance monitoring and/or LTS requirements on a watershed scale are included in the performance evaluations; those sites are noted on Table 4.1. Figure 4.1 shows the location of each of the CERCLA actions. Table 4.2 provides a summary of LTS requirements, and Figure 4.2 shows BCV Phase I ROD-designated land uses and interim controls in BCV. In this chapter, performance goals and objectives, monitoring results, and an assessment of the effectiveness of each completed action are presented. A review of compliance with any LTS requirements is also included (Sect. 4.2 .3 and Sect. 4.3.1.1).

Several single-project decisions within BCV predate the ROD for Phase I activities. These earlier actions do not contain specific performance criteria for reduction of contaminant flux or risk reduction at the watershed scale. The Phase I ROD, a watershed-scale decision, incorporates the preceding single-project actions and sets specific performance standards for contaminant flux and risk reduction for the entire watershed. The Phase I ROD also includes expected outcomes for the selected remedy against which effectiveness of individual actions is measured. The Phase I ROD addresses groundwater and surface water by dividing the valley into three zones and establishing performance standards for each zone in terms of resource uses and risks.

Completed CERCLA actions in the BCV Watershed are gauged against their respective action specific goals. However, CERCLA actions have yet to be fully implemented within the watershed. Therefore, monitoring of baseline conditions is conducted against which the effectiveness of the actions can be evaluated in the future. The collected data provides a preliminary evaluation of the early indicators of effectiveness at the watershed scale.

For background information of each remedy and performance standards, a compendium of all CERCLA decisions in the watershed within the context of a contaminant release conceptual model is provided in Chap. 4 of Vol. 1 of the 2007 RER (DOE 2007a). This information will be updated each year in the annual RER and republished every fifth year at the time of the CERCLA FYR.

\subsubsection{STATUS AND UPDATES}

In FY 2009, the D1 Focused Feasibility Study (FFS) and Proposed Plan (PP) for remediation of the Bear Creek Burial Grounds (BCBGs) were submitted to EPA and TDEC. Regulator comments were received in February and March. Future decision documents and their respective implementation have not been formalized at this time. 
Table 4.1. CERCLA actions in BCV Watershed

\begin{tabular}{|c|c|c|c|c|}
\hline CERCLA action & $\begin{array}{l}\text { Decision document, date signed } \\
(\mathbf{m m} / \mathbf{d d} / \mathbf{y y})\end{array}$ & Action/Document status ${ }^{a}$ & $\begin{array}{l}\text { Monitoring/ } \\
\text { LTS } \\
\text { required } \\
\end{array}$ & $\begin{array}{c}\text { RER } \\
\text { section }\end{array}$ \\
\hline \multicolumn{5}{|c|}{ Watershed-scale actions } \\
\hline \multirow[t]{2}{*}{ BCV Phase I ROD } & ROD (DOE/OR/01-1750\&D4): 06/16/00 & $\begin{array}{l}\text { Actions complete } \\
\text { BYBY PCCR (DOE/OR/01-2077\&D2) approved } \\
\text { (01/12/04). } \\
\text { OLF Soils Containment Pad RAR } \\
\text { (DOE/OR/01-1937\&D2) approved 07/16/01. }\end{array}$ & $\begin{array}{l}\text { Yes/Yes } \\
\text { No/No }\end{array}$ & 4.2 \\
\hline & $\begin{array}{l}\text { LUCIP (DOE/OR/01-2320\&D1) submitted } \\
\text { 09/29/06 }\end{array}$ & $\begin{array}{l}\text { Actions not yet implemented } \\
\text { - S-3 Site Pathway } 3 . \\
\text { - DARA Facility. }\end{array}$ & $\begin{array}{l}\text { No/Yes } \\
\text { No/Yes }\end{array}$ & \\
\hline BCV Phase II ROD & ROD: $T_{B D}^{b}$ & & & \\
\hline \multicolumn{5}{|c|}{ Single-project actions } \\
\hline $\begin{array}{l}\text { BCV OU } 2 \text { RA (Spoil } \\
\text { Area 1, SY-200 Yard) }\end{array}$ & ROD (DOE/OR/02-1435\&D2): 01/23/97 & $\begin{array}{l}\text { No additional actions required; institutional control and } \\
\text { S\&M ongoing. }\end{array}$ & No/Yes & 4.3.1 \\
\hline S-3 Site Tributary & AM (DOE/OR/01-1739\&D1): 06/25/98 & RmAR (DOE/OR/01-1945\&D2): 02/11/02. & Terminated & -- \\
\hline $\begin{array}{l}\text { Interception (Pathways } 1 \\
\text { and 2) }\end{array}$ & $\begin{array}{l}\text { AM Addendum (DOE/OR/01-1739\&D1/A1): } \\
10 / 20 / 00\end{array}$ & $\begin{array}{l}\text { RmAR Addendum (DOE/OR/01-1836\&D1/A1): 06/20/07 } \\
\text { (shutdown Pathways } 1 \text { and } 2 \text { system). }\end{array}$ & & \\
\hline
\end{tabular}

${ }^{a}$ Detailed information of the status of actions is from Appendix E of the FFA and is available at $\langle$ http://www.bechteljacobs.com/ettp ffa appendices.shtml $>$.

${ }^{6}$ D1 FFS and PP for remediation of the BCBGs submitted in FY 2009. Future decision documents and their respective implementation have not been formalized at this time.

DARA = Disposal Area Remedial Action 


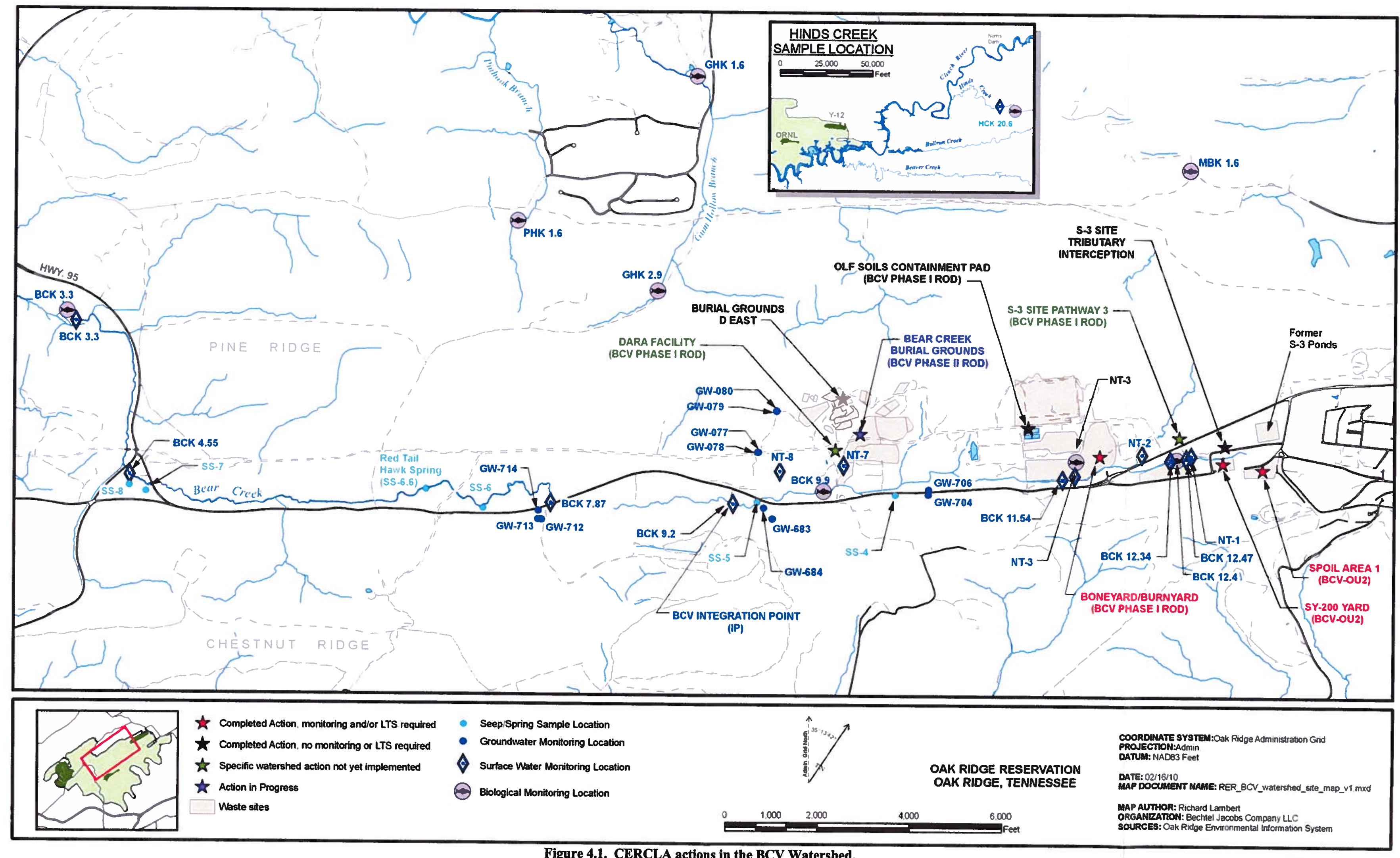

Figure 4.1. CERCLA actions in the BCV Watershed. 
This page intentionally left blank.

4-4 
Table 4.2. LTS requirements for CERCLA actions in BCV Watershed

\begin{tabular}{|c|c|c|c|c|}
\hline \multirow[b]{2}{*}{ Site/Project } & \multicolumn{2}{|c|}{ LTS Requirements } & \multirow[b]{2}{*}{ Status } & \multirow[b]{2}{*}{ RER section } \\
\hline & LUCSs & $\begin{array}{l}\text { Engineering } \\
\text { controls }\end{array}$ & & \\
\hline \multicolumn{5}{|c|}{ Watershed-scale actions } \\
\hline $\begin{array}{l}\text { BCV Phase I } \\
\text { ROD } \\
\text { - BYBY PCCR }\end{array}$ & $\begin{array}{l}\text { Watershed LUCs } \\
\text { Administrative: } \\
\text { - land use and } \\
\text { groundwater deed } \\
\text { restrictions } \\
\text { - property record } \\
\text { notices } \\
\text { - zoning notices } \\
\text { - permits program } \\
\text { Physical: } \\
\text { - access controls } \\
\text { - signs } \\
\text { - security patrols } \\
\text { BYBY PCCR specific: } \\
\text { - Access controls } \\
\text { - Signs }\end{array}$ & $\begin{array}{l}\text { BYBY PCCR specific: } \\
\text { Maintain cap at } \\
\text { BYBY }\end{array}$ & $\begin{array}{l}\text { Watershed LUCs } \\
\text { - Physical LUCs in } \\
\text { place. } \\
\text { - Administrative } \\
\text { LUCs required at } \\
\text { completion of } \\
\text { actions. } \\
\text { BYBY PCCR specific: } \\
\text { - LUCs in place. } \\
\text { - Engineering controls } \\
\text { remain protective. }\end{array}$ & 4.2 .3 \\
\hline \multicolumn{5}{|c|}{ Completed single project actions } \\
\hline $\begin{array}{l}\text { BCV OU2 } \\
\text { RA } \\
\text { (Spoil Area 1, } \\
\text { SY-200 Yard) }\end{array}$ & $\begin{array}{l}\text { Deed restrictions } \\
\text { - Access controls } \\
\text { (fencing) } \\
\text { - Signs }\end{array}$ & $\begin{array}{l}\text { Maintain vegetated } \\
\text { soil cover }\end{array}$ & $\begin{array}{l}\text { - LUCs in place. } \\
\text { Engineering controls } \\
\text { remain protective. }\end{array}$ & 4.3 .1 .1 \\
\hline
\end{tabular}

${ }^{a}$ Remaining actions have not been implemented but require interim access controls [e.g., S-3 Site Pathway 3 and Disposal Area Remedial Action (DARA) Facility].

${ }^{\mathrm{b}}$ Includes restrictions on surface water use.

BYBY $=$ Boneyard/Burnyard 
This page intentionally left blank. 


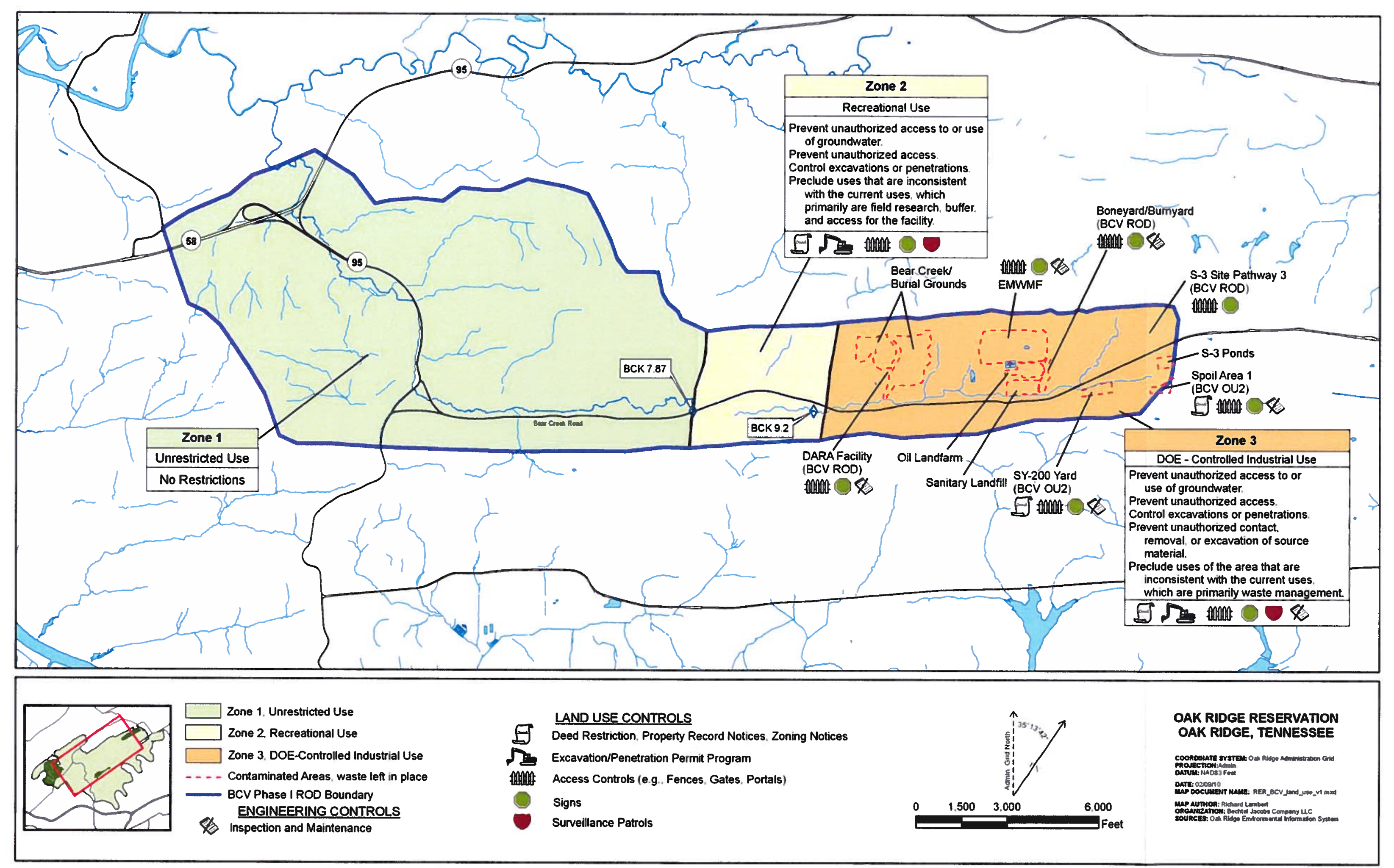

Figure 4.2. BCV Phase I ROD-designated land use and interim controls. 
This page intentionally left blank. 


\subsection{BEAR CREEK VALLEY PHASE I RECORD OF DECISION}

The selected remedy cited in the Phase I BCV ROD (DOE 2000b) involves source control and migration control strategies that reduce contaminant migration in shallow groundwater and surface water. These actions are expected to result in a reduction of contamination levels in groundwater and surface water downstream of the waste areas over time.

\subsubsection{Performance Goals and Monitoring Objectives}

The RAO for the BCV ROD (DOE 2000b) is to:

- protect future residential users of the valley in Zone 1 from risks from exposure to groundwater, surface water, soil, sediment, and waste sources;

- Protect a passive recreational user in Zone 2 from unacceptable risks from exposure to surface water and sediment;

- And protect industrial workers and maintenance workers in Zone 3 from unacceptable risks from exposure to soil and waste.

The three land use zones in BCV were identified previously on Figure 4.2. Consistent with the RAO, water quality goals are also established in the ROD for each zone as stated in Table 4.3.

Table 4.3. Groundwater and surface water goals, Bear Creek Valley Y-12 Plant, Oak Ridge, Tennessee ${ }^{\mathrm{a}}$

\begin{tabular}{|c|c|c|}
\hline $\begin{array}{l}\text { Area of the valley } \\
\text { (see Figure 4.2) }\end{array}$ & Current situation & Goal \\
\hline $\begin{array}{l}\text { Zone } 1 \text { - western half of Bear Creek } \\
\text { Valley }\end{array}$ & $\begin{array}{l}\text { No unacceptable risk posed to a } \\
\text { resident or a recreational user. } \\
\text { AWQC and groundwater MCLS are } \\
\text { not exceeded. }\end{array}$ & $\begin{array}{l}\text { Maintain clean groundwater and } \\
\text { surface water so that this area } \\
\text { continues to be acceptable for } \\
\text { unrestricted use. } \\
\text { Land use: unrestricted }\end{array}$ \\
\hline $\begin{array}{l}\text { Zone } 2-\text { a } 1 \text {-mile-wide buffer zone } \\
\text { between zones } 1 \text { and } 3\end{array}$ & $\begin{array}{l}\text { No unacceptable risk posed to a } \\
\text { recreational user. Risk to a resident } \\
\text { is within the acceptable risk range } \\
\text { except for a small area of } \\
\text { groundwater contamination. } \\
\text { Groundwater MCLs are exceeded, } \\
\text { but AWQC are not. }\end{array}$ & $\begin{array}{l}\text { Improve groundwater and surface } \\
\text { water quality in this zone consistent } \\
\text { with eventually achieving conditions } \\
\text { compatible with unrestricted use. } \\
\text { Land use: recreational (short- } \\
\text { term); unrestricted (long-term) }\end{array}$ \\
\hline $\begin{array}{l}\text { Zone } 3 \text {-eastern half of Bear Creek } \\
\text { Valley }\end{array}$ & $\begin{array}{l}\text { Contains all the disposal areas that } \\
\text { pose considerable risk. } \\
\text { Groundwater MCLS and AWQC are } \\
\text { exceeded. }\end{array}$ & $\begin{array}{l}\text { Conduct source control actions to } \\
\text { (1) achieve AWQC in all surface } \\
\text { water, (2) improve conditions in } \\
\text { groundwater to allow Zones } 1 \text { and } 2 \\
\text { to achieve the intended goals, and } \\
\text { (3) reduce risk from direct contact to } \\
\text { create conditions compatible with } \\
\text { future industrial use. }\end{array}$ \\
\hline & & Land use: controlled industrial \\
\hline
\end{tabular}

asource: Table 2.1 of BCV ROD (page 2-13). 
In addition to the watershed-wide water quality goals, the ROD provides site-specific water quality goals for the S-3 Site Pathway 3 and for the Boneyard/Burnyard (BYBY) actions, as presented in Table 4.4.

Table 4.4. Site-specific goals for remedial actions at the S-3 Site Pathway 3 and the BYBY ${ }^{\mathrm{a}}$

Remedial action goals for S-3 Site Pathway 3

- Prevent expansion of the nitrate plume into Zone 1.

- Reduce concentration of cadmium in NT-1 and upper Bear Creek to meet $A W Q C^{b}$

- Prevent future increase in release of uranium to Bear Creek to maintain annual flux below $27.2 \mathrm{~kg}$ total U at BCK 12.34 .

- Reduce seasonal nitrate flux at NT-1/Bear Creek confluence by $40 \%$. The seasonal nitrate flux benchmark will be defined by the FFA parties in remedial design.

"Source: Table 2.2 of BCV ROD (page 2-14).

${ }^{b}$ The Phase I ROD originally established the cadmium concentration performance standard as $3.9 \mu \mathrm{g} / \mathrm{L}$. This standard changed to $0.25 / \mathrm{L}$ due to change in the promulgated $A W Q C$.

The source removal actions related to principal threat source materials and groundwater control actions specified in the ROD comprise the actions that were envisioned to attain the stated water quality goals. The following components of the selected remedy are listed in the ROD:

- S-3 Site. Install trench at Pathway 3 for passive in situ treatment of shallow groundwater (DOE 2001b).

- Oil Landfarm Area. Actions in the Oil Landfarm Area include:

- Remove waste stored in Oil Landfarm Soil Containment Pad (OLFSCP) for commercial offsite disposal, and dismantle structure.

- Excavate source areas in BYBY and contaminated floodplain soils and sediments. Excavated materials meeting the WAC of the EMWMF will be disposed on-site; materials exceeding EMWMF WAC will be disposed off-site. Install clay cap over uncapped disposal areas at BYBY, and maintain existing caps.

- Implement hydraulic isolation measures at BYBY, including reconstruction of NT-3, elimination of stagnation points, and installation of drains or well points.

- Other Sites. Remove waste stored in the Disposal Area Remedial Action (DARA) facility for off-site disposal, and dismantle structure.

Field implementation of actions under the Phase I ROD was initiated in FY 2000. RAs in the Oil Landfarm Area are complete (BYBY and OLFSCP). Other key components of the remedy (S-3 Pathway 3 and DARA) have not yet been implemented.

The ROD included expected outcomes, target risk levels, and timeframes for attainment of goals for each of the BCV land use zones as outlined in Table 4.5. 
Table 4.5. Expected outcome of the selected remedy, Bear Creek Valley, Y-12 Plant, Oak Ridge, Tennessee ${ }^{a}$

\begin{tabular}{|c|c|c|c|c|c|}
\hline & \multirow[b]{2}{*}{ Zone 1} & \multirow[b]{2}{*}{ Zone 2} & \multicolumn{3}{|c|}{ Zone 3} \\
\hline & & & S-3 Site/Pathway 3 & BYBY/OLF Area & $B C B G S$ \\
\hline $\begin{array}{l}\text { Available land use } \\
\text { and time frame }\end{array}$ & $\begin{array}{l}\text { Unrestricted use (compatible with } \\
\text { residential use), available } \\
\text { immediately. }^{b}\end{array}$ & $\begin{array}{l}\text { Presently restricted use (compatible with } \\
\text { recreational use); compatible with } \\
\text { unrestricted use in } 50 \text { years. }\end{array}$ & $\begin{array}{l}\text { Restricted use, long-term } \\
\text { waste management } \\
\text { area/controlled industrial } \\
\text { use }\end{array}$ & $\begin{array}{l}\text { Restricted use; long-term } \\
\text { waste management } \\
\text { area/controlled industrial } \\
\text { use }\end{array}$ & $N / A$ \\
\hline $\begin{array}{l}\text { Available } \\
\text { groundwater use } \\
\text { and time frame }\end{array}$ & $\begin{array}{l}\text { Unrestricted use (compatible with } \\
\text { residential use) available } \\
\text { immediately (MCLs met) }\end{array}$ & $\begin{array}{l}\text { Presently restricted use (MCLs not met } \\
\text { for nitrates, compatible with recreational } \\
\text { use); with unrestricted use in } 50 \text { years. }\end{array}$ & Restricted use & Restricted use & $N / A$ \\
\hline $\begin{array}{l}\text { Available surface } \\
\text { water use and time } \\
\text { frame }\end{array}$ & $\begin{array}{l}\text { Unrestricted use (compatible with } \\
\text { residential use) available } \\
\text { immediately (AWQC met) }\end{array}$ & $\begin{array}{l}\text { Unrestricted use(compatible with } \\
\text { recreational use); available immediately } \\
\text { (AWQC met) }\end{array}$ & $\begin{array}{l}\text { Recreational use, } A W Q C \text { met } \\
\text { in } 5 \text { years following } \\
\text { implementation }\end{array}$ & $\begin{array}{l}\text { Recreational use, AWQC met } \\
\text { in } 5 \text { years following } \\
\text { implementation }\end{array}$ & $N / A$ \\
\hline $\begin{array}{l}\text { Cleanup levels, } \\
\text { residual risk }\end{array}$ & $\begin{array}{ll}- & M C L S \text { in groundwater } \\
- & \text { AWQC in surface water } \\
- & \text { risk to residential receptor } \\
& \text { below RAO of } 1 \times 10^{-5}\end{array}$ & $\begin{array}{l}\text { - } \quad \text { TBD for groundwater } \\
\text { - } A W Q C \text { in surface water } \\
\text { - } \text { risk to residential receptor below } \\
\text { RAO of } 1 \times 10^{-5}\end{array}$ & $\begin{array}{l}\text { - } \quad \text { TBD for groundwater } \\
\text { - } \text { AWQC in surface water } \\
\text { - } \quad \text { direct exposure risk to } \\
\text { industrial/terrestrial } \\
\text { receptors eliminated } \\
\text { - } \quad \text { risk to industrial receptor } \\
\text { below } R A O \text { of } 1 \times 10^{-5} \\
\text { - } \quad \text { Reduce seasonal nitrate } \\
\text { flux at the NT-1/Bear } \\
\text { Creek confluence by } 40 \%\end{array}$ & $\begin{array}{ll}- & T B D \text { for groundwater } \\
- & \text { AWQC in surface water } \\
- & \text { risk to industrial receptor } \\
& \text { below } R A O \text { of } 1 \times 10^{-5}\end{array}$ & $N / A$ \\
\hline $\begin{array}{l}\text { Anticipated } \\
\text { socioeconomic and } \\
\text { community } \\
\text { revitalization } \\
\text { impacts }\end{array}$ & $\begin{array}{l}\text { Property will meet conditions for } \\
\text { residential/recreational/ } \\
\text { industrial use }\end{array}$ & $\begin{array}{l}\text { Property will meet conditions compatible } \\
\text { with recreational/industrial use }\end{array}$ & $\begin{array}{l}\text { Waste area is capped and } \\
\text { used as a parking lot to } \\
\text { support Y-12 Plant } \\
\text { activities; surrounding area } \\
\text { available for additional } \\
\text { controlled industrial use }\end{array}$ & $\begin{array}{l}\text { Area devoted to waste } \\
\text { management; proposed } \\
\text { onsite disposal facility } \\
\text { provides potential to create } \\
\text { new jobs }\end{array}$ & $N / A$ \\
\hline $\begin{array}{l}\text { Anticipated } \\
\text { environmental and } \\
\text { ecological benefits } \\
\end{array}$ & Media not impacted & $\begin{array}{l}\text { Slightly impacted groundwater will be } \\
\text { restored }\end{array}$ & $\begin{array}{l}\text { Impacted surface water will } \\
\text { be restored }\end{array}$ & $\begin{array}{l}\text { Impacted surface water will } \\
\text { be restored, capping will } \\
\text { protect terrestrial species }\end{array}$ & $N / A$ \\
\hline
\end{tabular}

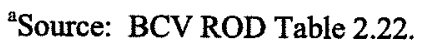

${ }^{b}$ Although the selected remedy will allow unrestricted land use for this zone, there are no plans to transfer ownership of this property.
N/A = not applicable
S-3 = Pathway 3
OLF $=$ Oil Landfarm
$\mathrm{TBD}=$ to be determined 


\subsubsection{Evaluation of Performance Monitoring Data}

This section presents the monitoring data that evaluates progress toward meeting the goals of the $\mathrm{BCV}$ ROD. Performance monitoring for the ROD includes surface water and groundwater monitoring, as well as biological monitoring. Monitoring locations are shown on Figure 4.1 and Figure 4.2. The performance metrics and monitoring parameters for each location are outlined in Table 4.6.

\subsubsection{Surface Water Monitoring}

\subsection{Surface Water Quality Metrics and Monitoring Requirements}

As identified in Section 4.2.1, the ROD goals include AWQC compliance, annual mass (flux) reductions for nitrate and uranium at several locations throughout the watershed, and carcinogenic risk to a receptor of $1 \times 10^{-5}$ at the IP. Monitoring is keyed to the boundaries between the three zones defined in the ROD. Key surface water monitoring locations in BCV include BCK 9.2, BCK 12.34, NT-3, SS-5, and NT-8 (Figure 4.1). BCK 9.2 is the IP which lies between Zones 2 and 3. BCK 12.34 is located near the Bear Creek headwater and serves as an IP for surface water contaminant discharges from the S-3 Ponds area. NT-3 was historically heavily impacted by contaminant discharges from the BYBY which has been remediated. NT- 8 carries runoff and contaminants from the western end of the BCBGs to Bear Creek a short distance above the BCK 9.2 IP.

\section{Zone 1}

Zone 1 of BCV constitutes the valley area west of BCK 7.87 (Figure 4.2). Surface water quality is monitored at BCK 7.87. For Zone 1 surface water, results are compared to AWQC (part of the FYR), consistent with the unrestricted use goal. In addition, risk-based concentrations (RBCs) for residential exposure to surface water $\left(1 \times 10^{-5}\right)$ are included as part of the evaluation. The AWQC comparison includes quarterly grab samples for metals and anions during the FYR year sampling in FY 2010.

\section{Zone 2}

Zone 2 of BCV constitutes the section of the valley located between BCK 7.87 and BCK 9.2 (Figure 4.2). As stated in Table 4.3, the ROD goal for Zone 2 is to improve groundwater and surface water quality consistent with eventually achieving unrestricted use in 50 years. The monitoring location for Zone 2 surface water is at BCK 9.2, which lies between Zones 2 and 3. BCK 9.2 has continuous flow monitoring and is sampled for ${ }^{234} \mathrm{U},{ }^{235} \mathrm{U}$, and ${ }^{238} \mathrm{U}$, with quarterly samples for metals, VOCs and nitrate during the FYR period. Zone 2 surface water results at BCK 9.2 are compared to a flux goal annually and to AWQC during the FYR sampling in FY 2010. In addition, RBCs for residential exposure to surface water $\left(1 \times 10^{-5}\right)$ are included as part of the evaluation.

\section{Zone 3}

Zone 3 of BCV is the section of the valley east of BCK 9.2 (Figure 4.2) that contains a currently operating CERCLA waste disposal facility (EMWMF) and former waste disposal sites. The remedial goals for Zone 3 are to attain AWQC in all surface water (short-term), and reduce risks from direct contact to achieve conditions compatible with a long-term, controlled industrial land use. Surface water is monitored at a number of surface water locations within Zone 3. These locations include BCK 11.54, and BCK 12.34 with continuous flow monitoring and weekly surface water samples analyzed for nitrates, ${ }^{234} \mathrm{U},{ }^{235} \mathrm{U}$, and ${ }^{238} \mathrm{U}$. There are also quarterly grab samples for metals including mercury at BCK 12.34 and NT-1 with semiannual grab samples at NT-2 and NT-3 during the FYR period sampling. 
Table 4.6. BCV Watershed CERCLA performance monitoring ${ }^{\mathrm{a}}$

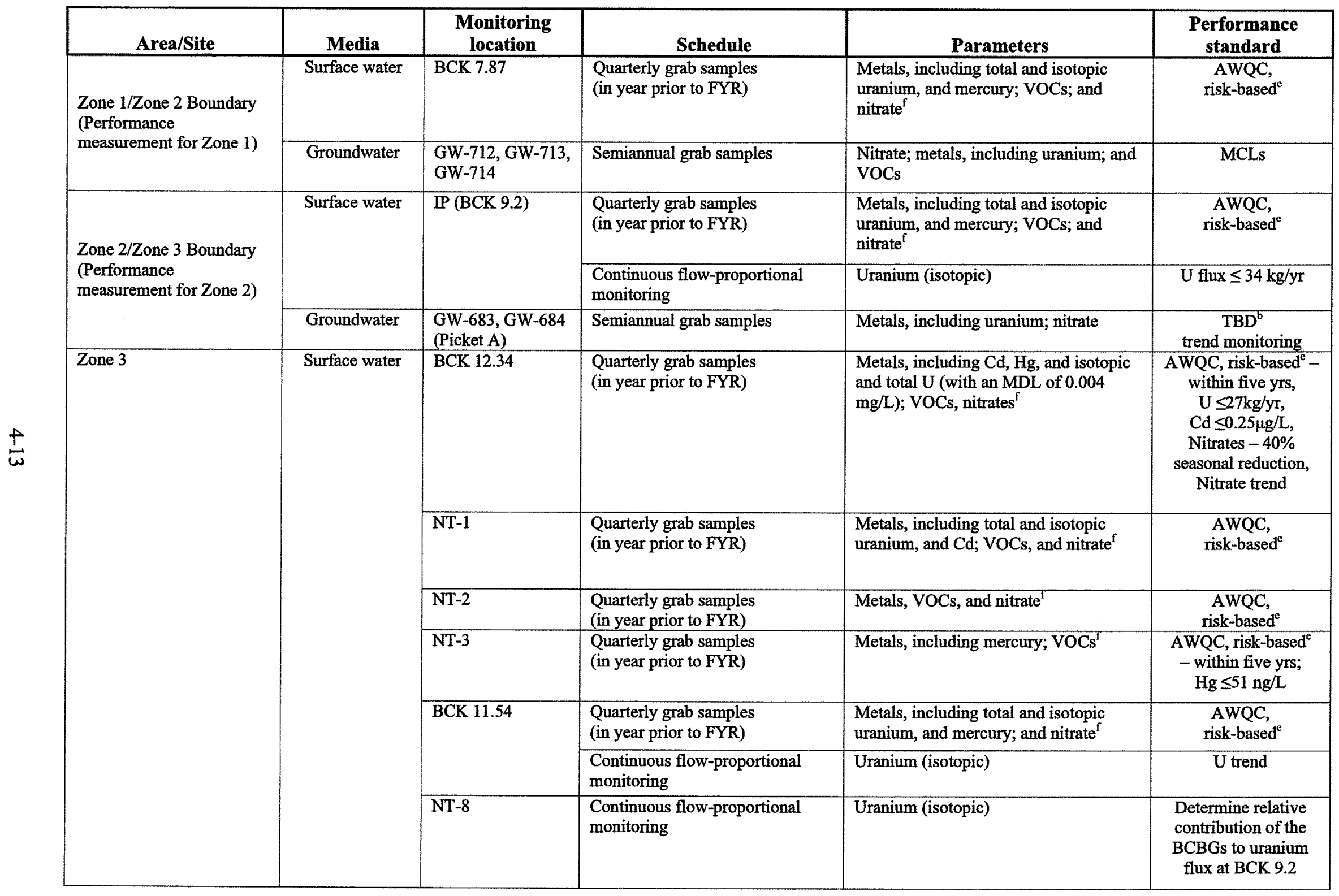


Table 4.6. BCV watershed CERCLA performance monitoring (cont.)

\begin{tabular}{|c|c|c|c|c|c|}
\hline Area/Site & Media & $\begin{array}{l}\text { Monitoring } \\
\text { location }\end{array}$ & Schedule & Parameters & $\begin{array}{l}\text { Performance } \\
\text { standard }\end{array}$ \\
\hline \multirow[t]{5}{*}{$\begin{array}{l}\text { Boneyard/Burnyard } \\
\text { (BYBY) }\end{array}$} & \multirow[t]{2}{*}{ Surface water } & \multirow[t]{2}{*}{ NT-3 } & $\begin{array}{l}\text { Monthly grab samples with } \\
\text { instantaneous flow measurement }\end{array}$ & Uranium (isotopic) & $\mathrm{U}$ flux $\leq 4.3 \mathrm{~kg} / \mathrm{yr}$ \\
\hline & & & $\begin{array}{l}\text { Quarterly grab samples } \\
\text { (in year prior to FYR) }\end{array}$ & Metals, including mercury; VOCs & AWQC Hg $\leq 51 \mathrm{ng} / \mathrm{L}$ \\
\hline & Biota & NT-3 & $\begin{array}{l}\text { Annually (until recovery } \\
\text { complete) }\end{array}$ & $\begin{array}{l}\text { In-stream sampling of fish and benthic } \\
\text { macroinvertebrate communities }\end{array}$ & $\begin{array}{l}\text { Aquatic community } \\
\text { data compared to data } \\
\text { available for similar } \\
\text { reference streams on } \\
\text { the ORR }\end{array}$ \\
\hline & Vegetation & NT-3 & $\begin{array}{l}\text { Annually (until recovery } \\
\text { complete) }\end{array}$ & Riparian recovery monitoring & $\begin{array}{c}\text { Percent plant } \\
\text { recovery, species } \\
\text { diversity, stream } \\
\text { vegetation overhang, } \\
\text { percent shading, } \\
\text { growth and survival } \\
\text { of planted species } \\
\text { compared to results of } \\
\text { networks of similar } \\
\text { riparian restoration } \\
\text { sites monitored. }\end{array}$ \\
\hline & $\begin{array}{l}\text { Stream channel } \\
\text { stability }\end{array}$ & NT-3 & $\begin{array}{l}\text { Annually (until recovery } \\
\text { complete) }\end{array}$ & Stream channel stability & $\begin{array}{l}\text { Qualitative field } \\
\text { measurements }\end{array}$ \\
\hline \multirow[t]{4}{*}{ S-3 Ponds Pathway $3^{c}$} & \multirow[t]{4}{*}{ Surface water } & \multirow[t]{2}{*}{ BCK 12.34} & $\begin{array}{l}\text { Weekly flow-proportional } \\
\text { composite samples }\end{array}$ & Isotopic uranium and nitrate & $\begin{array}{c}\text { U flux } \leq 27.2 \mathrm{~kg} / \mathrm{yr} \\
\text { Nitrate }-40 \% \\
\text { seasonal reduction }\end{array}$ \\
\hline & & & $\begin{array}{l}\text { Quarterly grab samples } \\
\text { (in year prior to FYR) }\end{array}$ & Metals, including $\mathrm{Cd}$ & $\begin{array}{c}\mathrm{Cd} \leq 0.25 \mu \mathrm{g} / \mathrm{L} \\
\mathrm{AWQC}-\text { within five } \\
\text { years }\end{array}$ \\
\hline & & NT-1 & Quarterly grab samples & Metals, including Cd & $\mathrm{Cd} \leq 0.25 \mu \mathrm{g} / \mathrm{L}$ \\
\hline & & NT-2 & $\begin{array}{l}\text { Weekly flow-proportional } \\
\text { composite samples }\end{array}$ & Nitrate (flux) & $\begin{array}{c}\text { Nitrate }-40 \% \\
\text { seasonal reduction in } \\
\text { flux }\end{array}$ \\
\hline
\end{tabular}


Table 4.6. BCV watershed CERCLA performance monitoring (cont.)

\begin{tabular}{|c|c|c|c|c|c|}
\hline Area/Site & Media & $\begin{array}{c}\text { Monitoring } \\
\text { location }\end{array}$ & Schedule & Parameters & $\begin{array}{l}\text { Performance } \\
\text { standard }\end{array}$ \\
\hline \multirow[t]{5}{*}{ S-3 Pathways 1 and $2^{g}$} & \multicolumn{5}{|c|}{ Monitoring to evaluate the effectiveness of the treatment systems is discontinued. } \\
\hline & Surface water & BCK 12.34 & $\begin{array}{l}\text { Weekly flow-proportional } \\
\text { composite samples }\end{array}$ & Nitrate, uranium isotopes & \multirow{3}{*}{$\begin{array}{c}\text { No additional } \\
\text { performance } \\
\text { measures imposed } \\
\text { with documentation } \\
\text { of the treatment } \\
\text { system shutdown. }\end{array}$} \\
\hline & & BCK 12.34 & $\begin{array}{l}\text { Quarterly grab samples } \\
\text { (in year prior to FYR) }\end{array}$ & Metals, including total uranium and $\mathrm{Hg}$ & \\
\hline & & BCK 9.2 & $\begin{array}{l}\text { Continue weekly flow- } \\
\text { proportional composite samples }\end{array}$ & Uranium isotopes & \\
\hline & Biota & $\begin{array}{l}\text { BCK } 3.3 \\
\text { BCK } 9.9 \\
\text { BCK } 12.4\end{array}$ & $\begin{array}{l}\text { Continue biological monitoring as } \\
\text { before } \mathrm{P} 1 \text { and } \mathrm{P} 2 \text { treatment } \\
\text { system shutdown }\end{array}$ & $\mathrm{Hg}$ and $\mathrm{PCBs}$ & $\begin{array}{l}\text { Measure changes in } \\
\text { quality of aquatic } \\
\text { habitat as compared } \\
\text { to reference sites. }\end{array}$ \\
\hline
\end{tabular}

${ }^{a}$ This table represents current requirements for monitoring that have been agreed upon by all FFA parties at the BCV Core Team Meeting held November 18,2008 . Currently recommended monitoring per this RER is not included on this table.

${ }^{b}$ Cleanup levels for groundwater are to be determined under future decisions for the BCV Watershed.

'RAs for the S-3 Pathway 3 have not been implemented; data are collected to establish a baseline against which performance of the action will be gauged.

${ }^{d}$ Correspondence from regulators (DOE 2007c) granting permission to shut down treatment system at S-3 Pathways $1 \& 2$ inadvertently included uranium as the parameter analyzed for the biota; however, the correct parameters should include mercury and PCBs. The correct parameters will be approved in the SAP/Quality Assurance Program Plan that will be submitted to the regulators fo review and approval.

RBC of $1 \times 10^{-5}$ residential receptor for Zones 1 and 2 and industrial for Zone 3.

fSampling will be conducted for COCs identified from the BCV RI for risk-based comparisons.

${ }^{8}$ Correspondence from regulators (DOE 2007c) granting permission to shut down treatment system at S-3 Pathways $1 \& 2$ requires continuation of monitoring at BCK 12.34 , BCK 9.2, BCK 3.3, BCK 9.9, BCK 12.4, as indicated. 
BCV Phase I ROD includes uranium flux goals which include:

- $\leq 34 \mathrm{~kg} / \mathrm{yr}$ at the BCK $9.2 \mathrm{IP}$,

- $\leq 27.2 \mathrm{~kg} / \mathrm{yr}$ for S-3 Ponds discharge at BCK 12.34, and

- $\leq 4.3 \mathrm{~kg} / \mathrm{yr}$ at the mouth of NT-3.

Additionally, AWQC for Zone 3 surface water results are compared to AWQC (during the FYR sampling in FY 2010).

Effectiveness of RAs at the BYBY is measured by water quality in the NT-3 stream. Monitoring at Bear Creek main stream station BCK 11.54, downstream of NT-3 (see Table 4.6 and Figure 4.1), now performs as an upstream IP for the BCBGs.

BCV Phase I ROD requires BYBY to meet AWQC in surface water at NT-3 and that surface water risk to an industrial receptor is below $1 \times 10^{-5}$. During the FYR years, grab samples are collected, at a minimum, monthly from NT-3 and analyzed for mercury and uranium with semiannually grab samples for metals analysis. The next FYR sampling year will occur in FY 2010.

\subsection{Surface Water Monitoring Results}

The discussion of surface water results is presented in this section in sequence of land use zone. The monitoring emphasis is on measuring remediation related reductions of COCs that are indicative of potential exposure risk for future land users. The status of BCV Watershed-scale long-term CERCLA decision making is provided in Figure 1.5 of the 2007 RER (DOE 2007a).

\section{Zone 1}

Surface water results are compared to AWQC, and evaluated against the RBCs for residential exposure to surface water $\left(1 \times 10^{-5}\right)$ consistent with the unrestricted land use goals. Surface water sampling for these evaluations takes place in the next FYR sampling year (FY 2010).

Variations in surface water contaminant concentrations and fluxes in Zones 2 and 3 affect surface water quality in Zone 1. During FY 2009, the flux of uranium discharged from Zone 3 sources increased in response to the above average rainfall with a commensurate increase in uranium flux into Zones 2 and 1 .

\section{Zone 2}

Surface water was monitored for uranium in FY 2009. Surface water results will be compared to AWQC during the next FYR sampling (i.e., FY 2010) to include metals, nitrate and uranium.

Uranium isotopes measured at BCK 9.2 represent those constituents as they migrate from Zone 3 into Zone 2. The FY 2009 average concentrations of ${ }^{234} \mathrm{U},{ }^{235} \mathrm{U}$, and ${ }^{238} \mathrm{U}$ were 8.8, 0.89, and $21.6 \mathrm{pCi} / \mathrm{L}$, respectively. The values for ${ }^{234} \mathrm{U}$ and ${ }^{238} \mathrm{U}$ exceeded the $\mathrm{RBCs}$ of 6.7 and $5.5 \mathrm{pCi} / \mathrm{L}<\mathrm{http}: / / \mathrm{epa}-$ prgs.ornl.gov/cgi-bin/radionuclides/rprg_search>, respectively. These RBC goals are equivalent to the ROD hypothetical residential exposure goal of a $1 \times 10^{-5}$ ELCR attributable to the uranium isotopes. Table 4.7 and Figure 4.3 present the historic average concentrations of isotopes of uranium and nitrate since the ROD was implemented. Over the period of monitoring, ${ }^{235} \mathrm{U}$ has been less than the $6.6 \mathrm{pCi} / \mathrm{L}$ $\mathrm{RBC}$ in Zone 2. Additional discussion of contaminant transport from Zone 3 into Zone 2 is presented below. 
Table 4.7. Historic average concentration of uranium isotopes and nitrate at the IP (BCK 9.2)

\begin{tabular}{cccccc}
\hline FY & $\begin{array}{c}\text { Uranium 234 } \\
\text { pCi/L }\end{array}$ & $\begin{array}{c}\text { Uranium 235 } \\
\text { pCi/L }\end{array}$ & $\begin{array}{c}\text { Uranium 238 } \\
\text { pCi/L }\end{array}$ & $\begin{array}{c}\text { Nitrate } \\
\text { mg/L }\end{array}$ & $\begin{array}{c}\text { Average } \\
\text { ORR } \\
\text { rainfall }^{\mathbf{a}}\end{array}$ \\
\hline RBC $^{b}$ & 6.7 & 6.6 & 5.5 & 58 & - \\
\hline 2001 & $\mathbf{1 3 . 7}$ & 0.7 & 28.5 & 9.9 & 45.9 \\
2002 & $\mathbf{1 2 . 4}$ & 0.8 & 24.8 & 12.9 & 52.7 \\
2003 & $\mathbf{9 . 4}$ & 1.2 & 18.4 & 11.1 & 73.7 \\
2004 & $\mathbf{8 . 5}$ & 1.1 & 17.7 & 8.4 & 56.4 \\
2005 & $\mathbf{7 . 3}$ & 0.7 & 15.9 & 6.6 & 58.9 \\
2006 & $\mathbf{9 . 9}$ & 0.9 & $\mathbf{2 1 . 3}$ & 9.8 & 46.4 \\
2007 & $\mathbf{8 . 8}$ & 0.9 & $\mathbf{1 8 . 8}$ & - & 36.8 \\
2008 & $\mathbf{9 . 1}$ & 0.9 & $\mathbf{2 1 . 0}$ & - & 49.3 \\
2009 & $\mathbf{8 . 8}$ & 0.8 & $\mathbf{2 1 . 6}$ & 4.8 & 62.5 \\
\hline
\end{tabular}

Bold values indicate the $\mathrm{RBC}$ goal is exceeded.

${ }^{a}$ Average rainfall in inches for rain gauges at Y-12, ETTP, ORNL, and DOE town site.

${ }^{b} \mathrm{RBC}$ from EPA, regional screening tables <http://www.epa.gov/reg3hwmd/risk/human/rbconcentration table/Generic_Tables/index.htm>, <http://epa-prgs.oml.gov/cgi-bin/radionuclides/rprg_search>.

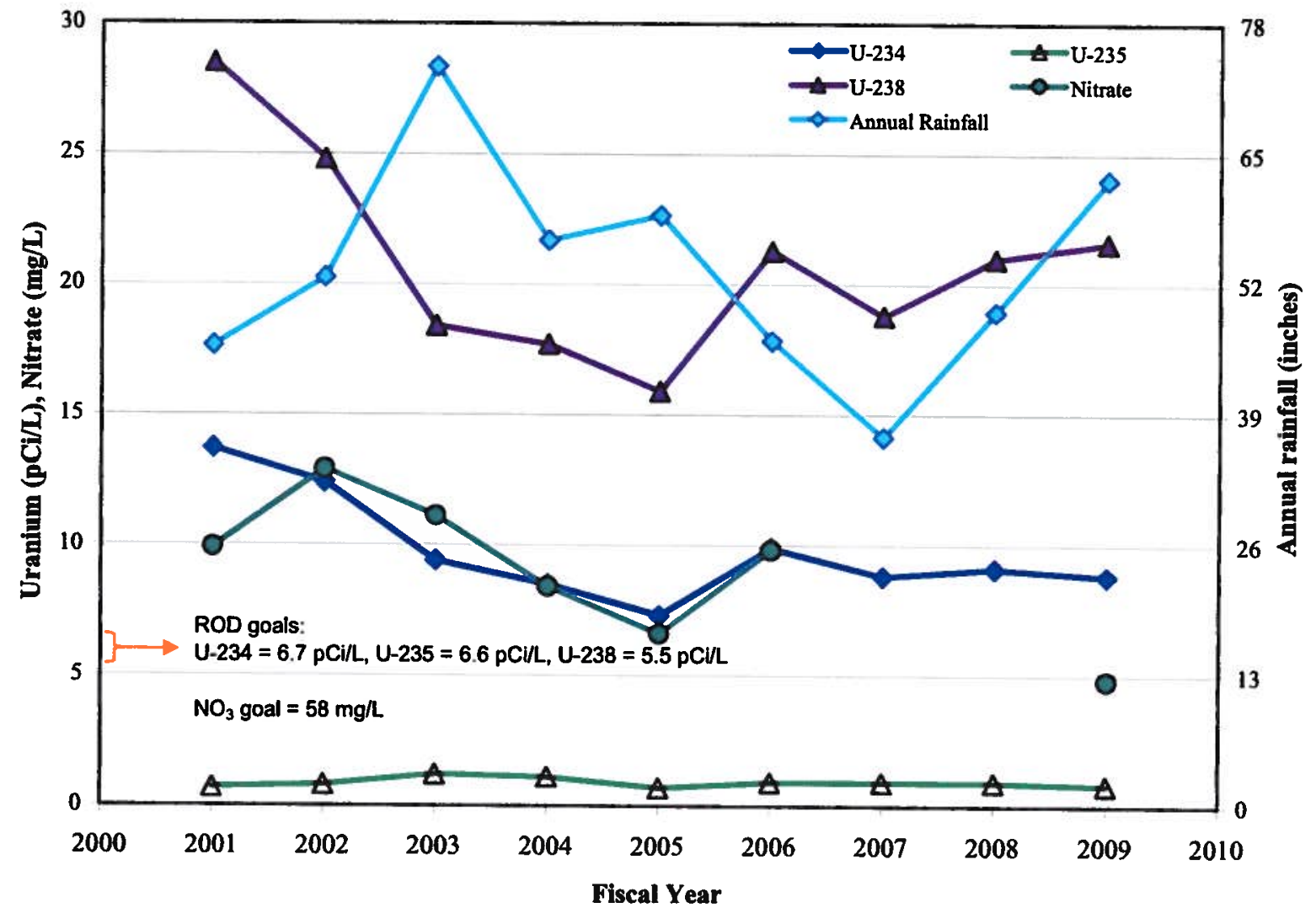

Figure 4.3. Average annual uranium isotope and nitrate concentrations at BCK 9.2 and annual rainfall. 
Nitrate concentrations measured at BCK 9.2 since ROD approval are compared to the RBC. Since FY 2000 the nitrate concentrations in surface water at the IP (BCK 9.47 prior to FY 2006 and BCK 9.2 thereafter) have not exceeded the residential drinking water non-carcinogenic $\mathrm{HI}$ level of $58 \mathrm{mg} / \mathrm{L}$ $<$ http://www.epa.gov/reg3hwmd/risk/human/rb-concentration table/Generic_Tables/index.htm> and since FY 2003 the average nitrate concentrations measured at BCK 9.2 have been below the $10 \mathrm{mg} / \mathrm{L}$ MCL. The principal source of nitrate contamination is legacy disposal of acid liquids in the S-3 Ponds in the headwaters of Bear Creek. Nitrate has been monitored historically at a number of locations in BCV. Concentrations are highest near the S-3 source and decrease with distance to the west and downstream. Table 4.7 shows the average concentration of nitrate at BCK 9.2 for years since the ROD was implemented. Figure 4.3 shows the average nitrate concentration in surface water at BCK 9.2 along with the annual average ORR rainfall.

\section{Zone 3}

Surface water monitoring includes sampling at the IP (BCK 9.2) and intermediate monitoring stations, including tributary monitoring of specific RA areas. Two key metrics were identified in the Phase I ROD for effectiveness of RAs in Zone 3-reduction of risk levels and uranium flux at the IP (BCK 9.2) to 34 $\mathrm{kg} / \mathrm{yr}$, and reduction of the uranium flux at BCK 12.34 to $27.2 \mathrm{~kg} / \mathrm{yr}$. As previously discussed, ${ }^{234} \mathrm{U}$ and ${ }^{238} \mathrm{U}$ activities at BCK 9.2 consistently exceed the $\mathrm{RBC}$.

The post-ROD history of measured uranium fluxes at BCK 9.2 and BCK 12.34, along with annual rainfall, are summarized in Table 4.8 and Figure 4.4 . The watershed flux goal ( $\leq 34 \mathrm{~kg} / \mathrm{yr}$ ) for the Zone 3 IP was not met in FY 2009 based on the $147.7 \mathrm{~kg}$ of uranium computed at BCK 9.2. The 2009 uranium flux at BCK 12.34 was $32.9 \mathrm{~kg} / \mathrm{yr}$ which is more than the flux goal of $27.2 \mathrm{~kg} / \mathrm{yr}$. Though flux is no longer calculated at NT-3 with flow composite monitoring, grab sample data from NT-3 was consistent with decreased concentrations measured since completion of the BYBY remedy. Based on the concentrations of the grab samples from 2009, the estimated total uranium flux contribution from BYBY (less than $4 \mathrm{~kg} / \mathrm{yr}$ ) continues to be a low percentage of the cumulative flux computed at BCK 9.2.

Table 4.8. Uranium flux at flow-paced monitoring locations in BCV

\begin{tabular}{|c|c|c|c|c|c|c|c|}
\hline FY & $\begin{array}{c}\text { BCK } \\
9.2 \\
\end{array}$ & SS-5 & NT-8 & $\begin{array}{l}\text { BCK } \\
11.54 \\
\end{array}$ & NT-3 & $\begin{array}{l}\text { BCK } \\
12.34 \\
\end{array}$ & $\begin{array}{l}\text { Average } \\
\text { rainfall }^{\mathrm{b}}\end{array}$ \\
\hline ROD Goal & 34 & - & - & - & 4.3 & 27.2 & - \\
\hline 2001 & 88.7 & 17.2 & - & - & 79.9 & 24.5 & $\overline{45.9}$ \\
\hline 2002 & 120.2 & 13.1 & - & 158.2 & 62.8 & 25.4 & 52.7 \\
\hline 2003 & 165.4 & 12.3 & - & 87.0 & 4.6 & 44.3 & 73.7 \\
\hline 2004 & 115.0 & 9.5 & - & 45.8 & 1.2 & 27.3 & 56.4 \\
\hline 2005 & 115.4 & 11.1 & - & 39.8 & 4.1 & 40.3 & 58.9 \\
\hline 2006 & 68.5 & - & - & 25.2 & 1.7 & 21.3 & 46.4 \\
\hline 2007 & 59.5 & - & - & 12.6 & $--^{c}$ & 15.8 & 36.8 \\
\hline 2008 & 73.2 & - & 27.9 & 15.9 & $--^{c}$ & 23.0 & 49.3 \\
\hline 2009 & 147.7 & 11.6 & $43.3^{d}$ & 27.2 & $--^{c}$ & 32.9 & 62.5 \\
\hline
\end{tabular}

Bold values indicate the Phase I ROD goal for uranium flux has not been met.

"All flux values are kilograms of uranium/year.

Average rainfall in inches for rain gauges at Y-12, ETTP, ORNL, and DOE town site.

${ }^{\circ} \mathrm{Goal}$ attained; flux monitoring discontinued FY 2007.

'Uranium isotope mass balancing at BCK 9.2 suggests NT-8 contributed about $60 \mathrm{~kg}$ in FY 2009. Approximately $17 \mathrm{~kg}$ infiltrated into karst seepage pathways upstream of the NT-8 flume. 


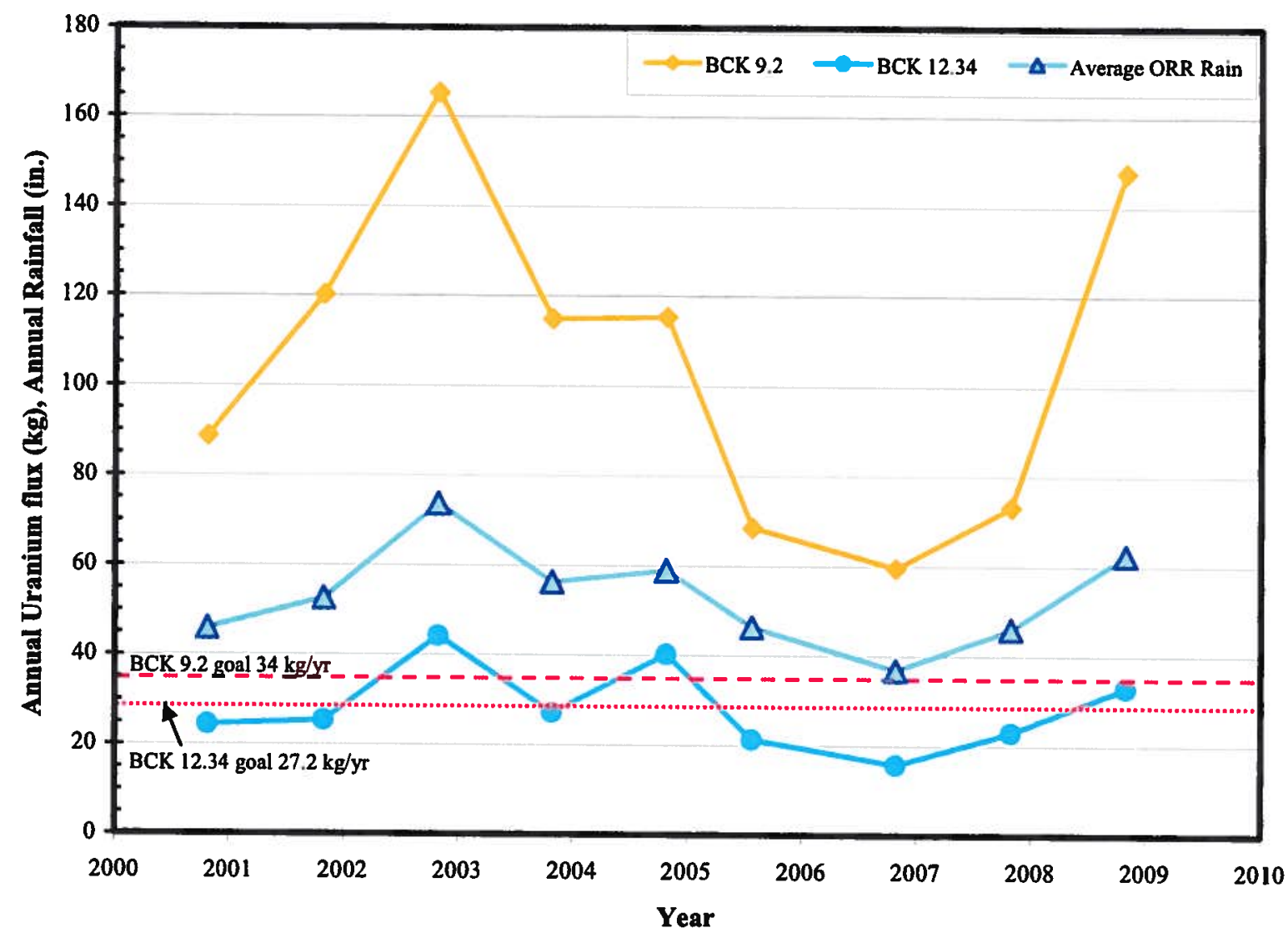

Figure 4.4. Post-ROD uranium flux at BCK 9.2 and BCK 12.34 and annual rainfall at the ORR.

Review of Figure 4.4 shows the relationship between rainfall and total uranium flux at BCK 9.2 and BCK 12.34. The amount of uranium that is mobilized from buried waste sources and residual groundwater contamination in the S-3 Pond area depends on the amount of rainfall that occurs. Increased rainfall causes increased groundwater recharge, more leachate formation, higher groundwater levels, and more contaminant transport from buried/below-grade sources to the streams. The relationship between annual rainfall and annual uranium fluxes measured at BCK 9.2 and BCK 12.34 is strongly linear during the post-ROD monitoring period as demonstrated in Figure 4.5. The higher mass flux and the greater positive slope of the trend at BCK 9.2 than at BCK 12.34 reflects the presence of a significant uranium source that enters Bear Creek between the two stations. During FY 2007, data collection indicated that NT-8 was a significant contributor of uranium to Bear Creek, and during FY 2009 continuous flow-paced monitoring of NT-8 documented that about $43 \mathrm{~kg}$ of uranium was discharged directly to Bear Creek (Table 4.8). The NT-8 sampling station is located in an area where a portion of the upstream flow sinks into the epikarst system beneath the channel which means the station does not measure all the flow in the tributary. An evaluation of the ratios of ${ }^{238} U /{ }^{234} U$ for all the Zone 3 surface water monitoring stations shows that each area has unique isotope ratios. To balance the isotope ratio measured at BCK 9.2, approximately $40 \%$ of the water must originate from the NT-8 source area. This isotopic balance suggests that about $17 \mathrm{~kg}$ of uranium is lost from NT-8 upstream of the flume as bed seepage from the stream into the karst flowpaths in limestone that enters Bear Creek indirectly between the mouth of NT-8 and the BCK 9.2 IP. Combining the $43 \mathrm{~kg}$ of measured uranium at NT-8 and the $17 \mathrm{~kg}$ inferred from uranium isotope mass balancing indicates that NT-8 contributed approximately $60 \mathrm{~kg}$ of uranium to Bear Creek in FY 2009. 


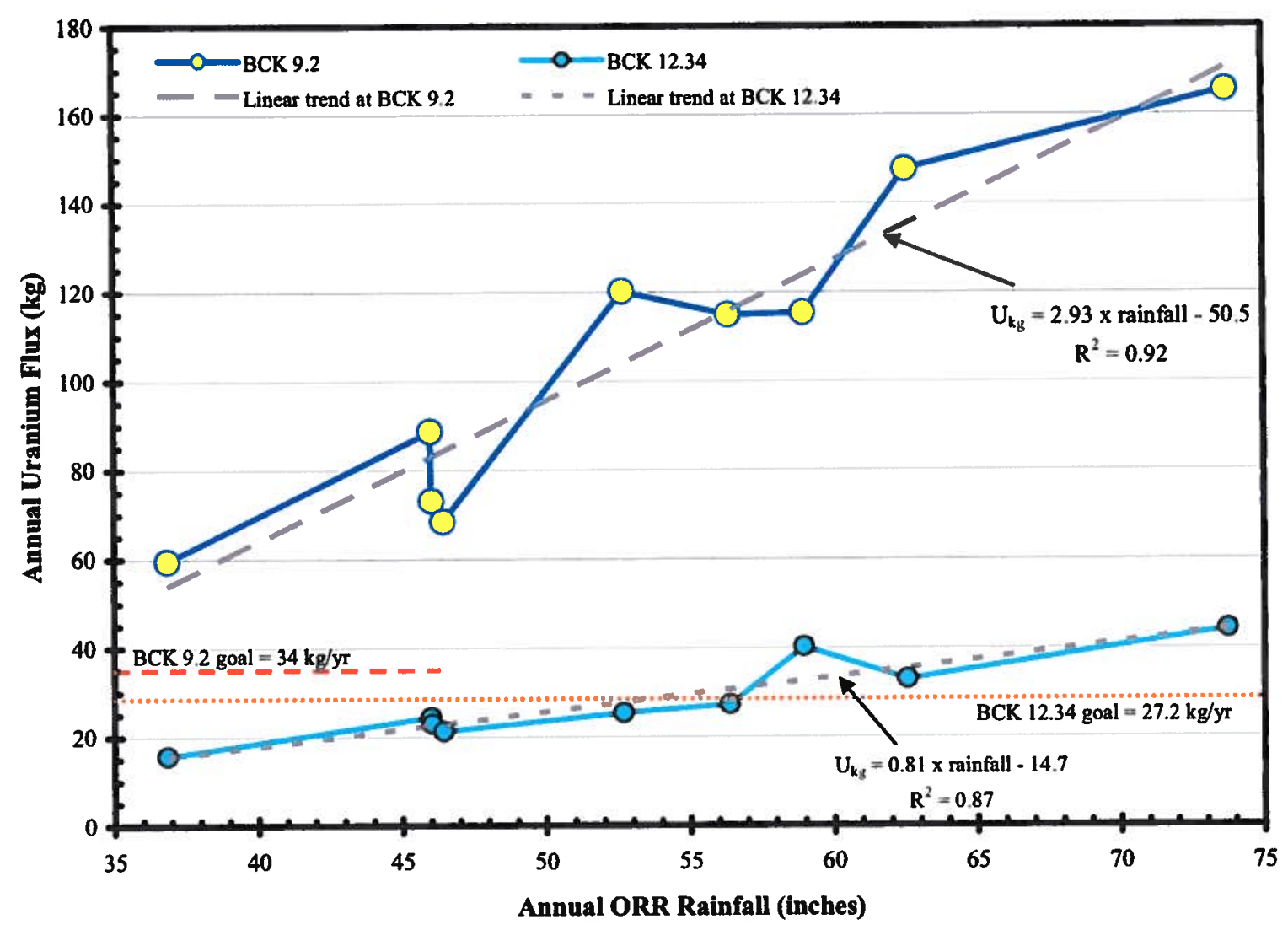

Figure 4.5. Average annual rainfall vs. annual uranium flux at BCK 9.2 and BCK 12.34.

Rough estimates of the uranium contributions from NT-3, NT-5, and NT-7 were made based on grab sample data. These estimates suggest that NT-3 may have contributed about $2 \mathrm{~kg}$ of uranium, NT-5 may have contributed 1 to $2 \mathrm{~kg}$ of uranium, and NT-7 may have contributed about $10 \mathrm{~kg}$ of uranium.

Including all directly measured and estimated uranium sources contributing to the stream, the mass balance of uranium in the Bear Creek system during FY 2009 shows that about 119 of the $148 \mathrm{~kg}$ of uranium is accounted for at monitoring stations. The remaining mass $(\sim 29 \mathrm{~kg})$ is attributed to ungauged inflows to Bear Creek from springs and seeps directly into the stream channel.

The difficulty in measuring the mass balance of uranium in the Bear Creek system has been an issue throughout the monitoring history. To further improve the flux measurement precision within the watershed, DOE will re-instate continuous uranium flux measurement at NT-3 and NT-5 and will add an additional instream monitoring location in the main stem of Bear Creek between NT-7 and spring SS-4.

Within Zone 3, industrial exposure scenario comparisons were applicable since the ROD remediation goal for that area is controlled industrial use. At BCK 12.34, near the S-3 Ponds, the average ${ }^{234} \mathrm{U}$, ${ }^{235} \mathrm{U}$, and ${ }^{238} \mathrm{U}$ activities were about 20,2 , and $39 \mathrm{pCi} / \mathrm{L}$, respectively. These results are based on analysis of continuous, flow-paced composite samples. The average activity level for ${ }^{234} \mathrm{U}$ met the industrial $\mathrm{RBC}$ goal of about $23 \mathrm{pCi} / \mathrm{L}$. The activity level for ${ }^{238} \mathrm{U}$ exceeded the industrial $\mathrm{RBC}$ of about $18 \mathrm{pCi} / \mathrm{L}$ $<$ http://epa-prgs.ornl.gov/cgi-bin/radionuclides/rprg_search>, using exposure duration of 250 days/year, exposure frequency of 25 years and $1 \mathrm{~L} / \mathrm{d}$ ingestion rate. The ${ }^{235} \mathrm{U}$ has been less than the $22 \mathrm{pCi} / \mathrm{L}$ industrial exposure goal since the ROD was implemented. 
Nitrate and cadmium are also key COCs in surface water in BCV. The principal source of nitrate contamination is legacy disposal of acid liquids in the S-3 Ponds, which created nitrate plumes in groundwater that discharge in the headwaters of Bear Creek. Nitrate has been monitored historically at a number of locations in BCV. Concentrations are highest near the S-3 source and decrease with distance to the west and downstream. As stated previously, Zone 3 is designated for industrial land use. The preliminary remediation goal (PRG) for nitrate in an industrial land use scenario is $160 \mathrm{mg} / \mathrm{L}$. Figure 4.6 shows the average nitrate concentration in surface water at BCK 12.34, along with the annual average ORR rainfall. The tendency for dilution of the nitrate concentrations during years of elevated rainfall is apparent in the graph with the mirror relationship between increased rainfall and decreased nitrate concentration. During FY 2009, the average nitrate concentration was $33 \mathrm{mg} / \mathrm{L}$ based on 52 weekly grab sample results. None of the grab samples collected during FY 2009 exceeded the PRG for nitrate. During the below average rainfall conditions of FY 2007 and 2008, the nitrate PRG was occasionally exceeded because of the absence of upstream runoff that dilutes groundwater seepage into NT-1 near the S-3 Ponds site.

The principal source of cadmium is also disposed liquids from the S-3 ponds area. Cadmium concentrations in the Bear Creek headwaters continuously exceeds the $0.25 \mu \mathrm{g} / \mathrm{L}$ AWQC in samples from the NT-01 and BCK 12.34 sampling locations. Samples obtained at BCK 12.34 during FY 2009 contained an average of $3.9 \mu \mathrm{g} / \mathrm{L}$ cadmium with a maximum measured concentration of $12.2 \mu \mathrm{g} / \mathrm{L}$. Sampling at BCK 9.2 at the downstream IP for Zone 3 indicates that cadmium meets the AWQC before the stream enters Zone 2.

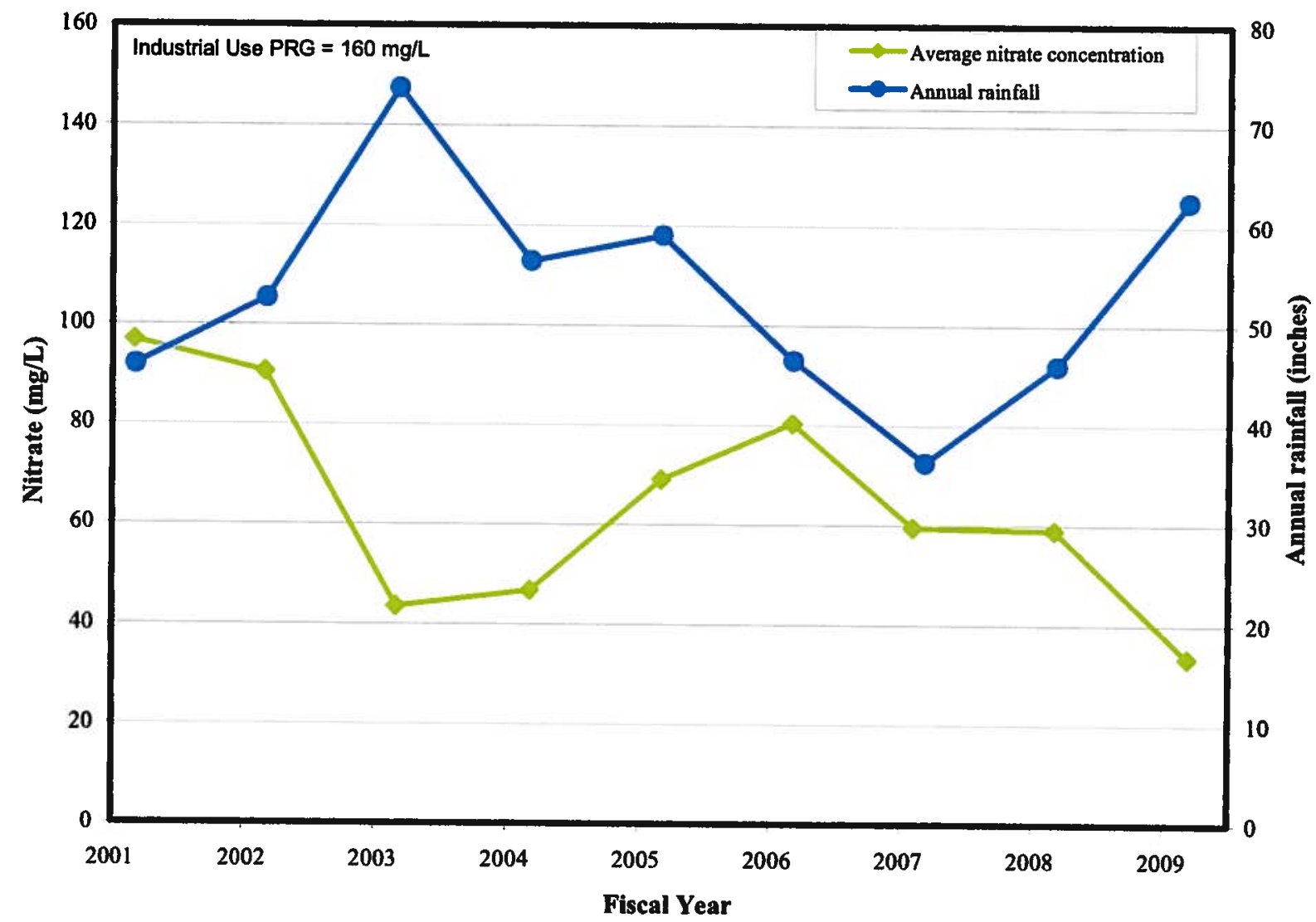

Figure 4.6. BCK 12.34 average nitrate concentration and annual ORR rainfall. 
Effectiveness of RAs at the BYBY is measured by water quality in the NT-3 stream (see tables 4.4 and 4.6, and Figure 4.1). In addition to surface water monitoring at the BYBY, the PCCR (DOE 2003d) specifies monitoring of benthic macroinvertebrate and fish communities in NT-3, and stream channel stability and riparian vegetation monitoring of the restored NT-3 channel. Benthic macroinvertebrate and fish community monitoring are presented in Sect. 4.2.2.3. Stream channel stability and riparian vegetation monitoring along NT-3 are also discussed in that section.

The remediation goal for the BYBY excavation was to attain less than $4.3 \mathrm{~kg} / \mathrm{yr}$ uranium from NT-3. The flux reduction goal was met and confirmed with sustained flux reduction in all years since the RA was completed in 2002. Regulatory approval to discontinue flow paced composite sampling at NT-3 and replace with monthly grab samples for uranium was granted in April 2007. There were ten grab samples collected during FY 2009 compared to nine during FY 2008 and eight during FY 2007. Grab samples could not be collected all 12 months since NT-3 is an intermittent stream that does not flow during low precipitation periods. The average uranium isotope activities for FY 2009 grab samples at NT-3 were $42 \mathrm{pCi} / \mathrm{L}^{234} \mathrm{U}, 2.5 \mathrm{pCi} / \mathrm{L}^{235} \mathrm{U}$, and $39.6 \mathrm{pCi} / \mathrm{L}^{238} \mathrm{U}$.

Uranium concentrations in NT-3 decreased significantly and uranium isotope ratios also changed following BYBY remediation. Table 4.9 is a tabulation of annual average activities of ${ }^{234} U$ and ${ }^{238} U$ measured in NT-3. BYBY remediation was completed in summer of 2002 and the FY 2002 and 2003 uranium activities show the rapid decrease following remediation. A gradual increase in uranium concentrations from 2004 through 2009 is apparent.

Table 4.9. Annual average ${ }^{234} \mathrm{U}$ and ${ }^{238} \mathrm{U}$ activities at NT-3

\begin{tabular}{|c|c|c|c|}
\hline Year & $\begin{array}{c}\text { Average } \\
{ }^{234} \mathbf{U} \\
\text { (pCi/L) }\end{array}$ & $\begin{array}{c}\text { Average } \\
{ }^{238} \mathrm{U} \\
(\mathrm{pCi} / \mathbf{L})\end{array}$ & \\
\hline FY 1999 & 208 & 450 & \\
\hline FY 2000 & 230 & 514 & \\
\hline FY 2001 & 196 & 476 & \\
\hline FY 2002 & 135 & 292 & BYBY remediation completed \\
\hline FY 2003 & 14 & 14 & \\
\hline FY 2004 & 7 & 6 & \\
\hline FY 2005 & 13 & 14 & \\
\hline FY 2006 & 17 & 16 & \\
\hline FY 2007 & 46 & 42 & \\
\hline FY 2008 & 41 & 39 & \\
\hline FY 2009 & 42 & 40 & \\
\hline
\end{tabular}

NT-3 surface water uranium isotope ratios were examined to evaluate the significance of this increase with regard to the BYBY remedy. Figure 4.7 shows that along with the reduction in total uranium activity in NT-3 following remediation, there was also a shift in the ${ }^{238} U /{ }^{234} U$ ratio. The ${ }^{238} U /{ }^{234} U$ decreased from average values of 2 to 3 downward to average values near 1, as shown in the upper portion of Figure 4.7. Prior to remediation, ${ }^{235} \mathrm{U}$ activities measured in NT-3 surface water were relatively high. The lower portion of Figure 4.7 shows that along with the downward shift of ${ }^{238} \mathrm{U} /{ }^{234} \mathrm{U}$ ratio that followed BYBY remediation, there was also a significant reduction in the ${ }^{235} \mathrm{U}$ activity in NT-3. Prior to remediation, ${ }^{235} \mathrm{U}$ was usually quantifiable in surface water samples; however, following remediation, many samples yield nondetectable results for ${ }^{235} \mathrm{U}$. These isotopic shifts in the NT-3 surface water suggest that the recent increases in uranium activity are related to a different contaminant source than the BYBY source, which 

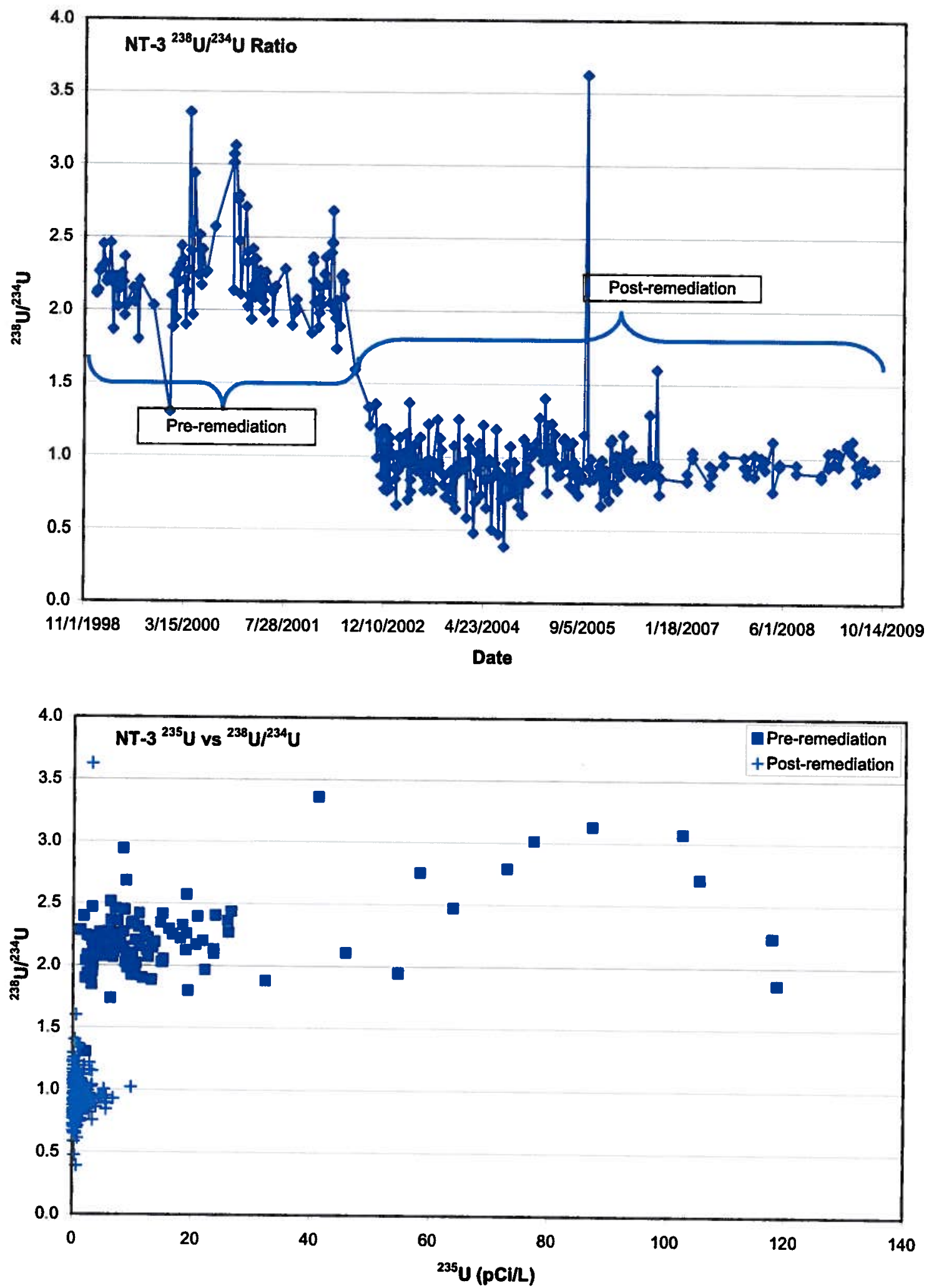

Figure 4.7. ${ }^{238} \mathrm{U} /{ }^{234} \mathrm{U}$ ratios and ${ }^{235} \mathrm{U}$ activity vs. ${ }^{238} \mathrm{U} /{ }^{234} \mathrm{U}$ ratios in NT-3 surface water. 
was excavated. As shown on Figure 4.8, two other waste disposal units remain in the NT-3 watershed the Hazardous Chemical Disposal Area (HCDA) and the Unit 6 Landfill. The uranium being measured in NT-3 surface water may be indicative of releases from one or both of these areas.

DOE recommends re-instating continuous flow-paced sampling of NT-3 to provide a good measure of the uranium flux contribution from NT-3 to the Bear Creek system.

The BCV ROD also requires that AWQC in surface water be met in NT-3. AWQC goals for NT-3 have been achieved through the BYBY RA. Along with the other monitoring changes discussed above for NT-3, regulatory approval was granted in correspondence from EPA and TDEC to reduce frequency of AWQC monitoring at NT-3 to every five years corresponding to the FYR. This monitoring is scheduled for FY 2010.

\subsubsection{Groundwater Monitoring}

RAOs for the BCV ROD, provided in Sect. 4.2.1, include "protect future residential users of the valley in Zone 1 from risks from exposure to groundwater..." Groundwater quality goals for each zone are described in Table 4.3, and Table 4.6 includes the BCV watershed CERCLA performance monitoring requirements that fulfill these objectives. Groundwater sampling locations are shown on Figure 4.9. At a minimum, wells GW-712, -713, and -714 (Picket W), located in the western portion of the valley at the Zone1/Zone 2 boundary, are monitored semiannually for nitrate; metals, including uranium; and VOCs. These three wells sample groundwater from the Maynardville Limestone. Wells GW-683 and GW-684 (Picket A) are located near the boundary of Zones 2 and 3 and are monitored semiannually for metals, including uranium, and nitrate. MCLs are used in Zone 1 as the screening criteria and concentration trends are used elsewhere to evaluate performance.

\section{Zone 1}

During 2009, groundwater monitoring in Zone 1 included sampling of one spring (SS-6) and three monitoring wells (GW-712, GW-713, and GW-714) that lie near the boundary with Zone 2. Well GW-712 is about $458 \mathrm{ft}$ deep. VOCs have never been detected in well GW-712. Table 4.10 includes results of nitrate analyses for wells GW-712, GW-713, and GW-714 from FY 2000 through FY 2009. Nitrate has been intermittently detected at low (less than $1.4 \mathrm{mg} / \mathrm{L}$ ) to trace concentrations and nitrate was detected at $0.052 \mathrm{mg} / \mathrm{L}$ in FY 2009. Uranium isotopes have been intermittently detected (maximum of $1.87 \mathrm{pCi} / \mathrm{L}$ ) ${ }^{234} \mathrm{U}$ in FY 2003 and ${ }^{234} \mathrm{U}$ was detected at $0.37 \mathrm{pCi} / \mathrm{L}$ in $\mathrm{FY} 2009$. Uranium-235 and ${ }^{238} \mathrm{U}$ were not detected during FY 2009.

Well GW-713 is about $315 \mathrm{ft}$ deep. Well GW-713 has experienced periodic trace-to-low (maximum $14 \mu \mathrm{g} / \mathrm{L}$ ) concentrations of PCE, TCE, 1,1,1-TCA, and 1,2-DCE, although no VOCs were detected in FY 2009. In the mid-1990s and in FY 2000, GW-713 experienced nitrate concentrations of about $1.3 \mathrm{mg} / \mathrm{L}$ and nitrate has been detected at concentrations less than $1 \mathrm{mg} / \mathrm{L}$ subsequently, with a detected concentration of $0.029 \mathrm{mg} / \mathrm{L}$ in FY 2009. Uranium isotopes have been intermittently detected in well GW-713 at low concentrations $(<1.7 \mathrm{pCi} / \mathrm{L})$, although no uranium isotopes were detected in FY 2009.

Well GW-714 is about $145 \mathrm{ft}$ deep. Site related VOCs have not been detected in well GW-714. Nitrate has been detected throughout the monitoring history of GW-714 and exhibits a decreasing trend. In the early 1990s, nitrate was detected at almost $5 \mathrm{mg} / \mathrm{L}$. In FY 2000, the nitrate concentration was about $4 \mathrm{mg} / \mathrm{L}$ and a steadily decreasing trend was observed with concentrations decreasing to about $1 \mathrm{mg} / \mathrm{L}$ in FY 2004, with further decreases to about $0.24 \mathrm{mg} / \mathrm{L}$ in FY 2009. Uranium isotopes are detected in well GW-714. Since FY 2000 , both ${ }^{234} U$ and ${ }^{238} U$ exhibited gradual increases from less than $1 \mathrm{pCi} / \mathrm{L}$ to 

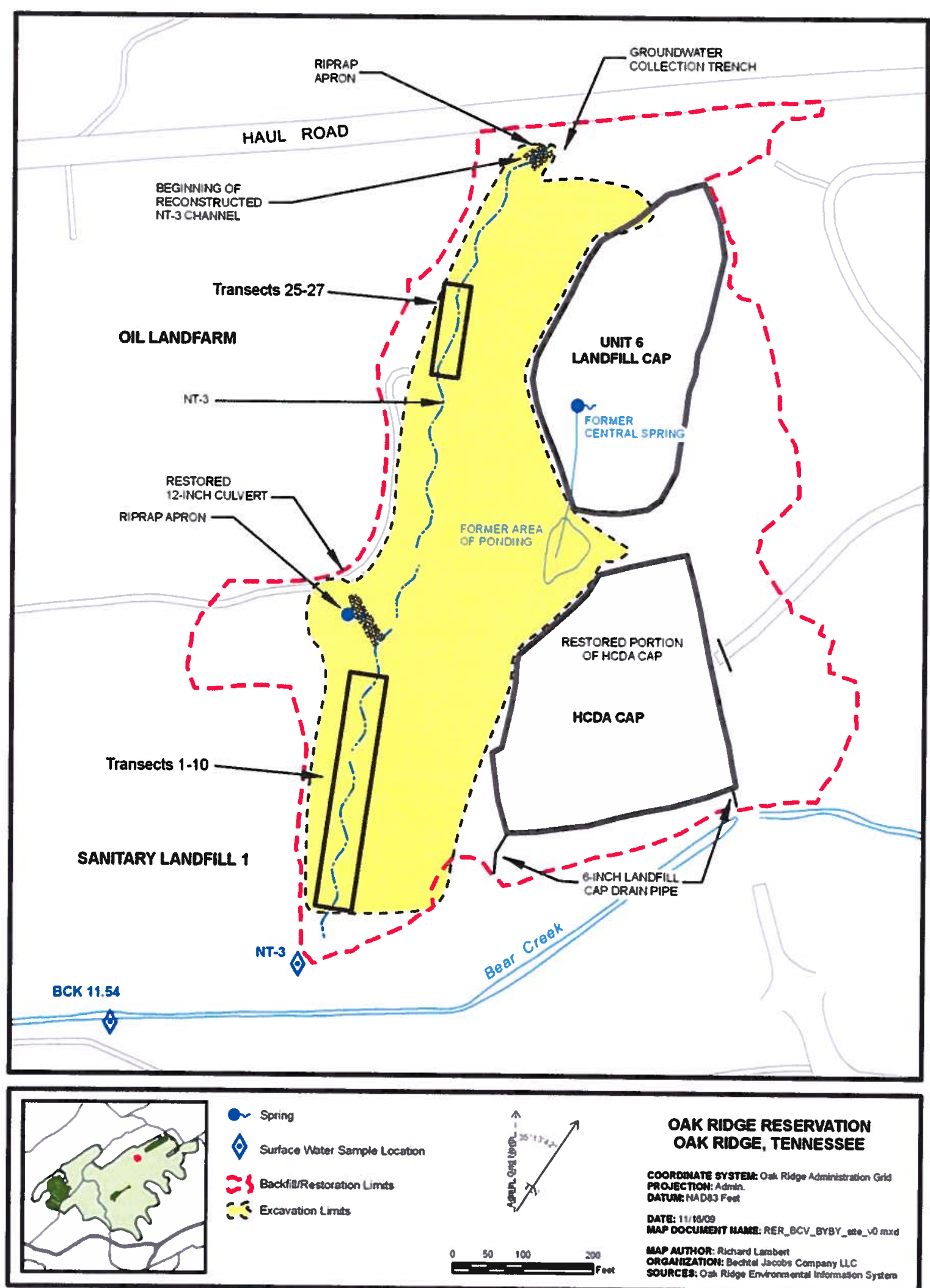

Figure 4.8. Location of Boneyard/Burnyard site and monitoring locations. 


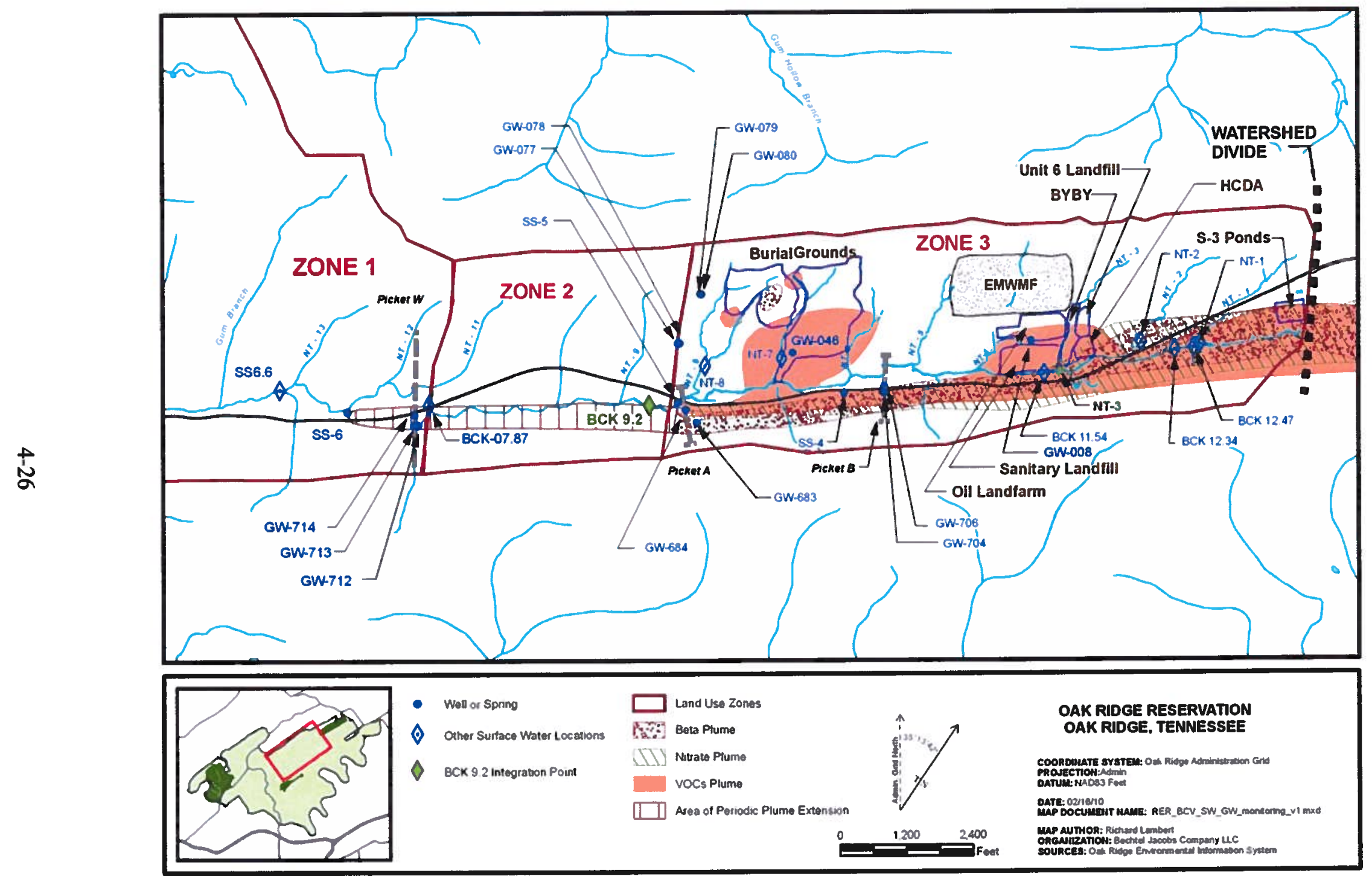

Figure 4.9. BCV Land Use Zones and surface water and groundwater monitoring locations. 
Table 4.10. Nitrate concentrations measured in wells GW-712, GW-713, and GW-714"

\begin{tabular}{cccccccc}
\hline \multicolumn{2}{c}{ GW-712 (458 ft deep) } & \multicolumn{3}{c}{ GW-713 (314 ft deep) } & \multicolumn{2}{c}{ GW-714 (145 ft deep) } \\
\hline Date & $\begin{array}{c}\text { Nitrate } \\
\text { (mg/L) }\end{array}$ & Qualifier & Date & $\begin{array}{c}\text { Nitrate } \\
\text { (mg/L) }\end{array}$ & Qualifier & Date & $\begin{array}{c}\text { Nitrate } \\
\text { (mg/L) }\end{array}$ \\
\hline $1 / 10 / 2000$ & 0.02 & & $1 / 6 / 2000$ & 0.67 & & $1 / 5 / 2000$ & 0.46 \\
$7 / 10 / 2000$ & 1.4 & & $7 / 10 / 2000$ & 1.3 & & $7 / 11 / 2000$ & 4 \\
$1 / 2 / 2001$ & 0.03 & & $1 / 3 / 2001$ & 0.33 & & $1 / 2 / 2001$ & 3.7 \\
$7 / 2 / 2001$ & 0.02 & $\mathrm{U}$ & $7 / 10 / 2001$ & 0.061 & & $7 / 2 / 2001$ & 1.8 \\
$1 / 3 / 2002$ & 0.02 & $\mathrm{U}$ & $1 / 3 / 2002$ & 0.02 & $\mathrm{U}$ & $1 / 2 / 2002$ & 1.6 \\
$7 / 1 / 2002$ & 0.034 & & $7 / 1 / 2002$ & 0.02 & $\mathrm{U}$ & $7 / 1 / 2002$ & 1.7 \\
$1 / 6 / 2003$ & 0.13 & & $1 / 6 / 2003$ & 0.16 & & $1 / 6 / 2003$ & 1.6 \\
$7 / 7 / 2003$ & 0.22 & & $7 / 7 / 2003$ & 0.2 & & $7 / 7 / 2003$ & 1.3 \\
$1 / 6 / 2004$ & 0.02 & $\mathrm{U}$ & $1 / 5 / 2004$ & 0.02 & $\mathrm{U}$ & $1 / 5 / 2004$ & 1.1 \\
$7 / 7 / 2004$ & 0.02 & $\mathrm{U}$ & $7 / 7 / 2004$ & 0.02 & $\mathrm{U}$ & $7 / 7 / 2004$ & 0.78 \\
$1 / 10 / 2005$ & 0.094 & & $1 / 10 / 2005$ & 0.02 & $\mathrm{U}$ & $1 / 10 / 2005$ & 0.67 \\
$7 / 6 / 2005$ & 0.021 & & $7 / 7 / 2005$ & 0.02 & $\mathrm{U}$ & $7 / 6 / 2005$ & 0.56 \\
$1 / 3 / 2006$ & 0.02 & $\mathrm{U}$ & $1 / 3 / 2006$ & 0.02 & $\mathrm{U}$ & $1 / 3 / 2006$ & 0.52 \\
$7 / 5 / 2006$ & 0.02 & $\mathrm{U}$ & $7 / 5 / 2006$ & 0.02 & $\mathrm{U}$ & $7 / 5 / 2006$ & 0.42 \\
$1 / 2 / 2007$ & 0.02 & $\mathrm{U}$ & $1 / 2 / 2007$ & 0.02 & $\mathrm{U}$ & $1 / 2 / 2007$ & 0.36 \\
$7 / 2 / 2007$ & 0.02 & $\mathrm{U}$ & $7 / 3 / 2007$ & 0.02 & $\mathrm{U}$ & $7 / 2 / 2007$ & 0.24 \\
$1 / 2 / 2008$ & 0.02 & $\mathrm{U}$ & $1 / 2 / 2008$ & 0.02 & $\mathrm{U}$ & $1 / 2 / 2008$ & 0.19 \\
$7 / 1 / 2008$ & 0.02 & $\mathrm{U}$ & $7 / 7 / 2008$ & 0.02 & $\mathrm{U}$ & $7 / 1 / 2008$ & 0.22 \\
$1 / 7 / 2009$ & 0.052 & & $1 / 7 / 2009$ & 0.028 & & $1 / 6 / 2009$ & 0.24 \\
$7 / 6 / 2009$ & 0.01 & $\mathrm{U}$ & $7 / 7 / 2009$ & 0.01 & & $7 / 6 / 2009$ & 0.34 \\
\hline
\end{tabular}

${ }^{a} \mathrm{EPA}$ drinking water maximum concentrations limit (MCL) is $10 \mathrm{mg} / \mathrm{L}$.

observed maximum levels of about $4.5 \mathrm{pCi} / \mathrm{L}{ }^{234} \mathrm{U}$ in FY 2003 and about $1.4 \mathrm{pCi} / \mathrm{L}{ }^{238} \mathrm{U}$ in FY 2004 . Following those observed maxima, uranium levels have decreased to less than $1 \mathrm{pCi} / \mathrm{L}$ for both isotopes. Uranium-235 is not routinely detected in well GW-714. The peak uranium isotope levels coincided with the FY 2003 and 2004 period of excess rainfall that affected groundwater and surface water contaminant levels across the ORR.

During the 1990s, low to trace concentrations of PCE, TCE, and 1,2-DCE were detected in SS-6 springwater. Chlorinated VOCs have not been detected at SS-6 since FY 1998. Nitrate is detected in SS-6 springwater. Nitrate concentrations are variable and, since FY 2000 , have fluctuated from a maximum of about $2.5 \mathrm{mg} / \mathrm{L}$ (in 2000) to a low of about $0.2 \mathrm{mg} / \mathrm{L}$ in 2005 . In FY 2009, the observed nitrate concentration was $0.68 \mathrm{mg} / \mathrm{L}$. Uranium isotopes $\left({ }^{234} \mathrm{U}\right.$ and $\left.{ }^{238} \mathrm{U}\right)$ are detected in SS-6 springwater. Measured activity levels are variable with a maximum ${ }^{234} \mathrm{U}$ level of about $5.9 \mathrm{pCi} / \mathrm{L}$ in FY 2000 and an FY 2009 value of about $2.2 \mathrm{pCi} / \mathrm{L}$. Measured activity levels for ${ }^{238} \mathrm{U}$ were highest in FY $2000(8.3 \mathrm{pCi} / \mathrm{L})$, with an FY 2009 result of about $2.4 \mathrm{pCi} / \mathrm{L}$.

Because of the intermittent nature of contaminant detection in the Zone 1 groundwater, an area of intermittent plume extension in the Maynardville Limestone is shown on Figure 4.9.

\section{Zone 2}

Groundwater monitoring used to evaluate conditions in the eastern end of Zone 2 consisted of sampling six wells along the boundary with Zone 3 near the western end of the BCBGs. These wells are near the land use zone boundary and are along the monitoring transect designated as Picket A in Figure 4.9. The 
groundwater quality goal for Zone 2 is to eventually achieve unrestricted use and, therefore, MCLs and residential RBCs are used as screening comparison levels. Wells GW-683 and GW-684 sample groundwater upgradient of its discharge at spring SS-5. Well GW-683 is $197.5 \mathrm{ft}$ deep and well GW-684 is $129.6 \mathrm{ft}$ deep. The principal contaminants detected in these wells that presently or have historically exceeded the screening criteria are nitrate and uranium isotopes (Figure 4.10). Nitrate is compared to the MCL of $10 \mathrm{mg} / \mathrm{L}$. Nitrate has been detected in wells GW-683 and GW-684 at concentrations less than half of the MCL since 2000 . The only constituent that exceeded residential risk target levels at the Zone 2 boundary is ${ }^{238} \mathrm{U}$. The FY $2009{ }^{238} \mathrm{U}$ activities measured at $\mathrm{GW}-683$ were $7.28 \mathrm{pCi} / \mathrm{L}$ in March and $6.15 \mathrm{pCi} / \mathrm{L}$ in July. Both values exceed the ${ }^{238} \mathrm{U} R \mathrm{RBC}$ of $5.5 \mathrm{pCi} / \mathrm{L}$. The activities of ${ }^{238} \mathrm{U}$ in GW-684 were similar, with $7.47 \mathrm{pCi} / \mathrm{L}$ measured in March and $7.08 \mathrm{pCi} / \mathrm{L}$ measured in July. Historic trends of nitrate and uranium isotopes show an apparent decrease in levels during 2003 through 2005, followed by an increase during 2006 through 2008. During 2003 through 2005, above normal rainfall appears to have caused dilution of contaminant concentrations in the Maynardville Limestone, followed by a gradual increase during the drought years of 2006 through 2008, and another decrease during FY 2009. Consistent with this inferred rainfall and contaminant concentration pattern, the nitrate and uranium concentrations showed a short-term decreasing trend during FY 2009 associated with the above average rainfall across the ORR.

Wells GW-683 and GW-684 sample groundwater contamination that originates from upgradient sources, such as the S-3 Ponds, and flows through karst conduits in the Maynardville Limestone prior to rising to discharge into Bear Creek as spring SS-5 (Figure 4.9). A portion of the groundwater contaminant plume shown on Figure 4.9 terminates at the known plume discharge point at SS-5. Groundwater sampling further to the west at the Picket W wells (Figure 4.9) shows the presence of nitrate and uranium, which are derived from upgradient sources. Transient episodes of groundwater contaminant migration must occur through bedrock groundwater flow pathways in Zone 2 in order for the observed deep groundwater contamination in Zone 1 to exist. A scarcity of groundwater monitoring wells in Zone 2 makes it impossible to precisely map and track groundwater contaminant transport pathways in that area.

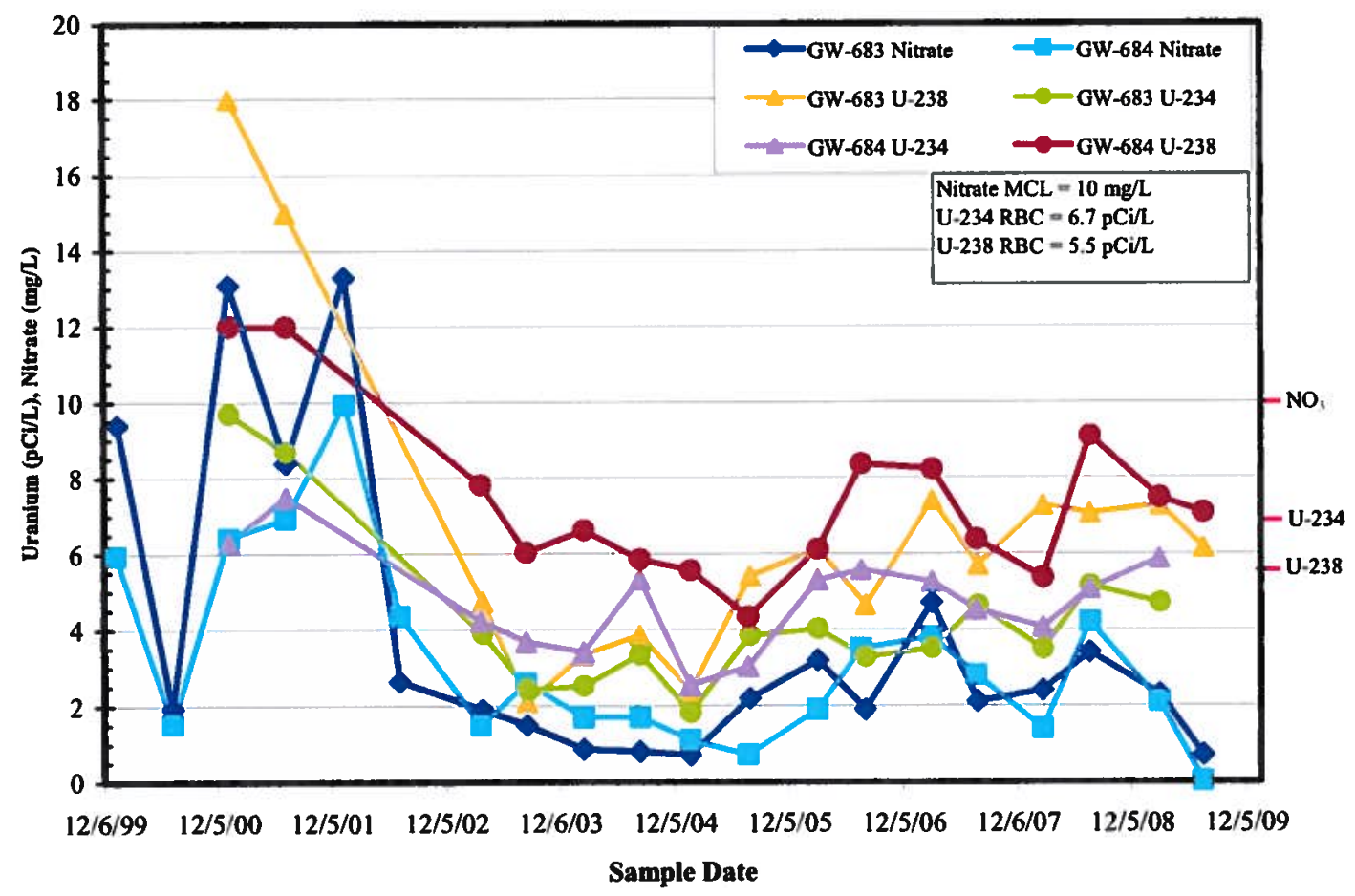

Figure 4.10. Constituents detected above RBC or MCL at wells GW-683 and GW-684. 
Wells GW-077 (100 ft deep), GW-078 (21 ft deep), GW-079 (65 ft deep), and GW-080 (30 ft deep) are sampled for metals, including uranium, and VOCs. Neither uranium nor VOCs were detected in any of these four wells during FY 2009. These are the only wells available to sample along the Zone $2 /$ Zone 3 boundary at the western edge of the BCBGs. The possibility of deeper groundwater contamination migration from the DNAPL area beneath the BCBGs cannot be evaluated with the existing well network.

\section{Zone 3}

Existing CERCLA decision documents pertinent to BCV do not stipulate groundwater RAs or RLs to be attained within Zone 3. The ROD indicates source area RAs included in the ROD are intended to improve conditions in groundwater for protection of water quality in Zones 1 and 2. Groundwater monitoring in Zone 3 includes monitoring of wells GW-704 and GW-706, which sample groundwater in the S-3 plume, and RCRA post-closure permit sampling of wells GW-008 near the Oil Landfarm and GW-046 in the BCBGs (Figure 4.9).

Wells GW-704 and GW-706 are in Picket B and sample groundwater from bedrock in the Maynardville Limestone exit pathway downgradient from the former S-3 Ponds and other source areas. The wells sample groundwater from depths of 256 and $182 \mathrm{ft}$, respectively, and are located midway between BCK 11.54 and SS-5. These wells contain uranium, VOCs, nitrate, and ${ }^{99} \mathrm{Tc}$. Contaminant levels in both wells have exhibited decreasing or stable contaminant signatures over the past several years. Principal contaminant concentration graphs for wells GW-704 and GW-706 are shown in Figure 4.11. Increased rainfall during FY 2009 caused a noticeable TCE concentration spike in the March sample. However, TCE concentrations decreased to previous levels in the July sample.

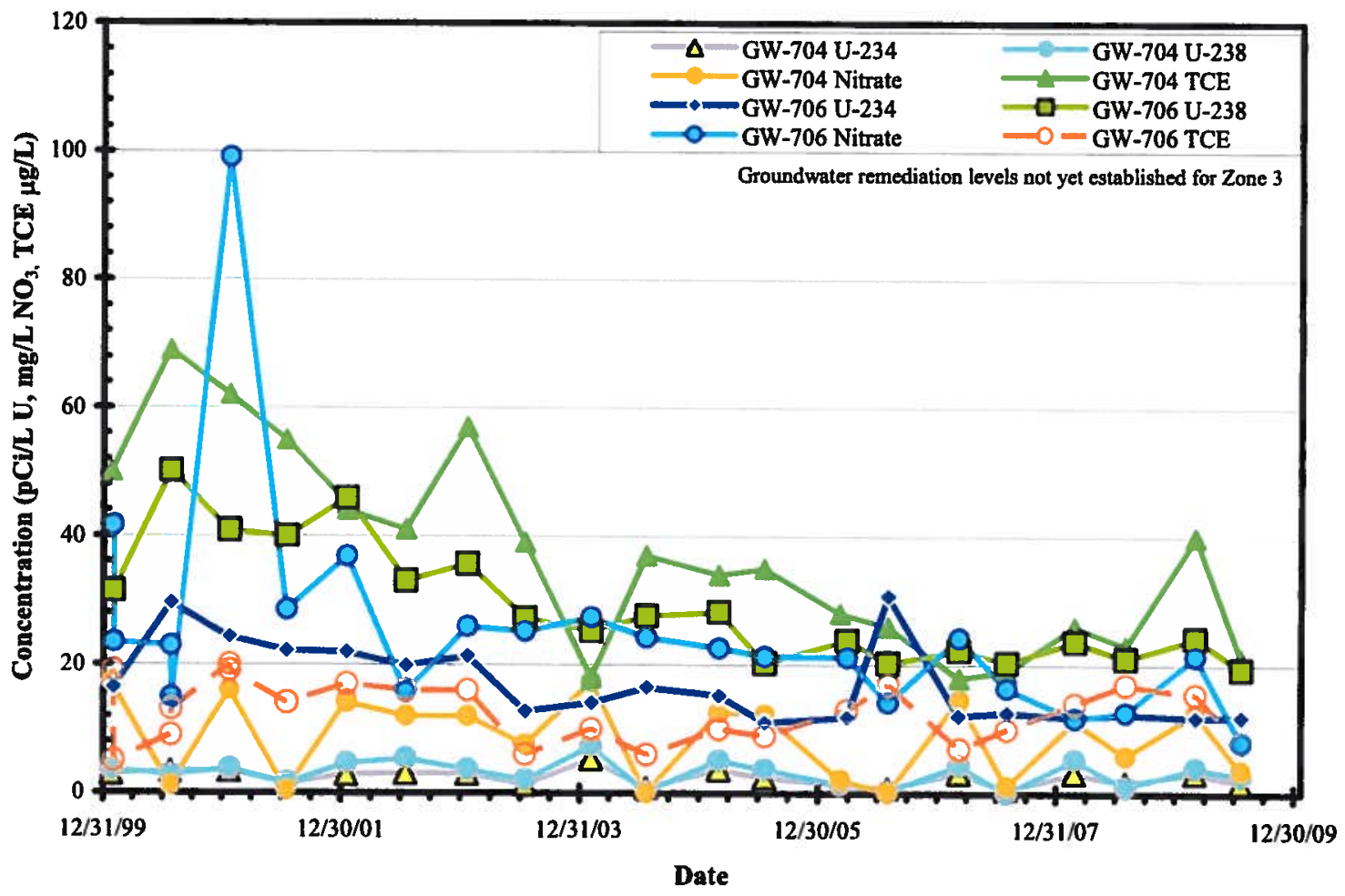

Figure 4.11. Principal contaminant trends in wells GW-704 and GW-706. 
Wells GW-008 and GW-046 are located at the Oil Landfarm and BCBGs, respectively. Well GW-008 samples groundwater from a depth of about $25 \mathrm{ft}$ and GW-046 samples groundwater from a depth of about $20 \mathrm{ft}$. Concentration trends for the principal COCs in these wells are shown in Figure 4.12. The relatively low VOC concentrations in GW-008 did not change greatly during FY 2009. However, VOC concentrations in well GW-046 increased sharply during the second half of the year.

Groundwater surveillance monitoring of the BCBGs conducted by the $\mathrm{Y}-12$ Groundwater Protection Program documents increasing VOC concentrations in the noncarbonate, fracture bedrock underlying the area. Contaminant plumes in Bear Creek Valley, as interpreted by the Y-12 Groundwater Protection Program, are depicted graphically in Figure 4.9. The concentration of PCE has exceeded $100 \mathrm{ppm}$ at a depth of $270 \mathrm{ft}$ in one well in the western BCBGs. PCE transformation products are also present at high concentrations in nearby wells and cis-1,2-DCE is routinely measured at $>2 \mathrm{ppm}$ concentrations in two wells. These contaminants are not detected to date in wells that lie further west of the burial grounds and Bear Creek Tributary NT-8. However, PCE, TCE, and cis-1,2-DCE are detected in surface water at the mouth of NT-8.

\subsubsection{Other Watershed Monitoring}

Aquatic biological monitoring of streams in BCV is used to measure the effectiveness of watershed-wide RAs. Additionally, stream habitat, stream channel stability and riparian vegetation are also monitored at the BYBY and Haul Road Mitigation sites to measure the effectiveness of specific restoration efforts at these sites. Biological monitoring data for streams in BCV, including NT-3 and the Haul Road Mitigation site, and for several reference streams (Figure 4.1) include results on (1) contaminant accumulation in fish, (2) fish community surveys, and (3) benthic macroinvertebrate community surveys. The aquatic biological monitoring, riparian monitoring and stream-channel monitoring discussed in the following sections presents the methodology and results of monitoring efforts in FY 2009.

\subsection{Aquatic Biological Monitoring in Bear Creek Watershed}

To evaluate instream contaminant exposure and potential human and ecological risks in the Bear Creek Watershed, fish are collected twice a year and analyzed for a suite of metals and PCBs at sampling locations BCK 3.3, BCK 9.9, and BCK 12.4 (Figure 4.1). An evaluation of overall ecological health of the streams is conducted by monitoring fish and benthic macroinvertebrate communities at $\mathrm{BCK} 3.3$, BCK 4.6, BCK 9.9, BCK 12.4, and NT-3 (a tributary to Bear Creek).

Mean mercury concentrations in rockbass from lower Bear Creek remained above $0.45 \mu \mathrm{g} / \mathrm{g}$ in fall 2008 and spring 2009 (Figure 4.13), approximately 2.5-fold higher than rockbass from the Hinds Creek reference site (Hinds Creek mean of $0.19 \mu \mathrm{g} / \mathrm{g}$ ) and above the EPA-recommended AWQC of $0.3 \mu \mathrm{g} / \mathrm{g}$. Concentrations of nickel, cadmium, and uranium continue to exceed reference concentrations in stoneroller minnows throughout Bear Creek. With the exception of nickel concentrations that were similar to the reference site, cadmium and uranium concentrations in fish were higher than reference values in 2009, (Figure 4.14, Figure 4.15, Figure 4.16), although note that minnows were not found at BCK 12.4 in spring 2009. In general, concentrations of these three metals in fish decrease with distance downstream.

PCB concentrations in stoneroller minnows in fall 2008 and spring 2009 averaged between 4-7 $\mu \mathrm{g} / \mathrm{g}$, continuing the long-term trend of elevated levels in fish (Figure 4.17). PCB levels in minnows collected from upper Bear Creek (BCK 9.9) have historically been higher than at the downstream site (BCK 3.3). While levels in fish from BCK 9.9 have fluctuated considerably from year to year, levels in fish from BCK 3.3 have been slowly increasing since 2003 such that they exceeded levels seen in BCK 9.9 fish in 2009 , though not significantly so ( $>>0.05$ ). In fact, PCB tissue concentrations at BCK $3.3(5.29 \pm 0.78$ $\mu \mathrm{g} / \mathrm{g}$ ) are twice the concentrations seen in 2008 at that site. 

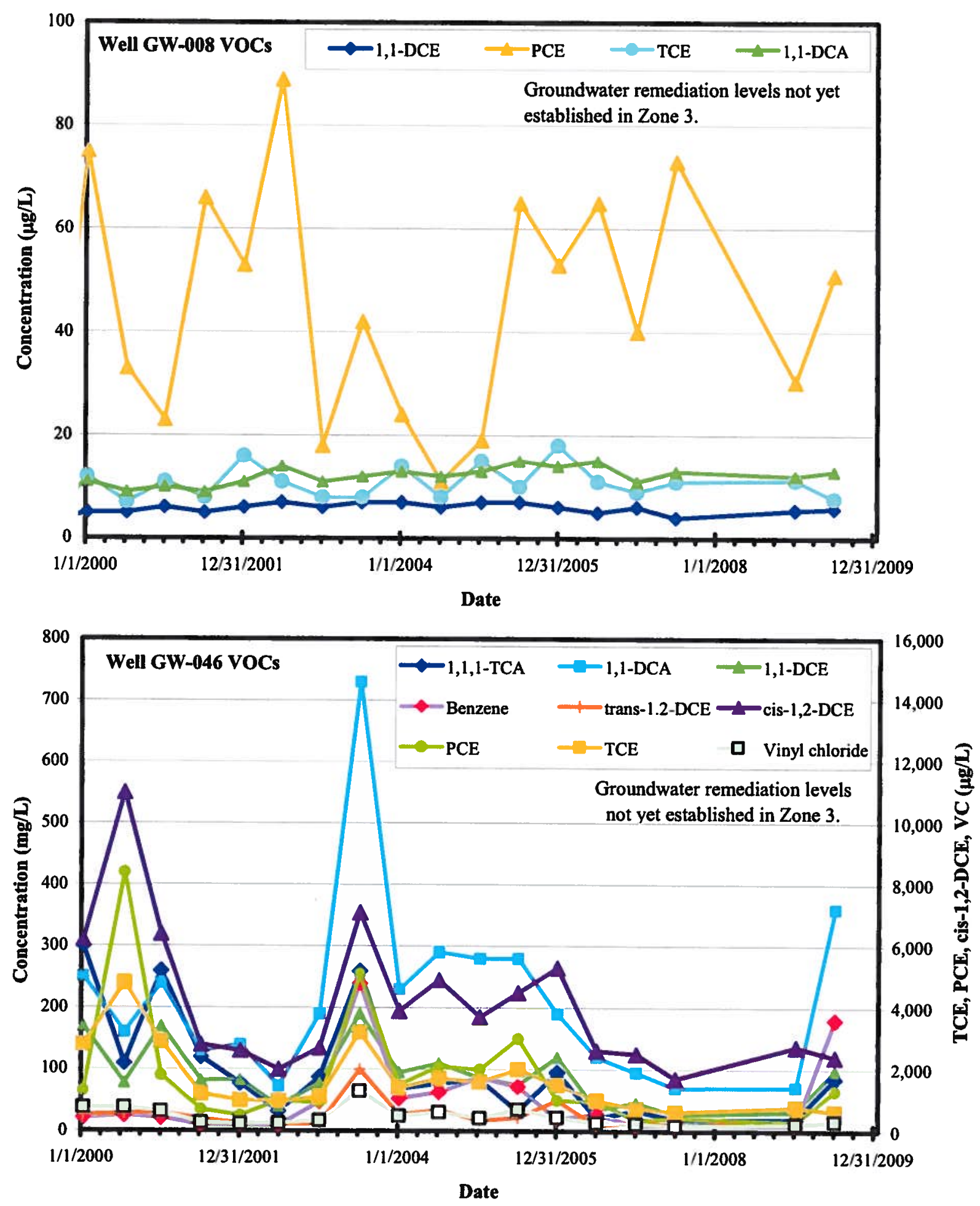

Figure 4.12. VOC concentration trends in wells GW-008 and GW-046. 


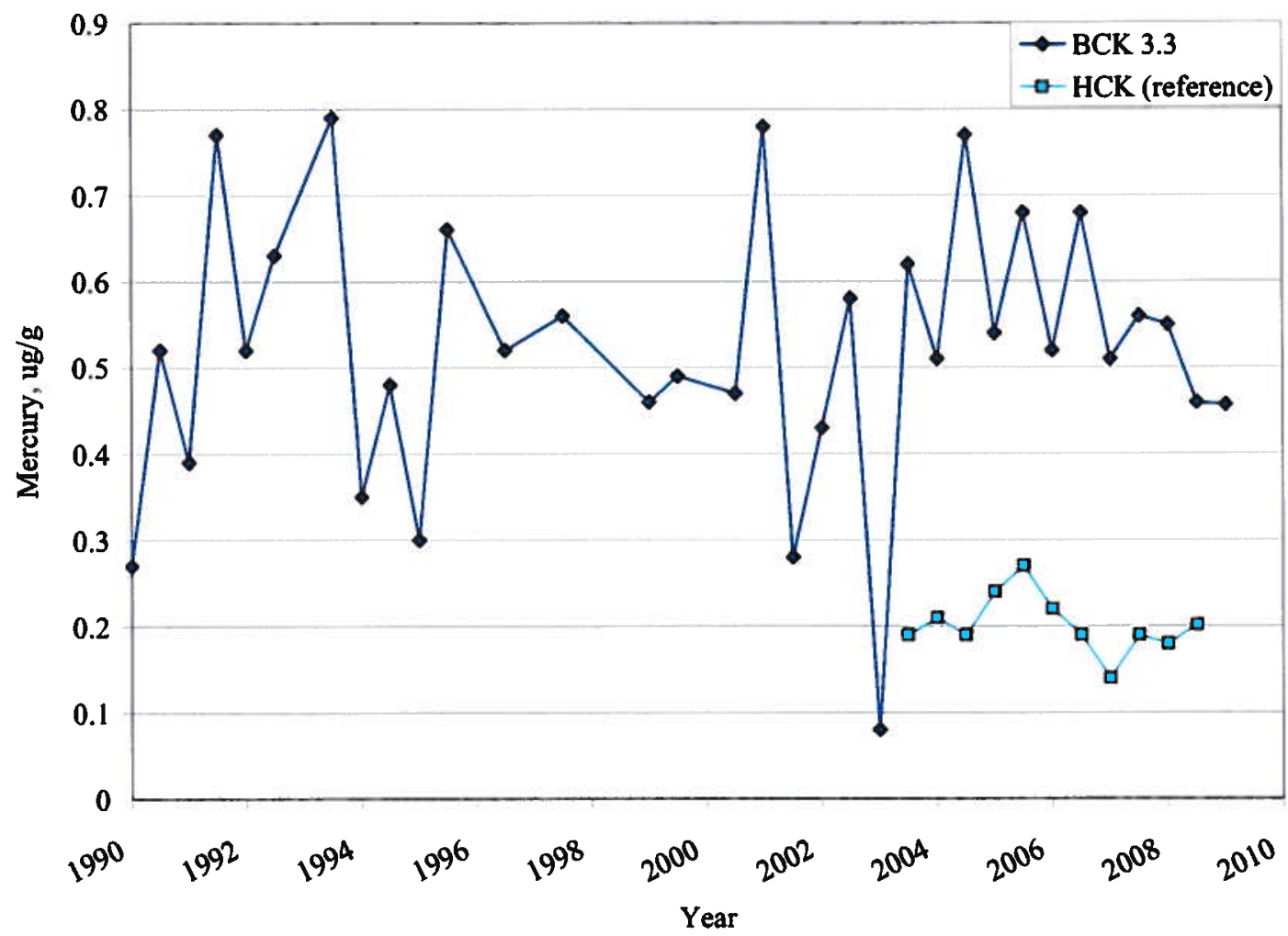

Figure 4.13. Mean concentrations of mercury in rockbass from lower Bear Creek, BCK 3.3, 1987-2009.

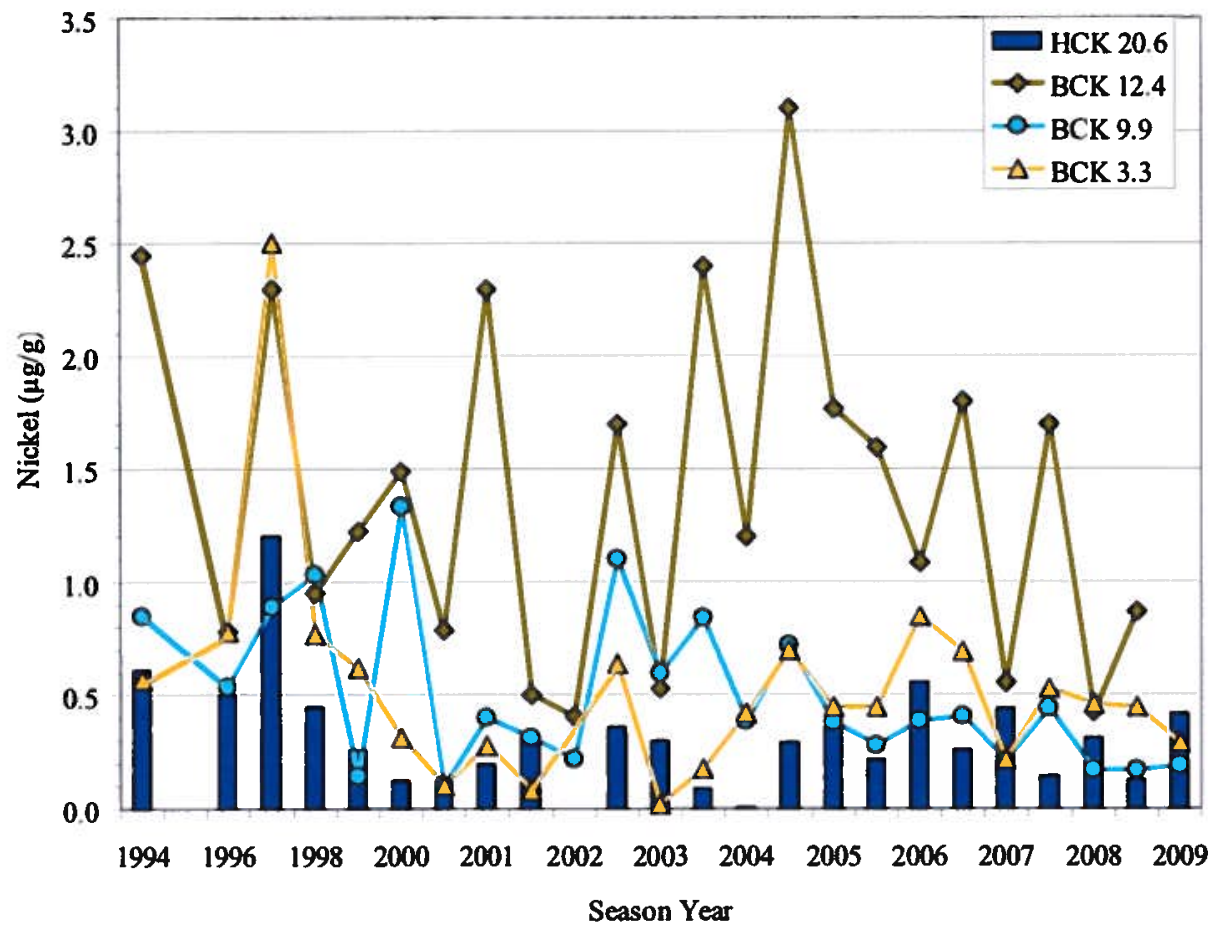

Figure 4.14. Mean nickel concentrations in stoneroller minnows at three sites in Bear Creek and a reference site (HCK 20.6), 1994-2009. 


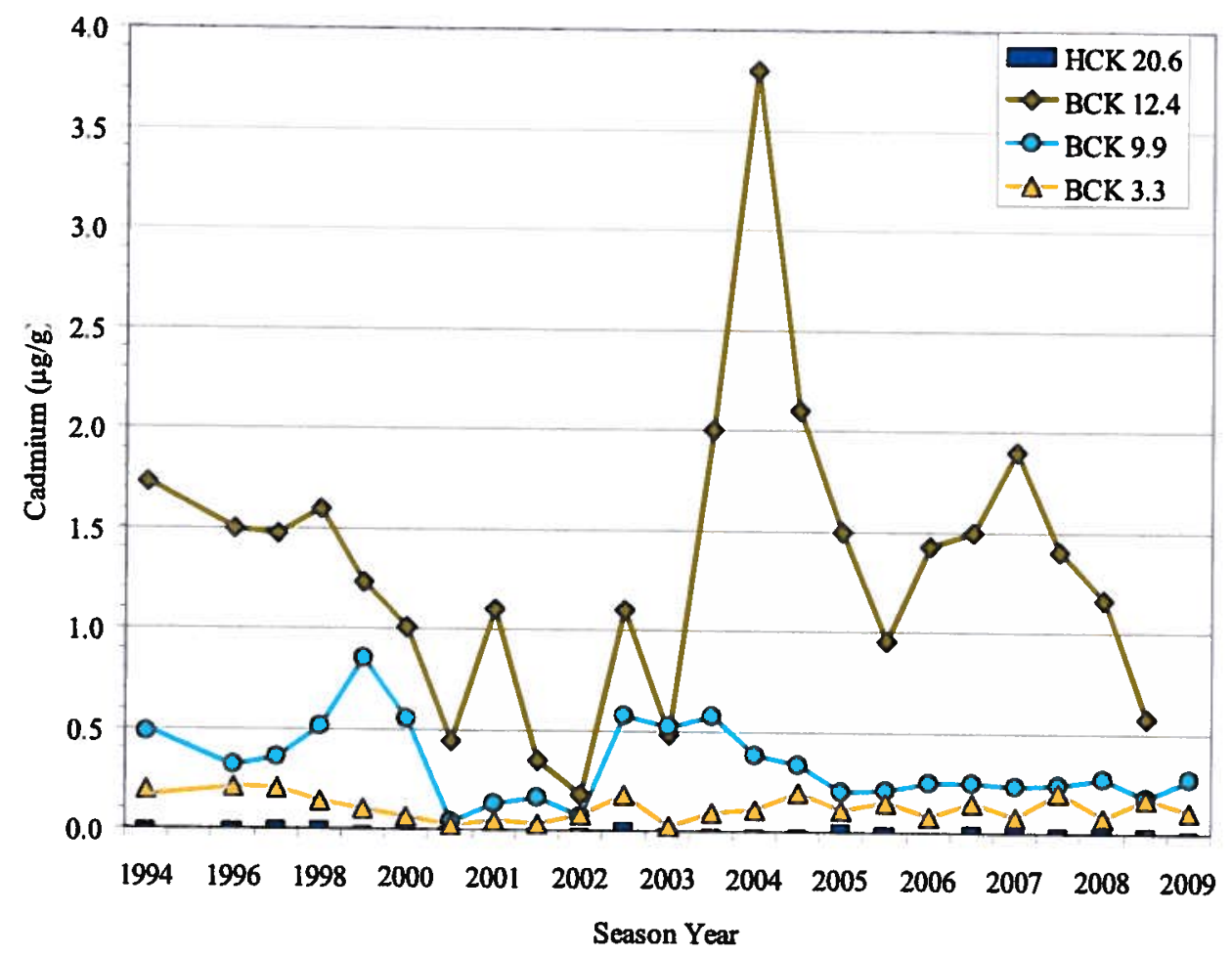

Figure 4.15. Mean cadmium concentrations in stoneroller minnows at three sites in Bear Creek and a reference site (HCK 20.6), 1994-2009.

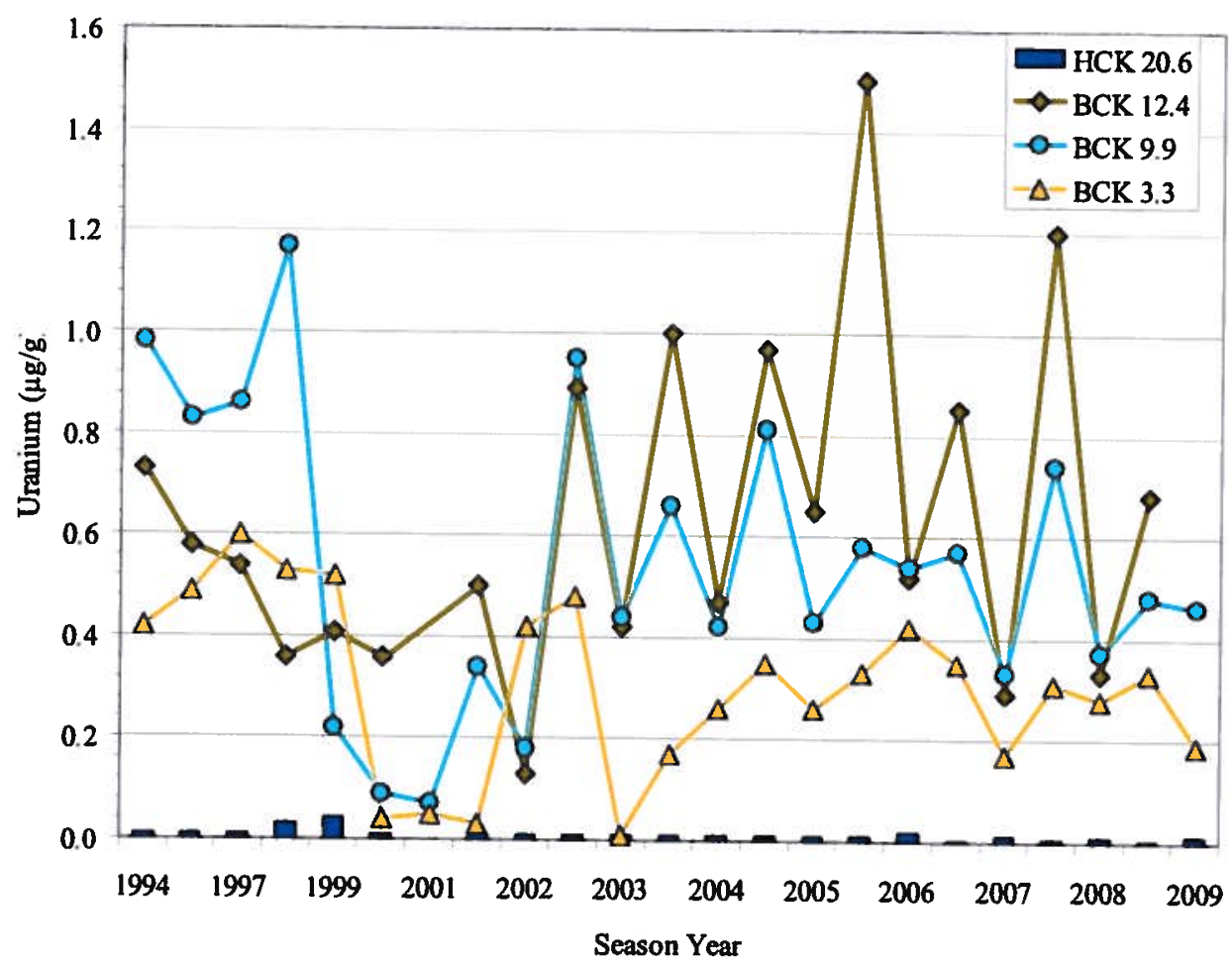

Figure 4.16. Mean uranium concentrations in stoneroller minnows at three sites in Bear Creek and a reference site (HCK 20.6), 1994-2009. 


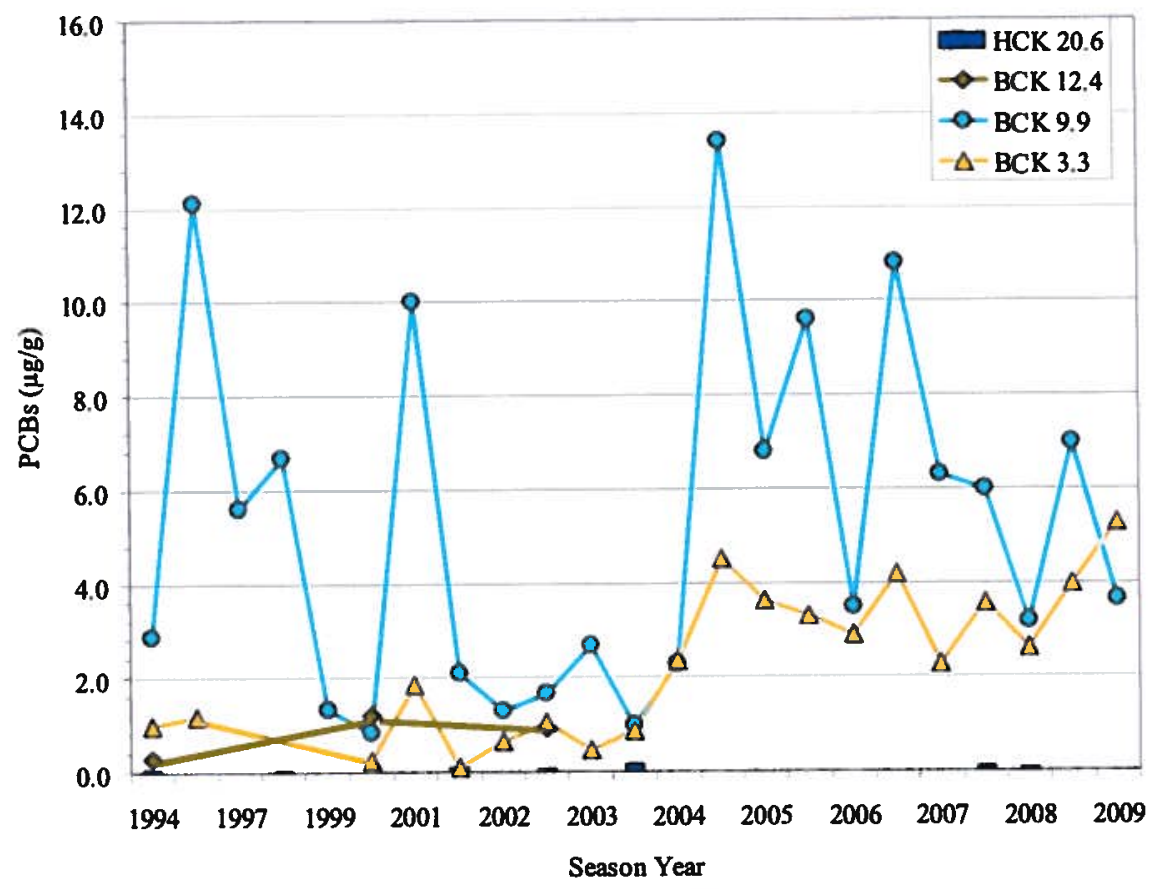

Figure 4.17. Mean PCB concentrations in stoneroller minnows at three sites in Bear Creek and a reference site (HCK 20.6), 1994-2009.

The fish communities in Bear Creek have generally been stable or display minor variation in terms of species richness in recent samples (Figure 4.18). The downstream sites (BCK 3.3 and BCK 4.6) have appropriate values for their size compared to a larger reference stream (BFK 7.6) and a smaller reference stream (MBK 1.6). This is especially encouraging for BCK 4.6, as it is located in the middle of the stream restoration section where a new stream channel and habitat were created. The sample site in the middle section of Bear Creek (BCK 9.9) has shown a steady increase in species richness, aided perhaps in recent years by the bypass of the downstream weir near BCK 4.6 which allowed more upstream migration of fish species. BCK 12.4 and NT-3 fish communities are at or slightly below total richness values of comparable reference streams, (MBK 1.6 and PHK 1.6), suggesting they are more susceptible to stress, e.g., from below-normal rainfall.

Upper Bear Creek (BCK 12.4) and NT-3 continue to support substantially fewer pollution-intolerant benthic macroinvertebrate taxa than nearby reference streams, and this difference is generally most pronounced during October sampling periods (Figure 4.19). Long-term trends in the number of intolerant invertebrate taxa at BCK 9.9 continue to indicate the presence of mild to moderate impacts, and as for BCK 12.4 and NT-3, evidence of degradation is most pronounced during October sampling periods. The number of pollution-intolerant taxa appeared to also be lower at the reference sites from 2007 through 2008, suggesting that the drought conditions during that period may have had exerted a significant influence on macroinvertebrate communities in area streams in general. Results for BCK 3.3 and BCK 4.6 continue to suggest that the condition of the invertebrate community at these sites is comparable to reference conditions. 


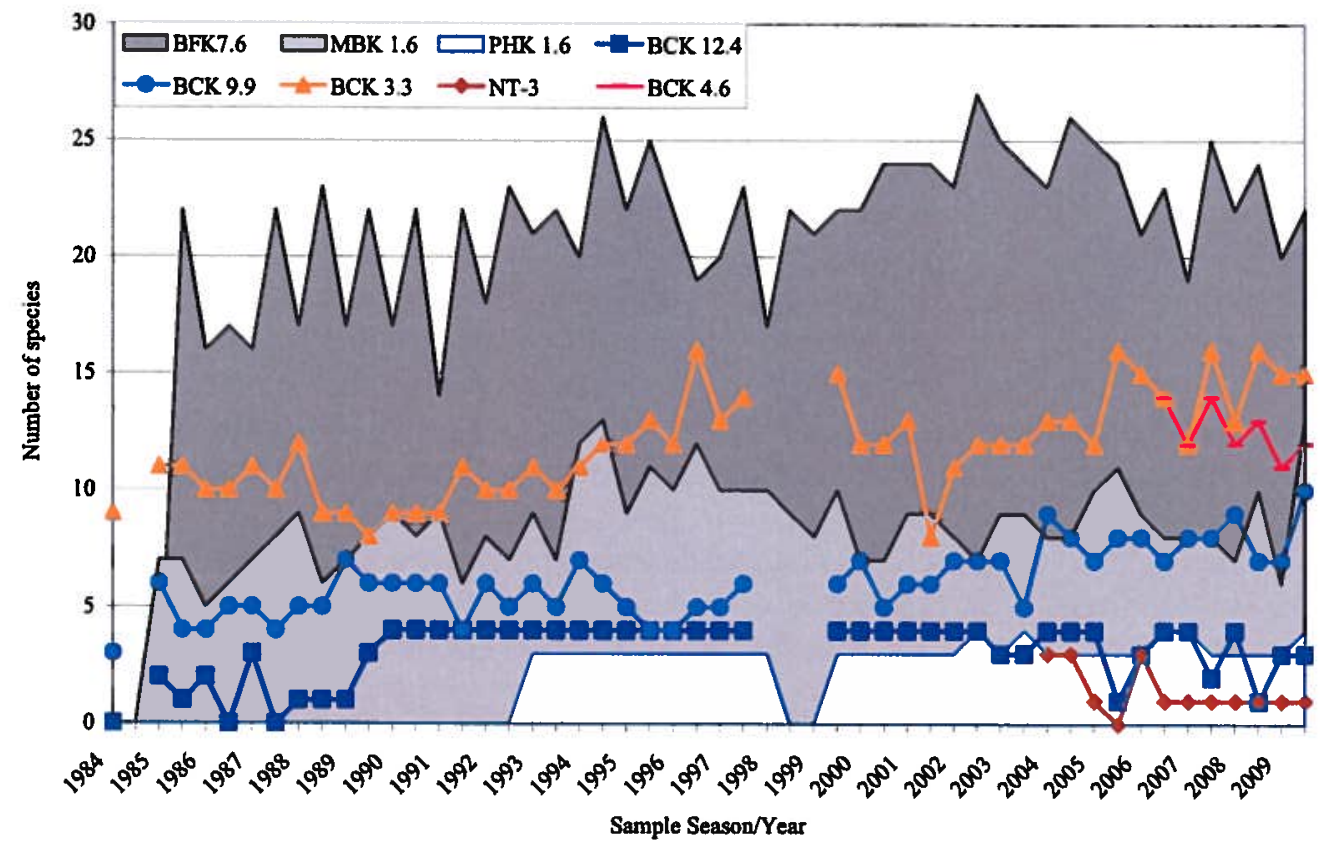

Figure 4.18. Species richness (number of species) in samples of the fish community in Bear Creek (BCK), NT-3, and reference streams, BFK, MBK, and Pinhook Branch (PHK), 1984-2009."

${ }^{\mathrm{a}}$ Interruptions in data lines for BCK and PHK sites indicate no results available for those periods.

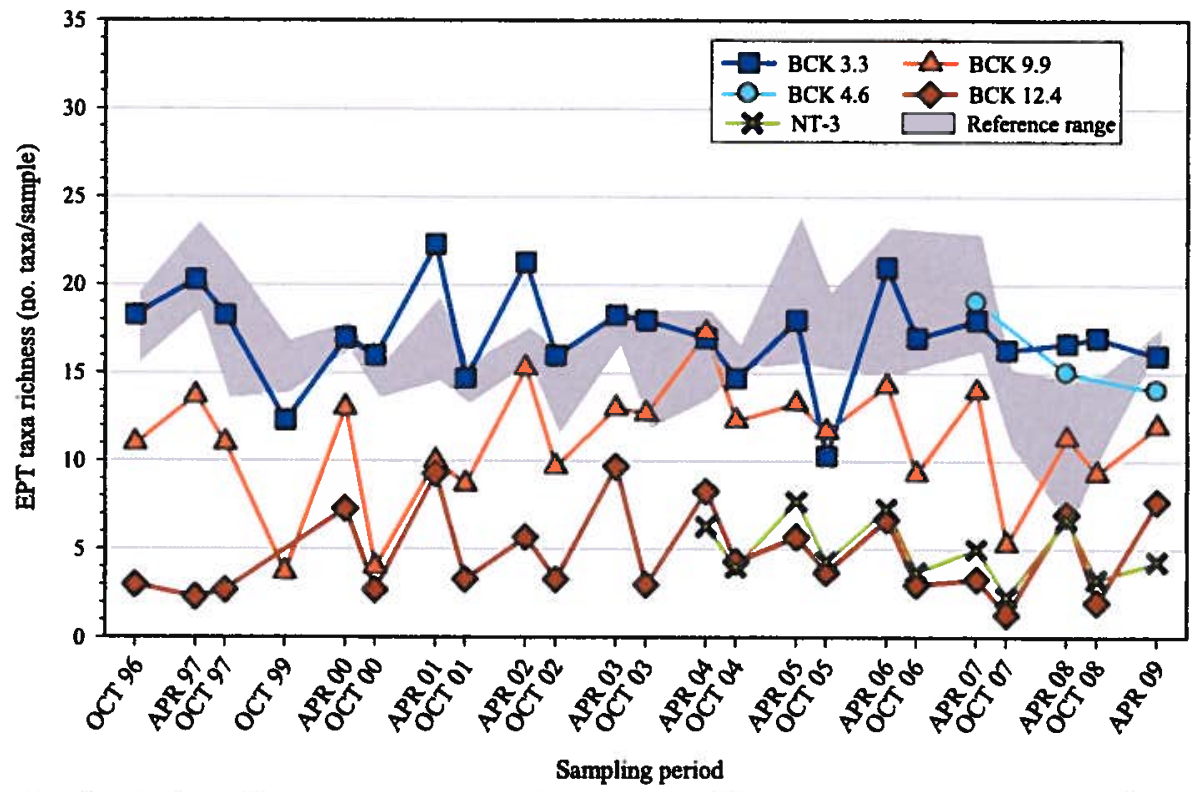

BCK = Bear Creek kilometer; NT3 = North Tributary \#3 to Bear Creek. EPT = Ephemeroptera, Plecoptera, and Trichoptera, or mayflies, caddisflies, and stoneflies.

Figure 4.19. Mean $(n=3)$ taxonomic richness of the pollution-intolerant taxa for the benthic macroinvertebrate community at sites in Bear Creek, NT-3, and range of mean values among reference streams (two sites in Gum Hollow Branch and one site in Mill Branch), October 1996-April 2009. 


\subsection{BYBY Stream Performance Monitoring}

\section{NT-3 Riparian Monitoring}

NT-3 stream habitat and riparian surveys were conducted in August 2009. Surveys continued for the sixth year, a year beyond the 5-year monitoring requirement (DOE 2003d), because restoration goals have not yet been reached (Peterson et al. 2009). Surveys included measures of in-stream habitat within established stream transects (Figure 4.8). Riparian habitat included primarily vegetation cover (\% cover and species diversity) within $10 \mathrm{~m}$ X $5 \mathrm{~m}$ plots corresponding to the surveyed stream habitat transects. Stream stability monitoring was discontinued in 2009 , as channel conditions have stabilized and the occurrence of significant channel instability is not likely in the future (Peterson et al. 2009).

Transect and plot results from the stream and riparian surveys are presented in tables 4.11 and 4.12. In general, NT-3 is a small first order stream that is around a half a meter wide in most places in summer. The stream widens during high flows to as much as 1-2 meters, with overland sheet flow in some bends

Table 4.11. Summary of transect physical habitat metrics for NT-3, August 25, 2009

\begin{tabular}{|c|c|c|c|c|c|c|c|c|c|}
\hline \multirow[b]{2}{*}{ Transect $^{b}$} & \multirow{2}{*}{$\begin{array}{l}\text { Stream } \\
\text { width } \\
(\mathrm{m})\end{array}$} & \multicolumn{7}{|c|}{ Percentage substrate $^{a}$} & \multirow[b]{2}{*}{$\begin{array}{c}\text { Percent } \\
\text { embeddedness }\end{array}$} \\
\hline & & $\begin{array}{c}\text { Plant } \\
\text { detritus }\end{array}$ & $\begin{array}{c}\text { Small } \\
\text { boulder }\end{array}$ & Cobble & Gravel & $\begin{array}{l}\text { Sand/ } \\
\text { fines }\end{array}$ & Silt & Clay & \\
\hline 0 & 0.7 & 12.5 & 0 & 0 & 75 & 0 & 12.5 & 0 & 39.1 \\
\hline 1 & 0.4 & 20 & 0 & 0 & 60 & 0 & 20 & 0 & 83.0 \\
\hline 2 & 0.4 & 0 & 0 & 0 & 60 & 20 & 20 & 0 & 49.0 \\
\hline 3 & 0.6 & 0 & 14 & 29 & 29 & 14 & 14 & 0 & 57.9 \\
\hline 4 & 0.6 & 0 & 29 & 0 & 71 & 0 & 0 & 0 & 19.9 \\
\hline 5 & 0.6 & 100 & 0 & 0 & 0 & 0 & 0 & 0 & 71.0 \\
\hline 6 & 0.5 & 17 & 0 & 0 & 83 & 0 & 0 & 0 & 63.3 \\
\hline 7 & 0.4 & 0 & 0 & 0 & 80 & 20 & $\mathbf{0}$ & 0 & 88.0 \\
\hline 8 & 0.4 & 0 & 0 & 0 & 33 & 0 & 33 & 33 & 13.0 \\
\hline 9 & 0.8 & 0 & $\mathbf{0}$ & 0 & 75 & 12.5 & 12.5 & 0 & 64.9 \\
\hline 10 & 1.1 & 0 & 0 & 12.5 & 80 & 12.5 & $\mathbf{0}$ & 0 & 28.0 \\
\hline 25 & 0.6 & $\mathbf{0}$ & $29^{d}$ & 14 & 57 & 0 & $\mathbf{0}$ & 0 & 44.4 \\
\hline 26 & 0.5 & 0 & 0 & $\mathbf{0}$ & 50 & 50 & $\mathbf{0}$ & $\mathbf{0}$ & 58.5 \\
\hline 27 & 0.5 & 0 & 0 & 0 & 80 & 20 & 0 & 0 & 45.8 \\
\hline
\end{tabular}

${ }^{a}$ Particle size ranges in mm: clay $=<0.004$, silt $=0.004-0.062$, sand/fine sediment $=0.062-2.0$, gravel $=2.0-64.0$, cobble $=64.0-250.0$, small boulder $=250.0-610.0$.

${ }^{b}$ Transects 0 through 10 and 25 through 27 are $10 \mathrm{~m}$ apart. Transects 10 and 25 are $150 \mathrm{~m}$ apart.

${ }^{c}$ Percent embeddedness $=$ percent of surface of predominant particles covered by fine sediment. Measurements were taken every $10 \mathrm{~cm}$ across transect.

$d_{29} \%$ of transect is represented by large boulder (not small boulder); particle size $=610.0-2000.0 \mathrm{~mm}$. 
Table 4.12. Vegetation metrics. The percent ground and canopy cover, plant species diversity, the amount of riparian overhang, and planted tree/shrub survival and condition for each monitored transect at the NT-3 restoration site, August 25, 2009

\begin{tabular}{cccccc}
\hline $\begin{array}{c}\text { Transect/ } \\
\text { Plot \# }\end{array}$ & \% Canopy & $\begin{array}{c}\text { \% Ground } \\
\text { Cover }\end{array}$ & $\begin{array}{c}\text { No. of plant } \\
\text { species }\end{array}$ & $\begin{array}{c}\text { L Bank } \\
\text { Overhang } \\
\text { (cm) }\end{array}$ & $\begin{array}{c}\text { R Bank } \\
\text { Overhang } \\
\text { (cm) }\end{array}$ \\
\hline 0 & 20 & 95 & 20 & 8 & 12 \\
1 & 3 & 100 & 9 & 11 & 22 \\
2 & 0 & 100 & 7 & 13 & 35 \\
3 & 1 & 100 & 9 & 10 & 28 \\
4 & 1 & 90 & 9 & 13 & 43 \\
5 & 20 & 100 & 9 & 11 & 24 \\
6 & 0 & 75 & 10 & 8 & 24 \\
7 & 0 & 100 & 9 & 13 & 12 \\
8 & 5 & 90 & 4 & 3 & 0 \\
9 & 1 & 90 & 8 & 19 & 0 \\
10 & 0 & 80 & 4 & 0 & 0 \\
25 & 2 & 80 & 11 & 17 & 11 \\
27 & 2 & 85 & 9 & 10 & 4 \\
2009 Ave & 4 & 91 & 9 & 10 & 17 \\
\hline
\end{tabular}

that allow for some riparian wetland development. In 2009 there was evidence of a large amount of rain in a short period, with grass lay down areas present consistent with flooding. Clear water was evident in many pools, and some included fish.

The 2009 sediment characterization was similar to last year in having a diversity of particle sizes. Stream sediments are primarily of a gravel substrate, with occasional cobbles, sand, fine sediments, and clays in some stream sections. The percent embeddedness (the percent of primary particles embedded in fine sediments) in 2009 was $52 \%$, lower than last year (67\%), also indicating that larger flow events have occurred which help remove the finer particles. However, over $50 \%$ embeddedness is a high number relative to unimpacted sites. The stream substrate of NT-3 was undoubtedly affected by the erosion of clay soils in the watershed as part of the restoration.

The results of the 2009 vegetation survey showed high percent cover (average 91\%) (Table 4.12). In general, ground cover was greatest near the stream and open-ground clay areas were primarily found on the sloped ground near the top of the stream banks. Not surprisingly, the riparian area is primarily open habitat; however, there is increased canopy and stream vegetation overhang in 2009 relative to previous years.

The average number of plants species observed per plot in 2009 (9) was substantially lower than previous years. The most aggressive plant species appear to be taking over survey plots. As in recent past years, the top of banks with poorest soils contained the greatest percentage of nonnative Lespedeza. Lespedeza cuneata, a well known invasive plant that commonly out competes with other species. The dominant herbaceous growth in most plots near the stream was big bluestem (Andropogon gerardii) and little bluestem (Schizachyrium scoparium), which were planted at the time of the stream restoration. Other native species less commonly encountered in 2009 included a variety of sedges, rushes, and grasses.

\section{B YB Y PerformanceSummary}

Because the habitat and ecological metrics are not yet comparable to nearby reference streams, stream habitat, riparian, and biological monitoring will continue at this time and be reevaluated at the FYR. 


\subsection{EMWMF Haul Road Mitigation Site}

In 2005, DOE ORO constructed an extension to the existing EMWMF haul road ("Haul Road") built as a component of the CERCLA remedy. DOE documented this decision in a CERCLA Explanation of Significant Differences (ESD) document (DOE 2004b), issued with the concurrence of EPA and the TDEC.

To the extent possible, environmental impacts as a result of Haul Road construction were avoided or minimized during the design phases of the project. However, the project could not avoid impacting 1.35 acres of wetland habitat within the road corridor. Environmental surveys of the affected environment were described in Environmental Survey Report for the ETTP: Environmental Management Waste Management Facility (EMWMF) Haul Road Corridor (Peterson et al. 2005).

As a result of the wetland losses from the Haul Road project, compensatory wetland mitigation was required. The wetland mitigation for the Haul Road project included both in-kind (e.g., wetland creation) and out-of-kind (e.g., stream restoration) mitigation, and was defined based on numerous interactions and advice from regulatory agencies, especially TDEC's DOE Oversight Office. The primary restoration action was associated with the bypass of the existing Bear Creek weir and the old U.S. Geological Survey gauging station to restore natural stream flow in this section of creek. As part of that effort, a new wetland was created within the old stream channel.

Monitoring of restored or created mitigation sites for five years is a conventional requirement of TDEC's wetland-mitigation Aquatic Resources Alteration Permit (as required by Sect 401 of the CWA). The monitoring strategy adopted, beginning shortly after construction was completed in the summer of 2006, addresses the substantive monitoring requirements of typical wetland and stream restorations and is similar in strategy to the NT-3 restoration monitoring (also conducted in the Bear Creek watershed). The following summary presented the 4th year of surveys conducted in the summer of 2009.

The monitoring of stream and riparian habitat focused on characterizing stream channel morphology, stream flow conditions, substrate type, size and embeddedness, and riparian vegetation development (Platts et al. 1983). All of these characteristics have effects on the types of biological communities that become established in a stream and the rate at which they become established. In-stream measurements were taken at transects established every $10 \mathrm{~m}$ along the entire length of the new channel. Riparian vegetation changes were monitored by use of established plots placed on each side of the stream, where percent cover and species diversity could be measured. The constructed wetland was evaluated using plotbased methods that allow for semiquantitative evaluations of plant species diversity and percent cover within the wetland zones. The survival and general condition of planted trees, shrubs, and herbs in the restoration area was also noted in the field.

Transect and plot results from the stream, riparian, and wetland surveys are presented in tables 4.13 and 4.14. The constructed stream section looked very different in 2009 relative to previous years. A large beaver dam was constructed downstream of the old and new Bear Creek stream channels, and significant flooding of the lower section of the survey reach prevented stream substrate surveys in that area. Bear Creek in the constructed section not impounded was about 3-4 m wide in 2009 , reflecting a slight widening consistent with increased precipitation and flows in 2009 relative to previous years. Relative to the unimpacted upstream section, the constructed stream channel is similar, although on average the section is shallower and wider than upstream. 
Table 4.13. Summary of transect physical habitat metrics for Bear Creek Weir, August 25, 2009

\begin{tabular}{|c|c|c|c|c|c|c|c|c|c|}
\hline \multirow[b]{2}{*}{ Transect $^{b}$} & \multirow{2}{*}{$\begin{array}{c}\text { Stream } \\
\text { width } \\
\text { (m) }\end{array}$} & \multicolumn{7}{|c|}{ Percentage substrate $^{a}$} & \multirow{2}{*}{$\begin{array}{l}\text { Percent } \\
\text { embed- } \\
\text { edness }\end{array}$} \\
\hline & & $\begin{array}{c}\text { Plant } \\
\text { detritus }\end{array}$ & $\begin{array}{c}\text { Bedrock } \\
\text { Rough }\end{array}$ & $\begin{array}{c}\text { Large } \\
\text { Boulder }\end{array}$ & $\underset{\text { boulder }}{\text { Small }}$ & Cobble & Gravel & $\begin{array}{l}\text { Sand/ } \\
\text { fines }\end{array}$ & \\
\hline \multicolumn{10}{|l|}{0} \\
\hline \multicolumn{10}{|l|}{1} \\
\hline \multicolumn{10}{|l|}{2} \\
\hline \multirow{2}{*}{\multicolumn{10}{|c|}{$\begin{array}{l}3 \\
4\end{array}$}} \\
\hline \multirow{2}{*}{\multicolumn{10}{|c|}{$\begin{array}{l}4 \\
5\end{array}$}} \\
\hline & & & & & & & & & \\
\hline 6 & 3.6 & $13^{d}$ & 0 & 0 & 0 & 0 & 87 & 0 & 20.5 \\
\hline 7 & 3.1 & 0 & 3 & 7 & 0 & 10 & 80 & 0 & 17.1 \\
\hline 8 & 4.9 & 3 & 20 & 0 & 0 & 33 & 43 & 0 & 33.9 \\
\hline 9 & 3.8 & 0 & 0 & 0 & 0 & 33 & 63 & 3 & 12.6 \\
\hline 10 & 2.8 & $5^{e}$ & 0 & 35 & 25 & 10 & 25 & 0 & 5.9 \\
\hline
\end{tabular}

${ }^{\circ}$ Particle size ranges in $\mathrm{mm}$ : sand/fine sediment $=0.062-2.0$, gravel $=2.0-64.0$, cobble $=64.0-250.0$, small boulder $=$ $250.0-610.0$, large boulder $=610.0-2000.0$, rough bedrock $>2000.0$.

${ }^{b}$ Transects are $10 \mathrm{~m}$ apart. Water was too deep at transects $0-5$ to measure substrate because of beaver dam downstream and recent heavy rainfalls.

'Percent embeddedness $=$ percent of surface of predominant particles covered by fine sediment. Measurements were taken every $10 \mathrm{~cm}$ across transect.

${ }^{d} 13 \%$ of transect is represented by root wads (not plant detritus).

' $5 \%$ of transect is represented by woody debris (not plant detritus).

Table 4.14. Vegetation metrics. The percent ground and canopy cover, plant species diversity, and the amount of riparian overhang for each monitored plot at the Bear Creek restoration site and the upstream reference location, August 25, 2009

\begin{tabular}{|c|c|c|c|c|c|}
\hline $\begin{array}{c}\text { Transect/ } \\
\text { Plot \# }\end{array}$ & $\%$ Canopy & $\%$ Ground Cover & $\begin{array}{l}\text { No. of plant } \\
\text { species }\end{array}$ & $\begin{array}{c}\text { L Bank } \\
\text { Overhang } \\
\text { (cm) } \\
\end{array}$ & $\begin{array}{c}\text { R Bank } \\
\text { Overhang } \\
\text { (cm) } \\
\end{array}$ \\
\hline \multicolumn{6}{|c|}{ Restored stream bank } \\
\hline 1 & & 100 & 6 & & \\
\hline 2 & & 100 & 4 & & \\
\hline 3 & & 95 & 9 & & \\
\hline 4 & & 100 & 7 & & \\
\hline 5 & & 100 & 9 & & \\
\hline 6 & 8 & 65 & 8 & 74 & 133 \\
\hline 7 & 2 & 100 & 7 & 0 & 84 \\
\hline 8 & 2 & 95 & 12 & 19 & 62 \\
\hline 9 & 3 & - & - & 109 & 69 \\
\hline 10 & 7 & - & - & 33 & 43 \\
\hline Ave 09 & 4 & 94 & 8 & 47 & 78 \\
\hline Ave 08 & 5 & 83 & 17 & 18 & 26 \\
\hline Ave 07 & 5 & 68 & 18 & 5 & 43 \\
\hline Ave 06 & 10 & 60 & 18 & 0 & 3 \\
\hline \multicolumn{6}{|c|}{ Created wetland } \\
\hline W1 & 30 & 100 & 14 & & \\
\hline W2 & 10 & 100 & 15 & & \\
\hline Ave 09 & 20 & 100 & 15 & & \\
\hline Ave 08 & 20 & 90 & 7 & & \\
\hline Ave 07 & 30 & 90 & 14 & & \\
\hline
\end{tabular}


Table 4.14. Vegetation metrics. (cont.)

\begin{tabular}{cccccc}
\hline $\begin{array}{c}\text { Transect/ } \\
\text { Plot \# }\end{array}$ & \% Canopy & \% Ground Cover & $\begin{array}{c}\text { No. of plant } \\
\text { species }\end{array}$ & $\begin{array}{c}\text { L Bank } \\
\text { Overhang } \\
\text { (cm) }\end{array}$ & $\begin{array}{c}\text { R Bank } \\
\text { Overhang } \\
\text { (cm) }\end{array}$ \\
\hline Ave 06 & 43 & 75 & 24 & & \\
\multicolumn{7}{c}{} & & & & \\
Upstream riparian reference plots (2006) & 100 & 27 & 0 & 0 \\
12 & 69 & 100 & 18 & 0 & 0 \\
13 & 80 & 100 & 26 & 0 & 0 \\
14 & 40 & 100 & 29 & 0 & 0 \\
15 & 60 & 100 & 25 & & \\
Average & 62 & 0 & 5 & & \\
SD & 17 & & & & \\
\hline
\end{tabular}

SD $=$ Standard deviation about the mean

Ave $=$ Average

Stream sediments are primarily of a gravel substrate, with occasional bedrock, boulders, cobble, sand, fine sediments, and clays in some stream sections. The reference section was similar with gravel predominating, but with less boulders, cobbles and rubble and a much higher percentage of organic debris (plant detritus, woody debris, and root wads). The percent embeddedness (the percent of primary particles embedded in fine sediments) was $18 \%$ in 2009 , substantially less that the $60 \%$ embeddedness observed in 2008. The lower numbers in 2009 are undoubtedly due to the greater amount of rain and substantial scouring flows in Bear Creek prior to the survey date. The fish and benthic community results from a stream reach within the constructed stream channel (BCK 4.6) also appeared to indicate that habitat conditions were good. Species richness for both of these key aquatic groups was similar to species richness in reference streams (Section 4.2.2.3.1).

The percent vegetation cover in riparian plots within the constructed section averaged $94 \%$, continuing an annually increasing trend, and very near the reference condition of $100 \%$ cover in all reference plots. Previous areas near the stream where vegetation growth was minimal were inundated with water on the survey date. Within the riparian plots, the species diversity was substantially lower than previous years, averaging eight species across all plots, reflecting the gradual dominance of the most aggressive plant species. Partridge Pea was particularly dominant in many upland plots and/or areas near the top of stream banks. Willow shrubs were also dominant especially near the water, and their growth habit largely prevented herbaceous growth underlying those plants. The reference site averaged 25 species.

At the wetland plots, $100 \%$ of the plots were covered with vegetation. Water was present in many of the wetland plots, reflecting the greater amount of precipitation in 2009. Previous concerns relative to enough water entering the wetland above the year were not apparent in 2009 , as there was a substantial flow through the wetland and flow overflowing the weir dam. In general, the created wetland was in good condition, with species diversity increasing from last year, potentially as a result of more water in the wetland.

\section{Summary}

After four years the constructed stream channel and wetland remediation is well on its way to recovery and appears to be at or near the reference conditions for many key metrics. The stream habitat is similar to reference reaches of the stream, the fish and benthic macroinvertebrate communities are as diverse as comparable reference streams, the riparian areas are well vegetated and there is no evidence of erosion, 
and the weir wetland is exhibiting luxurious growth with a high abundance and diversity of native wetland plants.

\subsubsection{Compliance with BCV LTS Requirements}

\subsubsection{Requirements}

Stewardship requirements outlined in the ROD (DOE 2000b) include LUCs to restrict groundwater and surface water use consistent with designated land use for each zone (Table 4.2, Figure 4.2). Objectives of these controls include preventing unauthorized contact, removal, or excavation of buried waste in the $\mathrm{BCV}$; preclude residential or recreational use of Zone 3; and prevent unauthorized access to contaminated groundwater in the BCV. The ROD also states that DOE will maintain the BCV Phase I sites as controlled industrial areas, and limit public access by posting signs and conducting security patrols. The individual RAs under the BCV Phase I ROD have the following additional stewardship activities.

- BYBY-The site will be inspected by the Y-12 S\&M Program quarterly until the site is stabilized, then on a semiannual basis. Surveillance activities include inspection of capped areas for unwanted vegetation and erosion, and inspection of access controls to the site. Routine maintenance includes mowing of the capped areas. Non-routine maintenance will be performed as necessary. There are no stewardship requirements specified for the OLFSCP.

- S-3 Ponds Pathway 3-Control and restrict access; once action is complete, inspect and maintain the passive in situ treatment system.

- DARA Solids Storage Facility-Control and restrict access.

\subsubsection{Status of Requirements for FY 2009}

Institutional controls in place in the BCV were maintained throughout FY 2009 as part of the BJC Y-12 S\&M Program and in conjunction with B\&W Y-12. Current land use restrictions in BCV (i.e., government-controlled, heavy-industrial land use in Zone 3 and access restrictions in Zone 2) were maintained. Individual RAs under the BCV Phase I ROD underwent routine site inspections conducted by the BJC Y-12 S\&M Program as follows:

- BYBY-All components of the site were inspected semiannually in FY 2009, including assessing the vegetative covers for erosion or subsidence; checking for blockage or erosion of the drainage control system; ensuring there are no construction activities and unauthorized materials within the area; evaluating that signs are not missing or damaged and contain correct contact information; ensuring access controls are in place and gates are locked; and ensuring the stability of the channel and banks of NT-3 from the Haul Road to the confluence with Bear Creek. No maintenance was required in FY 2009; however, this site received routine mowing.

- S-3 Ponds Pathway 3 and DARA Solids Storage Facility-These RAs have not yet been implemented. Access control requirements were maintained in FY 2009 and will be maintained until the actions are complete. These sites are not accessible to the public. Signs restricting access are in place and the areas are routinely patrolled by Y-12 security personnel.

\subsubsection{BCV ROD Performance Summary}

During FY 2009, surface water monitoring at the IP (BCK 9.2) showed that the ROD goal of $\leq 33 \mathrm{~kg} / \mathrm{yr}$ of uranium was not attained. The measured uranium flux at the IP was about $148 \mathrm{~kg}$. About $31 \%$ of the 
FY 2009 uranium flux is attributed to surface water discharged from the S-3 Ponds plume as measured at BCK 12.34 and about $41 \%$ of the FY 2009 uranium flux originated in the BCBGs and discharged to Bear Creek via NT-8. Other contributors to the total uranium flux include deeper groundwater flows in the S-3 plume that discharge to Bear Creek via springs SS-4 and SS-5 and diffuse bed seepage, as well as smaller contributions from NT-3, NT-5, and NT-7. During FY 2009, the risk level associated with uranium at the IP remained about twice the ROD goal. Nitrate concentrations measured at the IP during FY 2009 were less than the $58 \mathrm{mg} / \mathrm{L}$ RBC.

During FY 2009, the average nitrate concentration measured at BCK 12.34 near the S-3 Pond source area was less than the industrial RBC. The RBC for nitrate in an industrial land use scenario is $160 \mathrm{mg} / \mathrm{L}$. During FY 2009, the average nitrate concentration was $33 \mathrm{mg} / \mathrm{L}$ based on 52 weekly grab sample results. None of the samples exceeded the $160 \mathrm{mg} / \mathrm{L} \mathrm{RBC}$.

Groundwater monitoring during FY 2009 showed that groundwater contaminant trends in monitored areas are relatively stable and changes from FY 2008 levels are minor.

Stream habitat, riparian, and biological monitoring has continued in NT-3 and lower Bear Creek for a sixth year, a year beyond the 5-year monitoring requirement, to assess whether the restoration goals of BYBY have been achieved. The extent of further monitoring will be reevaluated in the FYR. Stream stability monitoring in NT-3 has been discontinued in 2009 as the channel has stabilized. 


\subsection{COMPLETED SINGLE ACTIONS IN BEAR CREEK VALLEY WITH MONITORING AND/OR LTS REQUIREMENTS}

\subsubsection{BCV OU2 Remedial Action}

Location of the Spoil Area 1 and SY-200 Yard (BCV OU 2) RA is shown on Figure 4.1. The primary objective of this action was to mitigate exposure to contaminated soil and waste left in place. The scope of the remedy was to address the principle threats at the sites by maintaining the existing waste covers and implementing specific access and use restrictions. Background information on this remedy and performance standards are provided in Chap. 4 of Vol. 1 of the 2007 RER (DOE 2007a). These sites have only stewardship requirements, which are provided in Table 4.2. A review of compliance with these stewardship requirements is included in Sect. 4.3.1.1.

No surface water or groundwater monitoring is required to verify the effectiveness of the RA.

\subsubsection{Compliance with LTS Requirements}

\subsection{Requirements}

Stewardship requirements specified in the BCV OU2 ROD (DOE 1996a) include physical barriers (fences, gates, and signs) to limit access to the site, deed restrictions to restrict construction at the sites and prohibit waste intrusion to mitigate direct exposure, and periodic physical surveillance of the soil cover and other features of the site and maintenance or repair, as required. Restrictions also require incorporation of indoor radon mitigative measures in accordance with EPA guidelines for any future structure built on-site. These sites are designated as restricted industrial use areas in the BCV Phase I ROD (DOE 2000b).

\subsection{Status of Requirements for FY 2009}

Spoil Area 1 and the SY-200 Yard sites were inspected quarterly by the Y-12 S\&M Program in FY 2009 for items including erosion of the cover, integrity of surface drainage control systems, evidence of rodent damage, proper signage, unlocked gates, and the presence of unauthorized materials within the area. Minor maintenance was required at the SY-200 Yard including removal of saplings and vegetation around the rip-rap perimeter, removal of trees that had fallen on the cap area, and repair of a sign that states, "No unauthorized vehicles beyond this point." Both sites received routine mowing. In addition, the deed restrictions for both Spoil Area 1 and the SY-200 Yard were verified at the Anderson County Register's of Deeds office. 


\subsection{BEAR CREEK VALLEY MONITORING CHANGES AND RECOMMENDATIONS}

Table 4.15 summarizes technical issues and recommendations for monitoring changes in the $\mathrm{BCV}$ Watershed.

Monitoring data in Zone 1 of BCV continue to exhibit trace-to-low contaminant concentrations, although contaminants have been detected only intermittently and concentrations have trended downward in more recent years. This intermittent nature of contaminant detection in Zone 1 is identified as a Current Issue in Table 4.15 below. The intermittent plume in the Maynardville Limestone will continue to be monitored during FY 2011.

The issues identified from previous years' RERs are carried forward for tracking purposes through resolution. While uranium releases to surface water in Bear Creek have been declining in recent years, the uranium flux at the IP returned to pre-remediation levels during FY 2009 and ungauged flux continues to be problematic. Data indicate the BCBGs continue to be a much more significant contribution of contamination to Bear Creek than previously thought, primarily via surface water discharges at NT-8. In addition, a slight increase in uranium concentrations at NT-3 and a notable shift in isotope ratios may indicate a release from a different source area at the BYBY area.

Although stream channel stability monitoring of NT-3 has been completed at the BYBY, DOE recommends that riparian monitoring and fish/macroinvertebrate monitoring continue until the FYR.

Issues that have been completed or resolved are identified as such at the end of the table and will not be included in subsequent RERs.

Table 4.15. Summary of BCV Watershed technical issues and recommendations

\begin{tabular}{|c|c|}
\hline Issue ${ }^{n}$ & Action/Recommendation \\
\hline \multicolumn{2}{|l|}{ 2010 Current Issue: } \\
\hline $\begin{array}{l}\text { 1. Monitoring results for Zone } 1 \text { of BCV exhibit } \\
\text { trace-to-low contaminant concentrations in } \\
\text { groundwater, thereby compromising the Phase I } \\
\text { ROD goal to maintain clean groundwater } \\
\text { acceptable for unrestricted use. }\end{array}$ & $\begin{array}{l}\text { 1. The contaminant concentrations have remained low and are } \\
\text { observed intermittently at various monitoring locations. In } \\
\text { FY } 2009 \text {, concentrations continued to trend downward or were not } \\
\text { observed at all. The intermittent plume in the Maynardville } \\
\text { Limestone will continue to be monitored during FY } 2011 \text {. }\end{array}$ \\
\hline \multicolumn{2}{|l|}{ Issues Carried Forward: } \\
\hline $\begin{array}{l}\text { 1. Results for BCK } 9.2 \text { show an increase in the } \\
\text { proportion of ungauged uranium flux beginning in } \\
\text { FY } 2002 \text {. Increasing uranium trends are not } \\
\text { observed at gauged monitoring stations, or in } \\
\text { principal groundwater exit points contributing to } \\
\text { Bear Creek surface flow. }(2006 \text { FYR })^{b}\end{array}$ & $\begin{array}{l}\text { 1. Uranium flux mass balance in the Bear Creek watershed is } \\
\text { complicated by the karst groundwater system. During FY } 2009 \text {, } \\
\text { approximately } 29 \mathrm{~kg} \text { of the total } 148 \mathrm{~kg} \text { were attributed to } \\
\text { ungauged sources. DOE recommends re-instatement of flow-paced } \\
\text { monitoring at NT-3 and NT-5 and creation of an additional flux } \\
\text { monitoring station downstream of SS-4 but upstream of NT-7 to } \\
\text { attempt to determine inputs directly to the stream channel from } \\
\text { karst discharges. }\end{array}$ \\
\hline $\begin{array}{l}\text { 2. In addition to surface water monitoring at the } \\
\text { BYBY, the PCCR (DOE 2003d) specifies five } \\
\text { years of riparian vegetation monitoring of the } \\
\text { restored NT-3 channel. (2008 RER) }\end{array}$ & $\begin{array}{l}\text { 2. DOE completed the fifth year of vegetation riparian monitoring at } \\
\text { BYBY during FY 2008. Results are reported in the } 2009 \text { RER. } \\
\text { DOE recommends that riparian monitoring, fish and } \\
\text { macroinvertebrate monitoring continue until the FYR. }\end{array}$ \\
\hline
\end{tabular}


Table 4.15. Summary of Bear Creek Valley Watershed technical issues and recommendations (cont.)

\begin{tabular}{|l|l|}
\hline \multicolumn{1}{|c|}{ Issue $^{\text {a }}$} & \multicolumn{1}{c|}{\begin{tabular}{c} 
Action/Recommendation \\
\hline Completed/Resolved Issues:
\end{tabular}} \\
$\begin{array}{l}\text { 1. In addition to surface water monitoring at the } \\
\text { years of stream channel stability. (2008 RER) }\end{array}$ & $\begin{array}{l}\text { 1. DOE completed the fifth year of stream channel stability monitoring } \\
\text { at BYBY during FY 2008. Results are reported in the 2009 RER. } \\
\text { DOE recommended that the annual stream channel stability } \\
\text { monitoring be discontinued and an erosion control inspection be } \\
\text { performed annually. Concurrence was received by the regulators. }\end{array}$ \\
$\begin{array}{l}\text { Multiple large-scale construction activities have } \\
\text { occurred in the eastern portion of the water shed } \\
\text { (e.g., EMWMF and the capping at BYBY). This } \\
\text { has resulted in large-scale clearing of mature } \\
\text { woodland-forested areas, extensive cut-and-fill } \\
\text { construction, complete diversion of NT-4, and } \\
\text { regarding most of the NT-3 drainage basin. This } \\
\text { may have altered runoff and infiltration patterns } \\
\text { and evapotranspiration rates. Additionally, } \\
\text { uranium flux attributable to NT-7 and NT-8 has } \\
\text { not been quantified since the RI. (2006 FYR) }\end{array}$ & See response to Item \#l above. \\
\hline
\end{tabular}

"Issues are identified in the table as either "ISSUE(S) CARRIED FORWARD" to indicate that the issue is carried over from a previous years' RER to track the issue through resolution, or as COMPLETED/RESOLVED ISSUES to indicate that the issue has been resolved and will not be tracked in subsequent RERs.

'The year of the RER or the FYR in which the issue originated is provided in parentheses, e.g., (2008 RER). 

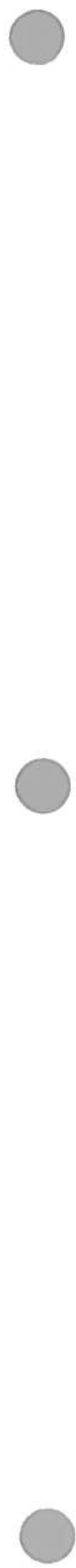


\section{CERCLA ACTIONS ON CHESTNUT RIDGE}

\subsection{CHESTNUT RIDGE OVERVIEW}

This chapter provides an update to CERCLA actions completed on ChR, all of which have performance monitoring and LTS requirements. ChR is not physically situated within one of the five established watersheds, but is located south of Y-12 on the ORR (Figure 5.1). Because ChR is dissected by a number of small tributaries rather than forming a single defining hydrologic watershed, all completed remedies have been single-action decisions to address known or potential sources of releases. This chapter presents performance goals and objectives, monitoring results, and a technical assessment of the results for each completed action. A review of compliance with LTS requirements is included (Sect. 5.2.4, Sect. 5.3.4, and Sect. 5.4.4), as well as any proposed monitoring changes and recommendations.

For background information of each remedy and performance standards, a compendium of all CERCLA decisions in ChR is provided in Chap. 5 of Vol. 1 of the 2007 RER (DOE 2007a). This information will be updated in the annual RER and republished every fifth year at the time of the CERCLA FYR. The status of ChR long-term CERCLA decision making is provided in Figure 1.5 of Vol. 1 of the 2007 RER (DOE 2007a).

Table 5.1 summarizes the CERCLA actions completed in ChR and Table 5.2 provides a summary of LTS requirements.

All of the actions to date along $\mathrm{ChR}$ have post-remediation monitoring and site inspection requirements.

\subsubsection{Status and Updates}

During FY 2009, no additional CERCLA actions were implemented or completed on ChR, nor were any associated FFA documents submitted or approved for CERCLA actions located on ChR. Monitoring in support of performance assessments and evaluations continued. 

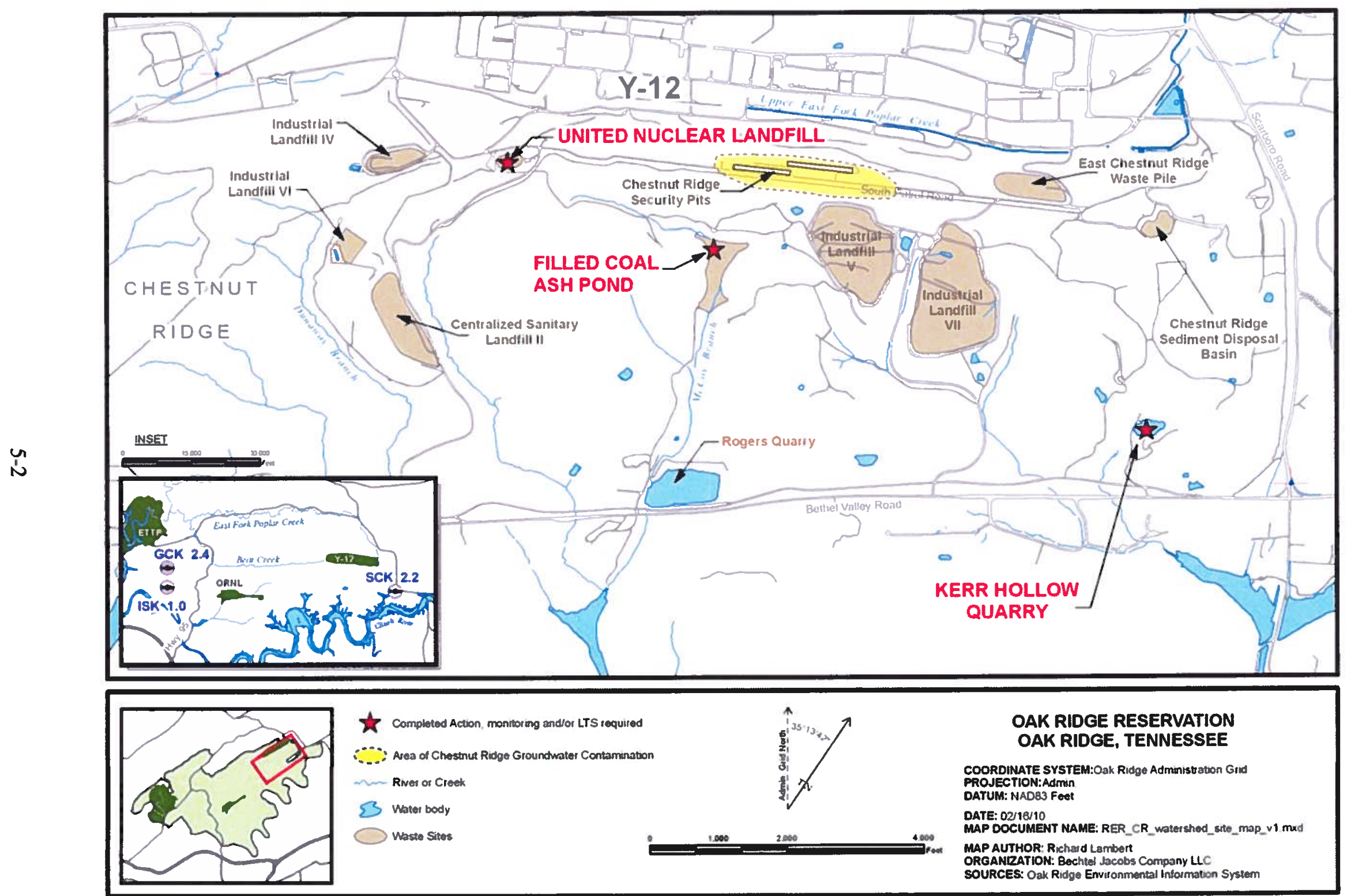

Figure 5.1. CERCLA actions in the Chestnut Ridge administrative watershed. 
Table 5.1. CERCLA actions on ChR

\begin{tabular}{|c|c|c|c|c|}
\hline CERCLA action & $\begin{array}{l}\text { Decision document, date signed } \\
(\mathrm{mm} / \mathrm{dd} / \mathbf{y y})\end{array}$ & Action/Document status ${ }^{a}$ & $\begin{array}{l}\text { Monitoring/ } \\
\text { LTS } \\
\text { required } \\
\end{array}$ & $\begin{array}{c}\text { RER } \\
\text { section }\end{array}$ \\
\hline UNC Disposal Site RA & ROD: $06 / 28 / 91$ & $\begin{array}{l}\text { RA complete. } \\
\text { PCR (DOE/OR/01-1128\&D1) approved 09/06/93. }\end{array}$ & Yes/Yes & 5.2 \\
\hline KHQ RA & $\begin{array}{l}\text { NFA ROD }{ }^{\mathrm{b}} \text { (DOE/OR/02-1398\&D2): } \\
09 / 29 / 95\end{array}$ & RA completed under approved RCRA closure plan. & Yes/Yes & 5.3 \\
\hline FCAP/Upper McCoy Branch RA & ROD (DOE/OR/02-1410\&D3): 02/21/96 & $\begin{array}{l}\text { RA complete. } \\
\text { RAR (DOE/OR/01-1596\&D1) approved 06/3/97. }\end{array}$ & Yes/Yes & 5.4 \\
\hline
\end{tabular}

a Detailed information of the status of ongoing actions is from Appendix E of the FFA and is available at <http://www.bechteliacobs.com/ettp ffa appendices.shtml>. ${ }^{b}$ CERCLA NFA ROD defers all monitoring and LTS/LUC requirements to the RCRA post-closure permits.

FCAP $=$ Filled Coal Ash Pond

$\mathrm{KHQ}=$ Kerr Hollow Quarry

NFA $=$ No Further Action

UNC = United Nuclear Corporation

Table 5.2. LTS requirements for CERCLA actions on ChR

\begin{tabular}{|c|c|c|c|c|}
\hline \multirow[b]{2}{*}{ Site/Project } & \multicolumn{2}{|c|}{ LTS Requirements } & \multirow[b]{2}{*}{ Status } & \multirow[b]{2}{*}{ RER section } \\
\hline & LUCs & Engineering controls & & \\
\hline UNC Disposal Site RA & & - Maintain cap & $\begin{array}{l}\text { - Engineering controls remain } \\
\text { protective. }\end{array}$ & 5.2 .4 \\
\hline KHQ RA ${ }^{a}$ & $\begin{array}{l}\text { Access controls (fences } \\
\text { and locked gates) } \\
\text { - Deed restrictions }\end{array}$ & - Inspections & $\begin{array}{l}\text { - LUCs in place. } \\
\text { Engineering controls remain } \\
\text { protective. }\end{array}$ & 5.3 .4 \\
\hline $\begin{array}{l}\text { FCAP/Upper McCoy Branch } \\
\text { RA }\end{array}$ & & $\begin{array}{l}\text { - Inspect and maintain dam, } \\
\text { slope, and spillway }\end{array}$ & $\begin{array}{l}\text { Engineering controls remain } \\
\text { protective. }\end{array}$ & 5.4 .4 \\
\hline
\end{tabular}

${ }^{a}$ All requirements deferred to RCRA post-closure permit.

FCAP $=$ Filled Coal Ash Pond

$\mathrm{KHQ}=\mathrm{Kerr}$ Hollow Quarry

UNC = United Nuclear Corporation 


\subsection{UNITED NUCLEAR CORPORATION SITE REMEDIAL ACTION}

The United Nuclear Corporation (UNC) Disposal Site is a 1.3-acre landfill located near the crest of ChR south of Y-12 (Figure 5.2). The ROD for the UNC Site (DOE 1991a) was approved in June 1991. Field activities began in May 1992 and were completed in August 1992. Remedial activities included construction of a multilayer cover system, installation of access controls, and implementation of a groundwater monitoring program using existing wells.

A more complete discussion of the UNC closure and a summary of performance goals and requirements are provided in Chap. 5 of Vol. 1 of the 2007 RER (DOE 2007a). This waste disposal facility utilized an unlined excavation in the thick soils near the crest of $\mathrm{ChR}$ for retention of approximately 11,000 55-gal drums of cement-fixed sludge, 18,000 drums of contaminated soil and 288 wooden boxes of contaminated building and process equipment demolition debris from the UNC uranium recovery facility in Wood River Junction, Rhode Island. In addition, Formerly Utilized Sites Remedial Action Program (FUSRAP) waste from the Elza Gate site in Oak Ridge was placed in the site before the final multilayer cap was constructed to limit percolation of rainwater into the waste.

\subsubsection{Performance Goals and Monitoring Objectives}

The major goal of the UNC RA, per the ROD, is to "ensure that mobile contaminants in the UNC waste, principally nitrate and ${ }^{90} \mathrm{Sr}$, are not leached to groundwater at a rate that would result in concentrations of these contaminants above safe drinking water standards." The FS for the UNC Site (DOE 1991b) included results of contaminant transport modeling that indicated possible impacts to groundwater including potential nitrate concentrations of as much as $193 \mathrm{mg} / \mathrm{L}$ and ${ }^{90} \mathrm{Sr}$ concentrations as great as about $50 \mathrm{pCi} / \mathrm{L}$. The ROD stated that the expected performance of the remedy is to control contaminant migration so that nitrate is less than the SDWA limit of $10 \mathrm{mg} / \mathrm{L}$ and no more than $2 \mathrm{pCi} / \mathrm{L}$ of ${ }^{90} \mathrm{Sr}$ would occur in groundwater, which is within the CERCLA risk range of $10^{-4}$ to $10^{-6}$. The ROD also states that groundwater concentration "is not expected to exceed $8 \mathrm{mg} / \mathrm{L}$ for nitrate." The PCR (DOE 1993a) specifies implementation of a groundwater monitoring program. Although specific frequencies, locations, and analytes are not mandated by the PCR, groundwater is monitored for COCs on which performance assessment is based (nitrate and ${ }^{90} \mathrm{Sr}$ ).

\subsubsection{Evaluation of Performance Monitoring Data - FY 2009}

Groundwater monitoring was performed in FY 2009 at upgradient well 1090 and downgradient wells GW-203, GW-205, GW-221 and at a downgradient spring designated UNC SW-1 (Figure 5.2). Samples were analyzed for metals, nitrate, gross alpha and beta activity, and ${ }^{90} \mathrm{Sr}$. Additional isotopic analyses were conducted on samples collected from well GW-205 as noted below. Data for nitrate, gross alpha and beta activity, and ${ }^{90} \mathrm{Sr}$ analyses for all wells are shown in Table 5.3.

In FY 2009, nitrate concentrations downgradient of the site have remained well below the $10 \mathrm{mg} / \mathrm{L}$ SDWA MCL and the "not expected to exceed range" of $8 \mathrm{mg} / \mathrm{L}$. Also, the downgradient concentrations were below the concentrations in the upgradient well. Strontium-90 is the specific radionuclide COC at UNC and a man-made beta-emitter. In FY $2009,{ }^{90} \mathrm{Sr}$ was not detected. 

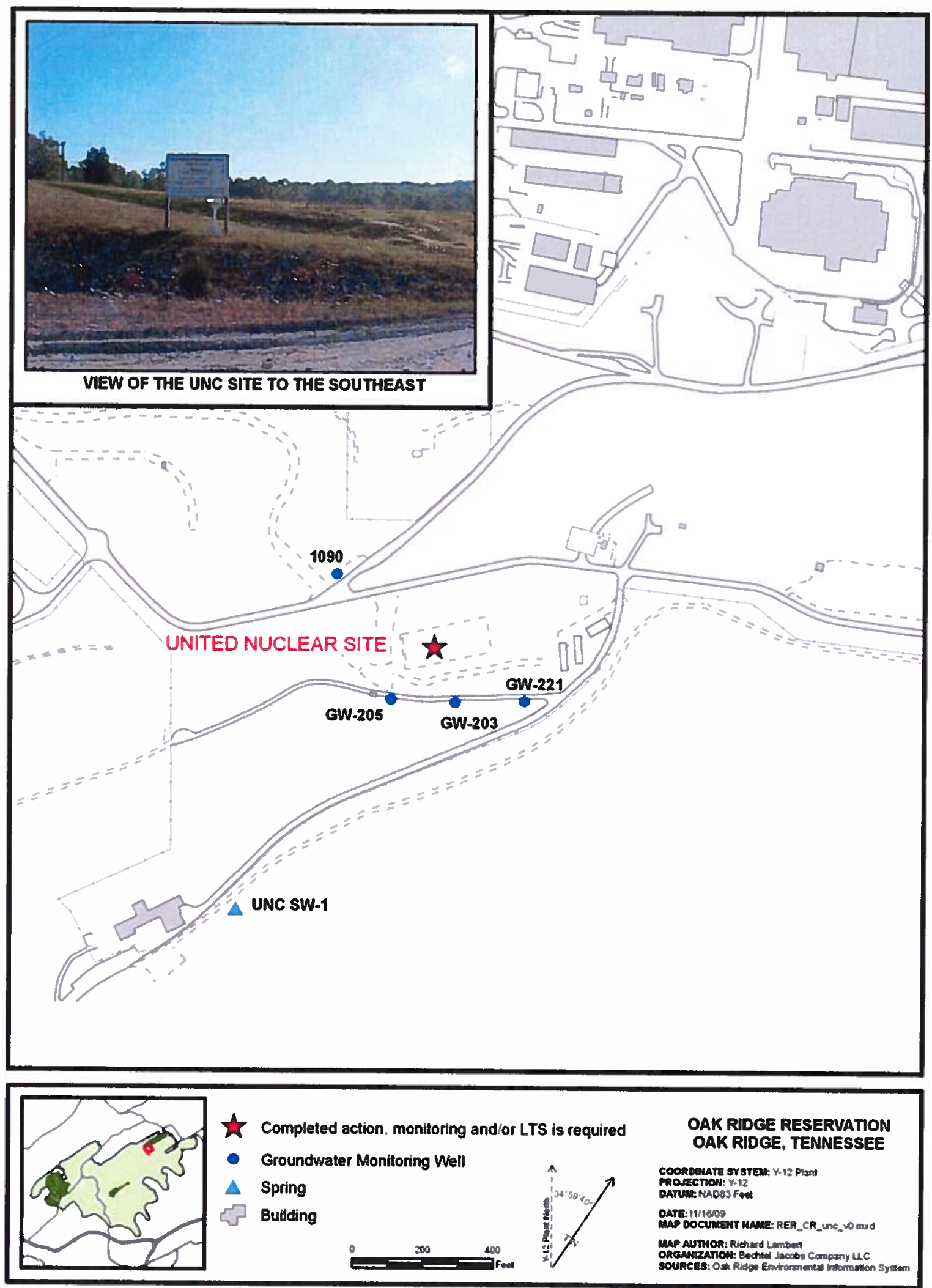

Figure 5.2. United Nuclear Corporation site map. 
Table 5.3. Analytical results for performance indicator constituents at the UNC Site, FY 2009

\begin{tabular}{|c|c|c|c|c|c|}
\hline \multirow[b]{2}{*}{ Date } & \multirow{2}{*}{$\begin{array}{c}\begin{array}{c}\text { Upgradient } \\
\text { well }\end{array} \\
1090\end{array}$} & \multicolumn{3}{|c|}{ Downgradient wells } & \multirow{2}{*}{$\begin{array}{c}\text { Downgradient } \\
\text { spring } \\
\text { UNC SW-1 }\end{array}$} \\
\hline & & GW-203 & GW-205 & GW-221 & \\
\hline \multicolumn{6}{|c|}{ Nitrate $(m g / L)$} \\
\hline Mar-09 & 0.7 & 0.44 & 0.072 & 0.47 & 0.063 \\
\hline Jul-08 & 0.32 & 0.48 & 0.07 & 0.21 & 0.14 \\
\hline \multicolumn{6}{|c|}{ Gross alpha (pCiL) } \\
\hline Mar-09 & $<2.64 \mathrm{U}$ & 4.34 & $<2.7 \mathrm{U}$ & $<2.01 \mathrm{U}$ & $<2.64 \mathrm{U}$ \\
\hline Jul-08 & $<2.73 \mathrm{U}$ & $<1.68 \mathrm{U}$ & $<2.52 \mathrm{U}$ & $<3.25 \mathrm{U}$ & $<1.84 \mathrm{U}$ \\
\hline \multicolumn{6}{|c|}{ Gross beta $(p C i / L)$} \\
\hline Mar-09 & $<4.16 \mathrm{U}$ & $<4.7 \mathrm{U}$ & $59.1 \pm 4.2$ & $<4.02 \mathrm{U}$ & $<4.43 \mathrm{U}$ \\
\hline Jul-08 & $<4.6 \mathrm{U}$ & $<3.76 \mathrm{U}$ & $64.3 \pm 4.26$ & $<4.04 \mathrm{U}$ & $<2.74 \mathrm{U}$ \\
\hline \multicolumn{6}{|c|}{${ }^{90}$ Strontium $(p C i / L)$} \\
\hline Mar-09 & $<1.54 \mathrm{U}$ & $<1.92 \mathrm{U}$ & $<1.61 \mathrm{U}$ & $<1.61 \mathrm{U}$ & \\
\hline Jul-08 & $<-1.84 \mathrm{U}$ & $<1.93 \mathrm{U}$ & $<2.3 \mathrm{U}$ & $<2.16 \mathrm{U}$ & \\
\hline \multicolumn{6}{|c|}{${ }^{40}$ Potassium (pCiL) } \\
\hline Mar-09 & - & - & $<134 \mathrm{U}$ & $=$ & $<158 \mathrm{U}$ \\
\hline Aug-09 & - & - & $<156 \mathrm{U}$ & & $<162 \mathrm{U}$ \\
\hline
\end{tabular}

\footnotetext{
Bolded value indicates gross alpha above the drinking water MCL level [15 picoCuries per liter $(\mathrm{pCi} / \mathrm{L})$ ] or gross beta above the effective dose equivalent $(50 \mathrm{pCi} / \mathrm{L})$ to the drinking water MCL $(4 \mathrm{mrem} / \mathrm{yr})$.

GW = groundwater well

$\mathrm{U}=$ Not detected or result less than minimum detectable activity
}

Gross alpha activities have remained well below the $15 \mathrm{pCi} / \mathrm{L}$ MCL in FY 2009. With the exception of well GW-205, gross beta activity in groundwater at the site was below the $50-\mathrm{pCi} / \mathrm{L}$ screening value for compliance with a 4-mrem/yr dose limit for man-made radionuclides. Gross beta results in FY 2009 for well GW-205 were 59 and $64 \mathrm{pCi} / \mathrm{L}$, which is consistent with results in previous years.

The history of monitoring at well GW-205 started in 1987. In 1998 the well purge method was changed from a standard 3-well-volume method to low-flow purging. Contemporaneous with that change, $\mathrm{pH}$, conductivity, beta activity and potassium concentrations increased, possibly an indication of grout or other alkaline material influence on local groundwater. Prior to the sampling method change the $\mathrm{pH}$ ranged between 7.5 and 8.5 and, following the method change, the $\mathrm{pH}$ has ranged between 9.5 and 10.5. During FY 2009, the pH at well GW-205 was 9.41 in March and 10.05 in July, which is consistent with past data.

During FY 2009, potassium-40 was not detected in the radiological analyses conducted on site groundwater. However, as discussed in the $2009 \mathrm{RER}$, natural potassium in the environment (in bedrock, soils, and groundwater) contains a known natural abundance of ${ }^{40} \mathrm{~K}$. The concentration of radioactive ${ }^{40} \mathrm{~K}$ based on its natural abundance in total elemental potassium has been calculated for all samples from GW-205. The calculated ${ }^{40} \mathrm{~K}$ activities closely track (within $\sim 20 \mathrm{pCi} / \mathrm{L}$ except for a single outlier) the beta activity values indicating that increased potassium concentrations that are detected under lower stress sampling are responsible for the increase in beta activity. Analyses for other beta-emitting radionuclides $\left({ }^{99} \mathrm{Tc},{ }^{90} \mathrm{Sr}\right)$ have not detected site-related contaminants other than low concentrations of ${ }^{90} \mathrm{Sr}$, which was not detected in FY 2009.

Figure 5.3 shows the measured beta activity, the computed beta activity attributable to the total potassium in groundwater samples, and the residual beta activity that would not be attributable to the natural potassium. Several of the samples had measured beta activities less than the computed potassium beta and, therefore, negative residual results are not plotted. As shown, the typical residual beta activity is near or less than $20 \mathrm{pCi} / \mathrm{L}$, with the exception of the single elevated beta value measured in July 2006 . 
Numeric drinking water criteria do not exist for the gross beta screening measurement in water supplies. This is because beta activity is a general measure of radioactivity and risk factors for different betaemitting radionuclides vary. However, various agencies have selected target levels ranging from about 25 to $50 \mathrm{pCi} / \mathrm{L}$, above which further identification of radionuclides and evaluation of risk is indicated.

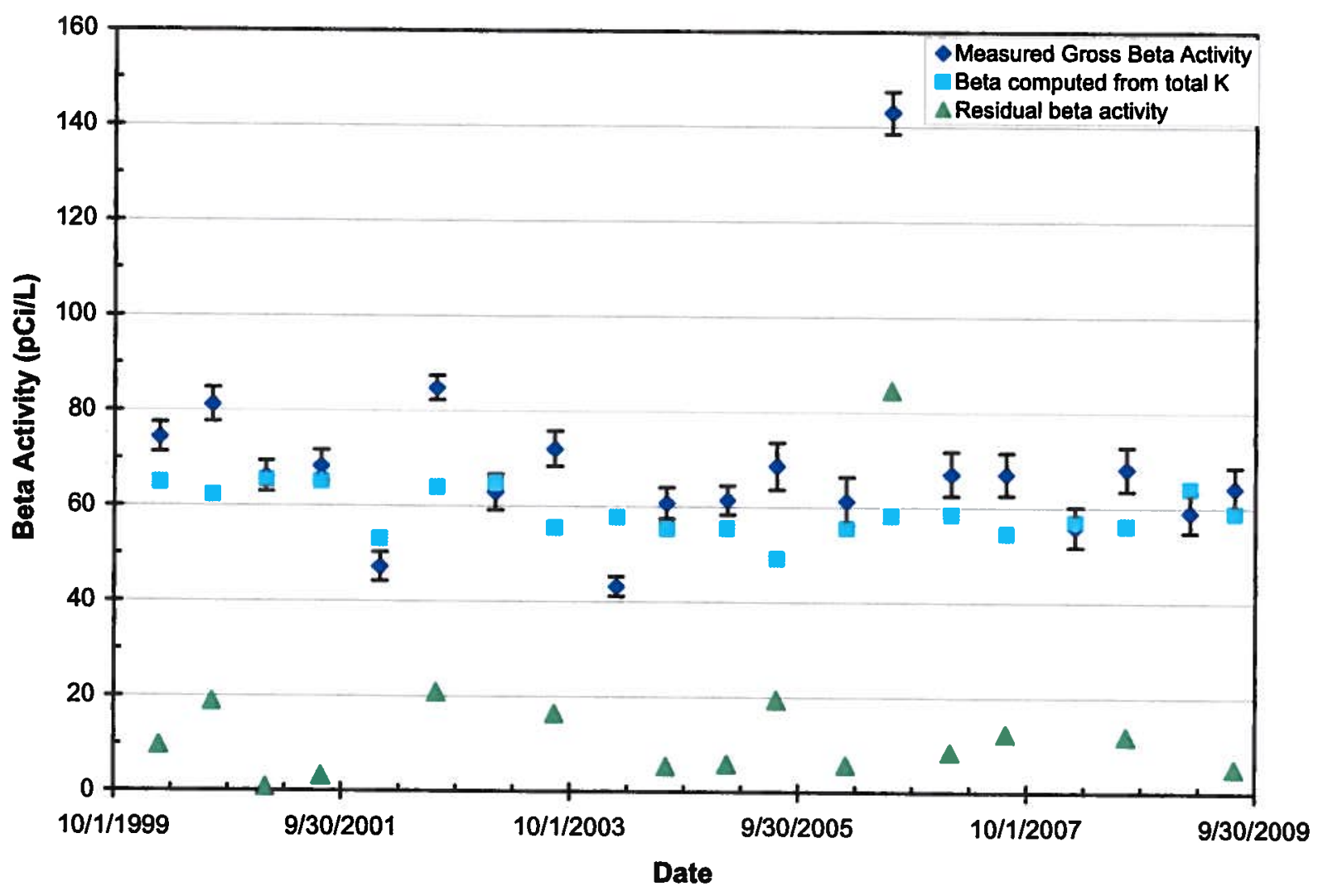

Figure 5.3. Well GW-205 measured and computed beta activity.

Table 5.4 presents the ${ }^{90} \mathrm{Sr}$ analytical results for the four monitoring wells at the UNC site for FY 2000 through FY 2009. Strontium-90 has been detected sporadically at low concentrations in groundwater adjacent to the UNC site but was not detected at any of the monitoring locations during FY 2009. The FY $200617.8 \mathrm{pCi} / \mathrm{L}$ result from well GW-205 exceeded the MCL EDE but was below the UNC site FS estimate of a maximum groundwater ${ }^{90} \mathrm{Sr}$ concentration of $50 \mathrm{pCi} / \mathrm{L}$. During the spring of FY $2008,{ }^{90} \mathrm{Sr}$ was detected at about $2.5 \mathrm{pCi} / \mathrm{L}$ in well GW-221. This result is similar to the level detected in this well during FY 2006.

During FY 2009, surface water was sampled at the nearest downgradient spring location (UNC SW-1) to determine if site related contaminants affect surface water. Analytical results indicate that nitrate and beta activity levels are below drinking water criteria and are similar to results from site monitoring wells. 
Table 5.4. UNC Site groundwater ${ }^{90}$ Sr results, ${ }^{\text {FY }} 2000$ through FY 2009

\begin{tabular}{ccccc}
\hline Sample date & 1090 & GW-203 & GW-205 & GW-221 \\
\hline Feb-99 & $<1.4 \mathrm{U}$ & $0.82 \mathrm{~J}$ & $<1.54 \mathrm{U}$ & $1.16 \mathrm{~J}$ \\
Aug-99 & $<1.48 \mathrm{U}$ & $<1.67 \mathrm{U}$ & $<1.47 \mathrm{U}$ & $<1.68 \mathrm{U}$ \\
Feb-00 & $<3.15 \mathrm{U}$ & $<3.14 \mathrm{U}$ & $<3.34 \mathrm{U}$ & $<3.25 \mathrm{U}$ \\
Aug-00 & $2.22 \mathrm{~J}$ & $<1.73 \mathrm{U}$ & $<4.33 \mathrm{U}$ & $<2.08 \mathrm{U}$ \\
Jan-01 & $<1.7 \mathrm{U}$ & $<1.8 \mathrm{U}$ & $0.53 \mathrm{~J}$ & $0.15 \mathrm{~J}$ \\
Jul-01 & $\mathbf{0 . 5 ~ J}$ & $<2.39 \mathrm{U}$ & $<1.47 \mathrm{U}$ & $0.23 \mathrm{~J}$ \\
Jan-02 & $0.16 \mathrm{~J}$ & $<1.56 \mathrm{U}$ & $0.51 \mathrm{~J}$ & $0.6 \mathrm{~J}$ \\
Jul-02 & $<1.92 \mathrm{U}$ & $1.28 \mathrm{~J}$ & $<1.91 \mathrm{U}$ & $<1.46 \mathrm{U}$ \\
Feb-03 & $<1.57 \mathrm{U}$ & $<1.39 \mathrm{U}$ & $<1.64 \mathrm{U}$ & $<1.59 \mathrm{U}$ \\
Aug-03 & $1.39 \mathrm{~J}$ & $<1.37 \mathrm{U}$ & $<1.44 \mathrm{U}$ & $1.3 \mathrm{~J}$ \\
Feb-04 & $0.73 \mathrm{~J}$ & $<0.99 \mathrm{U}$ & $<0.97 \mathrm{U}$ & $<1.04 \mathrm{U}$ \\
Aug-04 & $<1.06 \mathrm{U}$ & $0.65 \mathrm{~J}$ & $<0.96 \mathrm{U}$ & $0.73 \mathrm{~J}$ \\
Feb-05 & $0.61 \mathrm{~J}$ & $<1.05 \mathrm{U}$ & $<1.18 \mathrm{U}$ & $<1.04 \mathrm{U}$ \\
Jul-05 & $<1 \mathrm{U}$ & $<0.96 \mathrm{U}$ & $<1.76 \mathrm{U}$ & $<1 \mathrm{U}$ \\
Mar-06 & $<1.03 \mathrm{U}$ & $<1.36 \mathrm{U}$ & $<1.41 \mathrm{U}$ & $<1.13 \mathrm{U}$ \\
Jul-06 & $1.21 \mathrm{~J}$ & $1.34 \mathrm{~J}$ & 17.8 & 2.83 \\
Jan-07 & $<0.407 \mathrm{U}$ & $<0.437 \mathrm{U}$ & $<0.433 \mathrm{U}$ & $<0.443 \mathrm{U}$ \\
Jul-07 & $<0.617 \mathrm{U}$ & $<0.613 \mathrm{U}$ & $<0.184 \mathrm{U}$ & $<0.518 \mathrm{U}$ \\
Mar-08 & $<1.72 \mathrm{U}$ & $<2.11 \mathrm{U}$ & $<1.84 \mathrm{U}$ & $2.49 \pm 1.11$ \\
Aug-08 & $<-1.89 \mathrm{U}$ & $<2.04 \mathrm{U}$ & $<2.12 \mathrm{U}$ & $<2.08 \mathrm{U}$ \\
Mar-09 & $<1.54 \mathrm{U}$ & $<1.92 \mathrm{U}$ & $<1.61 \mathrm{U}$ & $<1.61 \mathrm{U}$ \\
Jul/Aug-09 & $<-1.84 \mathrm{U}$ & $<1.93 \mathrm{U}$ & $<2.3 \mathrm{U}$ & $<2.16 \mathrm{U}$ \\
\hline AAllva & & &
\end{tabular}

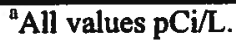

Bolded value exceeds $8 \mathrm{pCi} / \mathrm{L}$ EDE to the beta particle and photon activity $\mathrm{MCL}$ of $4 \mathrm{mrem} / \mathrm{yr}$.

$\mathrm{J}=$ estimated value

$\mathrm{U}=$ reported concentration was below the minimum detectable activity

\subsubsection{Performance Summary}

As discussed in the 2009 RER, elevated gross beta activity continues to be observed in downgradient well GW-205 at the UNC site, suggesting a potential contaminant release from the site. The gross beta activity does not appear to be caused by ${ }^{90} \mathrm{Sr}$, but does track closely to ${ }^{40} \mathrm{~K}$. A downgradient spring, added to the monitoring network in FY 2008 to assess the potential impacts of the UNC groundwater seepage on surface water quality, exhibits data consistent with results from other downgradient monitoring wells at the site that do not detect any COCs above an action limit.

\subsubsection{Compliance with LTS Requirements}

\subsubsection{Requirements}

The PCR (DOE 1993a) requires that surveillance activities continue for 30 years from RA completion to ensure that the cap is adequately containing the waste in the site (see Table 5.2). UNC RA construction was completed in August 1992. Specific requirements include a visual inspection of the cap be conducted quarterly for the first two years after construction, and semiannually thereafter. If necessary, restorative 
measures will be implemented. Minor deficiencies such as damaged drains or signs will be noted on the inspection forms and corrected. However, major deficiencies such as the collapse of the cap or major erosion problems will be reported. Required routine maintenance of the site includes mowing and replacement of any topsoil and vegetation, as required.

\subsubsection{Status of Requirements for FY 2009}

All components of the UNC site were inspected semiannually in FY 2009 by the Y-12 S\&M Program including erosion or settlement of the cover, integrity of surface drainage, evidence of rodent damage, proper signage, and integrity of benchmarks and monitoring wells. Minor maintenance included repair of a broken sign and routine mowing. Additionally, the UNC site is located within Y-12 property protection area and, as such, is not accessible to the public. The area is routinely patrolled by $\mathrm{Y}-12$ security personnel.

\subsubsection{Monitoring Changes and Recommendations for the UNC}

During FY 2007, elevated gross beta activity observed in downgradient well GW-205 at the UNC site suggested a potential contaminant release from the site. The UEFPC Core Team recommended continued monitoring in the existing wells, but added a downgradient spring to assess the potential impacts of UNC groundwater seepage on surface water quality. Gross beta results in FY 2009 for well GW-205 were consistent with results in previous years and still do not appear to be caused by elevated levels of ${ }^{90} \mathrm{Sr}$. Also, analytical results for the downgradient spring are well below any action criteria and are similar to results from other downgradient monitoring wells at the site. The monitoring history of the site is discussed in Sect. 5.2.2.

This issue and the associated recommendation from the 2007 RER (DOE 2007a) are noted in Sect. 5.5 CHESTNUT RIDGE MONITORING CHANGES AND RECOMMENDATIONS as a completed/resolved issue. No changes to monitoring at the UNC site are recommended at this time. 


\subsection{KERR HOLLOW QUARRY REMEDIAL ACTION}

The ROD (DOE 1995a) for Kerr Hollow Quarry (KHQ) (Figure 5.4) presents the decision for No Further Action (NFA) at the site, deferring all monitoring, reporting, and maintenance requirements to the RCRA post-closure permit (TDEC 1996) and amendments. Because the RCRA closure left contaminated material in place, the permit requires monitoring of groundwater. The RCRA post-closure permit for the ChR Hydrogeologic Regime was reissued in September 2006 (TDEC 2006), changing monitoring requirements from semiannual to annual beginning in January 2007.

A more complete discussion of the closure of KHQ and a summary of the regulatory history of the site are provided in Chap. 5 of Vol. 1 of the 2007 RER (DOE 2007a). This information will be updated in the annual RER and republished every fifth year at the time of the CERCLA FYR.

\subsubsection{Performance Goals and Monitoring Objectives}

The objective of the site closure was to prevent physical exposure to contaminants within the quarry and mitigate migration of contaminants to groundwater or surface water runoff. The RCRA closure was deemed protective of human health and the environment under CERCLA, resulting in the NFA ROD. The RCRA post-closure permit for the ChR Regime specifies annual detection monitoring, alternating between seasonally high and low flow conditions, to identify any potential future releases to groundwater from the unit. Statistical analysis for groundwater target list compounds is conducted for each annual sampling event. The statistical procedure included in the RCRA permit involves three steps: (1) comparison to a background value (e.g., a calculated upper tolerance limit), (2) trend analysis (Kendall-Tau method or equivalent) if the background value is exceeded, and (3) if the results fail the trend analysis, verification sampling is conducted. If statistically significant contamination is detected in groundwater at the site while conducting monitoring in accordance with the permit, notification is provided in accordance with the terms of the permit and any necessary remediation will be addressed under CERCLA.

The ROD states that monitoring of the surface water discharge point (Outfall 301) from the quarry will be performed as a best management practice (BMP). Because the outfall was typically dry, DOE obtained approval to discontinue monitoring of Outfall 301 at the quarry in 2002.

\subsubsection{Evaluation of Performance Monitoring Data - FY 2009}

During FY 2009, annual groundwater monitoring was conducted in upgradient/background well GW-231 and in downgradient/point-of-compliance wells GW-143, GW-144, and GW-145 (Figure 5.4) for metals, VOCs, and gross alpha and gross beta. Statistical analyses of target constituents were conducted in accordance with the post-closure permit requirements. Monitoring results and statistical analyses are reported to TDEC in post-closure permit monitoring reports. Site-specific background values were determined for each inorganic target list constituent using historical data for upgradient wells along ChR and including current monitoring results for upgradient well GW-231. Groundwater samples from all of the downgradient wells at the site had target list constituent concentrations below the applicable background values during FY 2009. Therefore, a release of target list constituents to groundwater is not indicated at KHQ and NFA was necessary per requirements of the post-closure permit. 


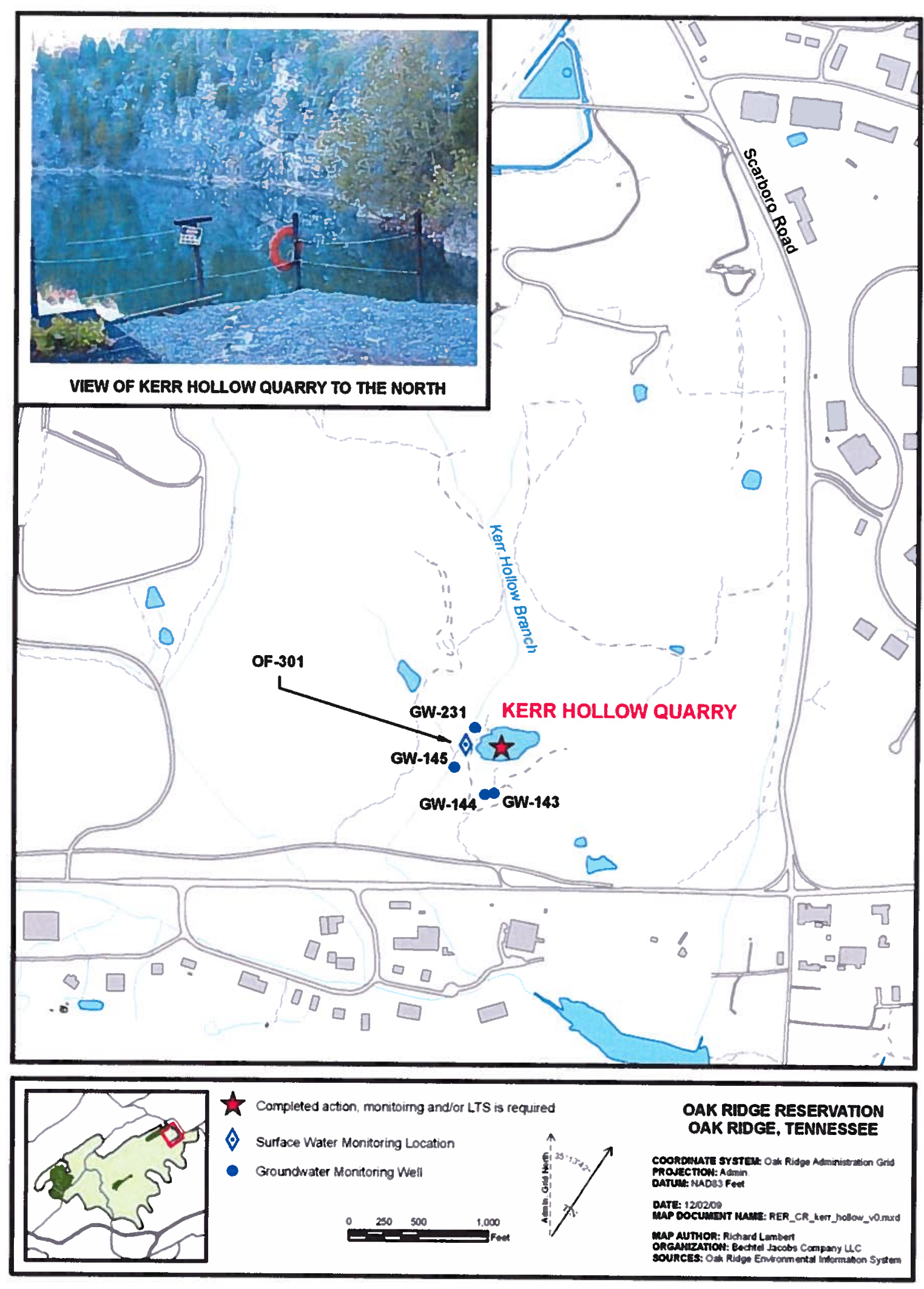

Figure 5.4. Kerr Hollow Quarry site map. 


\subsubsection{Performance Summary}

Results of statistical evaluations of 2009 groundwater analytical data for KHQ do not indicate a contaminant release for the uppermost aquifer and do not warrant any response action specified in the post-closure permit that governs the site.

\subsubsection{Compliance with LTS Requirements}

\subsubsection{Requirements}

The KHQ ROD (DOE 1995a) does not specify any LTS requirements; however, the RCRA post-closure permit requires that all security components, signage, survey benchmarks, and monitoring systems at KHQ be inspected quarterly throughout the post-closure care period of 30 years (see Table 5.2). Final closure certification for the site was February 22, 1995. As a RCRA closure, deed restrictions were required to be filed at the County Court House Register's of Deeds office.

\subsubsection{Status of Requirements for FY 2009}

KHQ was inspected quarterly in FY 2009 by the Y-12 S\&M Program for items including proper signage; integrity of benchmarks and monitoring wells; condition of the fences, gates, and locks; and condition of the access road. Minor maintenance included mowing, removing a fallen tree from across the upper access road, and repair of a sign that states, "Danger-Unauthorized Personnel Keep Out." A comprehensive monitoring well inspection was conducted in FY 2009. Additionally, the KHQ is located outside Y-12 property protection area; therefore, separate security fencing and signs exist at the site. The KHQ deed restrictions were filed on April 28, 1994 at the Anderson County Register's of Deeds Office and remain in place.

\subsubsection{Monitoring Changes and Recommendations for KHQ}

If statistically significant contamination is detected in groundwater at the site while conducting monitoring in accordance with the RCRA post-closure permit, any necessary remediation will be addressed under CERCLA.

No changes to monitoring at KHQ are recommended at this time. 


\subsection{FILLED COAL ASH POND/UPPER MCCOY BRANCH REMEDIAL ACTION}

The Filled Coal Ash Pond (FCAP) is situated south of Y-12 along the southern slope of ChR (see Figure 5.1 and Figure 5.5). The ChR OU2 ROD was approved on February 21, 1996 (DOE 1996b) to remediate FCAP and vicinity. The RAR was approved on June 3, 1997 (DOE 1997a) documenting the following actions: the crest of the dam was raised, the face of the dam was reinforced, a subsurface drain was installed, large trees from the face of the dam were removed, the emergency spillway was repaired (including removal of the steep slope to the east of the spillway), a settling basin and oxygenation weir were constructed at the foot of the dam, and a small wetland was replaced downstream of the settling basin. The RA also includes long-term monitoring of the dam and controls to limit access.

A more complete discussion of the FCAP remedy and a summary of performance goals and requirements are provided in Chap. 5 of Vol. 1 of the 2007 RER (DOE 2007a). This information will be updated in the annual RER and republished every fifth year at the time of the CERCLA FYR.

\subsubsection{Performance Goals and Monitoring Objectives}

The goal of the response action is to reduce risk posed by the site to "plants, animals and humans by: (1) upgrading containment of the coal ash with dam improvements and stabilization, (2) reducing contaminant migration into Upper McCoy Branch with a passive treatment system (existing wetland), and (3) restricting human access to the contamination by implementing institutional controls." The functional goals per the ROD are to do the following:

- minimize the migration of contaminants into surface water,

- minimize direct contact of humans and animals with the ash,

- reduce the potential for future failure of the dam, and

- preserve the local habitat in the long term.

The ROD requires that surface water be periodically sampled "and analyzed to verify that the passive treatment system reduces contaminant levels in water entering Upper McCoy Branch at least as well as the existing wetland and to evaluate whether the passive treatment system requires maintenance." The RAR (DOE 1997a) specifies that surface water samples "be collected and analyzed for the primary COCs (aluminum, arsenic, iron, manganese, and zinc) and other constituents of relevance to evaluating wetland performance at the site." Two locations, one at the influent to the wetland [McCoy Branch kilometer (MCK) 2.05] and one below the wetland (MCK 2.0), are monitored for metals, anions, radionuclides, and water quality parameters on a semiannual basis. Both monitoring locations are downstream of the contaminant source.

Monitoring of biological communities is conducted to evaluate protection of the ecosystem in the FCAP vicinity in accordance with applicable or relevant and appropriate requirements (ARARs) for protection of aquatic resources specified in the ROD. Biological communities are monitored near the wetland (MCK 1.9) and also below the Rogers Quarry dam (MCK 1.4 and MCK 1.6). Fish are also collected from Rogers Quarry for contaminant analysis on an annual basis.

\subsubsection{Evaluation of Performance Monitoring Data - FY 2009}

Results for surface water monitoring at FCAP in FY 2009 did not exceed the upper range of baseline values from pre-remediation monitoring conducted in 1996. Results for pre-remediation baseline monitoring and FY 2009 monitoring are presented in Table 5.5 and Table 5.6, respectively. The results are for unfiltered samples taken at locations above and below the wetland. 

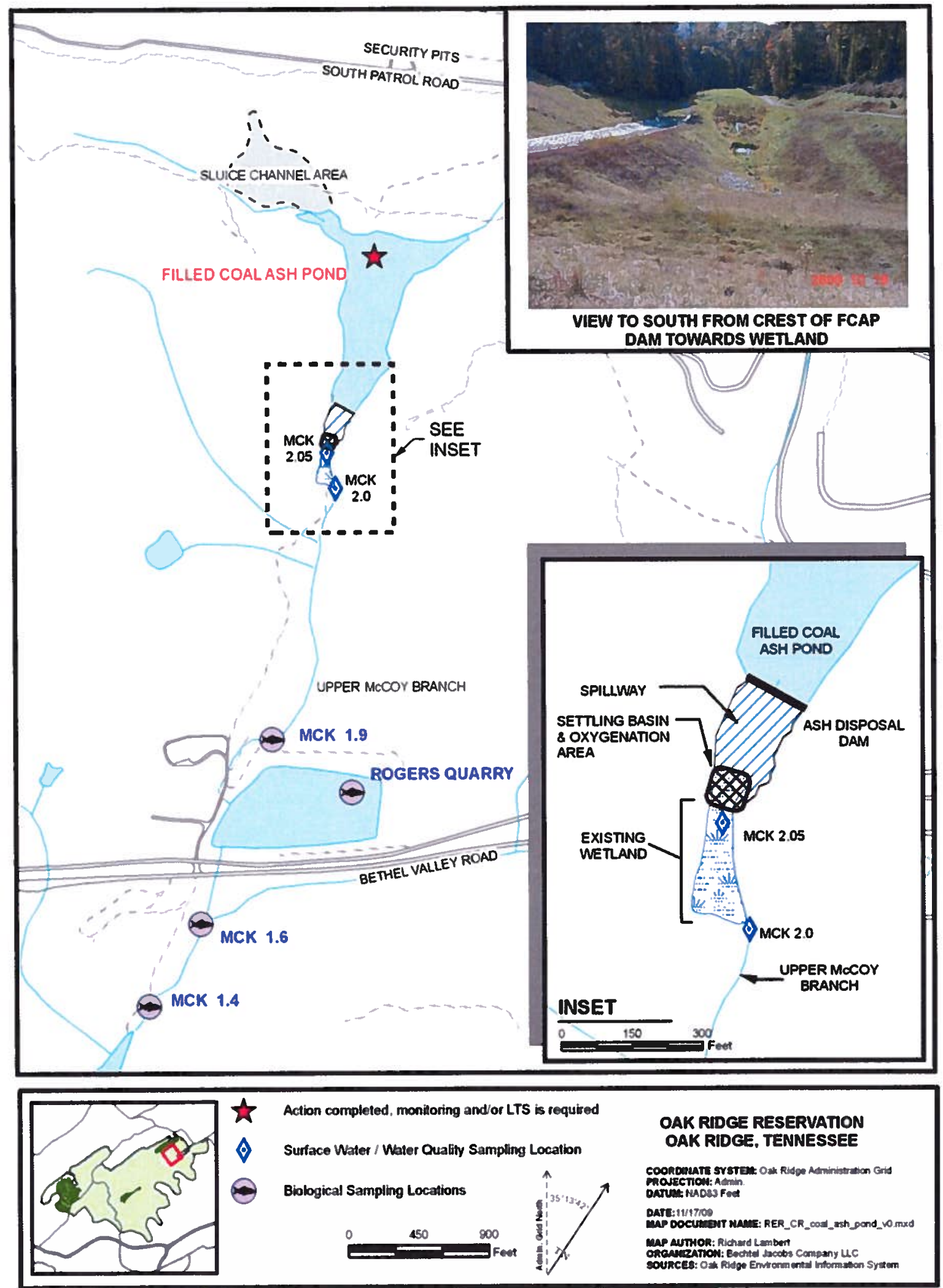

Figure 5.5. Filled Coal Ash Pond site map. 
Table 5.5. Summary of FCAP pre-remediation monitoring results, 1996

\begin{tabular}{llcc}
\hline \multicolumn{1}{c}{ Analyte } & Units & MCK 2.05 & MCK 2.0 \\
\hline Arsenic & $\mathrm{mg} / \mathrm{L}$ & $0.007-1.4$ & $0.029-1.2$ \\
Iron & $\mathrm{mg} / \mathrm{L}$ & $5.6-43$ & $0.6-48$ \\
Manganese & $\mathrm{mg} / \mathrm{L}$ & $0.47-3.8$ & $0.6-39.0$ \\
Zinc & $\mathrm{mg} / \mathrm{L}$ & $0.0094-0.056$ & ND-0.2 \\
\hline
\end{tabular}

"Dam effluent/wetland influent.

Wetland effluent.

$\mathrm{ND}=$ not detected

Table 5.6. Summary of FY 2009 post-remediation data from MCK 2.05 and MCK 2.0

\begin{tabular}{lcccccc}
\hline & \multicolumn{5}{c}{ Wet-season sample } & \multicolumn{3}{c}{ Dry-season sample } \\
\cline { 2 - 7 } \multicolumn{1}{c}{ Analyte } & & MCK 2.05 $^{\mathrm{a}}$ & MCK 2.0 & MCK 2.05 & MCK 2.0 & \\
Units & Mar-09 $^{\mathrm{b}}$ & Mar-09 & Sep-09 & Sep-09 & AWQC \\
\hline Aluminum & $\mathrm{mg} / \mathrm{L}$ & $0.050 \mathrm{U}$ & 0.084 & $0.050 \mathrm{U}$ & 0.160 & $\mathrm{~N} / \mathrm{A}$ \\
Arsenic & $\mathrm{mg} / \mathrm{L}$ & $\mathbf{0 . 1 0 1}$ & $0.005 \mathrm{U}$ & $\mathbf{0 . 0 2 1 2}$ & $\mathbf{0 . 0 1 5 9}$ & $0.01^{\mathrm{c}}$ \\
Iron & $\mathrm{mg} / \mathrm{L}$ & 4.56 & 0.114 & $\mathbf{0 . 4 0 2}$ & 0.374 & N/A \\
Manganese & $\mathrm{mg} / \mathrm{L}$ & 0.655 & 0.176 & 0.387 & 0.425 & N/A \\
Zinc & $\mathrm{mg} / \mathrm{L}$ & $\mathbf{0 . 0 1 \mathrm { U }}$ & $0.01 \mathrm{U}$ & $0.01 \mathrm{U}$ & $0.01 \mathrm{U}$ & $0.12^{\mathrm{d}}$ \\
\hline
\end{tabular}

${ }^{a}$ Dam effluent/wetland influent.

${ }^{b}$ Wetland effluent.

'Source: TDEC 1200-4-3-.03(4) recreation criteria for organisms only.

'Source: TDEC 1200-4-3-.03(3) criterion continuous concentration for protection of fish and aquatic life. AWQC for zinc are hardness dependent. The $0.12 \mathrm{mg} / \mathrm{L} A W Q C$ for zinc is based on the most conservative criterion for hardness.

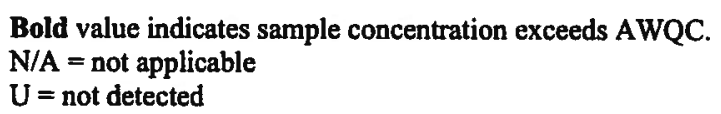

The FY 2009 concentrations of COCs (Al, As, Fe, Mn, and Zn) above (MCK 2.05) and below (MCK 2.0) the wetland (MCK 2.0) were slightly lower than the results from previous years. The March 2009 results, representing the wet-season results, are typically higher than the dry-season results. Results for COCs presented in Table 5.6 show a consistent pattern of the COC concentration in the wetland influent (MCK 2.05) greater than the concentration in the wetland effluent (MCK 2.0) except for manganese in the September 2009 samples. In FY 2009, only arsenic exceeded the AWQC at FCAP although concentrations have decreased since the RA.

The historic data presented in Figure 5.6 shows that elevated measurements in the upstream location (MCK 2.05) are almost ten times higher for iron than observed downstream of the wetland. The elevated measurements appear to occur when oxyhydroxide precipitate conditions are observed in the FCAP leachate, consistent with low rainfall conditions. 

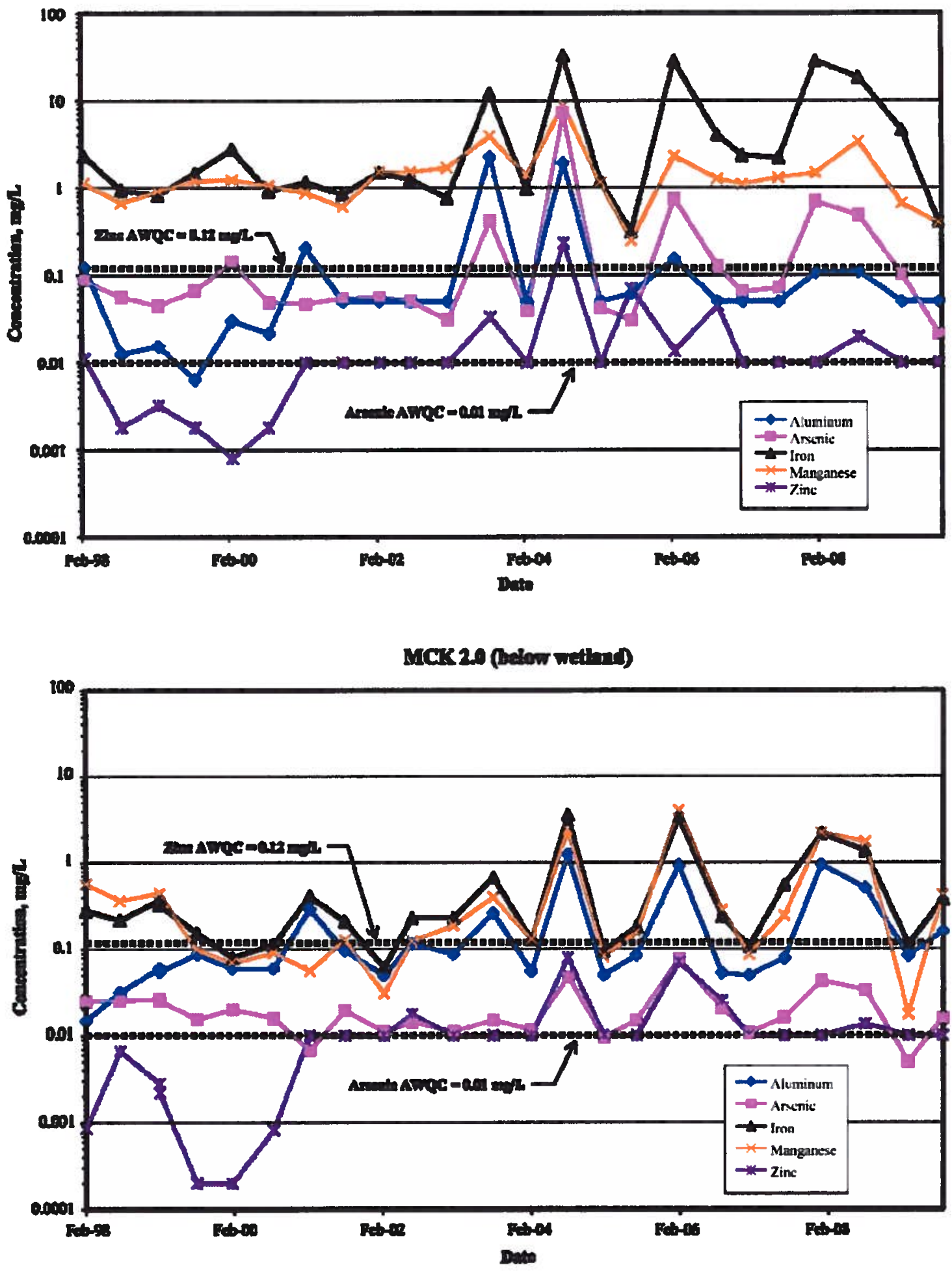

Figure 5.6. Historic data at MCK 2.0 and MCK 2.05 between FY 1998 and FY 2009. 


\subsubsection{Other Surface Water Monitoring}

\subsubsection{Biota Monitoring Results}

Fly-ash disposal from Y-12 into the FCAP, as well as direct disposals of ash into Rogers Quarry, affected water quality in the lower reaches of McCoy Branch and the quarry. Biological monitoring studies have documented contaminants in fish and impacts to biota in the lower reaches of the McCoy Branch watershed and Rogers Quarry. To evaluate in-stream exposure and potential human health risks in the McCoy Branch watershed, adult largemouth bass are collected from Rogers Quarry and analyzed for key COCs. An evaluation of overall ecological health in the stream is conducted by monitoring the fish and benthic macroinvertebrate communities.

Average selenium concentrations in largemouth bass in Rogers Quarry remained elevated $(2.2 \mu \mathrm{g} / \mathrm{g})$ in 2009 and were above typical background concentrations $(0.5 \mu \mathrm{g} / \mathrm{g})$, suggesting possible continuing low level inputs from the FCAP site (Figure 5.7). Arsenic concentrations continued to be at background levels. Average mercury concentrations in bass from Rogers Quarry (Figure 5.8) were lower in 2009 than they have been in over a decade $(0.54 \mu \mathrm{g} / \mathrm{g})$, although they remain within the range of values observed in the mid-1990s. This decrease in $\mathrm{Hg}$ levels in bass may also suggest low level Se inputs since selenium is known to have an antagonistic effect on mercury bioaccumulation.

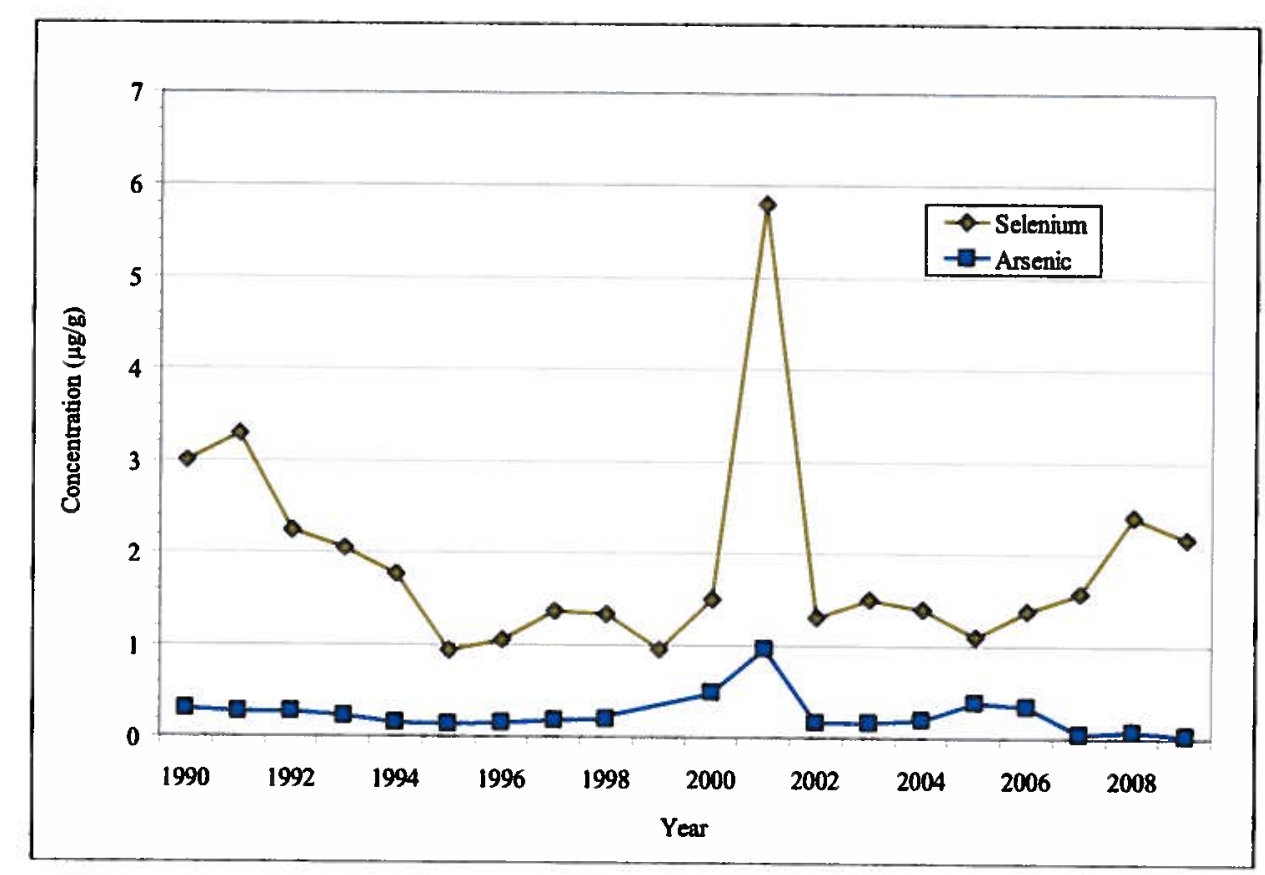

Figure 5.7. Mean concentrations of selenium and arsenic in fillets of largemouth bass from Rogers Quarry. 


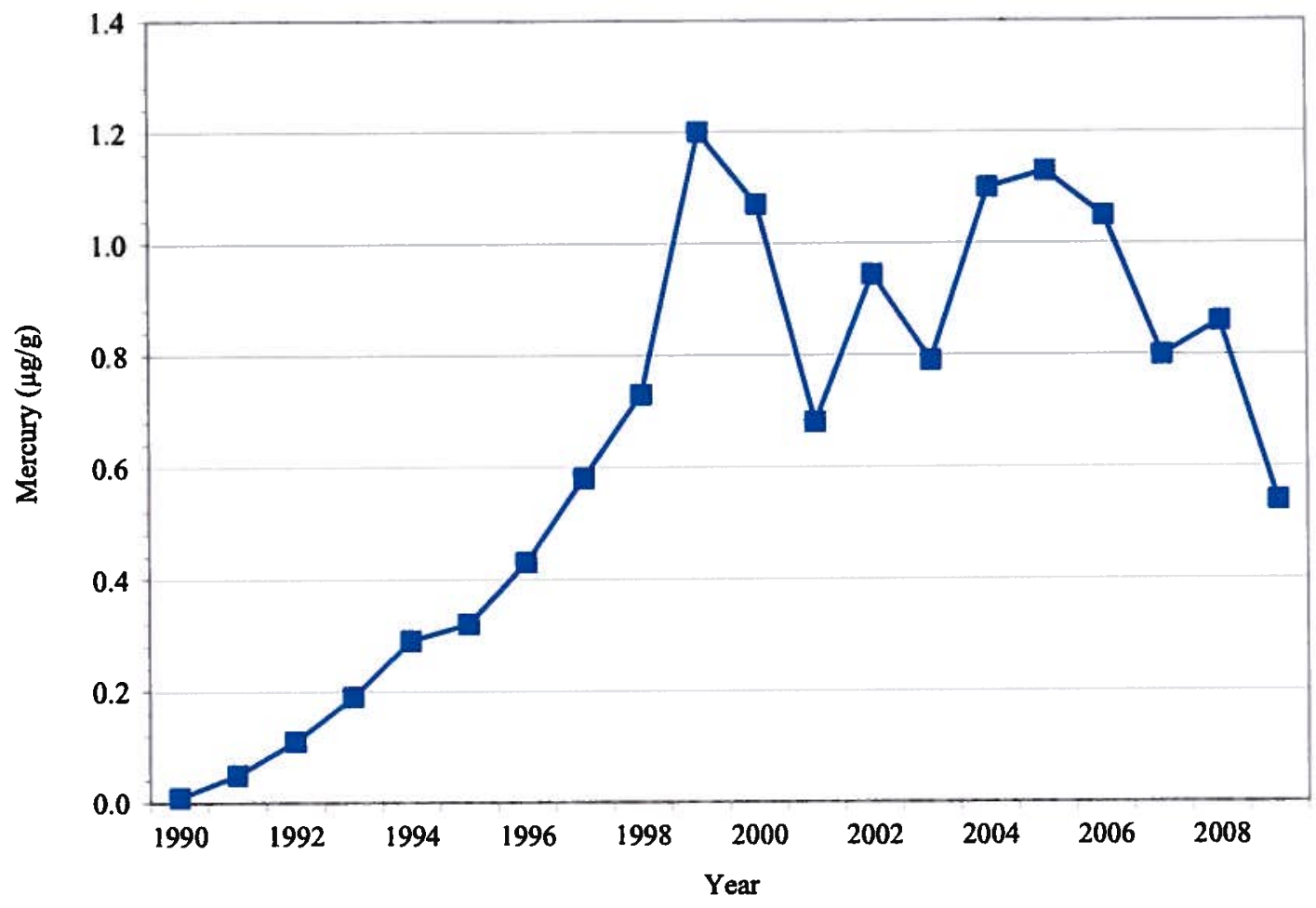

Figure 5.8. Mean concentrations of mercury in fillets of largemouth bass from Rogers Quarry.

The species richness (number of species) of the fish community at MCK 1.6 in McCoy Branch had been declining since 2004, but sampling in the last few years showed an increasing trend (Figure 5.9). There was also an increase in species at MCK 1.9, where introduction of the western blacknose dace appears to be successful. This is a continuation of the restoration effort above Rogers Quarry that began with the introduction of the banded sculpin in the mid-1990s. The number of pollution-intolerant benthic macroinvertebrate taxa at the downstream-most site in McCoy Branch (MCK 1.4) continues to exhibit a trend of having fewer taxa than reference sites in October, but generally more comparable numbers of taxa during April (Figure 5.10). The upstream-most site (MCK 1.9), in contrast, doesn't appear to exhibit the pronounced seasonal variation, with generally lower numbers of pollution intolerant taxa relative to the reference site, or the lower end of the reference range, over the last two years. 


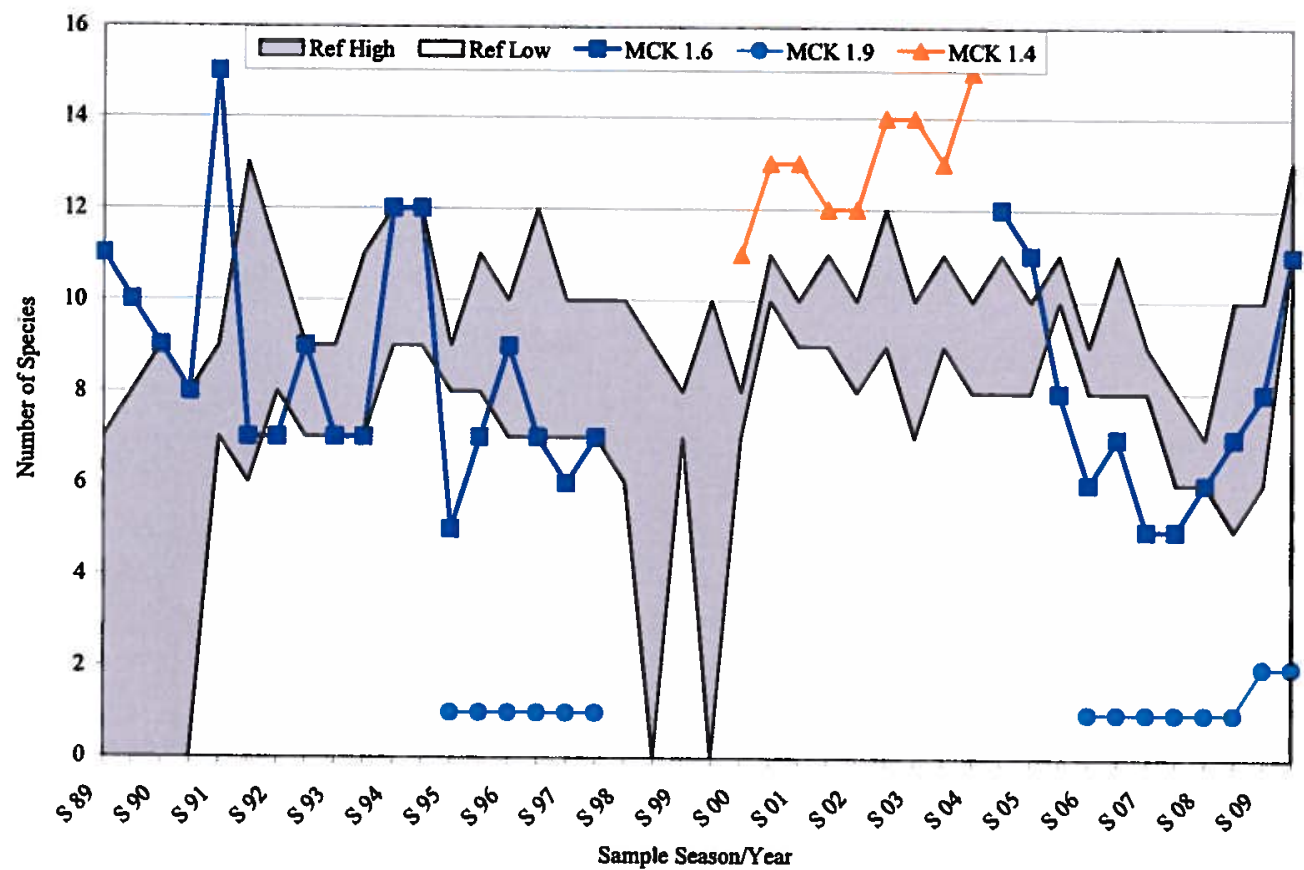

Figure 5.9. Species richness (number of species) in samples of the fish community in McCoy Branch (MCK) and three reference streams, Scarboro Creek (SCK), Grassy Creek (GCK), and Ish Creek (ISK) 1989-2009 (See Figure 5.1 for locations of reference sampling sites).

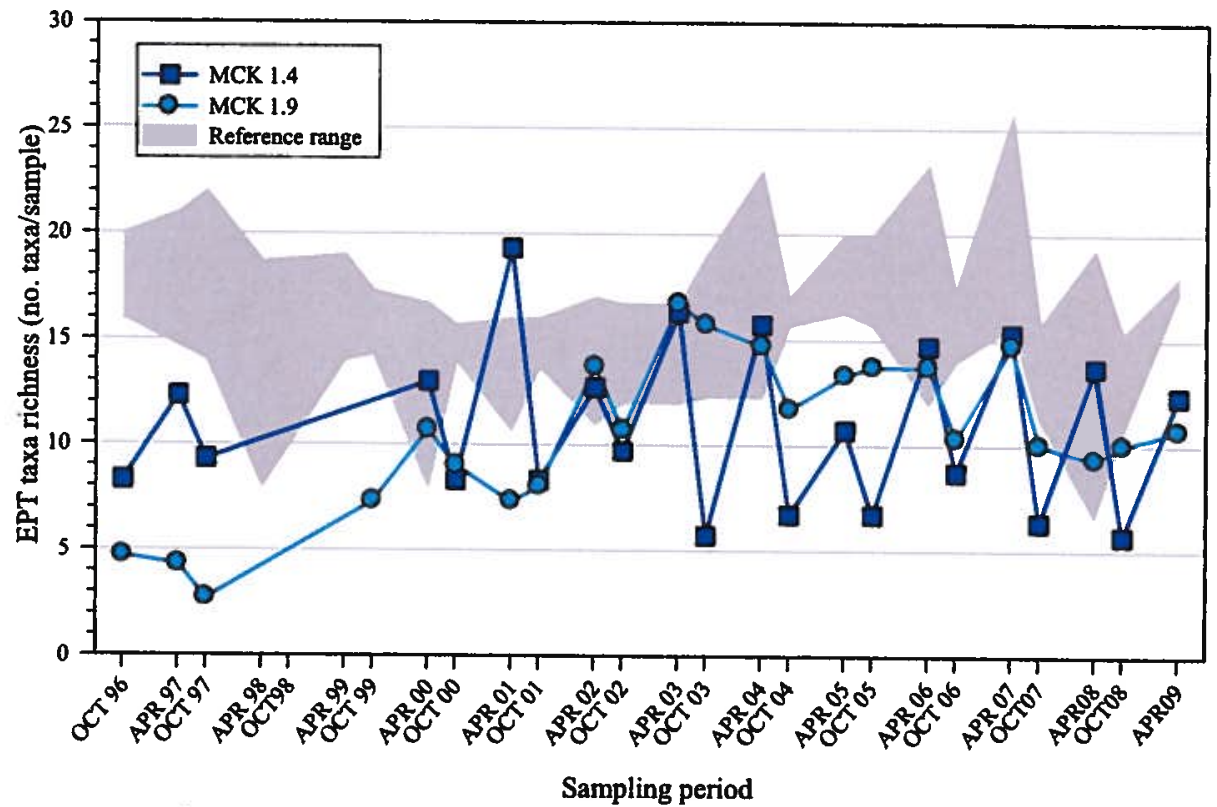

MCK = McCoy Branch kilometer, EPT = Ephemeroptera, Plecoptera, and Trichoptera, or mayflies, caddisflies, and stoneflies .

Figure 5.10. Mean $(n=3)$ taxonomic richness of the pollution-intolerant taxa for the benthic macroinvertebrate community at sites in McCoy Branch, and range of mean values among reference streams

(First Creek, Fifth Creek, Gum Hollow Branch, Mill Branch, Walker Branch, and WOC), 1996-2009. 


\subsubsection{Performance Summary}

The monitoring results since the RA indicate that the remedy is successfully lowering the concentration of COCs in surface water as it exits the wetland. Arsenic concentrations, however, generally exceeded the AWQC in both the upgradient and downgradient locations at the FCAP wetland although concentrations have decreased since implementation of the RA. Biological indicators show that McCoy Branch is improving but remain below the values observed in reference streams.

\subsubsection{Compliance with LTS Requirements}

\subsubsection{Requirements}

LTS requirements for FCAP are summarized in Table 5.2. The RAR (DOE 1997a) requires that inspections of the site be conducted quarterly throughout the post-remediation care period, and any required maintenance be conducted based on inspection findings. Post-remediation performance of FCAP is strongly dependent on adequate inspection and maintenance of the dam, spillway channel, adjacent slopes, settling basin, and wetlands. Because erosional damage is of great concern, the dam and spillway will also be inspected following any rainfall event equivalent to a 25 -year, 24-hour intensity.

\subsubsection{Status of Requirements for FY 2009}

All components of the FCAP were inspected quarterly in FY 2009 by the Y-12 S\&M Program including dam and slope stability, vegetative cover of dam and adjacent slopes, settling basin, spillway, underdrain discharge pipe, wetland area, benchmarks, and site security and access controls. Minor maintenance included removing vegetation from the spillway, removing downed trees from the slope of the dam, and clearing area around survey markers. There were no 25-year, 24-hour intensity rainfall events in FY 2009.

\subsubsection{Monitoring Changes and Recommendations for FCAP}

No changes to the monitoring network at FCAP are recommended at this time. 


\subsection{CHESTNUT RIDGE MONITORING CHANGES AND RECOMMENDATIONS}

Table 5.7 summarizes issues and recommendations for ChR. No additional issues were identified from evaluation of the FY 2009 monitoring data and, therefore, no changes to the existing monitoring network are recommended at this time. One issue has been completed concerning the elevated gross beta activity in downgradient monitoring well GW-205. The concentrations of gross beta will continue to be trended and reported in subsequent RERs.

Table 5.7. Summary of technical issues and recommendations

\begin{tabular}{|c|c|}
\hline Issue $^{b}$ & $\begin{array}{c}\text { Action/ } \\
\text { Recommendation }\end{array}$ \\
\hline \multicolumn{2}{|l|}{$\begin{array}{l}\text { 2010 Current Issue: } \\
\text { None. }\end{array}$} \\
\hline \multicolumn{2}{|l|}{ Completed/Resolved Issues: } \\
\hline $\begin{array}{l}\text { 1. Elevated } \mathrm{pH} \text {, gross beta activity, and } \\
\text { intermittent }{ }^{90} \mathrm{Sr} \text { concentrations observed in } \\
\text { downgradient monitoring well } \mathrm{GW}-205 \text { at the } \\
\text { UNC site suggest a potential contaminant } \\
\text { release from the site. (2007 RER) }\end{array}$ & $\begin{array}{l}\text { 1. The issue was discussed by the UEFPC Core Team in FY } 2007 . \\
\text { The UEFPC Core Team agreed to continue monitoring in existing } \\
\text { wells, but added a downgradient spring to assess the potential } \\
\text { impacts of UNC groundwater seepage on surface water quality. } \\
\text { Spring (UNC SW-1) was added to WRRP FY } 2008 \text { SAP. } \\
\text { Results are reported in the } 2009 \text { and } 2010 \text { RERs and are consistent } \\
\text { with other site monitoring data. Gross beta will continue to be } \\
\text { trended in future RERs. }\end{array}$ \\
\hline
\end{tabular}

"The year of the RER in which the issue originated is provided in parentheses, e.g., (2007 RER).

"Issues identified in the table as "Completed/Resolved Issues" indicate that the issue has been resolved and will not be tracked in subsequent RERs. 

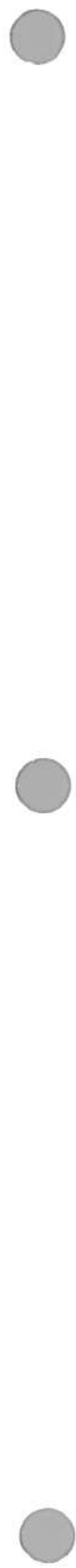


\section{CERCLA ACTIONS IN UPPER EAST FORK POPLAR CREEK WATERSHED}

\subsection{INTRODUCTION AND OVERVIEW}

This chapter provides an update to completed CERCLA actions in the UEFPC Watershed during FY 2009. Figure 6.1 shows the locations of the actions within the watershed. Only sites that have performance monitoring and/or LTS requirements, as noted in Table 6.1, are included in the performance evaluations provided in this chapter. In this chapter, performance goals and objectives, monitoring results, and an assessment of the effectiveness of each completed action are presented. A summary of LTS requirements is provided in Table 6.2, and a review of compliance with these requirements is included in Sects. 6.2.4 and 6.3.2.3. UEFPC Phase I and II ROD-designated land uses and interim controls are shown on Figure 6.2.

For background information on each remedy and performance standards, a compendium of all CERCLA decisions in the watershed within the context of a contaminant release conceptual model is provided in Chap. 6 of Vol. 1 of the 2007 RER (DOE 2007a). This information will be updated in the annual RER and republished every fifth year at the time of the CERCLA FYR.

Because many CERCLA actions have not yet been implemented within the UEFPC Watershed, monitoring data collected to date are not sufficient to assess the watershed-wide impact of the remedial strategy. Thus, this chapter provides only a preliminary evaluation of the early indicators of effectiveness at the watershed scale, such as contaminant trends at the surface water IP.

\subsubsection{Status and Updates}

Remediation of the UEFPC Watershed is being conducted in stages using a phased approach. Phase I addresses remediation of mercury-contaminated soil, sediment, and groundwater discharges that contribute contamination to surface water. Clean up and repair of storm sewers in the West End Mercury Area (WEMA) was initiated in FY 2009. The Storm Drain Engineering Study Report that documents the results has been completed and submitted to the regulators for approval. The initial phase included the videotaping of the storm sewer system to provide important data on the condition of the sewer lines. Future phases of this action will include the removal of contaminated sediments from the storm sewers and relining or replacement of leaking sewer sections. This action is part of three actions identified in the Phase I ROD to limit mercury migration by hydraulically isolating the WEMA. The Work Plan (DOE 2009j) was submitted to the regulators in September 2009. Results of the study will be used to prepare a RAWP for remediation of the storm sewers. As agreed with the UEFPC Core Team, sampling of three mercury outfalls $(150,160$, and 163) to monitor the WEMA was initiated in fall 2009.

A Characterization Plan for the 81-10 Area (DOE 2009k), the site of a historic mercury recovery process, was prepared and submitted to the regulators for approval in September. Characterization of soils in the 80-10 area, addressed under the Phase I ROD, is required to determine the nature and extent of contamination and the need for conducting a treatability study, and whether contamination in the 81-10 area is determined to be a source of mercury contamination in UEFPC.

The initial project of the Phase II Interim Remedial Action for Contaminated Soils and Scrapyard (i.e., the Phase II ROD) is remediation of the Y-12 Old Salvage Yard, approximately 14,446 tons of scrap metal 
This page intentionally left blank. 


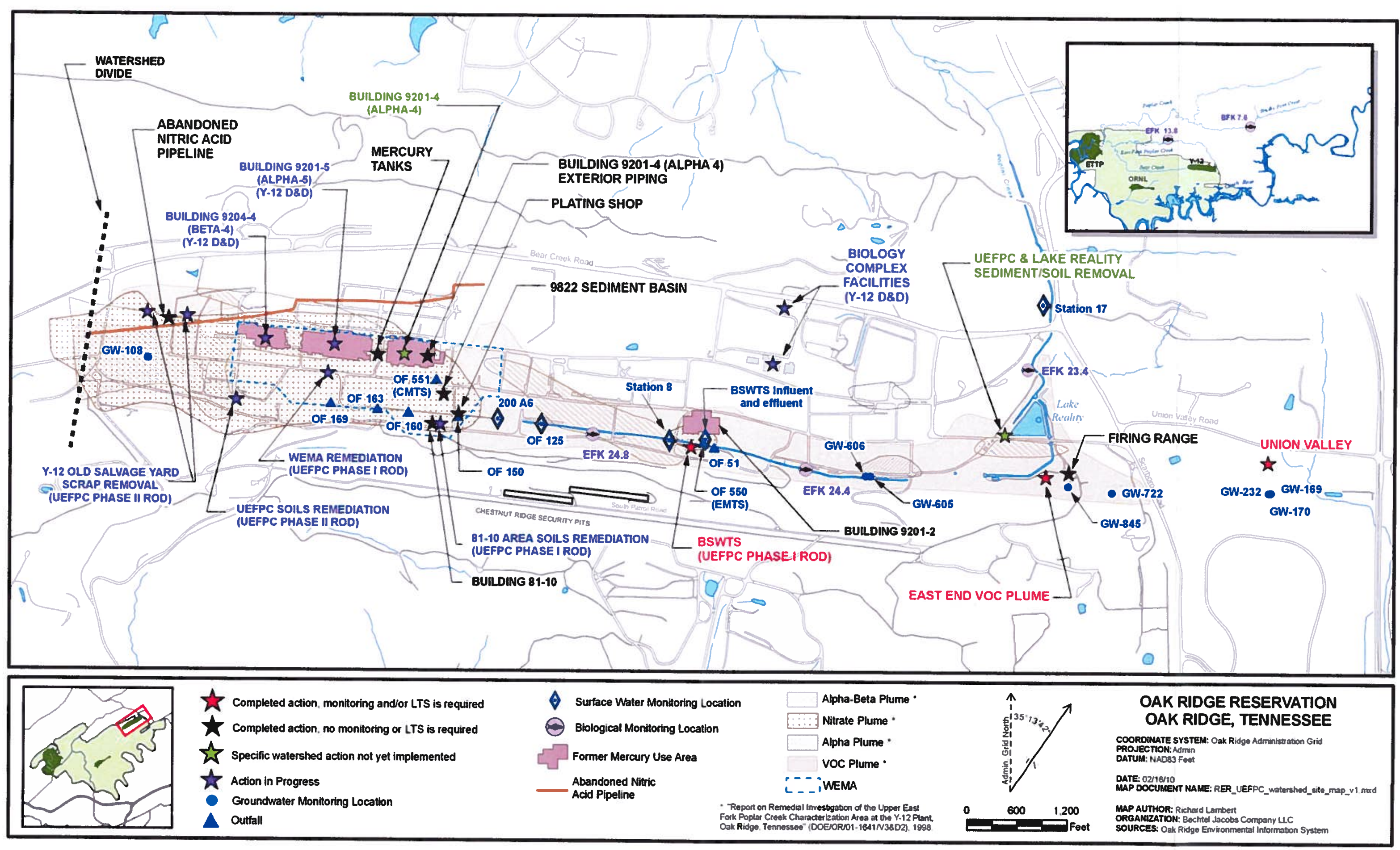

Figure 6.1. CERCLA actions in the Upper East Fork Poplar Creek Watershed. 
This page intentionally left blank. 
Table 6.1. CERCLA actions in UEFPC Watershed

\begin{tabular}{|c|c|c|c|c|}
\hline CERCLA action & $\begin{array}{c}\text { Decision document, date signed } \\
(\mathrm{mm} / \mathrm{dd} / \mathrm{yy})\end{array}$ & Action/Document status ${ }^{a}$ & $\begin{array}{l}\text { Monitoring/ } \\
\text { LTS required }\end{array}$ & $\begin{array}{c}\text { RER } \\
\text { section }\end{array}$ \\
\hline \multicolumn{5}{|c|}{ Watershed-scale actions } \\
\hline $\begin{array}{l}\text { Phase I Interim Source Control } \\
\text { Actions }\end{array}$ & $\begin{array}{l}\text { ROD (DOE/OR/01-1951\&D3): 05/02/02 } \\
\text { NSC: } 10 / 05 / 06 \\
\text { NSC: } 05 / 17 / 07 \\
\text { Erratum to the } 10 / 05 / 06 \text { NSC: } 06 / 09 / 08 \\
\text { NSC: submitted 09/30/09; pending approval }\end{array}$ & $\begin{array}{l}\text { Actions complete } \\
\text { - PCCR for BSWTS for Building } 9201-2 \\
\text { (DOE/OR/01-2218\&D1) approved 07/01/05. } \\
\text { Actions in progress } \\
\text { - WEMA remediation. } \\
\text { - UEFPC sediments (81-10 Area) } \\
\text { Actions not yet implemented } \\
\text { - UEFPC \& Lake Reality sediment/soil removal. }\end{array}$ & $\begin{array}{l}\text { TBD } \\
\text { TBD } \\
\text { TBD }\end{array}$ & - \\
\hline $\begin{array}{l}\text { Phase II Interim RA for } \\
\text { Contaminated Soils and Scrapyard }\end{array}$ & ROD (DOE/OR/01-2229\&D3): 04/21/06 & $\begin{array}{l}\text { Actions in progress } \\
\text { - RDR/RAWP for Y-12 Salvage Yard - Scrap } \\
\text { Removal (DOE/OR/01-2376\&D2) approved } \\
\text { 01/21/09. } \\
\text { - UEFPC soils remediation. }\end{array}$ & TBD & -- \\
\hline \multicolumn{5}{|c|}{ Single-project actions } \\
\hline $\begin{array}{l}\text { Y-12 EEVOC Plume Removal } \\
\text { Action }\end{array}$ & AM (DOE/OR/01-1819\&D2): 06/25/99 & RmAR (DOE/OR/01-2297\&D1): 06/07/06 & Yes/No & 6.3 .1 \\
\hline Union Valley & IROD (DOE/OR/02-1545\&D2): 07/10/97 & $--b$ & No/Yes & 6.3 .2 \\
\hline $\begin{array}{l}\text { Mercury Tanks Interim RA (Tanks } \\
\text { 2100-U, 2101-U, 2104-U) }\end{array}$ & IROD (DOE/OR/02-1164): 09/26/91 & RAR (DOE/OR/01-1169\&D1): 12/20/93 & No/No & - \\
\hline Plating Shop Container Areas NFA & ROD (DOE/OR-1049\&D3): 09/30/92 & NFA & No/No & -- \\
\hline ANAP (UEFPC OU 2) & ROD (DOE/OR/02-1265\&D2): 09/12/94 & NFA & No/No & - \\
\hline Bldg. 9201-4 Exterior Process Piping & AM (DOE/OR/02-1571\&D2): 04/22/97 & RmAR (DOE/OR/02-1650\&D1): 09/30/99 & No/No & -- \\
\hline $\begin{array}{l}\text { Lead Source Removal of Former } \\
\text { YS860, Firing Range Removal } \\
\text { Action }\end{array}$ & AM (DOE/OR/02-1622\&D1): 03/10/98 & RmAR (DOE/OR/01-1774\&D2): 02/24/99 & No/No & -- \\
\hline
\end{tabular}


Table 6.1 CERCLA actions in UEFPC Watershed (cont.)

\begin{tabular}{|c|c|c|c|c|}
\hline CERCLA action & $\begin{array}{l}\text { Decision document, date signed } \\
(\mathrm{mm} / \mathrm{dd} / \mathrm{yy})\end{array}$ & Action/Document status ${ }^{a}$ & $\begin{array}{l}\text { Monitoring/ } \\
\text { LTS required }\end{array}$ & $\begin{array}{c}\text { RER } \\
\text { section }\end{array}$ \\
\hline $\begin{array}{l}9822 \text { Sediment Basin and } 81-10 \\
\text { Sump Removal Action }\end{array}$ & AM (DOE/OR/01-1716\&D2): 06/19/98 & RmAR (DOE/OR/01-1763\&D2): 02/24/99 & $\mathrm{No} / \mathrm{No}$ & -- \\
\hline \multicolumn{5}{|c|}{ Y-12 decontamination and demolition projects } \\
\hline Y-12 Building D\&D & $\begin{array}{l}\text { TC AM (DOE/OR/01-2404\&D1): 05/04/09 } \\
\text { TC AM (DOE/OR/01-2405\&D1): 05/04/09 } \\
\text { TC AM (DOE/OR/01-2406\&D1): 05/04/09 }\end{array}$ & $\begin{array}{l}\text { Start of removal action. } \\
\text { Start of removal action. } \\
\text { Start of removal action. }\end{array}$ & $\begin{array}{l}\mathrm{TBD}^{\mathrm{c}} \\
\mathrm{TBD}^{\mathrm{c}} \\
\mathrm{TBD}^{\mathrm{c}}\end{array}$ & $\begin{array}{l}-- \\
--\end{array}$ \\
\hline
\end{tabular}

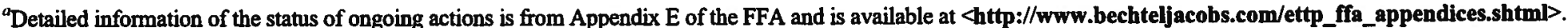

${ }^{\text {h}}$ This action was completed prior to uniform adherence to the RAR process; hence, no RAR exists for this decision.

'Action is not yet started or is in progress and, therefore, monitoring/LTS requirements are not identified.

ANAP = Abandoned Nitric Acid Pipeline

BSWTS = Big Spring Water Treatment System

EEVOC $=$ East End Volatile Organic Compound

NSC $=$ Non-Significant Change

IROD = Interim Record of Decision

WTS $=$ Water Treatment System 
Table 6.2. LTS requirements for CERCLA actions in UEFPC Watershed

\begin{tabular}{|c|c|c|c|c|}
\hline \multirow[b]{2}{*}{ Site/Project } & \multicolumn{2}{|c|}{ LTS Requirements } & \multirow[b]{2}{*}{ Status } & \multirow{2}{*}{$\begin{array}{c}\text { RER } \\
\text { section }\end{array}$} \\
\hline & LUCs & Engineering controls & & \\
\hline \multicolumn{5}{|c|}{ Watershed-scale actions } \\
\hline $\begin{array}{l}\text { ROD for Phase I } \\
\text { Interim Source } \\
\text { Control Actions in } \\
\text { the UEFPC } \\
\text { Watershed } \\
\text { - BSWTS PCCR }\end{array}$ & $\begin{array}{l}\text { Watershed LUCs } \\
\text { Administrative: } \\
\text { - land use and } \\
\text { groundwater deed } \\
\text { restrictions } \\
\text { - property record } \\
\text { notices } \\
\text { - zoning notices } \\
\text { - permits program } \\
\text { Physical: } \\
\text { - access controls } \\
\text { - signs } \\
\text { - security patrols }\end{array}$ & $\begin{array}{l}\text { - Maintenance of treatment } \\
\text { facilities }\end{array}$ & $\begin{array}{l}\text { - Physical LUCs in } \\
\text { place. } \\
\text { - Administrative } \\
\text { LUCs required at } \\
\text { completion of } \\
\text { actions. } \\
\text { - Engineering } \\
\text { controls remain } \\
\text { protective. }\end{array}$ & 6.2 .4 \\
\hline $\begin{array}{l}\text { UEFPC Union } \\
\text { Valley Interim } \\
\text { Action }\end{array}$ & $\begin{array}{l}\text { Institutional controls } \\
\text { related to groundwater } \\
\text { use. } \\
\text { - License agreements } \\
\text { - Annual property } \\
\text { owner notification } \\
\text { - Annual title } \\
\text { searches } \\
\text { - Annual water use } \\
\text { surveys } \\
\text { - Annual notification } \\
\text { to well drillers }\end{array}$ & & - LUCs in place. & 6.3 .2 .3 \\
\hline
\end{tabular}

${ }^{a}$ Remaining actions have not been implemented (e.g., West End Mercury Area).

BSWTS = Big Spring Water Treatment System

generally contaminated with depleted uranium. Cleanup of the 7-acre Y-12 Old Salvage Yard was initiated in May 2009. The salvage yard is located both within and outside the high security area of Y-12 bisected by the construction of Perimeter Intrusion Detection and Assessment System (PIDAS). In January 2009 the RDR/RAWP (DOE 2008i) was approved by the regulators. The Waste Handling Plan (DOE 20091) was approved in April. Complete disposition of all materials is expected by June 2011.

In FY 2009, the UEFPC Soils RAWP (DOE 2009m) was submitted to the regulators. This RAWP includes all remediation projects identified in the UEFPC Phase I and II RODs and sets forth a strategy for sequencing and performing these remediation activities. In addition, it integrates priorities for current planned soils remediation with proposed Integrated Facilities Disposition Program remediation activities.

Two Time-Critical Removal Actions (TC RmAs) were initiated in FY 2009 to remove legacy materials from the Alpha 5 and Beta 4 buildings and to demolish the Biology Complex Buildings. Waste Handling Plans were prepared for submission to the regulators. Completion of legacy material disposition from these facilities is anticipated by September 2011. Deactivation of the Biology Complex Facilities (Buildings 9769, 9211, 9220, 9224, and 9735) has been initiated. Demolition of these facilities is also expected by September 2011. 


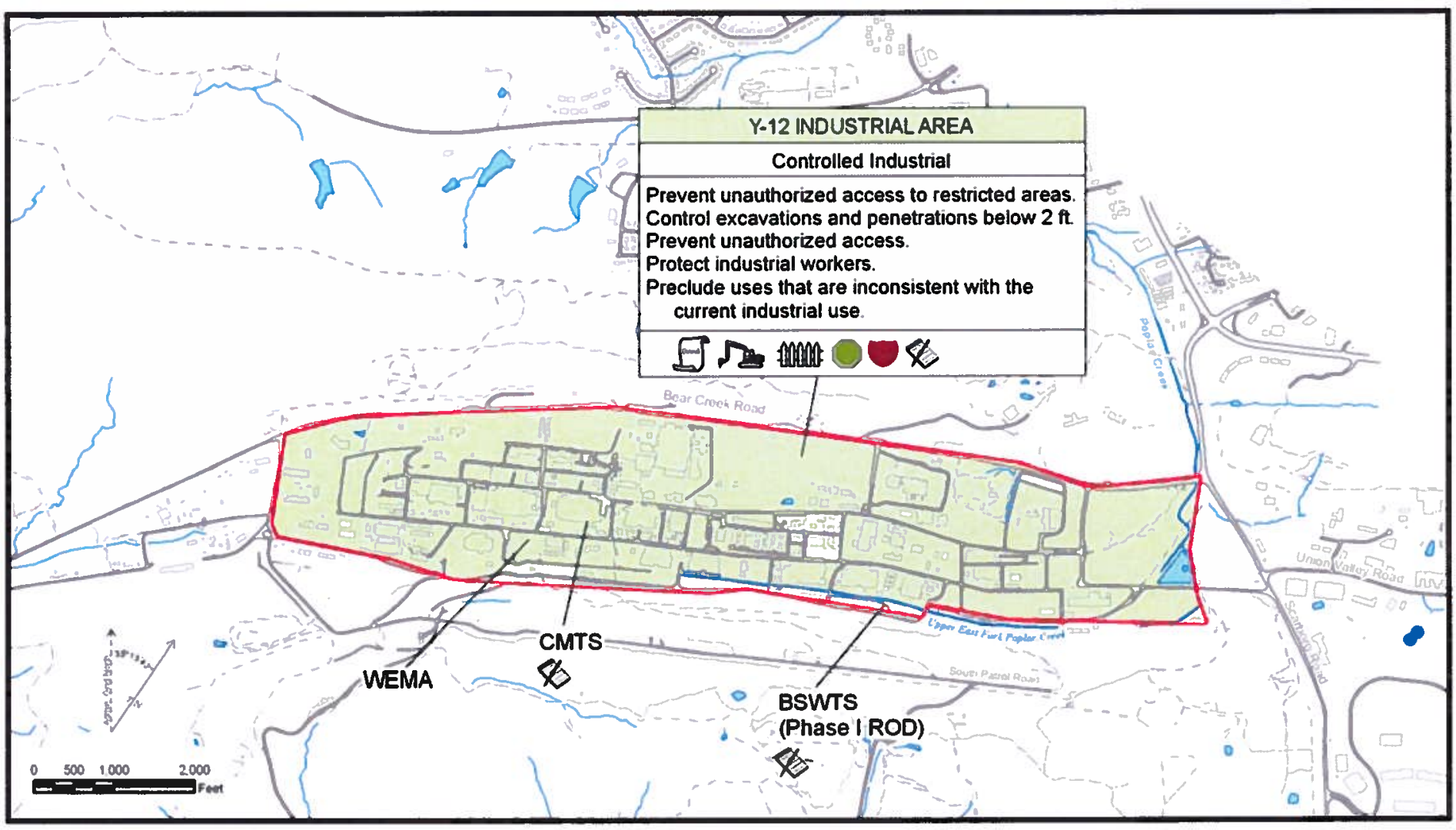

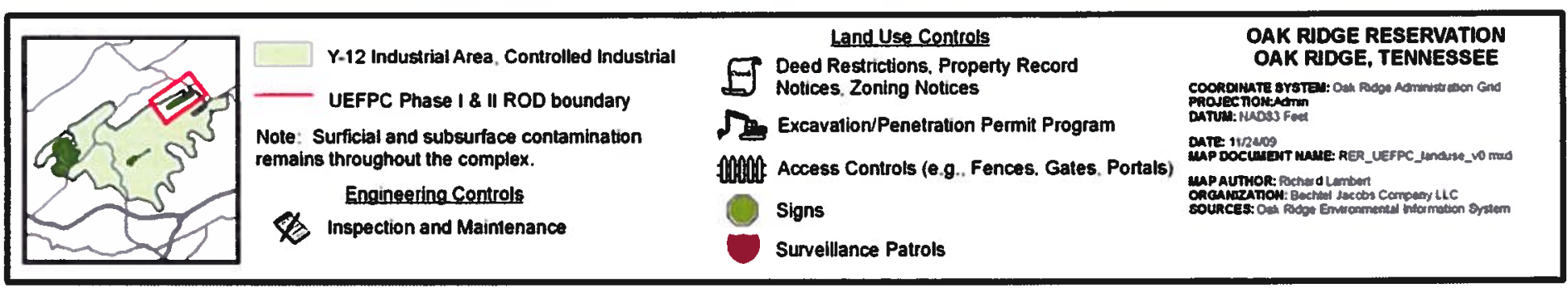

Figure 6.2. UEFPC Phase I and II ROD-designated land use and interim controls. 


\subsection{PHASE 1 INTERIM SOURCE CONTROL ACTIONS IN THE UEFPC CHARACTERIZATION AREA}

The ROD for Phase I Interim Source Control Actions (DOE 2002d) addresses a combination of source control and principal threat source material (e.g., sediment and soils) remedies designed to reduce mercury loading within UEFPC. The RAO for the selected remedy presented in the ROD is to restore surface water to human health recreational risk-based values at Station 17 (DOE 2002d). Principal components of the decision include:

- hydraulic isolation (e.g., capping contaminated soils) of the WEMA;

- removal of contaminated sediments in storm sewers, UEFPC, and Lake Reality;

- treatment of discharge from Outfall 51 (including a large-volume spring) and Bldg. 9201-2 sumps;

- temporary water treatment using existing facilities East End Mercury Treatment System (EEMTS) and the Central Mercury Treatment System (CMTS);

- LUCs to prevent consumption of fish from UEFPC and to control/monitor access by workers and the public; and

- monitoring of surface water (Station 17).

The Big Spring Water Treatment System (BSWTS) was constructed to treat discharge from Outfall 51 (including the large-volume spring) and to treat water from the Bldg. 9201-2 sumps. Mercury contaminated water was rerouted from Bldg. 9201-2 sumps and EEMTS to the BSWTS during December 2006. The EEMTS and Outfall 550 are no longer in operation.

\subsubsection{Performance Goals and Monitoring Objectives}

Performance goals and monitoring objectives of all the components of the Phase I Interim Source Control ROD are provided in Chap. 6 of Vol. 1 of the 2007 RER (DOE 2007a). Only monitoring performance goals of the actions that have been completed or are on-going are discussed in this section. These goals and objectives are summarized in Table 6.3, and monitoring locations are shown in Figure 6.1. Land use for Y-12, as identified in the Phase I ROD (DOE 2002d), is controlled industrial throughout the entire facility. (Note: The Phase I ROD only addresses surface water).

\subsubsection{Evaluation of Performance Monitoring Data - FY 2009}

\subsubsection{Surface Water Monitoring Data}

\subsection{Surface Water Quality Metrics and Monitoring Requirements}

Surface water quality metrics utilized to evaluate progress toward attainment of ROD goals are summarized in Table 6.3, and monitoring locations are shown in Figure 6.1. 
Table 6.3. Performance measures for Phase I Interim Source Control Actions in the UEFPC Watershed

\begin{tabular}{|c|c|c|c|c|}
\hline Site & UEFPC ROD goal & Performance standard & $\begin{array}{c}\text { Monitoring } \\
\text { location }\end{array}$ & Schedule and parameters \\
\hline Station 17 & $\begin{array}{l}\text { Reduce mercury levels to a } \\
\text { level protective of a } \\
\text { recreational receptor based } \\
\text { on fish consumption }\end{array}$ & $\begin{array}{c}0.2 \mu \mathrm{g} / \mathrm{L}(200 \mathrm{ppt}) \text { total } \\
\text { mercury }\end{array}$ & Station 17 & $\begin{array}{l}\text { Continuous flow-paced } \\
\text { monitoring for mercury } \\
\text { (minimum weekly collection } \\
\text { frequency); daily grab samples } \\
\text { as collected by NPDES } \\
\text { compliance program. }\end{array}$ \\
\hline $\begin{array}{l}\text { Building } \\
\text { 9201-2 WTS } \\
\text { (BSWTS) }\end{array}$ & $\begin{array}{l}\text { Reduce mercury levels to a } \\
\text { level protective of a } \\
\text { recreational receptor based } \\
\text { on fish consumption }\end{array}$ & $200 \mathrm{ppt}$ mercury & $\begin{array}{l}\text { WTS effluent } \\
\text { discharge } \\
\text { point }\end{array}$ & $\begin{array}{l}\text { Continuous flow-paced } \\
\text { monitoring for mercury and } \\
\text { metals (minimum weekly } \\
\text { collection frequency) prior to } \\
\text { and following system startup. }\end{array}$ \\
\hline CMTS & $\begin{array}{l}\text { Ongoing treatment of } \\
\text { effluents from WEMA } \\
\text { pending demonstration of } \\
\text { effectiveness of remedy } \\
\text { (hydraulic controls, capping) }\end{array}$ & $200 \mathrm{ppt}$ mercury & Outfall 551 & $\begin{array}{l}\text { Continuous flow-paced } \\
\text { monitoring for mercury } \\
\text { (minimum weekly collection } \\
\text { frequency); continue current } \\
\text { system performance monitoring } \\
\text { as required by operations and } \\
\text { maintenance specifications. }\end{array}$ \\
\hline $\begin{array}{l}\text { EEMTS no } \\
\text { longer } \\
\text { operational }\end{array}$ & $\begin{array}{l}\text { Treatment of effluents from } \\
\text { Bldg. } 9201-2 \text { sumps was tied- } \\
\text { in to BSWTS December } \\
2006\end{array}$ & $200 \mathrm{ppt}$ mercury & $\begin{array}{l}\text { Outfall } 550 \\
\text { flow piped to } \\
\text { the BSWTS in } \\
\text { December } \\
2006\end{array}$ & $\begin{array}{l}\text { Continuous flow-paced } \\
\text { monitoring for mercury } \\
\text { (minimum weekly collection } \\
\text { frequency); discontinued. }\end{array}$ \\
\hline WEMA & $\begin{array}{l}\text { Protect recreational surface } \\
\text { water users }\end{array}$ & $\begin{array}{l}\text { Reduction by } \sim 50 \% \text { of } \\
\text { mercury flux in WEMA } \\
\text { outfalls. Reduction will be } \\
\text { monitored in outfalls and is } \\
\text { anticipated within one year } \\
\text { of remediation. }\end{array}$ & $\begin{array}{l}\text { Outfalls } 160 \\
163 \text {, and } 169\end{array}$ & $\begin{array}{l}\text { Continuous flow-paced } \\
\text { monitoring for mercury } \\
\text { (minimum weekly collection } \\
\text { frequency) prior to remediation. }\end{array}$ \\
\hline $\begin{array}{l}\text { UEFPC and } \\
\text { Lake Reality }\end{array}$ & $\begin{array}{l}\text { Protect recreational surface } \\
\text { water users }\end{array}$ & $\begin{array}{l}\text { Reduction of } 70 \% \text { of Station } \\
8 \text { area ungauged mercury } \\
\text { flux and up to } 100 \% \text { of } \\
\text { ungauged mercury flux } \\
\text { between Stations } 8 \text { and } 17 \text {. } \\
\text { Reduction will be monitored } \\
\text { at Station } 8 \text { and Station } 17 \\
\text { and is anticipated within one } \\
\text { year of remediation. }\end{array}$ & $\begin{array}{l}\text { Station } 8 \text { and } \\
\text { Station } 17\end{array}$ & $\begin{array}{l}\text { Grabs at Station } 8 \text { weekly. } \\
\text { Station } 17 \text { daily (M-Th) grab for } \\
\text { mercury. }\end{array}$ \\
\hline
\end{tabular}

${ }^{\mathrm{a}}$ Baseline monitoring to start in FY 2010.

WTS $=$ Water Treatment System

The UEFPC Phase I ROD (DOE 2002d) includes a 200 ppt performance metric for mercury in surface water at the UEFPC IP (Station 17) based on an adult recreator consuming fish. Surface water monitoring at Station 17, including analysis for uranium and zinc, is conducted to gauge the cumulative effects of the various actions as they are completed. In addition, biological monitoring is performed to assess reductions of mercury in fish tissue at EFK 23.4. To achieve the watershed-wide mercury reduction objectives, individual components of the Phase I remedy have action-specific performance standards. The BSWTS, CMTS, and EEMTS effluent must meet the $0.2 \mu \mathrm{g} / \mathrm{L}$ (200 ppt) interim performance goal for mercury. 


\subsection{Surface Water Monitoring Results}

Continued monitoring of effluent from the CMTS (Outfall 551), which treats building sump discharges from the WEMA, is specified in the UEFPC Phase I ROD pending demonstration of the effectiveness of actions (e.g., hydraulic controls, storm sewer relining/replacement).

The UEFPC Phase I ROD states that the mercury limit for CMTS and EEMTS is 200 ppt. The EEMTS no longer treats groundwater from Bldg. 9201-2 sumps. EEMTS effluent (Outfall 550) is no longer monitored since the rerouting of the mercury-contaminated groundwater to the BSWTS was completed in December 2006.

The CMTS effluent discharges through Outfall 551. Effluent samples were collected from weekly composites at Outfall 551 and analyzed for mercury. The maximum mercury concentration was $79.7 \mathrm{ppt}$ on January 22, 2009, which is less than the performance standard of $200 \mathrm{ppt}$. The total volume of water treated in FY 2009 was 2,306,335 gal. A Non Significant Change (NSC) to the UEFPC Phase I ROD was approved in May 2007 so that the CMTS no longer receives water from sump pumps located in the basement of Bldg. 9201-5. The accumulated water from Bldg. 9201-5 is discharged to the sanitary system for treatment at the City of Oak Ridge's Publicly Owned Treatment Works. The CMTS continues treatment of Bldg. 9201-4 sump water (a much larger source of mercury). The CMTS experienced two periods of downtime during FY 2009: once in May and another time in June. Both times were due to power outages that lasted approximately one day.

Extensive mercury contamination exists in the WEMA as a result of historic process leaks and spills. Some of the mercury remains in the soil as elemental mercury metal. Movement of elemental mercury in the soil can occur as a result of pore pressure changes related to groundwater level fluctuations and rainfall percolation processes. As the mercury moves downward and laterally, it can seep into the subsurface storm drains through cracks and open joints. Once in the storm drains, the mercury is pushed to and accumulates in low points by the current of stormwater. Metallic mercury continues to be observed in a storm water catch basin (Manhole \#D3-418) in the WEMA southeast of Bldg. 9201-4. An estimated $1 \mathrm{lb}$ of mercury was recovered from this catch basin by Y-12 Operations personnel on March 19, 2009.

The main source of flow at Outfall 51 was Big Spring, located near the southeast corner of Bldg. 9201-2. Mercury contamination within shallow groundwater beneath and adjacent to Bldg. 9201-2 discharges at this spring. The spring discharge was captured within a brick enclosure (spring box) during Bldg. 9201-2 construction in 1943 and directed to UEFPC via a drainpipe. Big Spring flow was routed to the new BSWTS in the latter part of FY 2005 during test and start-up operations. As a result, the flow at Outfall 51 decreased significantly and consists now only of minor contributions from groundwater infiltration. While it was anticipated that construction and operation of BSWTS would cut off flow to Outfall 51, during BSWTS construction it was discovered that, in addition to flow from the spring box, Outfall 51 also provides a conduit for drainage of the BSWTS area shallow subsurface flow.

The BSWTS has been fully operational since September 26, 2005, with no significant downtime or operational problems during FY 2009. The UEFPC Phase I ROD specifies a $0.2 \mu \mathrm{g} / \mathrm{L}(200 \mathrm{ppt})$ goal for mercury in BSWTS effluent. Outfall 51 and BSWTS effluent are separate monitoring locations. Figure 6.3 provides a comparison of mercury concentrations at Outfall 51 and the BSWTS effluent. The average mercury concentration from Outfall 51 was $1.48 \mu \mathrm{g} / \mathrm{L}$ during FY 2009, which is very comparable to the $1.51 \mu \mathrm{g} / \mathrm{L}$ measured during FY 2008. The daily loading of mercury discharged from Outfall 51 ranged from 0.11 to 0.94 grams per day and averaged 0.36 grams per day based on monthly grab samples. The average BSWTS influent concentration was about $6.2 \mu \mathrm{g} / \mathrm{L}$. The BSWTS treated approximately 114.3 million gal of contaminated water, which was about 5.6 million gal more than was treated during FY 2008. Since July 2008, the BSWTS effluent is sampled continuously and weekly composite samples 
are analyzed for total mercury. The average mercury concentration in BSWTS effluent during FY 2009 was $0.025 \mu \mathrm{g} / \mathrm{L}$, which is nearly an order of magnitude less than the $0.2 \mu \mathrm{g} / \mathrm{L}$ goal specified in the UEFPC Phase I ROD. None of the weekly composite samples exceeded the $0.2 \mu \mathrm{g} / \mathrm{L}$ effluent goal during FY 2009. The FY 2009 total mercury flux discharged in the treated BSWTS effluent was approximately 11 grams. The system treatment effectiveness during FY 2009 was better than during FY 2007 and FY 2008.

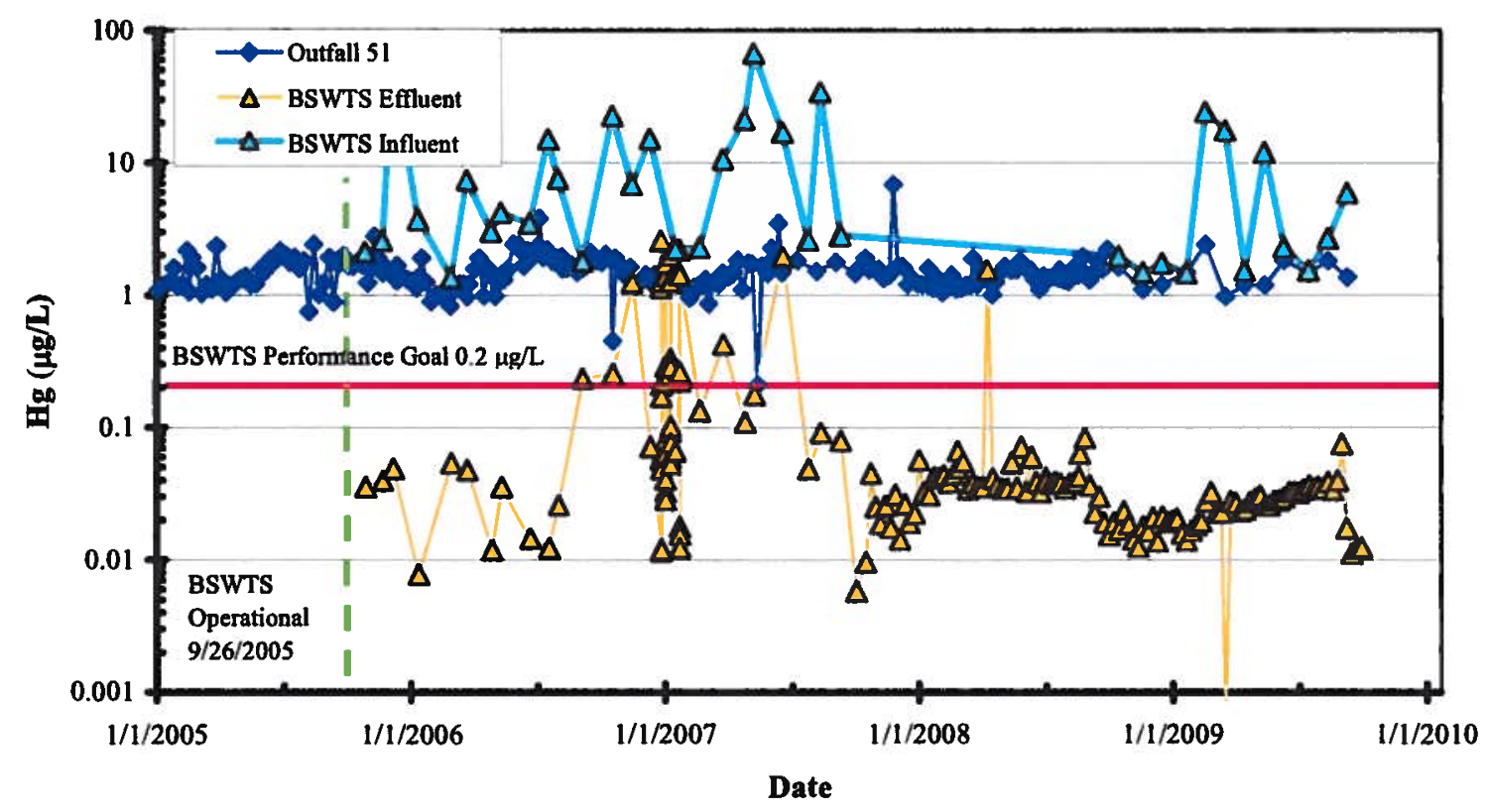

Figure 6.3. Mercury concentrations at Outfall 51 and BSWTS.

\section{WEMA (Outfall 200A6)}

Monitoring at Outfall 200A6 was modified at the beginning of FY 2007 to obtain continuous, 7-day flowpaced composite samples for mercury analysis. Outfall 200A6 is located in the main storm drain that carries discharge from the WEMA to the headwater of the UEFPC (Figure 6.1). This monitoring location serves as an IP for contamination leaving the WEMA. The flux of mercury measured at Outfall 200A6 for FY 2009 is shown on Figure 6.4. The FY 2009 flux was estimated to be about 3,500 grams, not inclusive of an anomalous mercury concentration spike that occurred in mid-July. The origin of the spike is not known, although it is thought to have been caused by uptake of solids in the sampler sometime during the week. This sediment spike may be related to a storm drain video inspection project in the WEMA. The spike was excluded from the total flux estimate because similar behavior was not reflected downstream during the July monitoring records. The average daily flux of mercury measured at Outfall $200 \mathrm{~A} 6$ was about $9.5 \mathrm{~g} / \mathrm{d}$ exclusive of the mid-July spike. This measured discharge is approximately $90 \%$ of the mercury flux discharged from the UEFPC measured at Station 17.

\section{Station 8}

Surface water monitoring at Station 8 is conducted to measure mercury concentrations and estimate mercury flux in the reach upstream to Outfall 200A6, and downstream to Station 17. Sampling consists of weekly grab sampling for mercury with a simultaneous instantaneous flow measurement. During FY 2009, the measured mercury concentrations at Station 8 ranged from 250 to $930 \mathrm{ng} / \mathrm{L}$ and averaged. 
Outfall 200A6 FY 2009 Mercury Data
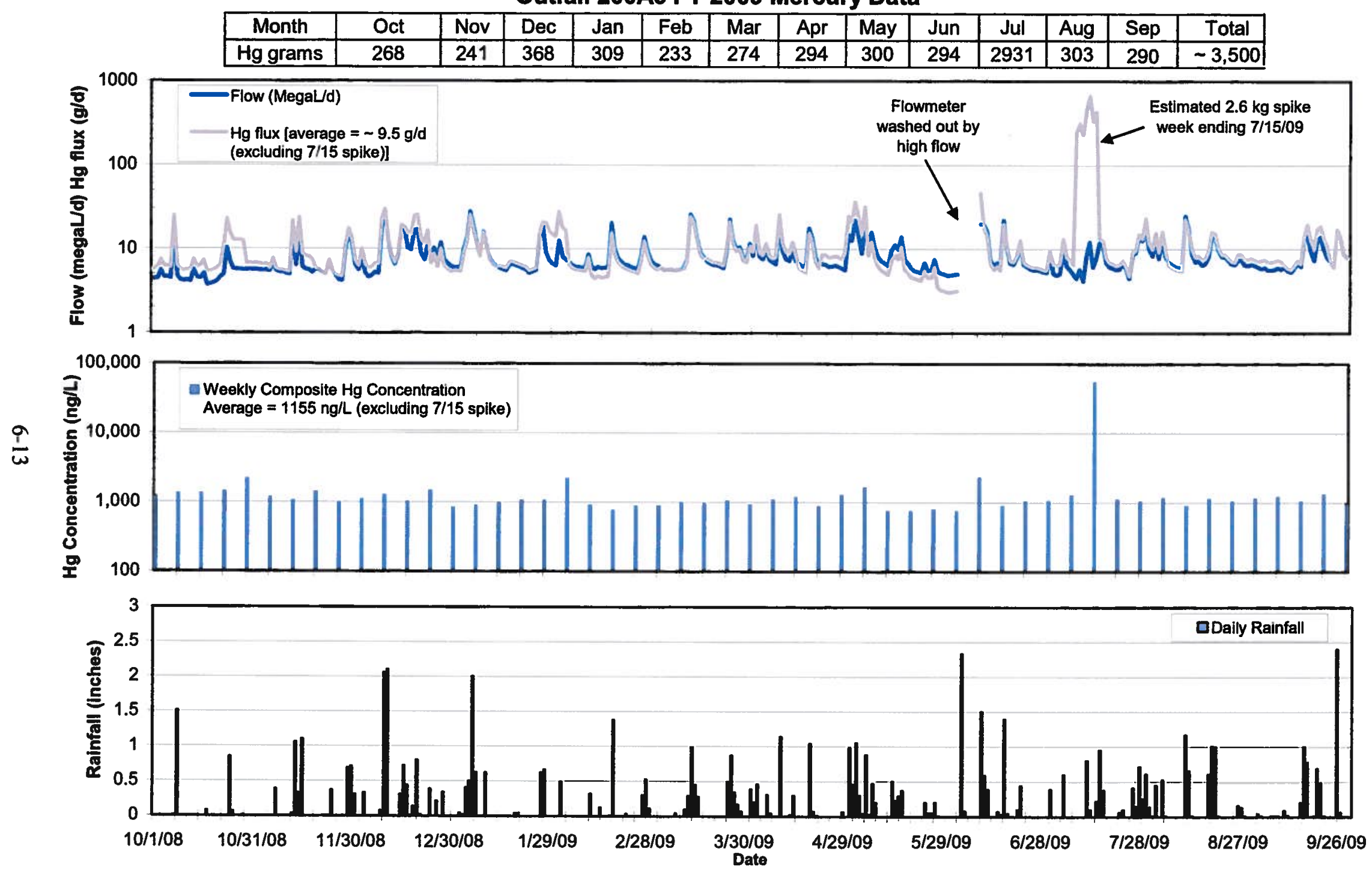

Figure 6.4. FY 2009 mercury concentrations and flux measured at Outfall 200A6. 
about $476 \mathrm{ng} / \mathrm{L}$. The daily mercury loading in UEFPC at Station 8 based on the grab samples and instantaneous flow measurements ranged from about $6 \mathrm{~g} / \mathrm{d}$ to about $51 \mathrm{~g} / \mathrm{d}$ and averaged about $13.5 \mathrm{~g} / \mathrm{d}$

\section{Station 17 (IP)}

Surface water monitoring in the UEFPC is conducted at Station 17, the IP where the stream leaves Y-12 site and DOE Property. The UEFPC Watershed remediation goals focus on reduction of mercury in surface water in and downstream of Y-12. Uranium and zinc are also COCs in UEFPC surface water.

Annual fluxes and average concentrations of uranium and mercury at Station 17 are provided in Table 6.4, Figure 6.5, and Figure 6.6. Locations of mercury source areas are shown on Figure 6.1. As shown in Table 6.4, the FY 2009 mercury discharge measured at Station 17 based on flow-paced continuous sampling data was about $3.9 \mathrm{~kg}$. About $10 \%$ of this flux is attributed to ungauged contributors from groundwater and storm drain discharges downstream of Outfall 200A6. Based on the flow-paced data, the other $\sim 90 \%$ originated from sources in the WEMA, as measured at Outfall 200A6. UEFPC RI and post-RI monitoring at four storm drain manholes in the WEMA indicate the relative importance of source areas to the overall mercury discharges. The general significance from greatest to least mercury contributions are (1) the area that drains the southern and western end of 9201-5 and 9204-4 (Outfall 169), (2) east end of 9201-5 and west end of 9201-4 (Outfall 163), (3) east end of 9201-4 and west end of 9204-2 (Outfall 150), and (4) the south side of 9201-4 (Outfall 160).

During FY 2010, continuous monitoring of mercury flux at outfalls $150,160,163$, and 169 will be started to measure mercury releases from the WEMA. Monitoring at Outfall 200A6 and Station 17 will continue.

Table 6.4. Annual uranium and mercury fluxesa and average concentrations at Station 17

\begin{tabular}{cccccc}
\hline Date & Hg flux (kg) & $\begin{array}{c}\text { Avg Hg } \\
(\mu \mathrm{g} / \mathbf{L})^{\mathbf{b} \mathbf{c}}\end{array}$ & U flux (kg) & Avg U (mg/L) & $\begin{array}{c}\text { Annual } \\
\text { rainfall (in) }\end{array}$ \\
\hline 2000 & 12.0 & $\mathbf{0 . 7 4 6}$ & 143 & 0.012 & 52 \\
2001 & 9.4 & $\mathbf{0 . 6 3 8}$ & 85 & 0.007 & 45.98 \\
2002 & 7.3 & $\mathbf{0 . 5 3 6}$ & 172 & 0.014 & 52.67 \\
2003 & 8.8 & $\mathbf{0 . 5 9 7}$ & 148 & 0.011 & 73.73 \\
2004 & 8.2 & $\mathbf{0 . 5 2 4}$ & 119 & 0.010 & 56.38 \\
2005 & 14.6 & $\mathbf{0 . 7 4 2}$ & 157 & 0.012 & 58.96 \\
2006 & 4.0 & $\mathbf{0 . 3 2 8}$ & 89 & 0.008 & 46.42 \\
2007 & 4.0 & $\mathbf{0 . 1 9 8}$ & 86 & 0.007 & 36.26 \\
2008 & 2.7 & $\mathbf{0 . 2 2 1}$ & 98 & 0.009 & 46.02 \\
2009 & 3.9 & $\mathbf{0 . 2 7 3}$ & 177 & 0.014 & 62.5 \\
\hline
\end{tabular}

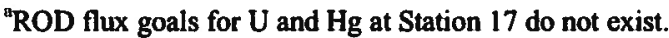

bold values exceed UEFPC Phase I ROD Hg concentration goal of $200 \mathrm{ppt}(0.2 \mu \mathrm{g} / \mathrm{L})$ for Station 17.

'Reported average is for 7-day continuous flow-paced samples. FY 2009 average $\mathrm{Hg}$ concentration from grab samples collected four days/week was $0.310 \mu \mathrm{g} / \mathrm{L}$.

Avg $=$ average 
Station 17 FY 2009 Mercury and Flow Data
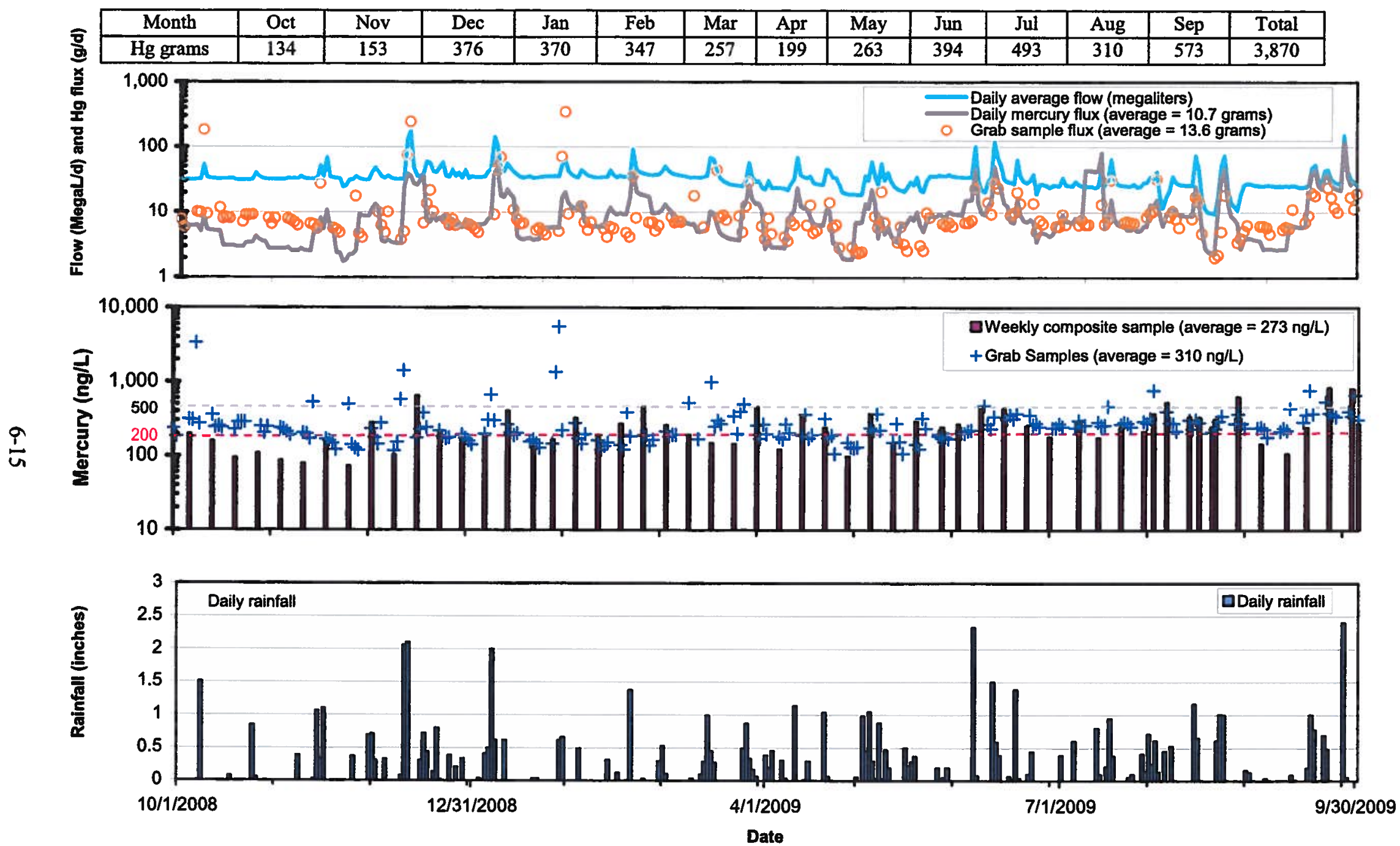

Figure 6.5. Summary of FY 2009 mercury discharge data from Station 17. 

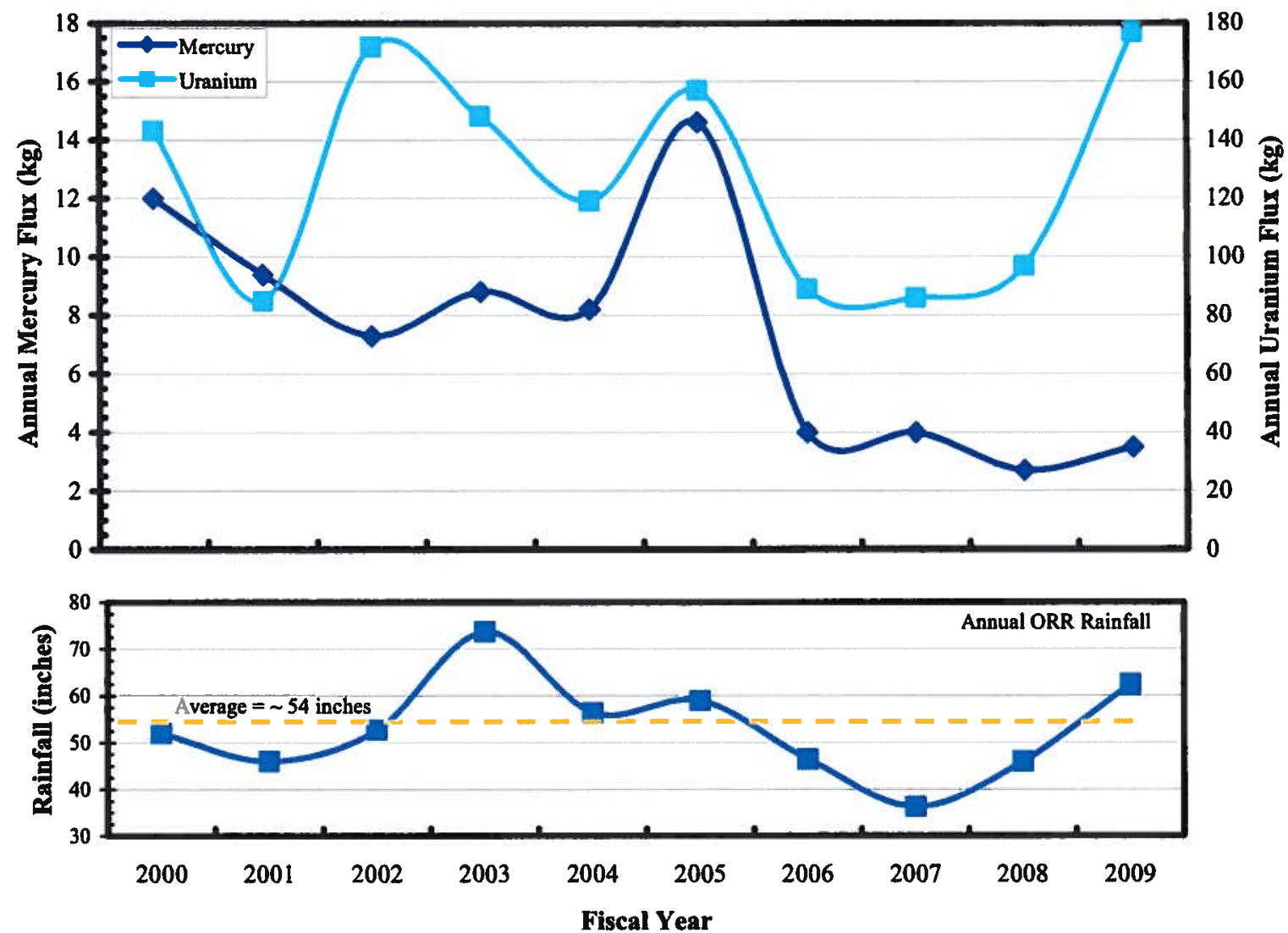

Figure 6.6. Annual mercury and uranium fluxes at Station 17 and annual ORR rainfall.

During prior years, mercury fluxes ranged from over $14 \mathrm{~kg}$ in FY 2005 to $4.0 \mathrm{~kg}$ measured in FY 2006 and FY 2007 and the lowest of $2.7 \mathrm{~kg}$ in FY 2008. The average flow-paced composite sampling mercury concentration measured during FY 2009 was $273 \mathrm{ng} / \mathrm{L}$ and the average concentration obtained from grab samples was $310 \mathrm{ng} / \mathrm{L}$. Both concentrations exceeded the ROD goal of $200 \mathrm{ng} / \mathrm{L}$. Flow-paced composite sampling is conducted to determine the average concentrations and loadings (fluxes) of contaminants in surface water, while grab sampling allows determination of instantaneous concentrations, (i.e., a "snapshot" that does not take low volume into consideration). Both sampling approaches are utilized at Station 17. The flow-paced composite average mercury concentration was lower than that obtained from grab samples collected at Station 17 on a 4 days/week frequency throughout the year. Reasons for this difference include differences in laboratory procedures for analysis and differences in the sampling processes used. The FY 2009 result reflects a continued significant improvement in conditions that started during FY 2006 when the BSWTS became operational. The mercury flux at Station 17 did increase in response to the above-average rainfall during FY 2009. However, the mercury flux increase was not large in proportion to the increase in rainfall compared to the FY 2006 through 2008 period. As shown on Figure 6.6, the mercury flux increase that occurred in 2005 near the end of three years of above-average rainfall was much greater than the increase observed during FY 2009.

Areas of radiologically contaminated groundwater in the UEFPC Watershed are shown on Figure 6.1. Uranium contamination in the UEFPC originates from groundwater seepage and storm water transport of surface contamination in Y-12. Groundwater contamination in the WEMA is a source of uranium flux from Outfall 200A6. Another significant source of uranium that may enter UEFPC is the former Oil Skimmer Basin located adjacent to the original UEFPC channel in the eastern end of the plant area. As shown in Table 6.4 and Figure 6.6, the uranium flux and average concentrations measured at Station 17 
during FY 2009 increased significantly from the drought years. The annual uranium flux is generally proportional to annual rainfall with higher uranium fluxes occurring during years of higher rainfall. The average uranium concentration measured at Station 17 was about $14 \mu \mathrm{g} / \mathrm{L}$, although three samples were equal to or greater than the $30 \mu \mathrm{g} / \mathrm{L} \mathrm{MCL}$. The maximum detected uranium concentration was $120 \mu \mathrm{g} / \mathrm{L}$.

Zinc was analyzed in weekly grab samples collected at Station 17 during FY 2009 for comparison to the AWQC $(120 \mu \mathrm{g} / \mathrm{L})$. Twenty-one of the results were below the detection limit $(10 \mu \mathrm{g} / \mathrm{L})$ and thirty-five samples yielded detectable concentrations that ranged from 10.1-127 $\mu \mathrm{g} / \mathrm{L}$. During FY 2009, one zinc sample collected on October 8, 2008 exceeded the AWQC. The average detected zinc concentration, excluding the $127 \mu \mathrm{g} / \mathrm{L}$ value, was about $27 \mu \mathrm{g} / \mathrm{L}$, which is well below the AWQC value.

\subsubsection{Other Watershed Monitoring}

\subsection{Aquatic Biological Monitoring}

The ecological health of East Fork Poplar Creek (EFPC) has been monitored since 1985. Data collected on contaminant bioaccumulation and the composition and abundance of communities of aquatic organisms provide direct evaluation of the effectiveness of abatement and remedial measures in improving ecological conditions in the stream. Since 1986, these studies have been augmented by twice yearly monitoring of aqueous mercury concentrations and speciation at sites throughout the length of EFPC.

Mercury in sunfish at EFK 23.4 (Figure 6.1) remained at levels similar to those observed for the past 20 years (Figure 6.7), showing no decreasing trend over time despite the large decrease in aqueous mercury concentration in UEFPC over time. A first glance at Figure 6.7 suggests that mercury levels in fish have increased in recent years, but this apparent trend is driven by a shift in fish species sampled rather than by an actual increase in $\mathrm{Hg}$ exposure or bioaccumulation at this site. Note that when redbreast sunfish (shown in red on Figure 6.7) could not be found at EFK 23.4, rockbass were collected instead (shown in green on Figure 6.7). Previous studies have shown that rockbass typically have $\sim 15 \%$ higher $\mathrm{Hg}$ levels than redbreast sampled concurrently from the same site, most likely because their diet includes higher trophic level organisms with greater mercury content.

There continues to be no decrease in mercury in fish in response to the abrupt change in aqueous mercury following completion of BSWTS in 2005. See Chap. 7 for additional information about mean mercury concentrations in sunfish in UEFPC and hydrologically-connected locations downstream in LEFPC and CR/PC. Mean concentrations of mercury and PCBs in stoneroller minnows at EFK 24.5 were $2.42 \pm 0.18$ $\mu \mathrm{g} / \mathrm{g}$ and $4.83 \pm 0.19 \mu \mathrm{g} / \mathrm{g}$, respectively. Mean PCB concentrations in sunfish at EFK $23.4(0.31 \mu \mathrm{g} / \mathrm{g})$ remained much lower than the peak levels observed in the mid-1990s (Figure 6.8). 


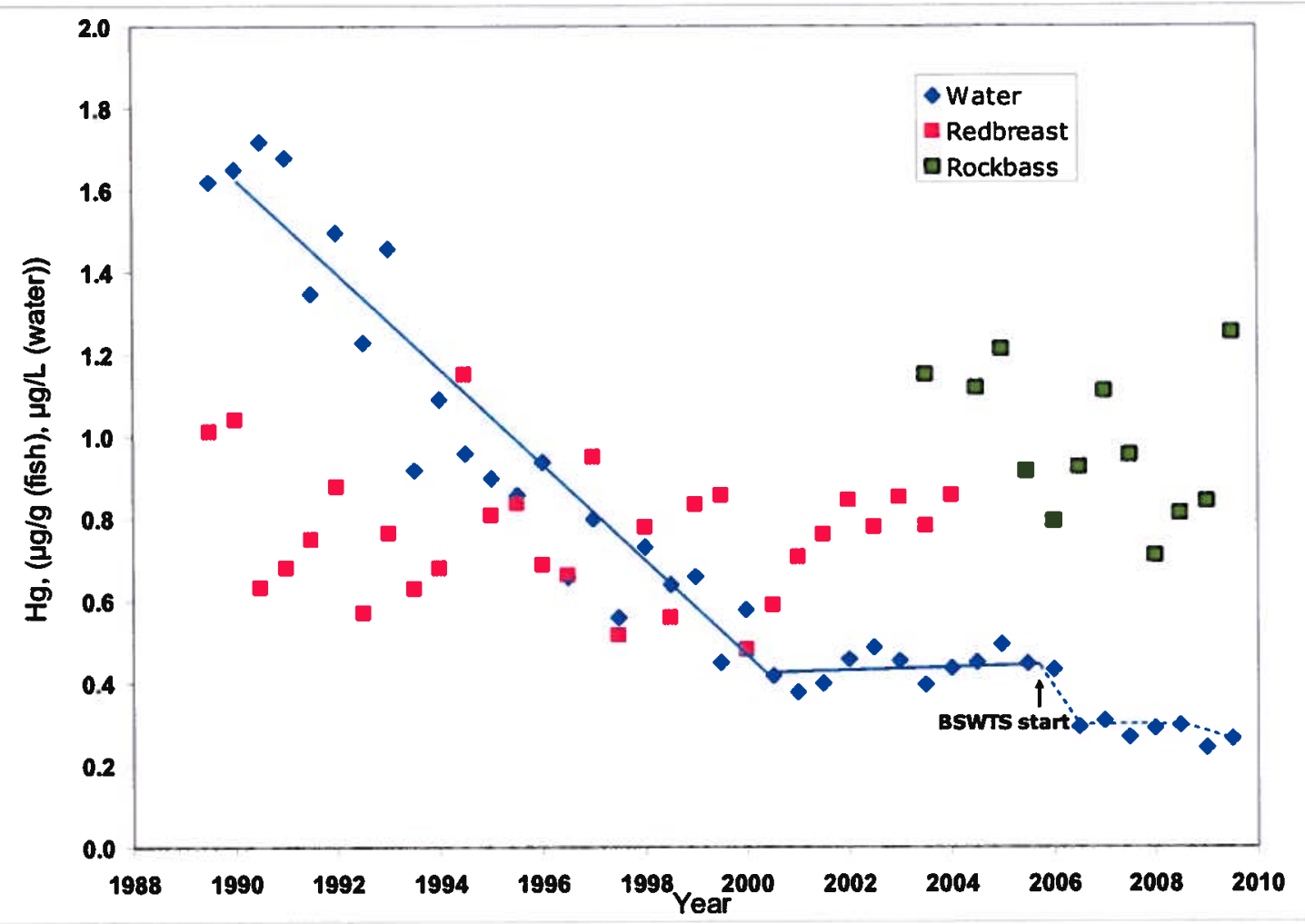

Figure 6.7. Mean concentration of mercury in redbreast sunfish and rockbass at EFK 23.4 versus trailing 6-month mean concentration of mercury in water.

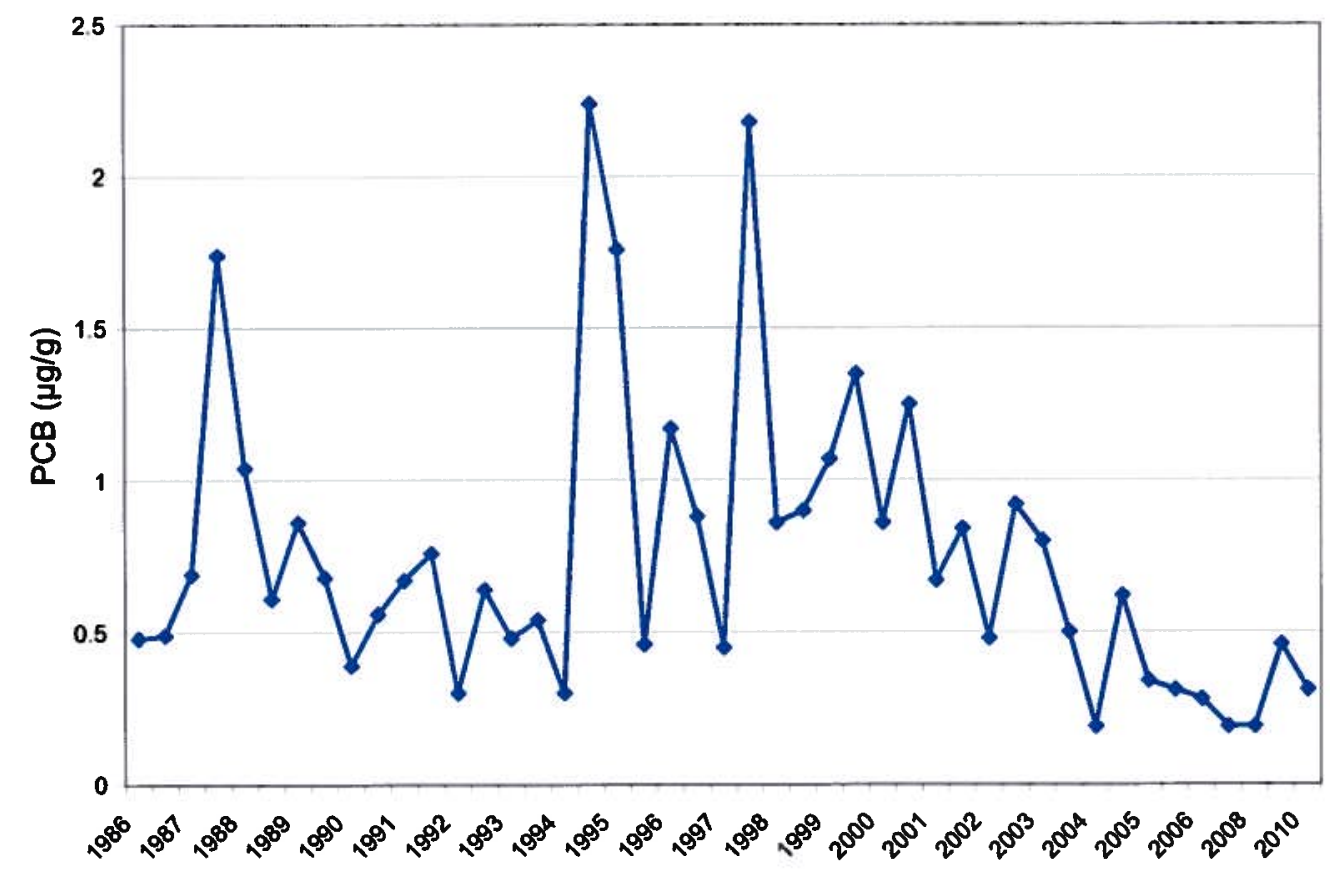

Figure 6.8. Mean concentrations of PCBs in redbreast sunfish and rockbass at EFK 23.4, 1985-2009. 
After substantial increases in the number of species at EFK 23.4 in the late 1980s and early to mid-1990s, the number of fish species has leveled out in recent years (Figure 6.9) and remains below comparable reference fish communities like BFK 7.6 (Figure 6.1). In contrast, the species richness (number of species) of the fish community further downstream at EFK 13.8 has continued to improve, often exceeding reference values. UEFPC (EFKs 24.4 and 23.4) exhibited no change from long-term trends of pollution-intolerant benthic macroinvertebrate taxa in 2009 , suggesting that the extent of recovery has stabilized to existing environmental conditions (Figure 6.10). The number of pollution-intolerant taxa at the Brushy Fork reference site in 2009 , on the other hand, was $50 \%$ lower then during the previous three years. While the reason for the reduction cannot be definitively determined, it was probably associated in part with an increased frequency of heavy rains in March and early April prior to sample collection. Flooding from heavy rain storms can increase invertebrate mortality. The apparent lack of response of the macroinvertebrate community in UEFPC from these storms is likely due to the fact that the species of pollution-intolerant taxa that have colonized the stream as recovery has progressed are some of the most tolerant of this group to environmental changes. The pollution-intolerant taxa at Brushy Fork, on the other hand, include not only those taxa similar to those occurring in UEFPC, they also include several taxa of greater intolerance to change that would be less able to tolerate frequent floods.

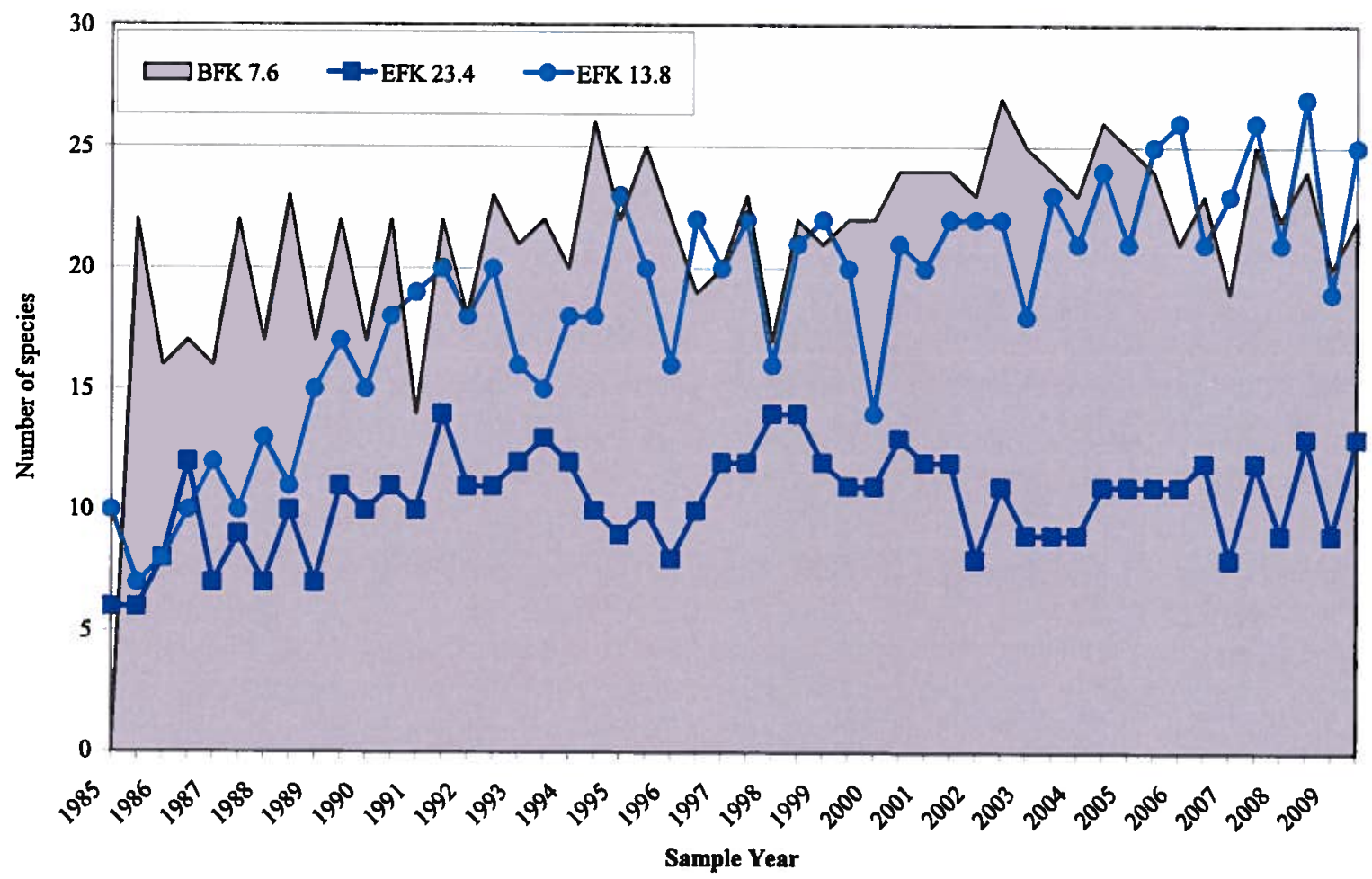

Figure 6.9. Species richness (number of species) in samples of the fish community in East Fork Poplar Creek (EFK) and a reference stream, Brushy Fork (BFK), 1985-2009. 


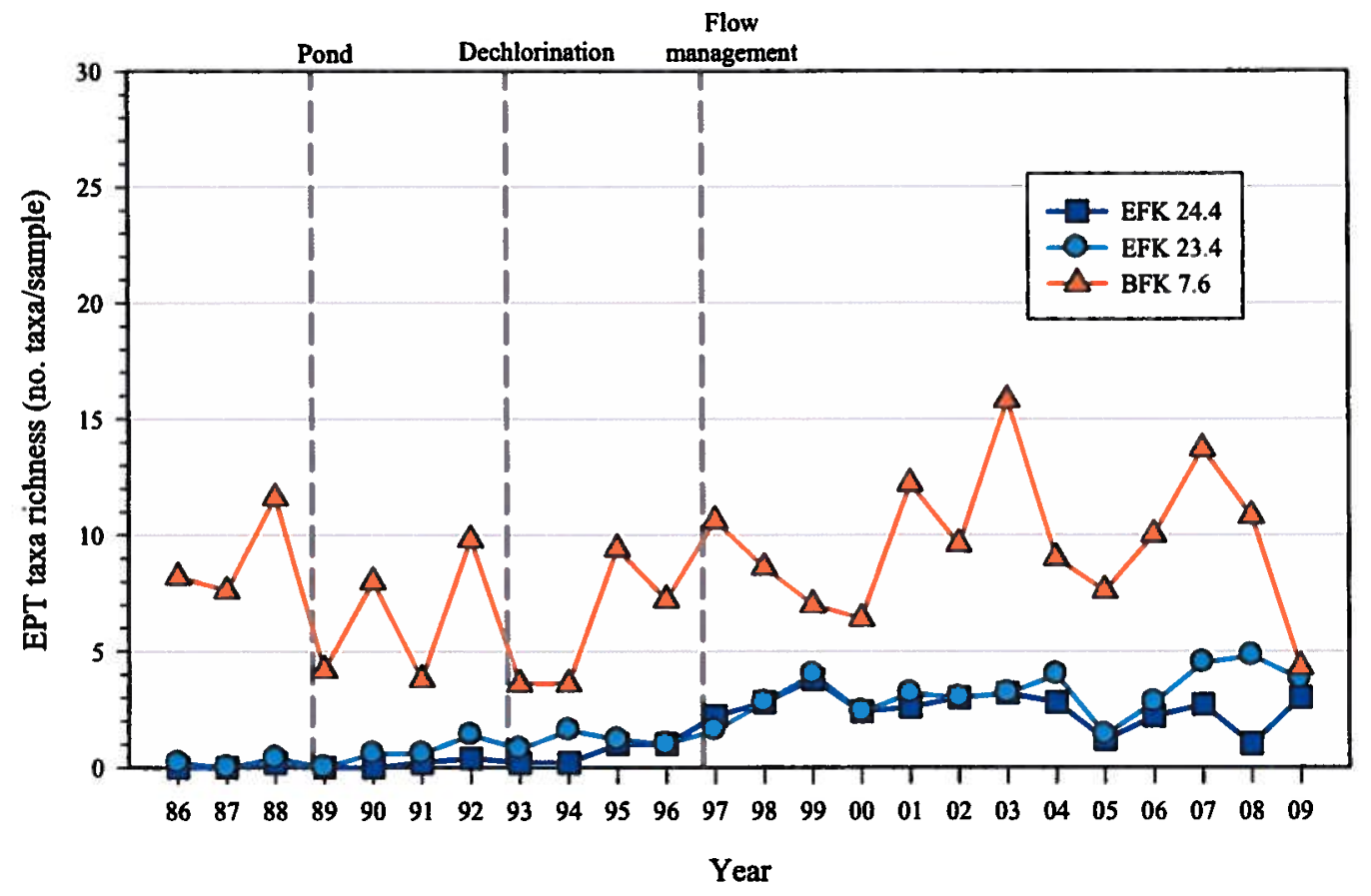

Figure 6.10. Mean ( $n=5 ; n=4$ after 2006) taxonomic richness of the pollution-intolerant taxa for the benthic macroinvertebrate community at sites in EFPC and Brushy Fork, April sampling periods, 1986-2009. a,b

${ }^{a}$ Major events in the 1980s and 1990s include New Hope Pond replacement with Lake Reality, dechlorination of discharges, and the start-up of flow management.

${ }^{b}$ EFK = East Fork Poplar Creek kilometer; BFK = Brushy Fork kilometer. EPT = Ephemeroptera, Plecoptera, and Trichoptera, or mayflies, caddisflies, and stoneflies.

\subsection{Groundwater Quality Monitoring}

The UEFPC Remedial Investigation/Feasibility Study (RI/FS) estimated that groundwater contamination underlies about half of the industrial portion of the UEFPC Watershed and VOCs, radionuclides, nitrate, and metals are the prevalent groundwater contaminants. Figure 6.1 incorporates the UEFPC RI/FS groundwater contaminant plume map that shows several areas of VOC and radiological contamination, as well as monitoring locations. Well GW-108 is a $58 \mathrm{ft}$ deep well located in the eastern portion of the S-3 Ponds Plume. Figure 6.11 shows analytical results for ${ }^{99} \mathrm{Tc}$ and nitrate in well GW-108. These contaminants, which far exceed their drinking water standards $(900 \mathrm{pCi} / \mathrm{L}$ EDE based on $4 \mathrm{mrem} / \mathrm{yr} \mathrm{MCL}$ for beta activity and photon particles for ${ }^{99} \mathrm{Tc}$, and $10 \mathrm{mg} / \mathrm{L}$ for nitrate), originate from the S-3 Ponds in a plume finger that seeps eastward into the UEFPC watershed. The data histories for both contaminants show large concentration spikes during FY 2009. The nitrate concentration spike is of lesser magnitude than a similar observation that occurred during FY 2005 and concentrations are expected to decrease from the peak near $40,000 \mathrm{mg} / \mathrm{L}$ in July. The ${ }^{99} \mathrm{Tc}$ spike was a single occurrence of a high activity near $80,000 \mathrm{pCi} / \mathrm{L}$ in January, followed by a value typical of previous data. These concentration spikes are thought to be a plume response to the above-normal rainfall of FY 2009. 


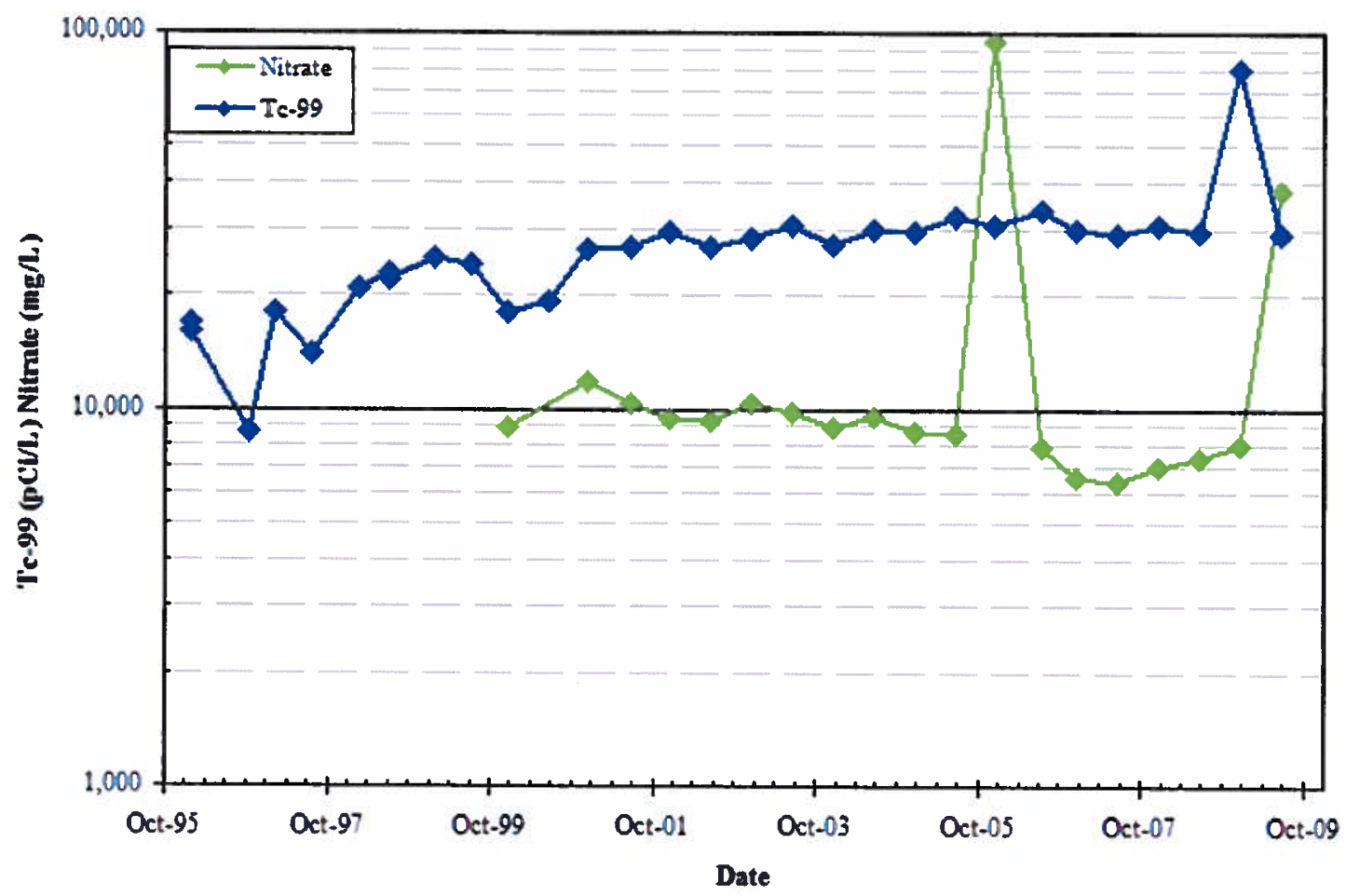

Figure 6.11. Well GW-108 nitrate and ${ }^{99} \mathrm{Tc}$ concentrations.

Wells GW-605 and GW-606 are located in the Maynardville Limestone exit pathway upgradient of the East End Volatile Organic Compound (EEVOC) plume interception and treatment system (see Figure 6.1). Well GW-605 is a relatively shallow well ( $40.5 \mathrm{ft}$ deep), while GW-606 is deeper (175 ft deep). Figure 6.12 shows concentrations of signature contaminants in wells GW-605 and GW-606. GW-605 exhibits long-term increasing trends in both VOC and alpha activity levels, although the alpha activity continued to decrease compared to levels measured in 2003. The alpha activity is associated with and unknown source of uranium contamination in groundwater in the area. The VOC concentrations are seasonally variable and exhibit a gradual decrease from levels measured during winter of 2006. Groundwater in the vicinity of GW-605 tends to follow the hydraulic gradient eastward into the edge of the EEVOC plume extraction well drawdown feature where it enters the plume treatment system. At well GW-606 concentrations of carbon tetrachloride and its degradation product chloroform have decreased since the FY 2000 time period, apparently as a consequence of EEVOC plume extraction. Nitrate was present in well GW-606 prior to initiation of groundwater withdrawal and treatment. As shown in Figure 6.12, the nitrate concentration increased after groundwater withdrawal started and has fluctuated in the concentration range between 8 and $16 \mathrm{mg} / \mathrm{L}$. During FY 2009, nitrate in GW-606 reached $16 \mathrm{mg} / \mathrm{L}$, which is the highest value measured at that location. Like the VOCs detected in well GW-605, the nitrate contamination is thought to be captured in the zone of influence of the EEVOC treatment system. Section 6.3.1 presents performance monitoring data relevant to the Y-12 East End VOC Plume removal action. 

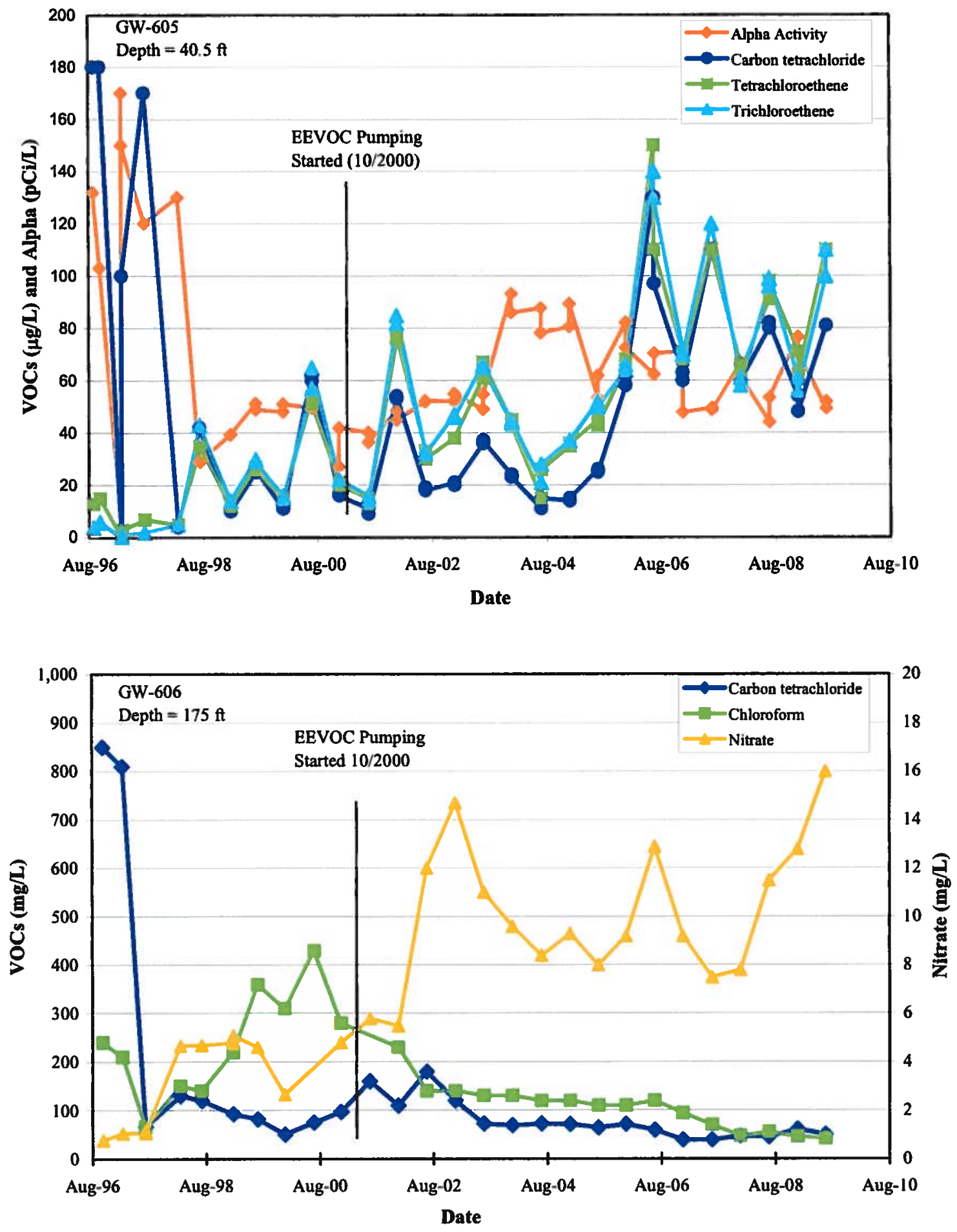

Figure 6.12. Wells GW-605 and GW-606 signature contaminant concentrations. 


\subsubsection{Performance Summary}

Surface water contaminant discharge conditions in UEFPC reflected the increased rainfall during FY 2009 relative to FY 2006 through FY 2008. During FY 2009, mercury discharges measured at the WEMA IP (Outfall 200A6) and at the watershed IP (Station 17) using flow-paced sampling were about 3.5 and $3.9 \mathrm{~kg}$, respectively. The $3.9 \mathrm{~kg}$ watershed discharge of mercury reflects the affect of aboveaverage rainfall during FY 2009. The BSWTS was fully operational during FY 2009 with no significant downtime or operational problems. The average effluent concentration for BSWTS was $0.025 \mu \mathrm{g} / \mathrm{L}$, which is less than the performance standard of $0.2 \mu \mathrm{g} / \mathrm{L}$.

Aquatic biological monitoring shows that mercury concentrations remain stable in fish tissue at EFK 23.4 near the watershed IP, although surface water mercury concentrations have decreased significantly as a result of BSWTS operation. PCB concentrations in fish tissue have apparently stabilized at about $0.2 \mathrm{ppm}$ which is a significant decrease from levels above $1 \mathrm{ppm}$ measured in 1999. Although fish and benthic communities in UEFPC are relatively stable, they continue to show impairment compared to the reference streams.

\subsubsection{Compliance with LTS Requirements}

\subsubsection{Requirements}

The UEFPC Phase I ROD (DOE 2002d) specifies LTS activities, such as maintenance and LUCs, to reduce the risk of human exposure to contaminants (see Table 6.2). Required maintenance activities include periodic inspections and repair of the WEMA asphalt caps upon completion. The LUCs include an EPP program, property record restrictions, property record notices, zoning notices, signs, and surveillance patrols for the former mercury use areas in $\mathrm{Y}-12$.

\subsubsection{Status of Requirements for FY 2009}

Because not all of the UEFPC Phase I ROD actions have been completed, no maintenance activities and LUCs were verified as part of this action in FY 2009. However, Y-12 is an active federal installation and many of the LUCs in the UEFPC are already in place to prevent consumption of fish from UEFPC and to control/monitor access by workers and the public, including an ongoing EPP program. Signs are in place and the security patrols continue to provide protection. Operation and maintenance of water treatment systems (CMTS and BSWTS) are discussed in Sect. 6.2.2. 


\subsection{COMPLETED SINGLE ACTIONS IN UEFPC WATERSHED WITH MONITORING AND/OR LTS REQUIREMENTS}

\subsubsection{Y-12 East End VOC Plume Removal Action}

The EEVOC Plume Removal Action was initiated in October 2000 as a non-TC RmA documented in an AM (DOE 1999b). Construction of the extraction/treatment system began in May 2000 and operation of the system started in October to prevent further migration of the VOC-contaminated groundwater plume off the ORR. At the request of the regulators so that performance could be evaluated, the system operated for five years before preparation and approval of the RmAR in FY 2006 (DOE 2006c). The RmAR recommended continuation of the current plume interception system and specified evaluation of the system performance in the annual RER.

\subsubsection{Performance Goals and Monitoring Objectives}

The goals of the action are to "reduce health and environmental risks associated with the migration of VOC-contaminated groundwater from the east end of Y-12. In addition, the action will reduce the potential risk from exposure to this contamination in off-site areas." The AM also includes a goal to mitigate off-site migration of contaminants. No specific numeric performance standards were established for the selected alternative. Existing human health or ecological risks specific to groundwater were evaluated during the UEFPC RI (DOE 1998a) and a Union Valley Interim Study was incorporated into the removal action. The risk assessments presented in the Union Valley Interim Study addressed hypothetical risks related to groundwater use, as well as potential risk related to exposure to spring discharges in Union Valley. These risk estimates form a comparative baseline for future performance evaluations in CERCLA FYRs.

As stated in the AM (DOE 1999b), system performance is measured by evaluating reductions in VOC concentrations downgradient of the extraction well (GW-845). The RmAR identified changes to monitoring frequencies and analysis, which were implemented in the FY 2007 monitoring. Quarterly sampling is performed on extracted groundwater from GW-845 with analysis including VOCs, metals, nitrate, and uranium. Additional analysis is performed on the effluent from the treatment system discharging to UEFPC. The performance goal of the treated effluent is to meet the AWQC recreational (for organism only) criteria ( $16 \mu \mathrm{g} / \mathrm{L}$ carbon tetrachloride). Semiannual sampling is performed at the downgradient multiport well (GW-722) and downgradient well cluster (GW-169 and GW-170) for VOCs analysis.

\subsubsection{Evaluation of Performance Monitoring Data}

\subsection{Groundwater Monitoring Data}

Figure 6.13 and Figure 6.14 show the EEVOC chlorinated hydrocarbon concentrations before pumping at well GW-845 was started in FY 2000 and in FY 2009 showing the region of maximum contaminant removal, respectively. Concentrations represent the sum of chlorinated volatile organic compounds (CVOCs). Two distinct contaminant sources are evident - a carbon tetrachloride source near the southwestern portion of the plume and a source of PCE and TCE near the northwestern portion of the plume. Comparison of the two figures shows that the groundwater pump and treat system has decreased CVOC concentrations along the extent of the southern half of the plume while concentrations along the northern edge have remained essentially constant. This contrast is attributed to the occurrence of less permeable bedrock at the base of the Maynardville Limestone and Nolichucky Shale contact area. The groundwater extraction system has fairly effectively withdrawn contaminant mass from the more 


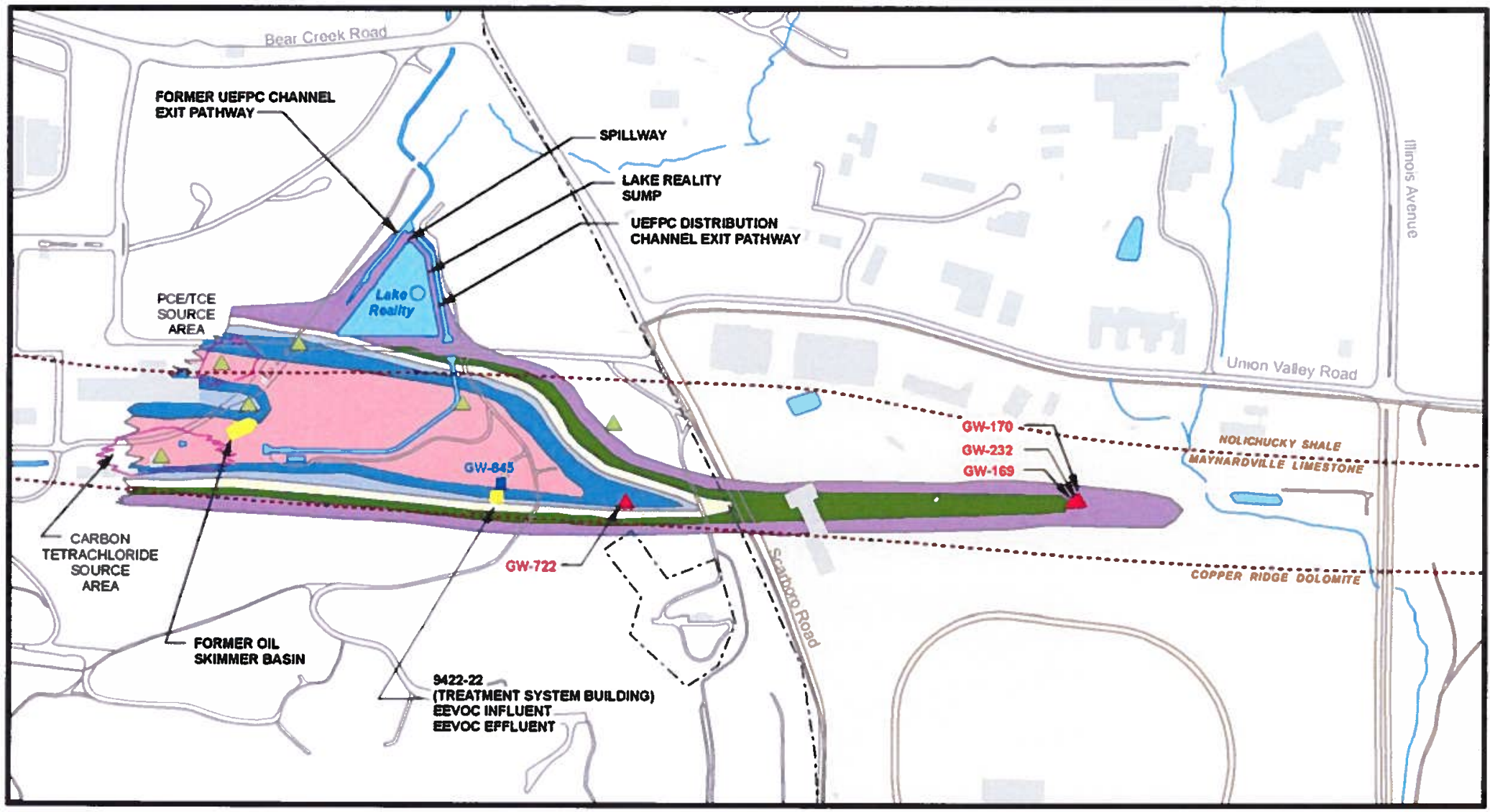

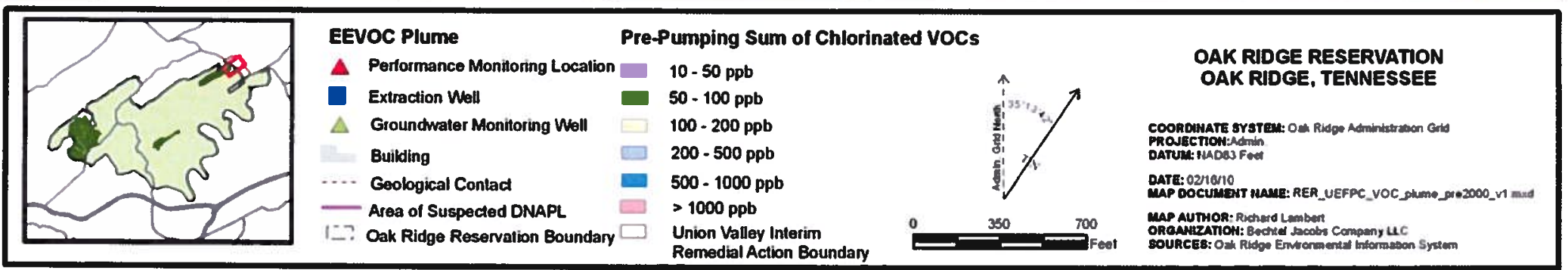

Figure 6.13. EEVOC Plume before pump and treatment system startup (1998-2000). 


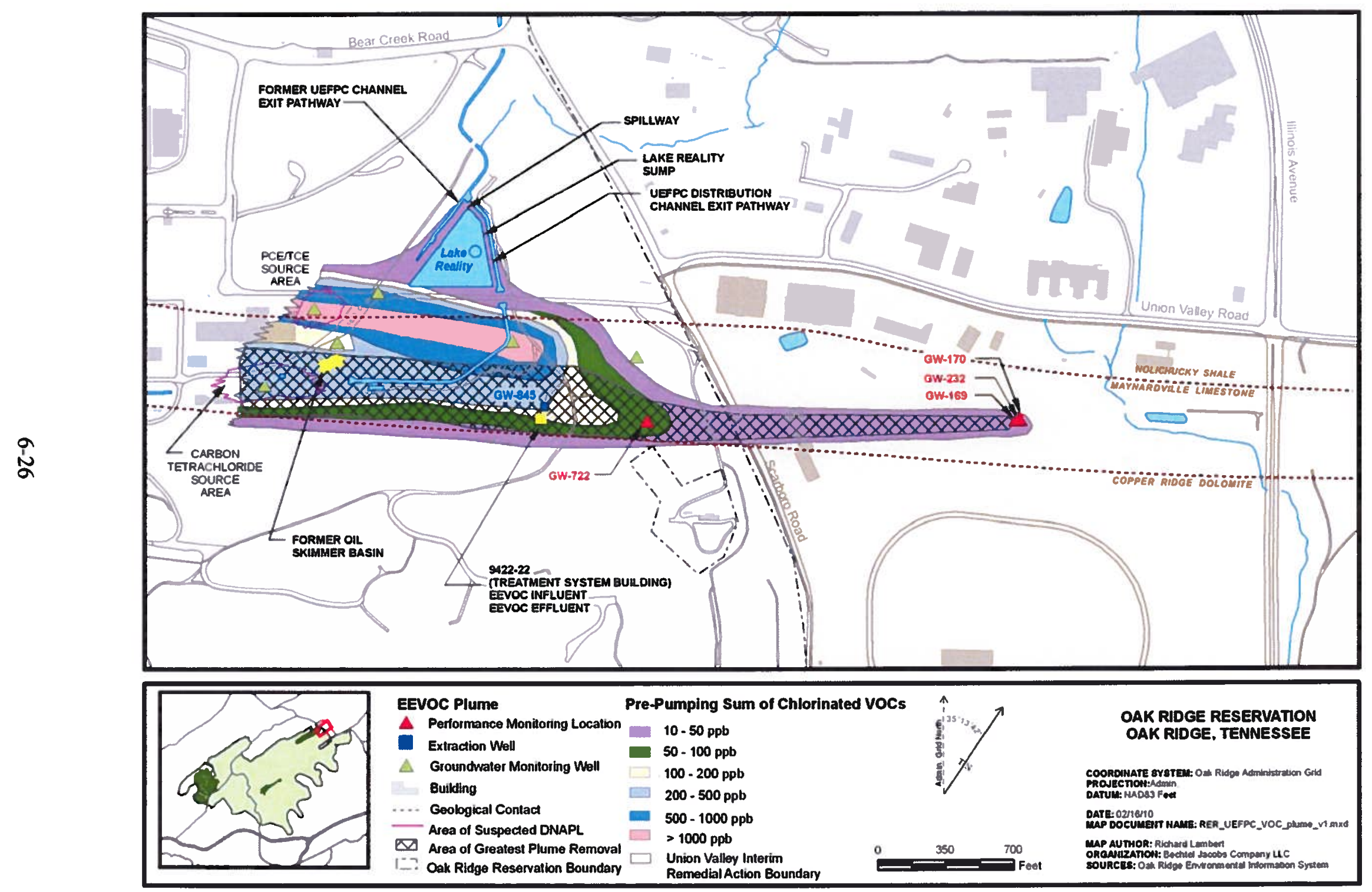

Figure 6.14. EEVOC Plume in FY 2009 showing region of maximum CVOC removal. 
permeable limestone area, but the contaminated groundwater is not as effectively withdrawn from the shaley bedrock. PCE and TCE are detected at low concentrations in the extracted groundwater that is sent to the treatment system, suggesting that there is capture of that portion of the plume, although the mass removal is small. Figure 6.15 shows the drawdown feature created by pumping of well GW-845 in plan view and in cross-sectional views. The asymmetrical drawdown feature is created because of the dipping attitude of bedrock and spatial variability of permeability. The screened interval of well GW-845 is $280 \mathrm{ft}$ long, as shown in Figure 6.15, which allows the well to capture contaminants from a large vertical region in bedrock. This extensive vertical capture capability increases the likelihood that this system will intercept contaminants seeping eastward in the Maynardville Limestone from source areas to the west in $\mathrm{Y}-12$ industrial area.

As stated in the AM (DOE 1999b), system performance is measured by evaluating reductions in VOC concentrations downgradient of the extraction well (GW-845). The RmAR specified quarterly sampling and analysis at the extraction well; well GW-722 located approximately $180 \mathrm{~m}$ (600 ft) downgradient of

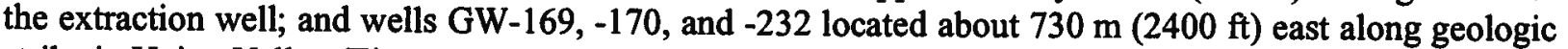
strike in Union Valley (Figure 6.13). Additional analyses for uranium, mercury, and nitrate were specified to evaluate whether long-term pumping mobilizes metals, radiological contaminants, or nitrate from upgradient sources within Y-12, such as the former Oil Skimmer Basin located approximately $300 \mathrm{~m}$ $(1000 \mathrm{ft})$ west of well GW-845 (Figure 6.13). Consistent with recommendations in the approved 2006 RER FYR and RmAR (DOE 2006c), sampling of well GW-232 in Union Valley has been discontinued and sampling frequency and target analytes at other AM-specified wells have been modified.

Treated groundwater is continuously discharged into the UEFPC. The RmAR requires at least quarterly sampling and analysis of influent and effluent for VOCs, metal, nitrate, and uranium. The TDEC AWQC for carbon tetrachloride (currently $16 \mu \mathrm{g} / \mathrm{L}$ ) is the ARAR applicable to this treated discharge, as discussed in Sect. 6.2.1.2.3.

\subsection{Maynardville Limestone Exit Pathway}

The EEVOC influent station is a valved sample port allowing collection of water before treatment and represents groundwater concentrations from well GW-845 completed in the Maynardville Limestone Exit Pathway. Data obtained to date indicate that carbon tetrachloride concentrations in the pumping well have stabilized at about $200 \mu \mathrm{g} / \mathrm{L}$ or less (Figure 6.16). Likewise, chloroform concentrations have stabilized at about 10 to $15 \mu \mathrm{g} / \mathrm{L}$.

Signature VOCs within the intermediate and deep intervals of the Maynardville Limestone directly downgradient of the pumping well (Figure 6.13) also decreased significantly relative to baseline data. This pathway is monitored via well GW-722 (Port 14 at $425 \mathrm{ft} \mathrm{bgs,} \mathrm{Port} 17$ at $385 \mathrm{ft}$ bgs, Port 20 at $333 \mathrm{ft}$ bgs, and Port 22 at $313 \mathrm{ft}$ bgs). The ports discussed here contain the highest concentrations of contaminants. Other ports in well GW-722 are sampled by the Y-12 Groundwater Protection Program. That monitoring confirms that carbon tetrachloride, PCE, and TCE are generally not detected or occur at concentrations below MCLs in other ports since the pump and treatment operation started. The FY 2009 analytical results for several signature VOCs in well GW-722, Port 17, are provided in Table 6.5. Sample Port 17 has historically shown some of the highest and most consistent VOC results; therefore, data from this sampling point are used to best illustrate carbon tetrachloride trends over time (Figure 6.16). Since operation of the extraction system, carbon tetrachloride concentrations has decreased from the 200 $1,000 \mu \mathrm{g} / \mathrm{L}$ range to less than $50 \mu \mathrm{g} / \mathrm{L}$. Overall, since system operations began, concentrations of PCE have decreased by a factor of about ten and similar trends have also been noted for TCE and DCE. The other sampling zones in well GW-722 show similar decreases in VOC concentrations. 
This page intentionally left blank.

6-28 

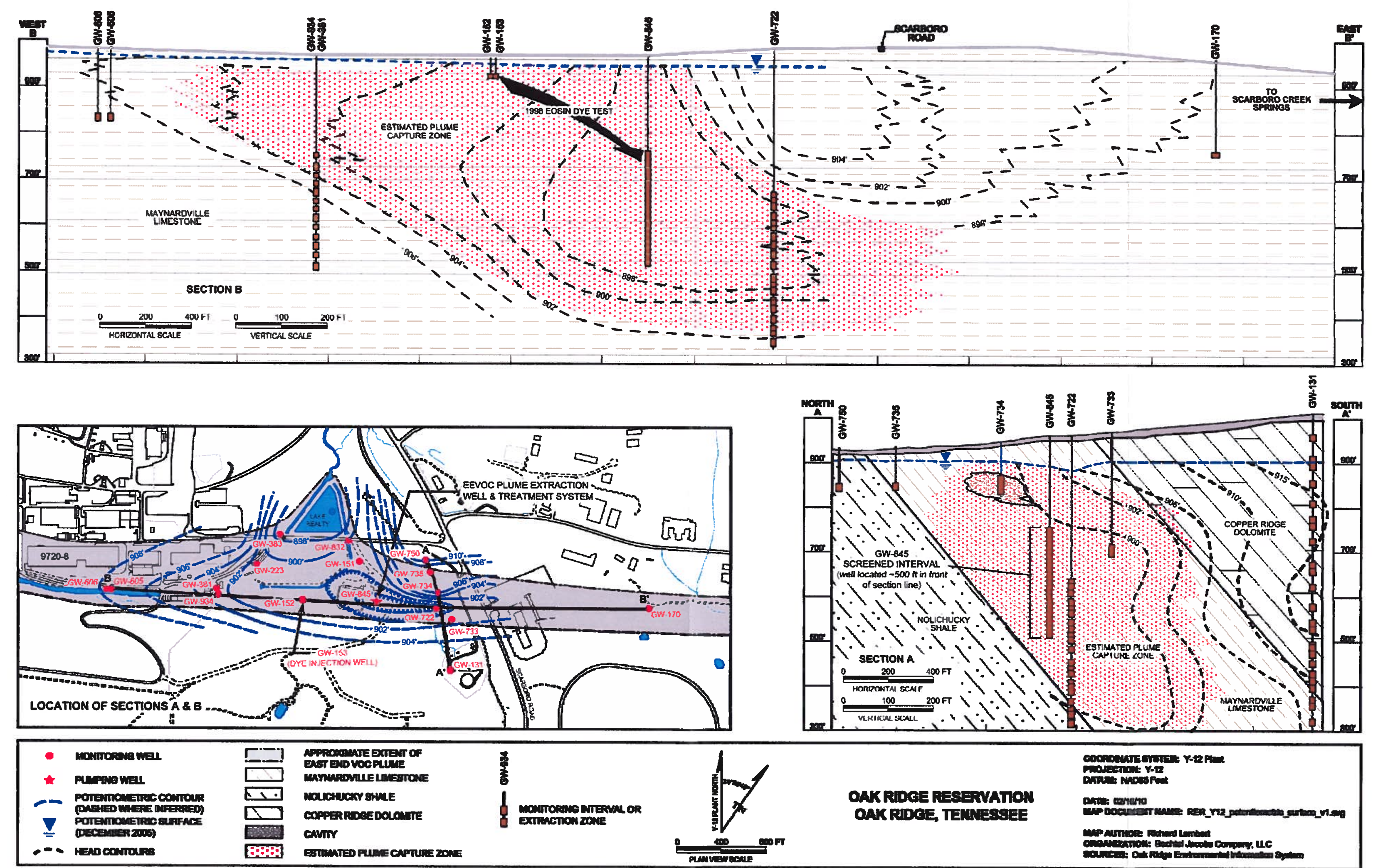

Figure 6.15. Potentiometric surface at the eastern Y-12 area 
This page is intentionally left blank. 

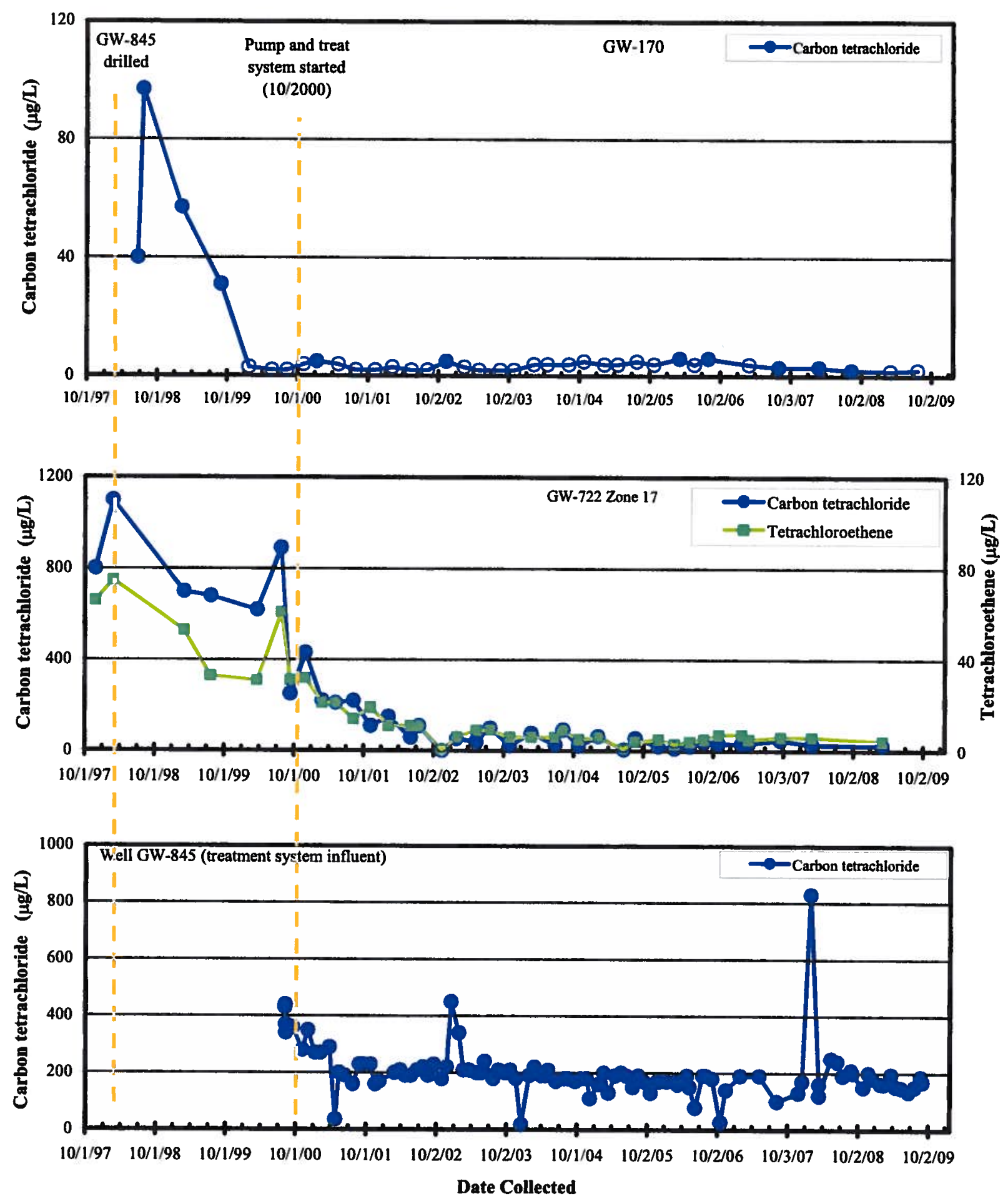

Open symbol indicates estimated ( $\mathrm{J}$ qualified) result less than required reporting limits

Figure 6.16. Selected VOC trends in the Maynardville Limestone exit pathway. 
Table 6.5. Selected FY 2009 data for Y-12 EEVOC Plume performance

\begin{tabular}{|c|c|c|c|c|c|}
\hline Chemical & $\begin{array}{c}\text { Station Name } \\
\text { Sample Date } \\
\text { Units } \\
\end{array}$ & $\begin{array}{l}\text { GW-169 } \\
3 / 4 / 2009\end{array}$ & $\begin{array}{c}\text { GW-169 } \\
7 / 23 / 2009\end{array}$ & $\begin{array}{l}\text { GW-170 } \\
3 / 4 / 2009\end{array}$ & $\begin{array}{c}\text { GW-170 } \\
7 / 23 / 2009\end{array}$ \\
\hline Alpha activity & $\mathrm{pCi} / \mathrm{L}$ & 4.66 & $<2.21(\mathrm{U})$ & $<3.98(\mathrm{U})$ & $<2.31$ (U) \\
\hline Beta activity & $\mathrm{pCi} / \mathrm{L}$ & 6.09 & 7.44 & $11.7 \pm 2.96$ & $13.6 \pm 2.57$ \\
\hline Carbon tetrachloride & $\mu \mathrm{g} / \mathrm{L}$ & $2.5 \mathrm{U}$ & $2.5 \mathrm{U}$ & $1.79 \mathrm{~J}$ & $2.1 \mathrm{~J}$ \\
\hline Chloroform & $\mu \mathrm{g} / \mathrm{L}$ & $5 \mathrm{U}$ & $5 U$ & $5 U$ & $5 \mathrm{U}$ \\
\hline Tetrachloroethene & $\mu \mathrm{g} / \mathrm{L}$ & $1.03 \mathrm{~J}$ & $1.25 \mathrm{~J}$ & $2.5 \mathrm{U}$ & $2.5 \mathrm{U}$ \\
\hline Trichloroethene & $\mu \mathrm{g} / \mathrm{L}$ & $2.5 \mathrm{U}$ & $2.5 \mathrm{U}$ & $1.08 \mathrm{~J}$ & $2.5 \mathrm{U}$ \\
\hline Nitrate & $\mathrm{mg} / \mathrm{L}$ & 0.62 & 0.35 & 0.27 & 0.22 \\
\hline Chemical & $\begin{array}{c}\text { Station Name } \\
\text { Sample Date } \\
\text { Units } \\
\end{array}$ & $\begin{array}{c}\text { GW-722-17 } \\
3 / 2 / 2009\end{array}$ & $\begin{array}{c}\text { GW-722-17 } \\
9 / 2 / 2009\end{array}$ & $\begin{array}{c}\text { GW-722- } \\
14 \\
3 / 2 / 2009\end{array}$ & $\begin{array}{c}\text { GW-722- } \\
14 \\
9 / 2 / 2009 \\
\end{array}$ \\
\hline Carbon tetrachloride & $\mu \mathrm{g} / \mathrm{L}$ & 23 & 16 & 20.3 & 26 \\
\hline Chloroform & $\mu \mathrm{g} / \mathrm{L}$ & $4.96 \mathrm{~J}$ & $4 \mathrm{~J}$ & $2.16 \mathrm{~J}$ & $2 \mathrm{~J}$ \\
\hline Tetrachloroethene & $\mu \mathrm{g} / \mathrm{L}$ & 4.21 & $1 \mathrm{~J}$ & $2.53 \mathrm{~J}$ & $4 \mathrm{~J}$ \\
\hline Trichloroethene & $\mu g / L$ & $2.5 \mathrm{U}$ & $5 \mathrm{U}$ & $1.04 \mathrm{~J}$ & $1 \mathrm{~J}$ \\
\hline
\end{tabular}

In Union Valley east of Illinois Avenue (Figures 6.13 and 6.14), signature VOCs (carbon tetrachloride, chloroform, PCE, and TCE) have historically been detected in wells GW-169 (water table interval) and GW-170 (intermediate interval; $120 \mathrm{ft}$ bgs), which are directly along strike to the east of Y-12 (Table 6.5). Well GW-170 has historically had the highest levels of carbon tetrachloride and chloroform with highly variable concentrations, but with an overall decline since 1994. Historical VOC concentrations in well GW-170 suggest that contaminant migration is episodic and may be driven primarily by rainfall events, which produce short-term concentration peaks. Since 2000, carbon tetrachloride concentrations have stabilized at about $5 \mu \mathrm{g} / \mathrm{L}$ or less. A sharp, persistent decrease of carbon tetrachloride concentrations occurred in well GW-170 prior to the EEVOC Plume treatment system start-up in October 2000, which correlated to an increase in $\mathrm{pH}$. The available data suggest that water quality in the Union Valley area west of Illinois Avenue may have been affected by large-scale construction activities near Scarboro Road, resulting in elevated $\mathrm{pH}$ conditions and increased surface water dilution in the shallow and intermediate zones of the Maynardville Limestone in this area. Signature VOCs observed in well GW-169 have remained consistently low over time at between 1 and $4 \mu \mathrm{g} / \mathrm{L}$.

Low levels of benzene ( 2 to $4 \mu \mathrm{g} / \mathrm{L}$ ) have been frequently detected in well GW-170 since first appearing in FY 2001. Benzene was not detected in FY 2002, but was routinely detected between FY 2003 and FY 2005, was detected in two of four samples collected in FY 2006, in one of two samples collected in FY 2007, and was reported at estimated ( $1 \mathrm{~J}$ ) levels in both samples collected during FY 2008, and was not detected in FY 2009. Wells that sample groundwater on DOE property in the exit pathway of the plume (GW-733, GW-722, and GW-734 shown on Figure 6.15) show less frequent and lower (estimated 1 to $2 \mu \mathrm{g} / \mathrm{L}$ ) benzene concentrations, which suggests that the benzene detected in off-site well GW-170 may not originate from the EEVOC plume. The off-site area is an industrial park. A source for benzene in the well has not been identified to date. 


\subsection{Treatment System Performance}

Treatment system performance monitoring began in November 2000 , following system startup. During FY 2009, the treatment system operated fairly reliably with minor, short-term outages (Figure 6.17).

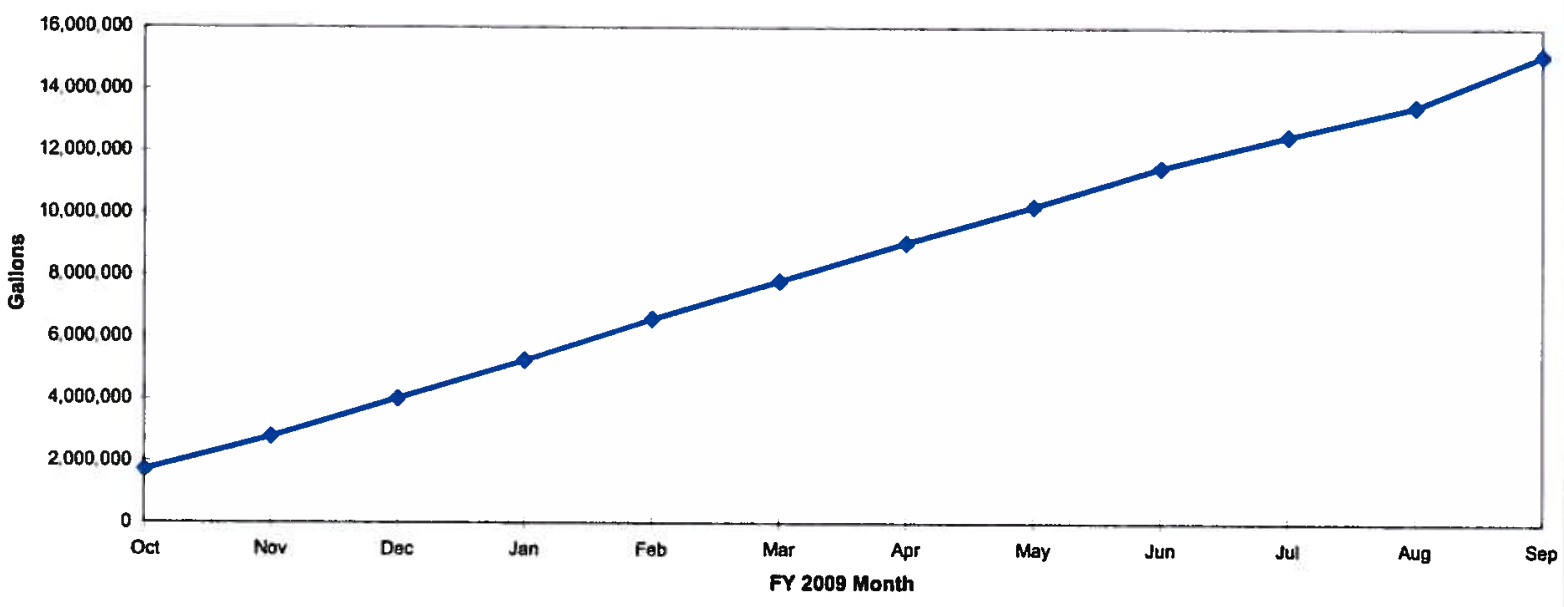

Figure 6.17. EEVOC treatment system waste operation during FY 2009.

To evaluate the effectiveness of the treatment system, influent and corresponding effluent samples have been collected since operations began. In FY 2009, concentrations of carbon tetrachloride in treatment system influent (from well GW-845) ranged from $135 \mu \mathrm{g} / \mathrm{L}$ to $200 \mu \mathrm{g} / \mathrm{L}$ and averaged $166 \mu \mathrm{g} / \mathrm{L}$ for the year (Table 6.6). The concentration range for carbon tetrachloride in the effluent stream was $12.9 \mu \mathrm{g} / \mathrm{L}$ to $104 \mu \mathrm{g} / \mathrm{L}$ and averaged $47.6 \mu \mathrm{g} / \mathrm{L}$. Removal efficiency for carbon tetrachloride averaged about $70 \%$ in FY 2009. Table 6.7 summarizes total mass removals for the principal VOCs since operations began in 2000.

An effluent concentration limit was not stipulated for the treatment system. However, to maintain protectiveness of the environment and to monitor the effectiveness of the treatment system, the EEVOC treatment system effluent is sampled and analyzed monthly for VOCs. The air stripper system performance is affected by ambient air temperature and relative humidity. During the warm, damp summer months, the effluent VOC concentrations typically increase relative to those measured during autumn and winter when relative humidity is lower. Maximum FY 2009 results of selected inorganic and radiological constituents in both influent and effluent samples are listed in Table 6.8. Reductions were observed for other signature VOCs detected in the influent stream, although removal efficiencies were lower than those observed for the carbon tetrachloride (Table 6.6 and Table 6.8).

During FY 2009, monitoring data for treatment system influent do not show any indication of substantially increased levels of total uranium or nitrate; however, an increasing trend may be appearing for ${ }^{234} U$ and ${ }^{238} U$. Figure 6.18 is a graph of the measured activities of ${ }^{234} U$ and ${ }^{238} U$ throughout the EEVOC treatment system operations to date. Prior to FY 2009, the activities were quite variable and data evaluation using the MAROS statistical data analysis software confirmed that there was no trend to data through FY 2008. Evaluation of the full dataset using the Mann-Kendall statistic indicates that the visible increase in both ${ }^{234} U$ and ${ }^{238} U$ during FY 2009 was sufficient to suggest increasing trends for both 
Table 6.6. Selected Y-12 EEVOC Plume treatment system performance data, FY 2009

\begin{tabular}{|c|c|c|c|c|c|}
\hline Chemical & Date & $\begin{array}{c}\text { Influent } \\
\text { result } \\
(\mu \mathrm{g} / \mathrm{L})\end{array}$ & 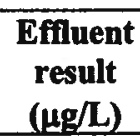 & $\begin{array}{c}\text { Percent } \\
\text { reduction }\end{array}$ & $\begin{array}{c}\text { Estimated net mass } \\
\text { removal (kg) }\end{array}$ \\
\hline Carbon tetrachloride & $\begin{array}{c}10 / 29 / 2008 \\
11 / 24 / 2008 \\
12 / 15 / 2008 \\
1 / 27 / 2009 \\
2 / 12 / 2009 \\
3 / 23 / 2009 \\
4 / 14 / 2009 \\
5 / 12 / 2009 \\
6 / 22 / 2009 \\
7 / 23 / 2009 \\
8 / 24 / 2009 \\
9 / 3 / 2009\end{array}$ & $\begin{array}{l}150 \\
200 \\
182 \\
163 \\
161 \\
195 \\
154 \\
148 \\
135 \\
151 \\
187 \\
169\end{array}$ & $\begin{array}{c}24 \\
28 \\
28.7 \\
38.5 \\
42 \\
75.7 \\
72.1 \\
62.8 \\
104 \\
64 \\
18.6 \\
12.9\end{array}$ & $\begin{array}{l}84 \% \\
86 \% \\
84 \% \\
76 \% \\
74 \% \\
61 \% \\
53 \% \\
58 \% \\
23 \% \\
58 \% \\
90 \% \\
92 \%\end{array}$ & $\begin{array}{l}0.81 \\
0.70 \\
0.71 \\
0.58 \\
0.60 \\
0.56 \\
0.39 \\
0.38 \\
0.15 \\
0.34 \\
0.61 \\
0.99\end{array}$ \\
\hline \multicolumn{2}{|c|}{ FY 2009 annual average: } & 166 & 47.6 & $70 \%$ & \\
\hline \multicolumn{2}{|c|}{ FY 2009 annual mass removal: } & & & & $6.8 \mathrm{~kg}$ \\
\hline Chloroform & $\begin{array}{c}10 / 29 / 2008 \\
11 / 24 / 2008 \\
12 / 15 / 2008 \\
1 / 27 / 2009 \\
2 / 12 / 2009 \\
3 / 23 / 2009 \\
4 / 14 / 2009 \\
5 / 12 / 2009 \\
6 / 22 / 2009 \\
7 / 23 / 2009 \\
8 / 24 / 2009 \\
9 / 3 / 2009\end{array}$ & $\begin{array}{l}13 \\
12 \\
9.52 \\
8.92 \\
9.08 \\
9.76 \\
8.77 \\
8.19 \\
7.99 \\
9.25 \\
10.6 \\
13.5\end{array}$ & $\begin{array}{c}6 \\
7 \\
5.32 \\
6.2 \\
7.33 \\
8.57 \\
6.98 \\
7.14 \\
7.78 \\
8.74 \\
4.64 \\
5 \mathrm{U}\end{array}$ & $\begin{array}{l}54 \% \\
42 \% \\
44 \% \\
30 \% \\
19 \% \\
12 \% \\
20 \% \\
13 \% \\
3 \% \\
6 \% \\
56 \% \\
63 \%\end{array}$ & $\begin{array}{c}0.05 \\
0.02 \\
0.02 \\
0.01 \\
0.01 \\
0.01 \\
0.01 \\
0.01 \\
0.001 \\
0.002 \\
0.02 \\
0.05\end{array}$ \\
\hline \multicolumn{2}{|c|}{ FY 2009 annual average: } & 10.0 & 6.7 & $30 \%$ & \\
\hline \multicolumn{2}{|c|}{ FY 2009 annual mass removal: } & & & & $0.20 \mathrm{~kg}$ \\
\hline PCE & $\begin{array}{c}10 / 29 / 2008 \\
11 / 24 / 2008 \\
12 / 15 / 2008 \\
1 / 27 / 2009 \\
2 / 12 / 2009 \\
3 / 23 / 2009 \\
4 / 14 / 2009 \\
5 / 12 / 2009 \\
6 / 22 / 2009 \\
7 / 23 / 2009 \\
8 / 24 / 2009 \\
9 / 3 / 2009\end{array}$ & $\begin{array}{c}31 \\
32 \\
24.4 \\
26.7 \\
25.8 \\
24.5 \\
23 \\
20 \\
20.9 \\
21.6 \\
24.8 \\
21.9\end{array}$ & $\begin{array}{c}6 \\
7 \\
5.55 \\
9.82 \\
11.7 \\
12.6 \\
12.3 \\
11.2 \\
18.7 \\
14.6 \\
3.83 \\
2.68\end{array}$ & $\begin{array}{l}81 \% \\
78 \% \\
77 \% \\
63 \% \\
55 \% \\
49 \% \\
47 \% \\
44 \% \\
11 \% \\
32 \% \\
85 \% \\
88 \%\end{array}$ & $\begin{array}{l}0.16 \\
0.10 \\
0.09 \\
0.08 \\
0.07 \\
0.06 \\
0.05 \\
0.04 \\
0.01 \\
0.03 \\
0.08 \\
0.12\end{array}$ \\
\hline \multicolumn{2}{|c|}{ FY 2009 annual average: } & 24.7 & 9.7 & $59 \%$ & \\
\hline \multicolumn{2}{|c|}{ FY 2009 annual mass removal: } & & & & $0.88 \mathrm{~kg}$ \\
\hline
\end{tabular}

${ }^{2}$ Estimated net mass removal is based on assumed constant flow rate of 25 gal per minute. Influent and effluent concentrations are assumed to be constant between sample events.

$\mathrm{U}=$ Result less than method reporting limits or minimum detectable activity 
Table 6.7. Estimated mass removals for key EEVOC Plume constituents since inception of treatment operations

\begin{tabular}{cccc}
\hline FY & $\begin{array}{c}\text { Carbon } \\
\text { tetrachloride }(\mathbf{k g})\end{array}$ & $\begin{array}{c}\text { Chloroform } \\
(\mathbf{k g})\end{array}$ & $\begin{array}{c}\text { Tetrachloroethene } \\
(\mathbf{k g})\end{array}$ \\
\hline FY 2001 & 9.18 & & \\
FY 2002 & 7.69 & 0.805 & 0.741 \\
FY 2003 & 9.96 & 0.396 & 0.81 \\
FY 2004 & 7.39 & 0.437 & 1.03 \\
FY 2005 & 6.33 & 0.269 & 0.832 \\
FY 2006 & 6.66 & 0.296 & 0.860 \\
FY 2007 & 5.67 & 0.338 & 0.856 \\
FY 2008 & 7.21 & 0.216 & 0.625 \\
FY 2009 & 6.8 & 0.368 & 1.07 \\
Totals & $\mathbf{6 6 . 9}$ & $\mathbf{0 . 2 0}$ & 0.88 \\
\hline
\end{tabular}

Table 6.8. Summary of Y-12 EEVOC Plume groundwater treatment system performance results, FY 2009

\begin{tabular}{lccc}
\hline \multicolumn{1}{c}{ Analyte $^{a}$} & Units & $\begin{array}{c}\text { Maximum influent } \\
\text { detect (GW-845) }\end{array}$ & $\begin{array}{c}\text { Maximum effluent } \\
\text { detect }\end{array}$ \\
\hline 2-Butanone & & & \\
Carbon tetrachloride & $\mu \mathrm{g} / \mathrm{L}$ & $10 \mathrm{U}$ & $10 \mathrm{U}$ \\
Chloroform & $\mu \mathrm{g} / \mathrm{L}$ & 200 & 104 \\
1,1-DCA & $\mu \mathrm{g} / \mathrm{L}$ & 13.5 & 8.57 \\
1,1,1-TCA & $\mu \mathrm{g} / \mathrm{L}$ & $0.3 \mathrm{~J}$ & $<5 \mathrm{U}$ \\
1,2-DCE (total) & $\mu \mathrm{g} / \mathrm{L}$ & $0.2 \mathrm{~J}$ & $<5 \mathrm{U}$ \\
Cis-1,2-DCE & $\mu \mathrm{g} / \mathrm{L}$ & $2.86 \mathrm{~J}$ & $2.16 \mathrm{~J}$ \\
Trans-1,2-DCE & $\mu \mathrm{g} / \mathrm{L}$ & $2.86 \mathrm{~J}$ & $2.16 \mathrm{~J}$ \\
PCE & $\mu \mathrm{g} / \mathrm{L}$ & $<5 \mathrm{U}$ & $<5 \mathrm{U}$ \\
TCE & $\mu \mathrm{g} / \mathrm{L}$ & 26.7 & 18.7 \\
Nitrate & $\mu \mathrm{g} / \mathrm{L}$ & 5 & $2.39 \mathrm{~J}$ \\
Total uranium & $\mathrm{mg} / \mathrm{L}$ & 0.95 & 0.96 \\
${ }^{234} \mathrm{U}$ & $\mathrm{mg} / \mathrm{L}$ & 0.019 & 0.019 \\
${ }^{235} \mathrm{MCi}$ & $\mathrm{pCi} / \mathrm{L}$ & $7.99 \pm 1.44$ & $10.4 \pm 1.83$ \\
${ }^{238} \mathrm{U}$ & $\mathrm{pCi} / \mathrm{L}$ & $0.631 \pm 0.407$ & $0.608 \pm 0.4$ \\
\end{tabular}

${ }^{a}$ All VOCs detected are listed.

GW = groundwater well

$\mathrm{U}=$ Result less than method reporting limits or minimum detectable activity

$\mathrm{J}=$ estimated value 


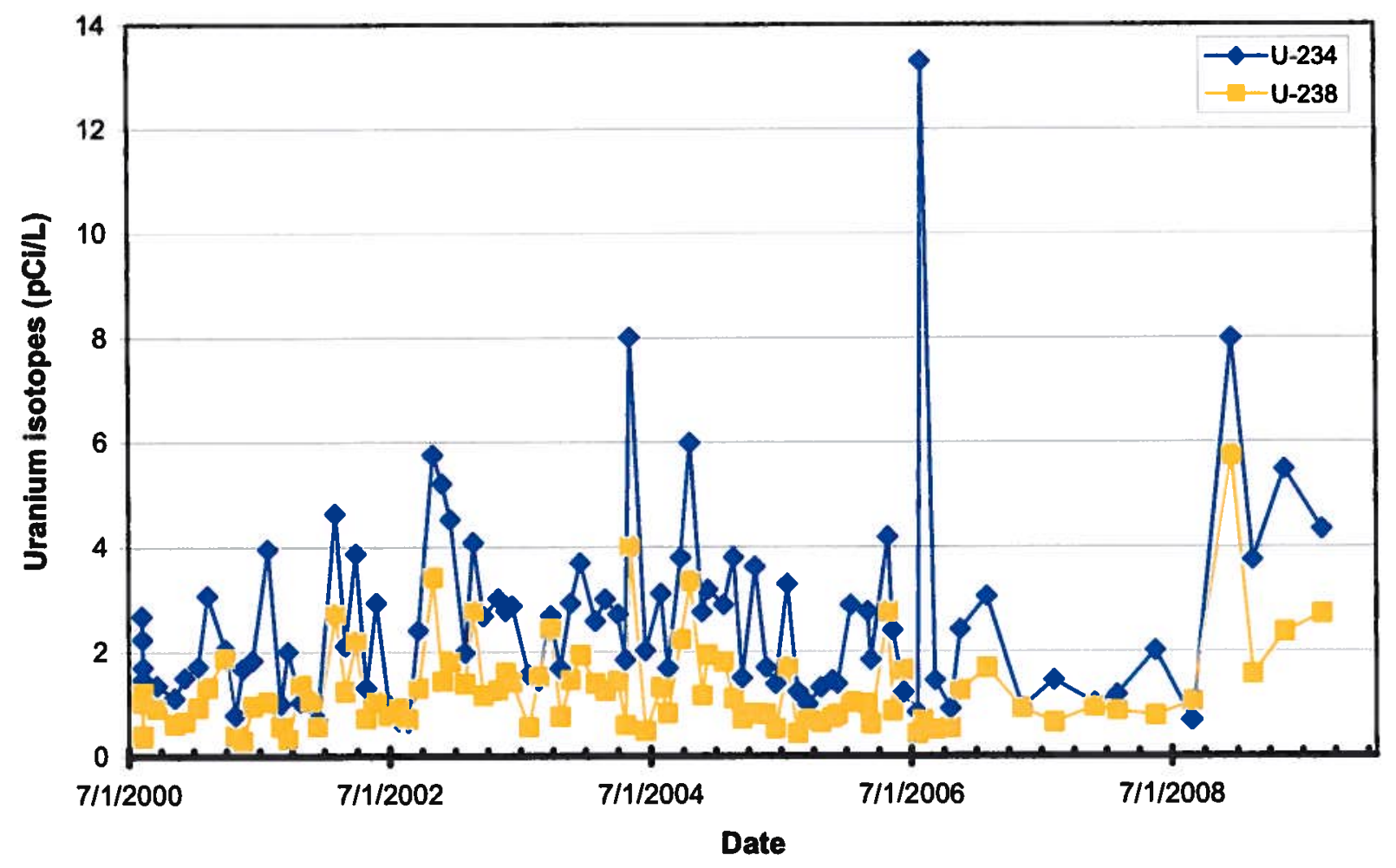

Figure 6.18. Measured activities of ${ }^{234} U$ and ${ }^{238} U$ in EEVOC treatment system influent.

radionuclides for the operational period. Linear regression analysis was less definite but indicated a probable increasing trend. Table 6.8 includes that average EEVOC treatment system influent and effluent uranium isotopic activities. The effluent levels are slightly higher than the influent levels because some evaporation occurs in the air stripper column which increases the dissolved uranium concentration slightly. The average isotopic activities in effluent equate to about $19 \mu \mathrm{g} / \mathrm{L}$, which is less than the $30 \mu \mathrm{g} / \mathrm{L}$ MCL reference concentration. Based on the average groundwater withdrawal rate throughout FY 2009, the uranium mass discharged from the EEVOC system was approximately 3 grams/day or about $1 \mathrm{~kg}$ for the year. This mass is a minor contribution to the yearly uranium mass measured at Station 17, (i.e., $177 \mathrm{~kg} / \mathrm{yr}$ ) (Sect. 6.2.2.1.2).

The AM for the EEVOC remedy acknowledged the potential for other contaminants to increase in the EEVOC collected groundwater over time as a result of the groundwater withdrawals. The AM recognized the possibility that the treatment process could be modified to accommodate treatment of other contaminants, as warranted.

\subsubsection{Performance Summary}

The EEVOC Plume treatment system performance is measured by evaluating reductions in VOC concentrations downgradient of the extraction well, GW-845. FY 2009 data indicate that the groundwater pump and treatment system has effectively withdrawn contaminant mass from the permeable limestone downgradient in Union Valley, thereby meeting the performance criteria of the AM. Increasing uranium isotopic levels in the influent and effluent streams indicate that groundwater contaminants from the Former Oil Skimmer Basin and other groundwater source areas to the west are being pulled into the extraction well zone of influence. Monitoring will continue to determine if levels continue to rise which could indicate the need, as identified in the $\mathrm{AM}$, to modify the treatment train to capture uranium in addition to treating the VOCs. 


\subsubsection{Compliance with LTS Requirements}

\subsection{Requirements}

No LTS requirements were specified in the decision documents for this site.

\subsection{Status of Requirements for FY 2009}

Although no requirements are specified, the site remained protected by the DOE 229 Boundary access controls and was regularly patrolled by security personnel. In addition, groundwater use remained restricted within Y-12 and Union Valley (See Sect. 6.3.2.3). 


\subsubsection{Union Valley Interim Action}

Location of the Union Valley Interim Action is shown on Figure 6.1. The primary objective of this interim action was to protect human health from a contaminated plume originating from beneath Y-12 and detected in the groundwater below privately owned land in Union Valley. Institutional controls were selected as the interim remedy to accomplish the following goals: ensure that public health is protected while final actions are being developed and implemented, and identify and prohibit, if necessary, future activities with a potential to accelerate the rate of contaminant migration from the characterization area (CA) or increase the extent of the contaminant plume.

Background information on this remedy and performance standards are provided in Chap. 7 of Vol. 1 of the 2007 RER (DOE 2007a).

This site has only LTS requirements. A review of compliance with these LTS requirements is included in Sect. 6.3.2.3.

\subsubsection{Performance Goals and Monitoring Objectives}

No surface water or groundwater monitoring is required as part of this interim action to verify the effectiveness of the RA. An associated action, the EEVOC Plume Removal Action, included construction of a groundwater treatment facility to prevent further migration of the VOC-contaminated groundwater plume off of the ORR into Union Valley. The EEVOC Plume performance monitoring objectives are discussed in Sect. 6.3.1 of this report.

\subsubsection{Evaluation of Performance Monitoring Data}

No surface water or groundwater monitoring is required as part of the Union Valley Interim Action. However, evaluation of performance monitoring data for the associated EEVOC Plume Removal Action is included in Sect. 6.3.1.2 of this report.

\subsubsection{Compliance with LTS Requirements}

\subsection{Requirements}

The ROD (DOE 1997c) requires that the DOE Program Office ensure that the required property title searches and appropriate notifications are made during the term of the ROD (i.e., until a final ROD is issued for the UEFPC CA). The DOE Real Estate Office is responsible for the following institutional controls:

- Complete an annual title search by the anniversary date of the ROD to determine whether any affected property has changed hands;

- Notify property owners, the Oak Ridge city manager, and the TDEC/DOE Oversight Division of their obligations under the agreements and update them on the status of the environmental investigations;

- Survey owners by telephone to determine whether any new groundwater wells have been constructed or planned or there are any new uses for surface water; and

- Notify licensed well drillers in Tennessee of the license agreements and their terms.

\subsection{Status of Requirements for FY 2009}

Compliance with all requirements was verified in FY 2009. The DOE-ORO Realty Officer provided documentation that property owners, the Oak Ridge City Manager, and TDEC-DOE/ORO had been 
notified of their respective obligations and that Tennessee licensed well drillers were notified of the license agreements and terms. Documentation that all required title searches were conducted by the anniversary date of the ROD (July $10^{\text {th }}$ ) and that property owners were surveyed by telephone, as required, was provided by the BJC Property Management Office. LUC verification information used to document these results is compiled by the BJC Property Management Office in conjunction with the DOE Realty Office. A copy of the documentation is submitted to the WRRP for use in summarizing annually in the RER the status of compliance with the LTS requirements. Original documents are maintained by the BJC PDCC for the Property Management Office.

\subsubsection{Issues and Recommendations}

No changes to the Union Valley Interim Action are recommended at this time. 


\subsection{UPPER EAST FORK POPLAR CREEK MONITORING CHANGES AND RECOMMENDATIONS}

Table 6.9 summarizes issues and recommendations for the UEFPC Watershed. No additional issues were identified from evaluation of the FY 2009 monitoring data and, therefore, no changes to the existing monitoring network are recommended at this time. Several issues remain unresolved from previous RERs and are carried forward for tracking purposes.

Table 6.9. Summary of UEFPC Watershed technical issues and recommendations

\begin{tabular}{|c|c|}
\hline Issue $^{a}$ & $\begin{array}{c}\text { Action/ } \\
\text { Recommendation }\end{array}$ \\
\hline $\begin{array}{l}2010 \text { Current Issue: } \\
\text { None. }\end{array}$ & \\
\hline $\begin{array}{l}\text { Issues Carried Forward: } \\
\text { 1. Mercury concentrations in fish within } \\
\text { the EFPC system remain elevated, } \\
\text { despite decreasing concentrations in } \\
\text { aqueous mercury levels. (2007 RER) }\end{array}$ & $\begin{array}{l}\text { 1. A team consisting of DOE EM, NNSA, and Office of Science has been } \\
\text { working together to develop a conceptual model(s) for mercury fate and } \\
\text { transport relevant to methyl mercury concentrations in the EFPC ecosystem. } \\
\text { The effort is being coordinated with the UEFPC Core Team. }\end{array}$ \\
\hline $\begin{array}{l}\text { 2. FY } 2005 \text { pre-action } \mathrm{Hg} \text { concen- } \\
\text { trations at Station } 17 \text { are above the } \\
\text { 200-ppt performance goal. } \mathrm{Hg} \\
\text { concentrations in fish in UEFPC have } \\
\text { yet to respond to commensurate } \\
\text { reductions of } \mathrm{Hg} \text { from historical } \\
\text { RMPE actions. Biota monitoring in } \\
\text { UEFPC shows impaired diversity and } \\
\text { density of pollution-intolerant } \\
\text { species. (2006 FYR) }\end{array}$ & $\begin{array}{l}2 \text { Remedial measures required by the UEFPC Phase I ROD are expected to } \\
\text { reduce Hg concentrations at Station 17, as well as in fish in UEFPC (see Issue } \\
\text { Carried Forward \#1 above). These measures include } \mathrm{Hg} \text { source removal and } \\
\text { surface water treatment. The BSWTS was fully operational during FY } 2009 \\
\text { and a corresponding decrease in } \mathrm{Hg} \text { flux from pre-action levels was observed } \\
\text { at Station } 17 \text {. Also, FY } 2009 \mathrm{Hg} \text { levels in LEFPC fish remain above federal } \\
\text { AWQC, but are less than peak levels observed in } 2001-2002 \text {. It is anticipated } \\
\text { that implementation of the Hg-source removal actions will result in a similar } \\
\text { decrease in flux at the IP. }\end{array}$ \\
\hline
\end{tabular}

\footnotetext{
"Issues are identified in the table as "ISSUES CARRIED FORWARD" to indicate that the issue is carried forward from a previous year's RER so as to track the issue through resolution.

${ }^{b}$ The year of the RER or the FYR in which the issue originated is provided in parentheses, e.g., (2007 RER).

NNSA = National Nuclear Security Administration

RMPE $=$ Reduction of Mercury in Plant Effluents
} 


\section{CERCLA OFF-SITE ACTIONS}

\subsection{INTRODUCTION AND OVERVIEW}

This chapter provides an update to completed CERCLA actions outside the DOE ORR, all of which have performance monitoring and/or LTS requirements (Table 7.1). In this section, performance goals and objectives, monitoring results, and an assessment of the effectiveness of each completed action are presented. Table 7.2 provides a summary of LTS requirements for each action and a review of compliance with those requirements is also included within the chapter.

For background information on each remedy and performance standards, a compendium of all CERCLA decisions for off-site actions is provided in Chap. 7 of Vol. 1 of the 2007 RER (DOE 2007a). This information will be updated in the annual RER and republished every fifth year at the time of the CERCLA FYR. The status of off-site long-term CERCLA decision making is provided in Figure 1.5 of Vol. 1 of the 2007 RER (DOE 2007a).

Poplar Creek, the Clinch River, and Watts Bar Reservoir comprise a single, hydrologically connected system through which contaminants originating from the ORR are transported. In September 1999, DOE recommended combining the monitoring plans for the CR/PC and LWBR OUs. This combined monitoring plan was revised in FY 2004 (DOE 2004a) to better identify and evaluate changes in COC concentrations in fish. However, the CERCLA decisions and evaluations of effectiveness are discussed separately within this report (Sects. 7.3 and 7.4).

\subsubsection{Status and Update}

DOE proposed a NSC (clarifying that the ROD decision included ecological protectiveness) to the LWBR ROD (DOE 1995c) to EPA and TDEC in December 2009. Per the 2008 RER, a Core Team will discuss changes to assure ecological protectiveness sampling in LWBR and CR/PC. Any additional or ambiguous sampling will be codified and changes, as appropriate, will be made to decision documents or provided in the applicable SAP/Quality Assurance Program Plan (QAPP).

Early morning on December 22 a retaining wall failed at the Tennessee Valley Authority (TVA) Kingston Fossil Plant in Roane County, Tennessee. More than 5.4 million cubic yards of coal ash spilled from an on-site holding pond to cover more than 300 acres of surrounding land and water. TVA, local, state and federal agencies continue to work on recovery and clean-up of the release of ash at the plant. 
Table 7.1. CERCLA actions at off-site locations

\begin{tabular}{llccc}
\hline & \multicolumn{1}{c}{$\begin{array}{c}\text { Decision document, date signed } \\
\text { CERCLA action }\end{array}$} & \multicolumn{1}{c}{ Action/Document status ${ }^{a}$} & $\begin{array}{c}\text { Monitoring/ } \\
\text { LTS } \\
\text { required }\end{array}$ & $\begin{array}{c}\text { RER } \\
\text { section }\end{array}$ \\
\hline & & Completed actions & \\
\hline LEFPC & ROD (DOE/OR/02-1370\&D2): 08/17/95 & RAR (DOE/OR/01-1680\&D5) approved 08/15/00 & Yes/Yes \\
& ESD (DOE/OR/02-1443\&D2): 11/15/96 & & 7.2 \\
CR/PC & ROD (DOE/OR/02-1547\&D3): 09/23/97 & RAR (DOE/OR/02-1627\&D3) approved 06/14/99 & Yes/Yes & 7.3 \\
LWBR & ROD (DOE/OR/02-1373\&D3): 09/29/95 & RAWP (DOE/OR/02-1376\&D3) approved 05/25/96 & Yes/Yes & 7.4 \\
\hline
\end{tabular}

${ }^{a}$ Detailed information of the status of ongoing actions is from Appendix E of the FFA and is available at <http://www.bechteljacobs.com/ettp_ffa_appendices.shtml $>$

${ }^{b}$ This action was completed prior to uniform adherence to the RAR process; hence, no RAR exists for this decision.

Table 7.2. LTS requirements for CERCLA actions at off-site locations

\begin{tabular}{|c|c|c|c|c|}
\hline \multirow[b]{2}{*}{ Site/Project } & \multicolumn{2}{|c|}{ LTS Requirements } & \multirow[b]{2}{*}{ Status } & \multirow{2}{*}{$\begin{array}{l}\text { RER } \\
\text { section }\end{array}$} \\
\hline & LUCs & Engineering controls & & \\
\hline LEFPC RA & $\begin{array}{l}\text { - Annual land use survey at Dean Stallings Ford } \\
\text { - Periodic survey to detect residential use of shallow } \\
\text { groundwater }\end{array}$ & & - LUCs in place. & 7.2 .4 \\
\hline CR/PC RA & $\begin{array}{l}\text { - Fish consumption advisories } \\
\text { - Permits for sediment disturbing activities } \\
\text { - Survey to confirm effectiveness of fish consumption } \\
\text { advisories (one time only) } \\
\text { - Survey of local irrigation practices (one time only prior } \\
\text { to issuing surface water ROD) }\end{array}$ & & - LUCs in place. & 7.3 .4 \\
\hline LWBR RA & $\begin{array}{l}\text { - Fish consumption advisories } \\
\text { - Permits for sediment disturbing activities }\end{array}$ & & - LUCs in place. & 7.4 .4 \\
\hline
\end{tabular}




\subsection{LOWER EAST FORK POPLAR CREEK REMEDIAL ACTION}

The ROD for LEFPC (DOE 1995d) addressed the mercury contamination in the floodplain sediments of the creek that runs from Y-12 (in the UEFPC Watershed) through the city of Oak Ridge (Figure 7.1). A complete discussion of the LEFPC ROD is provided in Chap. 7 of Vol. 1 of the 2007 RER (DOE 2007a).

\subsubsection{Performance Goals and Monitoring Objectives}

A major component of the selected remedy for LEFPC was for DOE to perform appropriate monitoring to ensure effectiveness of the remediation. The RAR for LEFPC (DOE 2000c) provides a description of all measures taken during the remedial activities to comply with ARARs and supplemental monitoring activities needed to support the subsequent FYR (through 2005). The following monitoring was performed during FY 2009:

- Monitored mercury inputs from UEFPC to LEFPC at Station 17. This requirement is covered by the mercury monitoring at Station 17 required by the UEFPC Phase I ROD.

- Performed an annual survey of the Dean Stallings Ford automobile dealership parking lot to ensure land use has not changed that would bring into question the protectiveness of leaving soils with $>400$ ppm mercury.

\subsubsection{Evaluation of Performance Monitoring Data - FY 2009}

As a requirement of the RAR, mercury releases from Y-12 have been, and continue to be, measured at Station 17, the point at which the government land transitions to city property along EFPC (Figure 7.1). Data are reported annually in the RERs. The average mercury concentration measured at Station 17 during 2009 was $310 \mathrm{ng} / \mathrm{L}$, which exceeds the $200 \mathrm{ng} / \mathrm{L}$ goal. A full discussion of the historical and current trends in mercury releases at Station 17 is presented in Chap. 6, Sect. 6.2.2.1.2 of this RER.

The effect of the upstream mercury source in EFPC and downstream dilution on mercury bioaccumulation in sunfish is depicted in Figure 7.2. Mercury levels in fish remain elevated from EFK 23.4 to EFK 6.3, but decreased in response to downstream dilution of EFPC in Poplar Creek, and of Poplar Creek in the Clinch River (Figure 7.1). Mean mercury concentrations in sunfish in the lower-most reaches of Poplar Creek and the Clinch River in 2009 were below the EPA's $0.3 \mu \mathrm{g} / \mathrm{g}$ fish-based federal AWQC, although levels in largemouth bass in Poplar Creek and the Clinch River, and channel catfish from Poplar Creek, did exceed the AWQC (Sect. 7.3). TDEC adopted EPA's $0.3 \mu \mathrm{g} / \mathrm{g}$ criterion for use in issuing the State of Tennessee's fish advisories in April 2007.

\subsubsection{Mercury input from UEFPC to downstream waters}

The downstream pattern of mercury accumulation in fish in EFPC and downstream sites in Poplar Creek and the Clinch River observed in spring 2009 was similar to previous years. The previously observed trend of increased mercury bioaccumulation at the downstream sites of EFPC property appears to be more pronounced, with $\mathrm{Hg}$ concentrations $>1 \mathrm{ppm}$ in rockbass at EFK 6.3 in 2009. The importance of sources within the EFPC drainage remains obvious, with mercury concentrations in fish decreasing sharply with dilution by the flow of Poplar Creek and the Clinch River. 
This page intentionally left blank. 


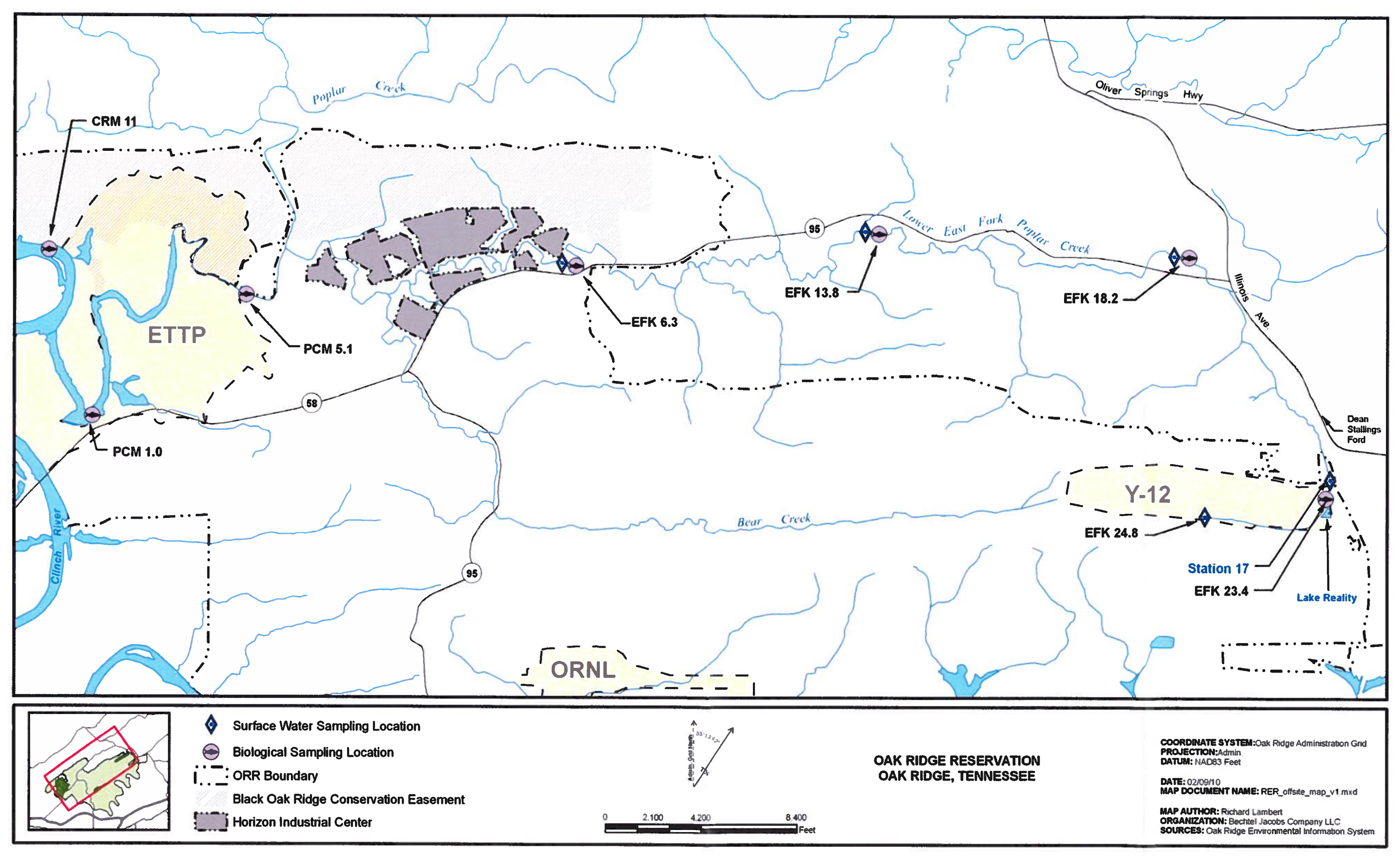

Figure 7.1. Site map of LEFPC 
This page intentionally left blank. 


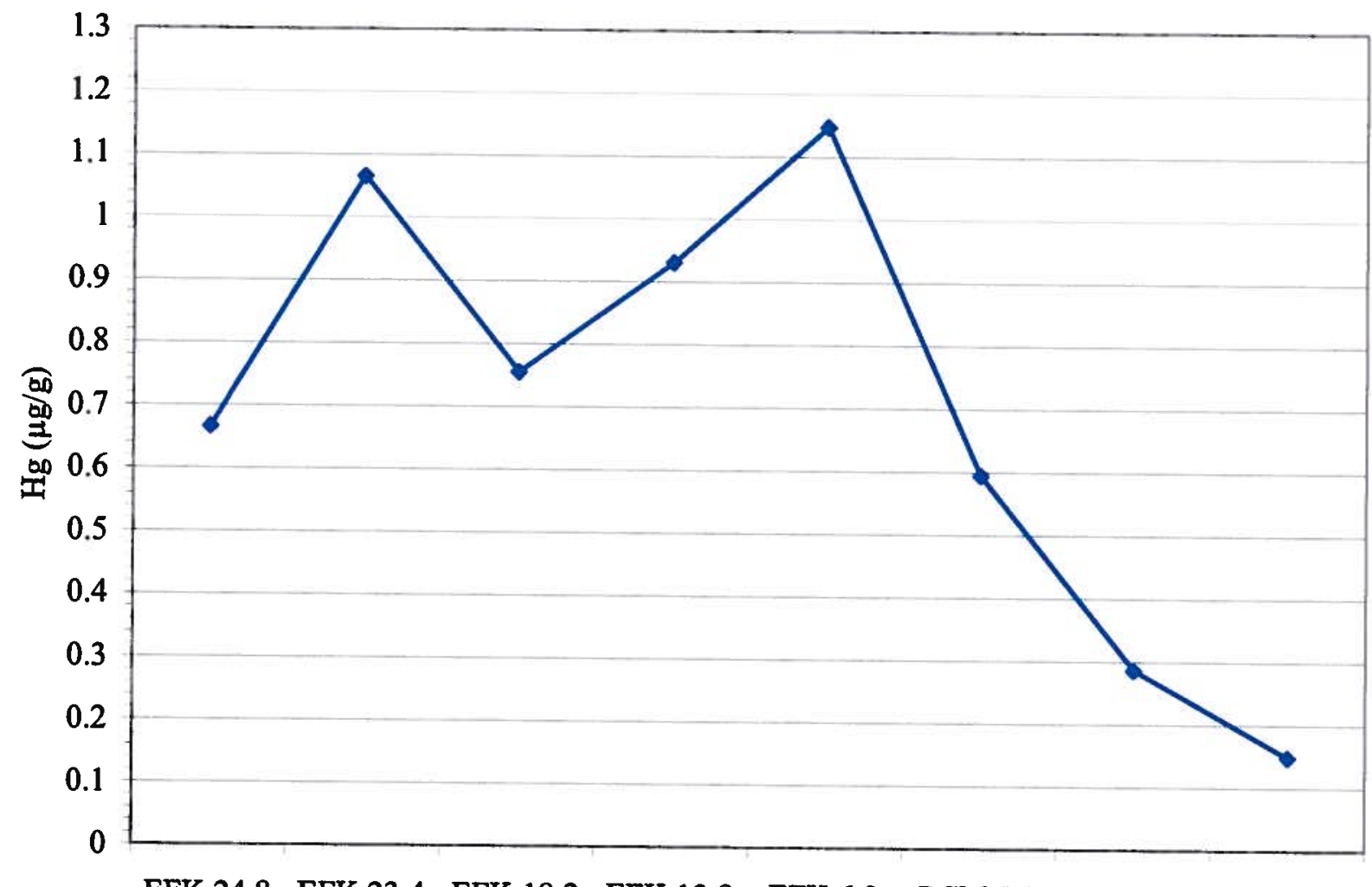

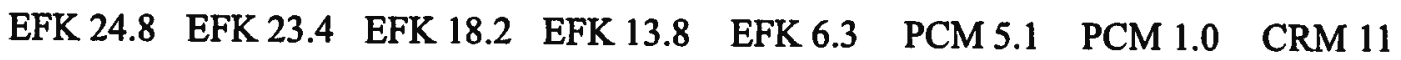

Figure 7.2. Spatial pattern of mercury bioaccumulation in bluegill (PCM 1 and CRM 11) redbreast sunfish (EFK 24.8, PCM 5.1) and rock bass (EFK 23.4-6.3) collected in spring 2009.

${ }^{a}$ Mean mercury concentrations in rock bass have been adjusted by 0.85 to account for differences in bioaccumulation factor between rock bass and redbreast sunfish.

\section{Watershed-wide sources of Hg to EFPC}

In order to better understand the relationship between $\mathrm{Hg}$ sources within the $\mathrm{Y}-12 \mathrm{NSC}$ and the contaminated watershed downstream, WRRP estimated the inventories of $\mathrm{Hg}$ in various compartments of LEFPC and annual export rate of $\mathrm{Hg}$ from the watershed downstream from Y-12 (Southworth et al. 2010). That investigation found that $\mathrm{Hg}$ export from the watershed had decreased substantially since 1984 , when it was measured by TVA as part of the Oak Ridge Task Force investigation of $\mathrm{Hg}$ contamination on the ORR (TVA 1985). The annual $\mathrm{Hg}$ export from the watershed has been estimated to have decreased from $227 \mathrm{~kg} / \mathrm{yr}$ in 1984 to about $66 \mathrm{~kg} / \mathrm{yr}$ using mean $\mathrm{Hg}$ concentration in waterborne solids from $2006-2008$ versus 1984. A larger decrease was observed at Station 17 (34 to $4 \mathrm{~kg} / \mathrm{yr}$, based on $2006-2008$ mean flux measured by WRRP) than from the watershed downstream (193 to $62 \mathrm{~kg} / \mathrm{yr}$ near the mouth of LEFPC). Similar decreases were observed both in the headwater, at Station 17 (decreased from 34 to $9 \mathrm{~kg} / \mathrm{yr}$ ), and near the mouth of LEFPC (decreased from 227 to $63 \mathrm{~kg} / \mathrm{yr}$ ). The basis for this estimate assumes that sediment load in EFPC has not changed since 1984 and is based on measured $\mathrm{Hg}$ concentration in suspended solids. A stormflow monitoring exercise in March 2009 found that far more mercury was exported from the watershed downstream from Y-12 than from the facility itself under wet weather conditions (Figure 7.3). However, the strong downstream gradients of $\mathrm{Hg}$ in water, suspended particulates, 
and the surface biofilm of EFPC continue to indicate that the continuous baseflow discharge of $\mathrm{Hg}$ from headwater sites remains the prime determinant of exposure of aquatic life to inorganic $\mathrm{Hg}$.

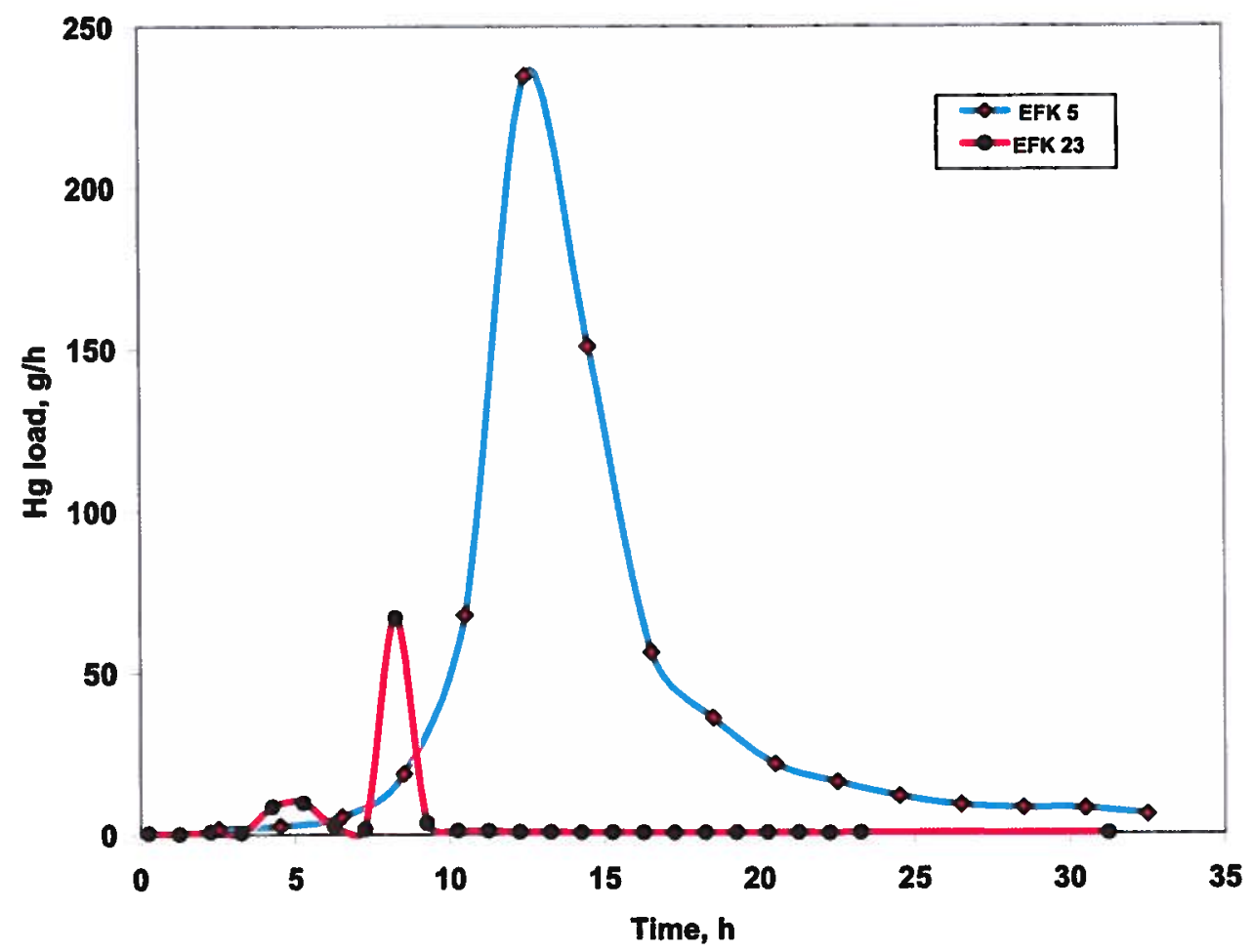

Figure 7.3. Mercury export from the headwaters (Y-12 plant) and rest of the watershed during a 24-h period in which $1.75 \mathrm{~cm}$ of rain fell on the watershed.

Mercury export was measured in the March 2009 storm event from ephemeral conveyances in two small catchments located in highly contaminated parts of the EFPC floodplain. Although there was significant mobilization and transport of $\mathrm{Hg}$ in these catchments when flowing, the mass flux of $\mathrm{Hg}$ to EFPC was a small fraction of the total $\mathrm{Hg}$ exported from the watershed during that event. Mobilization of particulate $\mathrm{Hg}$ from the stream bed and banks accounted for most of the $\mathrm{Hg}$ exported.

The mercury content of cores (three transects per reach) taken from gravel streambed sediments within four reaches of EFPC were used to estimate the inventory of $\mathrm{Hg}$ retained within the streambed. Profiles of $\mathrm{Hg}$ in soil from the surface of eroding (bare soil) streambanks were taken at three sites within each of the reaches to estimate the $\mathrm{Hg}$ concentration of soil that would enter the stream via bank erosion (Figure 7.4).

Samples of the surface biofilm coating rock substrates within the creek were also taken. When $\mathrm{Hg}$ inventories in those compartments were compared to export rates, the streambed biofilm was found to be only a minor, short-term repository while the inventory within the streambed gravel could sustain observed export rates for several years. However, relatively low rates of erosion of unprotected streambanks could possibly provide enough $\mathrm{Hg}$ to sustain high $\mathrm{Hg}$ export rates for a much longer period of time. 

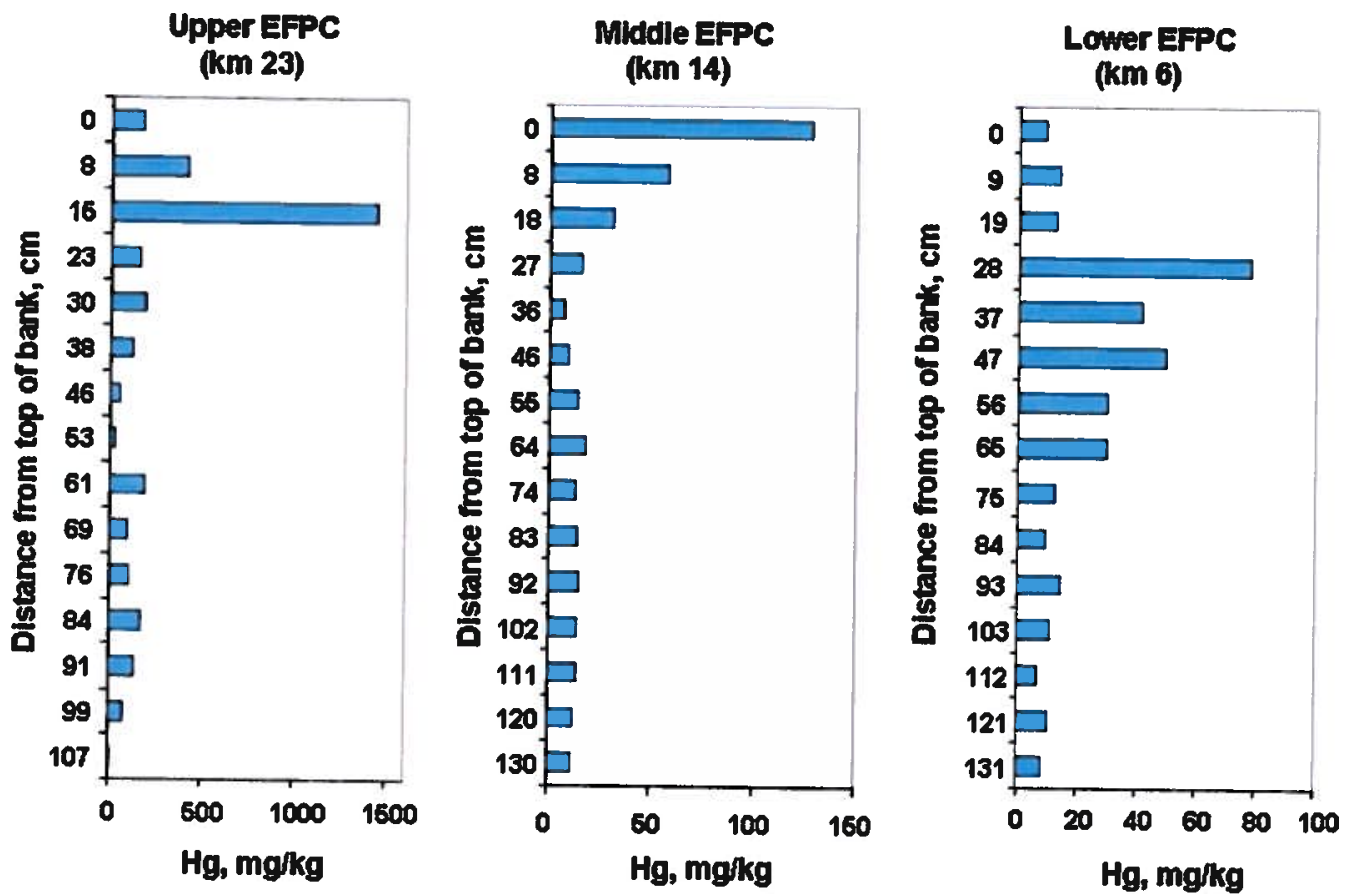

Figure 7.4. Profiles of $\mathrm{Hg}$ concentration in eroding streambanks along EFPC.

\subsubsection{Mercury trends in LEFPC}

The LEFPC ROD (DOE 1995d) addressed soil, floodplain sediment, and groundwater, and deferred surface water and creek bed sediments to a future ROD. When fish mercury concentrations were shown to be increasing over time at two locations in LEFPC in the early $2000 \mathrm{~s}$, concerns were raised about some of the assumptions in the LEFPC ROD regarding the importance of upstream industrial sources of mercury relative to floodplain or in-stream sediment sources. The gradual displacement of redbreast sunfish as the numerically dominant food/game species in EFPC has continued. Adequate numbers of adult sunfish could not be collected at most sites in EFPC. Where sunfish were not found, rock bass were collected instead. At EFK 6.3, both redbreast and rockbass were collected in spring 2009; interspecies differences in mercury bioaccumulation are apparent (Figure 7.5). Mean mercury concentrations in redbreast in LEFPC (EFK 6.3) were lower in $2009(0.59 \mu \mathrm{g} / \mathrm{g})$ than in recent years, but concentrations in rockbass remain higher there than at any other site in EFPC $(1.35 \mu \mathrm{g} / \mathrm{g}$; Figure 7.5$)$. A systematic analysis of the differences in mercury bioaccumulation between these two species is needed in order to be able to interpret long-term trends if rockbass continue to replace redbreast as the dominant species in EFPC. 


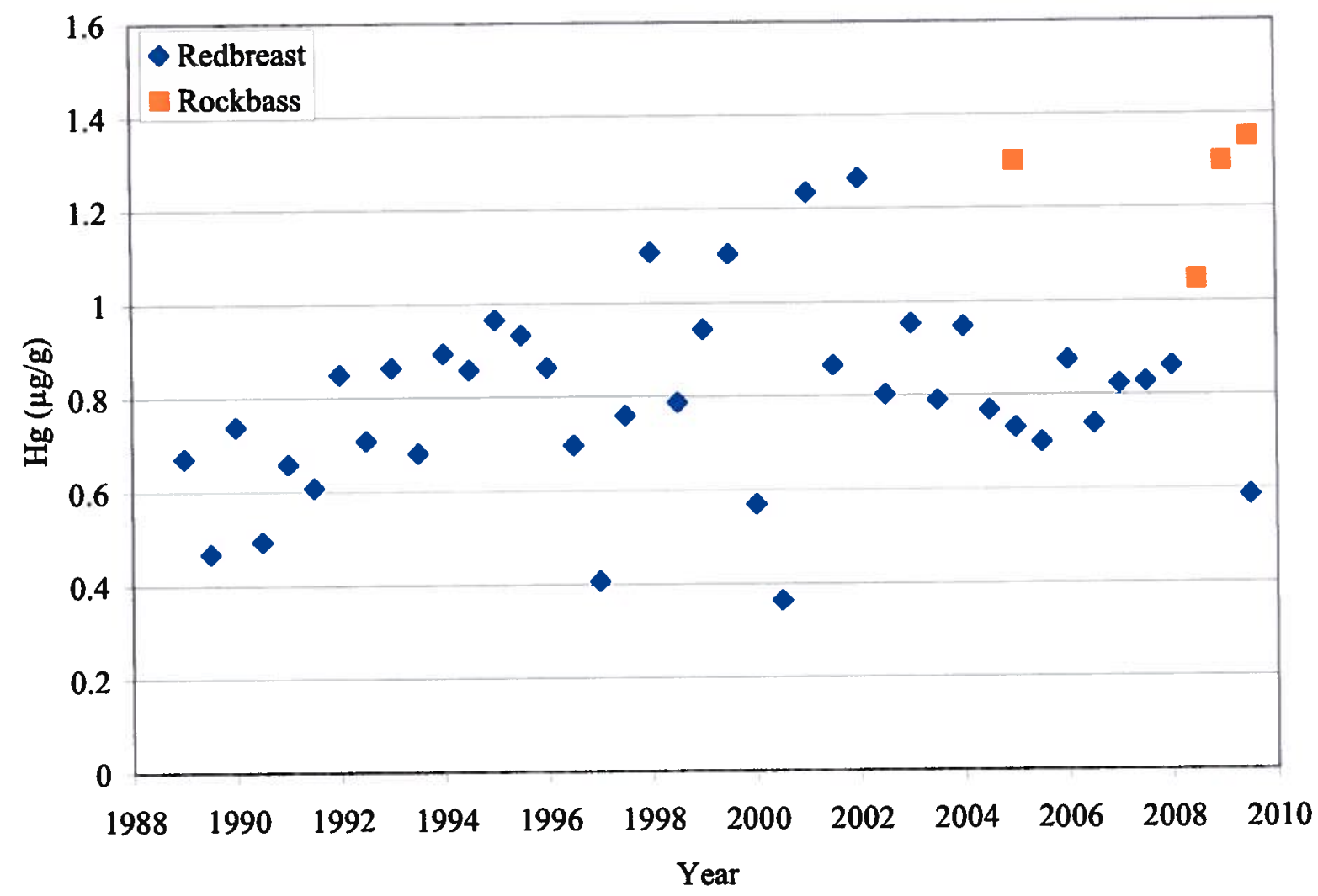

Figure 7.5. Mean mercury concentration in muscle tissue of redbreast sunfish at EFK 6.3."

"When redbreast sunfish could not be found, rockbass (orange boxes) were collected instead.

Methylmercury concentrations in water have exhibited a pronounced downstream increase in EFPC for the last decade, despite a consistent decrease in dissolved inorganic mercury concentrations with distance from the EFPC headwaters (Fig. 7.6). Understanding why MeHg in EFPC increases despite decreases in concentrations of inorganic mercury remains a key to the success of efforts to reduce mercury bioaccumulation in fish. Figure 7.6 shows long-term dissolved and total (dissolved + particulate) $\mathrm{MeHg}$ patterns at sites on EFPC, and reveals a seasonal pattern in $\mathrm{MeHg}$ concentrations. Methylmercury concentrations appear to be higher in the summer, both in the dissolved and particulate phase. The higher dissolved $\mathrm{MeHg}$ is due to greater microbial activity with higher temperatures in summer months, and higher particulate $\mathrm{MeHg}$ is due to greater primary production in the stream with the increased irradiance and temperature. The difference between dissolved and particulate $\mathrm{MeHg}$ increases with distance downstream in EFPC, suggesting higher bioaccumulation with increasing distance downstream. This is consistent with the higher $\mathrm{Hg}$ levels in fish observed at downstream sites. 

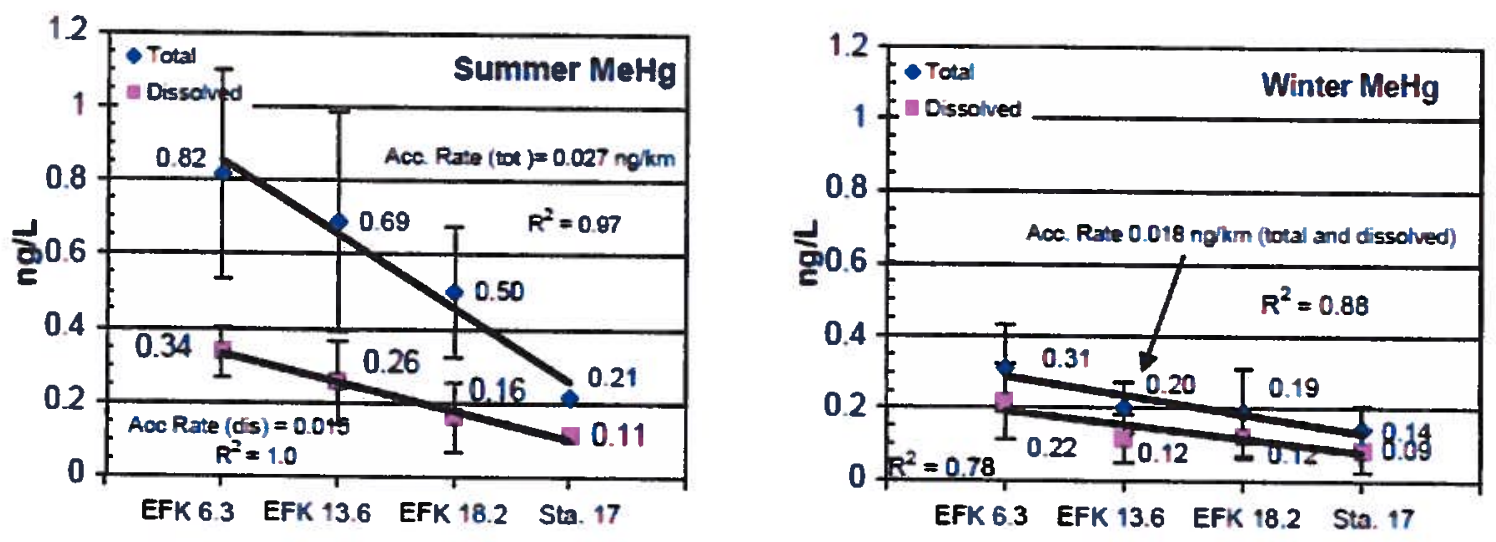

Figure 7.6. Aqueous methylmercury in LEFPC (2000-2008). Values are based on semiannual grab samples total and dissolved.

\subsubsection{Performance Summary}

Monitoring at Station 17 is conducted to measure the concentration and mass flux of mercury that is discharged from the UEFPC watershed. During FY 2009, the flow-paced continuous monitoring detected an average concentration of $273 \mathrm{ng} / \mathrm{L}$ and a mass flux of about $3.9 \mathrm{~kg}$ mercury. Analytical results obtained from grab samples collected on a 4-days per week basis detected an average mercury concentration of about $310 \mathrm{ng} / \mathrm{L}$. Although surface water mercury concentrations and fluxes have declined over recent years since BSWTS started operations, the levels of mercury in fish tissue in the LEFPC have remained elevated.

\subsubsection{Compliance with LTS Requirements}

\subsubsection{Requirements}

The LEFPC ROD (DOE 1995d) states that although residential use of soil horizon (shallow) groundwater is not realistic, as a safeguard, DOE will periodically monitor to detect any future residential use of the shallow groundwater.

The RAR (DOE 2000c) requires an annual survey to verify land use in the area of the Dean Stallings Ford automobile dealership parking lot has not changed since the issuance of the LEFPC ROD (DOE 1995d) and exposure pathways remain protected (Table 7.2).

\subsubsection{Status of Requirements for FY 2009}

A survey to detect residential use of shallow groundwater was performed in FY 2009 to verify survey results from FY 2007. A list of residential wells recorded in the Elverton, BV, and Windrock quadrangles was obtained from the TDEC, Division of Water Supply. There are no records of water wells in the area along LEFPC. No status change for FY 2009 was noted.

In FY 2009, DOE verified that the noted property is still paved for use as a parking lot.

\subsubsection{Monitoring Changes and Recommendations for LEFPC}

Changes to the monitoring strategy for LEFPC are not recommended at this time. 


\subsection{CLINCH RIVER/POPLAR CREEK}

The CR/PC OU extends 34 river miles from the mouth of the Clinch River at Tennessee River mile (TRM) 567.5 [Clinch River mile (CRM) 0.0] at Kingston, upstream past the Melton Hill Reservoir dam at CRM 23.1, to the upstream boundary of the ORR at CRM 43.7 (Figure 7.7). The CR/PC OU also includes the lower portion of Poplar Creek from the mouth of Poplar Creek on the Clinch River at CRM 12.0, upstream to its confluence with EFPC at Poplar Creek mile (PCM) 5.5 (Figure 7.7). A complete discussion of the CR/PC ROD is provided in Chap. 7 of Vol. 1 of the 2007 RER (DOE 2007a).

\subsubsection{Performance Goals and Monitoring Objectives}

A major component of the selected remedy for $\mathrm{CR} / \mathrm{PC}$ is for $\mathrm{DOE}$ to perform appropriate monitoring to ensure the institutional controls remain protective against the risk of potential exposure to COCs in sediments and fish tissue.

The original post-ROD monitoring plans for the action are in the RAR for the CR/PC OU (DOE 1999c). However, in September 1999, DOE recommended two broad changes to the monitoring plans for the LWBR and CR/PC OUs. The first was to combine the two OUs into a single entity for monitoring purposes. The second was to change the number and locations of monitoring stations and sampling techniques in both OUs. Based on these recommendations, which were based on the hydrological connection of Poplar Creek, Clinch River, and Watts Bar Reservoir. DOE implemented a combined monitoring plan for the LWBR and CR/PC OUs (DOE 1999d) in FY 2000.

Based on sampling results from 1999-2004, the combined monitoring plan was revised in FY 2004. This revised plan is presented in Combined Monitoring Plan for the Lower Watts Bar Reservoir and Clinch River/Poplar Creek Operable Units (DOE 2004a). The current plan consists of two components for the CR/PC: (1) annual monitoring of major COCs in fish, and (2) additional monitoring for CR/PC (sediment, surface water, turtles) once every five years to support the CERCLA FYR (Table 7.3).

The combined monitoring program uses a scientifically rigorous sampling design supporting the identification and evaluation of changes in $\mathrm{COC}$ concentrations in fish. This evaluation is directly applicable to the ROD-specified requirements to detect changes in fish contaminant concentrations and to evaluate whether institutional controls (i.e., the fish consumption advisory) are effective (DOE 2004a). If concentrations of contaminants in tissues of these species increase substantially, a study to determine the cause of the change may be warranted. Conversely, decreases in $\mathrm{COC}$ concentrations would support the evaluation of the need for continuing the fish advisory.

DOE addresses the ROD requirements for the CR/PC hydrologic unit by conducting annual sampling of contaminant concentrations in CR/PC fish. Sites sampled in FY 2009 include three sites in the Clinch River, a site in Poplar Creek, and two reference sites in Melton Hill Reservoir upstream of the OUs that are sampled for comparison purposes (Figure 7.7). The sites sampled are based on their position below key DOE inputs and stream/river exit points, as well as their importance as long-term measures of change. Most of the designated sites have been monitored annually since the mid-1980s and are important sites for evaluating long-term change (DOE 2003e). Target species are channel catfish, largemouth bass, and striped bass. Depending on the site and species, PCBs, mercury, and ${ }^{137} \mathrm{Cs}$ concentrations are determined in fish fillets. Snapping turtle tissue, including muscle, liver, and fats, are also checked for contaminants on a five-year cycle, and this sampling was last conducted in the summer of 2005 and will be completed again in 2010. 


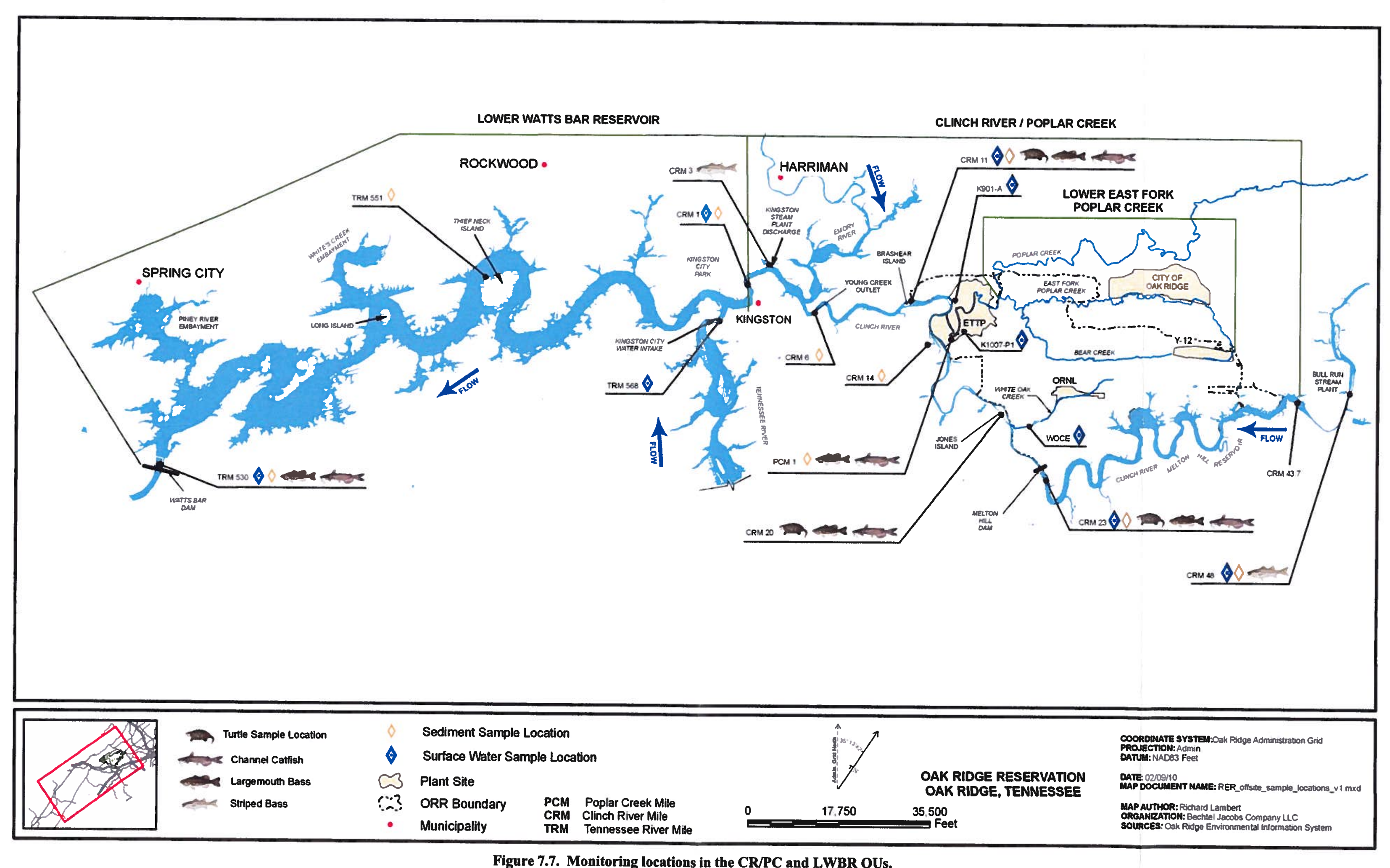


This page intentionally left blank.

7-14 
Surface water: CRM 48, CRM 23.4-24.7, WOCE, K-1007-P1 Pond, K-901-A Pond, CRM 10.5-12, and CRM 1, once every five years

Sediment: CRM 48, CRM 23.4-24.7, CRM 14-15, PCM 1, CRM 10.5-12, CRM 6-7, and CRM 1, once every five years

Fish: CRM 23.4-24.7, PCM 1, CRM 10.5-12, and CRM 19.7-20.7 (catfish and largemouth bass), annually, summer only

Bull Run Steam Plant effluent, Kingston Steam Plant effluent (striped bass), winter only

Turtles: CRM 23.4-24.7, CRM 19.7-20.7, and CRM 10.5-12, once every five years in summer
Surface water-isotopic uranium, total mercury, TAL metals, and hydrolab profile

Total metals, total mercury, and ${ }^{137} \mathrm{Cs}$. Samples from Poplar Creek will also be analyzed for ${ }^{99} \mathrm{Tc}$, ${ }^{234,235,238} \mathrm{U},{ }^{60} \mathrm{Co}$, and PCBs

PCBs (catfish only), total mercury, ${ }^{137} \mathrm{Cs}$ (CRM 19.7-20.7 only), and total lipid

PCBs and total lipid

PCBs, total mercury, ${ }^{137} \mathrm{Cs}$, and total lipid

\footnotetext{
${ }^{a}$ Analyses listed are those required to monitor action effectiveness.

$\mathrm{TAL}=$ target analyte list
}

Fish consumption advisories are issued by the TDEC http://www.state.tn.us/environment/wpc/publications/. The basis of the advisories can be FDA limits or on EPA or State risk calculations. TDEC has issued the following:

- East Fork of Poplar Creek including Poplar Creek embayment, from the mouth to New Hope Pond (in Y-12) for mercury and PCBs for no fish consumption and also to avoid contact with water.

- Clinch River arm of Watts Bar Reservoir for PCBs for no consumption of striped bass and a precautionary advisory for catfish and sauger. ${ }^{1}$

- Watts Bar Reservoir (Roane, Meigs, Rhea and Loudon) for PCBs for no consumption of catfish, striped bass, and hybrid (striped bass-white bass). Precautionary advisory for white bass, sauger, carp, smallmouth buffalo and largemouth bass.'

Signs are placed at main public access points and a press release is submitted to local newspapers. The list of advisories is also published in TWRA's annual fishing regulations.

\subsubsection{Evaluation of Performance Data - FY 2009}

The selected remedy identified in the CR/PC ROD (DOE 1997b) is still in place and effective in CR/PC: institutional controls prevent exposure to contaminated sediment [via the Watts Bar Interagency Working Group (WBIWG) activities], fish consumption advisories are issued by TDEC and annual monitoring is

\footnotetext{
'A precautionary advisory is for children, pregnant women and nursing mothers that they should not consume the named fish species, and all other persons should limit consumption of the named species to one meal per month.
} 
conducted to evaluate changes in contaminant levels. Performance monitoring for the CR/PC has primarily focused on contaminant trending in fish to address the ROD requirement of "annual monitoring to detect changes in CR/PC contaminant levels or mobility."

Results of FY 2009 monitoring for Poplar Creek and the Clinch River arm of Watts Bar Reservoir are presented in Table 7.4. Although PCB concentrations in channel catfish were higher at all sites than those observed in 2008, they remain substantially lower than levels observed during the 1980s and 1990s (Figure 7.8). PCB concentrations in CR/PC channel catfish have been trending downward for more than a decade, although there is substantial year-to-year variability (Figure 7.8). The influence of PCB $\mathrm{fl} x$ in the PC/EFPC drainage, which has historically been evident in higher PCB concentrations in catfish at PCM 1 , was again evident in 2009. A sharp increase in PCB levels in striped bass at CRM 3 and CRM 48 was observed in 2008, but this trend did not continue in 2009; levels in 2009 are comparable to those observed in 2007 (fish sampling at CRM 3 in 2009 took place after the December 2008 TVA ash spill). The increase from 2007 to 2008 was likely due to year-to-year variations in PCB levels since fish size and lipid content did not correlate with levels of PCBs. Despite the observed decrease in 2009, PCB levels in striped bass from Melton Hill Reservoir and the Clinch River portion of Watts Bar Reservoir are high enough to be of concern relative to human consumption. TDEC typically issues fish consumption advisories in water where fish exceed 0.8-1.0 ppm PCBs.

Mean mercury concentrations exceeded the federal EPA fish tissue-based recommended water quality criterion $(0.3 \mu \mathrm{g} / \mathrm{g}$ ) only in fish collected from PCM 1 (channel catfish $=0.39 \mu \mathrm{g} / \mathrm{g}$; largemouth bass $=0.38$ $\mu \mathrm{g} / \mathrm{g}$ ). Mercury levels in channel catfish were slightly higher than those observed in 2008 . Levels of ${ }^{137} \mathrm{Cs}$ were below analytical detection limits in all fish collected from the sample site downstream of ORNL.

\subsubsection{Performance Summary}

Performance monitoring of the Clinch River and Poplar Creek continues to indicate a downward trend in fish PCB concentrations since the late 1980s. PCB levels are at or below fish advisory levels in channel catfish in most recent years. However, very large fish, e.g., striped bass, are substantially higher. Mercury concentrations in fish at monitored sites continue to indicate the influence of mercury sources from EFPC, with the highest levels in fish in Poplar Creek and lower levels with distance downstream. Overall, the performance monitoring has been successful in addressing the ROD goal of evaluating changes in fish contaminant levels and how those levels compare to fish advisory limits.

\subsubsection{Compliance with LTS Requirements}

\subsubsection{Requirements}

LTS requirements specified in the RAR (DOE 1999c) include conducting a survey of irrigation practices and determining the effectiveness (i.e., awareness) of fish consumption advisories (Table 7.2). The CR/PC irrigation survey will be conducted before preparation of the decision document for the CR/PC surface water OU. A survey of local fishermen was conducted in the fall of 1998 and spring of 1999 to determine their awareness of the fish consumption advisory program. 
Table 7.4. Mean concentrations ( $N=6$ fish, \pm standard error) of total PCBs (Aroclor- 1248+1254+1260), total mercury, and ${ }^{137} \mathrm{Cs}$ in fish muscle fillet from off-site locations in FY 2009

\begin{tabular}{|c|c|c|c|c|c|c|}
\hline \multicolumn{2}{|r|}{ Monitoring location } & \multicolumn{2}{|c|}{ Total PCBs (mg/kg) } & \multicolumn{2}{|c|}{ Mercury (mg/kg) } & \multirow{2}{*}{$\begin{array}{l}\text { Cs-137 (pCi/g) } \\
\text { Channel catfish }\end{array}$} \\
\hline Site $^{\mathrm{a}}$ & Description & Channel catfish & Striped bass & Largemouth bass & Channel catfish & \\
\hline \multicolumn{7}{|c|}{ Clinch River } \\
\hline CRM 20 & Jones Island downstream of WOC & $0.42 \pm 0.09$ & & $0.14 \pm 0.05$ & $0.09 \pm 0.02$ & $<0.07$ \\
\hline CRM 11 & $\begin{array}{l}\text { Brashear Island downstream of Poplar } \\
\text { Creek }\end{array}$ & $0.28 \pm 0.08$ & & $0.24 \pm 0.04$ & $0.17 \pm 0.07$ & \\
\hline CRM 3 & Kingston Steam Plant discharge & & $0.89 \pm 16$ & & & \\
\hline \multicolumn{7}{|c|}{ Poplar Creek } \\
\hline PCM 1 & Near K-1007-P1 outlet & $0.86 \pm 0.81$ & & $0.38 \pm 0.09$ & $0.39 \pm 0.26$ & \\
\hline \multicolumn{7}{|c|}{ LWBR } \\
\hline $\begin{array}{l}\text { TRM } \\
530\end{array}$ & Watts Bar Reservoir forebay & $0.57 \pm 0.21$ & & $0.19 \pm 0.03$ & $0.16 \pm 0.02$ & \\
\hline \multicolumn{7}{|c|}{ Reference sites (upstream of $C R / P C-L W B R$ ) } \\
\hline CRM 48 & $\begin{array}{l}\text { Bull Run Steam Plant (Melton Hill } \\
\text { Reservoir) }\end{array}$ & & $1.42 \pm 0.30$ & & & \\
\hline CRM 23 & Melton Hill Reservoir forebay & $0.12 \pm 0.01$ & & $0.08 \pm 0.01$ & $0.06 \pm 0.01$ & \\
\hline
\end{tabular}

${ }^{\circ} \mathrm{CRM}=$ Clinch River mile, $\mathrm{PCM}=$ Poplar Creek mile, and TRM = Tennessee River mile. 

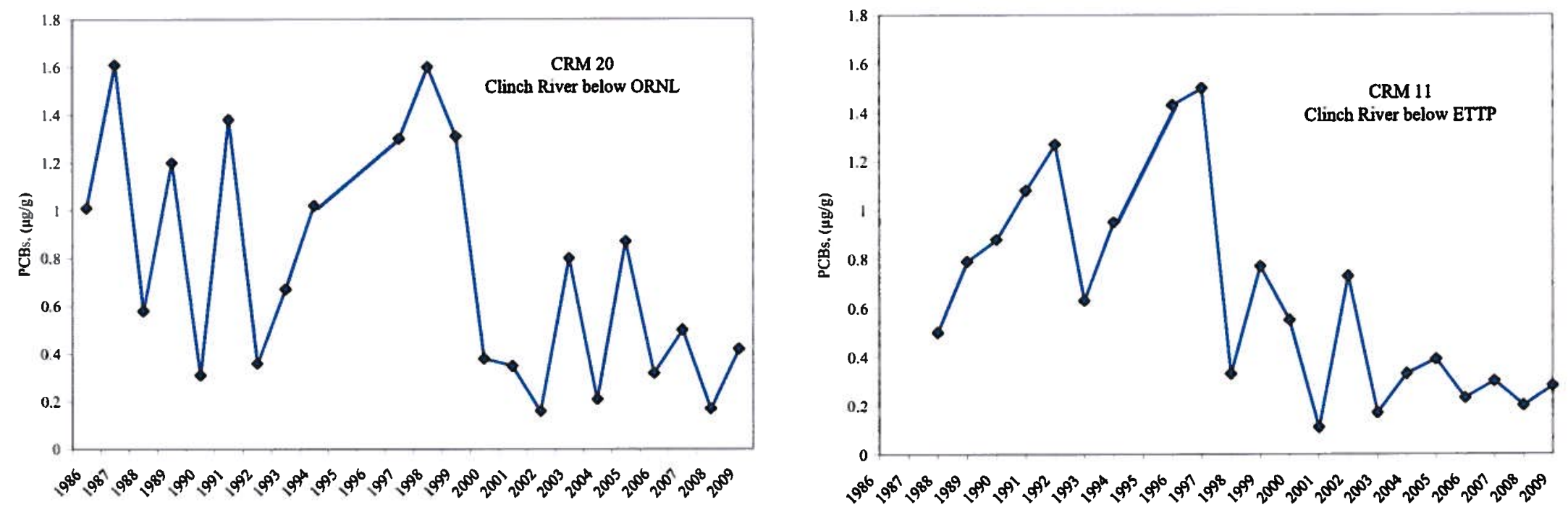

$\frac{N}{\infty}$
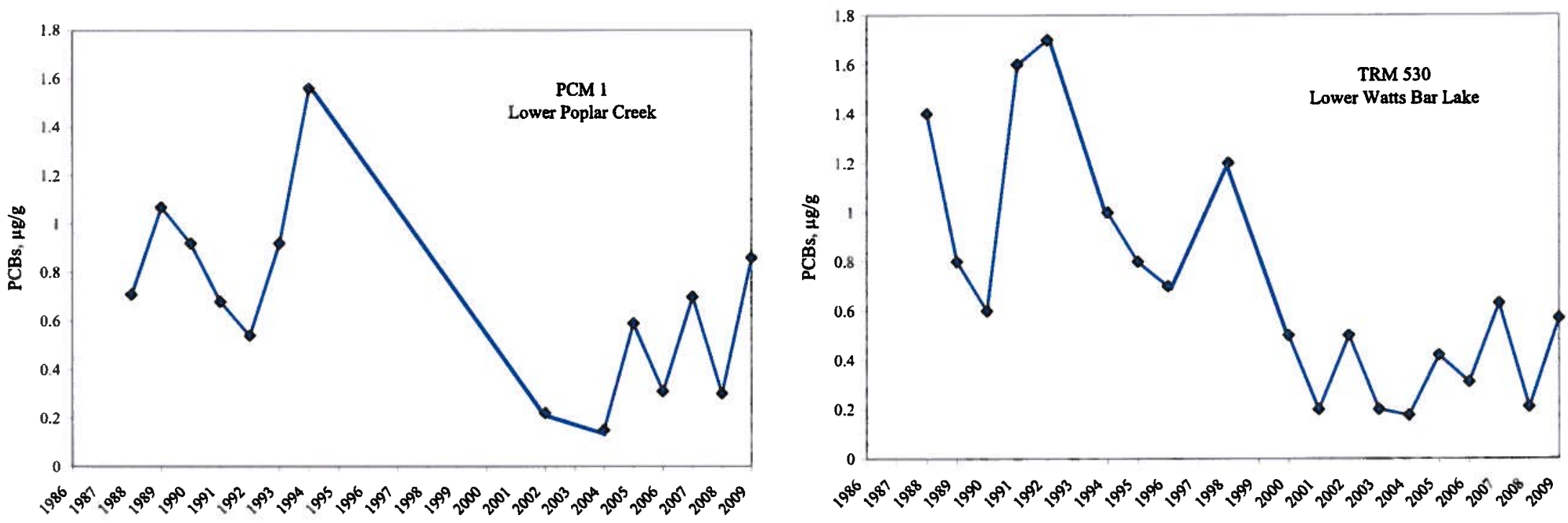

Figure 7.8. Average PCB concentrations in channel catfish from CR/PC and LWBR sites, 1986-2009. Courtesy of multiple programs, including BMAP, ASER, and Tennessee Valley Authority, 1986-2003. WRRP, 2004-2006. 


\subsubsection{Status of Requirements for FY 2009}

TDEC, Division of Water Pollution Control, maintains fish consumption advisories for the local area. The TWRA posts these advisories on their web site and it was last updated in August 2008. These same advisories are included in the TWRA's 2008 Fishing Regulations that is available on-line and where fishing licenses are sold (See Sect. 7.3.2).

After the TVA ash spill, the TWRA advised until further notice that fishing should be avoided in the lower section of the Emory River (Figure 7.7), and along with TDEC, urged the public to follow the fishing advisory for the lower Clinch River that existed prior to the ash spill. In the Clinch River arm of Watts Bar, there is a fish consumption advisory against eating striped bass and a precautionary advisory for catfish and sauger. A precautionary advisory means that children, pregnant women and nursing mothers should not consume the fish species named. All other persons should limit consumption of the named species to one meal per month. Given the data generated to date, TDEC feels the existing fishing advisory is protective of public health. The state will continue to monitor the levels of contaminants in fish tissue and will inform the public if current conditions change.

\subsubsection{Monitoring Changes and Recommendation for CR/PC}

No monitoring changes are recommended for CR/PC. 


\subsection{LOWER WATTS BAR RESERVOIR}

The LWBR OU extends 38 river miles from TRM 567.5, at the mouth of the Clinch River, downstream to the Watts Bar Reservoir dam at TRM 529.9 (Figure 7.7). A complete discussion of the LWBR ROD is provided in Chap. 7 of Vol. 1 of the 2007 RER (DOE 2007a).

\subsubsection{Performance Goals and Monitoring Objectives}

The original post-ROD monitoring plans for the action are in the RAWP for the LWBR OU (DOE 1996c). As discussed in Sect. 7.3.1, monitoring requirements for the LWBR are included with requirements for $\mathrm{CR} / \mathrm{PC}$ in a combined monitoring plan (DOE 2004a).

The overall goal of the remedy for LWBR is to protect human health and the environment by reducing exposure to: (1) contaminated sediment in the main river channel, and (2) contaminants in fish. The monitoring strategy for LWBR is provided in the combined monitoring plan and summarized in Table 7.5.

Table 7.5. Monitoring locations in LWBR

\begin{tabular}{ll}
\hline \multicolumn{1}{c}{ Monitoring stations } & \multicolumn{1}{c}{ Analyses $^{a}$} \\
\hline $\begin{array}{l}\text { Surface water: TRM 568.4 and TRM 530-532, } \\
\text { once every five years }\end{array}$ & $\begin{array}{l}\text { Surface water-isotopic uranium, } \\
\text { total mercury, TAL metals, and } \\
\text { hydrolab profile }\end{array}$ \\
$\begin{array}{l}\text { Sediment: TRM 551-556 and TRM 530-532, } \\
\text { once every five years }\end{array}$ & Total metals, total mercury, and ${ }^{137} \mathrm{Cs}$ \\
$\begin{array}{l}\text { Fish: TRM 530-532 (catfish and large mouth } \\
\text { bass), annually, summer only }\end{array}$ & PCBs, total mercury, and total lipid \\
\hline
\end{tabular}

\footnotetext{
Analyses listed are those required to monitor effectiveness.

TAL $=$ target analyte list
}

Fish consumption advisories are issued by the TDEC http://www.state.tn.us/environment/wpc/publications/. The basis of the advisories can be FDA limits or on EPA or State risk calculations. TDEC has issued the following:

- East Fork of Poplar Creek including Poplar Creek embayment, from the mouth to New Hope Pond (in Y-12) for mercury and PCBs for no fish consumption and also to avoid contact with water.

- Clinch River arm of Watts Bar Reservoir for PCBs for no consumption of striped bass and a precautionary advisory for catfish and sauger.

- Watts Bar Reservoir (Roane, Meigs, Rhea and Loudon) for PCBs for no consumption of catfish, striped bass, and hybrid (striped bass-white bass). Precautionary advisory for white bass, sauger, carp, smallmouth buffalo and largemouth bass.' 
Signs are placed at main public access points and a press release is submitted to local newspapers. The list of advisories is also published in TWRA's annual fishing regulations.

\subsubsection{Evaluation of Performance Monitoring Data - FY 2009}

The selected remedy defined in the ROD for the LWBR OU (DOE 1995c) is still in place and effective: (1) institutional controls prevent exposure to contaminated sediment; (2) fish consumption advisories are issued by TDEC; and (3) annual monitoring is conducted to evaluate changes in contaminant levels. A review of the efficacy of institutional controls preventing sediment exposure and the effectiveness of the fish consumption advisory was provided in the 2006 CERCLA/FYR (DOE 2007b). The results of that review suggest that institutional controls in place are effective in limiting human exposure, although some areas of the reservoir are not well posted and there are some groups of fisherman who do not follow advisories. The State of Tennessee is responsible for issuing fish consumption advisories and communicating relevant health information to the public.

Performance monitoring in LWBR has primarily focused on the Combined Monitoring Plan (DOE 2004a) requirements to evaluate changes in fish contaminant levels. These trending results are directly related to the ROD requirement that monitoring of water, sediment, and biota "be continued to determine if there is a change in the currently calculated risk that would pose a threat to human health and/or the environment." The ROD indicated that the response action (namely, monitoring of contaminant levels or mobility) was considered applicable to reducing ecological risk.

Monitoring results indicate that PCB concentrations in 2009 averaged $0.57 \mathrm{mg} / \mathrm{kg}$ in channel catfish (Table 7.4). In general, TDEC has issued fish consumption advisories when PCB levels in fish are approximately 0.8 to $1 \mathrm{mg} / \mathrm{kg}$ (or higher). PCB concentrations in channel catfish have remained below the advisory level since 1998. The current levels are substantially lower than the concentrations observed in the 1980s and 1990s when the advisories were first issued (Figure 7.8).

Mercury concentrations in fish from LWBR are also low, averaging equal to or less than $0.19 \mathrm{mg} / \mathrm{kg}$ (Table 7.4). This level is less that the federal EPA fish tissue-based recommended water quality criterion of $0.3 \mathrm{mg} / \mathrm{kg}$. Mercury concentrations in the $0.2 \mathrm{mg} / \mathrm{kg}$ range are typical of largemouth bass and channel catfish in Tennessee reservoirs.

\subsubsection{Performance Summary}

Performance monitoring results from LWBR obtained during FY 2009 continue to indicate that mercury and PCB levels in fish are below commonly-used fish advisory levels.

\subsubsection{Compliance with LTS Requirements}

\subsubsection{Requirements}

The RAWP (DOE 1996c) requires institutional controls (Table 7.2) for the LWBR, including: (1) continued use of TDEC's fish consumption advisories to limit exposure to contaminated fish, and (2) continued scrutiny of sediment-disturbing activities in LWBR by TDEC, TVA, U. S. Army Corps of Engineers (COE), and DOE to prevent exposure to potentially contaminated dredged soil.

\subsubsection{Status of Requirements for FY 2009}

TDEC, Division of Water Pollution Control, maintains fish consumption advisories for the local area. The TWRA posts these advisories on their web site and it was last updated in August 2008. These same 
advisories are also published in the TWRA's 2009 Fishing Regulations that are available on-line and where fishing licenses are sold.

The WBIWG, formed in 1991 and comprised of TDEC, TVA, COE, EPA, and DOE, provided continued controls on sediment-disturbing activity in the deep-water channel of the LWBR. In FY 2009, 30 dredging permit applications were received and reviewed by the WBIWG. All requests were approved.

After the TVA ash spill, the TWRA and TDEC urged the public to follow the fishing advisory for Watts Bar that existed prior to the ash spill. In the Tennessee River portion of Watts Bar there is a fish consumption advisory against eating striped bass, catfish, and hybrid (striped bass-white bass), and a precautionary advisory for white bass, sauger, carp, smallmouth buffalo, and largemouth bass. A precautionary advisory means that children, pregnant women and nursing mothers should not consume the fish species named. All other persons should limit consumption of the named species to one meal per month. Given the data generated to date, TDEC feels the existing fishing advisory is protective of public health. The state will continue to monitor the levels of contaminants in fish tissue and will inform the public if current conditions change.

\subsubsection{Monitoring Changes and Recommendations for LWBR}

No monitoring changes are recommended for LWBR. 


\subsection{OFF-SITE MONITORING CHANGES AND RECOMMENDATIONS}

No issues were identified based on an evaluation of FY 2009 performance monitoring data collected at off-site locations. Therefore, no changes to the monitoring strategy at these sites are recommended at this time.

Table 7.6. Summary of technical issues and recommendations

\begin{tabular}{|c|c|}
\hline \multicolumn{1}{|c|}{ Issue $^{\mathrm{a}}$} & $\begin{array}{c}\text { Action/ } \\
\text { Recommendation }\end{array}$ \\
\hline 2010 Current Issue: & \\
None. & \\
\hline
\end{tabular}


This page intentionally left blank. 


\section{CERCLA ACTIONS AT EAST TENNESSEE TECHNOLOGY PARK}

\subsection{INTRODUCTION AND OVERVIEW}

This chapter provides an update to CERCLA activities completed during FY 2009 at ETTP (Sect. 8.1.1). Only sites that have performance monitoring and/or LTS requirements are included in the performance evaluations; those sites are noted in Table 8.1. Performance goals and objectives, monitoring results, an assessment of the effectiveness of each completed action are presented, and a review of compliance with any LTS requirements (Table 8.2) is also provided, as appropriate (Sect. 8.2.1, Sect. 8.3.3, Sect. 8.4.1.4, Sect. 8.4.2.4, Sect. 8.4.3.1, Sect. 8.4.4.1, and Sect. 8.5.1). Figure 8.1 shows the locations of completed actions at ETTP.

Background information about each remedy and performance standards, and a compendium of all CERCLA decisions in the watershed within the context of a contaminant release conceptual model is provided in Chap. 8 of Vol. 1 of the 2007 RER (DOE 2007a). This information will be updated with information provided in the annual RER and republished every fifth year at the time of the CERCLA FYR.

ETTP does not have a sole surface water IP at which all upstream contaminant releases converge to exit the watershed; ETTP has several subwatersheds and, therefore, has several surface water IPs (Figure 8.1). Because many CERCLA decisions are in the process of being implemented (or have not been implemented yet) at ETTP, baseline monitoring data continue to be collected. This chapter includes preliminary evaluations of early indicators of effectiveness for each subwatershed, such as contaminant trends at the surface water IPs for the various subwatersheds.

For planning and administrative purposes, ETTP is divided into zones. Zone 1 comprises approximately 1400 acres outside the fenced main plant area, but within the area where most disposal activities took place, and Zone 2 comprises approximately 800 acres containing the main plant area. The remainder of the site, which encompasses approximately 2800 acres surrounding Zones 1 and 2, is primarily uncontaminated and part of DOE's planned footprint reduction. Figure 8.2 illustrates the land uses and interim controls identified in Zone 1 and Zone 2 RODs.

To date, most of the completed remedies at the ETTP have been single-action project decisions to address primary sources of contamination or primary release mechanisms. Concurrent with these actions, D\&D of most buildings at ETTP is occurring under CERCLA removal authority. While these actions ultimately help to reduce contaminant loading or minimize the potential for future releases to exit pathways from ETTP, the goals of many of these actions have not included specific, measurable performance criteria for reductions in flux or risk in surface water and groundwater at the watershed scale. Recent watershed-scale decisions relate to soil, buried waste, and subsurface structures for the protection of human health and to limit further contamination of groundwater through source reduction or removal. The remaining media (e.g., groundwater, surface water, and sediments) and ecological receptors will be evaluated and addressed by final sitewide decision(s). 
Table 8.1 CERCLA actions at ETTP

\begin{tabular}{|c|c|c|c|c|}
\hline CERCLA action & $\begin{array}{l}\text { Decision document: date signed } \\
\text { (mm/dd/yy) }\end{array}$ & Action/Document status ${ }^{a}$ & $\begin{array}{l}\text { Monitoring/ } \\
\text { LTS } \\
\text { required }\end{array}$ & $\begin{array}{l}\text { RER } \\
\text { section }\end{array}$ \\
\hline \multicolumn{5}{|c|}{ Watershed-scale actions } \\
\hline $\begin{array}{l}\text { Zone } 1 \text { Selected Contaminated Areas } \\
\text { Interim Remedial Actions }\end{array}$ & ROD (DOE/OR/01-1997\&D2): 11/08/02 & $\begin{array}{l}\text { PCCRs complete or in progress. } \\
\text { - Duct Island/K-901 Area PCCR (DOE/OR/01- } \\
\text { 2261\&D2) approved 04/03/06. } \\
\text { K-1007 Ponds/Powerhouse PCCR (DOE/OR/01- } \\
\text { 2294\&D2) approved 10/04/06. } \\
\text { K-770 Scrap Removal PCCR (DOE/OR/01-2348\&D1) } \\
\text { approved 5/30/07. } \\
\text { - FY 2008 PCCR for Units Z1-01, Z1-03, Z1-38, Z1-49 } \\
\text { (DOE/OR/01-2367\&D2) approved 04/23/08. }\end{array}$ & $\begin{array}{l}\text { No/Yes } \\
\text { No/Yes } \\
\text { No/Yes } \\
\text { No/Yes }\end{array}$ & 8.2 \\
\hline $\begin{array}{l}\text { Zone } 2 \text { Soil, Buried Waste, and } \\
\text { Subsurface Structure Remedial } \\
\text { Actions }\end{array}$ & ROD (DOE/OR/01-2161\&D2): 04/19/05 & $\begin{array}{l}\text { PCCRs complete or in progress. } \\
\text { - FY } 2006 \text { PCCR for Zone } 2 \text { (DOE/OR/01-2317\&D2) } \\
\text { approved 02/08/07. } \\
\text { - FY 2007 PCCR for Zone } 2 \text { (DOE/OR/01-2723\&D2) } \\
\text { approved 06/09/08. } \\
\text { - FY 2008 PCCR for EU Z2-33 in Zone } 2 \text { (DOE/OR/01- } \\
\text { 2368\&D2/R1) approved 09/28/09. } \\
\text { - FY 2009 PCCR for EU Z2-36 in Zone 2 (DOE/OR/01- } \\
\text { 2399\&D1) approved 06/03/09. } \\
\text { - FY 2009 PCCR for Zone } 2 \text { EUs 11, 12, 17, 18, 29, } 38 \\
\text { (DOE/OR/01-2415\&D1) submitted 09/18/09; approval } \\
\text { pending. }\end{array}$ & $\begin{array}{c}\text { Yes/Yes } \\
\text { No/Yes } \\
\text { No/Yes } \\
\text { No/Yes } \\
-\end{array}$ & 8.3 \\
\hline $\begin{array}{l}\text { ETTP Site-Wide Residual } \\
\text { Contamination RA }\end{array}$ & $\begin{array}{l}\text { ROD: TBD } \\
\text { AM (DOE/OR/01-2314\&D2): 03/12/07 } \\
\text { (K-1007-P and K-901-A holding ponds, } \\
\text { K-720 Slough, and } 770 \text { Embayment) }\end{array}$ & $\begin{array}{l}\text { TBD } \\
\text { - RmAWP (DOE/OR/01-2359\&D2) approved 12/18/08. }\end{array}$ & $\begin{array}{l}\quad \quad \text { TBD } \\
\text { Long-term } \\
\text { monitoring } \\
\text { plan } \\
\text { implemented } \\
\text { after action is } \\
\text { completed in } \\
\text { FY } 2010 .\end{array}$ & - \\
\hline
\end{tabular}


Table 8.1. CERCLA actions at ETTP (cont.)

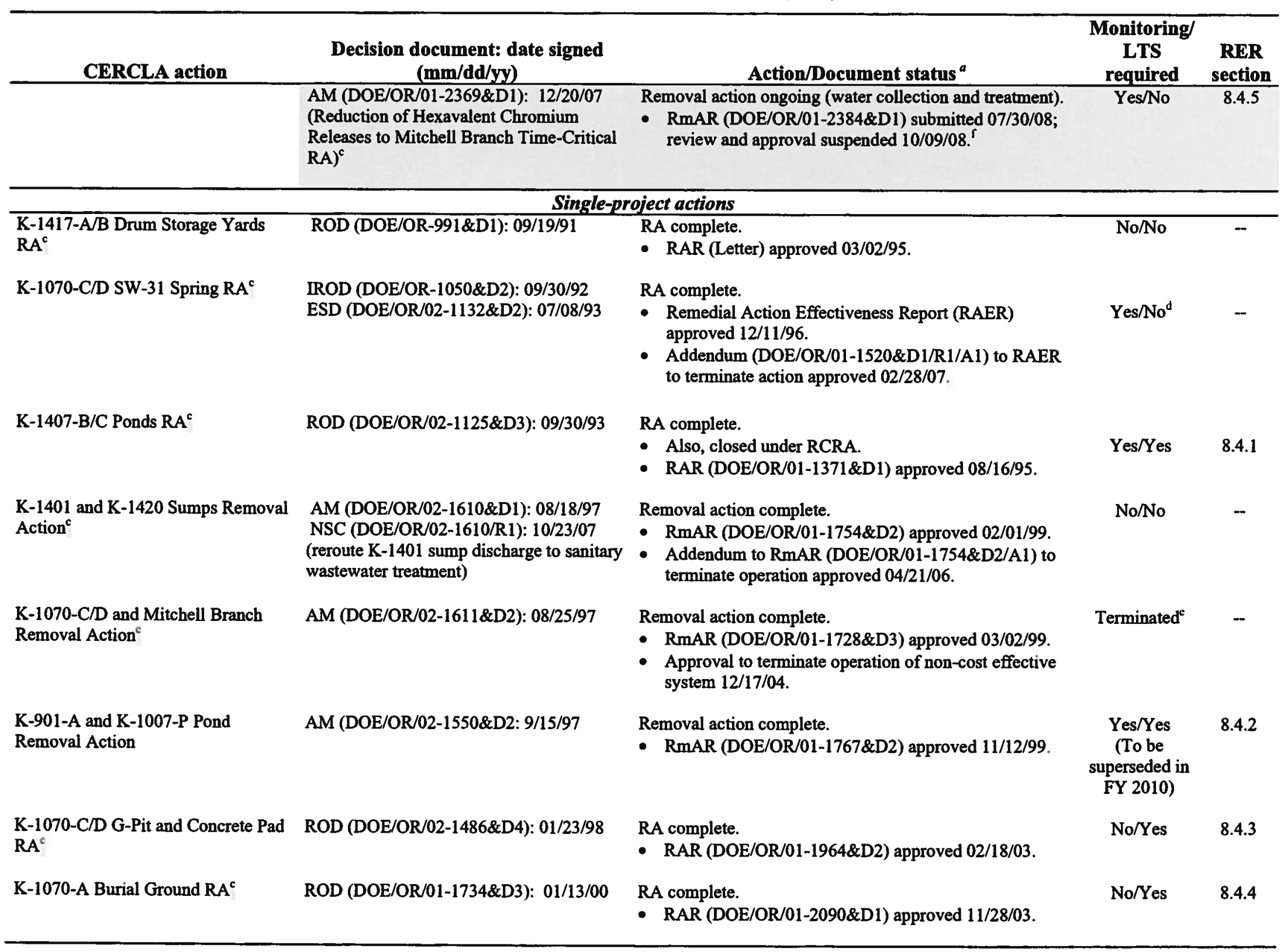


Table 8.1. CERCLA actions at ETTP (cont.)

\begin{tabular}{|c|c|c|c|c|}
\hline CERCLA action & $\begin{array}{l}\text { Decision document: date signed } \\
\text { (mm/dd/yy) }\end{array}$ & Action/Document status ${ }^{a}$ & $\begin{array}{l}\text { Monitoring/ } \\
\text { LTS } \\
\text { required } \\
\end{array}$ & $\begin{array}{r}\text { RER } \\
\text { section }\end{array}$ \\
\hline $\begin{array}{l}\text { K-1085 Old Firehouse Burn Area } \\
\text { Drum Burial Site Removal Action }\end{array}$ & AM (DOE/OR/01-1938\&D1): 03/27/01 & $\begin{array}{l}\text { Removal action complete. } \\
\text { RmAR (DOE/OR/01-2050\&D1) conditionally } \\
\text { approved 02/18/03. } \\
\text { - Completion Letter approved 01/19/07. }\end{array}$ & No/No & - \\
\hline Outdoor LLW Removal Action & AM (DOE/OR/01-2109\&D1): 11/14/03 & $\begin{array}{l}\text { Removal action complete. } \\
\text { - RmAR (DOE/OR/01-2225\&D2) approved 08/24/05. }\end{array}$ & No/No & - \\
\hline \multicolumn{5}{|c|}{ ETTP decontamination and demolition projects } \\
\hline $\begin{array}{l}\text { K-25 Auxiliary Facilities Group I } \\
\text { Building Demolition (KAFaD) }\end{array}$ & AM (DOE/OR/02-1507\&D2): 01/17/97 & $\begin{array}{l}\text { Removal action complete. } \\
\text { - RmAR (DOE/OR/01-1829\&D1) issued August } 1999 . \\
\text { Addendum I (DOE/OR/01-1829\&D1/A1) approved } \\
\text { 06/02/05. } \\
\text { Addendum II (DOE/OR/01-1829\&D1/A2) approved } \\
\text { 06/05/06. }\end{array}$ & No/No & - \\
\hline $\begin{array}{l}\text { K-29, K-31, and K-33 Equipment } \\
\text { Removal and Building } \\
\text { Decontamination }^{\mathrm{c}}\end{array}$ & AM (DOE/OR/02-1646\&D1): 09/30/97 & $\begin{array}{l}\text { Removal action complete. } \\
\text { - } \quad \text { Addendum (DOE/OR/01-2290\&D3) approved 06/08/07. } \\
\text { 09/26/07; EPA approved 01/25/08; TDEC } \\
\text { conditionally approved 11/01/07. } \\
\text { - Addendum (DOE/OR/01-2290\&D3/A2) approved } \\
\text { 03/16/09. }\end{array}$ & No/No & - \\
\hline $\begin{array}{l}\text { K-25 Auxiliary Facilities Group II, } \\
\text { Phase I Building Demolition, Main } \\
\text { Plant }^{\mathrm{c}}\end{array}$ & AM (DOE/OR/01-1868\&D2): 08/03/00 & $\begin{array}{l}\text { Removal action complete. } \\
\text { - RmAR (DOE/OR/01-2116\&D2) approved 09/24/04 }\end{array}$ & No/Yes & - \\
\hline $\mathrm{K}-25$ and $\mathrm{K}-27$ Buildings $\mathrm{D} \& \mathrm{D}^{\mathrm{c}}$ & $\begin{array}{l}\text { AM (DOE/OR/01-1988\&D2): 02/13/02 } \\
\text { NSC (DOE/OR/01-2259\&D1): } 12 / 16 / 05\end{array}$ & $\begin{array}{l}\text { Removal action in progress. } \\
\text { - PCCR (DOE/OR/01-2275\&D1) for Hazardous } \\
\text { Materials Abatement conditionally approved 12/19/05 } \\
\text { - Completion of Hg ampoules disposal in accordance } \\
\text { with the PCCR (DOE/OR/01-2275\&D1) approved } \\
03 / 17 / 06 \text {. } \\
\text { - Completion Letter, Disposition of Centrifuge and Y-12 } \\
\text { Materials, Excess Materials Removal, K-25/K-27 } \\
\text { D\&D 06/30/08. }\end{array}$ & No/No & - \\
\hline
\end{tabular}


Table 8.1. CERCLA actions at ETTP (cont.)

\begin{tabular}{|c|c|c|c|c|}
\hline CERCLA action & $\begin{array}{l}\text { Decision document: date signed } \\
(\mathrm{mm} / \mathrm{dd} / \mathbf{y y})\end{array}$ & Action/Document status ${ }^{a}$ & $\begin{array}{l}\text { Monitoring/ } \\
\text { LTS } \\
\text { required } \\
\end{array}$ & $\begin{array}{c}\text { RER } \\
\text { section }\end{array}$ \\
\hline $\begin{array}{l}\text { K-25 Auxiliary Facilities Group II, } \\
\text { Phase II Building Demolition, } \\
\text { K-1064 Peninsula Area }\end{array}$ & AM (DOE/OR/01-1947\&D2): 07/31/02 & $\begin{array}{l}\text { Removal action complete. } \\
\text { RmAR (DOE/OR/2339\&D1) approved 06/27/07. }\end{array}$ & No/Yes & 8.5 \\
\hline $\begin{array}{l}\text { K-25 Group II, Phase } 3 \text { Building } \\
\text { Demolition, Remaining Facilities }\end{array}$ & AM (DOE/OR/01-2049\&D2): 09/30/03 & $\begin{array}{l}\text { Removal action in progress. } \\
\text { FY 2004 PCCR PUF (DOE/OR/01-2193\&D2) } \\
\text { approved 03/28/05. } \\
\text { FY 2005 PCCR PUF (DOE/OR/01-2269\&D2) } \\
\text { approved 02/15/06. } \\
\text { FY 2005 PCCR LR/LC Facilities (DOE/OR/01- } \\
\text { 2270\&D2) approved 02/15/06. } \\
\text { FY 2006 PCCR PUF (DOE/OR/01-2326\&D2) } \\
\text { approved 06/07/07. } \\
\text { FY 2006 PCCR LR/LC Facilities (DOE/OR/01- } \\
\text { 2327\&D2) approved 06/06/07. } \\
\text { BOS D\&D-Labs D\&D PCCR (DOE/OR/01- } \\
\text { 2309\&D2) approved 08/30/07. } \\
\text { FY 2007 PCCR PUF (DOE/OR/01-2363\&D2) } \\
\text { approved 06/25/08. } \\
\text { FY 2007 PCCR LR/LC Facilities (DOE/OR/01- } \\
\text { 2362\&D1) pending approval. } \\
\text { K-29 Process Building PCCR (DOE/OR/01- } \\
\text { 2336\&D2) approved 10/18/07. } \\
\text { K-1420 Decon \& Recovery Facility PCCR } \\
\text { (DOE/OR/01-2341\&D2) approved 10/26/07. } \\
\text { Building K-1401 PCCR (DOE/OR/01-2365\&D2/A1) } \\
\text { approved 04/08/09. } \\
\text { FY 2008 PCCR LR/LC Facilities (DOE/OR/01- } \\
\text { 2394\&D1) approved 03/13/09. } \\
\text { FY 2008 PCCR PUF (DOE/OR/01-2395\&D1) } \\
\text { approved 02/09/09. }\end{array}$ & $\begin{array}{c}\text { No/No } \\
\text { No/No } \\
\text { No/No } \\
\text { No/No } \\
\text { No/Yes } \\
\text { No/Nog } \\
\text { No/No } \\
\text { h } \\
\text { No/Yes } \\
\text { No/Yes } \\
\text { No/Yesi } \\
\text { No/Yes } \\
\text { No/No }\end{array}$ & 8.5 \\
\hline
\end{tabular}

${ }^{a}$ Detailed information of the status of ongoing actions is from Appendix E of the FFA and is available at <http://www.bechteljacobs.com/ettp-ffa-appendices.html>.

${ }^{b}$ Once completed in FY 2010, monitoring activities associated with this AM (DOE 2007f) will supersede monitoring associated with the previous removal action (DOE 1997d) and will then be incorporated into the format of the annual RER. Until that time, the reader is referred to Sect. 8.4.2 for a summary of performance monitoring results for K-1007-P1 and K-901-A holding ponds.

${ }^{c}$ Action completed as defined/required in CERCLA decision document listed. However, site requires subsequent CERCLA decision/action, e.g., the Record of Decision for Soil, Buried Waste, and Subsurface Structure Actions in Zone 2, East Tennessee Technology Park, Oak Ridge, Tennessee (DOE 2005d).

${ }^{2}$ Collection and treatment of SW-31 Spring discharge is no longer required per addendum to the RAER. However, per the RAER, interim spring monitoring is required.

'See discussion of terminated action in FY 2007 RER Vol. 1, Chap. 8. 


\section{Table 8.1. CERCLA actions at ETTP (cont.)}

'EPA suspended review of the TC RmAR on 10/09/08. This document will be superseded by a non-time critical action RmAR.

${ }^{8}$ The PCCR for the Group II, Phase 3 BOS-LABS D\&D required surveys and monitoring of the slabs from K-1004 and K-1015. These slabs were removed in FY 2007 and monitoring is no longer required. The long term stewardship of these sites is no longer reported in the RER.

'Once the PCCR (DOE 2007i) is finalized, monitoring/LTS requirements will be included in the RER.

Although the Bldg. K-1401 PCCR documents the building demolition and prescribes LTS for the remaining slab, the K-1401 slab was removed in 2009 and LTS requirements are no longer implemented at the site. The removal of the slab is documented in the FY 2010 PCCR for EU Z2-31 in Zone 2 (DOE/OR/01-2443\&D1), which was submitted to the regulators in April 2010 and is pending approval.

BOS = Balance of Site

IROD = Interim Record of Decision

LR/LC = low risk/low complexity

PUF $=$ predominantly uncontaminated facilities

RAER $=$ Remedial Action/Effectiveness Report 
Table 8.2. LTS requirements for CERCLA actions at ETTP

\begin{tabular}{|c|c|c|c|c|}
\hline \multirow[b]{2}{*}{ Site/Project } & \multicolumn{2}{|c|}{ LTS requirements } & \multirow[b]{2}{*}{ Status } & \multirow{2}{*}{$\begin{array}{c}\text { RER } \\
\text { section } \\
\end{array}$} \\
\hline & LUCs & Engineering controls & & \\
\hline \multicolumn{5}{|c|}{ Watershed-scale actions } \\
\hline $\begin{array}{l}\text { ROD for Interim } \\
\text { Actions for Selected } \\
\text { Contaminated Areas } \\
\text { Within Zone 1, ETTP } \\
\text { - Duct Island/K-901 } \\
\text { Area PCCR } \\
\text { - K-1007 } \\
\text { Ponds/Powerhouse } \\
\text { PCCR } \\
\text { - K-770 Scrap } \\
\text { Removal PCCR } \\
\text { - FY 2008 PCCR for } \\
\text { EUs Z1-01, Z1-03, } \\
\text { Z1-38, and Z1-49 }\end{array}$ & $\begin{array}{l}\text { Watershed LUCs } \\
\text { Administrative: } \\
\text { - property record } \\
\text { restrictions } \\
\text { - property record notices } \\
\text { - zoning notices } \\
\text { - permits program } \\
\text { Physical: } \\
\text { - access controls } \\
\text { - signs } \\
\text { - security patrols } \\
\text { K-770 PCCR specific: } \\
\text { - fencing } \\
\text { - CA postings }\end{array}$ & $\frac{\mathrm{K}-770 \mathrm{PCCR} \text { specific: }}{\text { - radiological surveys }}$ & $\begin{array}{l}\text { Watershed LUCs } \\
\text { - Physical LUCs in } \\
\text { place. } \\
\text { - Administrative LUCs } \\
\text { required at } \\
\text { completion of } \\
\text { actions. } \\
\text { K-770 PCCR specific: } \\
\text { - LUCs in place. } \\
\text { - Engineering controls } \\
\text { remain protective. }\end{array}$ & 8.2 .1 \\
\hline $\begin{array}{l}\text { ROD for Soil, Buried } \\
\text { Waste and Subsurface } \\
\text { Structure actions in } \\
\text { Zone 2, ETTP } \\
\text { - FY 2006 PCCR } \\
\text { - FY } 2007 \text { PCCR } \\
\text { - FY } 2008 \text { PCCR } \\
\text { - FY } 2009 \text { PCCR }\end{array}$ & $\begin{array}{l}\text { Watershed LUCs } \\
\text { Administrative: } \\
\text { - property record } \\
\text { restrictions } \\
\text { - property record notices } \\
\text { - zoning notices } \\
\text { - permits program } \\
\text { Physical: } \\
\text { - access controls } \\
\text { - signs } \\
\text { - security patrols } \\
\text { K-1070-C/D Burial Ground } \\
\text { specific: } \\
\text { - access controls }\end{array}$ & & $\begin{array}{l}\text { Watershed LUCs } \\
\text { - Physical LUCs in } \\
\text { place. } \\
\text { - Administrative LUCs } \\
\text { required at } \\
\text { completion of } \\
\text { actions. } \\
\text { - Property record } \\
\text { restrictions filed upon } \\
\text { transfer of buildings } \\
\text { in Zone } 2 \text {. } \\
\text { K-1070-C/D Burial } \\
\text { Ground specific: } \\
\text { - LUCs in place. }\end{array}$ & 8.3 .3 \\
\hline \multicolumn{5}{|c|}{ Completed single-project actions } \\
\hline K-1407-B/C Ponds RA & $\begin{array}{l}\text { Access and activity } \\
\text { controls }\end{array}$ & $\begin{array}{l}\text { S\&M, including } \\
\text { - Periodic inspections } \\
\text { - Radiological and } \\
\text { industrial hygiene } \\
\text { surveillance }\end{array}$ & $\begin{array}{l}\text { - LUCs in place. } \\
\text { - Engineering controls } \\
\text { remain protective. }\end{array}$ & 8.4 .1 .4 \\
\hline $\begin{array}{l}\text { K-901-A Pond and } \\
\text { K-1007-P Ponds } \\
\text { Removal Action }\end{array}$ & - Signs & - Maintain weir & $\begin{array}{l}\text { LUCs in place. } \\
\text { Engineering controls } \\
\text { remain protective. }\end{array}$ & 8.4 .2 .4 \\
\hline $\begin{array}{l}\text { K-1070-C/D G-Pit and } \\
\text { Concrete Pad RA }\end{array}$ & $\begin{array}{l}\text { - Fences } \\
\text { - EPP program }\end{array}$ & $\begin{array}{l}\text { - Maintain vegetated soil } \\
\text { cover on concrete pad } \\
\text { - Periodic radiological } \\
\text { surveys }\end{array}$ & $\begin{array}{l}\text { - LUCs in place. } \\
\text { - Engineering controls } \\
\text { remain protective. }\end{array}$ & 8.4 .3 .1 \\
\hline
\end{tabular}


Table 8.2. LTS requirements for CERCLA actions at ETTP (cont.)

\begin{tabular}{|c|c|c|c|c|}
\hline \multirow[b]{2}{*}{ Site/Project } & \multicolumn{2}{|c|}{ LTS Requirements } & \multirow[b]{2}{*}{ Status } & \multirow{2}{*}{$\begin{array}{c}\text { RER } \\
\text { section }\end{array}$} \\
\hline & LUCs & Engineering controls & & \\
\hline K-1070-A Burial Ground & $\begin{array}{l}\text { - Access controls } \\
\text { - EPP program } \\
\text { - Surveillance patrols }\end{array}$ & - Maintain soil cover & $\begin{array}{l}\text { - LUCs in place. } \\
\text { Engineering } \\
\text { controls remain } \\
\text { protective. }\end{array}$ & 8.4 .4 .1 \\
\hline \multicolumn{5}{|c|}{ ETTP D\&D Projects } \\
\hline $\begin{array}{l}\text { K-25 Auxiliary Facilities } \\
\text { Group II, Phase } 1 \text { Building } \\
\text { Demolition, Main Plant }\end{array}$ & - EPP program & & - LUCs in place. & -- \\
\hline $\begin{array}{l}\text { K-25 Auxiliary Facilities } \\
\text { Group II, Phase } 2 \text { Building } \\
\text { Demolition, K-1064 } \\
\text { Peninsula Area }\end{array}$ & - CA postings & - radiological surveys & $\begin{array}{l}\text { LUCs in place. } \\
\text { Engineering controls } \\
\text { remain protective. }\end{array}$ & 8.5 .1 \\
\hline $\begin{array}{l}\text { K-25 Group I, Phase 3 } \\
\text { Building Demolition, } \\
\text { Remaining Facilities } \\
\text { - FY2006 PCCR-LR/LC } \\
\text { Facilities } \\
\text { - BOS D\&D-Labs D\&D } \\
\text { PCCR } \\
\text { - K-29 Process Building } \\
\text { PCCR } \\
\text { - K-1420 Decon \& Recovery } \\
\text { Facility PCCR } \\
\text { - Bldg K-1401 PCCR } \\
\text { - FY2008 PCCR-LR/LC } \\
\text { Facilities }\end{array}$ & - CA postings & - radiological surveys & $\begin{array}{l}\text { - LUCs in place. } \\
\text { - Engineering controls } \\
\text { remain protective. }\end{array}$ & 8.5 .1 \\
\hline
\end{tabular}

"All the slabs under this action were removed in FY 2007 and no longer require CA postings or radiological surveys.

BOS = balance of sites

EUs = Exposure Units 


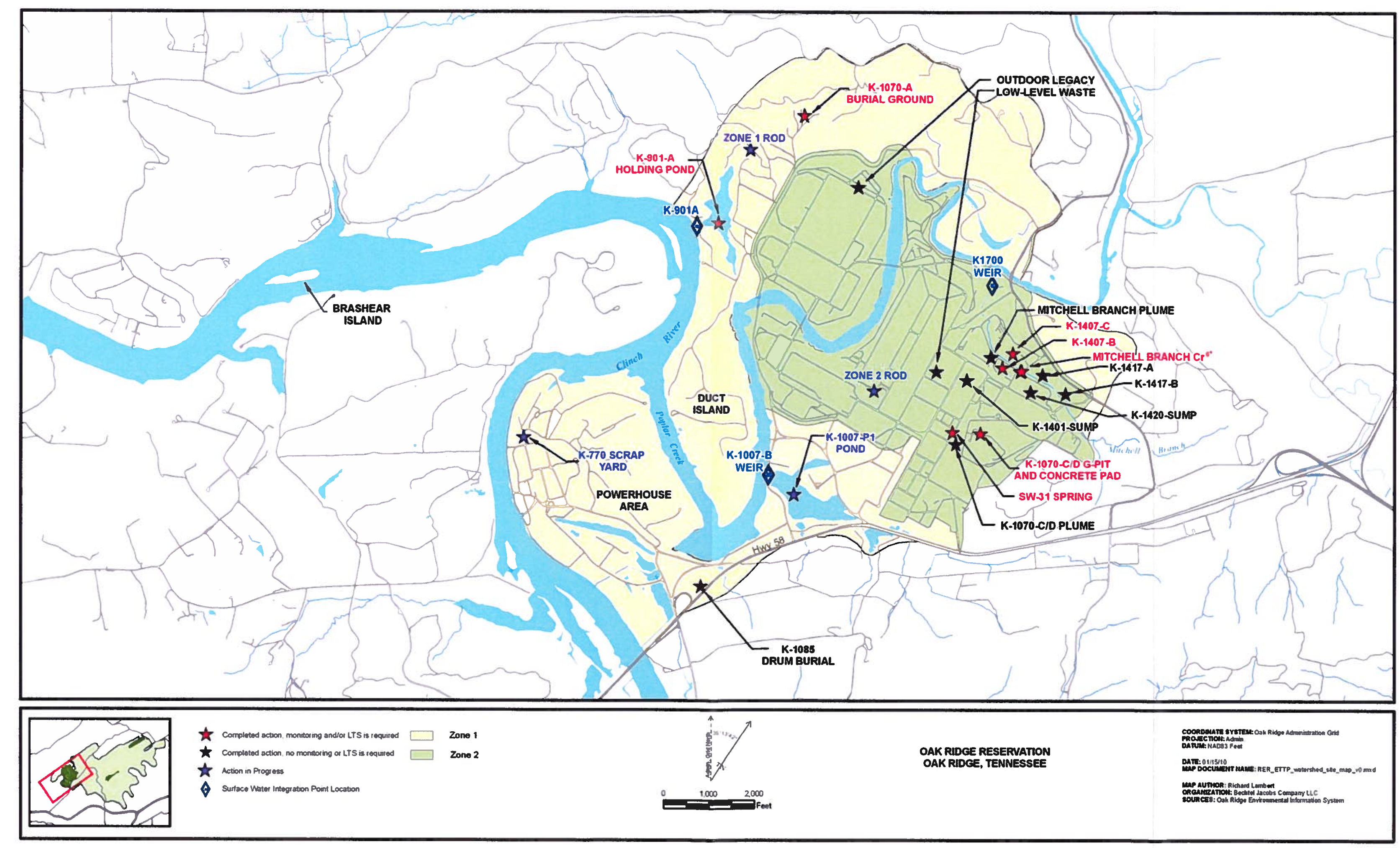

Figure 8.1. ETTP RA site map. 
This page intentionally left blank. 


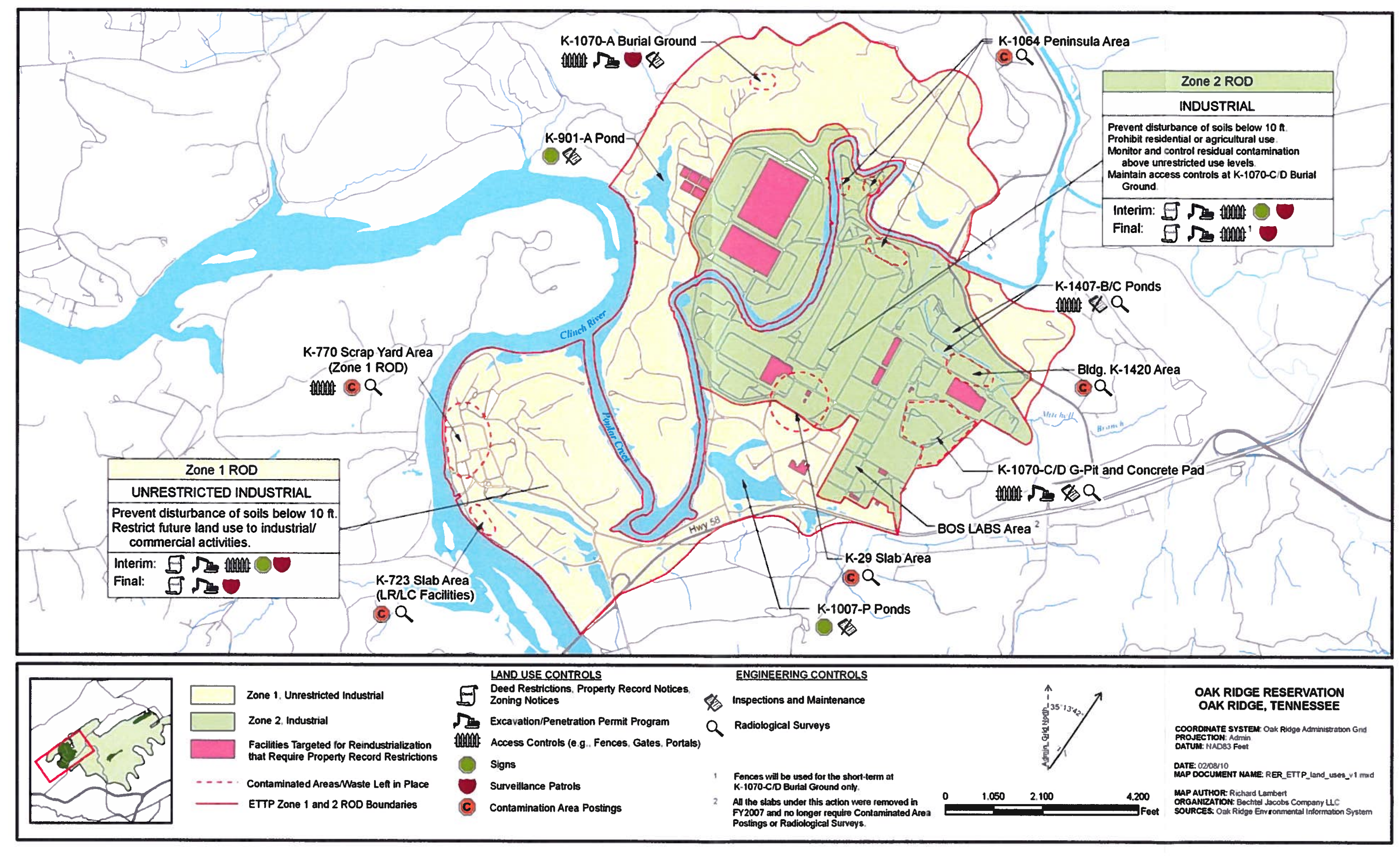

Figure 8.2. ETTP Zone 1 and 2 ROD-designated land uses and interim controls. 
This page intentionally left blank. 


\subsubsection{Status and Updates}

This section provides the status and updates of RAs and D\&D projects at ETTP for FY 2009. Historically, D\&D projects did not include any monitoring and/or LUCs and, therefore, were not included in the annual CERCLA document that evaluated monitoring data to assess the effectiveness of the RA, i.e., the RER. But now because some D\&D projects do have LUC requirements, D\&D projects are included in Table 8.1, although only those with LUCs will be discussed in the text.

\section{ETTP Watershed-scale Actions}

Soil Characterization continued in Zone 1 during FY 2009 to determine whether additional remediation is needed. An erratum to the Dynamic Verification Strategy (DVS) Remedial Action Work Plan (DOE 2007j) was submitted in FY 2009. The erratum did not include any additional monitoring or LTS requirements (see Sect. 8.2).

The D2/R1 version of the FY 2008 PCCR for Exposure Units (EUs) EU Z2-33 in Zone 2 (DOE 2008c) was approved on September 28, 2009 and the D1 version of the FY 2009 PCCR for EU Z2-36 in Zone 2 (DOE 2009f) was approved on June 3, 2009. In addition, the FY 2009 PCCR for Zone 2 EUs 11, 12, 17, 18,29 , and 38 (DOE 2009g) was submitted to the regulators in September 2009, and is pending approval. None of these post-decision documents include any requirements for monitoring, although controls are required to restrict land use to $10 \mathrm{ft}$ bgs. Details of these post-decision documents are discussed in Sect. 8.3.

Additional remediation activities to reduce ETTP groundwater and surface water contamination were initiated in FY 2009. These efforts included fish removal from three contaminated holding ponds with the largest pond being drained, recontoured, and revegetated. The D2 version of the RAWP was approved on December 18, 2008. Completion of remediation activities is planned for FY 2010. Details are provided in Sect. 8.4.2.

The two-phase groundwater treatability study at ETTP began in FY 2009 to support selection of a sitewide groundwater remediation process. Phase I will perform characterization activities necessary to design the Phase II pilot-scale demonstration. The Treatability Study Work Plan for Phase I (DOE 2008d) was approved December 15,2008. The Construction Start for Phase 1 of the Treatability Study (DOE 2008c) was submitted in April 2009. Field activities included the installation of seven 120-160 ft boreholes, borehole geophysics, Flexible Liner Underground Technologies, LLC (FLUTe) testing for DNAPL detection, and transmissivity testing. During FY 2009, DNAPL was encountered in bedrock in seven boreholes. Additional characterization efforts to bound DNAPL contaminants detected in one borehole and water sampling are planned for FY 2010.

Additionally, excavation of contaminated soil was initiated in two areas at ETTP during FY 2009. Removal of soil at the K-770 Scrapyard under the Zone 1 ROD began in May 2009 and is scheduled to be completed in FY 2010. The K-1070-B Burial Ground under the Zone 2 ROD began in September 2008 and planned completion is May 2011.

\section{ETTP Single-action Projects}

During FY 2007, hexavalent chromium was detected in surface water in Mitchell Branch in exceedance of the AWQC and was found to be discharging from Outfall 170. In response to this condition, DOE conducted a TC RmA to install and operate groundwater seepage collection pumps to capture chromiumcontaminated groundwater associated with the Outfall 170 discharge (See Section 8.4.1.2.2). The notice of intent to conduct the removal action was issued on November 5, 2007, and the AM was issued on 
December 20, 2007. The RmAR was issued July 30, 2008. A non-TC RmA was proposed in FY 2009 for a long-term solution to the release of hexavalent chromium to Mitchell Branch. An Engineering Evaluation/Cost Analysis (EE/CA) was drafted, and a final decision on the long-term action will be reached during FY 2010.

\section{ETTP Decontamination and Demolition Projects}

During FY 2009, most of the CERCLA actions at ETTP focused on completion of D\&D activities. Most buildings, except for property transfer candidates, are scheduled for demolition. The facilities that will remain are targeted for potential title transfer to private sector organizations under a reindustrialization program. During FY 2009, DOE's Reindustrialization Program transferred the Phase I Electrical Distribution System (all direct off-site main plant power lines) and Phase I Plant Roadway System (main plant entry and arterial roadways) to the City of Oak Ridge. DOE also transferred Buildings K-1000, K-1501 H\&L, and K-1008-F, as well as Land Parcels ED-4 and ED-5 West to the Community Reuse Organization of East Tennessee (CROET). To date, eleven facilities and five land parcels at ETTP have been transferred. Building demolition is performed as part of CERCLA removal actions, organized into several projects as follows:

K-25/K-27 Buildings. An AM for the demolition of the K-25 and K-27 buildings was signed in 2002, stipulating that the buildings be demolished to slab and the associated waste disposed. Hazardous materials removal, Phase 1 of the demolition, was completed in June 2005. A new plan for demolishing the buildings was developed in 2006 that would better protect workers from the deteriorated conditions in the buildings by removing high-risk components and demolishing the buildings from the outside using heavy equipment.

Full-scale demolition of the K-25 building began in December 2008 as workers began demolishing the west wing. At the end of FY 2009, two-thirds of the west wing had been demolished sending approximately 5,500 loads of demolition debris, 1,300 compressors, and 700 converters to the EMWMF. Pre-demolition activities continued in the east wing, including the removal of 104 of the 343 high-risk equipment items. Workers also continued performing vent, purge, drain and inspection activities; asbestos removal; and draining of lubrication oil and coolant from the process system in both the east and north wings. Pre-demolition work was also initiated in Building K-27.

K-29/K-31/K-33 Buildings Decontamination. The AM was approved in 1997 to decontaminate and remove equipment from the $\mathrm{K}-29, \mathrm{~K}-31$, and $\mathrm{K}-33$ gaseous diffusion buildings. The work was completed in FY 2005 and the RmAR was approved in FY 2007. Building K-29 was later demolished as part of the Group II, Phase 3 Remaining Facilities Demolition, after DOE determined that the facility was not suitable for reindustrialization.

Group I Auxiliary Facilities. In FY 1997, the AM to demolish five ETTP auxiliary facilities was signed. This project was completed in FY 2006 with the final addendum to the RmAR approved.

Group II, Phase 1 Main Plant Facilities. In FY 2000, DOE signed an AM to demolish the ETTP main plant facilities. This project began in August 2000 and was completed in December 2003. In FY 2004, the RmAR was approved.

Group II, Phase 2 Building Demolition (K-1064 Peninsula). DOE signed an AM in July 2002 for the demolition of 18 facilities and the removal of scrap material located in the K-1064 peninsula area. In FY 2007, the work was completed, and the RmAR was approved June 27, 2007. 
Group II, Phase 3 Remaining Facilities Demolition. In September 2003, an AM was approved to demolish approximately 500 remaining facilities at ETTP. The FY 2008 PCCR for the Low Risk/Low Complexity Facilities (DOE 2008g) and the FY 2008 PCCR for the PUFs (DOE 2008f) were both approved in FY 2009. In the FY 2008 Low Risk/Low Complexity Facilities PCCR, storm drain and surface water monitoring are required at the Building K-1024 slab along with radiological surveys of the slab. Interim access controls are also required at the K-1066-G yard and the hydrofluoric acid (HF) Tank Farm due to elevated radiological readings.

In FY 2009, four predominantly uncontaminated facilities (PUFs) and 11 low-risk/low-complexity facilities were demolished. In the Poplar Creek area, three high risk buildings were demolished: K-1231, $\mathrm{K}-1233$, and K-413. These actions are documented in the FY 2009 PCCR for the Predominantly Uncontaminated Facilities (DOE 2009h) and the FY 2009 PCCR for the Low Risk/Low Complexity Facilities (DOE 2009i) that were recently submitted to the EPA and TDEC for review. The Poplar Creek - 3HR PCCR (DOE 2009q) will be submitted in December 2009. Once approved, the FY 2009 Low Risk/Low Complexity Facilities PCCR will require storm drain and surface water monitoring along with radiological surveys at the Building $\mathrm{K}-1231-\mathrm{B}$ slab. Interim access controls are required at the former Building K-1035 slab site and the Building K-1204-3 slab. Monitoring results will be reported in the 2011 RER.

Over the past few years, completion of D\&D activities (mostly Group II, Phase 2 and Group II, Phase 3 actions) has been documented by various PCCRs (see Table 8.1), many of which included requirements for radiological surveys and access controls because slabs or portions of foundations were left in place. If radiological surveys indicated a slab or the remaining soil had residual contamination that exceeded the release criteria of DOE Order 5400.5, then interim access controls were implemented and the slab was posted and became part of the radiological surveillance and monitoring program. In general, storm water runoff from concrete pads is not sampled directly. The ETTP Environmental Compliance Program determines the effectiveness of the radiological control program through ongoing storm drain outfall sampling and instream water sampling, i.e., monitoring in compliance with the ETTP NPDES permit and storm water runoff plans.

Section 8.5 provides a summary of monitoring and reporting requirements for each of the D\&D closure projects that left slabs/foundations or contaminated soils in place. Because all D\&D activities have been completed as removal actions, the CERCLA Zone 1 and the Zone 2 RODs will determine the final remedy for the contaminated slabs, soils, and below-grade structures that remain. 


\subsection{ZONE 1 SELECTED CONTAMINATION AREAS INTERIM REMOVAL ACTION RECORD OF DECISION}

The ROD for Interim RAs for Selected Contaminated Areas within Zone 1 (Figure 8.2) of ETTP (Zone 1 ROD) focuses on known sources of releases and on known areas of soil contamination (DOE 2002c). Major components of the remedy include:

- excavation of contaminated soil in the K-895 Cylinder Destruct Facility Area and in the Powerhouse Area (including K-725 Beryllium Building Slab);

- $\quad$ excavation of the Blair Quarry burial area;

- $\quad$ removal of scrap metal and debris from the K-770 area;

- removal of sludge and demolition of the K-710 sludge beds and Imhoff tanks;

- characterization of areas with insufficient data to determine if a release occurred or if the potential for a release is present; and

interim LUCs to prevent access to remaining contamination.

Zone 1 was divided into four geographic areas for evaluation for unrestricted industrial use to $10 \mathrm{ft}$ bgsthe Duct Island Area, K-901 Area, K-1007 Ponds Area, and the Powerhouse Area. The final status assessments and associated data gap sampling efforts for the remaining areas of soil in these four geographic areas is being conducted using the DVS. These four areas are further divided into EUs (see Figure 8.3). The PCCR (DOE 2006e) for the Duct Island Area and K-901 Area of Zone 1 documents completion of the remedial activities at Blair Quarry, describes the risk assessment evaluations performed and determinations made using DVS, and identifies additional sites requiring RAs. A second PCCR (DOE 2006f) documents the characterization results of the DVS for the accessible EUs within the K-1007 Ponds Area and Powerhouse Area, and identifies additional areas that require remediation.

The K-770 Scrap Removal Project was conducted as part of the Zone 1 ROD and began shipping contaminated scrap from the K-770 Scrap Yard (Figure 8.1) to the EMWMF in July 2004. The PCCR (DOE 2007d) was approved in May 2007. Over 48,100 tons of waste material was shipped for disposal. Because the action under this ROD (DOE 2002c) did not remove all contamination, interim monitoring and LUCs are required to verify contamination is not migrating from the site, as discussed below (Sect. 8.2.1). Remediation of the K-770 soil initiated in FY 2009 will be documented in the K-1007 Ponds Area and Powerhouse North Area PPCR planned for FY 2010 and will supersede these interim monitoring and LUCs.

The FY 2008 PCCR for EUs Z1-01, Z1-03, Z1-38, Z1-49 in Zone 1 (DOE 2008b) was approved on April 23, 2008. This PCCR documents the RAs completed within each of the specified EUs - the Happy Valley Service Station FFA site in Z1-01, the K-1055 Gasoline/Diesel Station Tanks FFA site in Z1-03, the Duct Island South soil mounds in Z1-38, and the K-895 Cylinder Destruct Facility FFA site in Z1-49. The PCCR does not specify any monitoring requirements for the remediated sites; general LUCs for Zone 1 are reiterated.

Soil characterization continued in Zone 1 during FY 2009 to determine whether additional remediation is needed. An erratum to the DVS RAWP (DOE 2007j) was submitted in FY 2009. The erratum did not include any additional monitoring or LTS requirements. 

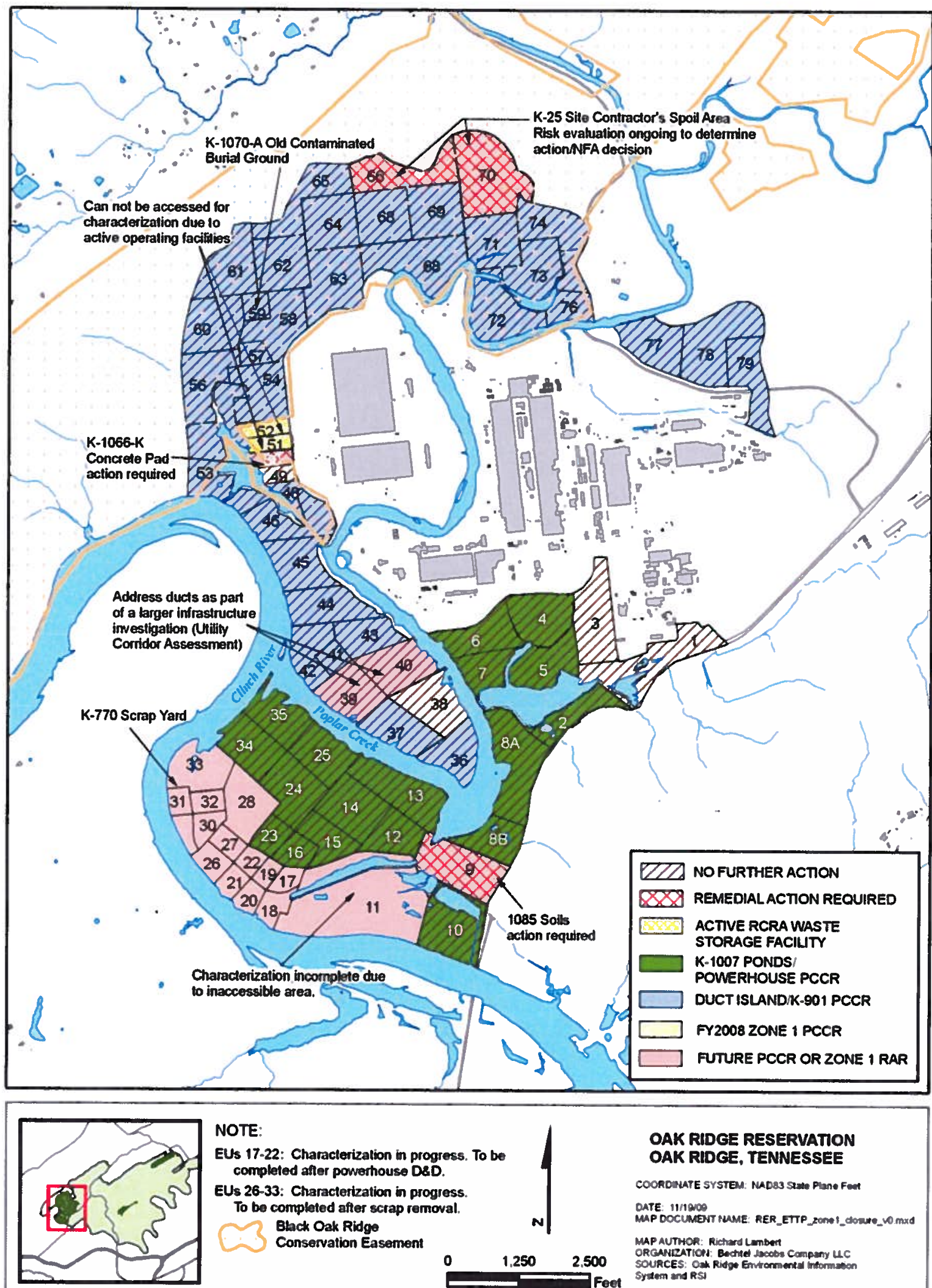

NOTE:

EUs 17-22: Characterizalion in progress. To be complated after powerhouse D\&D.

EUs 26-33: Characterization in progress. To be complated after scrap removal. Bhck Oak Ridgo

Conservation Easement

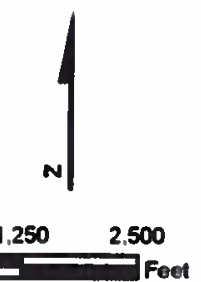

OAK RIDGE RESERVATION OAK RIDCE, TENNESSEE

COOROMUTE SYSTEM: MADS3 SLan PIAne Fan DATE $11 / 1000$

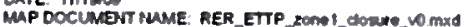
MAP AUTHOR: Richard Lembert

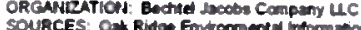
SOUACES: OA Ridge Enviementel imtormation

Figure 8.3. ETTP Zone 1 closure document and action status. 
A complete discussion of the ETTP Zone 1 ROD and a summary of actions are provided in Chap. 8 of Vol. 1 of the FY 2007 RER (DOE 2007a).

\subsubsection{Compliance with LTS Requirements}

\subsubsection{Requirements}

LTS requirements for CERCLA actions at ETTP are summarized in Table 8.2. The Zone 1 ROD (DOE 2002c) establishes "unrestricted industrial" as the land use for Zone 1, and requires LUCs to prevent disturbance of soils below $10 \mathrm{ft}$ in depth and to restrict future land use to industrial/commercial activities. To implement restrictions that prohibit more aggressive use of this area and to restrict access to this area until that land use has been achieved, seven LUCs will be implemented. Until the land use is achieved, reliance will be primarily on property record and zoning notices, the EPP program, access controls, and surveillance patrols. Once it has been established that Zone 1 is safe for unrestricted industrial use, property record restrictions, property record notices, zoning notices, excavation permits, and less significant surveillance patrols will be used. The objectives of these controls are as follows:

- Property record restrictions to restrict uses of the property by imposing limitations on its use and to prohibit uses of groundwater;

- Property record notices to provide notice to anyone searching records about the existence and location of contaminated areas and limitations on their use;

- Zoning notices to provide notice to the city about the existence and location of waste disposal and residual contamination areas for zoning/planning purposes;

- An EPP program to provide notice to permit requestors of the extent of contamination and prohibiting or limiting excavation/penetration activity;

- Access controls to control and restrict access to workers and the public in order to prevent unauthorized uses;

- Signs that provide notice or warning to prevent unauthorized access; and

- Surveillance patrols to control and monitor access by workers and the public.

The PCCRs completed under the Zone 1 ROD for the Duct Island/K-901 Area and K-1007 Ponds/Powerhouse Area state that, consistent with the Zone 1 ROD, the NFA decision means that an EU is available for unrestricted industrial use to a depth of $10 \mathrm{ft}$. bgs. All EUs that have been cleared for industrial use to a depth of $10 \mathrm{ft}$ bgs have a high probability of being cleared for industrial use to all depths, with the exception of EU 59 in the Duct Island Area and EU 9 at the K-1085 Burn Area in the Powerhouse Area. EU 59 contains the K-1070-A Old Contaminated Burial Ground where a previous RA was conducted (See Sect. 8.4.4). EU 59 does not pose a threat to groundwater and is considered NFA; however, subsurface data indicate unacceptable concentrations of radionuclides and organic chemicals for lifting of LUCs at depths below $10 \mathrm{ft}$. bgs. EU 9 does pose a threat to groundwater with a Zone 1 soils maximum RL exceedance, so an action is required at the K-1085 Old Firehouse Burn Area. Because formerly buried wastes and/or contaminated groundwater are present at depths in these EUs, LUCs are in place.

The FY 2008 Zone 1 PCCR documented the RAs completed within EUs Z1-01, Z1-03, Z1-38, and Z1-49. All EUs evaluated in this PCCR are proposed for unrestricted use below $10 \mathrm{ft}$. 
The K-770 Scrap Removal PCCR under the Zone 1 ROD requires additional LTS activities including controlling access to the K-770 Scrap Metal Yard and ensuring the fence surrounding the area remains intact. Additionally, interim controls such as maintaining $\mathrm{CA}$ postings and conducting radiological surveys are required at the following areas with residual radiological contamination above the release criteria of DOE Order 5400.5. These interim controls were required as needed during the K-770 soil removal in FY 2009, and will be superseded by an addendum to the K-1007 Ponds Area and Powerhouse North Area PCCR planned for submission in FY 2010.

- K-770 - The boundary of the CA and the flood control area will be surveyed annually to verify that no contamination has crossed the CA boundary into the adjoining flood control area. Release of this area will be conducted as part of the Powerhouse soils action.

- K-725 - The pad will be surveyed annually. Final disposition will be as part of the Power House soils action.

- K-736 - The slab is still located within the posted CA, so it is not necessary to post the slab as a fixed contamination area (FCA). If that portion of the CA where the slab remains is released from CA posting and control, the slab will be removed or the area will be posted as a FCA, and appropriate surveys will be performed.

- K-1300 - The area will be surveyed annually until remediated under the Zone 2 ROD.

- K-1066-G - Annual routine surveys will be performed on these Radioactive Materials Areas (RMAs) until final disposition occurs under the Zone 2 ROD.

Requirements provided in the PCCR (DOE 2007d) listed in Table 8.3 for the K-770 Scrap Removal Project include the following: (1) radiological surveillance, (2) storm drain characterization performed at least once within each NPDES permitting period ( $\leq 5$ years) for representative outfalls in each drain grouping, and (3) surface water monitoring. Figure 8.4 shows the locations of the storm drains and surface water locations relative to the K-770 Scrap Yard. Storm drain characterization and surface water monitoring results are used to verify the effectiveness of the Radiological Control Program.

Radiological gross alpha and gross beta surveys, at a minimum, are conducted annually. If radiological contamination is found to be migrating out of the contamination area, then additional controls are implemented. The frequency and level of surveillance and monitoring is established at each site by the radiological engineers responsible for the program, in accordance with requirements and criteria set forth in 10 CFR $\S 835$, Occupational Radiation Protection. Contamination monitoring programs are reviewed and changed annually by the Project Health Physicist to ensure that appropriate surveys are performed at a frequency that is consistent with existing and potential hazards and activities planned in the area.

In general, storm water runoff from concrete or asphalt pads is not sampled directly. Instead, the ETTP Environmental Compliance Program determines the effectiveness of the radiological control program through ongoing storm drain characterization sampling program and instream water sampling, i.e., monitoring in compliance with the ETTP NPDES Permit characterization requirements. Representative outfalls from storm drain discharges groupings are characterized at least once during each NPDES permitting period, a maximum of five years, for a minimum of gross alpha, gross beta, isotopic uranium, and ${ }^{99} \mathrm{Tc}$. Instream water monitoring is conducted at least annually downstream of ETTP at Clinch River kilometer CRK 16 Brashear Island [Clinch River mile (CRM) 9.5] for a minimum of gross alpha, gross beta, isotopic uranium, and ${ }^{99} \mathrm{Tc}$. Data are compared to screening levels established at $4 \%$ of DOE Order 5400.5 Derived Concentration Guidelines (DCGs) to maintain discharges as low as reasonably achievable (ALARA). When a screening level is exceeded, a field investigation is conducted to determine the source 
Table 8.3. LTS requirements for K-770 Scrap Removal Project facilities associated with remaining contaminated media

\begin{tabular}{|c|c|c|c|}
\hline Area/action & $\begin{array}{l}\text { Slab/Foundation } \\
\text { (annual survey) }\end{array}$ & $\begin{array}{c}\text { Storm drain } \\
\text { (characterize at least } \\
\text { once every NPDES } \\
\text { permit cycle) }\end{array}$ & Surface water \\
\hline $\begin{array}{l}\text { ROD for Interim Actions } \\
\text { in Zone } 1 \text { at ETTP/PCCR } \\
\text { for the K-770 Scrap } \\
\text { Removal Project }\end{array}$ & $\begin{array}{l}\text { K-770 Scrap Metal Yard soil } \\
\text { K-725 slab } \\
\text { K-736 slab } \\
\text { K-1300 area - contaminated soil and } \\
\text { concrete pad } \\
\text { K-1066-G yard - contaminated } \\
\text { material }\end{array}$ & $\begin{array}{l}\text { SD-724 } \\
\text { SD-730 } \\
\text { SD-740 } \\
\text { SD-750 } \\
\text { SD-770 } \\
\text { SD-780 } \\
\text { SD-800 } \\
\text { SD-820 } \\
\text { SD-830 } \\
\text { SD-860 } \\
\text { SD-870 } \\
\text { SD-880 } \\
\text { SD-890 } \\
\text { SD-892 }\end{array}$ & CRM 9. $5^{\mathrm{C}}$ (Brashear Island) \\
\hline
\end{tabular}

\footnotetext{
${ }^{\mathrm{a}}$ This area refers to the contaminated K-1302 pad and the soils area where the $\mathrm{K}-1300$ stack used to be. This is not referring to the $\mathrm{K}-1300$ clean spoils area.

bS-750 is not a required monitoring location per the PCCR, however, it drains an area of the rad contaminated K-770 scrap metal yard directly between SD-740 and SD-760. The omission of SD-750 in the PCCR is considered an oversight.

${ }^{c}$ The PCCR requires monitoring at Clinch River kilometer 16 Brashear Island, however, the actual sampling point is identified as CRM 9.5.

$\mathrm{SD}=$ storm drain
}

of the radiological release. Corrective measures are implemented, as needed. The ETTP Environmental Compliance Program provides an annual summary of analytical data and provides investigation details on any exceedance of screening levels in the Annual Site Environmental Report.

\subsubsection{Status of Requirements for FY 2009}

Restrictions were maintained for government-controlled industrial land use. The EPP functioned according to established procedures and plans for the site. Signs were maintained to control access, and surveillance patrols conducted as part of routine S\&M inspections were effective in monitoring access by unauthorized personnel.

A summary of the interim radiological monitoring conducted for the K-770 Scrap Removal PCCR in FY 2009 is included in Table 8.4. Radiological monitoring of the facilities listed in the table is performed as part of the Radiological Compliance Monitoring as required by 10 CFR $§ 835$ and adopted in the BJC Radiation Protection Plan (RPP). All surveys are performed and documented in compliance with applicable BJC procedures. Limits that apply to the surveys performed are found in Attachment D to 10 CFR $\$ 835$ and provided in Table 8.5. There were no exceedances noted for FY 2009. As stated above, the frequency of surveillance and monitoring is established at each site by the radiological engineers responsible for the program. In FY 2009, the frequency of surveys conducted at the K-770 Scrap Metal Yard soil and the K-1066-G yard decreased from the previous year as a result of remediation activities in progress or completed. The K-770 Scrap Metal Yard soil is now inspected only when worker entries are required. The K-1066-G yard contaminated material was removed in FY 2009 and monitoring is no longer required. Changes to the K-1066-G yard monitoring requirements will be documented in the FY 2010 Zone 2 PCCR. 


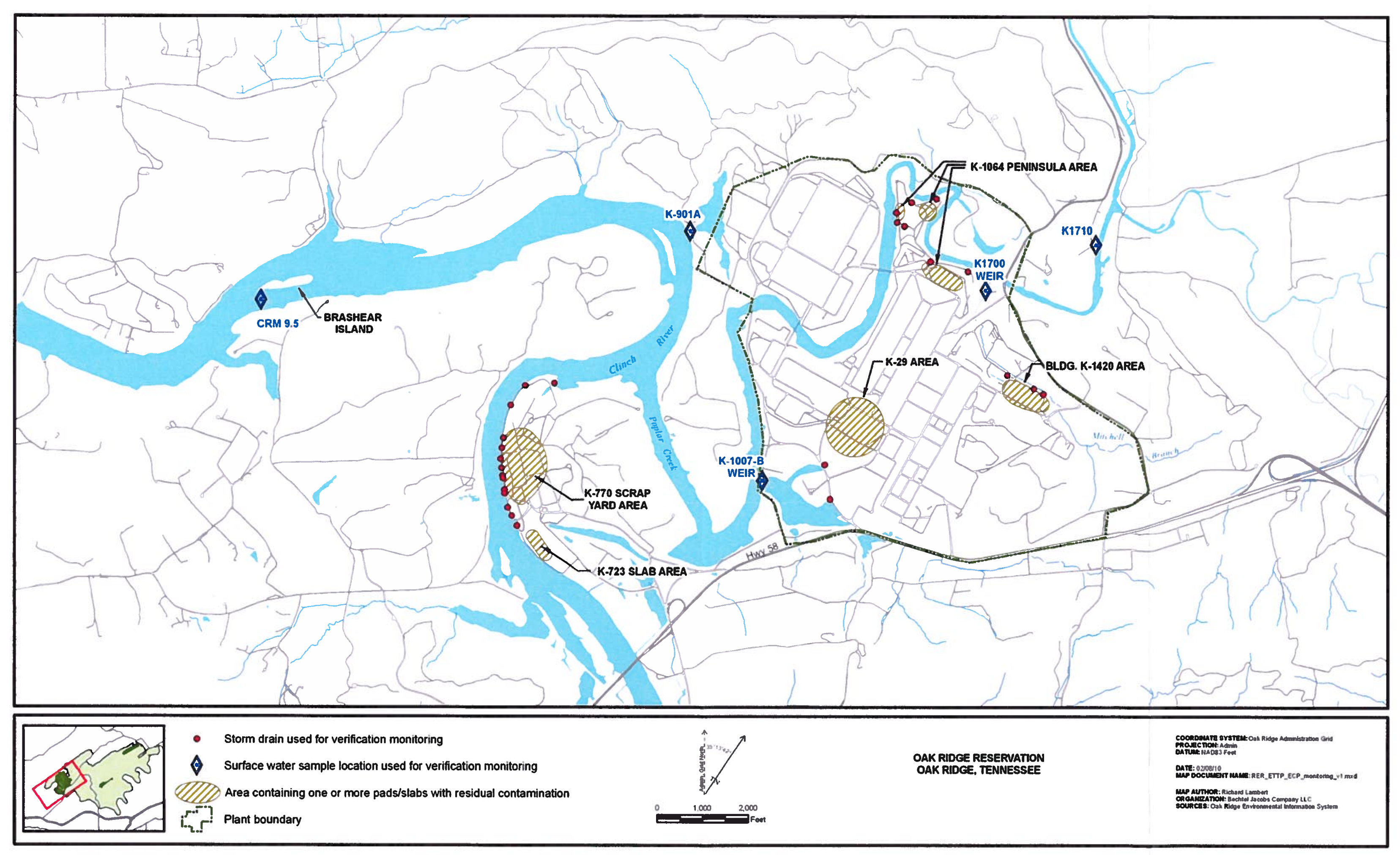

Figure 8.4. ETTP Compliance Program monitoring locations to verify radiological controls of remaining contaminated slabs. 
This page left intentionally blank. 
Table 8.4. Summary of radiological monitoring for K-770 Scrap Removal Project

\begin{tabular}{|c|c|c|c|c|}
\hline \multicolumn{5}{|c|}{ ROD for Interim Actions in Zone 1 at ETTP/PCCR for the K-770 Scrap Removal Project } \\
\hline Facility/Location & Status & $\begin{array}{l}\text { Survey } \\
\text { frequency" }\end{array}$ & Survey date(s) & $\begin{array}{l}\text { Survey } \\
\text { summary }\end{array}$ \\
\hline $\begin{array}{l}\text { K-770 Scrap Metal } \\
\text { Yard soil }\end{array}$ & Contamination Area & $\begin{array}{l}\text { Frequency changed } \\
\text { from annually to } \\
\text { survey performed } \\
\text { only when worker } \\
\text { entries required. }\end{array}$ & N/A & N/A \\
\hline K-725 slab & Fixed Contamination Area & Annually & $4 / 9 / 2009$ & $\begin{array}{l}\text { No removable } \\
\text { activity above } 10 \\
\text { CFR §835 limits } \\
\text { detected. }\end{array}$ \\
\hline K-736 slab & $\begin{array}{l}\text { Located within K-770 CA } \\
\text { and is not routinely surveyed. }\end{array}$ & N/A & N/A & N/A \\
\hline $\begin{array}{l}\text { K-1300 area - } \\
\text { contaminated soil and } \\
\text { concrete pad }\end{array}$ & Contamination Area & $\begin{array}{l}\text { Frequency changed } \\
\text { from annually to } \\
\text { none after fresh } \\
\text { concrete poured over } \\
\text { area. }^{c}\end{array}$ & N/A & N/A \\
\hline $\begin{array}{l}\mathrm{K}-1066-\mathrm{G} \text { yard - } \\
\text { contaminated material }\end{array}$ & $\begin{array}{l}\text { Remediation activities } \\
\text { completed. Radioactive } \\
\text { Material Area down-posted. }\end{array}$ & $\begin{array}{l}\text { Frequency changed } \\
\text { from annually to } \\
\text { none after } \\
\text { radiological areas } \\
\text { and items removed. }\end{array}$ & $6 / 16 / 2009$ & $\begin{array}{l}\text { No removable } \\
\text { activity above } 10 \\
\text { CFR } 8835 \text { limits } \\
\text { detected. }\end{array}$ \\
\hline
\end{tabular}

"The K-770 PCCR states that contamination monitoring programs should be reviewed annually by the Project Health Physicist to ensure that appropriate surveys are performed at a frequency that is consistent with existing and potential hazards and activities planned in the area.

'This area refers to the contaminated K-1 302 pad and the soils area where the K-1300 stack used to be. This is not referring to the $\mathrm{K}-1300$ clean spoils area.

'The K-1300 area-contaminated soil and concrete pad was covered with fresh concrete in FY 2008 and no longer requires an annual survey. This site will remain in the Radiation Protection Organization's database and surveys will still be required before any excavation/penetration activities.

$\mathrm{N} / \mathrm{A}=$ not applicable

CFR $=$ Code of Federal Regulation

Table 8.5. 10 CFR §835 limits

\begin{tabular}{|l|c|c|}
\hline \multicolumn{1}{|c|}{ Radionuclide } & \multicolumn{1}{|c|}{$\begin{array}{c}\text { Removable } \\
\mathbf{d p m} / \mathbf{1 0 0} \mathrm{cm}\end{array}$} & $\begin{array}{c}\text { Total } \\
\text { (Fixed + Removable) } \\
\mathbf{d p m} / \mathbf{1 0 0 c m}\end{array}$ \\
\hline U-Nat, U-235, U-238, and associated decay products & 1,000 & 5,000 \\
\hline $\begin{array}{l}\text { Transuranics, Ra-226, Ra-228, Th-230, Th-228, Pa-231, } \\
\text { Ac-227, I-125, I-129 }\end{array}$ & 20 & 500 \\
\hline $\begin{array}{l}\text { Th-Nat, Th-232, Sr-90, Ra-223, Ra-224, U-232, I-126, I- } \\
\text { 131, I-133 }\end{array}$ & 200 & 1000 \\
\hline $\begin{array}{l}\text { Beta-Gamma emitters (nuclides with decay modes other } \\
\text { than alpha emission or spontaneous fission) except Sr-90 } \\
\text { and others noted above. }\end{array}$ & 1,000 & 5,000 \\
\hline Tritium and tritiated compounds & 10,000 & N/A \\
\hline
\end{tabular}

CFR $=$ Code of Federal Regulations

dpm $=$ disintegrations per minute

Nat $=$ natural occurring 
Storm drain sampling and surface water monitoring of these areas were performed as part of the ETTP NPDES permit compliance monitoring and storm water runoff plans. A summary of the storm drain sampling and surface water monitoring conducted for the K-770 Scrap Removal PCCR in 2009 is included in Table 8.6. Storm drains 724, 730, 740, 750, 760, 770, and 780 are the outfalls that drain the specific storm water runoff from the K-770 Scrap Metal Yard. Storm water outfalls 800, 820, 830, 860, $870,880,890$, and 892 drain the larger areas of the K-770 Powerhouse area and are also reviewed as a conservative look at adjacent acreage.

Table 8.6. Summary of storm drain and surface water monitoring for K-770 Scrap Removal Project

\begin{tabular}{|c|c|c|c|c|}
\hline \multicolumn{5}{|c|}{ ROD for Interim Actions in Zone 1 at ETTP/PCCR for the K-770 Scrap Removal Project } \\
\hline Slab/Foundation & $\begin{array}{l}\text { Storm drain locations } \\
\text { (characterize at least } \\
\text { once every NPDES } \\
\text { permit cycle, } \leq 5 \text { yrs) }\end{array}$ & $\begin{array}{l}2009 \\
\text { Storm drain } \\
\text { monitoring } \\
\text { summary }^{\mathrm{a}}\end{array}$ & $\begin{array}{c}\text { Surface } \\
\text { water } \\
\text { locations } \\
\text { (annually) }\end{array}$ & $\begin{array}{c}2009 \\
\text { Surface water } \\
\text { monitoring } \\
\text { summary }\end{array}$ \\
\hline \multirow[t]{15}{*}{$\begin{array}{l}\text { K-770 Scrap Metal Yard soil } \\
\text { K-725 slab } \\
\text { K-736 slab }\end{array}$} & SD-724 & $\begin{array}{l}\text { Not sampled in } 2009 ; \\
\text { will be sampled as } \\
\text { part of the FY2010 } \\
\text { SWPPP Program }\end{array}$ & \multirow[t]{15}{*}{ CRM 9.5} & \multirow[t]{15}{*}{$\begin{array}{l}\text { Less than } 1 \% \text { of } \\
\text { the allowable } \\
\text { DCG }\end{array}$} \\
\hline & SD-730 & Not sampled in 2009 & & \\
\hline & SD-740 & Not sampled in 2009 & & \\
\hline & SD-750 ${ }^{b}$ & Not sampled in 2009 & & \\
\hline & SD-760 & Not sampled in 2009 & & \\
\hline & SD-770 & Not sampled in 2009 & & \\
\hline & SD-780 & Not sampled in 2009 & & \\
\hline & SD-800 & Not sampled in 2009 & & \\
\hline & SD-820 & Not sampled in 2009 & & \\
\hline & SD-830 & Not sampled in 2009 & & \\
\hline & SD-860 & Not sampled in 2009 & & \\
\hline & SD-870 & Not sampled in 2009 & & \\
\hline & SD-880 & Not sampled in 2009 & & \\
\hline & SD-890 & $\begin{array}{l}\text { Not sampled in } 2009 ; \\
\text { will be sampled as } \\
\text { part of the FY } 2010 \\
\text { SWPPP Program }\end{array}$ & & \\
\hline & SD-892 & Not sampled in 2009 & & \\
\hline
\end{tabular}

aStorm drain monitoring performed at least once within each NPDES permitting period ( $\leq 5$ years).

${ }^{b}$ SD-750 is not a required monitoring location per the PCCR, however, it drains an area of the rad contaminated K-770 scrap metal yard directly between SD-740 and SD-760.The omission of SD-750 in the PCCR is considered an oversight.

No storm water samples were collected from the K-770 Scrap Metal Yard drainage area as part of the FY 2009 Storm Water Pollution Prevention Program (SWPPP) sampling effort. However, samples will be collected from outfalls 724 and 890 as part of the NPDES permit renewal sampling effort that is included in the FY 2010 SWPPP monitoring program. Also, as part of the FY 2010 SWPPP, additional sampling for gross alpha, gross beta, isotopic uranium, and Tc-99 will be performed at outfall 724 in order to monitor radiological discharges that may be occurring as a result of ongoing remedial activities at the K-770 Scrap Yard. Surface water sampling results for two events at CRM 9.5 during FY 2009 provided values that calculated to less than $1 \%$ of the allowable DCG.

The northern section (see Figure 8.3) of ETTP Zone 1 was identified as a conservation easement, the Black Oak Ridge Conservation Easement (BORCE) on March 14, 2005. The BORCE is utilized for recreational use, e.g., hiking, bicycling, and select controlled deer hunts. The BORCE trailhead is posted with a sign which designates the trails that are available for use in the BORCE for recreational use. Additionally, trail maps are located within the BORCE at key intersections. The trailhead sign also states that there is no motorized use (except for select hunts) and users are to stay on the trails. However, the 
end use identified in the ETTP Zone 1 ROD is unrestricted industrial, i.e., recreational use was not designated. DOE acknowledges the land use differences that exist between the BORCE use and that which is in the Zone 1 ROD. This is included as an issue in Sect. 8.7. 


\subsection{ZONE 2 SOIL, BURIED WASTE, AND SUBSURFACE STRUCTURE REMOVAL ACTIONS RECORD OF DECISION}

The Zone 2 ROD (DOE 2005d) addresses contaminated soil, buried waste, and other subsurface structures within Zone 2 of ETTP (see Figure 8.2). The selected remedy consists primarily of removal of existing contamination and also establishes RLs based on anticipated future land use. LUCs, including institutional controls, are a key element of the action. Major components of the remedy include:

- Assess data sufficiency for each EU and supplement data as necessary to determine if RLs are exceeded. Verify all acreage in Zone 2 as compliant with soil RLs established by the ROD.

- Remove soil up to $10 \mathrm{ft}$ in depth that exceeds RLs set to protect a future industrial worker; remove soils to bedrock, water table, or acceptable levels of contamination to protect underlying groundwater to MCLs.

- Remove or decontaminate subsurface structures to average RLs met across an EU and maximum RLs met at any location to a depth of $10 \mathrm{ft}$.

- Remove the debris in the K-1070-B Burial Ground, regardless of depth, to minimize potential future impact to surface water; remove soil that exceeds RLs for protection of workers (upper $10 \mathrm{ft}$ ) or protection of groundwater (water table or bedrock).

- Remove the debris and soil in the K-1070-C/D Burial Ground that exceeds RLs for the protection of workers (upper $10 \mathrm{ft}$ ) or protection of groundwater (water table or bedrock).

- Implement LUCs to prevent exposure to residual soil contamination left on-site and/or to prevent residential use of the land.

Zone 2 was divided into 44 EUs for planning and evaluation purposes (See Figure 8.5). Final status assessments and associated data gap sampling efforts for accessible EUs in Zone 2 is being conducted using the DVS. The FY 2006 PCCR (DOE 2006d) addresses 108.8 acres in six EUs (Z2-02, Z2-07, $\mathrm{Z} 2-09, \mathrm{Z2}-10, \mathrm{Z} 2-27$, and Z2-42). Based on the results of the DVS evaluation, approximately 93.2 acres are recommended for unrestricted industrial use to $10 \mathrm{ft}$ bgs. Following completion of two recommended soil RAs in EU Z2-42 (K-1004-J Underground Tanks Site Soil Excavation and K-1004-J Vaults Remedial Action), the remaining 15.6 acres will be suitable for unrestricted industrial use to $10 \mathrm{ft}$ bgs and the action will be documented in the annual PCCR the year that the action is completed. The D2 version of the FY 2007 PCCR (DOE 2007e) was approved in June 2008. The PCCR addresses approximately 195 additional acres including 11 EUs (Z2-01, Z2-03, Z2-08, Z2-23, Z2-24, Z2-28, Z2-34, Z2-37, Z2-41, $\mathrm{Z2}-43$, and $\mathrm{Z2}-44$ ), of which about 143 acres are recommended for unrestricted industrial use to $10 \mathrm{ft}$ bgs. The PCCR describes the RAs performed in Zone 2 during FY 2007 and identified additional areas not defined in the Zone 2 ROD that require remediation based on the DVS evaluation results. After completion of two RAs in EU 28 (Soil Excavation) and EU-41 (Soil Excavation and K-1071 Concrete Pad Removal Action), the remaining 52 acres will be recommended for NFA.

The FY 2008 PCCR for EU Z2-33 in Zone 2 (DOE 2008c) was approved in September 2009. The PCCR addressed approximately 18 acres in EU Z2-33, of which all 18 acres are recommended for unrestricted industrial use to $10 \mathrm{ft}$ bgs. The PCCR describes the RAs performed in Zone 2 during FY 2008 and identified additional areas not defined in the Zone 2 ROD that require remediation based on the DVS evaluation results. The entire 18 acres are recommended for NFA. Additionally, two small surface soil 


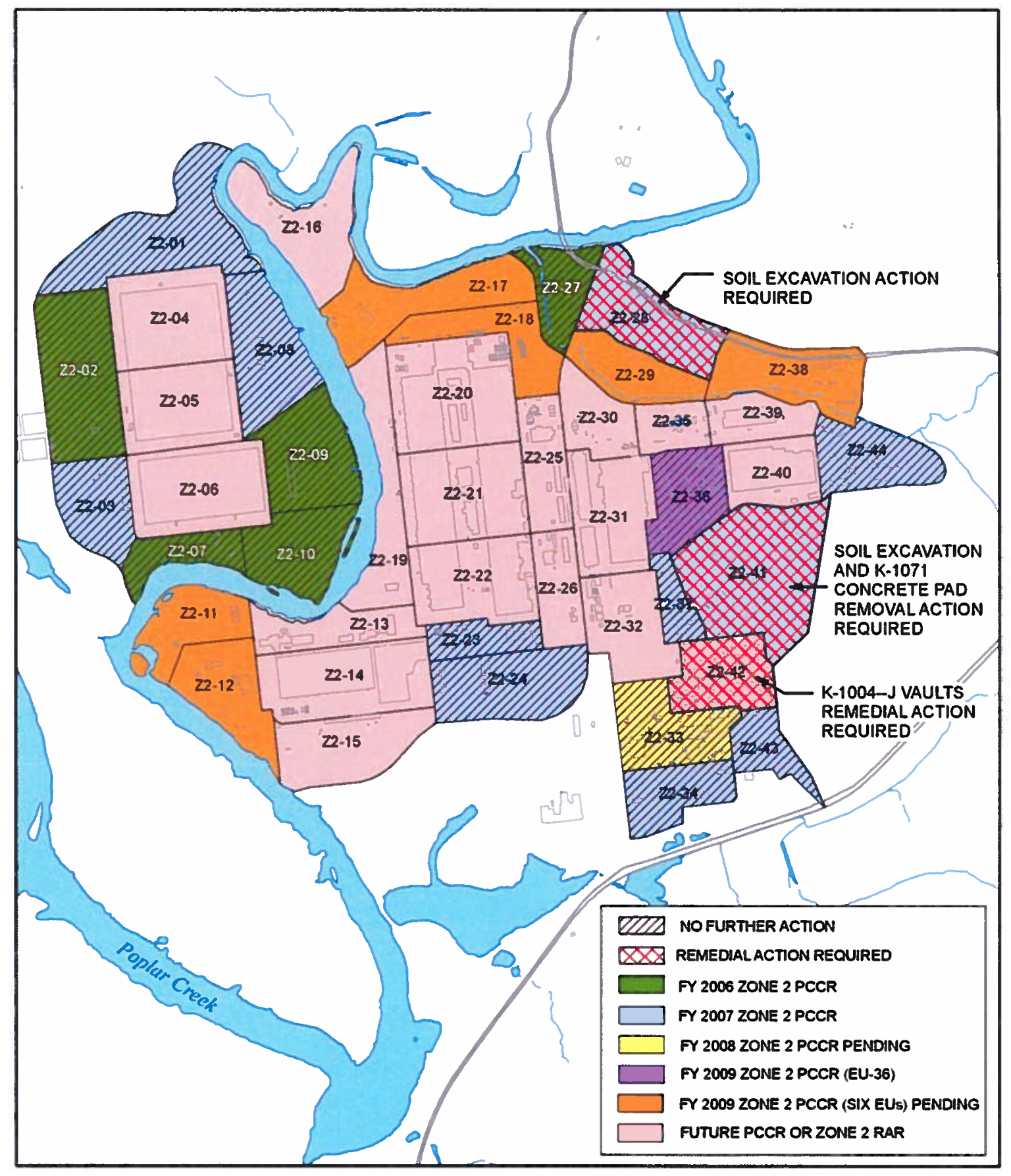

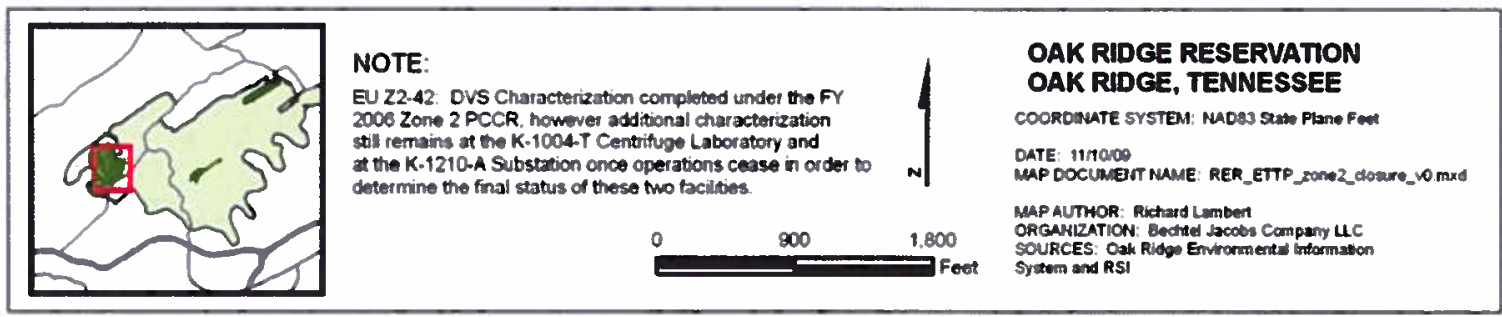

Figure 8.5. ETTP Zone 2 closure document and action status. 
areas in the adjacent EU Z2-42 and the K-1006 north basement sump were incorporated into the EU Z2-33 RA. Mowing is required at the Balance of Sites-Laboratories (BOS-LABS) area until native/no maintenance grasses can be planted.

The FY 2009 PCCR for EU Z2-36 in Zone 2 (DOE 2009f) was approved in June 2009. The PCCR addressed approximately 15 acres in EU Z2-36, of which all 15 acres are recommended for unrestricted industrial use to $10 \mathrm{ft}$ bgs. The PCCR describes the RAs performed in Zone 2 during FY 2008 and identified additional areas not defined in the Zone 2 ROD that require remediation based on the DVS evaluation results. The entire 15 acres are recommended for NFA. Finally, the FY 2009 PCCR for Zone 2 EUs 11, 12, 17, 18, 29, and 38 (DOE 2009g) was submitted to the regulators in September 2009, and is pending approval. None of these post-decision documents include any requirements for monitoring, although controls are required to restrict land use to $10 \mathrm{ft}$ bgs.

A complete discussion of the ETTP Zone 2 ROD and summary of actions is provided in Chap. 8 of Vol. 1 of the FY 2007 RER (DOE 2007a).

\subsubsection{Performance Goals and Monitoring Objectives}

The RAOs for Zone 2 are: (1) to protect human health under an industrial land use to an ECLR at or below $1 \times 10^{-4}$ and non-cancer risk levels at or below a $\mathrm{HI}$ of 1 , and (2) to protect groundwater to levels at or below MCLs. The industrial risk scenario is based on direct contact routes of exposure: (1) incidental ingestion, (2) inhalation of particulates and vapors, (3) dermal contact, and (4) external exposure. The industrial worker is assumed to have an exposure frequency of 2000 hours/year (8 hours/day for 250 days/year) and an exposure duration of 25 years (DOE 2005d). When soil removal actions are completed, they are deemed effective for industrial land use based on confirmatory sampling evaluated against the established RLs.

The monitoring requirements of the selected Zone 2 alternative include monitoring of groundwater adjacent to potential sources of groundwater contamination, including the K-1070-C/D Burial Ground (DOE 2005d). This monitoring will continue until a site-wide ROD at ETTP is approved. Monitoring of groundwater adjacent or downgradient of other contaminant sources throughout ETTP is addressed in Sect. 8.6 Other Watershed Monitoring at East Tennessee Technology Park.

\subsubsection{Evaluation of Performance Monitoring Data - FY 2009}

Monitoring locations, analytical parameters, and clean-up levels were not specified for groundwater monitoring at the K-1070-C/D Burial Ground, although the primary COCs in that area are VOCs. Semiannual samples are analyzed for VOCs and general water quality parameters in numerous wells and surface water locations outside the perimeter of the K-1070-C/D Burial Grounds. Monitoring at the site is focused on providing data for evaluating changes in contaminant concentrations near the source units or potentially discharging to surface water within the boundaries of the ETTP.

\subsubsection{Results of Groundwater Monitoring Adjacent to Potential Source Areas}

Monitoring wells UNW-114, TMW-011, and UNW-064 (Figure 8.6) monitor the VOC plume leaving the K-1070-C/D Burial Grounds. Results of monitoring at these wells show elevated VOC concentrations, although generally concentration in groundwater continue to decline or remain relatively stable since soil and debris removal in 1999 (Figures 8.7, 8.8, and 8.9). The primary VOC detected in well UNW-114 near the K-1070-C/D Burial Grounds during FY 2009 was the degradation product 1,1-DCA at 230-330 $\mu \mathrm{g} / \mathrm{L}$. Significant concentrations of 1,1-DCA were detected in wells TMW-011 $(663 \mu \mathrm{g} / \mathrm{L})$ and UNW-064 


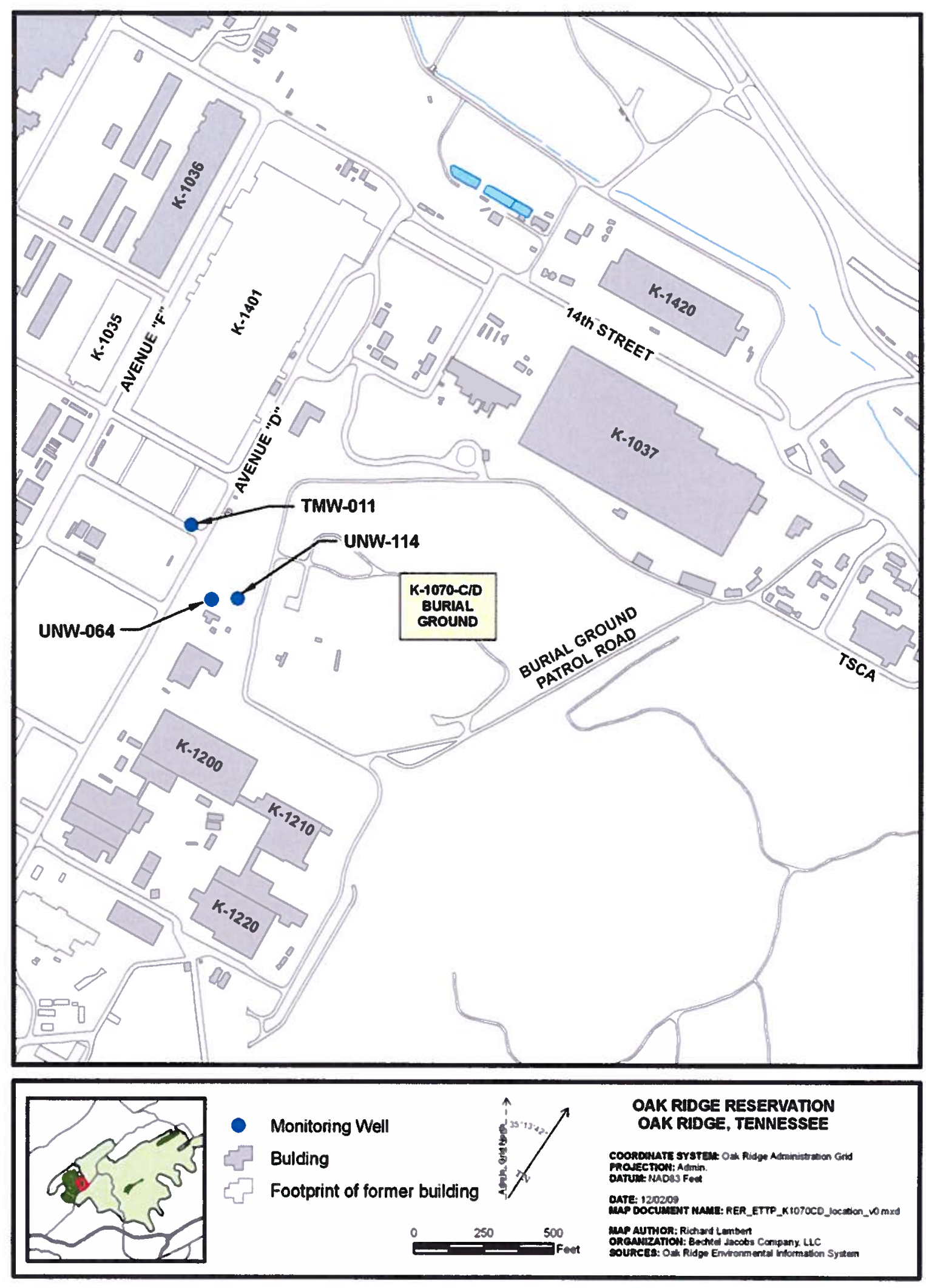

Figure 8.6. Location map for K-1070-C/D Burial Ground. 


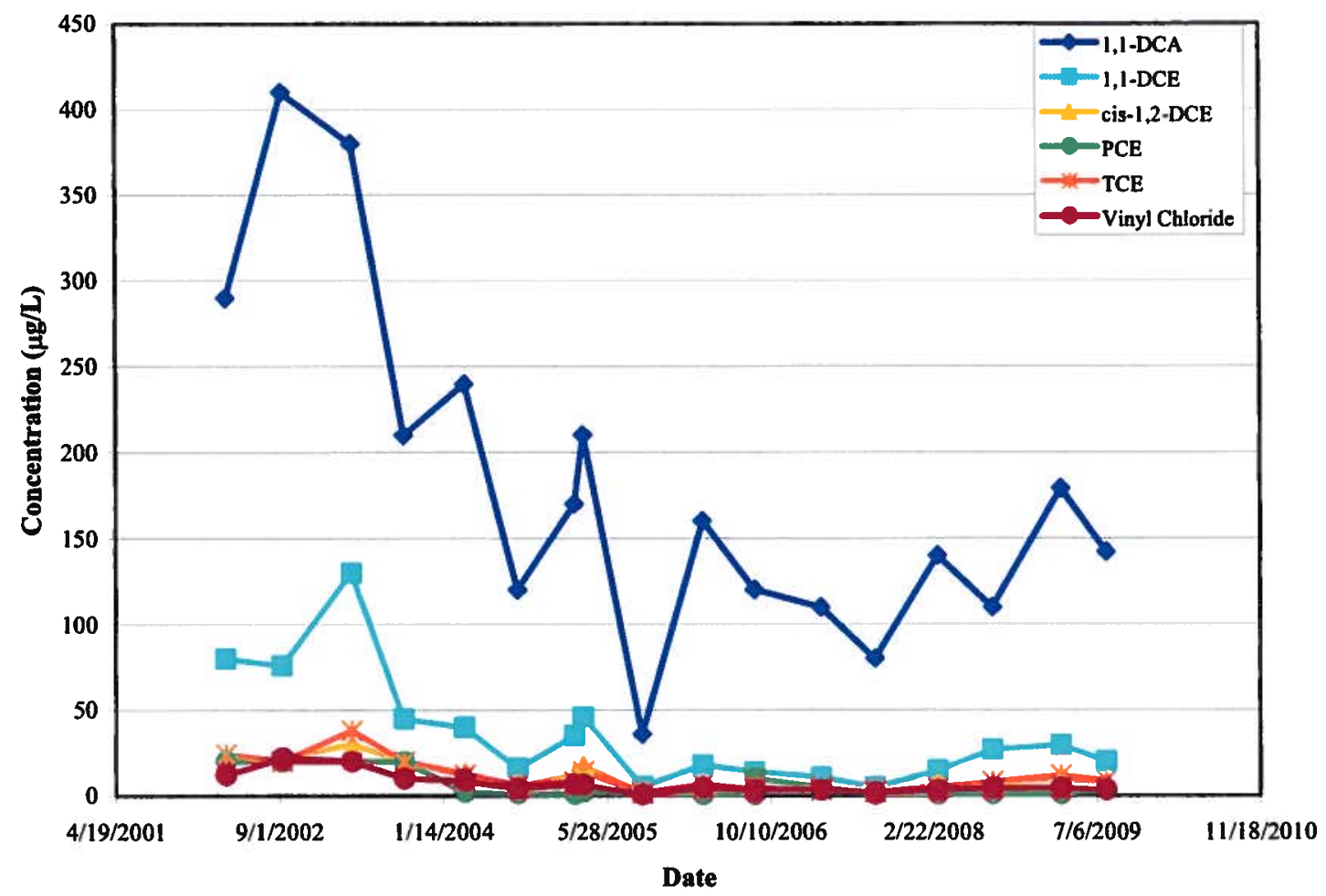

Figure 8.7. VOC concentrations in well UNW-064 for FY 2002 through FY 2009.

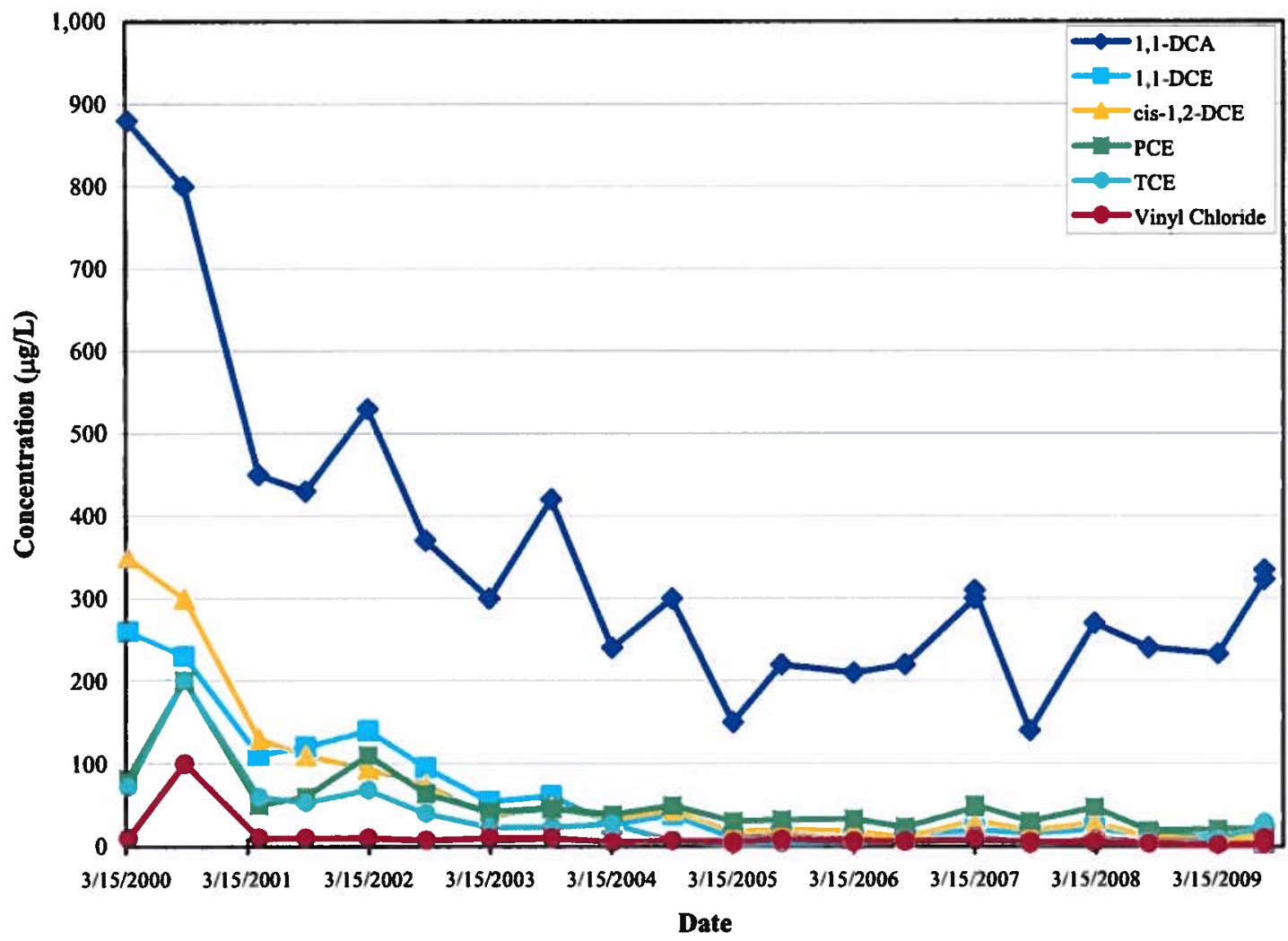

Figure 8.8. VOC concentrations in well UNW-114 for FY 2000 through FY 2009. 


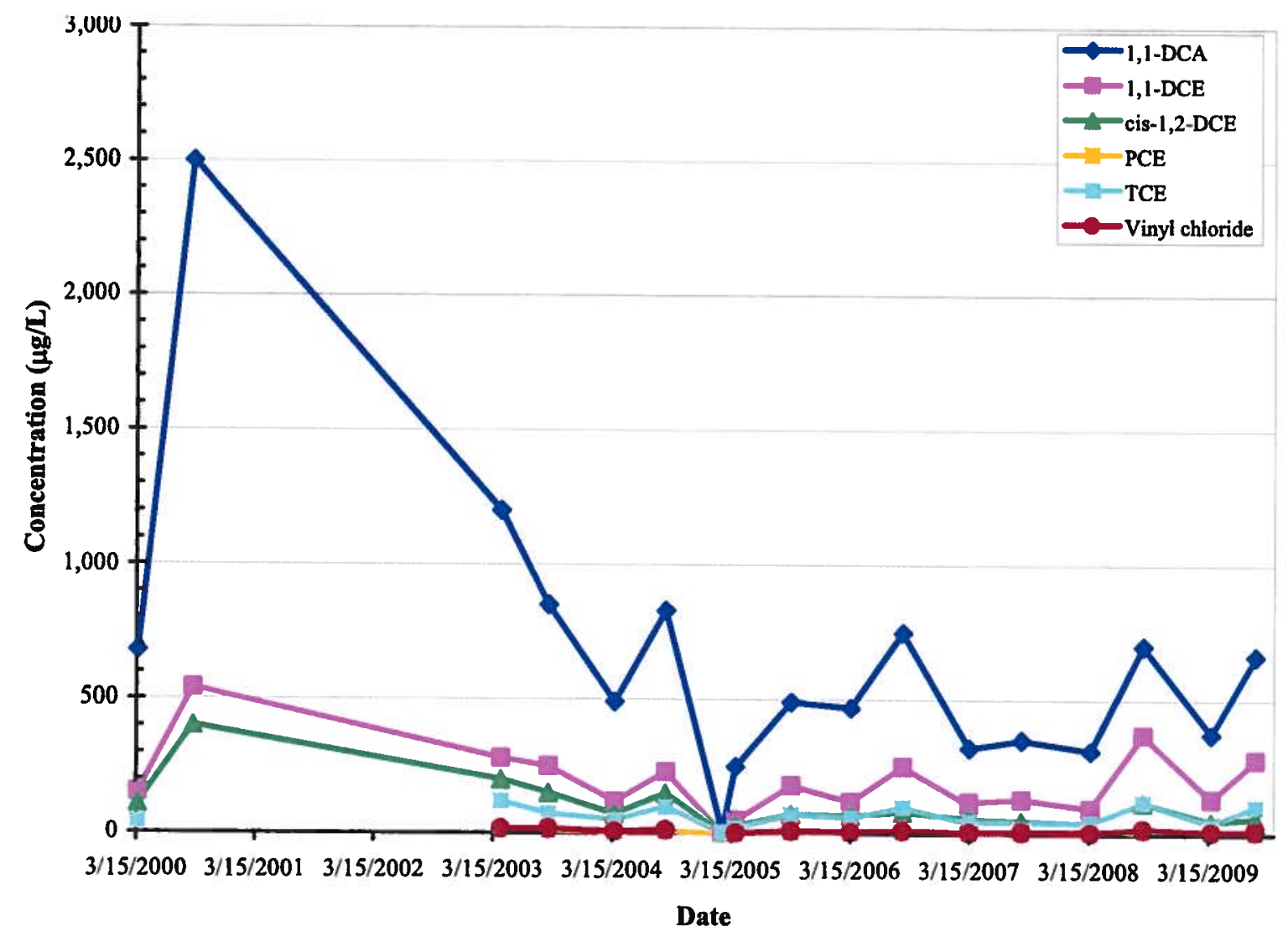

Figure 8.9. VOC concentrations in well TMW-011 for FY 2000 through FY 2009.

$(179 \mu \mathrm{g} / \mathrm{L})$. Other VOCs detected in concentrations $\geq 85 \mu \mathrm{g} / \mathrm{L}$ were $1,1-\mathrm{DCE}(279 \mu \mathrm{g} / \mathrm{L})$ and TCE $(105 \mu \mathrm{g} / \mathrm{L})$ at TMW-011 and chloroethane $(105-125 \mu \mathrm{g} / \mathrm{L})$ at UNW-064. MCLs were exceeded for 1,1-DCE $(7 \mu \mathrm{g} / \mathrm{L}), \mathrm{TCE}(5 \mu \mathrm{g} / \mathrm{L})$, and vinyl chloride $(2 \mu \mathrm{g} / \mathrm{L})$ at all three wells. The PCE concentration in well UNW-114 exceeded the MCL $(5 \mu \mathrm{g} / \mathrm{L})$ and the cis-1,2 DCE concentration in well TMW-011 decreased to less than the MCL $(70 \mu \mathrm{g} / \mathrm{L})$. Slight increases in concentrations of several VOCs were observed during FY 2009, presumably as a result of the above average rainfall.

\subsubsection{Performance Summary}

Removal of soil and debris from the K-1070-C/D Burial Grounds in 1999 has reduced the concentration of VOCs in groundwater downgradient of the removal area. An evaluation of VOC concentrations in wells UNW-064, UNW-114, and TMW-011 over the past several years indicates that generally VOC concentrations in groundwater have declined and remain relatively stable with fluctuations related to climatic cycles.

\subsubsection{Compliance with LTS Requirements}

\subsubsection{Requirements}

The Zone 2 ROD (DOE 2005d) establishes "industrial" as the land use to a depth of $10 \mathrm{ft}$. To implement restrictions that prohibit residential or agricultural use of this area under the Zone 2 ROD and to restrict access to this area until that end use has been achieved, seven LUCs will be implemented: (1) property 
record restrictions, (2) property record notices, (3) zoning notices, (4) EPP, (5) access controls, (6) signs, and (7) surveillance patrols. The objective of these controls are as follows:

- Control land use to prevent exposure to contamination by controlling excavations or soil penetrations below $10 \mathrm{ft}$, and prevent uses of the land involving exposures to human receptors greater than those from industrial use. Significant accumulations of material with residual contamination above unrestricted use levels will also be monitored and controlled. This will avoid accumulation of contamination placed in an area not currently designated for disposal that could re-establish a risk to a future industrial user.

- Prohibit the development and use of property for residential housing, elementary or secondary schools, childcare facilities, children's playground, other prohibited commercial uses, or agricultural use.

- Maintain the integrity of any existing or future monitoring system until the ETTP sitewide residual contamination RA is implemented.

- Control and restrict access to workers and the public to prevent unauthorized uses and maintain signs to provide notice or warning to prevent unauthorized access.

- Maintain the integrity of access controls and signs at the K-1070-C/D Burial Ground for as long as the residual debris represents a concern.

The FY 2008 Zone 2 PCCR was approved in FY 2009 and documented the RAs completed within EU Z2-33 and two small surface soil areas in EU Z2-42 and the K-1006 north basement sump. The EUs evaluated in this PCCR are recommended for unrestricted industrial use to $10 \mathrm{ft}$ bgs. However, a VOC groundwater plume is known to exist in the central portion of EU Z2-33 at a depth of $+/-25 \mathrm{ft}$ bgs. Therefore, it is proposed to retain land use restrictions below $10 \mathrm{ft}$ for EU Z2-33. Mowing is required at the BOS-LABS area in EU Z2-33 until native/no-maintenance grasses can be planted.

The FY 2009 PCCR for EU Z2-36 in Zone 2 was approved in June 2009. The EU evaluated in this PCCR is recommended for unrestricted industrial use to $10 \mathrm{ft}$ bgs. However, a VOC groundwater plume is known to exist in the central portion of EU Z2-36 at a depth of $+/-25 \mathrm{ft}$ bgs. Therefore, it is proposed to retain land use restrictions below $10 \mathrm{ft}$ for EU Z2-36.

The FY 2009 PCCR for Zone 2 EUs 11, 12, 17, 18, 29, and 38 was submitted to the regulators in September 2009, and is pending approval. The EUs evaluated in this PCCR are recommended for unrestricted industrial use to $10 \mathrm{ft}$ bgs. However, VOC groundwater plumes are beneath the southeast portions of EUs Z2-12 and Z2-18, and radiologically contaminated soils lie below the $10 \mathrm{ft}$ depth at the K-1407-C Retention Pond in EU Z2-29. Therefore, it is proposed to retain land use restrictions below $10 \mathrm{ft}$ for EUs Z2-12, Z2-18, and Z2-29.

Until remediation is complete and the industrial land use is achieved, the seven LUCs mentioned above will be implemented to restrict residential or agricultural use of the land. Reliance will be primarily on property record and zoning notices, the EPP program, access controls, and surveillance patrols. Once remediation is complete, property record restrictions, property record and other public notices, zoning notices, excavation permits, and less intensive surveillance patrols and fences for the short term at the $\mathrm{K}-1070-\mathrm{C} / \mathrm{D}$ Burial Grounds will be used. In addition, when an area within Zone 2 is transferred, property record restrictions and notices will be implemented. Details of these LUCs will be included in the ETTP Zone 1 and Zone 2 RARs. Fences, signs, and surveillance patrols will be used to restrict access only in the short term until remediation is complete. 


\subsubsection{Status of Requirements for FY 2009}

Short-term restrictions were maintained for government-controlled industrial land use. Signs were maintained to control access, and surveillance patrols conducted as part of routine S\&M inspections were effective in monitoring access by unauthorized personnel. The EPP program functioned according to established procedures and plans for the site. Signs and access controls at the K-1070-C/D Burial Ground were inspected monthly by the ETTP S\&M Program. 


\subsection{COMPLETED SINGLE ACTIONS AT ETTP WITH MONITORING AND/OR LTS REQUIREMENTS}

\subsubsection{K-1407-B/C Ponds Remedial Action}

The ROD for the K-1407-B/C Ponds (DOE 1993b) addressed potential risks associated with residual wastes and soils remaining in the $\mathrm{K}-1407-\mathrm{B} / \mathrm{C}$ Ponds from the initial removal of sludge conducted as a previous RCRA closure action. The location of the K-1407-B/C ponds at ETTP is shown in Figure 8.10.

Components of the selected remedy include the following activities:

- Placement of clean soil and rock fill for isolation and shielding,

- Maintenance of institutional controls, and

- Groundwater monitoring to assess performance of the action and develop information for use in reviewing the effectiveness of the remedy.

\subsubsection{Performance Goals and Monitoring Objectives}

The objective of the K-1407-B/C Ponds RA was to reduce potential threats to human health and the environment posed by residual metal, radiological, and VOC contamination within the pond soils (DOE 1993b).

The RAR (DOE 1995e) proposes semiannual groundwater monitoring for nitrate, metals, and selected radionuclides, including gross alpha and beta activity, ${ }^{99} \mathrm{Tc},{ }^{90} \mathrm{Sr},{ }^{137} \mathrm{Cs},{ }^{230,232} \mathrm{Th}$, and ${ }^{234,238} \mathrm{U}$. However, VOCs are the primary groundwater contaminant in the Mitchell Branch area of the ETTP. Remediation target concentrations were not established in the CERCLA decision documents for use in postremediation monitoring. As recommended by EPA, with concurrence from TDEC, performance monitoring is conducted in wells UNW-003, UNW-009, and the Mitchell Branch weir (K-1700 Weir), shown on Figure 8.10.

\subsubsection{Evaluation of Performance Monitoring Data}

\subsection{Monitoring Results - Groundwater (UNW-003, UNW-009)}

The primary groundwater contaminants in the K-1407-B and -C ponds area of the ETTP are VOCs, which are widespread in this portion of the plant, including contaminant sources upgradient of the ponds. Groundwater samples were collected at UNW-003 and UNW-009 in March and August 2009. Monitoring results for FY 2009 at wells are generally consistent with results from previous years. Gross alpha activity was detected at $4.1 \mathrm{pCi} / \mathrm{L}$ in March and at $14 \mathrm{pCi} / \mathrm{L}$ in August at $\mathrm{UNW}-003$ and was not detected at UNW-009 in March or August. Gross beta activity ranged from 13.4 to $20.6 \mathrm{pCi} / \mathrm{L}$ at UNW-003. The gross beta activity ranged from 5.23 to $5.97 \mathrm{pCi} / \mathrm{L}$ at $\mathrm{UNW}-009$. The radionuclide ${ }^{99} \mathrm{Tc}$ was detected at $31.9 \mathrm{pCi} / \mathrm{L}$ in UNW-003 in August but was not detected in March. An estimated ${ }^{90} \mathrm{Sr}$ activity of $2.21(J) \mathrm{pCi} / \mathrm{L}$ was detected at UNW-009 in March but not in August, and ${ }^{234} \mathrm{U}$ was detected in both sampling events at activities less than $1 \mathrm{pCi} / \mathrm{L}$. None of the metals having primary drinking water standards exceeded those levels. Aluminum and iron were elevated above their secondary drinking water standards in unfiltered sample aliquots, but only the field-filtered sample for iron from UNW-003 in 

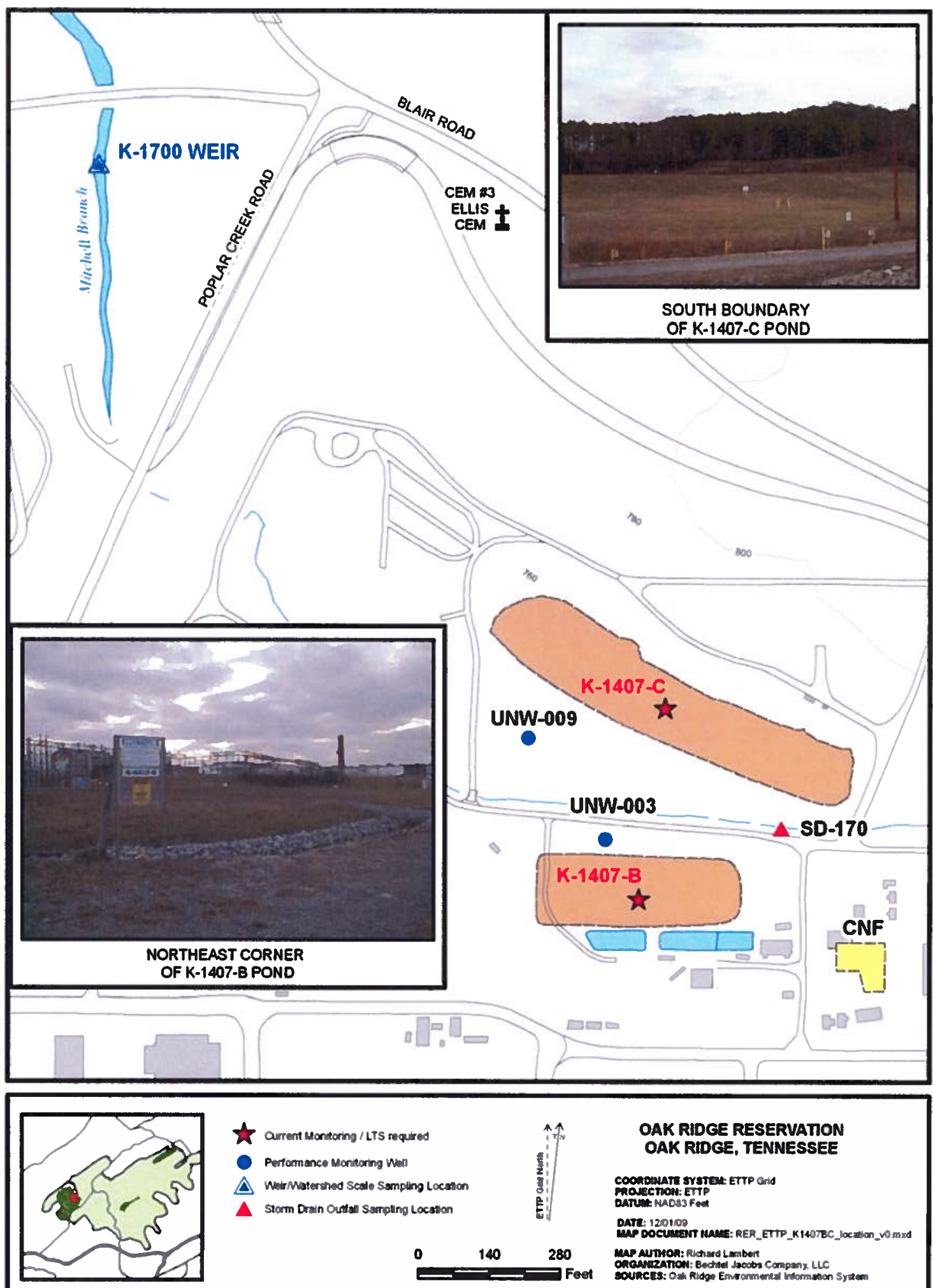

if arrent Monitoring / LTS nequred

- Perromince Monharing wen

$\triangle$ witrmaterstad Scall Ssmping Location

A Stom Drin Outall Samping Locstion

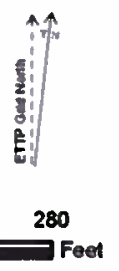

OAK RIDGE RESERVATION OAK RIDGE, TENNESSEE

coonoware sYateat ETTP and

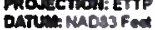

DAre: 120109

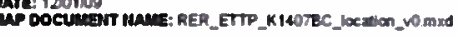

mas Aupron: Rith wo L tmbert

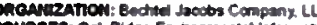

Figure 8.10. Location of K-1407-B/C Ponds. 
March also exceeded its secondary standard. Manganese exceeded its secondary drinking water standard in both filtered and unfiltered aliquots from both wells during both sampling events. The elevated manganese levels are likely caused by chemical reduction in the local groundwater induced by reductive dehalogenation of VOCs.

High concentrations of several VOCs are present in groundwater in well UNW-003 downgradient of the former K-1407-B Pond and adjacent to Mitchell Branch. Significant concentrations of parent compounds PCE $(150-200 \mu \mathrm{g} / \mathrm{L})$ and TCE $(>1 \mathrm{ppm})$ and the degradation products $1,1-\mathrm{DCE}(290-350 \mu \mathrm{g} / \mathrm{L})$, 1,1-DCA $(350-450 \mu \mathrm{g} / \mathrm{L})$, cis-1,2-DCE ( $>1 \mathrm{ppm})$, and vinyl chloride $(50 \mu \mathrm{g} / \mathrm{L})$ were detected at UNW003 in FY 2009. The detection of VOCs at concentrations well above $1,000 \mu \mathrm{g} / \mathrm{L}$ and the steady concentrations over recent years strongly suggest the presence of DNAPL in the vicinity of this well. The ETTP sitewide ROD will address groundwater contamination present in the area of the former ponds.

\subsection{Monitoring Results - Surface Water (K-1700 weir)}

Monitoring results for Mitchell Branch during FY 2009 are similar to historical monitoring results, except the trends for chromium and ${ }^{99} \mathrm{Tc}$ are decreasing compared to the previous year. No significant changes to water chemistry in Mitchell Branch are evident as a result of the RA at the former $\mathrm{K}-1407-\mathrm{B} / \mathrm{C}$ Ponds. VOCs were detected in surface water at the Mitchell Branch $(\mathrm{K}-1700)$ Weir (Figure 8.10), which is consistent with historical results for this location. Some, but not all of the VOC loading in Mitchell Branch originates from the former K-1407-B Pond. The VOCs detected included cis-1,2-DCE, 1,1-DCE, 1,1-DCA, chloroform, PCE, TCE, carbon tetrachloride, and vinyl chloride (see Sect. 8.6 for a discussion of water quality trends at the K-1700 Weir). The concentrations of TCE and vinyl chloride at this weir exceed the MCLs ${ }^{1}$ of 5 and $2 \mu \mathrm{g} / \mathrm{L}$, respectively, for these two compounds, although MCLs do not apply and are not ARARs for surface water on the ORR. Tennessee fish and aquatic life Water Quality Criteria (WQC) [TDEC 2004a] have not been established for DCE, TCE, vinyl chloride, chloroform, or PCE; however, there are Tennessee WQC for recreation (organisms only criteria) for chloroform, 1,1-DCE, PCE, TCE, and vinyl chloride. Concentrations of each detected VOC at the K-1700 Weir are less than the Tennessee WQC for recreation, organisms only.

Metals detected at the K-1700 Weir in FY 2009 include aluminum, barium, cadmium, iron, and manganese. Aluminum, iron, and manganese exceeded their secondary drinking water criteria in unfiltered samples. However, barium and cadmium did not exceed MCL reference concentrations in surface water at the K-1700 weir during FY 2009.

During FY 2007, hexavalent chromium was detected in surface water in Mitchell Branch in exceedance of the AWQC (11 $\mu \mathrm{g} / \mathrm{L})$ and was found to be discharging from Outfall 170 (Figure 8.10). In response to this condition, DOE conducted a TC RmA to install and operate groundwater seepage collection pumps to capture chromium-contaminated groundwater associated with the Outfall 170 discharge. By the end of FY 2008, the hexavalent chromium concentration was routinely at nondetection levels of less than $2 \mu \mathrm{g} / \mathrm{L}$ at both MIK 0.79 and the K-1700 Weir during dry conditions. The results of the dry weather sampling during FY 2009 indicate that the instream concentrations at MIK 0.79 continued to routinely be less than $2 \mu \mathrm{g} / \mathrm{L}$. The wet weather sampling results at the instream MIK 0.79 location included a maximum value of $10.1 \mu \mathrm{g} / \mathrm{L}$ with more typical results in the 4 to $5 \mu \mathrm{g} / \mathrm{L}$ range. During FY 2009, DOE initiated a non-TC $\mathrm{RmA}$ to address long-term management of the hexavalent chromium discharges. An EE/CA was drafted and a final decision regarding the long-term action will be reached during FY 2010.

During FY 2006, lead exceeded the fish and aquatic life criterion continuous concentration of $2.5 \mu \mathrm{g} / \mathrm{L}$; however, lead was not detected in Mitchell Branch during FY 2009.

\footnotetext{
${ }^{1}$ MCLs are used for screening purposes only.
} 


\subsubsection{Performance Summary}

FY 2009 monitoring results for UNW-003 and UNW-009 are similar to historical monitoring results. Monitoring of surface water at K-1700 Weir in Mitchell Branch is consistent with historic trends with chromium below the AWQC in FY 2009.

\subsubsection{Compliance with LTS Requirements}

\subsection{Requirements}

LTS requirements specified in the RAR (DOE 1995e) include maintenance of institutional controls (Table 8.2); specifically, conduct periodic inspections, radiological and industrial hygiene surveillances, ensure access and activity controls, and implement maintenance activities.

\subsection{Status of Requirements for FY 2009}

All components of the K-1407-B/C Ponds site were inspected in FY 2009 by the ETTP S\&M Program, including access controls and sign conditions; condition of vegetation including dead spots, excessive weeds or deep rooted vegetation, grass mowing, discoloration or withering of vegetation; soil/surface condition including evidence of soil erosion, gullies or rills, staining, debris or trash. No maintenance was required. 


\subsubsection{K-901-A and K-1007-P1 Holding Ponds}

The proposed non-TC RmA actions for the K-901-A and K-1007-P1 Holding Pond (Figures 8.11 and 8.12) ponds are prescribed in a new AM (DOE 2007f). The new AM for these ponds was approved in March 2007 and includes decisions for K-901-A Holding Pond, K-1007-P1 Holding Pond, K-720 Slough, and the K-770 Embayment. This new AM (DOE 2007f) supersedes the previous AM (DOE 1997d). Beginning in FY 2009, monitoring of the ponds began under a new SAP that addresses the sampling of fish tissue in all four of the ponds, as well as additional sampling unique to the ecological enhancement of the K-1007-P1 Holding Pond (DOE 2009n). In the case of the K-1007-P1 Holding Pond, the fish monitoring in FY 2009 represents baseline, pre-action sampling (Section 8.4.2.2).

Activities associated with the recently approved removal action include:

- $\quad$ K-1007-P1 Holding Pond

- Drain pond, modify the weir, kill undesirable fish, establish vegetation within the pond and the riparian zone, replace desirable fish, and adjust water quality to protect piscivorous wildlife and recreational fishermen.

- Institutional controls to prevent residential use, monitoring.

- $\quad$ K-901-A Holding Pond - Institutional controls to prevent residential use, monitoring.

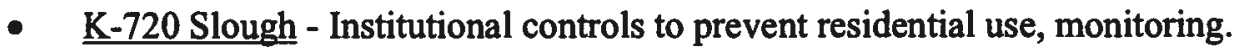

- $\quad$ K-770 Embayment - No action (Institutional controls specified in Zone 1 ROD remain in effect).

- $\quad$ K-1007-P3, P4, and P5 Holding Ponds - No action (Institutional controls specified in Zone 1 ROD remain in effect).

The goal of K-1007-P1 Holding Pond RAs is to establish a new steady-state condition within the pond that reduces risks from PCBs by enhancing components of the ecology that minimize PCB uptake. Once fully implemented, the ecological enhancement action will reduce risks by interdicting contaminant exposure pathways associated with both human and ecological receptors.

Actions conducted at the K-1007-P1 Holding Pond in FY 2009 include the following:

- Delivery and placement of 19,600 cubic yards of soil to re-contour the K-1007-P1 Holding Pond bottom, creating shallow water environments conducive to the establishment of beneficial aquatic vegetation.

- Removal of undesirable fish (i.e., fish that bioaccumulate PCBs, cause resuspension of contaminated sediment, or consume aquatic vegetation) from the K-1007-P1, -P3 and -P4 Holding Ponds.

- Planting of approximately 65,000 aquatic plants, including 50,000 emergent plants, nearly 10,000 floating-leaf plants, and 5,000 submersed plants. 

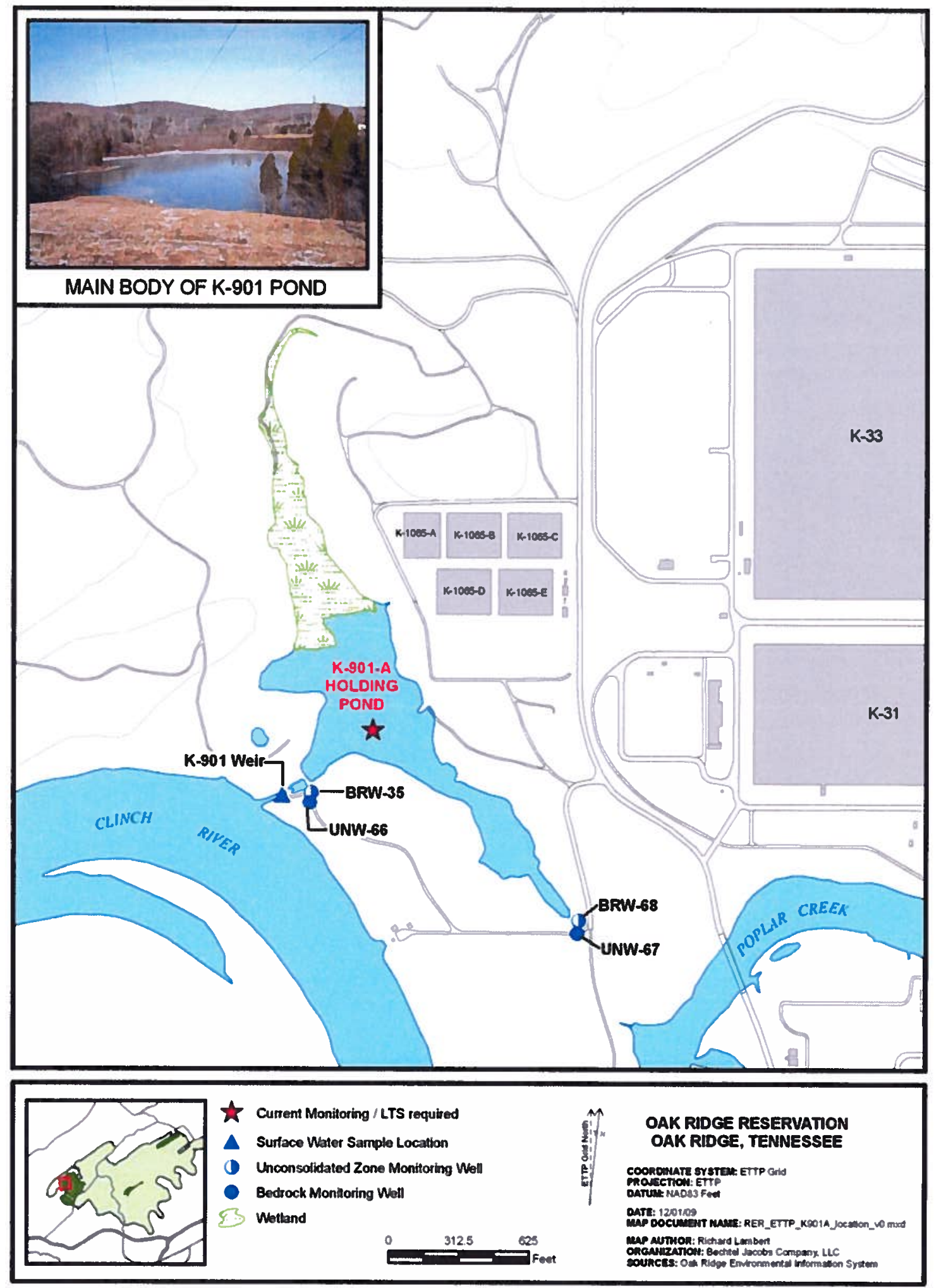

Figure 8.11. Location of K-901-A Holding Pond. 


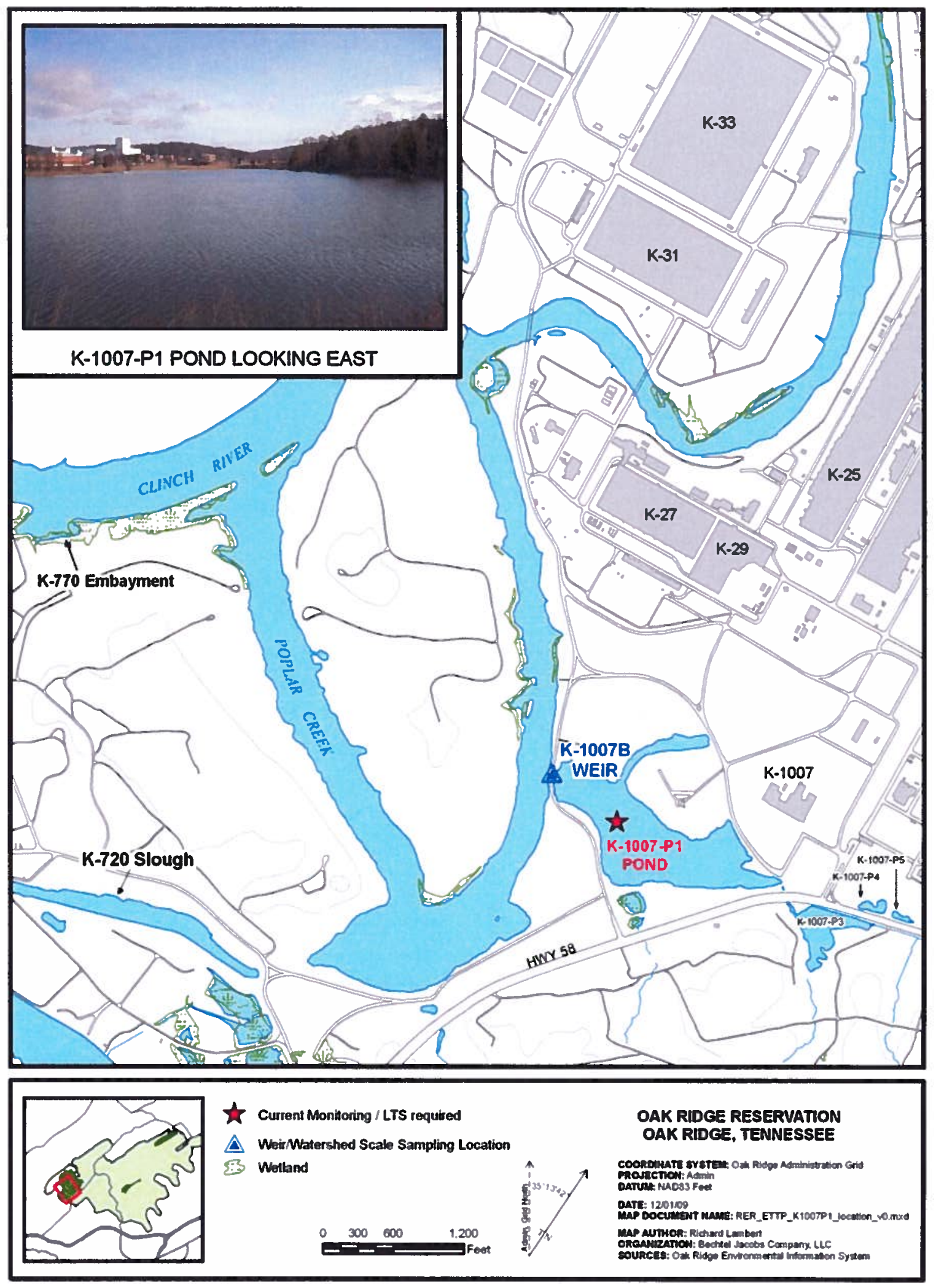

Figure 8.12. Location of K-1007-P1 Holding Pond. 
- Construction of an 880-ft long fish barrier and modification of the existing K-1007-P1 Holding Pond weir to prevent the migration of undesirable fish species from Poplar Creek into the K-1007-P1 Holding Pond.

- Management of herbivorous wildlife to protect the newly planted vegetation.

- Temporary dewatering of the pond to facilitate re-contouring, planting and fish removal activities.

Additional RAs planned for FY 2010 include restocking the K-1007-P1 Holding Pond with desirable fish species (primarily sunfish and various minnows), planting of native vegetation within the pond, and establishment of a riparian buffer zone to discourage geese from using the pond and to improve habitat.

\subsubsection{Performance Goals and Monitoring Objectives}

Monitoring of the K-1007-P1 Holding Pond will be performed in two phases (DOE 2009n). The first phase is operational monitoring that will begin after the pond has been restocked and will continue until the pond has achieved a state where aquatic vegetation and a desirable mix of fish species have been established. Operational monitoring is scheduled to begin in FY 2010 and will be reported in the RER, as well as the CERCLA FYR.

The second phase of monitoring of the K-1007-P1 Holding Pond will begin once the desired pond ecology has been established. Monitoring during this phase will be used to determine if PCB uptake in the fish remain below protective risk-based levels. This phase of monitoring will also be performed in the K-901-A Holding Pond and the K-720 Slough beginning in FY 2010. Performance monitoring results will be reported in the RER and the FYR.

Per the AM, "...A PCB concentration level of $1 \mathrm{mg} / \mathrm{kg}$ in fish fillets $(2.3 \mathrm{mg} / \mathrm{kg}$ whole body) was set based upon levels shown to be protective of piscivorous wildlife, consistent with surrounding water bodies, and below FDA recommendations..." During FY 2009, baseline monitoring was still conducted in the K-1007-P1 Holding Pond and is presented in the following section (Sect. 8.4.2.2).

\subsubsection{Evaluation of Baseline Monitoring Data}

Assessment of PCB uptake and exposure in the K-1007-P1 Holding Pond continued in FY 2009, and included the collection and analysis of fillets and whole body fish samples; fish samples were also collected from the K-901-A Holding Pond and K-720 Slough for analysis of PCBs. All fish samples from the K-1007-P1 Holding Pond were collected in February 2009, and represent the last baseline collections from the K-1007-P1 Holding Pond before fish removal with rotenone the week of June 4 and pond recontouring in late June to early July. All other 2009 sampling activities were completed after the water in the K-1007-P1 Holding Pond was allowed to return to its normal level in mid-July.

The target fish species for analysis of PCBs in the K-901-A Holding Pond and K-720 Slough were gizzard shad (Dorosoma cepedianum) and largemouth bass (Micropterus salmoides) for analysis of whole body tissue and fillets, respectively. It was not possible to collect the total number of bass needed from each body of water (i.e., 20); therefore, common carp (Cyprinus carpio) were also collected at both locations to provide a combined total of 20 bass and carp. Carp were selected because they are widely distributed, they are present at both locations, and they have been used historically in other monitoring efforts on the ORR for contaminant analyses. 
PCB concentrations in largemouth bass collected in 2009 from the K-1007-P1 Holding Pond remained within the range of historical observations (Figure 8.13), averaging $14.85 \mu \mathrm{g} / \mathrm{g}$ (Table 8.7). These levels are 10-20 fold higher than the PCB concentration target level from the AM (1.0 ppm). Large year-to-year variations in PCB concentrations in bass have been observed at this site, and may be due to fluctuations in the relative abundance of gizzard shad prey, which accumulate much higher levels of PCBs than other forage species. Concentrations of PCBs in bluegill fillets in the K-1007-P1 Holding Pond continued to be elevated in 2009, averaging $3.22 \mu \mathrm{g} / \mathrm{g}$ (Table 8.7) compared with $2.77 \mu \mathrm{g} / \mathrm{g}$ in 2008 . Whole fish bluegill composites from the K-1007-P1 Holding Pond were $\sim$-fold higher than in fillets of the same species (Table 8.7).

Mean PCB concentrations in bass from the K-901-A Holding Pond and the K-720 Slough were over an order of magnitude less than the values observed in the K-1007-P1 Holding Pond, with values averaging 0.56 and $0.18 \mu \mathrm{g} / \mathrm{g}$, respectively. Long-term trends for the K-901-A Holding Pond are shown in (Figure 8.14) and reveal similar year-to-year fluctuations to those observed in the K-1007-P1 Holding Pond. There was a marked difference in PCB levels in gizzard shad collected from the K-901-A Holding Pond and the K-720 Slough. In the K-720 Slough, PCB levels in shad were low, and were comparable to levels in largemouth bass at that site $(0.22 \mu \mathrm{g} / \mathrm{g})$, while in the K-901-A Holding Pond, shad levels were six-fold higher than in largemouth bass. Levels in carp were similar between the two ponds (Table 8.7).

Caged Asiatic clams (Corbicula fluminea) were placed near and within various storm drains entering the the K-1007-P1 and K-901-A Holding Ponds for a four week exposure from June 24 to July 22, 2009. PCB concentrations in clams were again elevated in storm drains entering the K-1007-P1 Holding Pond (averaging between $0.32-1.72 \mu \mathrm{g} / \mathrm{g}$ in SD 100, SD 490, and SD 120), with substantially lower PCB values in clams placed at the K-901-A Holding Pond $(0.15 \mu \mathrm{g} / \mathrm{g})$.

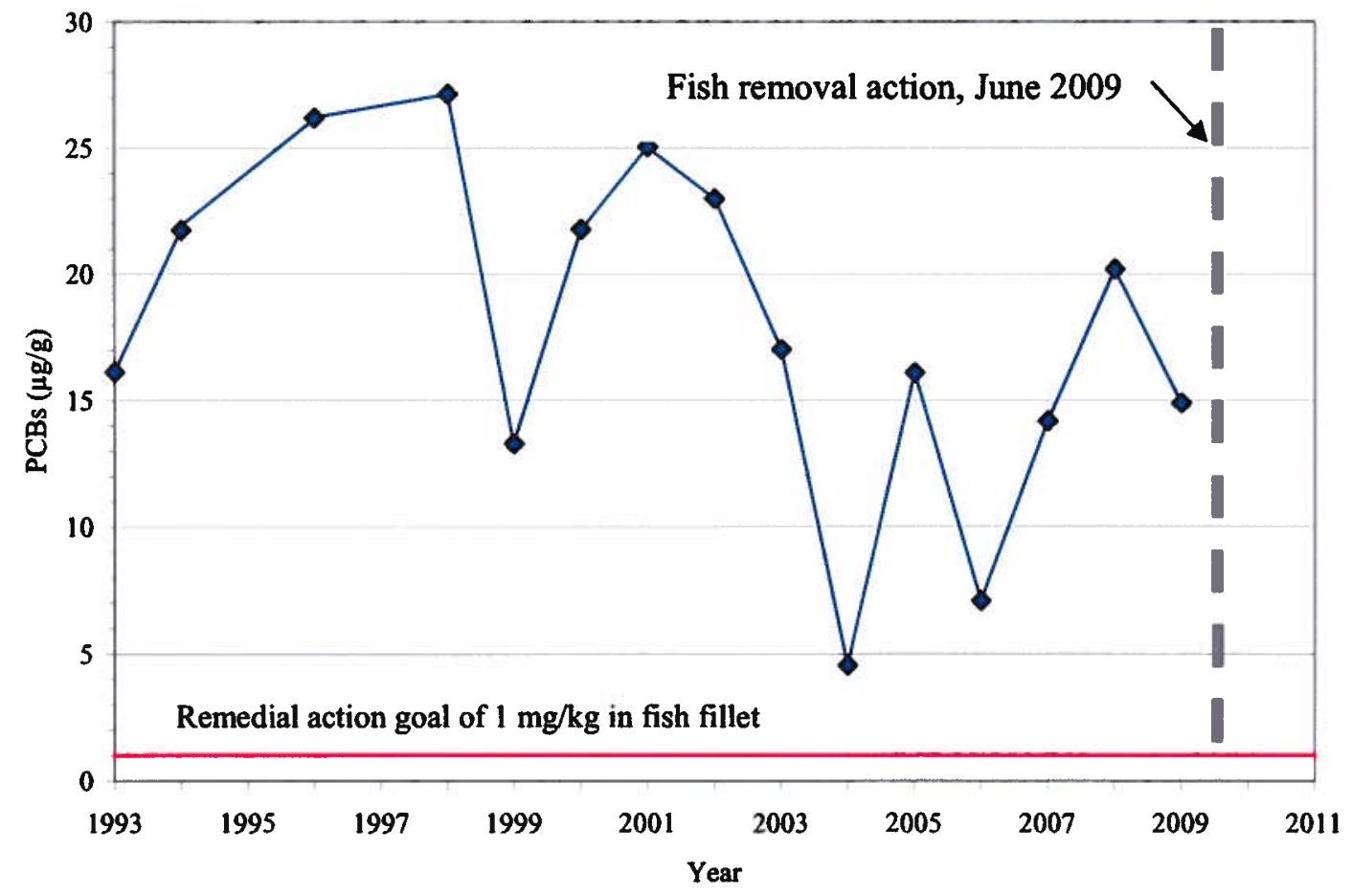

Figure 8.13. Mean concentrations of PCBs in largemouth bass fillets from K-1007-P1 Holding Pond, 1993-2009, representing baseline trends prior to the non-TC RmA. 


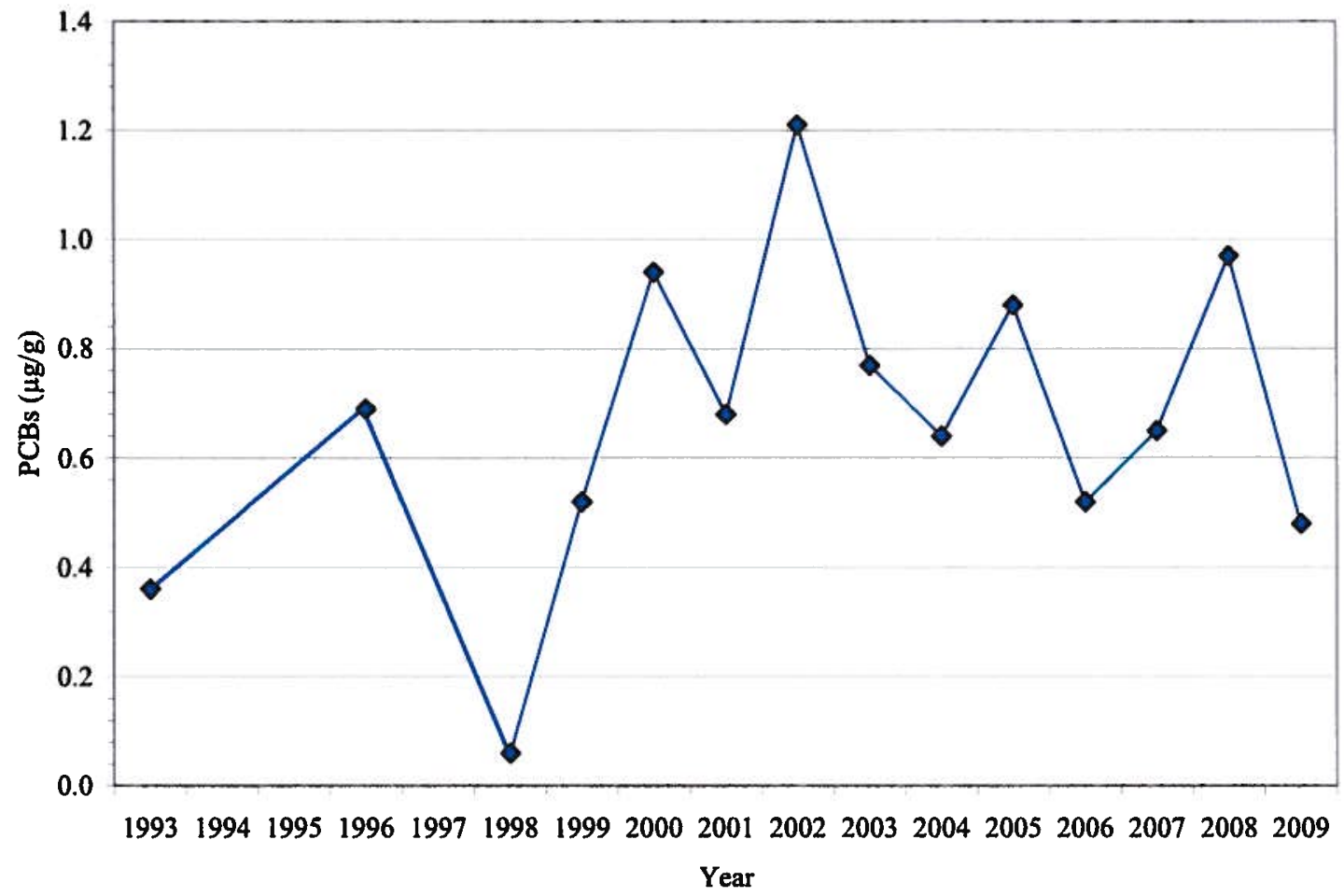

Figure 8.14. Mean concentrations of PCBs in largemouth bass from K-901-A Holding Pond, 1993-2009. 
Table 8.7. Total PCB (Aroclors 1248, 1254, and 1260) concentrations in fish from the K-1007-P1 Holding Pond, K-720 Slough, and K-901-A Holding Pond, 2009

\begin{tabular}{|c|c|c|c|c|c|c|}
\hline Site & Species & Sample size & Aroclor 1248 & Aroclor 1254 & Aroclor 1260 & Total PCBs \\
\hline \multirow[t]{3}{*}{$\begin{array}{l}\text { K-1007-P1 } \\
\text { Holding Pond }\end{array}$} & Largemouth Bass & 6 & $\begin{array}{l}4.28 \pm 1.77 \\
(1.6-12.0)\end{array}$ & $\begin{array}{l}7.25 \pm 2.24 \\
(3.6-18.0)\end{array}$ & $\begin{array}{l}4.03 \pm 1.53 \\
(1.5-11.0)\end{array}$ & $\begin{array}{l}14.85 \pm 5.43 \\
(5.8-41.0)\end{array}$ \\
\hline & Bluegill sunfish fillets & 20 & $\begin{array}{c}0.94 \pm 0.015 \\
(0.04-3.1)\end{array}$ & $\begin{array}{l}1.55 \pm 0.26 \\
(0.04-5.4)\end{array}$ & $\begin{array}{l}0.72 \pm 0.13 \\
(0.01-2.3)\end{array}$ & $\begin{array}{c}3.22 \pm 0.52 \\
(0.09-10.8)\end{array}$ \\
\hline & $\begin{array}{l}\text { Bluegill sunfish } \\
\text { composites }\end{array}$ & $\begin{array}{l}6 \text { (10 fish } \\
\text { each) }\end{array}$ & $\begin{array}{c}3.77 \pm 0.23 \\
(3.00-4.40)\end{array}$ & $\begin{array}{c}5.88 \pm 0.44 \\
(4.00-7.00)\end{array}$ & $\begin{array}{c}2.40 \pm 0.24 \\
(1.40-3.80)\end{array}$ & $\begin{array}{c}12.07 \pm 0.81 \\
(8.70-14.20)\end{array}$ \\
\hline \multirow[t]{3}{*}{ K-720 Slough } & Largemouth Bass & 8 & 0 & $\begin{array}{c}0.09 \pm 0.01 \\
(0.04-0.12)\end{array}$ & $\begin{array}{c}0.1 \pm 0.01 \\
(0.07-0.15)\end{array}$ & $\begin{array}{c}0.18 \pm 0.02 \\
(0.12-0.27)\end{array}$ \\
\hline & Gizzard shad & $\begin{array}{c}6 \text { (10 fish } \\
\text { each) }\end{array}$ & 0 & $\begin{array}{l}0.08 \pm 0.01 \\
(0.07-0.1)\end{array}$ & $\begin{array}{l}0.14 \pm 0.01 \\
(0.1-0.16)\end{array}$ & $\begin{array}{l}0.22 \pm 0.012 \\
(0.17-0.26)\end{array}$ \\
\hline & Carp & 12 & $\begin{array}{c}0.1 \pm 0.08 \\
(0.02-0.26)\end{array}$ & $\begin{array}{c}0.26 \pm 0.05 \\
(0.04-0.63)\end{array}$ & $\begin{array}{c}0.28 \pm 0.05 \\
(0.09-0.64)\end{array}$ & $\begin{array}{l}0.57 \pm 0.11 \\
(0.2-1.53)\end{array}$ \\
\hline \multirow[t]{3}{*}{$\begin{array}{l}\text { K-901-A Holding } \\
\text { Pond }\end{array}$} & Largemouth Bass & 7 & $\begin{array}{c}0.01 \pm 0.001 \\
(0.0-0.01)\end{array}$ & $\begin{array}{c}0.11 \pm 0.03 \\
(0.04-0.22)\end{array}$ & $\begin{array}{c}0.45 \pm 0.11 \\
(0.19-0.86)\end{array}$ & $\begin{array}{c}0.56 \pm 0.13 \\
(0.26-1.11)\end{array}$ \\
\hline & Gizzard shad & $\begin{array}{l}6 \text { (10 fish } \\
\text { each) }\end{array}$ & 0 & $\begin{array}{l}0.71 \pm 0.052 \\
(0.59-0.93)\end{array}$ & $\begin{array}{l}2.3 \pm 0.15 \\
(2.0-3.0)\end{array}$ & $\begin{array}{c}3.01 \pm 0.21 \\
(2.59-3.93)\end{array}$ \\
\hline & Carp & 13 & $\begin{array}{l}0.006 \pm 0.0003 \\
(0.005-0.006)\end{array}$ & $\begin{array}{c}0.09 \pm 0.01 \\
(0.02-0.17)\end{array}$ & $\begin{array}{l}0.54 \pm 0.10 \\
(0.14-1.2)\end{array}$ & $\begin{array}{c}0.63 \pm 0.12 \\
(0.17-1.37) \\
\end{array}$ \\
\hline
\end{tabular}

${ }^{\mathrm{a}}$ Values are mean concentrations $(\mu \mathrm{g} / \mathrm{g}) \pm \mathrm{SE}$; range in parentheses.

${ }^{b}$ Monitoring represents preremediation conditions. 


\subsubsection{Performance Summary}

Performance monitoring at the K-1007-P1 Holding Pond will begin in FY 2010. The baseline trends show PCBs in largemouth bass around $15 \mathrm{ppm}$ as a long-term average. Clam studies continue to indicate that storm drains are a source of PCBs to the K-1007-P1 Holding Pond, but resuspension of contaminated sediments in the pond are a more likely important source of PCBs to resident biota. The 2009 RAs at the K-1007-P1 Holding Pond are designed to reduce sediment mobilization and subsequent bioaccumulation in fish. At the K-901-A Holding Pond in 2009, largemouth bass accumulated PCB concentrations similar to the long-term average. There is little long-term data in order to evaluate time trends at the K-720 Slough.

\subsubsection{Compliance with LTS Requirements}

\subsection{Requirements}

The RmAR (DOE 1999e) states that S\&M personnel will conduct routine activities including verifying and repairing damage after storms or flooding, verifying signs are visible and in place, and maintaining the weirs between the K-1007-P1 Holding Pond and Poplar Creek and the K-901-A Pond and Clinch River.

\subsection{Status of Requirements for FY 2009}

Activities conducted at the ponds in FY 2009 included inspections by the ETTP S\&M Program for visible evidence of storm or flood damage, inspections of the weirs for evidence of debris or vegetation or erosion of the banks, and inspections of the warning signs. No maintenance was required. 


\subsubsection{K-1070-C/D G-Pit and Concrete Pad Remedial Action}

The K-1070-C/D G-Pit is the primary source of organic contaminant releases to soil and groundwater in the area. The Concrete Pad, located in the southeastern portion of the K-1070-C/D area, was determined to pose an unacceptable health risk to workers from future exposure to soil radiological contaminants. The location of the area at ETTP is shown in Figure 8.15. Components of the remedy included:

- Excavation of the G-Pit contents, interim storage of the material, treatment, and disposal, and

- Placement of a 2-ft soil cover over the Concrete Pad.

A complete discussion of the RA at K-1070-C/D G-Pit and Concrete Pad is provided in Chap. 8 of Vol. 1 of the FY 2007 RER (DOE 2007a).

\subsubsection{Compliance with LTS Requirements}

\subsection{Requirements}

The decision documents for this site require interim LTS activities including maintaining institutional controls (see Table 8.2). Specifically, inspections of the soil cover over the pad are to be conducted weekly to look for erosion, and the grass on the cover is to be mowed at an estimated frequency of five times a year. Annual radiological walkover surveys are to be conducted to confirm the effectiveness of the Concrete Pad soil cover in preventing exposure to ionizing radiation. Existing institutional controls will continue to include semiannual inspections of the fence, as well as ensuring the existing EPP Program remains in place. These controls are to continue until final decisions are made for the K-1070C/D OU in the ETTP Zone 2 ROD.

\subsection{Status of Requirements for FY 2009}

The site was inspected by the ETTP S\&M Program in FY 2009 for items including condition of the warning signs, condition of fencing and locked gate, condition of the Concrete Pad soil cover and maintenance of vegetation including the presence of excessive weeds or deep-rooted vegetation, need for grass mowing, or discoloration or withering of vegetation. No maintenance was required. 


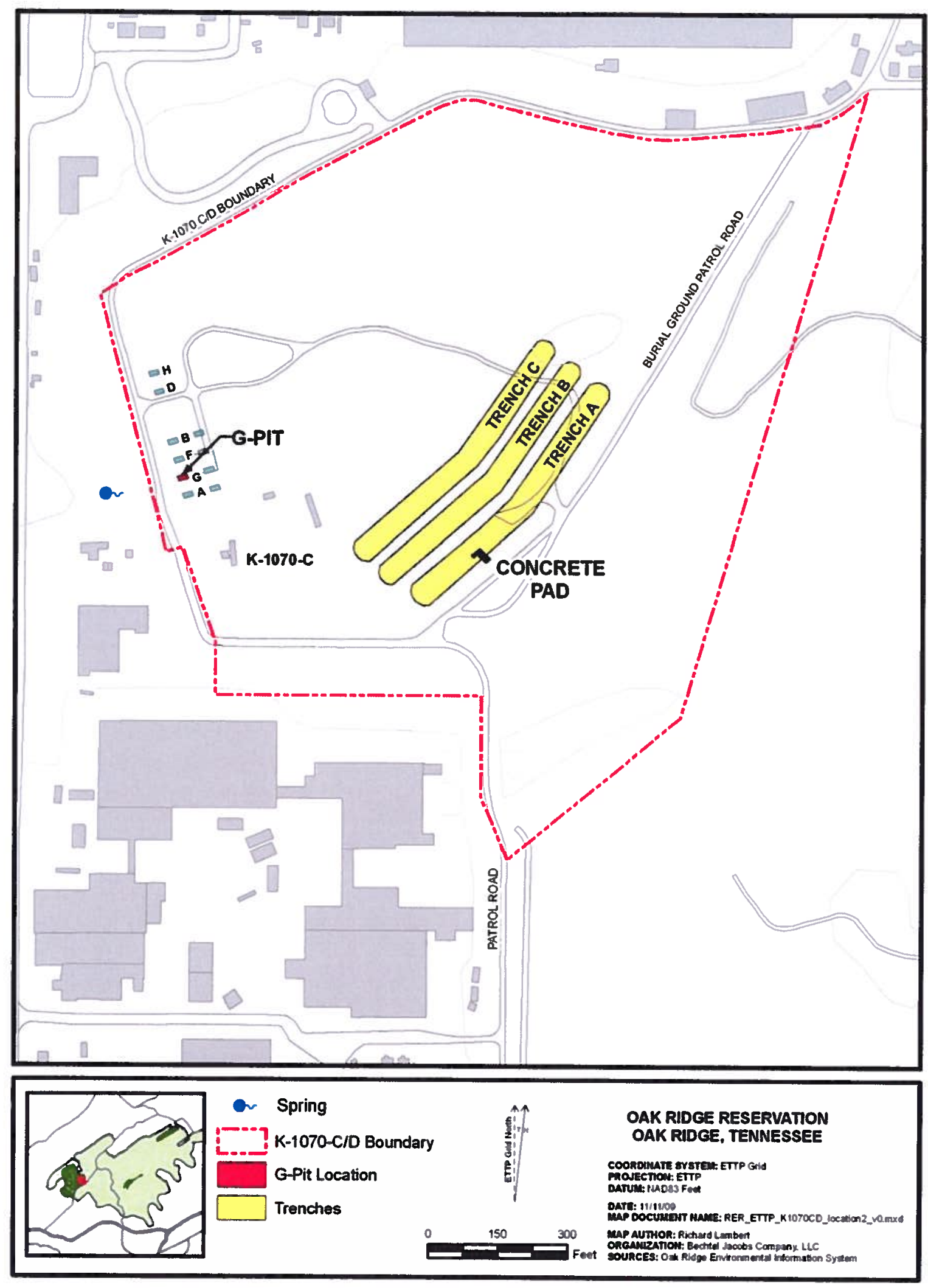

Figure 8.15. Location of K-1070-C/D G-Pit and Concrete Pad. 


\subsubsection{K-1070-A Burial Ground Remedial Action}

The selected remedy in the ROD (DOE 2000d) for the K-1070-A Burial Grounds (Figure 8.16) included waste removal and disposal, along with institutional controls. Major components of the remedy include:

- Waste characterization,

- Excavation and disposal,

- Residual soil characterization, and

- Backfilling excavated areas with clean fill.

The source removal action addressed the present and projected future principal threats posed by the K-1070-A Burial Ground, primarily by chlorinated VOCs and radionuclides. No known unacceptable residual risk from soils for industrial or recreational land use remain within the K-1070-A Burial Ground fenced area subsequent to completion of the RA defined in the ROD (DOE 2000d).

Post-action monitoring requirements are not specified for this action, and cleanup standards for environmental media were not identified (DOE 2003f). Until a groundwater decision is finalized, DOE monitors downgradient Spring 21-002 as an exit pathway point (Sect. 8.6).

A complete discussion of the RA at K-1070-A Burial Ground is provided in Chap. 8 of Vol. 1 of the 2007 RER (DOE 2007a).

\subsubsection{Compliance with LTS Requirements}

\subsection{Requirements}

The ROD states that following implementation of the RA, protectiveness at the site will be ensured through continuation of current ETTP sitewide controls including physical and administrative access restrictions, surveillance, security patrols, restrictions on excavation, and restrictions on groundwater and surface water use (DOE 2000d). In addition, the RAR (DOE 2003f) states that to maintain the effectiveness of the soil cover, the cover will be inspected monthly and the grass on the site will be mowed at an estimated frequency of five times a year. If erosion is found, "clean" soil will be used to repair the eroded area, and the area will be reseeded, if necessary.

\subsection{Status of Requirements for FY 2009}

The site was inspected during FY 2009 by the ETTP S\&M Program for evidence of soil erosion, gullies or rills; staining, and debris or trash on the soil cover; dead spots, excessive weeds or deep rooted vegetation, need to mow, and discoloration or withering of vegetation. No maintenance was performed. 

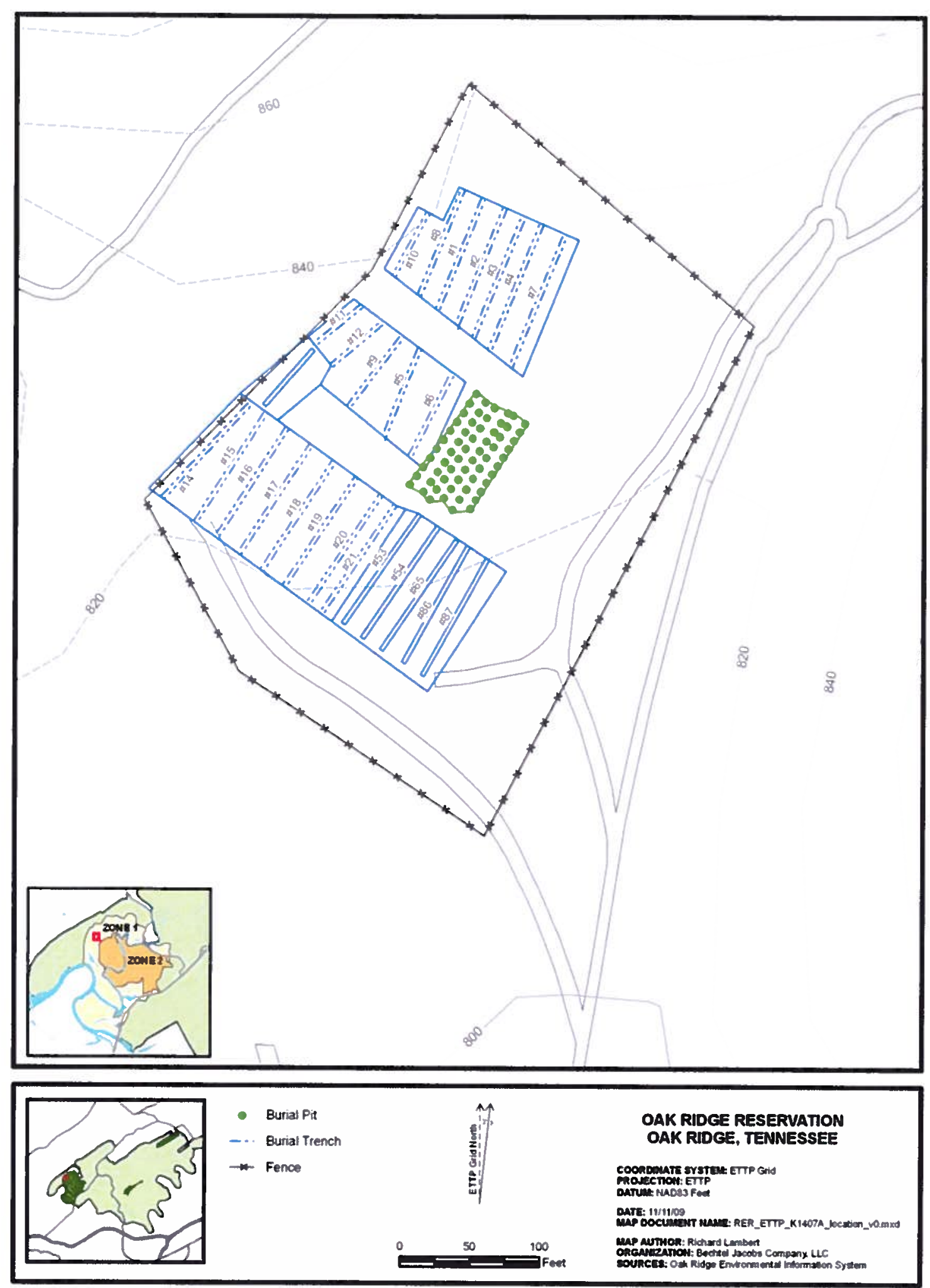

Figure 8.16. Location of former K-1070-A Burial Ground at ETTP. 


\subsubsection{Mitchell Branch Chromium Reduction}

The TC RmA to address releases of chromium into Mitchell Branch was documented in the Action Memorandum for Reduction of Hexavalent Chromium Releases into Mitchell Branch (DOE 2007c). The location of the removal action is noted on Figure 8.17.

Figure 8.17 shows the locations of Mitchell Branch, relevant monitoring locations, the affected storm drain section and the hexavalent chromium plume area. The action was taken due to releases of hexavalent chromium into Mitchell Branch from the storm drain 170 outfall and from seeps at the headwall of the storm drain 170 discharge point. The plume discharge resulted in levels of hexavalent chromium that exceeded State of Tennessee AWQC. At MIK 0.71 and 0.79 , which are locations in Mitchell Branch immediately downstream from the storm drain 170 discharge point, hexavalent chromium levels were measured at levels as high as $0.78 \mathrm{mg} / \mathrm{L}$, which exceeded the State of Tennessee hexavalent chromium water quality chronic criterion of $0.011 \mathrm{mg} / \mathrm{L}$ for the protection of fish and aquatic life. On July 20, 2007, TDEC Division of Water Pollution Control issued a Notice of Violation to DOE for the hexavalent chromium release. Since hexavalent chromium has not been used in process operations at ETTP for over thirty years, the release of hexavalent chromium into Mitchell Branch is a legacy problem and not an ongoing, current operations issue. Therefore, DOE in coordination with EPA and TDEC determined that the appropriate response to this release was a CERCLA TC RmA. On November 5, 2007 (DOE 2007k) DOE notified the EPA and TDEC of their intent to conduct a CERCLA TC RmA.

Activities associated with the removal action included:

- Located the chromium release path to the storm drain system and into Mitchell Branch.

- Installed a grout wall to impede the release of hexavalent chromium through storm drain 170 headwall seeps into Mitchell Branch.

- Installed two interception wells into the gravel bed that surrounds the storm drain 170 discharge pipes to collect the hexavalent chromium groundwater plume before it infiltrates the storm drain 170 collection system network piping.

- The system operations began in December 2007. The collected groundwater is treated at the Central Neutralization Facility, which is a NPDES permitted facility that currently provides services to CERCLA and non-CERCLA industrial operations at ETTP.

A RmAR for the TC RmA was issued in July 2008 (DOE 2008e).

\subsubsection{Performance Goals and Monitoring Objectives}

Monitoring of the removal action is documented in the RmAR (DOE 2008e). The water quality performance monitoring is performed and evaluated by the Environmental Compliance organization, and the data is presented in the Annual Site Environmental Report as well as the RER. The goals of the removal action are to collect and treat the hexavalent chromium contaminated groundwater to reduce its toxicity prior to discharge and to protect the water quality in Mitchell Branch at levels consistent with the AWQC. The chromium sampling points identified in the $R m A R$ are as follows: 

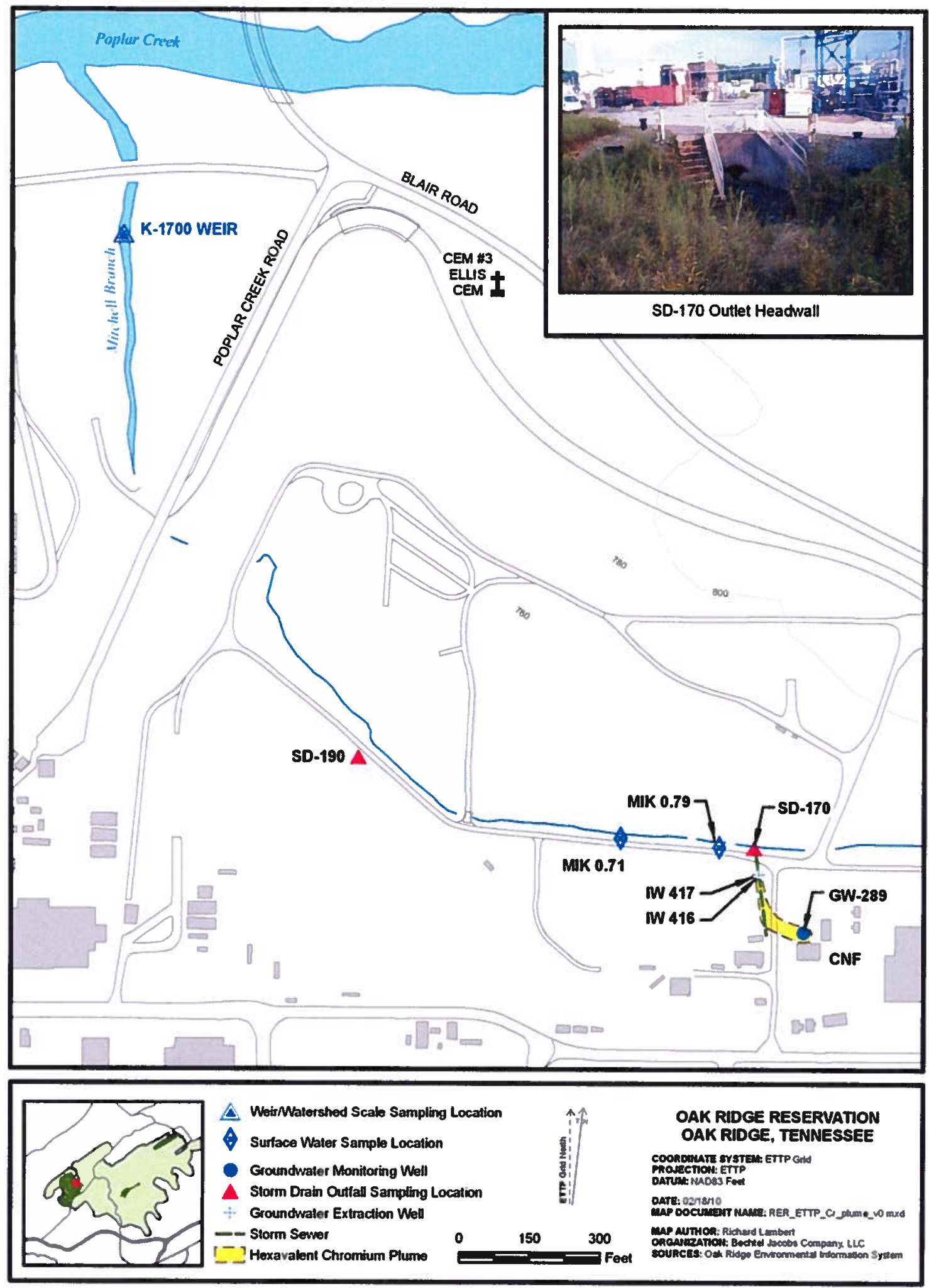

Figure 8.17. Location of chromium releases to Mitchell Branch. 
- at the storm drain 170 discharge point.

- Mitchell Branch instream location (MIK 0.71 / MIK 0.79) that is downstream from storm drain 170. The instream location below storm drain 170 provides an opportunity for the discharges to mix with the Mitchell Branch receiving stream which is considered to be the appropriate location to compare hexavalent chromium concentrations with the AWQC value of $0.011 \mathrm{mg} / \mathrm{L}$.

- Collection system that captures the combined flow from interception wells 416 and 417 .

- Monitoring Well 289 (location in the groundwater plume).

\subsubsection{Evaluation of Performance Monitoring Data}

The long-term water quality monitoring results in Mitchell Branch downstream from storm drain 170 are provided in Figure 8.18.

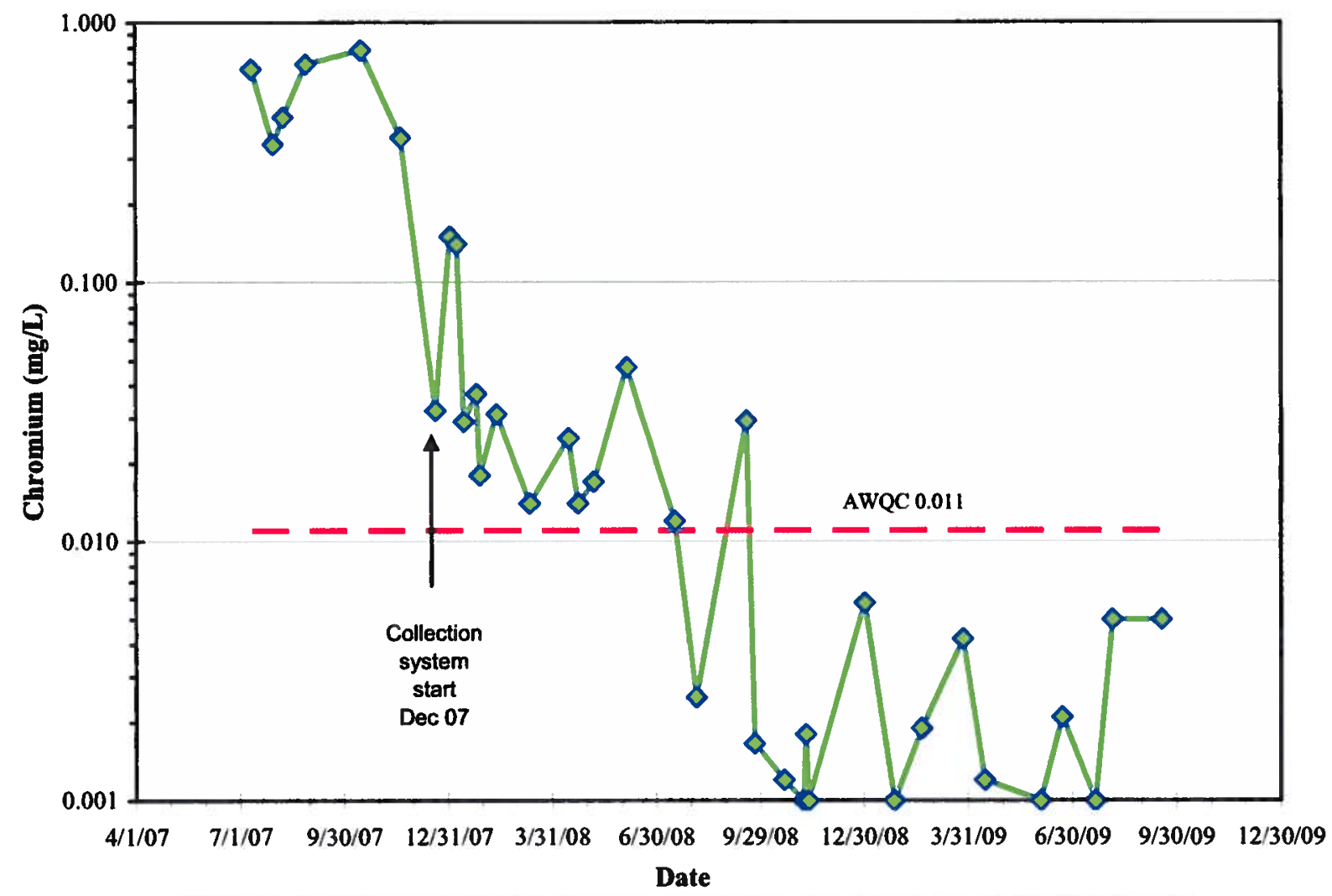

Figure 8.18. Mitchell Branch (MIK 0.79) chromium concentrations, FY 2007-2009.

The surface water results in Mitchell Branch show that the chromium collection system has been effective in reducing the levels of chromium from a maximum measured value of $0.78 \mathrm{mg} / \mathrm{L}$ to levels that are now consistently below the AWQC value of $0.011 \mathrm{mg} / \mathrm{L}$ during dry and wet weather periods.

Short-term results are discussed in the following section. 


\subsection{Surface Water Monitoring Short Term Data}

The chromium performance monitoring results for FY 2009 are provided in Table 8.8.

Sampling and analysis of the chromium in the plume and in SD-170 established that essentially all of the detected chromium is hexavalent chromium with only a small proportion of the less hazardous trivalent chromium. Therefore, routine sampling and analysis utilizes the total chromium analysis which is less expensive and has less restrictive sample handling requirements and all the detected chromium is presumed to be hexavalent chromium. Periodic confirmatory hexavalent chromium analyses are conducted. The instream sampling results at MIK 0.71/0.79 varied from nondetect levels to a maximum of $0.0101 \mathrm{mg} / \mathrm{L}$ during FY 2009. As noted all results were less than the AWQC value of $0.011 \mathrm{mg} / \mathrm{L}$.

The results at SD-170 varied from nondetect levels to a maximum amount of $0.036 \mathrm{mg} / \mathrm{L}$ in December of 2008. It should be noted that improvements to the chromium collection system were made in January of 2009 that resulted in an ability to pump at higher and more consistent rates. After December 2008, the maximum value from that point forward was $0.0117 \mathrm{mg} / \mathrm{L}$ in March of 2009.

The chromium results for the combined water flows that are collected in interception wells 416 and 417 varied from a low of $0.558 \mathrm{mg} / \mathrm{L}$ to a maximum value of $0.990 \mathrm{mg} / \mathrm{L}$.

The chromium results at well 289 varied from a low of $1.23 \mathrm{mg} / \mathrm{L}$ to a maximum value of $4.0 \mathrm{mg} / \mathrm{L}$.

\subsection{Treatment System Performances}

As noted in the previous section, a significant upgrade was implemented for the chromium collection system in January of 2009. The enhancement to the chromium collection system was completed with the replacement of pneumatic pumps with electric pumps. The electric pumps provided the capacity for higher pump rate flows while also providing more consistent performance due to reduced maintenance requirements.

\subsubsection{Performance Summary}

Water sampling in FY 2009 indicates the removal action continues to be highly effective in achieving the goal to meet AWQC levels of $0.011 \mathrm{mg} / \mathrm{L}$ for hexavalent chromium in Mitchell Branch immediately downstream from the storm drain 170 discharge.

\subsubsection{Compliance with LTS Requirements}

\subsection{Requirements}

The RmAR (DOE 2008e) for the TC RmA did not include any LTS requirements.

\subsection{Status of Requirements for FY 2009}

No LTS requirements were specified in the decision document for this site. 
Table 8.8. FY 2009 performance monitoring results for reduction of hexavalent chromium releases into Mitchell Branch

\begin{tabular}{|c|c|c|c|c|c|c|c|c|c|c|c|c|}
\hline Sample Date & Oct-08 & Nov-08 & Dec-08 & Jan-09 & Feb-09 & Mar-09 & Apr-09 & Jun-09 & Jun-09 & Jul-09 & Aug-09 & Sep-09 \\
\hline $\begin{array}{l}\text { Location } \\
\text { Description }\end{array}$ & $\begin{array}{c}\text { Total } \\
\text { Chrom- } \\
\text { ium } \\
(\mathrm{mg} / \mathrm{L})\end{array}$ & $\begin{array}{c}\text { Total } \\
\text { Chrom- } \\
\text { ium } \\
\text { (mg/L) }\end{array}$ & $\begin{array}{c}\text { Total } \\
\text { Chromi } \\
\operatorname{um}_{(\mathrm{mg} / \mathrm{L})}\end{array}$ & $\begin{array}{c}\text { Total } \\
\text { Chrom- } \\
\text { ium } \\
\text { (mg/L) }\end{array}$ & $\begin{array}{c}\text { Total } \\
\text { Chrom- } \\
\text { ium } \\
(\mathrm{mg} / \mathrm{L})\end{array}$ & $\begin{array}{c}\text { Total } \\
\text { Chrom- } \\
\text { ium } \\
\text { (mg/L) }\end{array}$ & $\begin{array}{c}\text { Total } \\
\text { Chrom- } \\
\text { ium } \\
(\mathrm{mg} / \mathrm{L})\end{array}$ & $\begin{array}{c}\text { Total } \\
\text { Chrom- } \\
\text { ium } \\
\text { (mg/L) } \\
\end{array}$ & $\begin{array}{c}\begin{array}{c}\text { Total } \\
\text { Chrom- } \\
\text { ium } \\
(\mathrm{mg} / \mathrm{L})\end{array} \\
\end{array}$ & $\begin{array}{c}\text { Total } \\
\text { Chrom- } \\
\text { ium } \\
\text { (mg/L) } \\
\end{array}$ & $\begin{array}{c}\text { Total } \\
\text { Chrom } \\
\text {-ium } \\
\text { (mg/L) } \\
\end{array}$ & $\begin{array}{c}\text { Total } \\
\text { Chrom } \\
\text {-ium } \\
\text { (mg/L) }\end{array}$ \\
\hline $\begin{array}{l}\text { Mitchell Branch } \\
\text { kilometer 0.71/0.79 } \\
\text { (MIK 0.71/0.79) } \\
\text { downstream from } \\
\text { Storm Drain } 170 \\
\text { (SD-170) }\end{array}$ & $0.001 \mathrm{U}$ & $0.001 \mathrm{U}$ & 0.0058 & 0.0101 & $0.0019 \mathrm{~J}$ & 0.0042 & $0.001 \mathrm{~J}$ & $0.001 \mathrm{U}$ & $0.0021 \mathrm{~J}$ & $0.001 \mathrm{U}$ & 0.005 & 0.005 \\
\hline SD-170 & $0.001 \mathrm{U}$ & $0.001 \mathrm{U}$ & 0.0364 & 0.0113 & $0.003 \mathrm{~J}$ & 0.0117 & 0.005 & $0.0013 \mathrm{~J}$ & 0.0036 & $0.0013 \mathrm{~J}$ & 0.010 & 0.007 \\
\hline $\begin{array}{l}\text { Collection System } \\
\text { (Intercepter wells } \\
416,417 \text { ) }\end{array}$ & 0.835 & 0.721 & 0.901 & N/A & 0.990 & 0.708 & 0.747 & 0.651 & 0.683 & 0.558 & 0.658 & 0.631 \\
\hline Well 289 & 4.000 & 3.300 & 2.420 & N/A & 1.500 & 1.230 & 2.340 & 3.380 & 3.330 & 3.330 & 1.640 & 1.680 \\
\hline $\begin{array}{l}\text { Collection System } \\
\text { Pumping Rate, gpm }\end{array}$ & 7.4 & 6.8 & 9.8 & 12.2 & 12.0 & 12.2 & 13.0 & 12.5 & 12.2 & 12.2 & 12.2 & 12.2 \\
\hline $\begin{array}{l}\text { SD-170 Base Flow } \\
\text { Rates, gpm }\end{array}$ & 11 & 5 & 87 & 12007 & 153 & 153 & 65 & 38 & 225 & 21 & 123 & 195 \\
\hline Weather Conditions & Dry & Dry & Dry & Wet & Wet & Wet & Wet & Dry & Wet & Dry & Wet & Wet \\
\hline
\end{tabular}

$\mathrm{U}$ flag indicates a nondetection at the analytical detection limit, $\mathrm{J}$ flag indicates estimated value.

N/A: No sample taken. 


\subsection{COMPLETED DEMOLITION PROJECTS WITH ACCESS CONTROLS AND LTS REQUIREMENTS}

Over the past several years, most of the CERCLA actions at ETTP focused on completion of D\&D activities documented by various PCCRs, some of which included interim requirements for monitoring and access controls because slabs or portions of foundations were left in place. If radiological surveys indicated a slab exceeded the release criteria of DOE Order 5400.5, then interim access controls were implemented and the slab was posted and became part of the radiological surveillance and monitoring program. Table 8.9 identifies the completed D\&D projects with remaining contaminated media and the slabs/soil requiring interim LUCs and monitoring. Section 8.5.1 details these LTS requirements and their status. The ETTP Zone 1 and Zone 2 RODs will determine the final remedy for the contaminated slabs and soil.

Table 8.9. LTS requirements for D\&D facilities associated with remaining contaminated media

\begin{tabular}{|c|c|c|c|}
\hline Area/action" & $\begin{array}{l}\text { Slab/Foundation } \\
\text { (annual survey) }\end{array}$ & $\begin{array}{c}\text { Storm drain } \\
\text { (characterize at least } \\
\text { once every NPDES } \\
\text { permit cycle) }\end{array}$ & $\begin{array}{l}\text { Surface water } \\
\text { (annually) }\end{array}$ \\
\hline $\begin{array}{l}\text { Group II, Phase } 2 \\
\text { RmAR for K-1064 Peninsula } \\
\text { Area }\end{array}$ & $\begin{array}{l}\text { K-1025-A slab } \\
\text { K-1025-B slab } \\
\text { K-1025-C slab } \\
\text { K-1025-D slab } \\
\text { K-1064-D slab } \\
\text { K-1025-E } \\
\text { K-1064 Salvage Material } \\
\text { Yard soil (survey } \\
\text { performed only when } \\
\text { worker entries required) }\end{array}$ & $\begin{array}{l}\text { SD-230 } \\
\text { SD-240 } \\
\text { SD-270 } \\
\text { SD-280 } \\
\text { SD-294 } \\
\text { SD-296 } \\
\text { SD-297 }\end{array}$ & $\begin{array}{l}\text { Surface water from Poplar } \\
\text { Creek downstream (K-1007- } \\
\text { P1 Holding Pond weir) and } \\
\text { upstream from ETTP } \\
\text { Mitchell Branch, and the } \\
\text { K-901-A Pond. }\end{array}$ \\
\hline $\begin{array}{l}\text { Group II, Phase } 3 \\
\text { PCCR, Bldg. K-1420 }\end{array}$ & $\begin{array}{l}\text { K-1420 slab - storm flow } \\
\text { runoff } \\
\text { Uranium Recovery Room } \\
\text { and calciner room - quarterly } \\
\text { radiological survey } \\
\text { Pad boundary - annual } \\
\text { radiological survey } \\
\end{array}$ & $\begin{array}{l}\text { SD-158 } \\
\text { SD-160 } \\
\text { SD-170 }\end{array}$ & Weir K-1700 \\
\hline $\begin{array}{l}\text { Group II, Phase } 3 \\
\text { FY } 2006 \text { PCCR for Low } \\
\text { Risk/Low Complexity } \\
\text { Facilities }\end{array}$ & K-723 slab & $\begin{array}{l}\text { SD-780 } \\
\text { SD-800 } \\
\text { SD-820 } \\
\text { SD-830 } \\
\end{array}$ & CRM 9.5 Brashear Island ${ }^{b}$ \\
\hline $\begin{array}{l}\text { Group II, Phase } 3 \\
\text { PCCR for K-29 }\end{array}$ & K-29 slab & SD-490 & Weir K-1007-B4 \\
\hline $\begin{array}{l}\text { Group II, Phase } 3 \\
\text { FY } 2008 \text { PCCR for Low } \\
\text { Risk/Low Complexity } \\
\text { Facilities }\end{array}$ & $\begin{array}{l}\text { K-1024 slab - Fixed } \\
\text { Contamination Area }\end{array}$ & $\begin{array}{l}\text { SD-230 } \\
\text { SD-240 }\end{array}$ & Poplar Creek location K-716 \\
\hline
\end{tabular}

aThe PCCR for the Group II, Phase 3 BOS-LABS D\&D requires surveys and monitoring of the slabs from K-1004 and K-1015. These slabs were removed in FY 2007 and monitoring is no longer required. The long-term stewardship of these sites is no longer reported in the RER. Also, the PCCR for the Bldg. K-401 demolition requires LTS of the remaining slab. However, the slab was removed in 2009, making LTS no longer necessary.

'The PCCR requires monitoring at CR kilometer 16 Brashear Island, however, the actual sampling point is identified as CRM 9.5 


\subsubsection{Compliance with LTS Requirements}

\subsubsection{Requirements}

PCCRs for the various D\&D projects listed in Table 8.9 include the following requirements: (1) annual radiological surveillance, (2) storm drain characterization performed at least once within each NPDES permitting period ( $\leq 5$ years) for representative outfalls in each storm groupings, and (3) annual surface water monitoring. Figure 8.4 shows the locations of the storm drains and surface water locations relative to areas containing the remaining contamination. Storm drain characterization and surface water monitoring results are used to verify the effectiveness of the Radiological Control Program.

If radiological contamination is found to be migrating out of the contamination area, then additional controls are implemented. The frequency and level of surveillance and monitoring is established at each site by the radiological engineers responsible for the program, in accordance with requirements and criteria set forth in 10 CFR $\S 835$, Occupational Radiation Protection.

In general, storm water runoff from concrete or asphalt pads is not sampled directly (the K-1420 slab is an exception). Instead, The ETTP Environmental Compliance Program verifies the effectiveness of the radiological control program through ongoing storm drain sampling and instream water sampling, i.e., monitoring in compliance with the ETTP NPDES permit and storm water runoff plans. Storm drain discharges are characterized at least once during each NPDES permitting period, a maximum of five years, for a minimum of gross alpha, gross beta, isotopic uranium, and ${ }^{99} \mathrm{Tc}$. Instream water monitoring is conducted at least annually at Mitchell Branch Weir, K-1007-P1 Holding Ponds Weir (K-1007-B4), K-901-A Pond Weir, upstream of ETTP in Poplar Creek, and downstream of ETTP at CRM 9.5 (Brashear Island), and at Poplar Creek location K-716 for a minimum of gross alpha, gross beta, isotopic uranium, and ${ }^{99} \mathrm{Tc}$. Data are compared to screening levels established at 4\% of DOE Order 5400.5 DCG to maintain discharges ALARA.

\subsubsection{Status of Requirements for FY 2009}

Radiological monitoring of the facilities listed below (Table 8.10) is performed as part of the Radiological Compliance Monitoring, as required by $10 \mathrm{CFR} \S 835$ and adopted in the BJC RPP. All surveys are performed and documented in compliance with applicable BJC procedures. Limits that apply to the surveys performed are found in Attachment D to 10 CFR $\S 835$, as provided in Table 8.11.

Storm drain characterization sampling, as conducted as part of the ETTP NPDES permit compliance monitoring program, and surface water monitoring were performed as a means to verify the effectiveness of the Radiological Control Program (see Figure 8.4). A summary of the storm drain sampling and surface water monitoring conducted for these D\&D areas, along with storm flow sampling at the K-1420 slab in FY 2009, is included in Table 8.12 and is detailed below.

No outfalls from the K-1064 Peninsula Area RmAR outfall grouping were sampled during FY 2009. The results from the instream sampling in Poplar Creek downstream from the K-1064 Peninsula area were less than $1 \%$ of the allowable DCG.

Based upon low radiological sampling results observed during FY 2007 and 2008 sampling events, a recommendation was made in the 2009 RER to discontinue the sampling of storm water runoff from the $\mathrm{K}-1420 \mathrm{pad}$. The recommendation to discontinue sampling was still pending CERCLA Core Team action during FY 2009 and is included as an "Issue Carried Forward" in Table 8.15, therefore SWPPP sampling effort per the Bldg. K-1420 PCCR continued throughout FY 2009. Samples were collected at the north side of the K-1420 building footprint in an area near the former calciner room. 
Table 8.10. Summary of radiological monitoring information for ETTP D\&D sites

\begin{tabular}{|c|c|c|c|c|}
\hline $\begin{array}{c}\text { Facility/Locatio } \\
\text { n } \\
\end{array}$ & Status & $\begin{array}{c}\text { Survey } \\
\text { frequency }\end{array}$ & $\begin{array}{l}\text { Survey } \\
\text { date(s) }\end{array}$ & Survey summary \\
\hline \multicolumn{5}{|c|}{ Group II, Phase 2 RmAR for K-1064 Peninsula Area } \\
\hline K-1025-A slab & Fixed Contamination Area & Quarterly & $\begin{array}{l}12 / 3 / 08,3 / 10 / 09 \\
6 / 22 / 09,10 / 6 / 09 \\
\end{array}$ & $\begin{array}{l}\text { No removable activity above } \\
\text { CFR } \$ 835 \text { limits detected. }\end{array}$ \\
\hline K-1025-B slab & Fixed Contamination Area & Quarterly & $\begin{array}{l}12 / 3 / 08,3 / 10 / 09 \\
6 / 22 / 09,10 / 6 / 09 \\
\end{array}$ & $\begin{array}{l}\text { No removable activity above } \\
\text { CFR } \$ 835 \text { limits detected. } \\
\end{array}$ \\
\hline $\mathrm{K}-1025-\mathrm{C}$ slab & Fixed Contamination Area & Quarterly & $\begin{array}{l}12 / 3 / 08,3 / 10 / 09 \\
6 / 11 / 09,10 / 12 / 09 \\
\end{array}$ & $\begin{array}{l}\text { No removable activity above } \\
\text { CFR } \$ 835 \text { limits detected. } \\
\end{array}$ \\
\hline K-1025-D slab & Fixed Contamination Area & Quarterly & $\begin{array}{l}12 / 3 / 08,3 / 10 / 09 \\
6 / 11 / 09,10 / 12 / 09 \\
\end{array}$ & $\begin{array}{l}\text { No removable activity above } \\
\text { CFR } \$ 835 \text { limits detected. }\end{array}$ \\
\hline K-1064-D slab & Fixed Contamination Area & Annually & $4 / 21 / 2009$ & \begin{tabular}{|l|} 
No removable activity above \\
CFR $\$ 835$ limits detected.
\end{tabular} \\
\hline $\mathrm{K}-1025-\mathrm{E}$ & Fixed Contamination Area & Quarterly & $\begin{array}{c}12 / 23 / 08 \\
3 / 10 / 09,6 / 11 / 09 \\
10 / 12 / 09 \\
\end{array}$ & $\begin{array}{l}\text { No removable activity above } \\
\text { CFR } \$ 835 \text { limits detected. }\end{array}$ \\
\hline $\begin{array}{l}\text { K-1064 Salvage } \\
\text { Material Yard soil }\end{array}$ & Contamination Area & $\begin{array}{c}\text { Survey performed } \\
\text { only when worker } \\
\text { entries required }\end{array}$ & $\mathrm{N} / \mathrm{A}$ & $\mathrm{N} / \mathrm{A}$ \\
\hline \multicolumn{5}{|c|}{ Group II, Phase 3 PCCR Bldg. K-1420 } \\
\hline $\begin{array}{l}\mathrm{K}-1420 \text { slab - } \\
\text { storm flow runoff }\end{array}$ & $\begin{array}{l}\text { N/A to Radiological } \\
\text { Controls. }\end{array}$ & $\begin{array}{c}\text { N/A to } \\
\text { Radiological } \\
\text { Controls. }\end{array}$ & $\begin{array}{c}\text { N/A to } \\
\text { Radiological } \\
\text { Controls. }\end{array}$ & N/A to Radiological Controls. \\
\hline $\begin{array}{l}\text { Uranium } \\
\text { Recovery Room } \\
\text { and calciner room }\end{array}$ & Fixed Contamination Area & Annually & $7 / 14 / 2009$ & $\begin{array}{l}\text { No removable activity above } \\
\text { CFR } \S 835 \text { limits detected. }\end{array}$ \\
\hline $\begin{array}{l}\mathrm{K}-1420 \mathrm{Pad} \\
\text { boundary }\end{array}$ & Fixed Contamination Area & Annually & $7 / 13 / 2009$ & $\begin{array}{l}\text { No removable activity above } \\
\text { CFR } \$ 835 \text { limits detected. }\end{array}$ \\
\hline \multicolumn{5}{|c|}{ Group II, Phase 3 FY 2006 PCCR for Low Risk/Low Complexity Facilities } \\
\hline K-723 slab & Fixed Contamination Area & Annually & $12 / 19 / 2008$ & $\begin{array}{l}\text { No removable activity above } \\
\text { CFR } \$ 835 \text { limits detected. }\end{array}$ \\
\hline \multicolumn{5}{|c|}{ Group II, Phase 3} \\
\hline K-29 slab & Fixed Contamination Area & Annually & $9 / 28 / 2009$ & $\begin{array}{l}\text { No removable activity above } \\
\text { CFR } \$ 835 \text { limits detected. }\end{array}$ \\
\hline \multicolumn{5}{|c|}{ Group II, Phase 3} \\
\hline K-1024 slab & Fixed Contamination Area & Annually & $6 / 17 / 09$ & $\begin{array}{l}\text { No removable activity above } \\
\text { CFR } \$ 835 \text { limits detected. }\end{array}$ \\
\hline
\end{tabular}

"The PCCRs for these D\&D projects state that contamination monitoring programs should be reviewed annually by the Project Health Physicists to ensure that appropriate surveys are performed at a frequency that is consistent with existing and potential hazards and activities planned in the area.

CFR $=$ Code of Federal Regulations

N/A = not applicable

Table 8.11. 10 CFR §835 limits

\begin{tabular}{|l|c|c|}
\hline \multicolumn{1}{|c|}{ Radionuclide } & $\begin{array}{c}\text { Removable } \\
\text { dpm/100cm }\end{array}$ & $\begin{array}{c}\text { Total } \\
\text { (Fixed + } \\
\text { Removable) } \\
\text { dpm/100cm }\end{array}$ \\
\hline U-Nat, U-235, U-238, and associated decay products & 1,000 & 5,000 \\
\hline Transuranics, Ra-226, Ra-228, Th-230, Th-228, Pa-231, Ac-227, I-125, I-129 & 20 & 500 \\
\hline Th-Nat, Th-232, Sr-90, Ra-223, Ra-224, U-232, I-126, I-131, I-133 & 200 & 1000 \\
\hline $\begin{array}{l}\text { Beta-Gamma emitters (nuclides with decay modes other than alpha emission or } \\
\text { spontaneous fission) except Sr-90 and others noted above. }\end{array}$ & 1,000 & 5,000 \\
\hline Tritium and tritiated compounds dpm = disintegrations per minute & 10,000 & N/A \\
\hline CFR = Code of Federal Regulations natural occurring
\end{tabular}


Table 8.12. Summary of storm drain and surface water monitoring information

\begin{tabular}{|c|c|c|c|c|}
\hline Slab/Foundation & $\begin{array}{c}\text { Storm drain locations } \\
\text { (characterize at least } \\
\text { once every NPDES } \\
\text { permit cycle, } \leq 5 \text { yrs) }\end{array}$ & $\begin{array}{l}2009 \\
\text { Storm drain } \\
\text { monitoring } \\
\text { summary }^{\mathrm{a}}\end{array}$ & $\begin{array}{c}\text { Surface water } \\
\text { locations } \\
\text { (annually) }\end{array}$ & $\begin{array}{c}2009 \\
\text { Surface water } \\
\text { monitoring } \\
\text { summary }\end{array}$ \\
\hline \multicolumn{5}{|c|}{ Group II, Phase $2 \quad$ RmAR for K-1064 Peninsula Area ${ }^{b}$} \\
\hline \multirow{7}{*}{$\begin{array}{l}\text { K-1025-A slab } \\
\text { K-1025-B slab } \\
\text { K-1025-C slab } \\
\text { K-1025-D slab } \\
\text { K-1025-E } \\
\text { K-1064-D slab } \\
\text { K-1064-H slab }\end{array}$} & SD-230 & Not sampled in 2009 & \multirow{7}{*}{$\begin{array}{l}\text { Surface water from } \\
\text { Poplar Creek } \\
\text { downstream and } \\
\text { upstream from ETTP } \\
\text { K-1064 Peninsula } \\
\text { area }\end{array}$} & \multirow{7}{*}{$\begin{array}{l}\text { Less than } 1 \% \text { of } \\
\text { the allowable } \\
\text { DCG }\end{array}$} \\
\hline & SD-240 & Not sampled in 2009 & & \\
\hline & SD-270 & Not sampled in 2009 & & \\
\hline & SD-280 & Not sampled in 2009 & & \\
\hline & SD-294 & Not sampled in 2009 & & \\
\hline & SD-296 & Not sampled in 2009 & & \\
\hline & SD-297 & Not sampled in 2009 & & \\
\hline \multicolumn{5}{|c|}{ Group II, Phase $3 \quad$ PCCR for Bldg. K-1420 } \\
\hline \multirow[t]{3}{*}{$\begin{array}{l}\mathrm{K}-1420 \text { slab - } \\
\text { storm flow runoff }\end{array}$} & SD-158 & $\begin{array}{l}2009 \text { results above } \\
\text { screening criteria but } \\
\text { similar to historical } \\
\text { trends and below DCGs }\end{array}$ & Weir K-1700 & \multirow[t]{3}{*}{$\begin{array}{l}\text { Results during } \\
2009 \text { were less } \\
\text { than } 3 \% \text { of the } \\
\text { DCGs }\end{array}$} \\
\hline & SD-160 & $\begin{array}{l}2009 \text { results above } \\
\text { screening criteria but } \\
\text { similar to historical } \\
\text { trends and below DCGs }\end{array}$ & & \\
\hline & SD-170 & $\begin{array}{l}2009 \text { results above } \\
\text { screening criteria but } \\
\text { similar to historical } \\
\text { trends and below DCGs }\end{array}$ & & \\
\hline \multicolumn{5}{|c|}{ Group II, Phase 3} \\
\hline \multirow[t]{4}{*}{ K-723 slab } & SD-780 & Not sampled in 2009 & \multirow{4}{*}{$\begin{array}{l}\text { CRM 9.5 Brashear } \\
\text { Island }\end{array}$} & \multirow{4}{*}{$\begin{array}{l}\text { Less than } 1 \% \text { of } \\
\text { the allowable } \\
\text { DCG }\end{array}$} \\
\hline & SD-800 & Not sampled in 2009 & & \\
\hline & SD-820 & Not sampled in 2009 & & \\
\hline & SD-830 & Not sampled in 2009 & & \\
\hline \multicolumn{5}{|c|}{ Group I, Phase 3} \\
\hline $\mathrm{K}-29$ slab & SD-490 & $\begin{array}{l}2009 \text { results above } \\
\text { screening criteria but } \\
\text { similar to historical } \\
\text { trends and below DCGs }\end{array}$ & $\begin{array}{l}\text { K-1007-P1 Pond } \\
\text { Weir (Weir K-1007- } \\
\text { B4) }\end{array}$ & $\begin{array}{l}\text { Less than } 1 \% \text { of } \\
\text { the allowable } \\
\text { DCG }\end{array}$ \\
\hline \multicolumn{5}{|c|}{ Group I, Phase 3} \\
\hline \multirow[t]{2}{*}{ K-1024 slab } & SD-130 & Not sampled in 2009 & \multirow{2}{*}{$\begin{array}{l}\text { Poplar Creek location } \\
\text { K-716 }\end{array}$} & \multirow{2}{*}{$\begin{array}{l}\text { Less than } 1 \% \text { of } \\
\text { the allowable } \\
\text { DCG }\end{array}$} \\
\hline & SD-240 & Not sampled in 2009 & & \\
\hline
\end{tabular}

${ }^{a}$ Storm drain monitoring performed at least once within each NPDES permitting period ( $\leq 5$ years).

bK-1064 Salvage Material Yard soil requires rad surveys under the K-1064 RmAR. However, it does not require storm water monitoring per the RmAR.

${ }^{\mathrm{C}} \mathrm{K}-1064 \mathrm{H}$ slab requires storm water monitoring under the K-1064 RmAR. However, it does not require rad surveys per the RmAR. 
As noted in the K-1420 PCCR, the acceptable dose rate in surface water for piscivorous wildlife is $100 \mathrm{mrad}$ per day. The total uranium activity on the K-1420 pad that will result in a 100 mrad per day dose in Mitchell Branch is $2,600 \mathrm{pCi} / \mathrm{L}$. As noted in Table 8.13 and Figure 8.19 , analytical data collected since April 2007 through 2009 indicates that concentrations of total uranium from storm runoff from the $\mathrm{K}-1420$ pad are several orders of magnitude below the $2,600 \mathrm{pCi} / \mathrm{L}$ total uranium action level.

Table 8.13. K-1420 Slab Storm Water Runoff Performance Monitoring

\begin{tabular}{|c|c|c|c|c|c|}
\hline Sample Month & $\begin{array}{c}\text { U-233/234 } \\
\mathbf{p C i / L}\end{array}$ & $\begin{array}{c}\mathbf{U}-235 / 236 \\
\mathbf{p C i} / \mathbf{L}\end{array}$ & $\begin{array}{c}\mathbf{U}-238 \\
\mathbf{p C i} / \mathbf{L}\end{array}$ & $\begin{array}{c}\text { Total Uranium } \\
\mathbf{p C i} / \mathbf{L}\end{array}$ & $\begin{array}{c}\text { Action Level } \\
\text { Total Uranium }\end{array}$ \\
\hline April 2007 & 194 & 12 & 25 & 231 & 2,600 \\
\hline November 2007 & 15 & 1 & 3 & 19 & 2,600 \\
\hline December 2007 & 29 & 2 & 5 & 35 & 2,600 \\
\hline January 2008 & 17 & 1 & 3 & 22 & 2,600 \\
\hline February 2008 & 12 & 0 & 2 & 14 & 2,600 \\
\hline March 2008 & 11 & 1 & 2 & 14 & 2,600 \\
\hline August 2008 & 11 & 1 & 2 & 14 & 2,600 \\
\hline December 2008 & $63 \mathrm{U}$ & $0.88 \mathrm{U}$ & $1.2 \mathrm{E}$ & 65 & 2,600 \\
\hline March 2009 & $63 \mathrm{U}$ & $2.45 \mathrm{U}$ & 6 & 71 & 2,600 \\
\hline September 2009 & 36 & 2 & 7 & 45 & 2,600 \\
\hline October 2009 & 69 & 5 & 13 & 87 & 2,600 \\
\hline
\end{tabular}

$\mathrm{E}=$ estimated value due to matrix interference

$\mathrm{U}=$ analyte not detected in sample

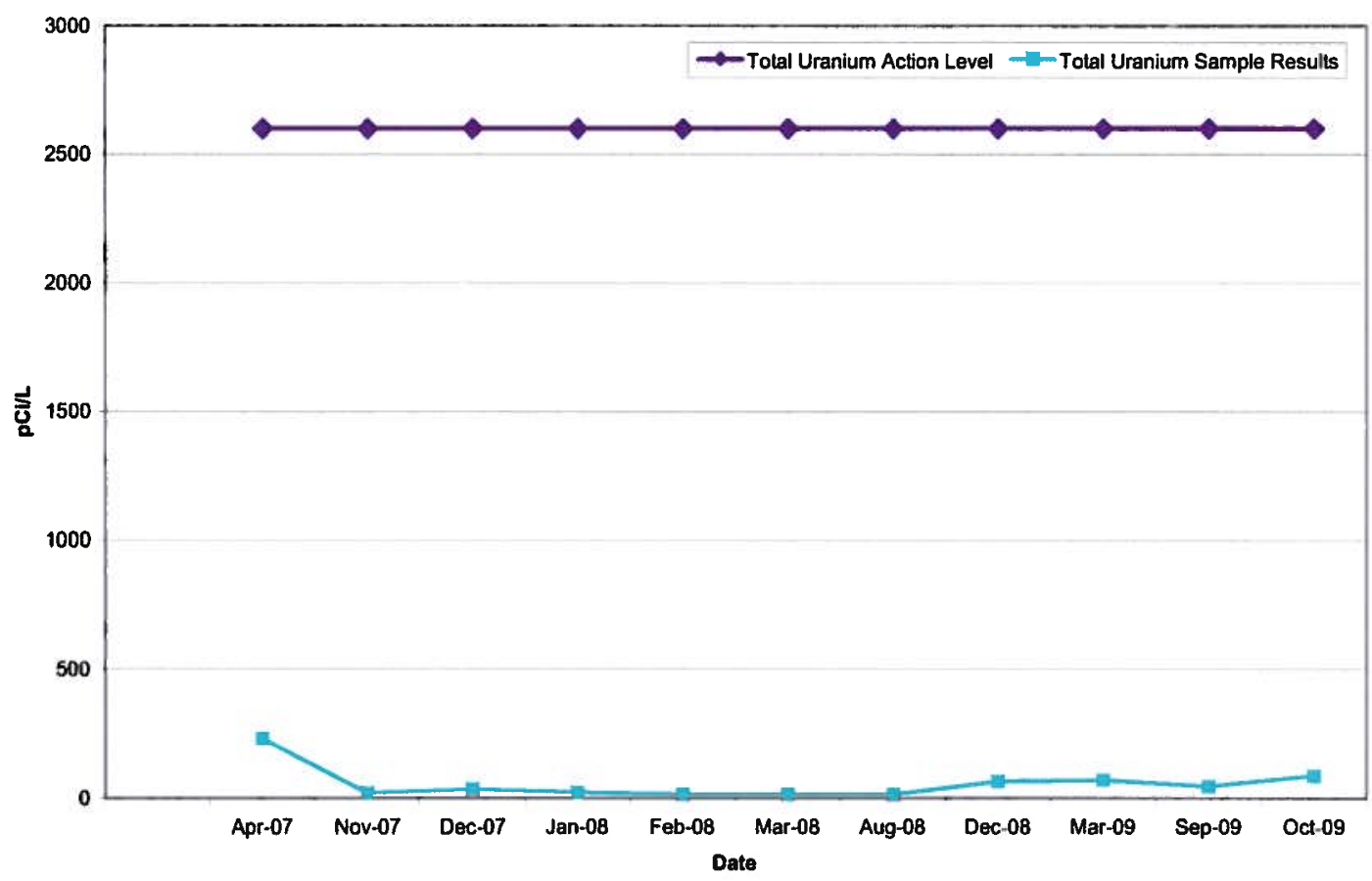

Figure 8.19. K-1420 Pad Storm Water Runoff Sample Results. 
Per the K-1420 PCCR, if the concentration of total uranium is below $2,600 \mathrm{pCi} / \mathrm{L}$, this will confirm that storm water runoff from Building K-1420 slab is stabilized, and sampling of the pad during rain events can be discontinued. Based upon the uranium levels that are well below the action level in the PCCR, it is recommended that storm water sampling runoff from the K-1420 pad be discontinued. This recommendation will be submitted to the CERCLA Core Team for concurrence in FY 2010 (Table 8.15).

As identified in the K-1420 PCCR and in addition to the K-1420 pad runoff sampling previously discussed, storm water samples from outfalls 158,160 , and 170 will be characterized during each NPDES permitting period and at least annually samples will be collected at the $\mathrm{K}-1700$ weir. Data collected in FY 2009 from outfalls 158, 160, and 170 shows that a number of the radiological parameters were detected at levels that exceeded the screening levels due to legacy soil contamination in the drainage areas that will be evaluated in accordance with the Zone 2 ROD. Although elevated above screening levels, the results from FY 2009 sampling events were fairly consistent with, or below, the levels found in historical analytical data. The samples from the K-1700 weir were below screening levels for all radiological parameters during FY 2009 and as shown in Table 8.12, the cumulative results were less than $3 \%$ of the DCG.

No changes are proposed to sampling plans identified in the K-1420 PCCR for outfalls 158 , 160 , and 170 or at the K-1700 weir.

No outfalls identified in the FY 2006 PCCR for Low Risk/Low Complexity Facilities were sampled during FY 2009. The results from instream sampling in the Clinch River at CRM 9.5 downstream from the applicable outfall discharge points were less than $1 \%$ of the allowable DCG.

As required by the K-29 PCCR, storm water Outfall 490 was sampled during FY 2009 and the analytical data were consistent with historical data. The only radiological parameter that exceeded screening criteria was gross beta radiation. Gross beta radiation was detected in the discharge from storm water Outfall 490 at a level of $57.1 \mathrm{pCi} / \mathrm{L}$, which exceeds the drinking water EDE of $50 \mathrm{pCi} / \mathrm{L}$ based on a $4 \mathrm{mrem} / \mathrm{yr} \mathrm{MCL}$ for beta activity and photon particles. All of the analytical results for beta-emitting isotopic specific parameters from Outfall 490 were orders of magnitude below the established DCG levels.

The following land and buildings at ETTP have been transferred from DOE to the East Tennessee CROET and contain property record restrictions except for K-1515, ED-1, ED-4, and ED-7, which were determined to be clean: ED-1 Horizon Center (leased 1/16/96, clean parcel transferred 4/29/03), K-1007 (transferred 6/7/05), K-1225 (transferred 6/7/05), K-1330 (transferred 6/7/05), K-1580 (transferred 6/7/05), K-1036 (transferred 2/14/06), K-1400 (transferred 2/14/06), ED-5 East (transferred 10/19/07), ED-7 (clean parcel transferred 11/13/07), K-1652 (transferred 1/4/08), K-1513 (transferred 5/29/08), K-1515 (clean parcel transferred 5/29/08), ED-5 West (transferred 12/22/08), K-1000 (transferred 2/12/09), K-1501 H\&L (7/10/09), ED-4 (clean parcel transferred 7/10/09), and K-1008-F (transferred 9/9/09). 


\subsection{OTHER WATERSHED MONITORING AT EAST TENNESSEE TECHNOLOGY PARK}

This section provides a summary of ETTP sitewide groundwater and surface water conditions, including a discussion of exit pathway contaminant migration. It includes an update on conditions as characterized by the biological monitoring in area surface water bodies.

The status of ETTP long-term CERCLA decision making is provided in Figure 1.5 of Vol. 1 of the 2007 RER (DOE 2007a).

\subsubsection{Major Site Contaminant Plumes}

Extensive groundwater monitoring at the ETTP site has identified VOCs as the most significant groundwater contaminant on site. For purposes of analyzing the groundwater contaminant issues at ETTP, the RI/FS subdivided the site into several distinct areas-Mitchell Branch watershed, K-1004 and K-1200 area, the K-27/K-29 area, and the K-901 area (Figure 8.20). Each of these areas has significant VOC contamination in groundwater. The principal chlorinated hydrocarbon chemicals that were used at ETTP were PCE, TCE, and 1,1-DCA.

Figure 8.20 shows the distribution and concentrations of the primary chlorinated hydrocarbon chemicals and their transformation products, respectively. Several plume source areas are identified within the regions of the highest VOC concentrations. In these areas, the primary chlorinated hydrocarbons have been present for decades and mature contaminant plumes have evolved. The degree of transformation, or degradation, of the primary chlorinated hydrocarbon compounds is highly variable across the ETTP site. In the vicinity of the $\mathrm{K}-1070-\mathrm{C} / \mathrm{D}$ source, a high degree of degradation has occurred, although a strong source of contamination still remains in the vicinity of the "G-Pit", where approximately 9000 gal of chlorinated hydrocarbon liquids were disposed in an unlined pit. Other areas where transformation is significant include the K-1401 Acid Line leak site, and the K-1407-B Pond area. Transformation processes are weak or inconsistent at the K-1004 and K-1200 area, K-1035, K-1413, and K-1070-A Burial Ground, and little transformation of TCE is observed in the K-27/K-29 source and plume area.

\subsubsection{Exit Pathway Monitoring}

Groundwater exit pathway monitoring sites are shown in Figure 8.20. Groundwater monitoring results for the exit pathways are discussed below starting with the Mitchell Branch exit pathway and then progressing in a counterclockwise fashion.

The Mitchell Branch exit pathway is monitored using surface water data from the K-1700 Weir on Mitchell Branch and wells BRW-083 and UNW-107. Figure 8.21 shows the detected concentrations of TCE, 1,2-DCE (essentially all cis-1, 2-DCE), and vinyl chloride at the K-1700 Weir on Mitchell Branch from FY 1994 through FY 2009. These contaminants are the major contaminants in Mitchell Branch, although low concentrations of carbon tetrachloride, chloroform, and TCA are sometimes detected. VOC concentrations measured during FY 2009 were below TDEC recreational organisms only AWQC levels at K-1700. 

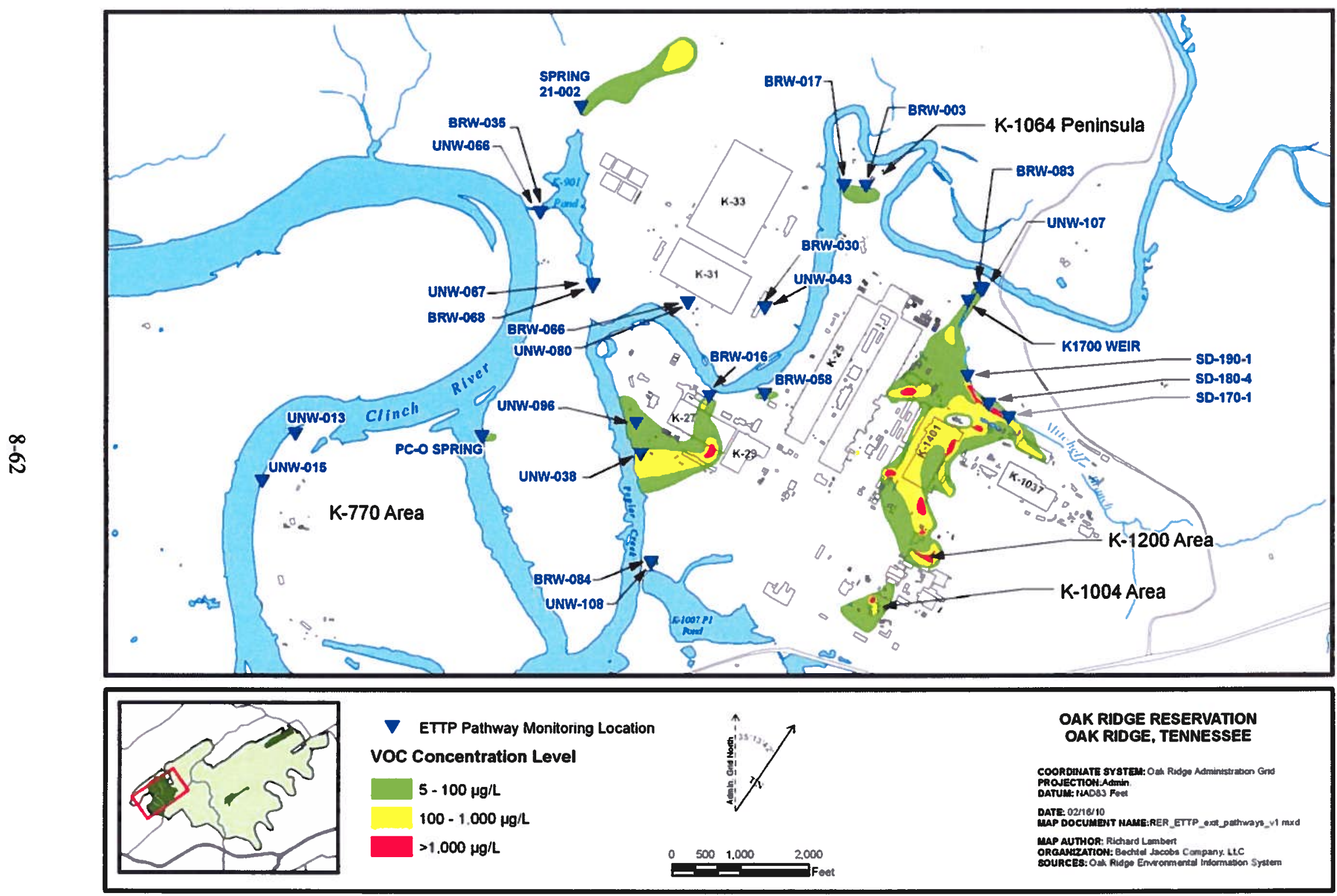

Figure 8.20. ETTP exit pathways monitoring locations. 


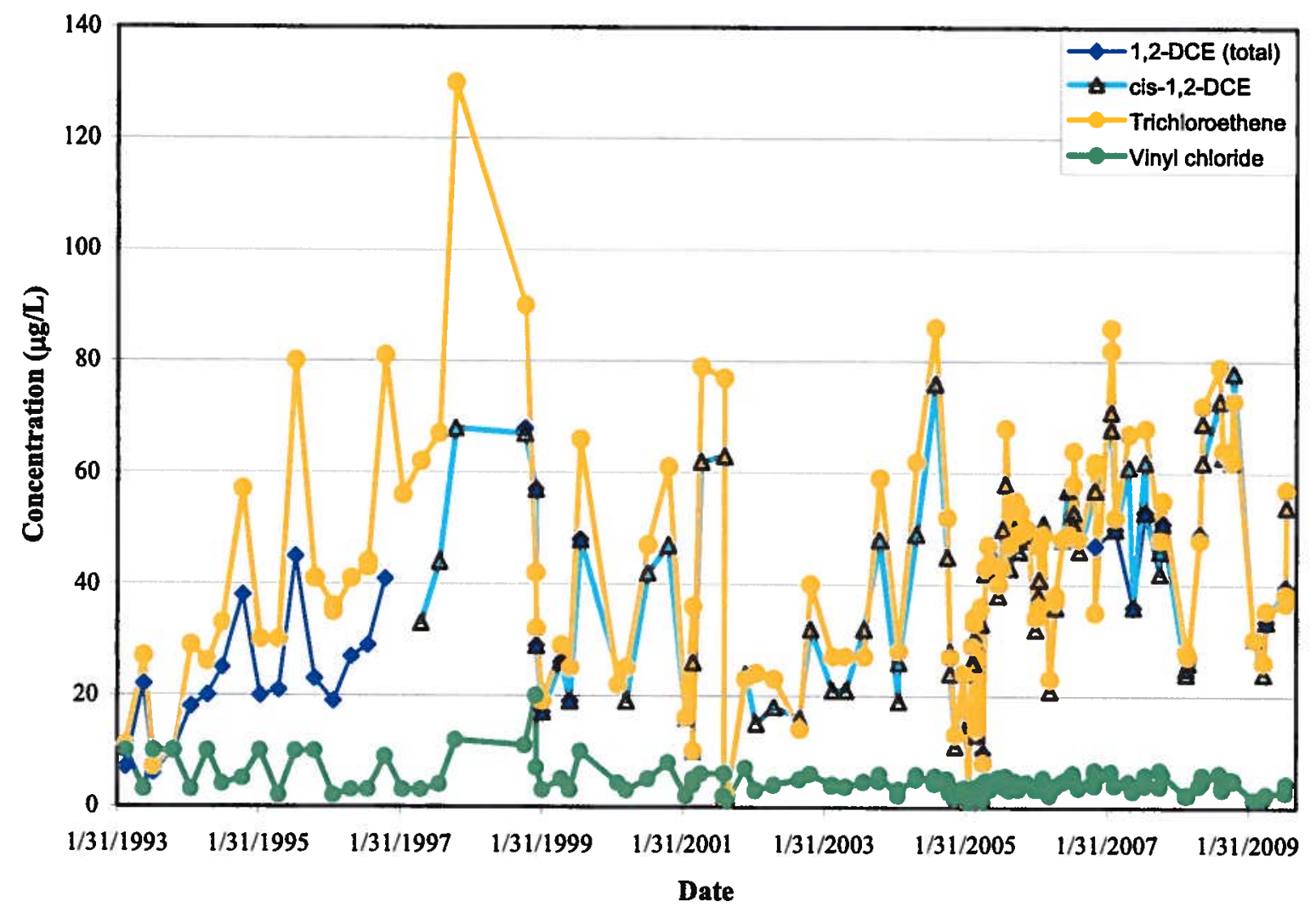

Figure 8.21. K-1700 Weir VOC concentrations.

Wells BRW-083 and UNW-107, located near the mouth of Mitchell Branch, have been monitored since 1994. Table 8.14 shows the history and concentrations of detected VOCs in groundwater. Detection of VOCs in groundwater near the mouth of Mitchell Branch is considered an indication of the migration of the Mitchell Branch VOC plume complex. The intermittent detection of VOCs in this exit pathway is thought to be a reflection of variations in groundwater flowpaths that can fluctuate with seasonal hydraulic head conditions which are strongly affected by rainfall. PCE and TCE were detected at BRW-083 during FY 2009 as a result of the above average rainfall.

Wells BRW-003 and BRW-017 monitor groundwater at the K-1064 Peninsula burn area. Figure 8.22 shows the history of VOC concentrations in groundwater from FY 1994 through FY 2009. TCE concentrations have declined in both wells: 1,1,1-TCA has declined in well BRW-003, and cis-1,2-DCE is detected at variable concentrations between about 4 and $8 \mu \mathrm{g} / \mathrm{L}$ in FY 2009. 
Table 8.14. VOCs detected in groundwater in the Mitchell Branch Exit Pathway

\begin{tabular}{|c|c|c|c|c|c|}
\hline Well & Date & $\begin{array}{c}\text { cis-1,2- } \\
\text { Dichloroethene }\end{array}$ & Tetrachloroethene & Trichloroethene & $\begin{array}{c}\text { Vinyl } \\
\text { chloride }\end{array}$ \\
\hline BRW-083 & $8 / 29 / 2002$ & ND & 5 & 28 & ND \\
\hline & $3 / 16 / 2004$ & 0.69 & 2.2 & 9.9 & ND \\
\hline & $8 / 26 / 2004$ & 2 & 4.7 & 20 & ND \\
\hline & $3 / 14 / 2007$ & 5 & 9 & 28 & ND \\
\hline & $3 / 20 / 2008$ & ND & ND & ND & ND \\
\hline & $8 / 21 / 2008$ & ND & ND & ND & ND \\
\hline & $3 / 12 / 2009$ & ND & ND & 1.31 J & ND \\
\hline & $8 / 3 / 2009$ & ND & 2.66 & 14.2 & ND \\
\hline & $8 / 3 / 1998$ & ND & ND & 3 & ND \\
\hline & $8 / 26 / 2004$ & 4.7 & ND & 3.6 & ND \\
\hline & $8 / 21 / 2006$ & 3.4 & 14 & 2 & 1.2 \\
\hline & $3 / 13 / 2007$ & 25 & $2 J$ & 23 & $2^{\circ}$ \\
\hline & $8 / 21 / 2007$ & 17 & ND & 30 & 0.3 J \\
\hline & $3 / 5 / 2008$ & ND & ND & ND & ND \\
\hline & $8 / 18 / 2008$ & ND & ND & ND & ND \\
\hline & $3 / 12 / 2009$ & ND & ND & ND & ND \\
\hline & $7 / 30 / 2009$ & ND & ND & ND & ND \\
\hline
\end{tabular}

anetection occurred in a field replicate. Constituent not detected in regular sample.

Bold table entries exceed primary drinking water MCL screening values (PCE, TCE $=5 \mu \mathrm{g} / \mathrm{L}$, cis-1,2-DCE $=70 \mu \mathrm{g} / \mathrm{L}$, vinyl chloride $=2 \mu \mathrm{g} / \mathrm{L}$ )

All concentrations $\mu \mathrm{g} / \mathrm{L}$.

BRW $=$ bedrock wells $\quad J=$ estimated value $\quad \mathrm{ND}=$ Not Detected $\quad \mathrm{UNW}=$ unconsolidated wells

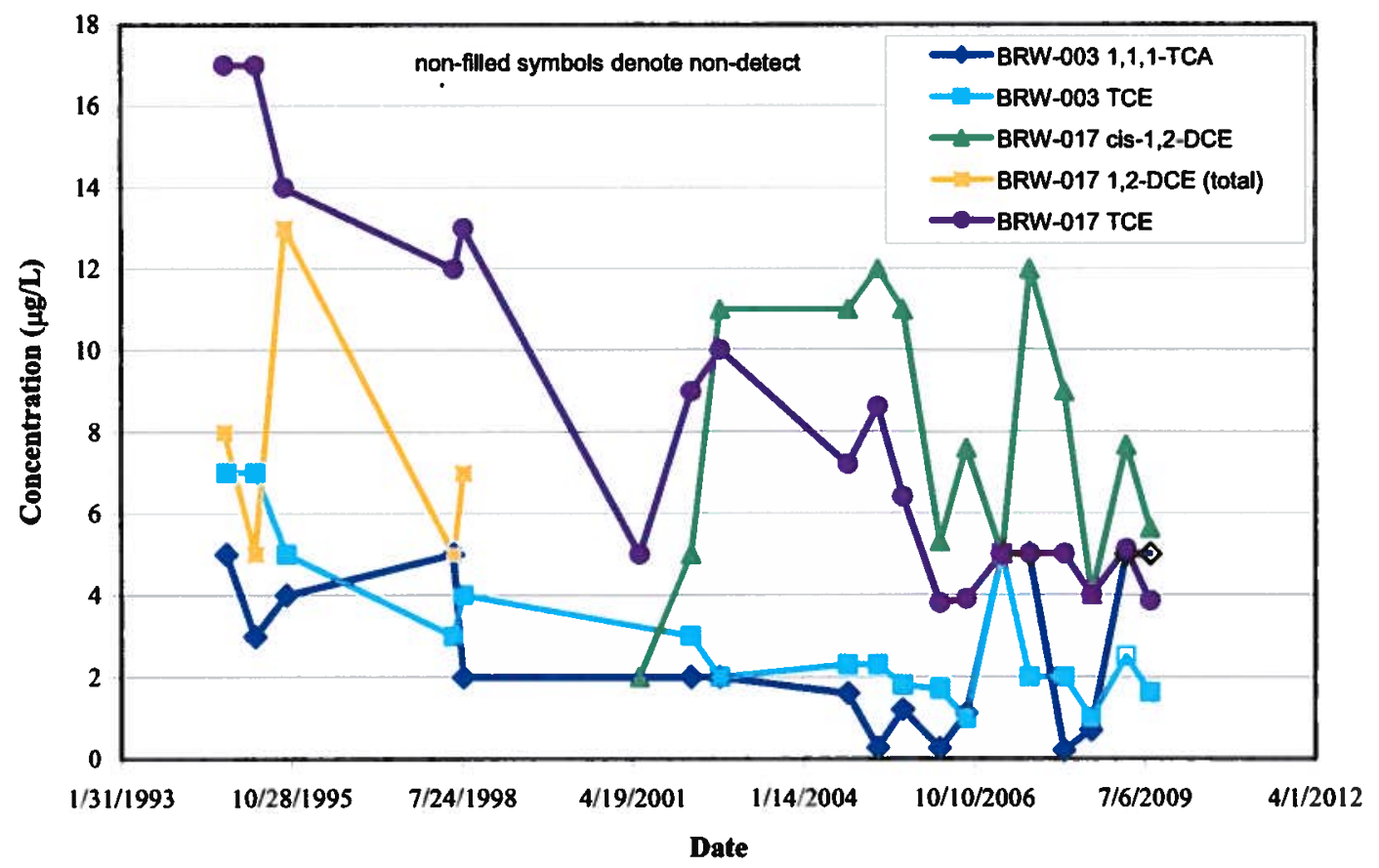

Figure 8.22. VOC concentrations in groundwater at K-1064 Peninsula area. 
Groundwater is monitored in four wells (BRW-066, BRW-030, UNW-080, and UNW-043) that lie between buildings K-31/K-33 and Poplar Creek, as shown on Figure 8.20. VOCs are not COCs in this area; however, leaks of recirculated cooling water have left residual subsurface chromium contamination. Figure 8.23 shows the history of chromium detection in wells at K-31/K-33. Well UNW-043 exhibits the highest residual chromium concentrations of any in the area. Chromium concentrations in well UNW-043 correlate with the turbidity of samples, and acidification of unfiltered samples that contain suspended solids often causes detection of high metals content because the acid preservative dissolves metals that are adsorbed to the solid particles at the normal groundwater $\mathrm{pH}$. During FY 2006, an investigation was conducted to determine if groundwater in the vicinity of the $\mathrm{K}-31 / \mathrm{K}-33$ buildings contained residual hexavalent chromium from recirculated cooling water leaks. The data indicated the chromium in groundwater near the leak sites was essentially all the less toxic trivalent species. During FY 2008 and FY 2009, field filtered and unfiltered samples were collected from UNW-043. As shown on Figure 8.23, the samples filtered in the field prior to acid preservation contained very little chromium and the dissolved chromium levels did not exceed the MCL. This indicates that most of the chromium in this area is particle-bound rather than dissolved in groundwater.

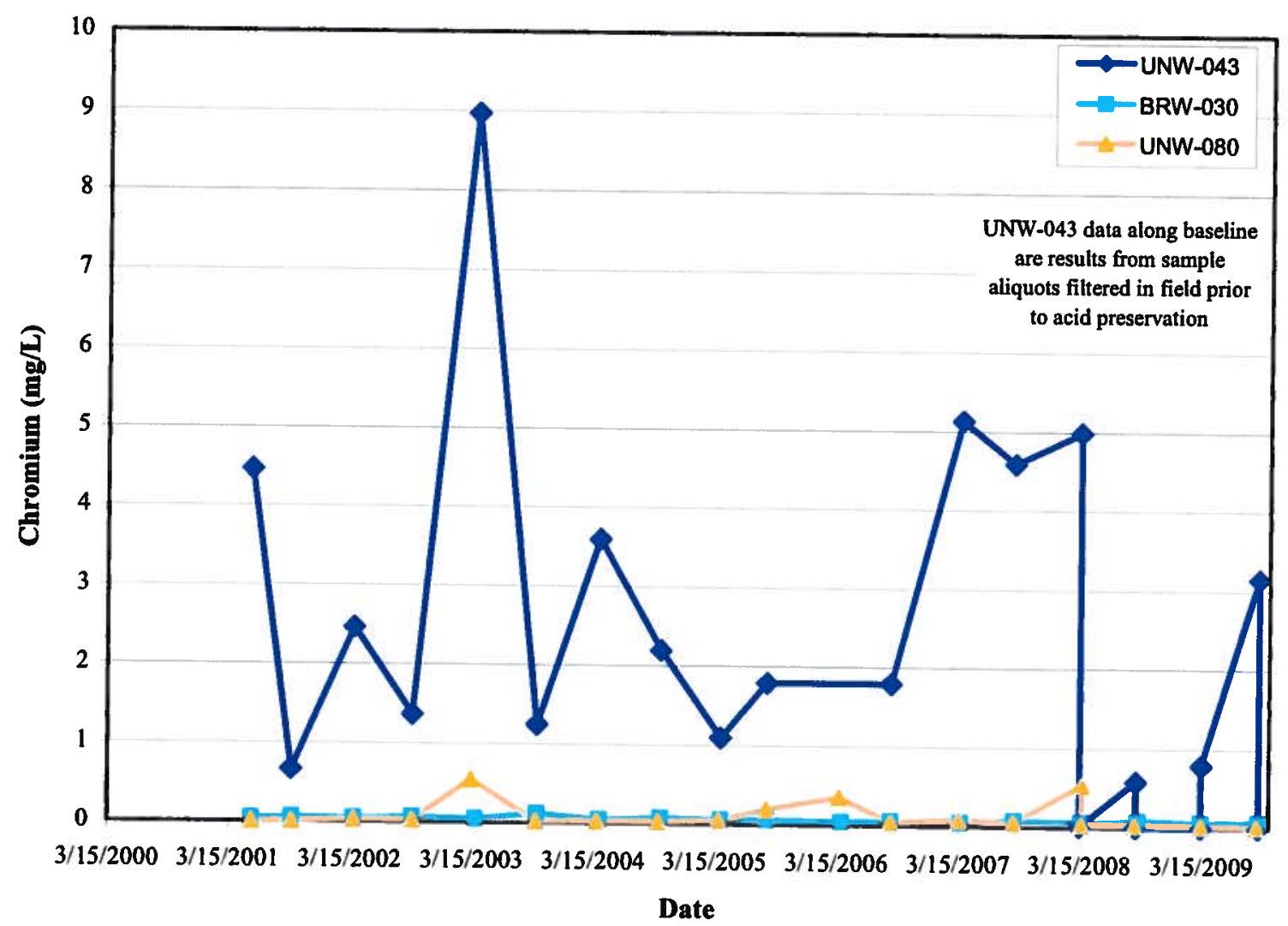

Figure 8.23. Chromium concentrations in groundwater in the K-31/K-33 area.

Several exit pathway wells are monitored in the K-27/K-29 area, as shown on Figure 8.20. Figure 8.24 shows the history of detected VOC concentrations in wells both north and south of K-27 and K-29. The source of VOC contamination in well BRW-058 is not suspected to be from K-27/K-29 area operations. VOC concentrations in this area show very slowly declining concentrations. 


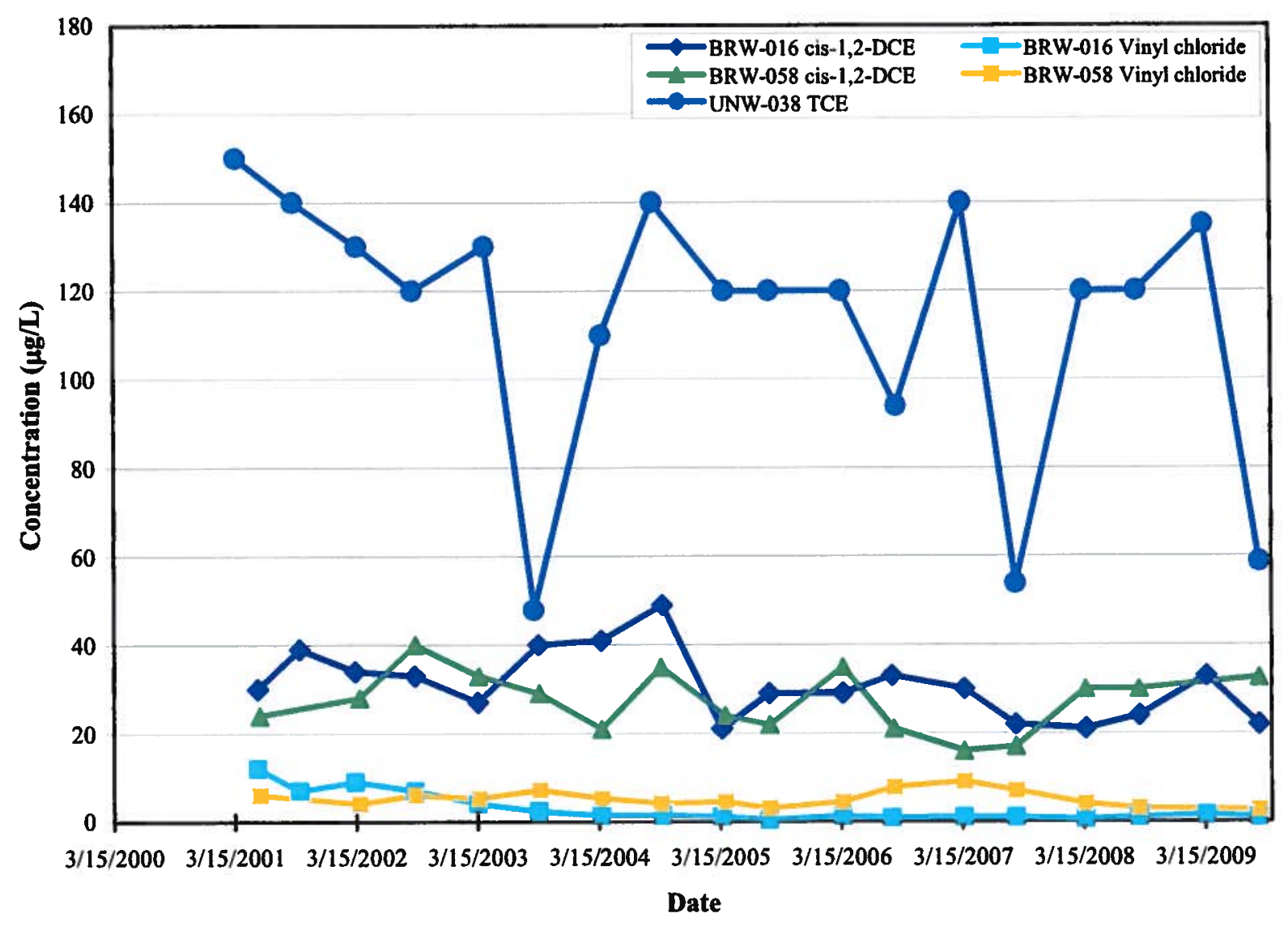

Figure 8.24. Detected VOC concentrations in groundwater exit pathway wells near K-27 and K-29.

Wells BRW-084 and UNW-108 are exit pathway monitoring locations at the northern edge of the K-1007-P1 Pond (see Fig. 8.20). These wells have been monitored intermittently from 1994 through 1998 and semiannually from FY 2001 through FY 2009. The first detections of VOCs in these wells occurred during FY 2006 with detection of low $(\sim 10 \mu \mathrm{g} / \mathrm{L}$ or less) concentrations of TCE and cis-1,2-DCE. The source area for these VOCs is not known. Volatile organic compounds were not detected in either of these wells during FY 2009. Metals were detected and associated with the presence of high turbidity in the samples. No primary or secondary MCLs for metals were exceeded in sample aliquots that were fieldfiltered prior to acid preservation during FY 2009.

Exit pathway groundwater in the K-901-A Holding Pond area (see Figure 8.20) is monitored by four wells (BRW-035, BRW-068, UNW-066, and UNW-067) and two springs (21-002 and PC-0). Very low concentrations $(<5 \mu \mathrm{g} / \mathrm{L})$ of VOCs are occasionally detected in wells adjacent to the K-901-A Holding Pond. However, these contaminants are not persistent in groundwater west and south of the pond. No VOCs were detected in the K-901-A Pond exit pathway wells during FY 2009, and alpha and beta activity levels were less than $15 \mathrm{pCi} / \mathrm{L}$ and $25 \mathrm{pCi} / \mathrm{L}$, respectively. TCE is the most significant groundwater contaminant detected in the springs, and the historic TCE concentrations are shown in Figure 8.25. Spring PC- 0 was added to the sampling program in 2004. During the spring through autumn seasons, spring PC0 is submerged beneath the Watts Bar lake level, so this location is accessible for sampling only during winter when the lake level is lowered by TVA. At spring 21-002, 1,1,1-TCA, 1,2-DCE, carbon tetrachloride, and PCE are sometimes present at concentrations typically less than $5 \mu \mathrm{g} / \mathrm{L}$. The TCE concentration at spring 21-002 increased in the FY 2009 sample from levels near $5 \mu \mathrm{g} / \mathrm{L}$ to about 25 
$\mu \mathrm{g} / \mathrm{L}$. This increase is thought to be caused by increased groundwater discharge caused by above-average rainfall.

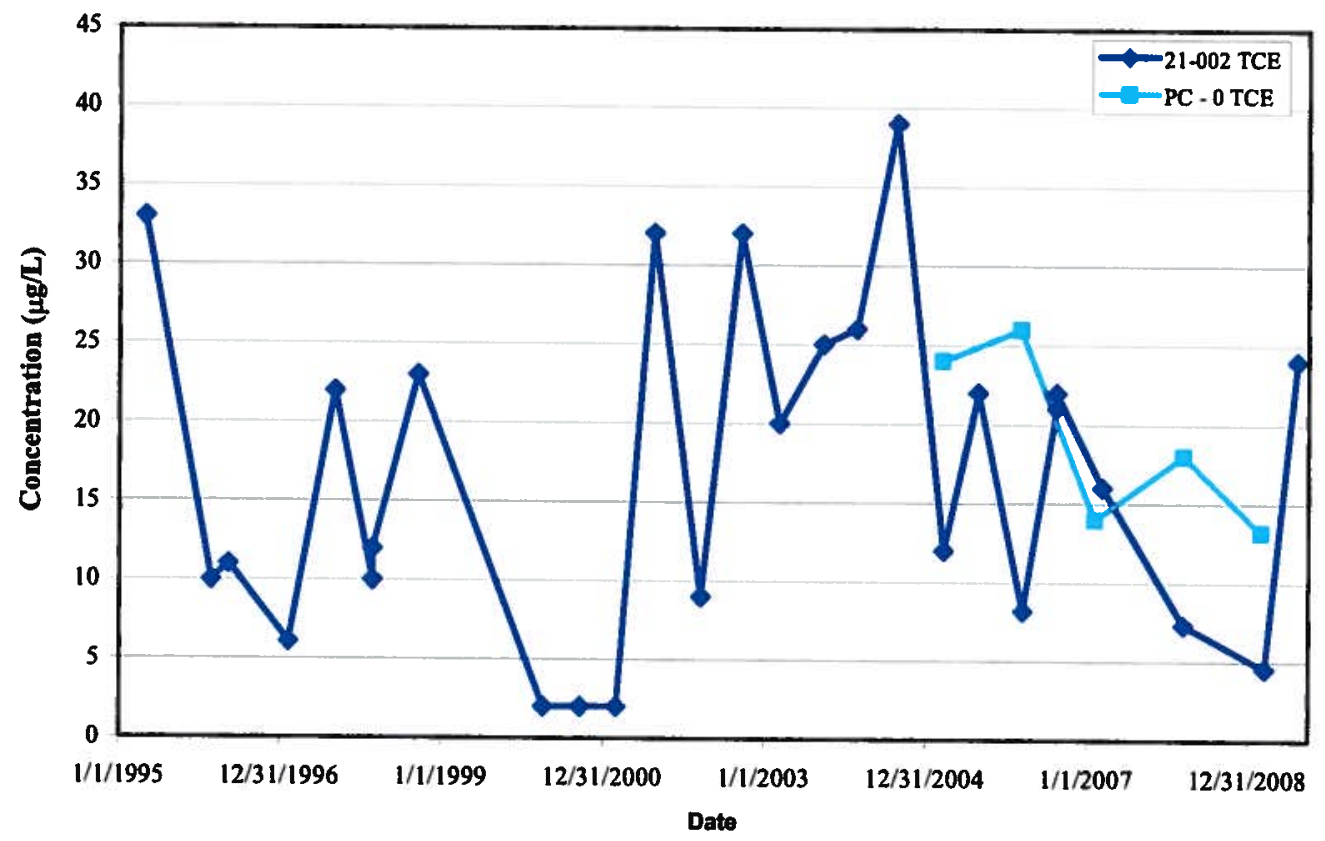

Figure 8.25. TCE concentrations in K-901 area springs.

Exit pathway groundwater monitoring is also conducted at the K-770 area, where wells UNW-013 and UNW-015 are used to assess radiological groundwater contamination along the Clinch River (see Figure 8.20). Figure 8.26 shows the history of measured alpha and beta activity in this area. Analytical results indicate that the alpha activity is largely attributable to uranium isotopes, and well UNW-013 historically contained ${ }^{99} \mathrm{Tc}$ that is a strong beta-emitting radionuclide responsible for the elevated beta activity in that well. 


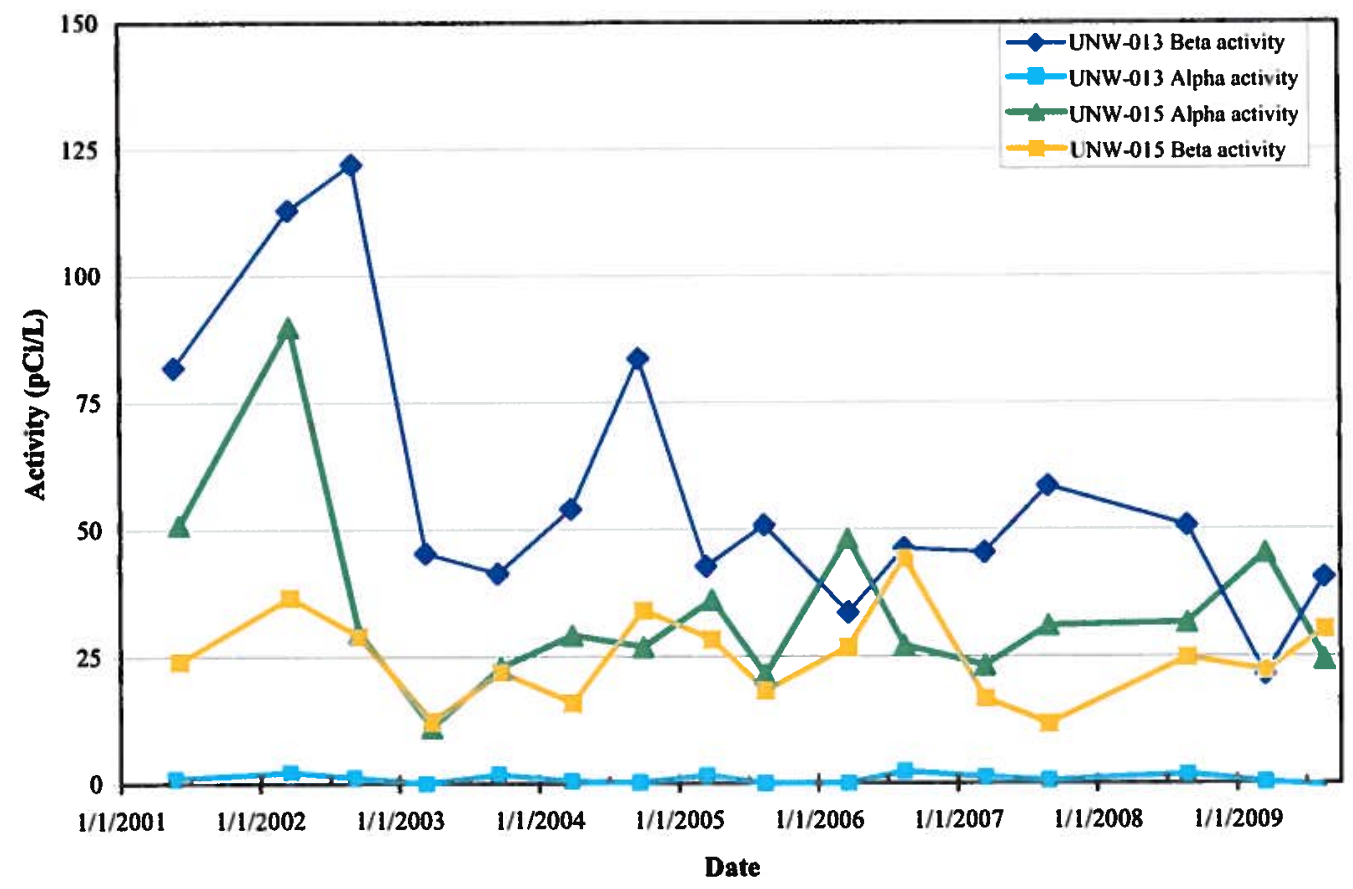

Figure 8.26. History of measured alpha and beta activity in the $\mathrm{K}-\mathbf{7 7 0}$ area.

\subsubsection{Aquatic Biological Monitoring}

Long-term trends in PCB accumulation in fish from the K-901-A and K-1007-P1 ponds were presented in Sect. 8.4.2.2.

Biological monitoring in Mitchell Branch, conducted by the ETTP Biological Monitoring and Abatement Program (BMAP), includes: (1) contaminant accumulation in fish, (2) fish community surveys, and (3) benthic macroinvertebrate surveys. Mean PCB concentration in redbreast sunfish collected from Mitchell Branch in FY 2009 averaged $0.99 \mu \mathrm{g} / \mathrm{g}$, within the range of values seen in recent years but well below historically high levels in the late 1990 s and early 2000 s when levels in fish were in the $3-4 \mu \mathrm{g} / \mathrm{g}$ range (Figure 8.27). The $1-2 \mu \mathrm{g} / \mathrm{g}$ range is still a relatively high level of PCBs for sunfish, which are low in lipids and don't accumulate PCBs to the same degree as species such as largemouth bass and channel catfish. Caged Asiatic clams (Corbicula fluminea) were placed in Mitchell Branch above and below storm drain discharges for a four-week exposure (June 24 - July 22, 2009) to evaluate the importance of PCB sources to the creek. As has been the case in the past, the highest PCBs in clams were at downstream sites, with the highest levels at MIK 0.2 and below SD 190 (2.43 and $2.03 \mu \mathrm{g} / \mathrm{g}$, respectively). Levels of PCBs in clams from Mitchell Branch upstream of SD 190 decreased from $>0.5 \mu \mathrm{g} / \mathrm{g}$ in FY 2008 to $0.23 \mu \mathrm{g} / \mathrm{g}$ in FY 2009 at MIK 0.5 (below SD 180), and from $\sim 0.3-0.4 \mu \mathrm{g} / \mathrm{g}$ to $0.1-0.25 \mu \mathrm{g} / \mathrm{g}$ at sites immediately upstream and downstream of SD 170. 


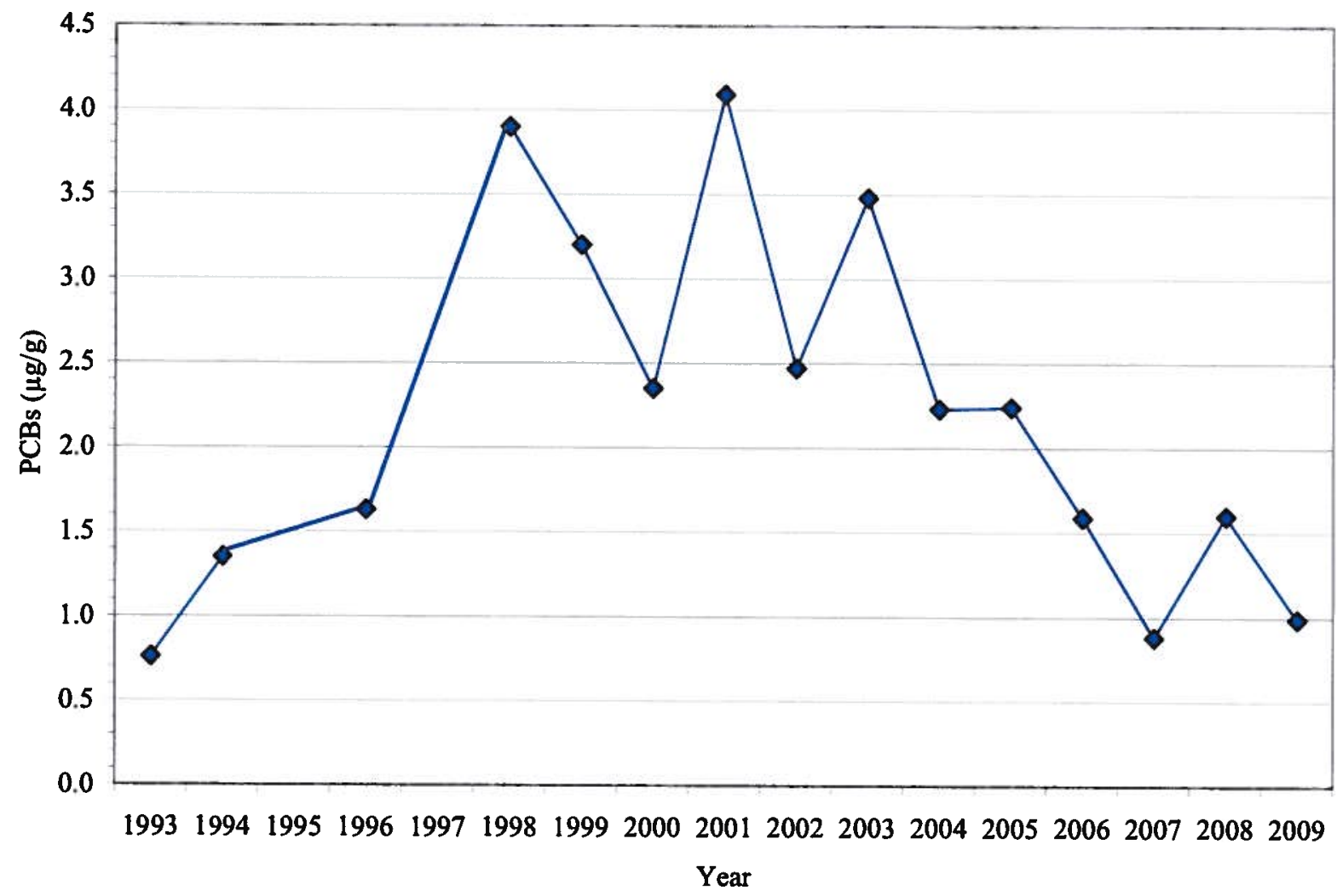

Figure 8.27. Mean PCB concentrations in redbreast sunfish from Mitchell Branch, 1993-2009.

The species richness (number of species) of the fish community in Mitchell Branch (MIK 0.45) has improved since construction of the interceptor trench in early 1998 (Figure 8.28), and has stabilized in recent samples. Fish community impacts associated with the trench in the late 1990 s were likely due to physical changes that affected habitat. The trench was operational until February of 2005, at which time it was shut down. The fish community values for MIK 0.45 are now in the range of richness values of comparable reference streams. Although similar in overall species richness, the fish community at MIK 0.45 does have fewer sensitive species and at lower densities than at comparable reference streams. The presence of sensitive species may increase as water quality improves and habitat stabilizes. 


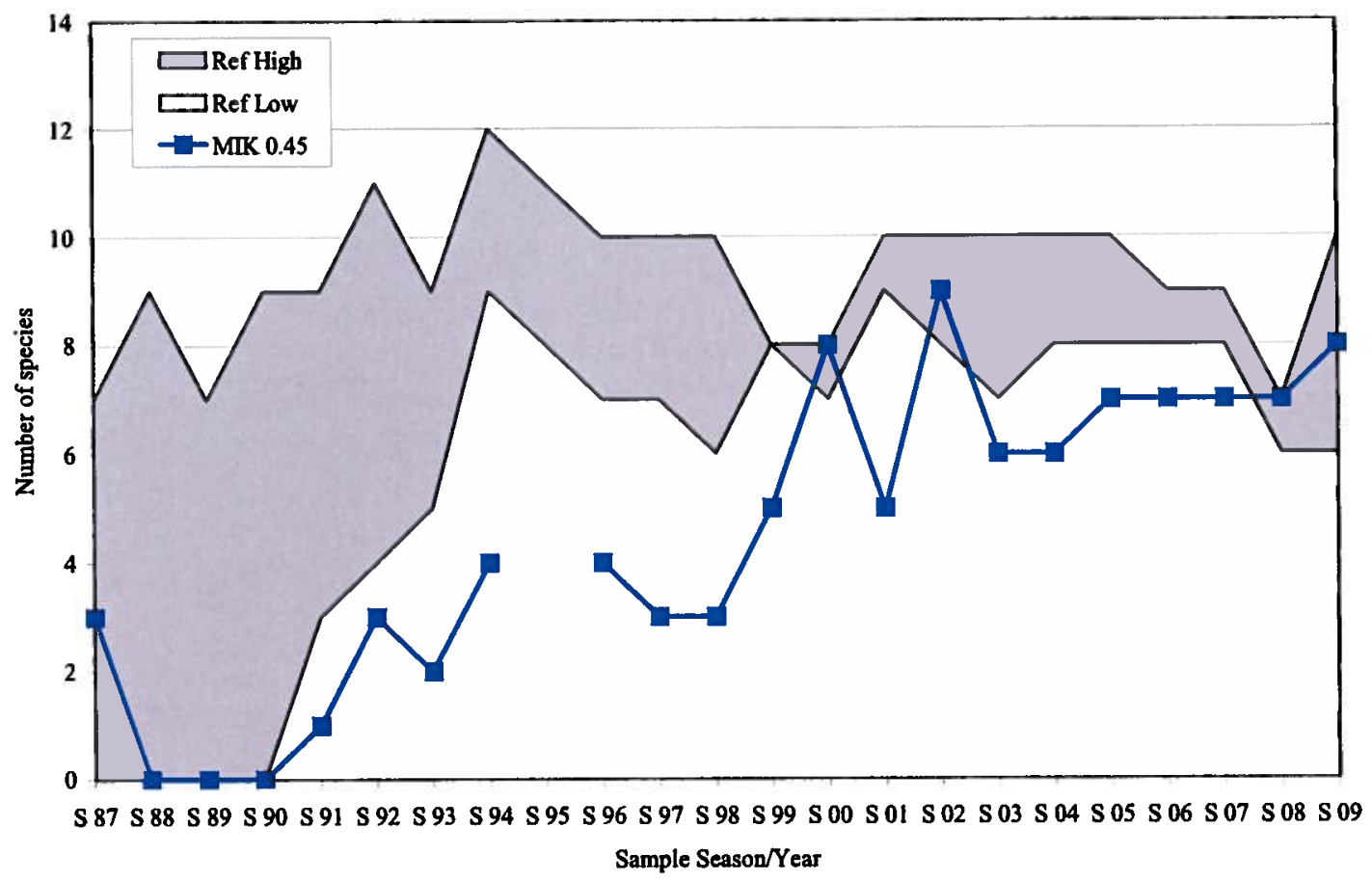

Figure 8.28. Species richness (number of species) in spring samples of the fish community in Mitchell Branch (MIK) and a range of reference streams (Ref. High-Low), 1986 to 2009."

"Interruptions in data lines indicate missing samples.

Results from benthic macroinvertebrate assessments of Mitchell Branch continue to indicate that the conditions in the lower reaches of the stream are slightly to moderately degraded (Figure 8.29). The number of pollution-intolerant taxa at the three most-downstream sites continues to be $>20 \%$ lower than at the reference site (MIK 1.4). Furthermore, there has been a general tendency for the number of pollution-intolerant taxa to fluctuate more between sampling periods at the downstream sites then at reference site, which is often a characteristic of aquatic communities living in unstable conditions (e.g., periodic releases of pollutants or habitat disturbances). 


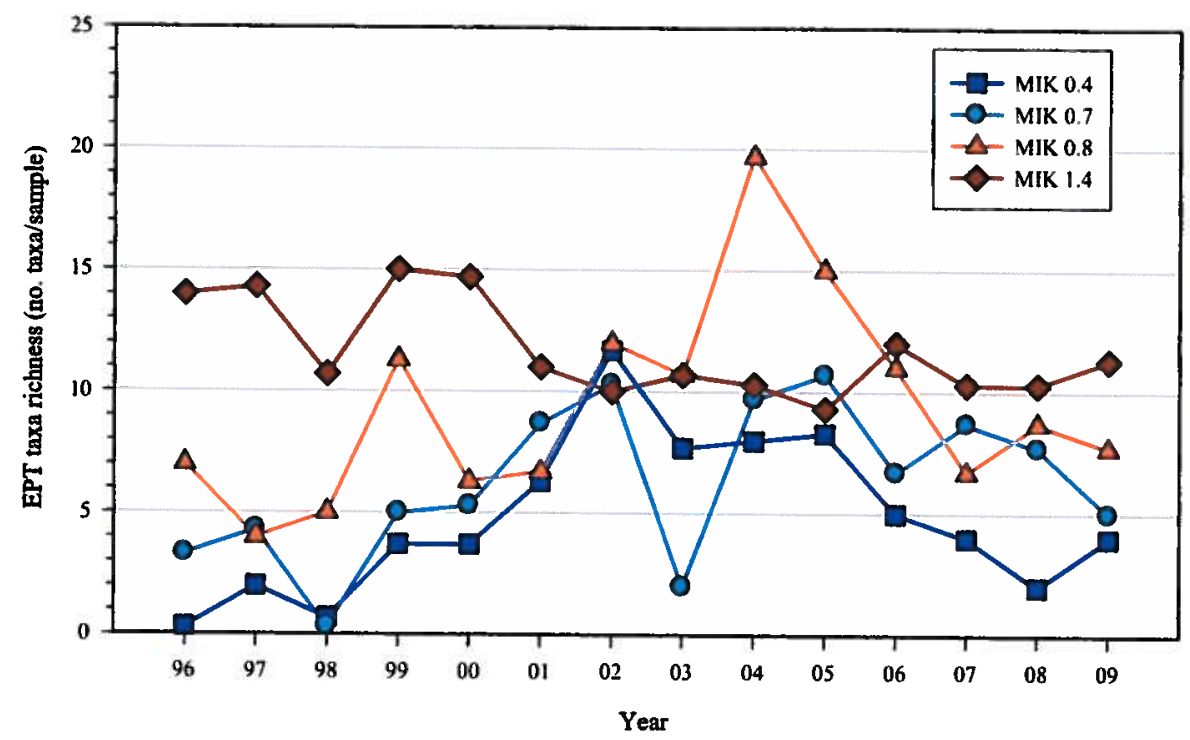

EPT = Ephemeroptera, Plecoptera, and Trichoptera, or mayflies, caddisflies, and stoneflies.

Figure 8.29. Mean $(n=3)$ taxonomic richness of the pollution-intolerant taxa for the benthic macroinvertebrate community at sites in Mitchell Branch at the ETTP, April sampling periods, 1996-2009.

\subsubsection{Monitoring Summary}

During FY 2009, monitoring results for the principal surface water and groundwater locations indicate that contaminant levels are generally stable to decreasing in most instances. The hexavalent chromium collection system and treatment functioned as planned and protected surface water quality in Mitchell Branch. Contaminants detected during previous years in exit pathway groundwater near the K-1007-P1 weir were not detected in FY 2009. Low concentrations of PCE and TCE greater than the MCL were detected in a bedrock well in the exit pathway at the mouth of Mitchell Branch. These contaminants have been detected previously but were not present during recent drought years. Most of the groundwater plumes monitoring results indicate stable contaminant levels compared to recent years. 


\subsection{EAST TENNESSEE TECHNOLOGY PARK MONITORING CHANGES AND RECOMMENDATIONS}

Table 8.15 summarizes the issue(s) and associated recommendation(s) for the ETTP administrative watershed. The BORCE located in the northern section of Zone 1 at ETTP is utilized for recreational use; however, the end use identified in the ETTP Zone 1 ROD is unrestricted industrial. DOE acknowledges the disparity in the land use and plans to initiate an ESD to the Zone 1 Interim ROD (DOE 2002c) to change that portion of the land use from industrial to recreational.

The issue from the 2009 RER and recommendation that additional monitoring of the K-1420 pad be discontinued, remains unresolved and is being carried forward for tracking purposes.

Table 8.15. Summary of technical issues and recommendations

\begin{tabular}{|c|c|}
\hline Issue $^{a}$ & $\begin{array}{c}\text { Action/ } \\
\text { Recommendation }\end{array}$ \\
\hline \multicolumn{2}{|l|}{2010 Current Issue: } \\
\hline $\begin{array}{l}\text { 1. The northern section of ETTP Zone } 1 \\
\text { has been identified as a conservation } \\
\text { easement (BORCE). The BORCE is } \\
\text { utilized for recreational use: hiking, } \\
\text { bicycling, and select controlled deer } \\
\text { hunts. The end use identified in the } \\
\text { ETTP Zone } 1 \text { ROD is unrestricted } \\
\text { industrial, i.e., recreational use was not } \\
\text { designated. (2010 RER) }\end{array}$ & $\begin{array}{l}\text { 1. DOE acknowledges the land use differences that exist between the BORCE use } \\
\text { and that which is in the Zone } 1 \text {. The end use of the portion of Zone } 1 \text { that is also } \\
\text { identified as part of the BORCE will be changed from industrial to recreational } \\
\text { in an ESD to the Zone } 1 \text { Interim ROD (DOE 2002c) with the appropriate level } \\
\text { of public participation. The Addendum to the Phased Construction Completion } \\
\text { Report for the Duct Island Area and K-90I Area in Zone I, East Tennessee } \\
\text { Technology Park, Oak Ridge, Tennessee (DOE/OR/01-2261\&D2/A1/R1) } \\
\text { includes the risk assessment to support this change. }\end{array}$ \\
\hline \multicolumn{2}{|l|}{ Issues Carried Forward: } \\
\hline $\begin{array}{l}\text { 1. Per the } \mathrm{K}-1420 \mathrm{PCCR} \text {, if the } \\
\text { concentration of total uranium } \\
\text { continues to show results below } \\
2,600 \mathrm{pCi} / \mathrm{L} \text {, this will confirm that } \\
\text { storm water runoff from Building } \\
\mathrm{K}-1420 \text { slab is stabilized, and sampling } \\
\text { of the pad during rain events will be } \\
\text { discontinued. Based on results from } \\
\text { the past year, additional monitoring of } \\
\text { the } \mathrm{K}-1420 \text { pad can be discontinued. } \\
(2009 \mathrm{RER})^{\mathrm{b}}\end{array}$ & $\begin{array}{l}\text { 1. The ETTP Core Team is currently reviewing sampling results. If approved, the } \\
\text { change will be reflected in the } 2011 \text { RER. }\end{array}$ \\
\hline
\end{tabular}

"Issues identified in the table as "Current Issue" indicate an issue identified during evaluation of current FY 2009 data. Issues identified as "Issues Carried Forward" indicate that the issue is carried forward from a previous year's RER so as to track the issue though resolution.

${ }^{b}$ The year of the RER or the FYR in which the issue originated is provided in parentheses, e.g., (2009 RER). 


\section{CERCLA ACTIONS AT OTHER SITES}

\subsection{INTRODUCTION AND OVERVIEW}

This chapter presents the remedial effectiveness evaluation for CERCLA actions that are not physically situated within one of the five established watersheds or ChR, but are located on the ORR. Presently, only the White Wing Scrap Yard (WWSY) and the Oak Ridge Associated University (ORAU) South Campus Facility (SCF) fall into this category. Table 9.1 summarizes the status of these actions, and Table 9.2 provides a summary of the LTS requirements. Both remedies have been single-action decisions to address known or potential sources of releases.

\subsubsection{Status of Updates}

During FY 2009, no additional CERCLA actions were implemented or completed at the WWSY or at the ORAU SCF. Neither were there any FFA documents submitted or approved for CERCLA actions located on the ORR but physically located outside one of the five established watersheds.

\subsection{WHITE WING SCRAP YARD (WAG 11) SURFACE DEBRIS REMEDIAL ACTION}

The WWSY is located north of the western end of BCV, as is shown on Figure 9.1. The scope of this action (Table 9.1) included removal of contaminated surface debris retrievable without excavation. Some buried materials remain at the site. WWSY has only LTS requirements (Table 9.2). A review of compliance with these LTS requirements is included in Sect. 9.2.1. Background information on this remedy and performance standards are provided in Chap. 9 of Vol. 1 of the 2007 RER (DOE 2007a).

\subsubsection{Compliance with LTS Requirements}

\subsubsection{Requirements}

There are no requirements for post-remediation monitoring and no LTS requirements listed in the Interim Record of Decision (IROD) (DOE 1992). However, the Interim RA PCR (DOE 1994b) states, "because the interim remedial action was to remove debris, no operation and maintenance are necessary as a result of the interim action. However, long-term surveillance and maintenance will continue until decisions are made for future and/or final CERCLA remedial actions at the site."

\subsubsection{Status of Requirements for FY 2009}

The site underwent monthly inspections in FY 2009 performed by the Y-12 S\&M Program to inspect components including damaged or missing radiation roping or signs delineating radiation areas; deteriorating access road conditions or damaged or missing gate locks; debris buildup or blockage at the fence/creek boundaries; unauthorized materials placed within the area; damage to site perimeter fencing; and unlocked gate or missing or damaged radiation signs. Additionally, inspections included the separate fenced-in area west of the scrap yard. S\&M personnel inspected the fencing by walking the entire perimeter of the site and the west fenced area. Maintenance included clearing fallen trees from the fencing and roadway, repairing damaged fencing, and routine mowing. 
Table 9.1. CERCLA actions at other sites on the ORR

\begin{tabular}{lccc}
\hline \multicolumn{1}{c}{ CERCLA action } & $\begin{array}{c}\text { Decision document, date signed } \\
\text { (mm/dd/yy) }\end{array}$ & $\begin{array}{c}\text { Monitoring/ } \\
\text { LTS } \\
\text { required }\end{array}$ & $\begin{array}{c}\text { Action/Document status } \\
\text { section }\end{array}$ \\
\hline $\begin{array}{l}\text { WWSY (WAG 11) } \\
\text { Surface Debris RA }\end{array}$ & IROD (DOE/OR/1055\&D4): 10/06/92 & PCR $^{\mathrm{b}}$ (DOE/OR01/-1263\&D2) approved 09/14/94. \\
ORAU SCF & & & No/Yes \\
& $\begin{array}{l}\text { ROD (DOE/OR/02-1383\&D3): } 12 / 28 / 95 \\
\text { NSC: } 12 / 20 / 06\end{array}$ & RAR (DOE/OR/02-1474\&D2) approved 08/20/96. & Yes/Yes \\
\hline
\end{tabular}

${ }^{a}$ Detailed information of the status of ongoing actions is from Appendix E of the FFA and is available at <http://www.bechteljacobs.com/ettp_ffa_appendices.shtml>.

${ }^{b}$ This action was completed prior to uniform adherence to the RAR process; hence, no RAR exists for this decision.

Table 9.2. LTS requirements for CERCLA actions at other sites on the ORR

\begin{tabular}{|l|l|l|l|l|}
\hline \multirow{2}{*}{ Site/Project } & \multicolumn{2}{|c|}{ LTS Requirements } & \multicolumn{2}{c|}{ RER } \\
\cline { 2 - 5 } & \multicolumn{1}{|c|}{ LUCs } & Engineering controls & & \multicolumn{1}{c|}{ section } \\
\hline WWSY (WAG 11) Surface Debris RA & $\begin{array}{l}\text { Long-term S\&M } \\
\text { ORAU SCF RA }\end{array}$ & $\begin{array}{l}\text { Environmental Notice filed at } \\
\text { Register of Deeds }\end{array}$ & & LUCs in place \\
\hline
\end{tabular}




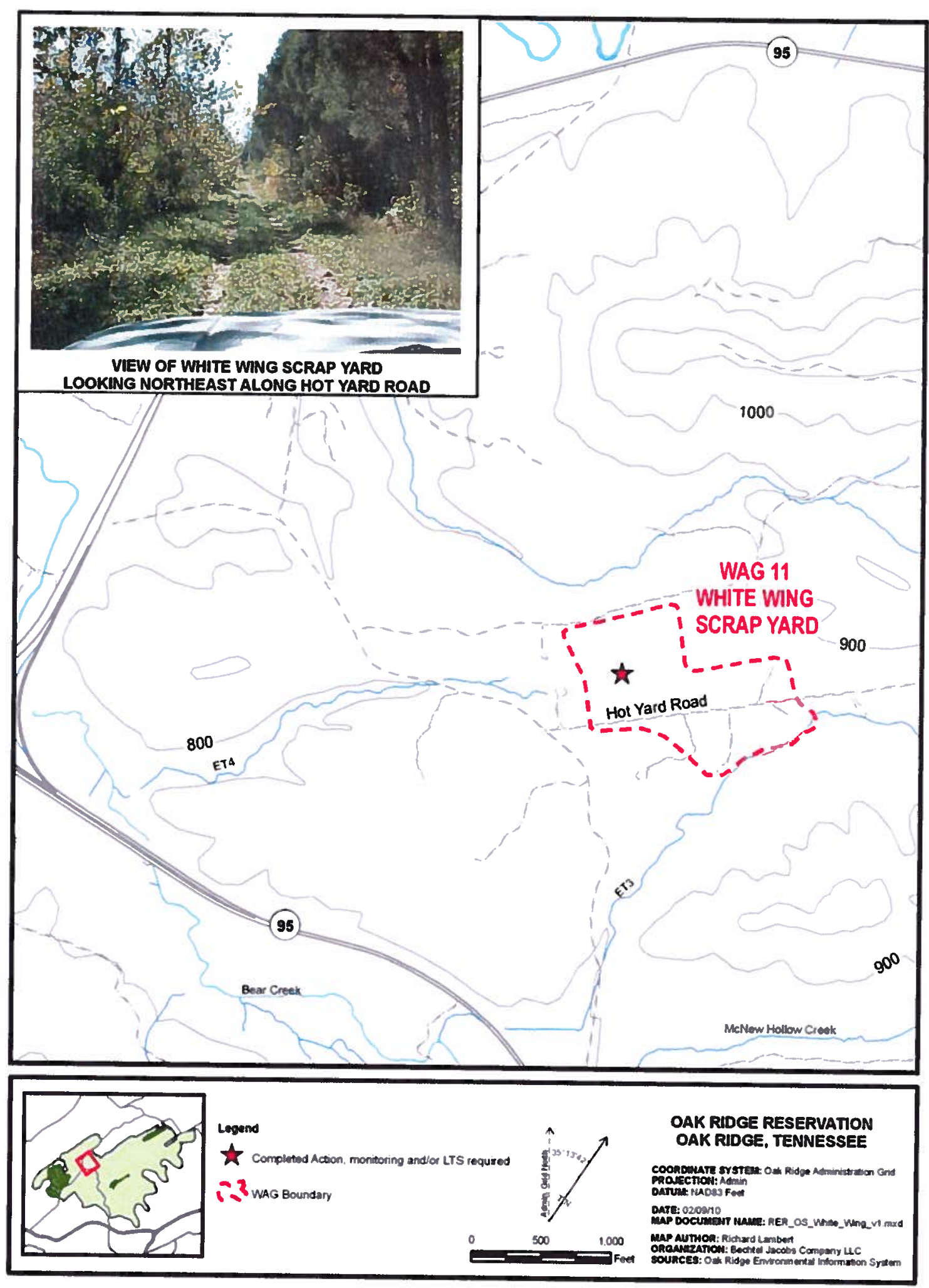

Figure 9.1. Location of White Wing Scrap Yard (WAG 11). 


\subsection{ORAU SOUTH CAMPUS FACILITY}

The SCF is a former experiment station where the radionuclide effects on animals were studied (Figure 9.2). In 1995, a ROD was signed that specified groundwater monitoring in the vicinity of a VOC contaminated area and LUCs that include a groundwater-use restriction. The land use restrictions have been maintained and groundwater monitoring has been conducted at the site. These activities are specified in the documents listed in Table 9.1 and are discussed in this section. Table 9.2 provides a summary of LTS requirements. A complete discussion of the facility and CERCLA decision is provided in Chap. 7 of Vol. 1 of the 2007 RER (DOE 2007a).

\subsubsection{Performance Goals and Monitoring Objectives}

The SCF ROD (DOE 1995c) did not establish clear goals for groundwater quality; however, it did specify periodic monitoring of groundwater at selected wells and at a surface seep location. During the FY 2006 FYR of the decision, it was recommended that the remedy be redefined as a monitored natural attenuation remedy for groundwater with the ultimate goal of reaching MCLs for the volatile organic contamination in groundwater at the site. Additionally, in the FY 2006 FYR, continued annual sampling of two wells (GW-841 and GW-842) and a surface water location was recommended.

\subsubsection{Evaluation of Performance Monitoring Data - FY 2009}

During FY 2009, samples were collected from wells GW-841 and GW-842 and surface water locations SCF-WS1 and SCF-WS2 and were analyzed for VOCs. Figure 9.3 shows the concentrations of detected VOCs in wells GW-841 and GW-842 from FY 1994 through FY 2009. Volatile organic contaminant concentrations in wells GW-841 and GW-842 have exhibited a long-term decreasing concentration history. The 2009 results, which were below drinking water standard concentrations, show continuing decreased concentrations compared to the short-term increase observed during summer 2006. VOC concentrations remain higher at GW-841 than at GW-842, indicative of the lingering dissolved contamination near the spill site. TCE and its transformation product, cis-1,2-DCE, are detected in nearly equivalent concentrations at the wells indicating that degradation of the TCE is continuing to occur. PCE has been detected only sporadically at estimated low concentrations in well GW-841 and was not detected in the 2009 sample. No site-related VOCs were detected in the two surface water samples collected during FY 2009.

\subsubsection{Compliance with LTS Requirements}

\subsubsection{Requirements}

The ROD (DOE 1995c) requires that a notification of the contamination be placed in the property title to alert potential owners of risk. A notice was filed with the Anderson County Register of Deeds on August 28, 1996.

\subsubsection{Status of Requirements for FY 2009}

An on-line search of the Anderson County Register's of Deeds web site was conducted in FY 2009 and verified that the notice remains filed. 


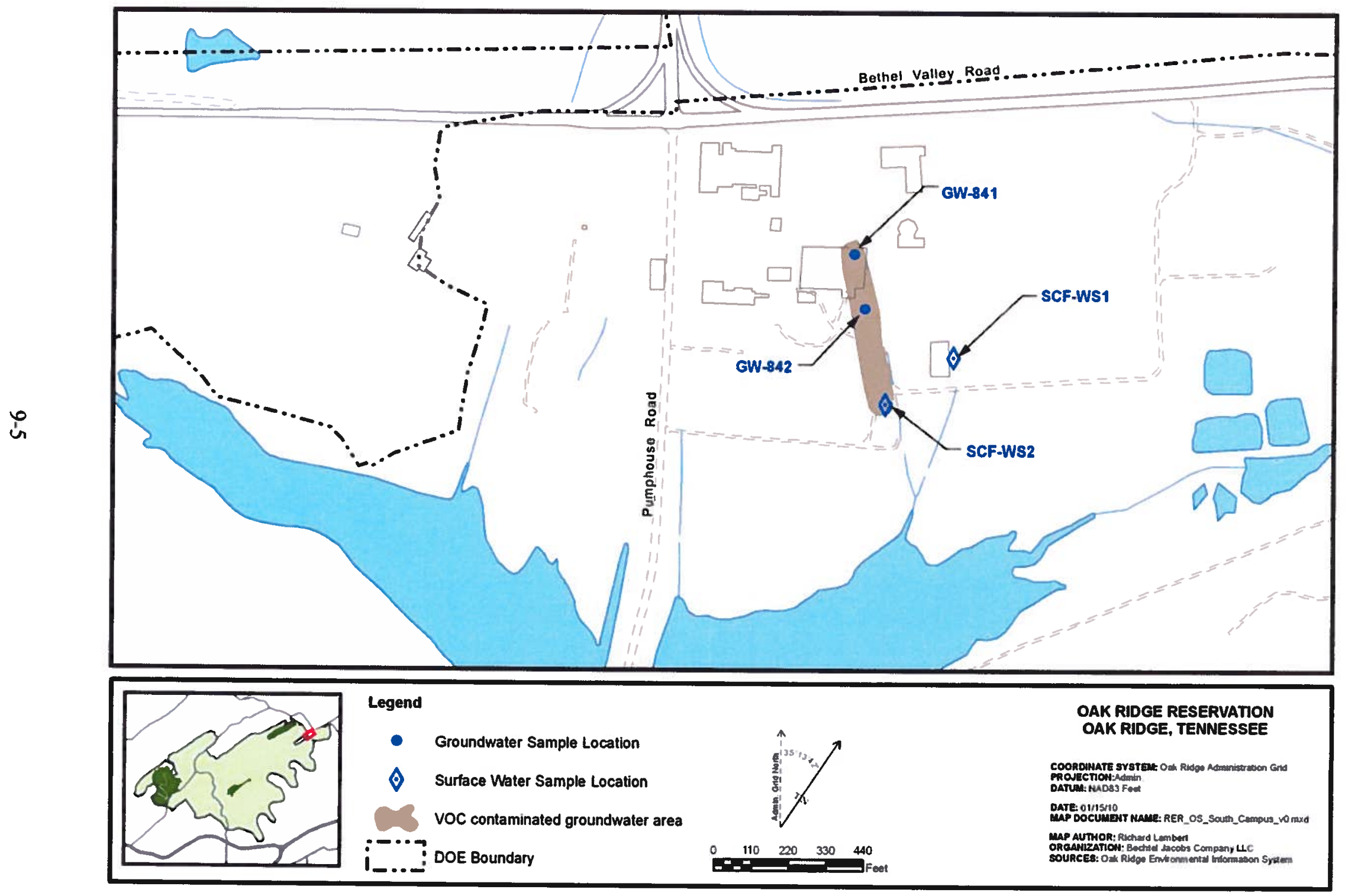

Figure 9.2. South Campus Facility monitoring locations and contaminated groundwater area. 


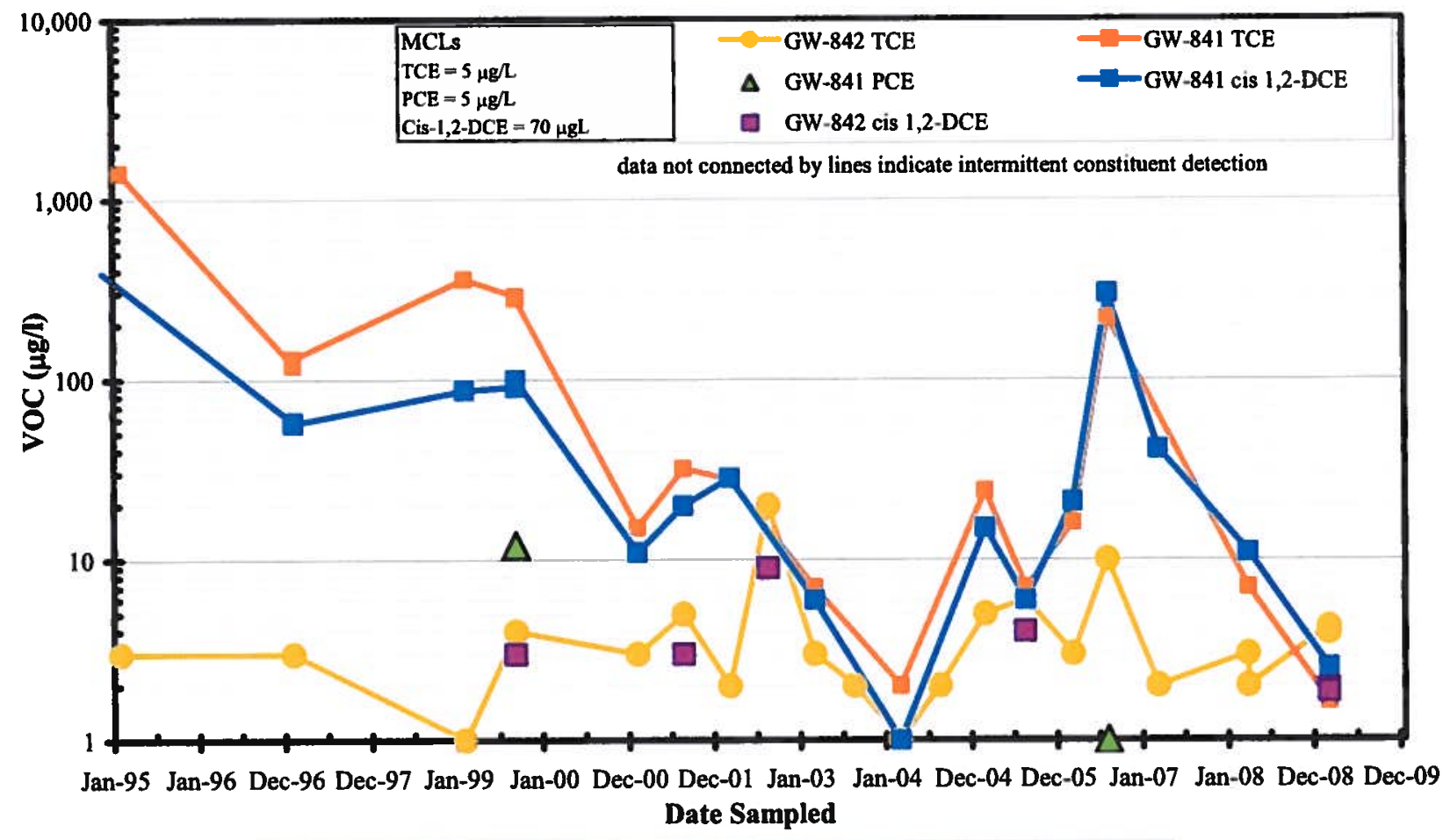

Figure 9.3. VOC concentrations in wells GW-841 and GW-842 at SCF.

\subsubsection{Monitoring Changes and Recommendations for ORAU SCF}

Volatile organic contaminant concentrations in groundwater at the SCF have exhibited a long-term decreasing concentration history, consistent with a monitored natural attenuation remedy. No monitoring changes at the site are recommended at this time, as reflected in Table 9.3.

Table 9.3. Summary of technical issues and recommendations

\begin{tabular}{|l|c|}
\hline \multicolumn{1}{|c|}{ Issue $^{\mathrm{a}}$} & $\begin{array}{c}\text { Action/ } \\
\text { Recommendation }\end{array}$ \\
\hline$\frac{2010 \text { Current Issue: }}{\text { None. }}$ & \\
\hline
\end{tabular}




\section{REFERENCES}

Ashwood, T. L. (editor) 1993. Seventh Report on the Oak Ridge National Laboratory Biological Monitoring and Abatement Program for White Oak Creek Watershed and the Clinch River, ORNL/TM-12385, Oak Ridge National Laboratory, Oak Ridge, TN.

BJC 2006. Oak Ridge National Laboratory Surveillance \& Maintenance Program Facility Inspection and Training Manual, BJC/OR-2288, Bechtel Jacobs Company LLC, Oak Ridge, TN.

BJC 2009. Quality Assurance Project Plan for the Water Resources Restoration Program, U.S. Department of Energy, Oak Ridge Reservation, Oak Ridge, Tennessee, BJC/OR/-235/R2/A2. Bechtel Jacobs Company LLC, Oak Ridge, TN.

DOE 1991a. Record of Decision United Nuclear Corporation Disposal Site Declaration, Y-12 Plant, Oak Ridge, Tennessee, U.S. Department of Energy, Environmental Restoration Division, Oak Ridge, TN.

DOE 1991b. Feasibility Study for the United Nuclear Corporation Disposal Site at the Oak Ridge Y-12 Plant, Oak Ridge, Tennessee, ES/ER-15\&D1, Y/ER/Sub-90/VK168/3\&D1, U.S. Department of Energy, Environmental Restoration Division, Oak Ridge, TN.

DOE 1992. Interim Record of Decision for the Oak Ridge National Laboratory, Waste Area Grouping 11, Surface Debris, Oak Ridge, Tennessee, DOE/OR-1055\&D4, U. S. Department of Energy, Environmental Restoration Division, Oak Ridge, TN.

DOE 1993a. Post-Construction Report for the United Nuclear Corporation Disposal Site at the Oak Ridge Y-12 Plant, Oak Ridge, Tennessee, DOE/OR/01-1128\&D1, U. S. Department of Energy, Environmental Restoration Division, Oak Ridge, TN.

DOE 1993b. Record of Decision for the K-1407-B/C Ponds at the Oak Ridge K-25 Site, Oak Ridge, Tennessee, DOE/OR/01-1125\&D3, U.S. Department of Energy, Environmental Restoration Division, Oak Ridge, TN.

DOE 1994a. Action Memorandum for the Waste Area Grouping 1 Corehole 8 Removal Action at Oak Ridge National Laboratory, Oak Ridge, Tennessee, DOE/OR/02-1317\&D2, U. S. Department of Energy, Environmental Restoration Division, Oak Ridge, TN.

DOE 1994b. Interim Remedial Action Post-Construction Report for Waste Area Grouping 11 at Oak Ridge National Laboratory, Oak Ridge, Tennessee, DOE/OR/01-1263\&D2, U. S. Department of Energy, Environmental Restoration Division, Oak Ridge, TN.

DOE 1995a. Record of Decision for Kerr Hollow Quarry at the Oak Ridge Y-12 Plant, Oak Ridge, Tennessee, DOE/OR/02-1398\&D2, U.S. Department of Energy, Office of Environmental Restoration and Waste Management, Oak Ridge, TN.

DOE 1995b. Record of Decision for Oak Ridge Associated Universities, South Campus Facility, Oak Ridge, Tennessee, DOE/OR/02-1383\&D3, U.S. Department of Energy, Environmental Restoration Division, Oak Ridge, TN. 
DOE 1995c. Record of Decision for the Lower Watts Bar Reservoir Operable Unit, Oak Ridge Reservation, Oak Ridge, Tennessee, DOE/OR/02-1373\&D3, U. S. Department of Energy, Office of Environmental Restoration and Waste Management, Oak Ridge, TN.

DOE 1995d. Record of Decision for Lower East Fork Poplar Creek, Oak Ridge, Tennessee, DOE/OR/021370\&D2, U. S. Department of Energy, Environmental Restoration Division, Oak Ridge, TN.

DOE 1995e. Remedial Action Report for the K-1407-B Holding Pond and the K-1407-C Retention Basin, Oak Ridge, Tennessee, DOE/OR/01-1371\&D1, U.S. Department of Energy, Office of Environmental Management, Oak Ridge, TN.

DOE 1996a. Record of Decision for the Bear Creek Operable Unit 2 (Spoil Area 1 and SY-200 Yard) at the Oak Ridge Y-12 Plant, Oak Ridge, Tennessee, DOE/OR/02-1435\&D2, U. S. Department of Energy, Environmental Restoration and Waste Management Division, Oak Ridge, TN.

DOE 1996b. Record of Decision for Chestnut Ridge Operable Unit 2 (Filled Coal Ash Pond and Vicinity), Oak Ridge, Tennessee, DOE/OR/02-1410\&D3, U.S. Department of Energy, Environmental Restoration Division, Oak Ridge, TN.

DOE 1996c. Remedial Action Work Plan for Lower Watts Bar Reservoir in Tennessee, DOE/OR/02$1376 \& D 3$, U.S. Department of Energy, Office of Environmental Restoration and Waste Management, Oak Ridge, TN.

DOE 1997a. Remedial Action Report on Chestnut Ridge Operable Unit 2 (Filled Coal Ash Pond and Vicinity) at the Oak Ridge Y-12 Plant, OakRidge, Tennessee, DOE/OR/01-1596\&D1, U. S. Department of Energy, Office of Environmental Management, Oak Ridge, TN.

DOE 1997b. Record of Decision for the Clinch River/Poplar Creek Operable Unit, Oak Ridge, Tennessee, DOE/OR/02-1547\&D3, U.S. Department of Energy, Office of Environmental Management, Oak Ridge, TN.

DOE 1997c. Record of Decision for an Interim Action for Union Valley, Upper East Fork Poplar Creek Characterization Area, Oak Ridge, Tennessee, DOE/OR/02-1545\&D2, U. S. Department of Energy, Office of Environmental Management, Oak Ridge, TN.

DOE 1997d. Action Memorandum for the K-901-A Holding Pond and the K-1007-P1 Pond Removal Action, East Tennessee Technology Park, Oak Ridge, Tennessee, DOE/OR/02-1550\&D2, U. S. Department of Energy, Office of Environmental Management, Oak Ridge, TN.

DOE 1998a. Report on the Remedial Investigation of the Upper East Fork Poplar Creek Characterization Area at the Oak Ridge Y-12 Plant, Oak Ridge, Tennessee, DOE/OR/01-1641/V1-V4\&D2, U. S. Department of Energy, Office of Environmental Management, Oak Ridge, TN.

DOE 1999a. Action Memorandum Addendum for the Waste Area Grouping 1 Corehole 8 Removal Action at Oak Ridge National Laboratory, Oak Ridge, Tennessee, DOE/OR/01-1831\&D2, U. S. Department of Energy, Office of Environmental Management, Oak Ridge, TN.

DOE 1999b. Action Memorandum for the Oak Ridge Y-12 Plant East End Volatile Organic Compound Plume, Oak Ridge, Tennessee, DOE/OR/01-1819\&D2, U. S. Department of Energy, Office of Environmental Management, Oak Ridge, TN. 
DOE 1999c. Remedial Action Report for Clinch River/Poplar Creek in East Tennessee, DOE/OR/021627\&D3, U. S. Department of Energy, Office of Environmental Management, Oak Ridge, TN.

DOE 1999d. Combined Monitoring Plan for the Lower Watts Bar Reservoir and Clinch River Poplar Creek Operable Units at the Oak Ridge Reservation, Oak Ridge, Tennessee, DOE/OR/01-1820\&D1, U. S. Department of Energy, Office of Environmental Management, Oak Ridge, TN.

DOE 1999e. Removal Action Report for the K-901-A Holding Pond and K-1007-P-1 Pond Removal Action at the East Tennessee Technology Park, Oak Ridge, Tennessee, DOE/OR/01-1767\&D2, U. S. Department of Energy, Office of Environmental Management, Oak Ridge, TN.

DOE 2000a. Record of Decision for Interim Actions for the Melton Valley Watershed, Oak Ridge National Laboratory, Oak Ridge, Tennessee, DOE/OR/01-1826\&D3, U.S. Department of Energy, Office of Environmental Management, Oak Ridge, TN.

DOE 2000b. Record of Decision for the Phase I Activities in Bear Creek Valley at the Oak Ridge Y-12 Plant, Oak Ridge, Tennessee, DOE/OR/01-1750\&D4, U. S. Department of Energy, Office of Environmental Management, Oak Ridge, TN.

DOE 2000c. Remedial Action Report on the Lower East Fork Poplar Creek Project, Oak Ridge, Tennessee, DOE/OR/01-1680\&D5, U.S. Department of Energy, Office of Environmental Management, Oak Ridge, TN.

DOE 2000d. Record of Decision for the K-1070-A Burial Ground, East Tennessee Technology Park, Oak Ridge, Tennessee, DOE/OR/01-1734\&D3, U. S. Department of Energy, Office of Environmental Management, Oak Ridge, TN.

DOE 2000e. 2000 Remediation Effectiveness Report for the U.S. Department of Energy Oak Ridge Reservation, Oak Ridge, Tennessee, DOE/OR/01-1858\&D2, U. S. Department of Energy, Office of Environmental Management, Oak Ridge, TN.

DOE 2001a. Removal Action Report for Uranium Deposit Removal at the Molten Salt Reactor Experiment at Oak Ridge National Laboratory, Oak Ridge, Tennessee, DOE/OR/01-1918\&D2, U. S. Department of Energy, Office of Environmental Management, Oak Ridge, TN.

DOE 2001b. Removal Action Report on the Bear Creek Valley S-3 Ponds Pathways 1 and 2 at the Y-12 National Security Complex, Oak Ridge, Tennessee, DOE/OR/01-1945\&D2, U. S. Department of Energy, Office of Environmental Management, Oak Ridge, TN.

DOE 2002a. Record of Decision for Interim Actions in Bethel Valley Watershed, Oak Ridge, Tennessee, DOE/OR/01-1862\&D4, U.S. Department of Energy, Office of Environmental Management, Oak Ridge, TN.

DOE 2002b. Removal Action Report on the Gunite and Associated Tanks Stabilization Project at the Oak Ridge National Laboratory, Oak Ridge, Tennessee, DOE/OR/01-2010\&D1, U. S. Department of Energy, Office of Environmental Management, Oak Ridge, TN.

DOE 2002c. Record of Decision for Interim Actions in Zone 1, East Tennessee Technology Park, Oak Ridge, Tennessee, DOE/OR/01-1997\&D2, U.S. Department of Energy, Office of Environmental Management, Oak Ridge, TN. 
DOE 2002d. Record of Decision for Phase I Interim Source Control Actions in the Upper East Fork Poplar Creek Characterization Area, OakRidge, Tennessee, DOE/OR/01-1951\&D3, U.S. Department of Energy, Office of Environmental Management, Oak Ridge, TN.

DOE 2003a. Department of Energy Oak Ridge Operations Environmental Management Program LongTerm Stewardship Program, Office of Environmental Management, U.S. Department of Energy, Oak Ridge, TN.

DOE 2003b. Remedial Action Report on the Surface Impoundments Operable Unit at the Oak Ridge National Laboratory, Oak Ridge, Tennessee, DOE/OR/01-2086\&D1, U. S. Department of Energy, Office of Environmental Management, Oak Ridge, TN.

DOE 2003c. Removal Action Report for the Metal Recovery Facility, Building 3505, at the Oak Ridge National Laboratory, Oak Ridge, Tennessee, DOE/OR/01-2000\&D2/R1, U. S. Department of Energy, Office of Environmental Management, Oak Ridge, TN.

DOE 2003d. Phased Construction Completion Report for the Bear Creek Valley Boneyard/Burnyard Remediation Project at the Y-12 National Security Complex, Oak Ridge, Tennessee, DOE/OR/012077\&D2, U. S. Department of Energy, Office of Environmental Management, Oak Ridge, TN.

DOE 2003e. 2003 Remediation Effectiveness Report for the U.S. Department of Energy, Oak Ridge Reservation, Oak Ridge, Tennessee, DOE/OR/01-2058\&D2, U. S. Department of Energy, Office of Environmental Management, Oak Ridge, TN.

DOE 2003f. Remedial Action Report for the K-1070-A Burial Ground at the East Tennessee Technology Park, Oak Ridge, Tennessee, DOE/OR/01-2090\&D1, U. S. Department of Energy, Office of Environmental Management, Oak Ridge, TN.

DOE 2004a. Combined Monitoring Plan for the Lower Watts Bar Reservoir and Clinch River Poplar Creek Operable Units at the Oak Ridge Reservation, Oak Ridge, Tennessee, DOE/OR/01-1820\&D3, U. S. Department of Energy, Office of Environmental Management, Oak Ridge, TN.

DOE 2004b. Explanation of Significant Differences for the Record of Decision for the Disposal of Oak Ridge Reservation Comprehensive Environmental Response, Compensation, and Liability Act of 1980 Waste, Oak Ridge, Tennessee, DOE/OR/01-2194\&D2, U.S. Department of Energy, Office of Environmental Management, Oak Ridge, TN.

DOE 2005a. Addendum to the Remedial Design Report/Remedial Action Work Plan for the Solid Waste Storage Area 4 Burial Grounds and Intermediate Holding Pond Remediation Project, Oak Ridge National Laboratory, Oak Ridge, Tennessee, DOE/OR/01-1915\&D2/A2/R1, U. S. Department of Energy, Office of Environmental Management, Oak Ridge, TN.

DOE 2005b. Engineering Study Report for Groundwater Actions in Bethel Valley, Oak Ridge Tennessee, DOE/OR/01-2219\&D2, U.S. Department of Energy, Office of Environmental Management, Oak Ridge, TN.

DOE 2005c. Phased Construction Completion Report for the Remediation of Tanks T-1, T-2, and HFIR at the Oak Ridge National Laboratory, Oak Ridge, Tennessee, DOE/OR/01-2238\&D1, U. S. Department of Energy, Office of Environmental Management, Oak Ridge, TN. 
DOE 2005d. Record of Decision for Soil, Buried Waste, and Subsurface Structure Actions in Zone 2, East Tennessee Technology Park, Oak Ridge, Tennessee, DOE/OR/01-2161\&D2, U. S. Department of Energy, Office of Environmental Management, Oak Ridge, TN.

DOE 2006a. 2006 Remediation Effectiveness Report/Second Reservation-wide CERCLA Five Year Review for the U.S. Department of Energy Oak Ridge Reservation, Oak Ridge, Tennessee, DOE/OR/01-2289\&D2, U.S. Department of Energy, Office of Environmental Management, Oak Ridge, TN.

DOE 2006b. Land Use Control Implementation Plan for the Melton Valley Watershed at the Oak Ridge National Laboratory, Oak Ridge, Tennessee, DOE/OR/01-1977\&D6, U. S. Department of Energy, Office of Environmental Management, Oak Ridge, TN.

DOE 2006c. Removal Action Report for the Oak Ridge Y-12 Plant East End Volatile Organic Compound Plume, Oak Ridge, Tennessee, DOE/OR/01-2297\&D1, U. S. Department of Energy, Office of Environmental Management, Oak Ridge, TN.

DOE 2006d. Fiscal Year 2006 Phased Construction Completion Report for the Zone 2 Soils, Slabs, and Subsurface Structures at East Tennessee Technology Park, Oak Ridge, Tennessee, DOE/OR/012317\&D1, U. S. Department of Energy, Office of Environmental Management, Oak Ridge, TN.

DOE 2006e. Phased Construction Completion Report for the Duct Island Area and K-901 Area in Zone 1 East Tennessee Technology Park, Oak Ridge, Tennessee, DOE/OR/01-2261\&D2, U. S. Department of Energy, Office of Environmental Management, Oak Ridge, TN.

DOE 2006f. Phased Construction Completion Report for the K-1007 Ponds Area and Powerhouse North Area in Zone 1 at East Tennessee Technology Park, Oak Ridge, Tennessee, DOE/OR/01-2294\&D2, U. S. Department of Energy, Office of Environmental Management, Oak Ridge, TN.

DOE 2007a. 2007 Remediation Effectiveness Report for the U.S. Department of Energy Oak Ridge Reservation, Oak Ridge, Tennessee, DOE/OR/01-2337\&D2/V1\&V2, U. S. Department of Energy, Office of Environmental Management, Oak Ridge, TN.

DOE 2007b. 2006 Remediation Effectiveness Report/Second Reservation-wide CERCLA Five Year Review for the U.S. Department of Energy Oak Ridge Reservation, Oak Ridge, Tennessee, DOE/OR/01-2289\&D3, U.S. Department of Energy, Office of Environmental Management, Oak Ridge, TN.

DOE 2007c. Addendum to the Removal Action Report for the Bear Creek Valley Interception Trenches for the S-3 Uranium Plume, Pathway 1 and 2 at the Oak Ridge Y-12 Plant, Oak Ridge, Tennessee, DOE/OR/01-1836\&D1/A1, U. S. Department of Energy, Office of Environmental Management, Oak Ridge, TN.

DOE 2007d. Phased Construction Completion Report for the K-770 Scrap Removal Project of the Zone 1 Remediation at the East Tennessee Technology Park, Oak Ridge, Tennessee, DOE/OR/01-2348\&D1, U. S. Department of Energy, Office of Environmental Management, Oak Ridge, TN.

DOE 2007e. Fiscal Year 2007 Phased Construction Completion Report for the Zone 2 Soils, Slabs, and Subsurface Structures at East Tennessee Technology Park, Oak Ridge, Tennessee, DOE/OR/012723\&D1, U. S. Department of Energy, Office of Environmental Management, Oak Ridge, TN. 
DOE 2007f. Action Memorandum for the Ponds at the East Tennessee Technology Park, Oak Ridge, Tennessee: K-1007-P Holding Ponds, K-901-A Holding Pond, K-720 Slough, and K-770 Embayment, Oak Ridge, Tennessee, DOE/OR/01-2314\&D2, U. S. Department of Energy, Office of Environmental Management, Oak Ridge, TN.

DOE 2007g. Remedial Action Report for the Melton Valley Watershed at the Oak Ridge National Laboratory, Oak Ridge, Tennessee, DOE/OR/01-2343\&D1, U.S. Department of Energy, Office of Environmental Management, Oak Ridge, TN.

DOE 2007h. Melton Valley Surveillance and Maintenance Plan, Oak Ridge, Tennessee, DOE/OR/012342\&D1, U.S. Department of Energy, Office of Environmental Management, Oak Ridge, TN.

DOE 2007i. Fiscal Year 2007 Phased Construction Completion Report for the Low Risk/Low Complexity Facilities of the Remaining Facilities Demolition Project at the East Tennessee Technology Park, Oak Ridge, Tennessee, DOE/OR/01-2362\&D1, U.S. Department of Energy, Office of Environmental Management, Oak Ridge, TN.

DOE 2007j. Remedial Action Work Plan for Dynamic Verification Strategy for Zone 1 East Tennessee Technology Park, Oak Ridge, Tennessee, DOE/OR/01-2182\&D4, U.S. Department of Energy, Office of Environmental Management, Oak Ridge, TN.

DOE 2007k. Action Memorandum for Reduction of Hexavalent Chromium Releases Into Mitchell Branch at the East Tennessee Technology Park, Oak Ridge, Tennessee, DOE/OR/01-2369\&D1, U. S. Department of Energy, Office of Environmental Management, Oak Ridge, TN.

DOE 2008a. 2008 Remediation Effectiveness Report for the U.S. Department of Energy Oak Ridge Reservation, Oak Ridge, Tennessee, DOE/OR/01-2366\&D2/V2, U. S. Department of Energy, Office of Environmental Management, Oak Ridge, TN.

DOE 2008b. FY 2008 Phased Construction Completion Report for Exposure Units Z1-01, Z1-03, Z1-38, and Z1-49 in Zone 1 at the East Tennessee Technology Park, Oak Ridge, Tennessee, DOE/OR/012367\&D2, U. S. Department of Energy, Office of Environmental Management, Oak Ridge, TN.

DOE 2008c. Fiscal Year 2008 Phased Construction Completion Report for EU Z2-33 in Zone 2, East Tennessee Technology Park, Oak Ridge, Tennessee, DOE/OR-2368\&D1, U. S. Department of Energy, Office of Environmental Management, Oak Ridge, TN.

DOE 2008d. Phase I Treatability Study Work Plan for Sitewide Groundwater at the East Tennessee Technology Park, Oak Ridge, Tennessee, DOE/OR/01-2387\&D1, U. S. Department of Energy, Office of Environmental Management, Oak Ridge, TN.

DOE 2008e. Removal Action Report for the Reduction of Hexavalent Chromium Releases into Mitchell Branch at the East Tennessee Technology Park, Oak Ridge, Tennessee, DOE/OR/01-2384\&D1, U. S. Department of Energy, Office of Environmental Management, Oak Ridge, TN.

DOE 2008f. FY 2008 Phased Construction Completion Report for the Predominantly Uncontaminated Facilities of the Remaining Facilities Demolition Project at the East Tennessee Technology Park, Oak Ridge, Tennessee, DOE/OR/01-2395\&D1, U. S. Department of Energy, Office of Environmental Management, Oak Ridge, TN. 
DOE 2008g. Fiscal Year 2008 Phased Construction Completion Report for the Low Risk/Low Complexity Facilities of the Remaining Facilities Demolition Project at the East Tennessee Technology Park, Oak Ridge, Tennessee, DOE/OR/01-2394\&D1, U. S. Department of Energy, Office of Environmental Management, Oak Ridge, TN.

DOE 2008h. Phased Construction Completion Report for the Removal and Transfer of the Uranium from the Molten Salt Reactor Experiment Facility at the Oak Ridge National Laboratory, Oak Ridge, Tennessee, DOE/OR/01-2256\&D1, U.S. Department of Energy, Office of Environmental Management, Oak Ridge, TN.

DOE 2008i. Remedial Design Report/Remedial Action Work Plan for Scrap Metal at the Y-12 Old Salvage Yard at the Y-12 National Security Complex, Oak Ridge, Tennessee, DOE/OR/01-2376\&D2, Department of Energy, Office of Environmental Management, Oak Ridge, TN.

DOE 2009a. Remedial Design Report/Remedial Action Work Plan for Soils, Sediments and Dynamic Characterization Strategy for Bethel Valley, Oak Ridge, Tennessee, DOE/OR/01-2378\&D3, U. S. Department of Energy, Office of Environmental Management, Oak Ridge, TN.

DOE 2009b. Addendum to the Remedial Design Report/Remedial Action Work Plan for the Decontamination and Decommissioning of Non-Reactor Facilities in Bethel Valley at the Oak Ridge National Laboratory, Oak Ridge, Tennessee, DOE/OR/01-2428\&D1/A1, U. S. Department of Energy, Office of Environmental Management, Oak Ridge, TN.

DOE 2009c. Time-Critical Removal Action Memorandum for the Facility 3026 C\&D Wooden Superstructure at the Oak Ridge National Laboratory, Oak Ridge, Tennessee, DOE/OR/012402\&D2, U. S. Department of Energy, Office of Environmental Management, Oak Ridge, TN.

DOE 2009d. Time-Critical Removal Action Memorandum for the 2000 Complex Facilities Demolition at the Oak Ridge National Laboratory, Oak Ridge, Tennessee, DOE/OR/01-2412\&D1, U. S. Department of Energy, Office of Environmental Management, Oak Ridge, TN.

DOE 2009e. Time-Critical Removal Action Memorandum for Buildings 3074 and 3136, and the 3020 Stack at the Oak Ridge National Laboratory, Oak Ridge, Tennessee, DOE/OR/01-2407\&D1, U. S. Department of Energy, Office of Environmental Management, Oak Ridge, TN.

DOE 2009f. Fiscal Year 2009 Phased Construction Completion Report for EU Z2-36 in Zone 2, East Tennessee Technology Park, Oak Ridge, Tennessee, DOE/OR/01-2399\&D1, U.S. Department of Energy, Office of Environmental Management, Oak Ridge, TN.

DOE 2009g. Fiscal Year 2009 Phased Construction Completion Report for Zone 2 Exposure Units 11, 12, 17, 18, 29, and 38 at East Tennessee Technology Park, Oak Ridge, Tennessee, DOE/OR/012415\&D1, U.S. Department of Energy, Office of Environmental Management, Oak Ridge, TN.

DOE 2009h. FY 2009 Phased Construction Completion Report for the Predominantly Uncontaminated Facilities, DOE/OR/01-2434\&D1, U.S. Department of Energy, Office of Environmental Management, Oak Ridge, TN.

DOE 2009i. FY 2009 Phased Construction Completion Report for Low Risk/Low Complexity Facilities, DOE/OR/01-2435\&D1, U.S. Department of Energy, Office of Environmental Management, Oak Ridge, TN. 
DOE 2009j. Engineering Study Report for the West End Mercury Area (WEMA) Storm Sewer Remediation Project at the Y-12 National Security Complex, Oak Ridge, Tennessee, DOE/OR/012429\&D1, U.S. Department of Energy, Office of Environmental Management, Oak Ridge, TN.

DOE 2009k. Characterization Plan for the 81-10 Area in the Upper East Fork Poplar Creek Area at the Oak Ridge Y-12 National Security Complex, DOE/OR/01-2419\&D1, U.S. Department of Energy, Office of Environmental Management, Oak Ridge, TN.

DOE 20091. Waste Handling Plan, Part 1 for Scrap Metal at the Y-12 Old Salvage Yard at the Y-12 National Security Complex, Oak Ridge, Tennessee, DOE/OR/01-2385\&D2, U.S. Department of Energy, Office of Environmental Management, Oak Ridge, TN.

DOE 2009m. Upper East Fork Poplar Creek Soils Remedial Action Work Plan, DOE/OR/01-2423\&D1, U.S. Department of Energy, Office of Environmental Management, Oak Ridge, TN.

DOE 2009n. ETTP Ponds Post-Action Sampling and Analysis Plan, East Tennessee Technology Park, Oak Ridge, Tennessee, DOE/OR/01-2389\&D1, U.S. Department of Energy, Office of Environmental Management, Oak Ridge, TN.

DOE 2009o. Remedial Action Report for the Melton Valley Watershed at the Oak Ridge National Laboratory, Oak Ridge, Tennessee, DOE/OR/01-2343\&D1/A1, U.S. Department of Energy, Office of Environmental Management, Oak Ridge, TN.

DOE 2009p. Remedial Action Report for the Melton Valley Watershed at the Oak Ridge National Laboratory, Oak Ridge, Tennessee, DOE/OR/01-2343\&D1/A2, U.S. Department of Energy, Office of Environmental Management, Oak Ridge, TN.

DOE 2009q. Phased Construction Completion Report for Poplar Creek High-Risk Facilities K-1231, K-1233, and K-413 at the East Tennessee Technology Park, Oak Ridge, Tennessee, DOE/OR/012244\&D1, U.S. Department of Energy, Office of Environmental Management, Oak Ridge, TN.

DOE, EPA, and TDEC 1999. Memorandum of Understanding for Implementation of a Land Use Control Assurance Plan (LUCAP) for the United States Department of Energy Oak Ridge Reservation. Attachment: Land Use Control Assurance Plan for the Oak Ridge Reservation, Oak Ridge, TN.

Peterson, M. J., N. R. Giffen, M. G. Ryon, L. R. Pounds, and E. L. Ryan, Jr., 2005. Environmental Survey Report for the ETTP: Environmental Management Waste Management Facility (EMWMF) Haul Road Corridor, Oak Ridge, Tennessee, ORNL/TM-2005/215, Oak Ridge National Laboratory, Oak Ridge, TN.

Peterson, M. J., J. G. Smith, M. G. Ryon, W. K. Roy, and J. A. Darby, 2009. Stream Mitigation Monitoring of North Tributary 3 (NT-3), Bear Creek Valley, Oak Ridge, Tennessee. ORNL/TM2009/053.

Platts, W. S., W. F. Megahan, and G. W. Minshall, 1983. Methods for evaluating stream, riparian, and biotic conditions. U.S. Forest Service General Technical Report INT-138. Intermountain Forest and Range Experimental Station, Ogden, Utah. 60 pp.

Southworth, George, Mark Greeley, Mark Peterson, Kenneth Lowe, and Richard Ketelle, 2010. Sources of Mercury to East Fork Poplar Creek Downstream from the Y-12 National Security Complex: Inventories and Export Rates, ORNL/TM (number to be determined), Oak Ridge, TN. 
TDEC 1996. Post-Closure Permit for the Chestnut Ridge Hydrogeologic Regime, TNHW-088, Oak Ridge Y-12 Plant, Oak Ridge, Tennessee EPA I.D. No. TN 3890090001 , June 1996, Tennessee Department of Environment and Conservation-Division of Solid Waste Management.

TDEC 2004a. Revised Rules of Tennessee Department of Environment and Conservation, Tennessee Water Pollution Control Board, Division of Water Pollution Control, Chap. 1200-4-3, "General Water Quality Criteria," Nashville, TN, January (revised).

TDEC 2006. RCRA Post-Closure Permit for Chestnut Ridge Hydrogeologic Regime, TNHW-128, Y-12 National Security Complex, Oak Ridge, Tennessee, EPA I.D. No. TN3 89009 0001, September 2006, Tennessee Department of Environment and Conservation-Division of Solid Waste Management, Nashville, TN.

TVA 1985. Instream Contaminant Study, Task 3: Sediment Transport. Report to the U.S. Department of Energy, Oak Ridge Operations Office. Office of Natural Resources and Economic Development, Tennessee Valley Authority, Knoxville, TN. 


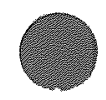

.

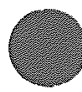




\title{
11. BIBLIOGRAPHY
}

\subsection{BETHEL VALLEY WATERSHED DOCUMENTS}

\author{
Watershed-scale actions
}

\section{BV Interim Actions}

DOE 2002. Record of Decision for Interim Actions in Bethel Valley Watershed, Oak Ridge, Tennessee, DOE/OR/01-1862\&D4, U.S. Department of Energy, Office of Environmental Management, Oak Ridge, TN.

Adler, D. G., July 12, 2004, DOE-ORO, letter to Ms. Mary McKee, Bechtel Jacobs Company, Subject: Bethel Valley Administrative Record, Reference: Letter from Steve J. Smith, DE-AC05980R22700: Transmittal of the D1 Version of the Notification of Non-Significant Change to the Record of Decision for Interim Actions in Bethel Valley: Addition of Hot Storage Garden (3597) (DOE/OR/01-2152\&D1) dated June 28, 2004.

Adler, D. G., December 3, 2004, DOE-ORO, letter to J. Crane, Region IV, and D. McCoy, TDEC DOE Oversight Div., Subject: Notice of Non-Significant Change to the Record of Decision for Interim Actions in Bethel Valley, Oak Ridge, Tennessee (DOE/OR/01-1862\&D4).

Kopotic, J. and Adler, D. G., September 10, 2009, DOE-ORO, letter to J. Crane, Region IV, and R. Petric, TDEC DOE Oversight Div., Subject: Notice of Non-Significant Change to the Record of Decision for Interim Actions in Bethel Valley, Oak Ridge, Tennessee (DOE/OR/01-1862\&D4).

Kopotic, J. and Adler, D. G., October 26, 2009, DOE-ORO, letter to J. Crane, Region IV, and R. Petric, TDEC DOE Oversight Div., Subject: Notice of Non-Significant Change Errata Pages to the Record of Decision for Interim Actions in Bethel Valley, Oak Ridge, Tennessee (DOE/OR/011862\&D4).

DOE 2005. Phased Construction Completion Report for the Remediation of Tanks T-1, T-2, and HFIR at Oak Ridge National Laboratory, Oak Ridge, Tennessee, DOE/OR/01-2238\&D1, U.S. Department of Energy, Office of Environmental Management, Oak Ridge, TN.

DOE 2009. Remedial Design Report/Remedial Action Work Plan for Soils, Sediments and Dynamic Characterization Strategy for Bethel Valley, Oak Ridge, Tennessee, DOE/OR/01-2378\&D4, U. S. Department of Energy, Office of Environmental Management, Oak Ridge, TN.

\section{Single-project actions}

\section{WAG 1 Corehole 8 Plume Removal Action (Plume Collection)}

DOE 1994. Action Memorandum for the Waste Area Grouping 1 Corehole 8 Removal Action at Oak Ridge National Laboratory, Oak Ridge, Tennessee, DOE/OR/02-1317\&D2, U. S. Department of Energy, Environmental Restoration Division, Oak Ridge, TN.

DOE 1999. Action Memorandum Addendum for the Waste Area Grouping 1 Corehole 8 Removal Action at Oak Ridge National Laboratory, Oak Ridge, Tennessee, DOE/OR/01-1831\&D2, U. S. Department of Energy, Office of Environmental Management, Oak Ridge, TN. 
DOE 1999. Phase I Operations Letter Report for Construction of a Groundwater Pre-Treatment System and Groundwater Extraction at Well 4411 (DOE/OR/01-1832\&D1, U. S. Department of Energy, Environmental Restoration Division, Oak Ridge, TN.

DOE 1995. Remedial Action Report for the Corehole 8 Removal Action at Oak Ridge National Laboratory, Oak Ridge, Tennessee, DOE/OR/01-1380\&D1, U. S. Department of Energy, Environmental Restoration Division, Oak Ridge, TN.

DOE 2000. Phase II Operations Report for Groundwater Extraction at Well 4411, Oak Ridge National Laboratory, Oak Ridge, Tennessee, DOE/OR/01-1882\&D1, U. S. Department of Energy, Office of Environmental Management, Oak Ridge, TN.

\section{Building 3001 Canal Removal Action}

DOE 1996. Action Memorandum for Building 3001 Canal, Oak Ridge National Laboratory, Oak Ridge, Tennessee, DOE/OR/02-1533\&D2, U.S. Department of Energy, Office of Environmental Restoration and Waste Management, Oak Ridge, TN.

DOE 1997. Removal Action Report on the Building 3001 Canal at Oak Ridge National Laboratory, Oak Ridge, Tennessee, DOE/OR/01-1599\&D2, U. S. Department of Energy, Office of Environmental Management, Oak Ridge, TN.

\section{SIOU RA}

DOE 1997. Record of Decision for the Surface Impoundments Operable Unit, Oak Ridge National Laboratory, Oak Ridge, Tennessee, DOE/OR/02-1630\&D2, U. S. Department of Energy, Office of Environmental Management, Oak Ridge, TN.

DOE 1999. Remedial Action Report on the Surface Impoundments Operable Unit C (3539) and D (3540) at the Oak Ridge National Laboratory, Oak Ridge, Tennessee, DOE/OR/01-1784\&D2, U. S. Department of Energy, Office of Environmental Management, Oak Ridge, TN.

DOE 2003. Remedial Action Report on the Surface Impoundments Operable Unit at the Oak Ridge National Laboratory, Oak Ridge, Tennessee, DOE/OR/01-2086\&D2, U. S. Department of Energy, Office of Environmental Management, Oak Ridge, TN.

\section{MRF RA}

DOE 2000. Action Memorandum for the Demolition of the Metal Recovery Facility, Building 3505 at the Oak Ridge National Laboratory, Oak Ridge, Tennessee, DOE/OR/01-1843\&D2, U. S. Department of Energy, Office of Environmental Management, Oak Ridge, TN.

DOE 2003. Removal Action Report for the Metal Recovery Facility, Building 3505, at the Oak Ridge National Laboratory, Oak Ridge, Tennessee, DOE/OR/01-2000\&D2/R1, U. S. Department of Energy, Office of Environmental Management, Oak Ridge, TN.

\section{WAG 1 Tank WC-14 Time-Critical Removal Action (Liquid removal)}

DOE 1995. Action Memorandum for the Waste Area Grouping 1 Tank WC-14 Removal at Oak Ridge National Laboratory, Oak Ridge, Tennessee, DOE/OR/02-1322\&D2, U. S. Department of Energy, Environmental Restoration Division, Oak Ridge, TN. 
DOE 1995. Remedial Action Report for the Waste Area Grouping 1 Tank WC-14 Removal Action at Oak Ridge National Laboratory, Oak Ridge, Tennessee, DOE/OR/01-1397\&D1, U. S. Department of Energy, Environmental Restoration Division, Oak Ridge, TN.

\section{WAG 1 Tank WC-14 Time-Critical Removal Action (Sludge removal)}

DOE 1997. Time-Critical Removal Action Memorandum for the Waste Area Grouping 1 Tank WC-14 at the Oak Ridge National Laboratory, DOE/OR/02-1598\&D2, U. S. Department of Energy, Office of Environmental Management, Oak Ridge, TN.

DOE 1998. Removal Action Report on Tank WC-14 at Waste Area Grouping 1, Oak Ridge National Laboratory, Oak Ridge, Tennessee, DOE/OR/01-1738\&D2, U. S. Department of Energy, Office of Environmental Management, Oak Ridge, TN.

\section{Waste Evaporator Facility Removal Action}

DOE 1995. Action Memorandum for the Building 3506 Waste Evaporator Facility Removal Action at Oak Ridge National Laboratory, Oak Ridge, Tennessee, DOE/OR/02-1381\&D2, U. S. Department of Energy, Environmental Restoration Division, Oak Ridge, TN.

DOE 1996. Removal Action Report on the Waste Evaporator Facility, Building 3506 at Oak Ridge National Laboratory, Oak Ridge, Tennessee, DOE/OR/01-1460\&D1, U. S. Department of Energy, Environmental Restoration Division, Oak Ridge, TN.

\section{GAAT OU Interim Removal Action}

DOE 1997. Record of Decision for Interim Action: Sludge Removal from the Gunite and Associated Tanks Operable Unit, Waste Area Grouping 1, Oak Ridge National Laboratory, Oak Ridge, Tennessee, DOE/OR/02-1591\&D3, U.S. Department of Energy, Office of Environmental Management, Oak Ridge, TN.

DOE 2001. Remedial Action Report on the Gunite and Associated Tanks Interim Remedial Action Project at the Oak Ridge National Laboratory, Oak Ridge, Tennessee, DOE/OR/01-1955\&D1, U. S. Department of Energy, Office of Environmental Management, Oak Ridge, TN.

\section{Inactive LLLW Tanks Removal Action}

DOE 1994. Action Memorandum for the Bethel Valley Main Plant Inactive Liquid Low-Level Radioactive Waste Tanks at the Oak Ridge National Laboratory, Oak Ridge, Tennessee, DOE/OR/01-1813\&D1, U. S. Department of Energy, Office of Environmental Management, Oak Ridge, TN.

DOE 1999. Action Memorandum Addendum for the Bethel Valley Main Plant Inactive Liquid Low-Level Radioactive Waste Tanks, Oak Ridge National Laboratory, Oak Ridge, Tennessee, DOE/OR/01-1833\&D2, U.S. Department of Energy, Office of Environmental Management, Oak Ridge, TN.

DOE 2001. Removal Action Report for the Bethel Valley Main Plant Inactive Liquid Low-Level Radioactive Waste Tanks at Oak Ridge National Laboratory, Oak Ridge, Tennessee, DOE/OR/011953\&D2, U. S. Department of Energy, Office of Environmental Management, Oak Ridge, TN. 


\section{GAAT Stabilization Removal Action (Shells/Risers)}

DOE 2001. Action Memorandum to Stabilize Gunite and Associated Tanks at the Oak Ridge National Laboratory, Oak Ridge, Tennessee, DOE/OR/01-1957\&D2, U. S. Department of Energy, Office of Environmental Management, Oak Ridge, TN.

DOE 2002. Removal Action Report on the Gunite and Associated Tanks Stabilization Project at the Oak Ridge National Laboratory, Oak Ridge, Tennessee, DOE/OR/01-2010\&D1, U. S. Department of Energy, Office of Environmental Management, Oak Ridge, TN.

\section{Single-project action; pending additional action}

\section{Corehole 8 Plume Source (Tank W-1A) Removal Action}

DOE 1998. Action Memorandum for the Corehole 8 Plume Source (Tank W-1A) Removal Action at the Oak Ridge National Laboratory, Oak Ridge, Tennessee, DOE/OR/01-1749\&D1, U. S. Department of Energy, Office of Environmental Management, Oak Ridge, TN.

DOE 2001. Removal Action Report for the Corehole 8 Plume Source (Tank W-1A) at Oak Ridge National Laboratory, Oak Ridge, Tennessee, DOE/OR/01-1969\&D1, U. S. Department of Energy, Office of Environmental Management, Oak Ridge, TN.

\section{ORNL decontamination and demolition projects}

\section{Non-Reactor Facilities D\&D}

DOE 2009. Time-Critical Removal Action Memorandum for the 2000 Complex Facilities Demolition at the Oak Ridge National Laboratory, Oak Ridge, Tennessee, DOE/OR/01-2412\&D1, U. S. Department of Energy, Office of Environmental Management, Oak Ridge, TN.

DOE 2009. Time-Critical Removal Action Memorandum for Buildings 3074 and 3136, and the 3020 Stack at the Oak Ridge National Laboratory, Oak Ridge, Tennessee, DOE/OR/01-2407\&D1, U. S. Department of Energy, Office of Environmental Management, Oak Ridge, TN.

\section{BV Isotopes Facilities D\&D}

DOE 2009. Time-Critical Removal Action Memorandum for the Facility 3026 C\&D Wooden Superstructure at the Oak Ridge National Laboratory, Oak Ridge, Tennessee, DOE/OR/012402\&D2, U. S. Department of Energy, Office of Environmental Management, Oak Ridge, TN. 


\subsection{MELTON VALLEY WATERSHED DOCUMENTS}

\section{Interim Actions}

DOE 2000. Record of Decision for Interim Actions for the Melton Valley Watershed at the Oak Ridge National Laboratory, Oak Ridge, Tennessee, DOE/OR/01-1826\&D3, U. S. Department of Energy, Office of Environmental Management, Oak Ridge, TN.

DOE 2004. Amendment to the Record of Decision for Interim Actions for the Melton Valley Watershed at Oak Ridge National Laboratory, Oak Ridge, Tennessee: Revised Remedial Action for Seepage Trenches 5 and 7, DOE/OR/01-2170\&D1, U. S. Department of Energy, Office of Environmental Management, Oak Ridge, TN.

DOE 2003. Explanation of Significant Differences for the Record of Decision for Interim Actions for the Melton Valley Watershed at Oak Ridge National Laboratory, Oak Ridge, Tennessee, DOE/OR/012040\&D2, U. S. Department of Energy, Office of Environmental Management, Oak Ridge, TN.

DOE 2004. Explanation of Significant Differences for the Record of Decision for Interim Actions for the Melton Valley Watershed at Oak Ridge National Laboratory, Oak Ridge, Tennessee, Addition of Units to the Selected Remedy, DOE/OR/01-2165\&D1, U. S. Department of Energy, Office of Environmental Management, Oak Ridge, TN.

DOE 2005. Explanation of Significant Difference for the Record of Decision for Interim Actions for the Melton Valley Watershed, Deletion of Molten Salt Reactor Experiment Ancillary Facilities from the Selected Remedy, DOE/OR/01-2249\&D1, U. S. Department of Energy, Environmental Restoration Division, Oak Ridge, TN.

DOE 2006. Land Use Control Implementation Plan for the Melton Valley Watershed at the Oak Ridge National Laboratory, Oak Ridge Tennessee, DOE/OE/01-1977\&D6, U. S. Department of Energy, Office of Environmental Management, Oak Ridge, TN.

DOE 2006. Phased Construction Completion Report (PCCR) for the Old Hydrofracture Facility Decontamination and Decommissioning Project at the Oak Ridge National Laboratory, Oak Ridge, Tennessee, DOE/OR/01-2014\&D2, U.S. Department of Energy, Office of Environmental Management, Oak Ridge, TN.

DOE 2006. Phased Construction Completion Report for the Hydrofracture Well Plugging and Abandonment Project at the Oak Ridge National Laboratory Oak Ridge, Tennessee, DOE/OR/01$2138 \& D 1$, U. S. Department of Energy, Office of Environmental Management, Oak Ridge, TN.

DOE 2006. Phased Construction Completion Report for the Hydrologic Isolation at Solid Waste Storage Area 6 at the Oak Ridge National Laboratory, Oak Ridge, Tennessee, DOE/OR/01-2285\&D1, U. S. Department of Energy, Office of Environmental Management, Oak Ridge, TN.

DOE 2006. Phased Construction Completion Report for Hydrologic Isolation of Solid Waste Storage Area 5 at the Oak Ridge National Laboratory, Oak Ridge, Tennessee, DOE/OR/01-2286\&D1, U. S. Department of Energy, Office of Environmental Management, Oak Ridge, TN

DOE 2006. Phased Construction Completion Report (PCCR) for the Solid Waste Storage Area 4 and the Intermediate Holding Pond at the Oak Ridge National Laboratory, Oak Ridge, Tennessee, 
DOE/OR/01-2300\&D1, U.S. Department of Energy, Office of Environmental Management, Oak Ridge, TN.

DOE 2006. Phased Construction Completion Report for Trenches 5 and 7 and HRE Fuel Wells, In-Situ Grouting Project, Oak Ridge, Tennessee, DOE/OR/01-2302\&D1, U. S. Department of Energy, Office of Environmental Management, Oak Ridge, TN.

DOE 2006. Phased Construction Completion Report for the New Hydrofracture Facility Decontamination and Decommissioning Project at Oak Ridge National Laboratory, Oak Ridge, Tennessee, DOE/OR/01-2306\&D1, U.S. Department of Energy, Office of Environmental Management, Oak Ridge, TN.

DOE 2006. Phased Construction Completion Report for the Homogeneous Reactor Experiment Ancillary Facilities Decontamination and Decommissioning Project at Oak Ridge National Laboratory, Oak Ridge, Tennessee, DOE/OR/01-2307\&D1, U. S. Department of Energy, Office of Environmental Management, Oak Ridge, TN.

DOE 2006. Phased Construction Completion Report for Hydrologic Isolation at the Seepage Pits and Trenches Area at the Oak Ridge National Laboratory, Oak Ridge, Tennessee, DOE/OR/012310\&D1, U. S. Department of Energy, Office of Environmental Management, Oak Ridge, TN.

DOE 2006. Phased Construction Completion Report for the Melton Valley Soils and Sediments Project at Oak Ridge National Laboratory, Oak Ridge, Tennessee, DOE/OR/01-2315\&D1, U. S. Department of Energy, Office of Environmental Management, Oak Ridge, TN.

DOE 2006. Phased Construction Completion Report for the 7841 Equipment Storage Area and $7802 F$ Storage Shed Decontamination and Decommissioning Project at Oak Ridge National Laboratory, Oak Ridge, Tennessee, DOE/OR/01-2323\&D1, U.S. Department of Energy, Office of Environmental Management, Oak Ridge, TN.

DOE 2006. Explanation of Significant Differences for the Record of Decision for Interim Actions for the Melton Valley Watershed at the Oak Ridge National Laboratory, Oak Ridge, Tennessee: Deletion of STTs From the Selected Remedy, DOE/OE/01-2333\&D1, U. S. Department of Energy, Office of Environmental Management, Oak Ridge, TN.

DOE 2007. Remedial Action Report for the Melton Valley Watershed at Oak Ridge National Laboratory, Oak Ridge, Tennessee, DOE/OR/01-2343\&D1, U.S. Department of Energy, Office of Environmental Management, Oak Ridge, TN.

DOE 2009. Remedial Action Report for the Melton Valley Watershed at the Oak Ridge National Laboratory, Oak Ridge, Tennessee, DOE/OR/01-2343\&D1/A1, U.S. Department of Energy, Office of Environmental Management, Oak Ridge, TN.

DOE 2009. Remedial Action Report for the Melton Valley Watershed at the Oak Ridge National Laboratory, Oak Ridge, Tennessee, DOE/OR/01-2343\&D1/A2, U.S. Department of Energy, Office of Environmental Management, Oak Ridge, TN. 


\section{Single-project actions}

\section{WOCE}

ORNL 1992. White Oak Creek Embayment Time-Critical CERCLA Removal Action Sediment-Retention Structure, ORNL/ER/Sub/91-KA931/4, Oak Ridge National Laboratory, Oak Ridge, TN.

\section{WAG 13 Cesium Plots}

DOE 1992. Interim Record of Decision for Oak Ridge National Laboratory, Waste Area Grouping 13, Cesium Plots, Oak Ridge, Tennessee, DOE/OR-1059\&D4, U.S. Department of Energy, Environmental Restoration Division, Oak Ridge, TN.

DOE 1994. Interim Remedial Action Post-Construction Report for Waste Area Grouping 13 at Oak Ridge National Laboratory, Oak Ridge, Tennessee, DOE/OR/01-1218\&D2, U. S. Department of Energy, Environmental Restoration Division, Oak Ridge, TN.

\section{WAG 5 Seep C}

DOE 1994. Action Memorandum for the Waste Area Grouping 5 Seep C at Oak Ridge National Laboratory, Oak Ridge, Tennessee, DOE/OR/02-1235\&D2, U. S. Department of Energy, Environmental Restoration Division, Oak Ridge, TN.

DOE 1995. Post-Construction Report for Waste Area Grouping 5 Seeps Removal Action at Oak Ridge National Laboratory, Oak Ridge, Tennessee, DOE/OR/01-1334\&D2, U. S. Department of Energy, Environmental Restoration Division, Oak Ridge, TN.

\section{WAG 5 Seep D}

DOE 1994. Action Memorandum for the Waste Area Grouping 5 Seep D at Oak Ridge National Laboratory, Oak Ridge, Tennessee, DOE/OR/02-1283\&D2, U. S. Department of Energy, Environmental Restoration Division, Oak Ridge, TN.

DOE 1995. Post-Construction Report for Waste Area Grouping 5 Seeps Removal Action at Oak Ridge National Laboratory, Oak Ridge, Tennessee, DOE/OR/01-1334\&D2, U. S. Department of Energy, Environmental Restoration Division, Oak Ridge, TN.

\section{WAG 4 Seep Control}

DOE 1996. Action Memorandum for the Waste Area Grouping 4 Seeps at Oak Ridge National Laboratory, Oak Ridge, Tennessee, DOE/OR/02-1440\&D2, U. S. Department of Energy, Environmental Restoration Division, Oak Ridge, TN.

DOE 1996. Removal Action Report on Waste Area Grouping 4 Seeps 4 and 6 at Oak Ridge National Laboratory, Oak Ridge, Tennessee, DOE/OR/01-1544\&D2, U. S. Department of Energy, Environmental Restoration Division, Oak Ridge, TN.

\section{MSRE D\&D Reactive Gas}

DOE 1997. Removal Action Report on the Molten Salt Reactor Experiment Time-Critical Removal Action at Oak Ridge National Laboratory, Oak Ridge, Tennessee, DOE/OR/01-1623\&D2, U. S. Department of Energy, Office of Environmental Management, Oak Ridge, TN. 


\section{MSRE D\&D Uranium Deposit Removal}

DOE 1996. Action Memorandum for Uranium Deposit Removal at the Molten Salt Reactor Experiment, DOE/OR/02-1488\&D2, U. S. Department of Energy, Office of Environmental Restoration and Waste Management, Oak Ridge, TN.

DOE 2001. Removal Action Report for Uranium Deposit Removal at the Molten Salt Reactor Experiment at Oak Ridge National Laboratory, Oak Ridge, Tennessee, DOE/OR/01-1918\&D2, U. S. Department of Energy, Office of Environmental Management, Oak Ridge, TN.

\section{OHF Tank Sludges}

DOE 1996. Action Memorandum for Waste Area Grouping 5 Old Hydrofracture Facility Tanks at the Oak Ridge National Laboratory, Oak Ridge, Tennessee, DOE/OR/02-1487\&D2, U. S. Department of Energy, Office of Environmental Restoration and Watershed Management, Oak Ridge, TN.

DOE 1998. Removal Action Report for the Contents Removal of the Old Hydrofracture Facility Tanks, DOE/OR/01-1759\&D1, U.S. Department of Energy, Office of Environmental Management, Oak Ridge, TN.

\section{OHF Tanks and Impoundment}

DOE 1999. Action Memorandum for the Old Hydrofracture Facility Tanks and Impoundment at the Oak Ridge National Laboratory, Oak Ridge, Tennessee, DOE/OR/01-1751\&D3, U. S. Department of Energy, Office of Environmental Management, Oak Ridge, TN.

DOE 2000. Action Memorandum Addendum for the Old Hydrofracture Facility Tanks and Pond at the Oak Ridge National Laboratory, Oak Ridge, Tennessee, DOE/OR/01-1866\&D2, U. S. Department of Energy, Office of Environmental Management, Oak Ridge, TN.

DOE 2001. Removal Action Report for the Old Hydrofracture Facility Tanks and Pond, Process Waste Sludge Basin, and T-4 Waste Pit at Oak Ridge National Laboratory, Oak Ridge, Tennessee, DOE/OR/011908\&D2, U. S. Department of Energy, Office of Environmental Management, Oak Ridge, TN.

\section{MSRE D\&D Fuel Salt Removal}

DOE 1998. Record of Decision for Interim Action to Remove Fuel and Flush Salts from the Molten Salt Reactor Experiment Facility, DOE/OR/02-1671\&D2, U.S. Department of Energy, Office of Environmental Management, Oak Ridge, TN.

DOE 2007. Explanation of Significant Differences for the Record of Decision for Interim Action to Remove Fuel and Flush Salts From the Molten Salt Reactor Experiment Facility at the Oak Ridge National Laboratory, Oak Ridge, Tennessee, DOE/OR/01-2088\&D2, U. S. Department of Energy, Office of Environmental Management, Oak Ridge, TN. 


\subsection{BEAR CREEK WATERSHED DOCUMENTS}

\section{BCV Phase I ROD}

DOE 2000. Record of Decision for the Phase I Activities in Bear Creek Valley at the Oak Ridge Y-12 Plant, Oak Ridge, Tennessee, DOE/OR/01-1750\&D4, U. S. Department of Energy, Office of Environmental Management, Oak Ridge, TN.

DOE 2001. Phased Construction Completion Report for the Bear Creek Valley Oil Landfarm Soil Containment Pad at the Y-12 National Security Complex Oak Ridge, Tennessee, DOE/OR/011937\&D2, U. S. Department of Energy, Office of Environmental Management, Oak Ridge, TN.

DOE 2003. Phase Construction Completion Report for the Bear Creek Valley Boneyard/Burnyard Remediation Project at the Y-12 National Security Complex Oak Ridge, Tennessee, DOE/OR/012077\&D2, U. S. Department of Energy, Office of Environmental Management, Oak Ridge, TN.

DOE 2006. Land Use Control Implementation Plan for Phase I Activities in the Bear Creek Valley at the Oak Ridge Y-12 Plant, Oak Ridge, Tennessee, DOE/OR/01-2320\&D1, U. S. Department of Energy, Office of Environmental Management, Oak Ridge, TN.

\section{Single-project actions}

\section{BCV OU 2 RA Spoil Area 1, SY-200 Yard}

DOE 1996. Record of Decision for Bear Creek Operable Unit 2 (Spoil Area 1 and SY-200 Yard) at the Oak Ridge Y-12 Plant, Oak Ridge, Tennessee, DOE/OR/02-1435\&D2, U. S. Department of Energy, Environmental Restoration and Waste Management Division, Oak Ridge, TN.

\section{S-3 Site Tributary Interception (Pathways 1 \& 2)}

DOE 1998. Action Memorandum for the Bear Creek Valley Tributary Inspection Trenches for the S-3 Uranium Plume, Oak Ridge, Tennessee, DOE/OR/01-1739\&D1, U. S. Department of Energy, Office of Environmental Management, Oak Ridge, TN.

DOE 2000. Addendum to the Action Memorandum for the Bear Creek Valley Tributary Interception Trenches for the S-3 Uranium Plume, Oak Ridge, Tennessee, DOE/OR/01-1739\&D1/A1, U. S. Department of Energy, Office of Environmental Management, Oak Ridge, TN.

DOE 2001. Removal Action Report on the Bear Creek Valley S-3 Ponds Pathways 1 and 2 at the Y-12 National Security Complex, Oak Ridge, Tennessee, DOE/OR/01-1945\&D2, U. S. Department of Energy, Office of Environmental Management, Oak Ridge, TN.

DOE 2007. Addendum to the Removal Action Report for the Bear Creek Valley Interception Trenches for the S-3 Uranium Plume, Pathways 1 and 2 at the Oak Ridge Y-12 Plant, Oak Ridge, Tennessee, DOE/OR/01-1836\&D1/A1, U.S. Department of Energy, Office of Environmental Management, Oak Ridge, TN. 


\subsection{CHESTNUT RIDGE}

\section{UNC Disposal Site RA}

DOE 1991. Record of Decision United Nuclear Corporation Disposal Site Declaration, Y-12 Plant, Oak Ridge, Tennessee, U. S. Department of Energy, Environmental Restoration Division, Oak Ridge, TN.

DOE 1993. Post-Construction Report for the United Nuclear Corporation Disposal Site at the Y-12 Plant, Oak Ridge, Tennessee, DOE/OR/01-1128\&D1, U. S. Department of Energy, Environmental Restoration Division, Oak Ridge, TN.

\section{KHQ RA}

DOE 1995. Record of Decision for Kerr Hollow Quarry at the Oak Ridge Y-12 Plant, Oak Ridge, Tennessee, DOE/OR/02-1398\&D2, U.S. Department of Energy, Office of Environmental Restoration and Waste Management, Oak Ridge, TN.

\section{FCAP/Upper McCoy Branch RA}

DOE 1996. Record of Decision for Chestnut Ridge Operable Unit 2 (Filled Coal Ash Pond and Vicinity), Oak Ridge, Tennessee, DOE/OR/02-1410\&D3, U. S. Department of Energy, Environmental Restoration Division, Oak Ridge, TN.

DOE 1997. Remedial Action Report on Chestnut Ridge Operable Unit 2 (Filled Coal Ash Pond and Vicinity) at the Oak Ridge Y-12 Plant, Oak Ridge, Tennessee, DOE/OR/01-1596\&D1, U. S. Department of Energy, Office of Environmental Management, Oak Ridge, TN. 


\subsection{UEFPC WATERSHED DOCUMENTS}

\section{Phase I Interim Source Control Actions}

DOE 2002. Record of Decision for Phase I Interim Source Control Actions in the Upper East Fork Poplar Creek Characterization Area, Oak Ridge, Tennessee, DOE/OR/01-1951\&D3, U. S. Department of Energy, Office of Environmental Management, Oak Ridge, TN.

Lopez-Ferre', M., and Adler, D. G., DOE-ORO, August 30, 2006, letter to J. Crane, Region IV, and D. McCoy, TDEC DOE Oversight Div., Proposed Changes in Upper East Fork Poplar Creek Mercury Monitoring, Non-Significant Change to the "Record of Decision for Phase I Interim Source Control Actions in the Upper East Fork Poplar Creek Characterization Area, Oak Ridge, Tennessee." NSC approved October 5, 2006.

Adler, D.G., DOE-ORO, December 20, 2006, letter to J. Crane, Region IV, and D. McCoy, TDEC DOE Oversight Div., re: Proposed Non-Significant Changes to Two Signed Records of Decisions, Discontinuation of Building 9205-1 Sump Water Treatment, Non-Significant Change to the Record of Decision for Phase I Interim Source Control Actions in the Upper East Fork Poplar Creek Characterization Area, Oak Ridge, Tennessee, (DOE/OR/01-1951\&D3). Change to the Record of Decision for Oak Ridge Associated Universities South Campus Facility, Oak Ridge, Tennessee, (DOE/OR/02-1383\&D3). NSC approved May 17, 2007.

Lopez-Ferre', M., and Adler, D. G., DOE-ORO, September 17, 2007, letter to J. Crane, Region IV, and D. McCoy, TDEC DOE Oversight Div., Erratum to the Mercury Monitoring Non-Significant Change to the "Record of Decision for Phase I Interim Source Control Actions in the Upper East Fork Poplar Creek Characterization Area, Oak Ridge, Tennessee." NSC approved June 9, 2008.

DOE 2005. Phased Construction Completion Report for the Big Spring Water Treatment System at the Y-12 National Security Complex, Oak Ridge, Tennessee, DOE/OR/01-2218\&D1, U. S. Department of Energy, Office of Environmental Management, Oak Ridge, TN.

DOE 2006. Record of Decision for Phase II Interim Actions for Contaminated Soils and Scrapyard in Upper East Fork Poplar Creek, Oak Ridge, Tennessee, DOE/OR/01-2229\&D3, U. S. Department of Energy, Office of Environmental Management, Oak Ridge, TN.

DOE 2008. Remedial Design Report/Remedial Action Work Plan for Scrap Metal at the Y-12 Old Salvage Yard at the Y-12 National Security Complex, Oak Ridge, Tennessee, DOE/OR/01-2376\&D2, U. S. Department of Energy, Office of Environmental Management, Oak Ridge, TN.

\section{Single-project actions}

\section{Y-12 Plant EEVOC Plume Removal Action}

DOE 1999. Action Memorandum for the Oak Ridge Y-12 Plant East End Volatile Organic Compound Plume, Oak Ridge, Tennessee, DOE/OR/01-1819\&D2, U. S. Department of Energy, Office of Environmental Management, Oak Ridge, TN.

DOE 2006. Removal Action Report for the Oak Ridge Y-12 Plant East End Volatile Organic Plume, Oak Ridge, Tennessee, DOE/OR/01-2297\&D1, U. S. Department of Energy, Office of Environmental Management, Oak Ridge, TN. 


\section{Union Valley}

DOE 1997. Record of Decision for an Interim Action for Union Valley, Upper East Fork Poplar Creek Characterization Area, Oak Ridge, Tennessee, DOE/OR/02-1545\&D2, U. S. Department of Energy, Office of Environmental Management, Oak Ridge, TN.

\section{Mercury Tanks Interim Remedial Action}

DOE 1991. Record of Decision, Interim Action for the Mercury Tank Remediation, DOE/OR/02-1164, U. S. Department of Energy, Environmental Restoration Division, Oak Ridge, TN.

DOE 1993. Post-Construction Report for the Mercury Tanks Interim Action at the Oak Ridge Y-12 Plant, Oak Ridge, Tennessee, DOE/OR/01-1169\&D1, U. S. Department of Energy, Environmental Restoration Division, Oak Ridge, TN.

\section{Plating Shop Container Areas Remedial Action}

DOE 1992. Record of Decision for the Y-12 Plating Shop Container Areas, Oak Ridge Y-12 Plant, Oak Ridge, Tennessee, DOE/OR-1049\&D3, U. S. Department of Energy, Environmental Restoration Division, Oak Ridge, TN.

\section{ANAP (UEFPC OU 2)}

DOE 1994. Record of Decision for the Upper East Fork Poplar Creek Operable Unit 2 (Abandoned Nitric Acid Pipeline) at the Oak Ridge Y-12 Plant, Oak Ridge, Tennessee, DOE/OR/02-1265\&D2, U. S. Department of Energy, Environmental Restoration Division, Oak Ridge, TN.

\section{Building 9201-4 Exterior Process Piping}

DOE 1997. Action Memorandum for Building 9201-4, Exterior Process Piping Removal at the Y-12 Plant, Oak Ridge,Tennessee, DOE/OR/02-1571\&D2, U. S. Department of Energy, Office of Environmental Management, Oak Ridge, TN.

DOE 1997. Removal Action Report for Building 9201-4 Exterior Process Piping Removal at the Y-12 Plant, Oak Ridge, Tennessee, DOE/OR/02-1650\&D1, U. S. Department of Energy, Office of Environmental Management, Oak Ridge, TN.

\section{Lead Source Removal at the Former YS-860, Firing Ranges Removal Action}

DOE 1997. Action Memorandum for Lead Source Removal at the Former YS-860 Firing Ranges, Y-12 Plant, Oak Ridge, Tennessee, DOE/OR/02-1622\&D1, U. S. Department of Energy, Office of Environmental Management, Oak Ridge, TN.

DOE 1999. Removal Action Report for the Lead Source Removal at the Former YS-860 Firing Ranges, Oak Ridge Y-12 Plant, Oak Ridge, Tennessee, DOE/OR/01-1774\&D2, U. S. Department of Energy, Office of Environmental Management, Oak Ridge, TN.

\section{Sediment Basin and 81-10 Sump Removal Action}

DOE 1998. Action Memorandum for the Y-12 Plant 9822 Sediment Basin and Building 81-10 Sump, Oak Ridge, Tennessee, DOE/OR/01-1716\&D2, U.S. Department of Energy, Office of Environmental Management, Oak Ridge, TN. 
DOE 1999. Removal Action Report for the 9822 Sediment Basin and Building 81-10 Sump at the Oak Ridge Y-12 Plant, Oak Ridge, Tennessee, DOE/OR/01-1763\&D2, U. S. Department of Energy, Office of Environmental Management, Oak Ridge, TN.

\section{Y-12 decontamination and demolition projects}

\section{Y-12 Building D\&D}

DOE 2009. Action Memorandum for Time-Critical Removal of Legacy Materials from Buildings 9201-5 and 9204-4 at the Y-12 National Security Complex, Oak Ridge, Tennessee, DOE/OR/01-2404\&D1, U. S. Department of Energy, Office of Environmental Management, Oak Ridge, TN.

DOE 2009. Action Memorandum for Time-Critical Removal Action for Demolition of Building 9735 and the Building 9206 Filter House at the Y-12 National Security Complex, Oak Ridge, Tennessee, DOE/OR/01-2405\&D1, U. S. Department of Energy, Office of Environmental Management, Oak Ridge, TN.

DOE 2009. Action Memorandum for Time-Critical Removal Action for Demolition of Buildings 9211, 9220, 9224 and 9769 (Biology Complex) at the Y-12 National Security Complex, Oak Ridge, Tennessee, DOE/OR/01-2406\&D1, U.S. Department of Energy, Office of Environmental Management, Oak Ridge, TN. 


\subsection{OFF-SITE LOCATIONS DOCUMENTS}

\section{LEFPC}

DOE 1995. Record of Decision for Lower East Fork Poplar Creek, Oak Ridge, Tennessee, DOE/OR/021370\&D2, U. S. Department of Energy, Environmental Restoration Division, Oak Ridge, TN.

DOE 1996. Explanation of Significant Differences for the Lower East Fork Poplar Creek Record of Decision, Oak Ridge, Tennessee, DOE/OR-02-1443\&D2, U. S. Department of Energy, Environmental Restoration Division, Oak Ridge, TN.

DOE 2000. Remedial Action Report on the Lower East Fork Poplar Creek Project, Oak Ridge, Tennessee, DOE/OR/01-1680\&D5, U.S. Department of Energy, Office of Environmental Management, Oak Ridge, TN.

\section{CR/PC}

DOE 1997. Record of Decision for the Clinch River/Poplar Creek Operable Unit, Oak Ridge, Tennessee, DOE/OR/02-1547\&D3, U.S. Department of Energy, Office of Environmental Management, Oak Ridge, TN.

DOE 1997. Remedial Action Report for Clinch River/Poplar Creek in East Tennessee, DOE/OR/02-1627\&D3, U. S. Department of Energy, Office of Environmental Management, Oak Ridge, TN.

\section{LWBR}

DOE 1995. Record of Decision for the Lower Watts Bar Reservoir, DOE/OR/02-1373\&D3, U. S. Department of Energy, Office of Environmental Restoration and Waste Management, Oak Ridge, TN.

DOE 1996. Remedial Action Work Plan for Lower Watts Bar Reservoir, DOE/OR/02-1376\&D3, U.S. Department of Energy, Office of Environmental Restoration and Waste Management, Oak Ridge, TN. 


\subsection{ETTP DOCUMENTS}

\section{Watershed-scale actions}

\section{Zone 1 Selected Contaminated Areas Interim Removal Actions}

DOE 2002. Record of Decision for Interim Actions in Zone 1, East Tennessee Technology Park, Oak Ridge, Tennessee, DOE/OR/01-1997\&D2, U. S. Department of Energy, Office of Environmental Management, Oak Ridge, TN.

DOE 2006. Phased Construction Completion Report for the Duct Island Area and K-901 Area in Zone 1, East Tennessee Technology Park, Oak Ridge, Tennessee, DOE/OR/01-2261\&D2, U. S. Department of Energy, Office of Environmental Management, Oak Ridge, TN.

DOE 2006. Phased Construction Completion Report for the K-1007 Ponds Area and the Powerhouse North Area in Zone 1 at East Tennessee Technology Park, Oak Ridge, Tennessee, DOE/OR/012294\&D2, U. S. Department of Energy, Office of Environmental Management, Oak Ridge, TN.

DOE 2007. Phased Construction Completion Report for the K-770 Scrap Removal Project of the Zone 1 Remediation at the East Tennessee Technology Park, Oak Ridge, Tennessee, DOE/OR/01-2348\&D1, U. S. Department of Energy, Office of Environmental Management, Oak Ridge, TN.

DOE 2008. FY 2008 Phased Construction Completion Report for Exposure Units Z1-01, Z1-03, Z1-38, and Z1-49 in Zone 1 at the East Tennessee Technology Park, Oak Ridge, Tennessee, DOE/OR/012367\&D2, U. S. Department of Energy, Office of Environmental Management, Oak Ridge, TN.

\section{Zone 2 Soil, Buried Waste, and Subsurface Structure Removal Actions}

DOE 2005. Record of Decision for Soil, Buried Waste, and Subsurface Structure Actions in Zone 2, East Tennessee Technology Park, Oak Ridge, Tennessee, DOE/OR/01-2161\&D2, U. S. Department of Energy, Office of Environmental Management, Oak Ridge, TN.

DOE 2006. Fiscal Year 2006 Phased Construction Completion Report for the Zone 2 Soils, Slabs, and Subsurface Structures at East Tennessee Technology Park, Oak Ridge, Tennessee, DOE/OR/012317\&D2, U. S. Department of Energy, Office of Environmental Management, Oak Ridge, TN.

DOE 2008. Fiscal Year 2007 Phased Construction Completion Report for the Zone 2 Soils, Slabs, and Subsurface Structures at East Tennessee Technology Park, Oak Ridge, Tennessee. DOE/OR/012723\&D2, U. S. Department of Energy, Office of Environmental Management, Oak Ridge, TN.

DOE 2009. Fiscal Year 2008 Phased Construction Completion Report for EU Z2-33 in Zone 2, East Tennessee Technology Park, Oak Ridge, Tennessee, DOE/OR/01-2368\&D2/R1, U. S. Department of Energy, Office of Environmental Management, Oak Ridge, TN.

DOE 2009. Fiscal Year 2009 Phased Construction Completion Report for EU Z2-36 in Zone 2, East Tennessee Technology Park, Oak Ridge, Tennessee, DOE/OR/01-2399\&D1, U. S. Department of Energy, Office of Environmental Management, Oak Ridge, TN.

DOE 2009. Fiscal Year 2009 Phased Construction Completion Report for Zone 2 Exposure Units 11, 12, 17, 18, 29, and 38 at East Tennessee Technology Park, Oak Ridge, Tennessee, DOE/OR/01$2415 \& D 1$, U. S. Department of Energy, Office of Environmental Management, Oak Ridge, TN. 


\section{ETTP Site-Wide Residual Contamination RA}

DOE 2007. Action Memorandum for the Ponds at the East Tennessee Technology Park, Oak Ridge, Tennessee: K-1007-P Holding Ponds, K-901-A Holding Pond, K-720 Slough, and K-770 Embayment, Oak Ridge, Tennessee, DOE/OR/01-2314\&D2, U. S. Department of Energy, Office of Environmental Management, Oak Ridge, TN.

DOE 2008. Removal Action Work Plan for the Removal Action at the Ponds at the East Tennessee Technology Park, Oak Ridge, Tennessee, DOE/OR/01-2359\&D2, U. S. Department of Energy, Office of Environmental Management, Oak Ridge, TN.

\section{Single-project actions}

\section{Reduction of Hexavalent Chromium Releases to Mitchell Branch Time-Critical RA}

DOE 2007. Action Memorandum for Reduction of Hexavalent Chromium Releases Into Mitchell Branch at the East Tennessee Technology Park, Oak Ridge, Tennessee, DOE/OR/01-2369\&D1, U. S. Department of Energy, Office of Environmental Management, Oak Ridge, TN.

DOE 2008. Removal Action Report for the Reduction of Hexavalent Chromium Releases Into Mitchell Branch at the East Tennessee Technology Park, DOE/OR/01-2384\&D1, U. S. Department of Energy, Office of Environmental Management, Oak Ridge, TN.

\section{K-1417-A/B Drum Storage Yards Interim RA}

DOE 1991. Interim Action Record of Decision for the K-1417-A and K-1417-B Drum Storage Yards, Oak Ridge $K-25$ Site, DOE/OR-991, U. S. Department of Energy, Environmental Restoration Division, Oak Ridge, TN.

\section{K-1070 C/D SW-31 Spring RA}

DOE 1992. Interim Record of Decision for the Oak Ridge K-25 Site K-1070 Operable Unit SW-31 Spring, Oak Ridge K-25 Site, DOE/OR-1050\&D2, U. S. Department of Energy, Environmental Restoration Division, Oak Ridge, TN.

DOE 1993. Explanation of Significant Differences for the Interim Record of Decision for the Oak Ridge K-25 Site, K-1070 Operable Unit SW31 Spring, Oak Ridge, Tennessee, DOE/OR/02-1132\&D2, U. S. Department of Energy, Environmental Restoration Division, Oak Ridge, TN.

DOE 2007. Addendum to the Remedial Action/Effectiveness Report for the K-1070 Operable Unit SW31 Spring Phase 2 Remedial Action at the Oak Ridge K-25 Site, Oak Ridge, Tennessee, DOE/OR/011520\&D1/R1/A1, U. S. Department of Energy, Office of Environmental Management, Oak Ridge, TN.

\section{K-1407-B/C Ponds RA}

DOE 1993. Record of Decision for the K-1407-B/C Ponds at the Oak Ridge K-25 Site, Oak Ridge, Tennessee, DOE/OR/02-1125\&D3, U. S. Department of Energy, Environmental Restoration Division, Oak Ridge, TN. 
DOE 1995. Remedial Action Report for the K-1407-B Holding Pond and the K-1407-C Retention Basin, DOE/OR/01-1371\&D1, U.S. Department of Energy, Office of Environmental Management, Oak Ridge, TN.

\section{K-1401 and K-1420 Sumps Removal Action}

DOE 1997. Action Memorandum for Rerouting of Sump Discharge from Buildings K-1401 and K-1420, East Tennessee Technology Park, Oak Ridge, Tennessee, DOE/OR/02-1610\&D1, U. S. Department of Energy, Office of Environmental Management, Oak Ridge, TN.

DOE 1998. Removal Action Report on the K-1401/K-1420 Sumps Removal Action at the East Tennessee Technology Park, Oak Ridge, Tennessee, DOE/OR/01-1754\&D2, U. S. Department of Energy, Office of Environmental Management, Oak Ridge, TN.

DOE 2006. Addendum for Removal Action Report on the K-1401/K-1420 Sumps Removal Action at the East Tennessee Technology Park, Oak Ridge, Tennessee, DOE/OR/01-1754\&D2/A1, U. S. Department of Energy, Office of Environmental Management, Oak Ridge, TN.

January 2007. Notification of Non-Significant Change to the Action Memorandum for Rerouting of Sump Discharge from Buildings K-1401 and K-1420: Change of Treatment and Discharge Location, DOE/OR/02-1610\&R1, U.S. Department of Energy, Office of Environmental Management, Oak Ridge, TN.

\section{K-1070-C/D and Mitchell Branch Removal Action}

DOE 1997. Action Memorandum for Mitchell Branch and K-1070-C/D Removal Action East Tennessee Technology Park, Oak Ridge, Tennessee, DOE/OR/02-1611\&D2, U. S. Department of Energy, Office of Environmental Management, Oak Ridge, TN.

DOE 1998. Removal Action Report on the Mitchell Branch and K-1070-C/D Removal Action at the East Tennessee Technology Park, Oak Ridge, Tennessee, DOE/OR/01-1728\&D3, U. S. Department of Energy, Office of Environmental Management, Oak Ridge, TN.

\section{K-901-A and K-1007-P Pond Removal Action}

DOE 1997. Action Memorandum for the K-901-A Holding Pond and the K-1007-P1 Pond Removal Action, East Tennessee Technology Park, Oak Ridge, Tennessee, DOE/OR/02-1550\&D2, U. S. Department of Energy, Office of Environmental Management, Oak Ridge, TN.

DOE 1999. Removal Action Report for the K-901-A Holding Pond and K-1007-P-1 Pond Removal Action at the East Tennessee Technology Park, Oak Ridge, Tennessee, DOE/OR/01-1767\&D2, U. S. Department of Energy, Office of Environmental Management, Oak Ridge, TN.

\section{K-1070-C/D G-Pit and Concrete Pad RA}

DOE 1998. Record of Decision for the K-1070-C/D Operable Unit, East Tennessee Technology Park, Oak Ridge, Tennessee, DOE/OR/02-1486\&D4, U. S. Department of Energy, Office of Environmental Management, Oak Ridge, TN. 
DOE 2002. Remedial Action Report for the K-1070-C/D G-Pit and Concrete Pad, East Tennessee Technology Park, Oak Ridge, Tennessee, DOE/OR/01-1946\&D2, U. S. Department of Energy, Office of Environmental Restoration and Waste Management, Oak Ridge, TN.

\section{K-1070-A Burial Ground RA}

DOE 2000. Record of Decision for the K-1070-A Burial Ground, East Tennessee Technology Park, Oak Ridge, Tennessee, DOE/OR/01-1734\&D3, U.S. Department of Energy, Office of Environmental Management, Oak Ridge, TN.

DOE 2003. Remedial Action Report for the K-1070-A Burial Ground, East Tennessee Technology Park, Oak Ridge, Tennessee, DOE/OR/01-2090\&D1, U. S. Department of Energy, Office of Environmental Management, Oak Ridge, TN.

\section{K-1085 Old Firehouse Burn Area Drum Burial Site}

DOE 2001. Action Memorandum for the K-1085 Old Firehouse Burn Area Drum Burial Site, East Tennessee Technology Park, Oak Ridge, Tennessee, DOE/OR/01-1938\&D1, U. S. Department of Energy, Office of Environmental Management.

DOE 2002. Removal Action Report for the K-1085 Old Firehouse Burn Area Drum Burial Site, East Tennessee Technology Park, DOE/OR/01-2050\&D1, U. S. Department of Energy, Office of Environmental Management, Oak Ridge, TN.

\section{Outdoor LLW Removal Action}

DOE 2003. Action Memorandum for the Outdoor Low-Level Waste East Tennessee Technology Park, Oak Ridge, Tennessee, DOE/OR/01-2109\&D1, U.S. Department of Energy, Office of Environmental Management, Oak Ridge, TN.

DOE 2005. Removal Action Report for the Legacy Low-Level Waste Stored Outdoors at East Tennessee Technology Park, Oak Ridge, Tennessee, DOE/OR/01-2225\&D2, U. S. Department of Energy, Office of Environmental Management, Oak Ridge, TN.

\section{K-25 Auxiliary Facilities Group I Building Demolition (KAFaD)}

DOE 1997. Action Memorandum for the Group I Auxiliary Facilities, K-25 Site, Oak Ridge, Tennessee, DOE/OR/02-1507\&D2, U.S. Department of Energy, Office of Environmental Restoration and Waste Management, Oak Ridge, TN.

DOE 1999. Removal Action Report for the K-25 Auxiliary Facilities Decommissioning Group I Buildings Demolition Project at the East Tennessee Technology Park, Oak Ridge, Tennessee, DOE/OR/01-1829\&D1, U.S. Department of Energy, Office of Environmental Restoration and Waste Management, Oak Ridge, TN

DOE 2005. Removal Action Report Addendum (Waste Disposition) for the K-25 Auxiliary Facilities Decommissioning Group I Building Demolition Project at the East Tennessee Technology Park, Oak Ridge, Tennessee, DOE/OR/01-1829\&D1/A1, U. S. Department of Energy, Office of Environmental Restoration and Waste Management, Oak Ridge, TN.

DOE 2006. Addendum II for Waste Disposition to the Removal Action Report for the K-25 Auxiliary Facilities Decommissioning Group I Building Demolition Project at the East Tennessee Technology 
Park, Oak Ridge, Tennessee, DOE/OR/01-1829\&D1/A2, U.S. Department of Energy, Office of Environmental Restoration and Waste Management, Oak Ridge, TN.

\section{K-29, K-31, and K-33 Equipment Removal and Building Decontamination}

DOE 1997. Action Memorandum for Equipment Removal and Building Decontamination for Buildings $K-29, K-31$, and $K-33$ at the East Tennessee Technology Park, Oak Ridge, Tennessee, DOE/OR/021646\&D1, U. S. Department of Energy, Environmental Restoration Division, Oak Ridge, TN.

DOE 2007. Removal Action Report for Equipment Removal and Building Decontamination for Buildings $K-29, K-31$, and K-33, East Tennessee Technology Park, Oak Ridge, Tennessee, DOE/OR/012290\&D3, U. S. Department of Energy, Environmental Restoration Division, Oak Ridge, TN.

DOE 2007. Addendum to the Removal Action Report for Equipment Removal and Building Decontamination for Buildings K-29, K-31, and K-33, East Tennessee Technology Park, Oak Ridge, Tennessee, DOE/OR/01-2290\&D3/A1, U. S. Department of Energy, Environmental Restoration Division, Oak Ridge, TN.

\section{K-25 Auxiliary Facilities Group II, Phase I, Building Demolition, Main Plant}

DOE 2000. Action Memorandum for the K-25 Auxiliary Facilities Demolition Project Main Plant Buildings, East Tennessee Technology Park, Oak Ridge, Tennessee, DOE/OR/01-1868\&D2, U. S. Department of Energy, Office of Environmental Management, Oak Ridge, TN.

DOE 2004. Removal Action Report for the K-25 Auxiliary Facilities Demolition Project Main Plant Buildings at the East Tennessee Technology Park, Oak Ridge, Tennessee, DOE/OR/01-2116\&D2, U. S. Department of Energy, Office of Environmental Management, Oak Ridge, TN.

\section{K-25 and K-27 Buildings D\&D}

DOE 1988. Action Memorandum for the Decontamination and Decommissioning of the $K-25$ and $K-27$ Buildings, East Tennessee Technology Park, Oak Ridge, Tennessee, DOE/OR/01-1988\&D2, U. S. Department of Energy, Office of Environmental Management, Oak Ridge, TN.

DOE 2005. Notification of Non-Significant Change to the Action Memorandum for the Decontamination and Decommissioning of the K-25 and K-27 Buildings, East Tennessee Technology Park, Oak Ridge, Tennessee: Preservation of North Wing and Placement of Concrete Rubble in East and West Wing Vaults of the K-25 Building, DOE/OR/01-2259\&D1, U.S. Department of Energy, Office of Environmental Management, Oak Ridge, TN.

DOE 2005. Phased Construction Completion Report for Phase I, Hazardous Materials Abatement, of the Decontamination and Decommissioning of the K-25 and K-27 Buildings, East Tennessee Technology Park, Oak Ridge, Tennessee, DOE/OR/01-2275\&D1, U. S. Department of Energy, Office of Environmental Management, Oak Ridge, TN.

\section{K-25 Auxiliary Facilities Group II, Phase II Building Demolition, K-1064 Peninsula Area}

DOE 2002. Action Memorandum for the Group II Buildings, Phase II Demolition Project East Tennessee Technology Park, Oak Ridge, Tennessee, DOE/OR/01-1947\&D1, U. S. Department of Energy, Office of Environmental Management, Oak Ridge, TN. 
DOE 2007. Removal Action Report for the Group II Buildings, Phase II Demolition Project at the East Tennessee Technology Park, Oak Ridge, Tennessee, DOE/OR/01-2339\&D1, U. S. Department of Energy, Office of Environmental Management, Oak Ridge, TN.

\section{K-25 Group II, Phase 3 Building Demolition, Remaining Facilities}

DOE 2003. Action Memorandum for the Remaining Facilities Demolition Project at East Tennessee Technology Park, Oak Ridge, Tennessee, DOE/OR/01-2049\&D2, U. S. Department of Energy, Office of Environmental Management, Oak Ridge, TN.

DOE 2005. Fiscal Year 2004 Phased Construction Completion Report for the Predominantly Uncontaminated Facilities of the Remaining Facilities Demolition Project at the East Tennessee Technology Park, Oak Ridge, Tennessee, DOE/OR/01-2193\&D2, U. S. Department of Energy, Office of Environmental Management, Oak Ridge, TN.

DOE 2005. Fiscal Year 2005 Phased Construction Completion Report for the Predominantly Uncontaminated Facilities of the Remaining Facilities Demolition Project at the East Tennessee Technology Park, Oak Ridge, Tennessee, DOE/OR/01-2269\&D2, U. S. Department of Energy, Office of Environmental Management, Oak Ridge, TN.

DOE 2006. Fiscal Year 2005 Phased Construction Completion Report for the Low-Risk/Low-Complexity Facilities of the Remaining Facilities Demolition Project at the East Tennessee Technology Park, Oak Ridge, Tennessee, DOE/OR/01-2270\&D2, U. S. Department of Energy, Office of Environmental Management, Oak Ridge, TN.

DOE 2007. Phased Construction Completion Report for the Laboratory Area Facilities of the Remaining Facilities Demolition Project at the East Tennessee Technology Park, Oak Ridge, Tennessee, DOE/OR/01-2309\&D2, U. S. Department of Energy, Office of Environmental Management, Oak Ridge, TN.

DOE 2007. Fiscal Year 2006 Phased Construction Completion Report for the Low Risk/Low Complexity Facilities of the Remaining Facilities Demolition Project at the East Tennessee Technology Park, Oak Ridge, Tennessee, DOE/OR/01-2327\&D2, U.S. Department of Energy, Office of Environmental Management, Oak Ridge, TN.

DOE 2007. Phased Construction Completion Report for Building K-29 of the Remaining Facilities Demolition Project at the East Tennessee Technology Park, Oak Ridge, Tennessee, DOE/OR/012336\&D2, U. S. Department of Energy, Office of Environmental Management, Oak Ridge, TN.

DOE 2007. Phased Construction Completion Report for Building K-1420 of the Remaining Facilities Demolition Project at the East Tennessee Technology Park, Oak Ridge, Tennessee, DOE/OR/012341\&D2, U. S. Department of Energy, Office of Environmental Management, Oak Ridge, TN.

DOE 2007. Fiscal Year 2007 Phased Construction Completion Report for the Predominantly Uncontaminated Facilities of the Remaining Facilities Demolition Project at the East Tennessee Technology Park, Oak Ridge, Tennessee, DOE/OR/01-2362\&D1, U. S. Department of Energy, Office of Environmental Management, Oak Ridge, TN.

DOE 2008. Fiscal Year 2007 Phased Construction Completion Report for the Predominantly Uncontaminated Facilities of the Remaining Facilities Demolition Project at the East Tennessee 
Technology Park, Oak Ridge, Tennessee, DOE/OR/01-2363\&D2, U. S. Department of Energy, Office of Environmental Management, Oak Ridge, TN.

DOE 2008. Erratum to the Phased Construction Completion Report for Building K-1401 of the Remaining Facilities Demolition Project at the East Tennessee Technology Park, Oak Ridge, Tennessee, DOE/OR/01-2365\&D2/A1, U.S. Department of Energy, Office of Environmental Management, Oak Ridge, TN.

DOE 2008. Fiscal Year 2008 Phased Construction Completion Report for the Low Risk/Low Complexity Facilities of the Remaining Facilities Demolition Project at the East Tennessee Technology Park, Oak Ridge, Tennessee, DOE/OR/01-2394\&D1, U. S. Department of Energy, Office of Environmental Management, Oak Ridge, TN.

DOE 2008. Fiscal Year 2008 Phased Construction Completion Report for the Predominantly Uncontaminated Facilities of the Remaining Facilities Demolition Project at the East Tennessee Technology Park, Oak Ridge, Tennessee, DOE/OR/01-2395\&D1, U. S. Department of Energy, Office of Environmental Management, Oak Ridge, TN. 


\subsection{OTHER SITES}

\section{WWSY (WAG 11) Surface Debris Interim RA}

DOE 1992. Interim Record of Decision for the Oak Ridge National Laboratory, Waste Area Grouping 11, Surface Debris, Oak Ridge, Tennessee, DOE/OR-1055\&D4, U. S. Department of Energy, Environmental Restoration Division, Oak Ridge, TN.

DOE 1994. Interim Remedial Action Post-Construction Report for Waste Area Grouping 11 at Oak Ridge National Laboratory, Oak Ridge, Tennessee, DOE/OR/01-1263\&D2, U. S. Department of Energy, Environmental Restoration Division, Oak Ridge, TN.

\section{ORAU SCF}

DOE 1995. Record of Decision for Oak Ridge Associated Universities, South Campus Facility, Oak Ridge, Tennessee, DOE/OR/02-1383\&D3, U.S. Department of Energy, Environmental Restoration Division, Oak Ridge, TN.

Adler, D.G., December 20, 2006, DOE-ORO, letter to J. Crane, Region IV, and D. McCoy, TDEC DOE Oversight Div., re: Proposed Non-Significant Changes to Two Signed Records of Decisions, Discontinuation of Building 9205-1 Sump Water Treatment, Non-Significant Change to the Record of Decision for Phase I Interim Source Control Actions in the Upper East Fork Poplar Creek Characterization Area, Oak Ridge, Tennessee, (DOE/OR/01-1951\&D3). Change to the Record of Decision for Oak Ridge Associated Universities South Campus Facility, Oak Ridge, Tennessee, (DOE/OR/02-1383\&D3).

DOE 1996. Remedial Action Report for Post-Record of Decision Monitoring at Oak Ridge Associated Universities, South Campus Facility, Oak Ridge, Tennessee, DOE/OR/02-1474\&D2, U. S. Department of Energy, Office of Environmental Management, Oak Ridge, TN. 


\section{CERTIFICATION OF LAND USE CONTROL IMPLEMENTATION}

FY 2009

The Land Use Control Assurance Plan (LUCAP) requires that the Manager, Department of Energy (DOE) Oak Ridge Office (ORO) annually certify in the Remediation Effectiveness Report (RER) that Land Use Control Implementation Plans (LUCIPs) included as Appendix A of the LUCAP (i.e., approved LUCIPs) are being implemented on the Oak Ridge Reservation. This certification will identify any non-compliance with these LUCIPs and describe steps taken to address any such non-compliance(s). Certification is provided for fiscal year (FY) 2009, comprising the period October 1, 2008, through September 30, 2009. The LUCAP also requires that the annual report serve to notify the EPA and TDEC of any change in the designated officials or of land use changes that are not considered major, as described in Section 2.8 of the LUCAP.

The LUCIP for Melton Valley watershed was approved by EPA and TDEC in May, 2006, and revised through errata to the Melton Valley Remedial Action Report in 2009. Land use controls that were implemented in Melton Valley during FY 2009 are identified in Table A.1.

In accordance with Section 2.9 of the LUCAP (DOE, EPA, and TDEC 1999), I certify based on the information and belief formed after reasonable inquiry that all required land use controls in Melton Valley have been implemented in accordance with the approved LUCIP for the watershed (DOE 2006b). The Land Use Controls in Table A.1 have been implemented, as required.

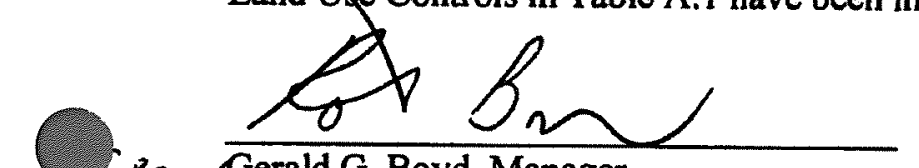

Gerald G. Boyd, Manager

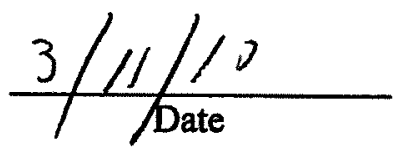


This page intentionally left blank.

A-4 
Table A.1. Verification of Land Use Controls for the Melton Valley Watershed LUCIP requirements being certified as of September 30, $2009^{1}$

\begin{tabular}{|c|c|c|c|c|c|}
\hline \multicolumn{6}{|c|}{ MV LUCIP Requirements } \\
\hline Type of control & Affected areas & Implementation & Frequency & $\begin{array}{c}\text { Verification } \\
\text { Requirements }\end{array}$ & $\begin{array}{c}\text { Certification } \\
\text { Documentation }^{2}\end{array}$ \\
\hline $\begin{array}{l}\text { DOE land } \\
\text { notation } \\
\text { (property record } \\
\text { restrictions) } \\
\text { A. Land use } \\
\text { B. Groundwater }\end{array}$ & \begin{tabular}{|l|} 
All waste management \\
areas and other areas \\
where hazardous \\
substances are left in place \\
at levels requiring land use \\
and/or groundwater \\
restrictions.
\end{tabular} & $\begin{array}{l}\text { To be drafted and implemented by } \\
\text { DOE upon completion of all } \\
\text { remediation activities or transfer of } \\
\text { affected areas. Filed within } 90 \text { days } \\
\text { after EPA and TDEC approval of } \\
\text { the RAR. }\end{array}$ & \begin{tabular}{|l|} 
Verify annually \\
that information \\
is being \\
maintained \\
properly.
\end{tabular} & $\begin{array}{l}\text { Verify information } \\
\text { properly recorded at } \\
\text { County Register of } \\
\text { Deeds Office(s). }\end{array}$ & $\begin{array}{l}\text { Certified. } \\
\text { WRRP personnel verified } \\
\text { that the MV Land Notation is } \\
\text { being maintained properly } \\
\text { with the Roane County } \\
\text { Register of Deeds office. }\end{array}$ \\
\hline $\begin{array}{l}\text { 2. Property Record } \\
\text { notices }\end{array}$ & \begin{tabular}{|l|} 
SWSA 6 ICMAs/HTF; \\
All waste management \\
areas and other areas \\
where hazardous \\
substances are left in place \\
at levels requiring land use \\
and/or groundwater \\
restrictions.
\end{tabular} & $\begin{array}{l}\text { Notice provided by DOE EM to the } \\
\text { public as soon as practicable, but no } \\
\text { later than } 90 \text { days after approval of } \\
\text { the LUCIP. This notice will be } \\
\text { supplemented with the DOE Land } \\
\text { Notation after completion of } \\
\text { remediation (see above). }\end{array}$ & $\begin{array}{l}\text { Verify annually } \\
\text { that information } \\
\text { is being } \\
\text { maintained } \\
\text { properly. }\end{array}$ & $\begin{array}{l}\text { Verify information } \\
\text { properly recorded at } \\
\text { County Register of } \\
\text { Deeds Office(s). }\end{array}$ & $\begin{array}{l}\text { Certified. } \\
\text { WRRP personnel verified } \\
\text { that the MV Property Record } \\
\text { Notice, as well as the DOE } \\
\text { Land Notation and survey } \\
\text { plat, are being maintained } \\
\text { properly on the EM website } \\
\text { and at the DOE Information } \\
\text { Center and that the DOE } \\
\text { Land Notation remains } \\
\text { properly recorded at the } \\
\text { Roane County Register of } \\
\text { Deeds office. The MV } \\
\text { Property Record Notice was } \\
\text { placed in local newspapers } \\
\text { during December } 2007 \text {. }\end{array}$ \\
\hline $\begin{array}{l}\text { 4. Excavation/ } \\
\text { penetration } \\
\text { permit program }\end{array}$ & $\begin{array}{l}\text { Remediation systems and } \\
\text { all waste management } \\
\text { areas and areas where } \\
\text { hazardous } \\
\text { substances/structures } \\
\text { remain after remediation at } \\
\text { levels requiring land use } \\
\text { and/or groundwater } \\
\text { restrictions. }\end{array}$ & $\begin{array}{l}\text { Currently established and } \\
\text { functioning. }\end{array}$ & $\begin{array}{l}\text { Monitor } \\
\text { annually to } \\
\text { ensure it is } \\
\text { functioning } \\
\text { properly. }\end{array}$ & $\begin{array}{l}\text { Verify functioning of } \\
\text { permit program against } \\
\text { existing procedures. }\end{array}$ & $\begin{array}{l}\text { Certified. } \\
\text { MV Engineer verified that } \\
\text { the EPP program was } \\
\text { functioning during FY } 09 \\
\text { against existing procedures. }\end{array}$ \\
\hline
\end{tabular}


Table A.1. Verification of Land Use Controls for the Melton Valley Watershed LUCIP requirements being certified as of September 30, 2009 (cont.) ${ }^{1}$

\begin{tabular}{|c|c|c|c|c|c|}
\hline \multicolumn{6}{|c|}{ MV LUCIP Requirements } \\
\hline Type of control & Affected areas & Implementation & Frequency & $\begin{array}{c}\text { Verification } \\
\text { Requirements }\end{array}$ & $\begin{array}{c}\text { Certification } \\
\text { Documentation }\end{array}$ \\
\hline $\begin{array}{l}\text { 5. State advisories/ } \\
\text { postings (e.g., no } \\
\text { fishing or contact } \\
\text { advisory) }\end{array}$ & $\begin{array}{l}\text { White Oak Lake and } \\
\text { White Oak Creek } \\
\text { Embayment }\end{array}$ & $\begin{array}{l}\text { Although not a requirement, } \\
\text { advisories and postings may be } \\
\text { established by TDEC in the future. }\end{array}$ & $\begin{array}{l}\text { Inspect no less } \\
\text { than annually. }\end{array}$ & $\begin{array}{l}\text { Conduct field survey } \\
\text { and assess signs } \\
\text { condition (i.e., remain } \\
\text { intact, erect, and } \\
\text { legible). }\end{array}$ & $\begin{array}{l}\text { Certified. } \\
\text { MV S\&M manager } \\
\text { conducted field survey and } \\
\text { verified that adequate } \\
\text { warning signs have been } \\
\text { posted by DOE at White Oak } \\
\text { Lake dam and at access to } \\
\text { the White Oak Creek } \\
\text { Embayment and meet the } \\
\text { intent of the State } \\
\text { advisories/postings. Per the } \\
\text { description of the control in } \\
\text { the RAR, although not a } \\
\text { requirement, advisories and } \\
\text { postings may be established } \\
\text { by TDEC in the future. }\end{array}$ \\
\hline $\begin{array}{l}\text { 6. Access controls } \\
\text { (e.g., fences, } \\
\text { gates, portals) }\end{array}$ & $\begin{array}{l}\text { At } 20 \text { locations throughout } \\
\text { Melton Valley Watershed } \\
\text { near major access points. }\end{array}$ & $\begin{array}{l}\text { If necessary, selected in the design } \\
\text { or construction completion reports. }\end{array}$ & $\begin{array}{l}\text { Inspect no less } \\
\text { than annually. }\end{array}$ & $\begin{array}{l}\text { Conduct field surveys of } \\
\text { all controls to assess } \\
\text { condition (i.e., remain } \\
\text { erect, intact, and } \\
\text { functioning). }\end{array}$ & $\begin{array}{l}\text { Certified. MV S\&M } \\
\text { manager conducted field } \\
\text { survey and verified that } \\
\text { access controls are in place } \\
\text { around MV. }\end{array}$ \\
\hline 7. Signs & $\begin{array}{l}\text { At } 20 \text { locations throughout } \\
\text { Melton Valley Watershed } \\
\text { near major access points. } \\
\text { At } 6 \text { of the } 20 \text { locations } \\
\text { around the White Oak } \\
\text { Lake and White Oak Creek } \\
\text { Embayment at major } \\
\text { access points. }\end{array}$ & $\begin{array}{l}\text { In place within } 6 \text { months of } \\
\text { approval of the LUCIP. }\end{array}$ & $\begin{array}{l}\text { Inspect no less } \\
\text { than annually. }\end{array}$ & $\begin{array}{l}\text { Conduct field survey of } \\
\text { all signs to assess } \\
\text { condition (i.e., remain } \\
\text { erect, intact, and } \\
\text { legible). }\end{array}$ & $\begin{array}{l}\text { Certified. } \\
\text { MV S\&M manager } \\
\text { conducted field survey and } \\
\text { verified that signs are in } \\
\text { place at } 20 \text { locations around } \\
M V \text {, and that } 6 \text { of the } 20 \text { sign } \\
\text { locations around the White } \\
\text { Oak Lake and White Oak } \\
\text { Creek Embayment also } \\
\text { provide notice to resource } \\
\text { users of contamination and } \\
\text { prohibit fishing/contact }\end{array}$ \\
\hline
\end{tabular}


Table A.1. Verification of Land Use Controls for the Melton Valley Watershed

LUCIP requirements being certified as of September 30, 2009 (cont.) ${ }^{1}$

\begin{tabular}{|c|c|c|c|c|c|}
\hline \multicolumn{6}{|c|}{ MV LUCIP Requirements } \\
\hline Type of control & Affected areas & Implementation & Frequency & $\begin{array}{c}\text { Verification } \\
\text { Requirements }\end{array}$ & $\begin{array}{c}\text { Certification } \\
\text { Documentation }\end{array}$ \\
\hline $\begin{array}{l}\text { 8. Surveillance } \\
\text { patrols }\end{array}$ & $\begin{array}{l}\text { Patrol of selected areas } \\
\text { throughout Melton Valley, } \\
\text { as necessary. }\end{array}$ & $\begin{array}{l}\text { Effective immediately following } \\
\text { LUCIP approval and conducted no } \\
\text { less frequently than once a quarter. }\end{array}$ & $\begin{array}{l}\text { Adequacy of } \\
\text { necessary } \\
\text { patrols assessed } \\
\text { no less than } \\
\text { annually. }\end{array}$ & $\begin{array}{l}\text { Verify against } \\
\text { procedures/plans that } \\
\text { routine patrols } \\
\text { conducted. }\end{array}$ & $\begin{array}{l}\text { Certified. } \\
\text { MV S\&M manager verified } \\
\text { that surveillance patrols were } \\
\text { conducted according to S\&M } \\
\text { procedure. }\end{array}$ \\
\hline \multicolumn{6}{|c|}{ Additional Project-Specific PCCR Requirements } \\
\hline None specified ${ }^{(3)}$ & \begin{tabular}{|l|} 
MV ISG Trenches $5 \& 7$ \\
SWSA 6 \\
SWSA 4 \\
Pit and Trenches \\
SWSA 5 \\
TRU Trenches, \\
Soils and Sediments \\
\end{tabular} & & & & \\
\hline
\end{tabular}

${ }^{1}$ Zoning notice to City Planning Commission will be completed if/when Melton Valley contaminated areas are transferred out of DOE federal control.

${ }^{2}$ Documentation of verification completed by WRRP annually.

${ }^{3}$ No attachments to Appendix A of the MV LUCIP as of September 30, 2009. 


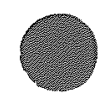

2.

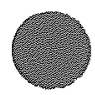




\section{APPENDIX B}

\section{MELTON VALLEY GROUNDWATER DATA}


This page intentionally left blank. 


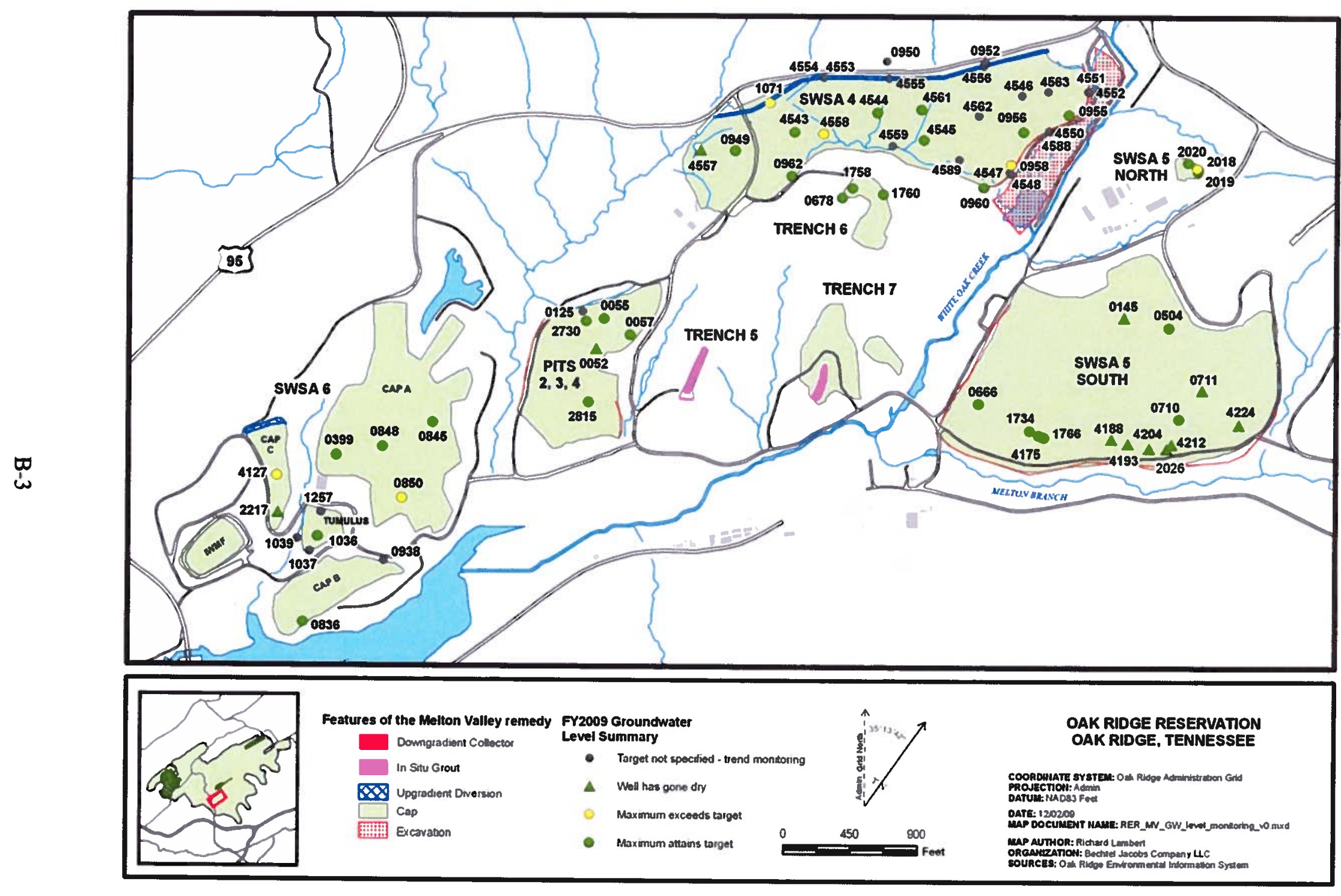

Figure B.1. Locations of groundwater elevation monitoring in Melton Valley. 
Table B.1. FY 2009 Melton Valley Groundwater Level Summary

\begin{tabular}{|c|c|c|c|c|c|c|c|c|c|}
\hline Well & Area & $\begin{array}{c}\text { Measurement } \\
\text { Frequency }\end{array}$ & $\begin{array}{l}\text { Maximum } \\
\text { Elevation }\end{array}$ & $\begin{array}{c}\text { Observed } \\
\text { Range }\end{array}$ & $\begin{array}{c}\text { Target } \\
\text { Elevation }\end{array}$ & $\begin{array}{l}\text { Target } \\
\text { Range }\end{array}$ & $\begin{array}{l}\text { Meets } \\
\text { TE }\end{array}$ & $\begin{array}{c}\text { Meets } \\
\text { Fluctuations } \\
\end{array}$ & Comment \\
\hline 0052 & PT-2,3,4 & $\bar{M}$ & dry & -- & 791.0 & - & & -- & \\
\hline 0055 & PT-2,3,4 & $\mathrm{C}$ & 786.71 & 0.52 & 795.00 & -- & $\mathrm{Y}$ & - & Fluctuates below waste zone \\
\hline 0057 & PT-2,3,4 & $\mathbf{M}$ & 783.86 & 2.89 & 795.00 & -- & $\mathrm{Y}$ & -- & Fluctuates below waste zone \\
\hline 0125 & PT-2,3,4 & $\mathbf{M}$ & 784.76 & 3.11 & 778.70 & 1.83 & - & -- & Outside Cap \\
\hline 2730 & PT-2,3,4 & $\mathbf{M}$ & 778.47 & 1.06 & 791.00 & - & $\mathrm{Y}$ & -- & Fluctuates below waste zone \\
\hline 2815 & PT $-2,3,4$ & $\mathbf{M}$ & 770.28 & 1.43 & 789.00 & -- & Y & - & Fluctuates below waste zone \\
\hline 0678 & PT-Trench 6 & $\mathbf{M}$ & 822.83 & 4.60 & 836 & 1.35 & - & - & Outside Cap \\
\hline 1758 & PT-Trench 6 & $\mathbf{M}$ & 829.94 & 4.58 & 836 & 4.42 & $\mathrm{Y}$ & $\mathrm{N}$ & Fluctuates below waste zone \\
\hline 1760 & PT-Trench 6 & $\mathbf{M}$ & 820.61 & 3.02 & 836 & 1.00 & $\mathrm{Y}$ & $\mathbf{N}$ & Fluctuates below waste zone \\
\hline 0949 & SWSA 4 & $\mathrm{C}$ & 803.63 & 0.65 & 813.78 & 1.48 & $\mathrm{Y}$ & -- & Fluctuates below waste zone \\
\hline 0950 & SWSA 4 & $\mathrm{C}$ & 829.8 & 9.27 & - & - & -- & -- & Outside Cap, UGT Monitoring \\
\hline 0952 & SWSA 4 & $\mathbf{M}$ & 815.01 & 6.10 & 810.44 & - & - & -- & Outside Cap, UGT Monitoring \\
\hline 0955 & SWSA 4 & $\mathbf{M}$ & 759.30 & 3.65 & 759.42 & 1.03 & $\mathrm{Y}$ & $\mathbf{N}$ & $\begin{array}{l}\text { Checking } \\
\text { Calibration caused high }\end{array}$ \\
\hline 0956 & SWSA 4 & $\mathrm{C}$ & 768.29 & 0.25 & 770.49 & 0.40 & $\mathrm{Y}$ & $\mathrm{Y}$ & fluctuation \\
\hline 0958 & SWSA 4 & $Q$ & 762.31 & 2.20 & 761.25 & 0.72 & $\mathbf{N}$ & $\mathbf{N}$ & Fluctuates with DGT level \\
\hline 0960 & SWSA 4 & $\mathbf{Q}$ & 965.28 & 2.22 & -- & -- & -- & -- & Outside Cap \\
\hline 0962 & SWSA 4 & $\mathrm{Q}$ & 819.09 & 3.66 & 822.85 & 0.57 & $\mathbf{Y}$ & $\mathbf{N}$ & Fluctuates below waste zone \\
\hline 1071 & SWSA 4 & $\mathbf{Q}$ & 802.58 & 0.58 & 802.44 & 0.79 & $\mathbf{N}$ & $\mathrm{Y}$ & \\
\hline 4543 & SWSA 4 & $\mathrm{C}$ & 799.70 & 1.71 & 803.31 & & $\mathrm{Y}$ & - & \\
\hline 4544 & SWSA 4 & $\mathrm{C}$ & 789.59 & 0.63 & 791.89 & & $\mathrm{Y}$ & -- & \\
\hline 4545 & SWSA 4 & $\mathrm{C}$ & dry & & 777.25 & & $\mathrm{Y}$ & & \\
\hline 4546 & SWSA 4 & $\mathrm{C}$ & dry & & - & 1.1 & $\mathrm{Y}$ & & \\
\hline 4553 & SWSA 4 & $\mathbf{M}$ & 818.62 & 3.91 & & & - & & Outside Cap, UGT Monitoring \\
\hline 4554 & SWSA 4 & $\mathbf{M}$ & 810.79 & 1.64 & & & -- & & UGT Monitoring \\
\hline 4555 & SWSA 4 & $\mathrm{C}$ & 810.15 & 1.30 & NA & 1.25 & - & & UGT Monitoring \\
\hline 4556 & SWSA 4 & $\mathrm{C}$ & 807.45 & 3.26 & NA & & -- & & UGT Monitoring \\
\hline 4557 & SWSA 4 & $\mathbf{M}$ & dry & - & NA & -- & $\mathrm{Y}$ & - & \\
\hline 4558 & SWSA 4 & $\mathbf{M}$ & 789.91 & 0.42 & & 0.18 & - & $\mathbf{N}$ & \\
\hline 4559 & SWSA 4 & $\mathbf{M}$ & 777.58 & 0.17 & & 0.38 & -- & $\mathbf{Y}$ & \\
\hline 4561 & SWSA 4 & $\mathbf{M}$ & 791.49 & 0.73 & & & & & \\
\hline 4562 & SWSA 4 & $\mathbf{M}$ & 783.33 & 0.63 & & & & & \\
\hline 4563 & SWSA 4 & $\mathrm{C}$ & 778.31 & 0.75 & & & & & \\
\hline
\end{tabular}


Table B.1. FY 2009 Melton Valley Groundwater Level Summary (cont.)

\begin{tabular}{|c|c|c|c|c|c|c|c|c|c|}
\hline Well & Area & $\begin{array}{c}\text { Measurement } \\
\text { Frequency }\end{array}$ & $\begin{array}{l}\text { Maximum } \\
\text { Elevation }\end{array}$ & $\begin{array}{c}\text { Observed } \\
\text { Range }\end{array}$ & $\begin{array}{c}\text { Target } \\
\text { Elevation }\end{array}$ & $\begin{array}{l}\text { Target } \\
\text { Range }\end{array}$ & $\begin{array}{c}\text { Meets } \\
\text { TE }\end{array}$ & $\begin{array}{c}\text { Meets } \\
\text { Fluctuations } \\
\end{array}$ & Comment \\
\hline 4588 & SWSA 4 & $\mathrm{C}$ & 761.18 & 3.68 & & & & & DGT Monitoring \\
\hline 4589 & $\begin{array}{l}\text { SWSA } 4 \\
\text { SWSA } 4\end{array}$ & $\mathrm{C}$ & 772.86 & 1.03 & & & & & DGT Monitoring \\
\hline 4547 & $\begin{array}{c}\text { DGT } \\
\text { SWSA } 4\end{array}$ & $\mathrm{C}$ & 763.07 & 5.63 & & & & & DGT Monitoring \\
\hline 4548 & $\begin{array}{c}\text { DGT } \\
\text { SWSA } 4\end{array}$ & C & 763.02 & 4.34 & & & & & DGT Monitoring \\
\hline 4550 & $\begin{array}{c}\text { DGT } \\
\text { SWSA } 4\end{array}$ & C & 762.63 & 4.85 & & & & & DGT Monitoring \\
\hline 4551 & $\begin{array}{c}\text { DGT } \\
\text { SWSA } 4\end{array}$ & C & 764.13 & 5.89 & & & & & DGT Monitoring \\
\hline 4552 & $\begin{array}{c}\text { DGT } \\
\text { SWSA } 4\end{array}$ & $\mathrm{C}$ & 764.71 & 5.01 & & & & & DGT Monitoring \\
\hline 4595 & $\begin{array}{c}\text { DGT } \\
\text { SWSA } 4\end{array}$ & $\mathrm{C}$ & 763.16 & 3.60 & & & & & DGT Monitoring \\
\hline 4596 & $\begin{array}{c}\text { DGT } \\
\text { SWSA } 4\end{array}$ & C & 763.17 & 6.30 & & & & & DGT Monitoring \\
\hline 4598 & $\begin{array}{c}\text { DGT } \\
\text { SWSA } 4\end{array}$ & $\mathrm{C}$ & 761.22 & 3.95 & & & & & DGT Monitoring \\
\hline 4599 & $\begin{array}{c}\text { DGT } \\
\text { SWSA } 4\end{array}$ & $\mathrm{C}$ & 763.30 & 2.77 & & & & & DGT Monitoring \\
\hline 4605 & $\begin{array}{c}\text { DGT } \\
\text { SWSA } 4\end{array}$ & $\mathrm{C}$ & 761.21 & 3.44 & & & & & DGT Monitoring \\
\hline 4606 & $\begin{array}{c}\text { DGT } \\
\text { SWSA } 4\end{array}$ & $\mathrm{C}$ & 764.40 & 5.89 & & & & & DGT Monitoring \\
\hline 4607 & $\begin{array}{c}\text { DGT } \\
\text { SWSA } 4\end{array}$ & C & 762.64 & 4.32 & & & & & DGT Monitoring \\
\hline 4611 & DGT & C & 764.25 & 4.88 & & & & & DGT Monitoring \\
\hline 2018 & SWSA 5-N & $\mathbf{M}$ & 822.27 & - & 822.2 & 2.5 & $\mathbf{N}$ & - & \\
\hline 2019 & SWSA 5-N & $\mathbf{M}$ & 811.04 & 6.60 & 824.30 & 1.67 & $\mathrm{Y}$ & $\mathbf{N}$ & Fluctuates below waste zone \\
\hline 2020 & SWSA 5-N & $\mathbf{M}$ & 821.90 & 0.05 & 828.20 & 0.78 & $\mathbf{Y}$ & $\mathrm{Y}$ & \\
\hline 0145 & SWSA 5-S & C & dry & -- & 829.10 & 1.9 & $\mathrm{Y}$ & - & \\
\hline 0436 & SWSA 5-S & $\mathbf{M}$ & 768.46 & 0.93 & 773.90 & 2.35 & $\mathbf{Y}$ & $\mathrm{Y}$ & \\
\hline 0504 & SWSA 5-S & $\mathbf{M}$ & 810.71 & 0.05 & 813.10 & 1.83 & $\mathbf{Y}$ & $\mathbf{Y}$ & \\
\hline 0666 & SWSA 5-S & $\mathbf{M}$ & 769.72 & 0.40 & 776.10 & 1.35 & $\mathbf{Y}$ & $\mathrm{Y}$ & \\
\hline 0710 & SWSA 5-S & $\mathbf{M}$ & 782.01 & 1.04 & 791.50 & 1.10 & $Y$ & $\mathbf{Y}$ & \\
\hline 0711 & SWSA 5-S & $\mathbf{M}$ & dry & - & 806.1 & 2.9 & $\mathrm{Y}$ & - & \\
\hline
\end{tabular}


Table B.1. FY 2009 Melton Valley Groundwater Level Summary (cont.)

\begin{tabular}{|c|c|c|c|c|c|c|c|c|c|}
\hline Well & Area & $\begin{array}{l}\text { Measurement } \\
\text { Frequency }\end{array}$ & $\begin{array}{l}\text { Maximum } \\
\text { Elevation }\end{array}$ & $\begin{array}{l}\text { Observed } \\
\text { Range }\end{array}$ & $\begin{array}{c}\text { Target } \\
\text { Elevation }\end{array}$ & $\begin{array}{l}\text { Target } \\
\text { Range }\end{array}$ & $\begin{array}{l}\text { Meets } \\
\text { TE }\end{array}$ & $\begin{array}{c}\text { Meets } \\
\text { Fluctuations }\end{array}$ & Comment \\
\hline 1734 & SWSA 5-S & $\mathrm{C}$ & dry & - & 776.70 & 2.2 & $\mathbf{Y}$ & $\cdots$ & \\
\hline 1766 & SWSA 5-S & $\mathbf{M}$ & dry & - & 773.9 & 2.1 & $\mathbf{Y}$ & - & \\
\hline 2026 & SWSA 5-S & $\mathrm{C}$ & dry & - & 773.3 & 1.2 & $\mathrm{Y}$ & - & \\
\hline 4175 & SWSA 5-S & $\mathbf{M}$ & dry & - & 775.80 & 4.10 & $Y$ & - & \\
\hline 4188 & SWSA 5-S & $\mathbf{M}$ & dry & - & 772.90 & 1.63 & $\mathrm{Y}$ & - & \\
\hline 4193 & SWSA 5-S & $\mathbf{M}$ & dry & - & 775.40 & 1.32 & $\mathrm{Y}$ & - & \\
\hline 4204 & SWSA 5-S & $\mathbf{M}$ & dry & - & 773.00 & 1.40 & $\mathrm{Y}$ & - & \\
\hline 4212 & SWSA 5-S & $\mathbf{M}$ & dry & - & 773.7 & 1.68 & $\mathrm{Y}$ & - & \\
\hline 4224 & SWSA 5-S & $\mathbf{M}$ & dry & $\ldots$ & 781.6 & 1.88 & $\mathrm{Y}$ & -- & \\
\hline 0399 & SWSA 6 & $\mathbf{M}$ & 776.41 & 3.67 & 782.90 & 1.36 & $\mathrm{Y}$ & $\mathbf{N}$ & $\begin{array}{l}\text { Fluctuates below waste zone } \\
\text { Near cap edge, fluctuates below }\end{array}$ \\
\hline 0836 & SWSA 6 & $\mathbf{M}$ & 747.03 & 2.35 & 753.00 & -- & $\mathrm{Y}$ & -- & $\begin{array}{l}\text { waste zone } \\
\text { Bedrock well, fluctuates below }\end{array}$ \\
\hline 0845 & SWSA 6 & $\mathbf{M}$ & 782.28 & 1.24 & 784.10 & 0.82 & $\mathbf{Y}$ & $\mathbf{N}$ & waste zone \\
\hline 0848 & SWSA 6 & $\mathbf{M}$ & 778.10 & 0.42 & 779.20 & 0.27 & $\mathrm{Y}$ & $\mathbf{N}$ & $\begin{array}{l}\text { Bedrock well, Steadily declining } \\
\text { Seasonally exceeds target }\end{array}$ \\
\hline 0850 & SWSA 6 & $\mathrm{C}$ & 767.29 & 2.76 & 765.90 & 2.1 & $\mathbf{N}$ & $\mathbf{N}$ & elevation \\
\hline 0938 & SWSA 6 & $\mathbf{M}$ & 756.6 & 3.15 & 753.80 & - & - & -- & Outside cap, bedrock well \\
\hline 1036 & SWSA 6 & $\mathrm{C}$ & 763.53 & 4.27 & 768.00 & -- & $\mathrm{Y}$ & -- & \\
\hline 1037 & SWSA 6 & $\mathbf{M}$ & 759.00 & 5.12 & 767.00 & -- & - & -- & Outside cap \\
\hline 1039 & SWSA 6 & $\mathbf{M}$ & 763.23 & 3.70 & 768.00 & -- & -- & - & Outside cap \\
\hline 1257 & SWSA 6 & $\mathbf{M}$ & 769.48 & 3.82 & 769.00 & - & - & $\cdots$ & Outside cap \\
\hline 2217 & SWSA 6 & $\mathrm{C}$ & dry & -- & 767.6 & 2.5 & $\mathrm{Y}$ & - & \\
\hline 4127 & SWSA 6 & $\mathbf{M}$ & 774.37 & 2.52 & 772.30 & 2.25 & $\mathbf{N}$ & $\mathbf{N}$ & Bedrock well \\
\hline
\end{tabular}

$\mathrm{C}=$ continuous groundwater level monitoring using pressure transducer and data logger

$M=$ monthly manual groundwater level measurements

$Q=$ quarterly manual groundwater level measurements 

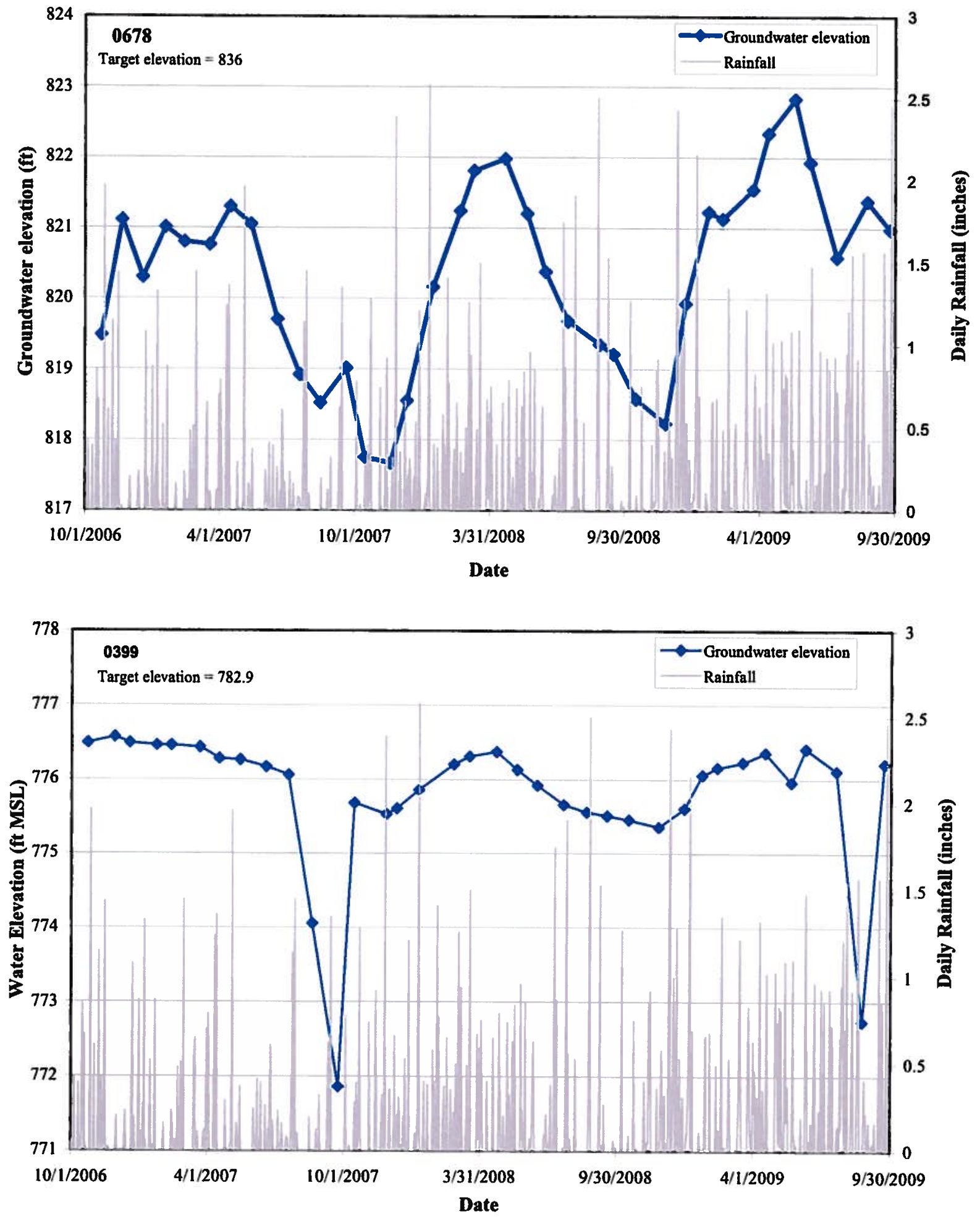

Figure B.2. Well hydrographs for wells 0678 and 0399. 

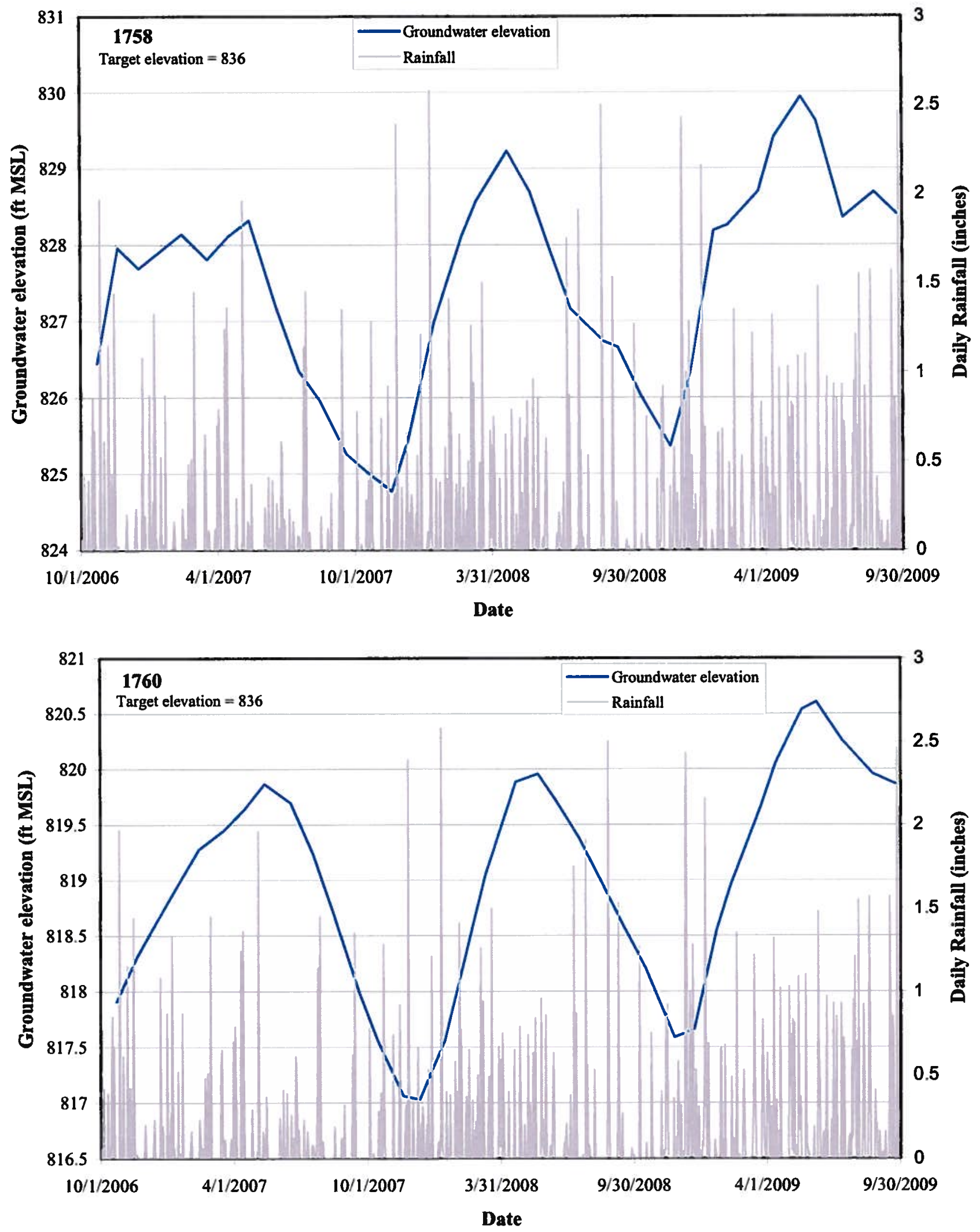

Figure B.3. Well hydrographs for wells 1758 and 1760. 

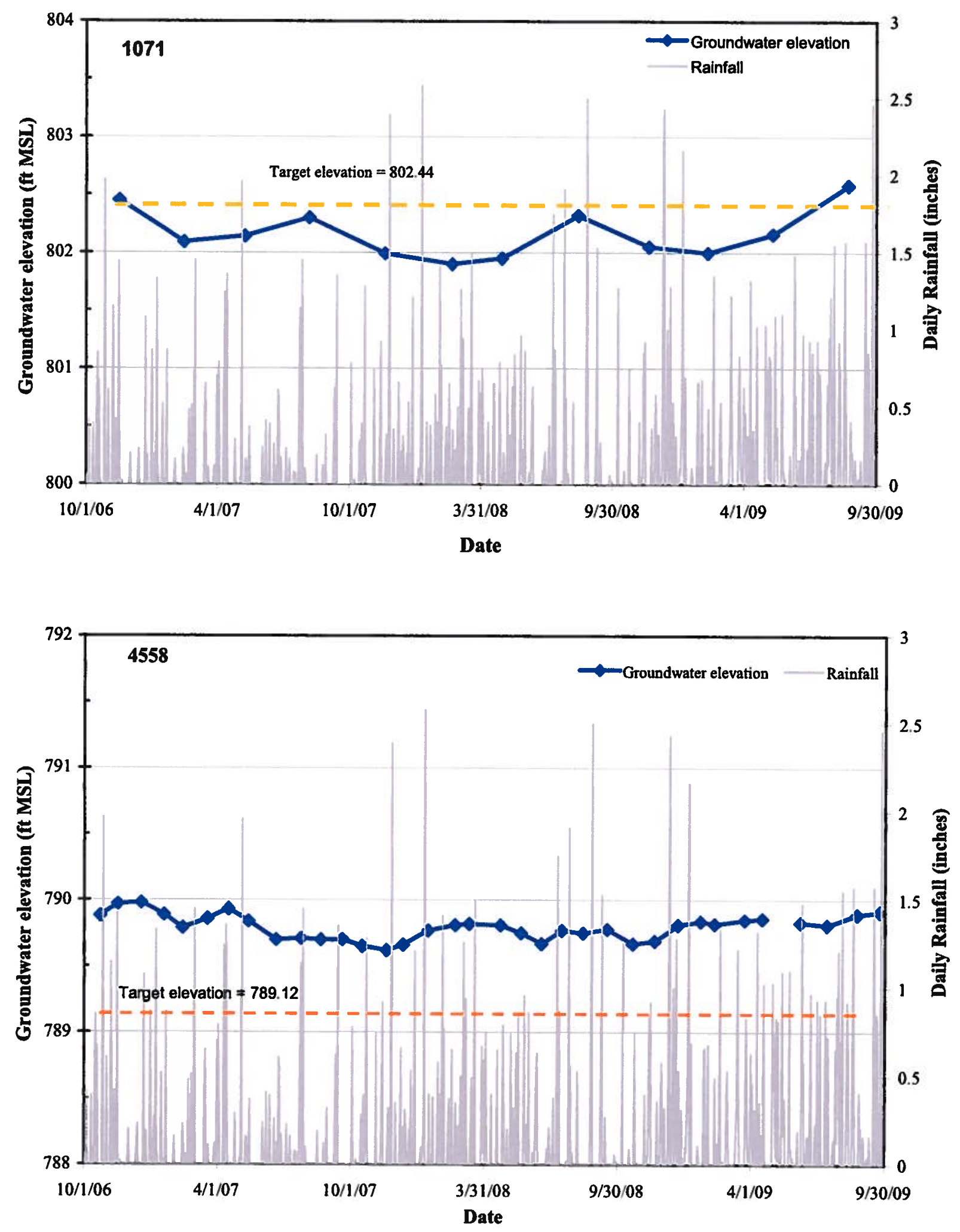

Figure B.4. Well hydrographs for wells 1071 and 4558. 

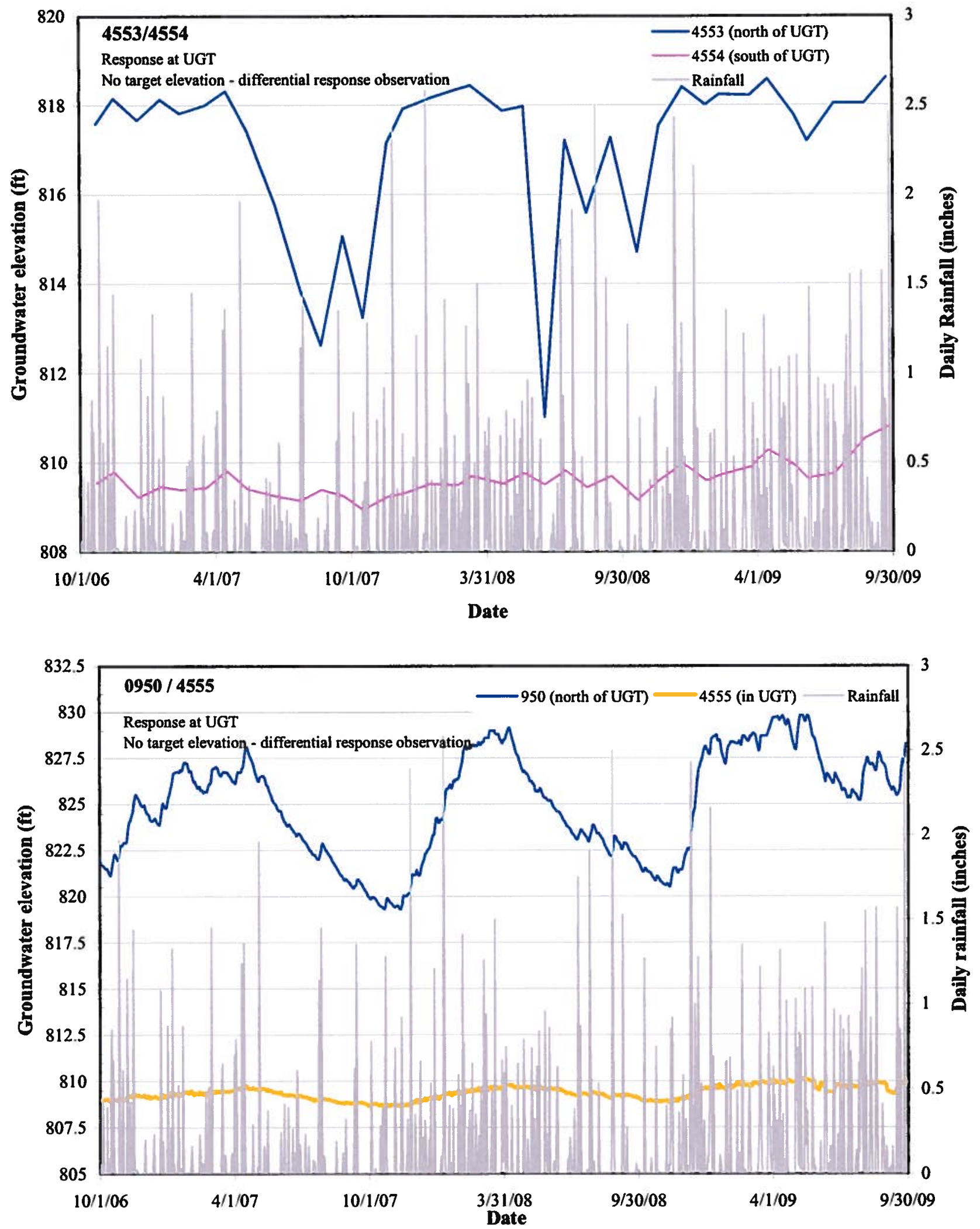

Figure B.5. Well hydrographs for wells $4553 / 4554$ and $0950 / 4555$.

B-10 

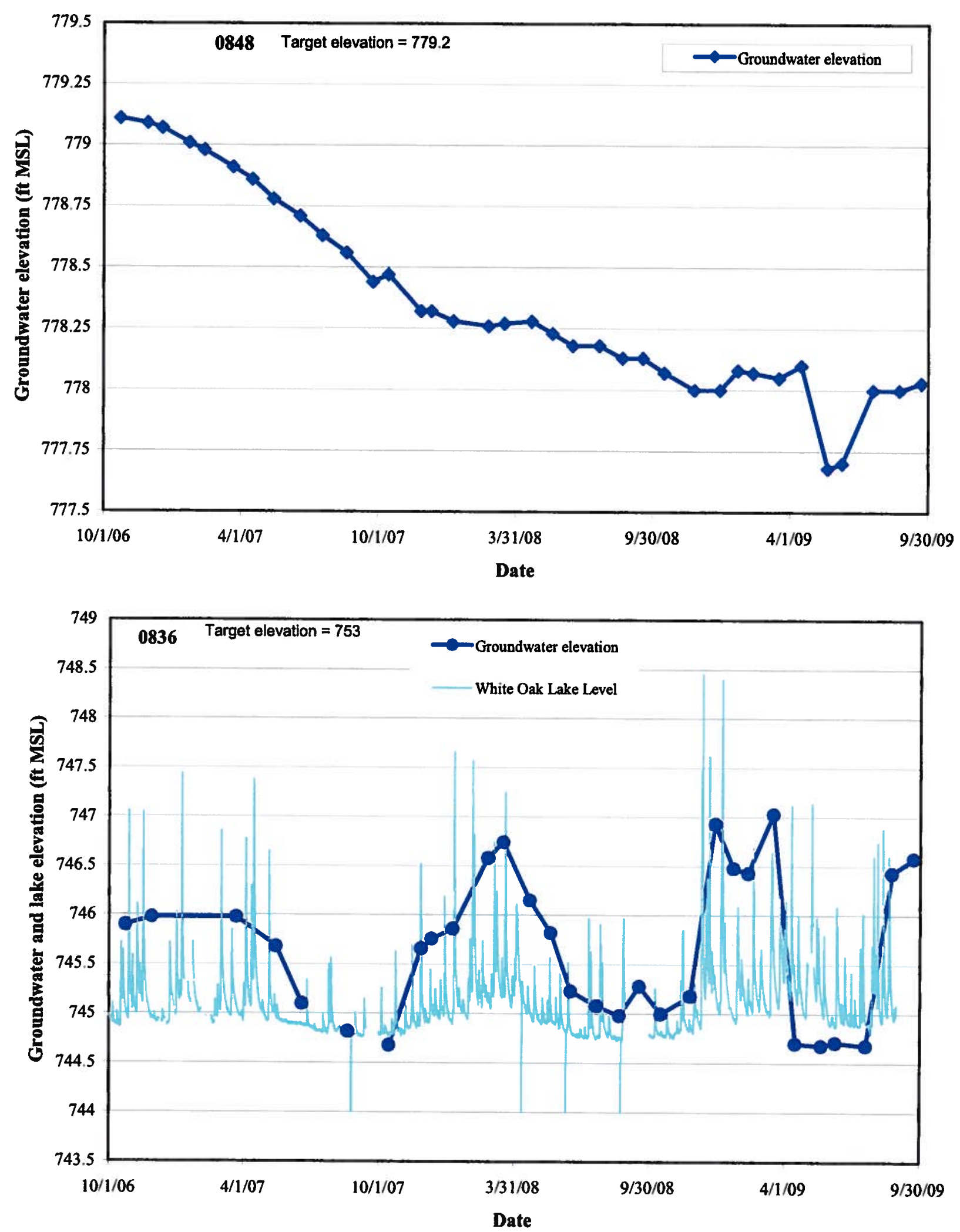

Figure B.6. Well hydrographs for well pairs 0848 and 0836.

B-11 

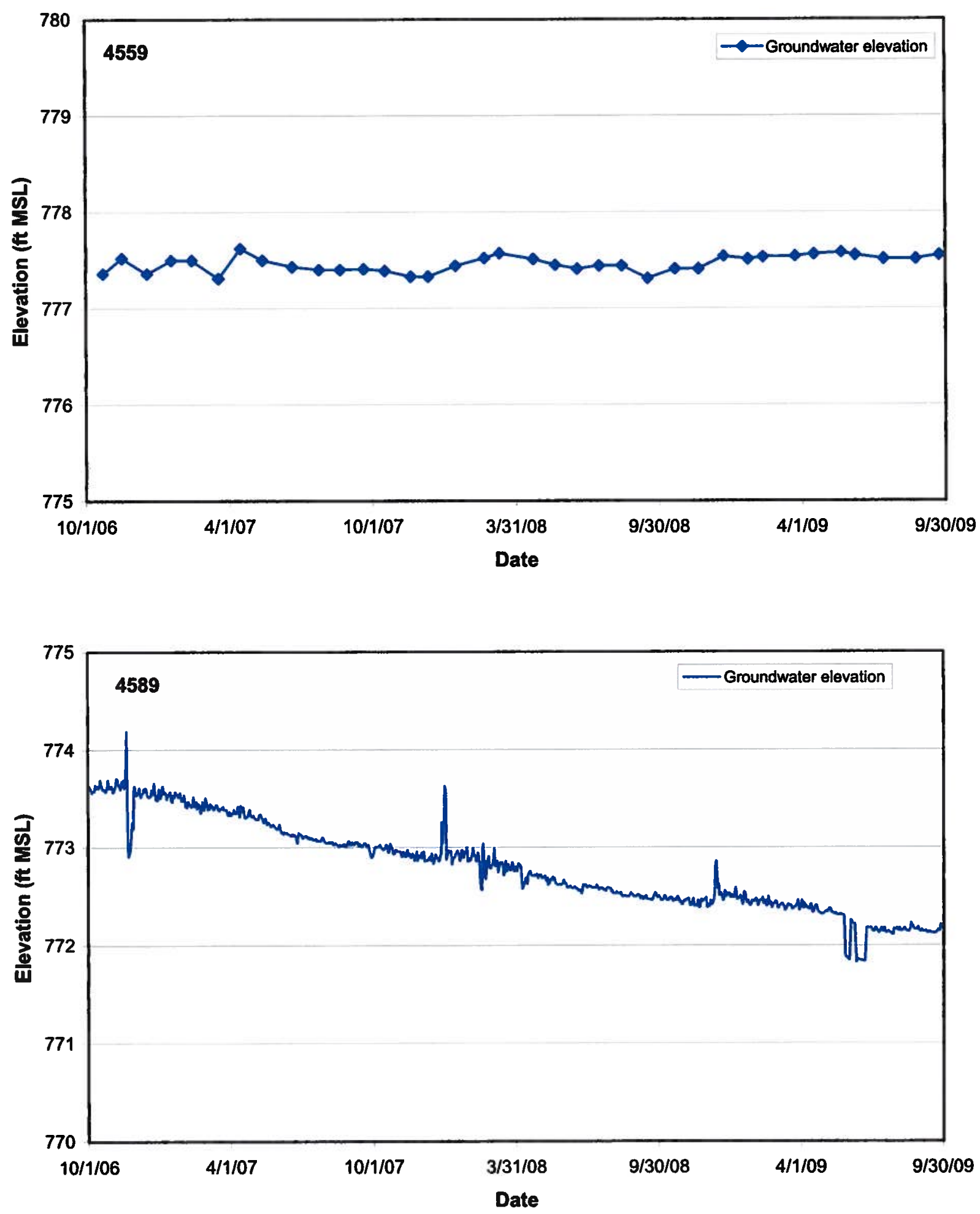

Figure B.7. Well hydrographs for wells 4559 and 4589. 

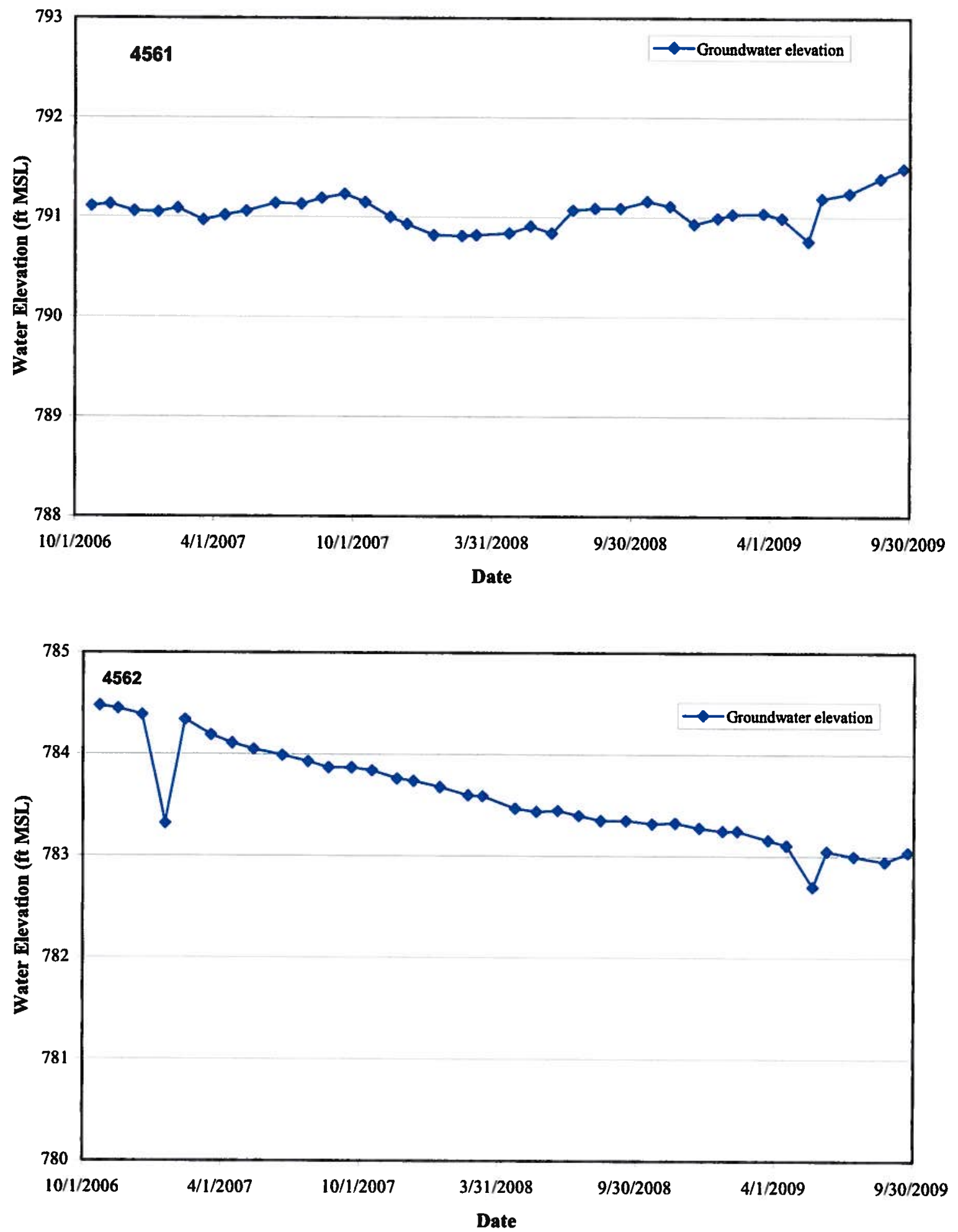

Figure B.8. Well hydrographs for wells 4561 and 4562.

B-13 

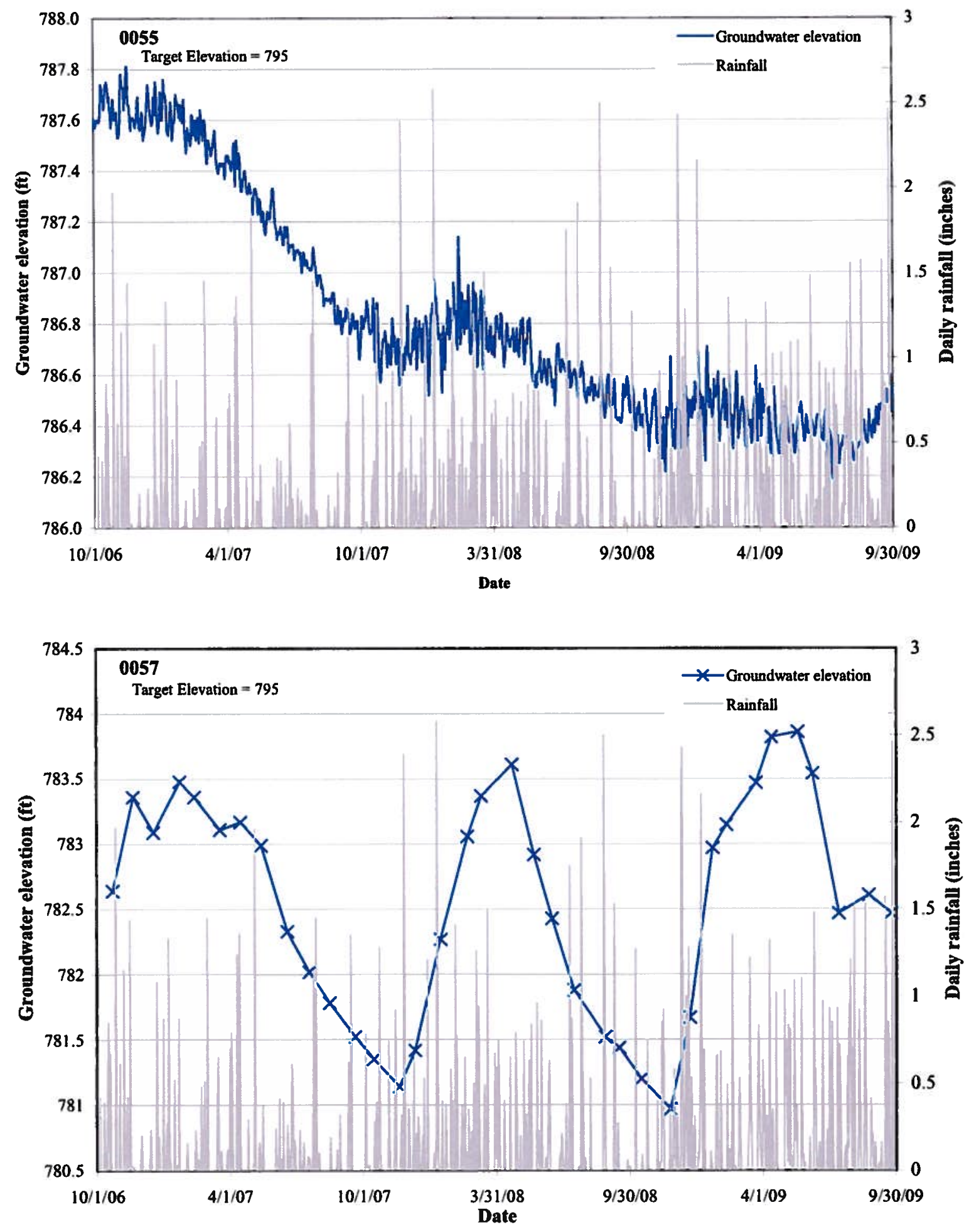

Figure B.9. Well hydrographs for wells 0055 and 0057. 

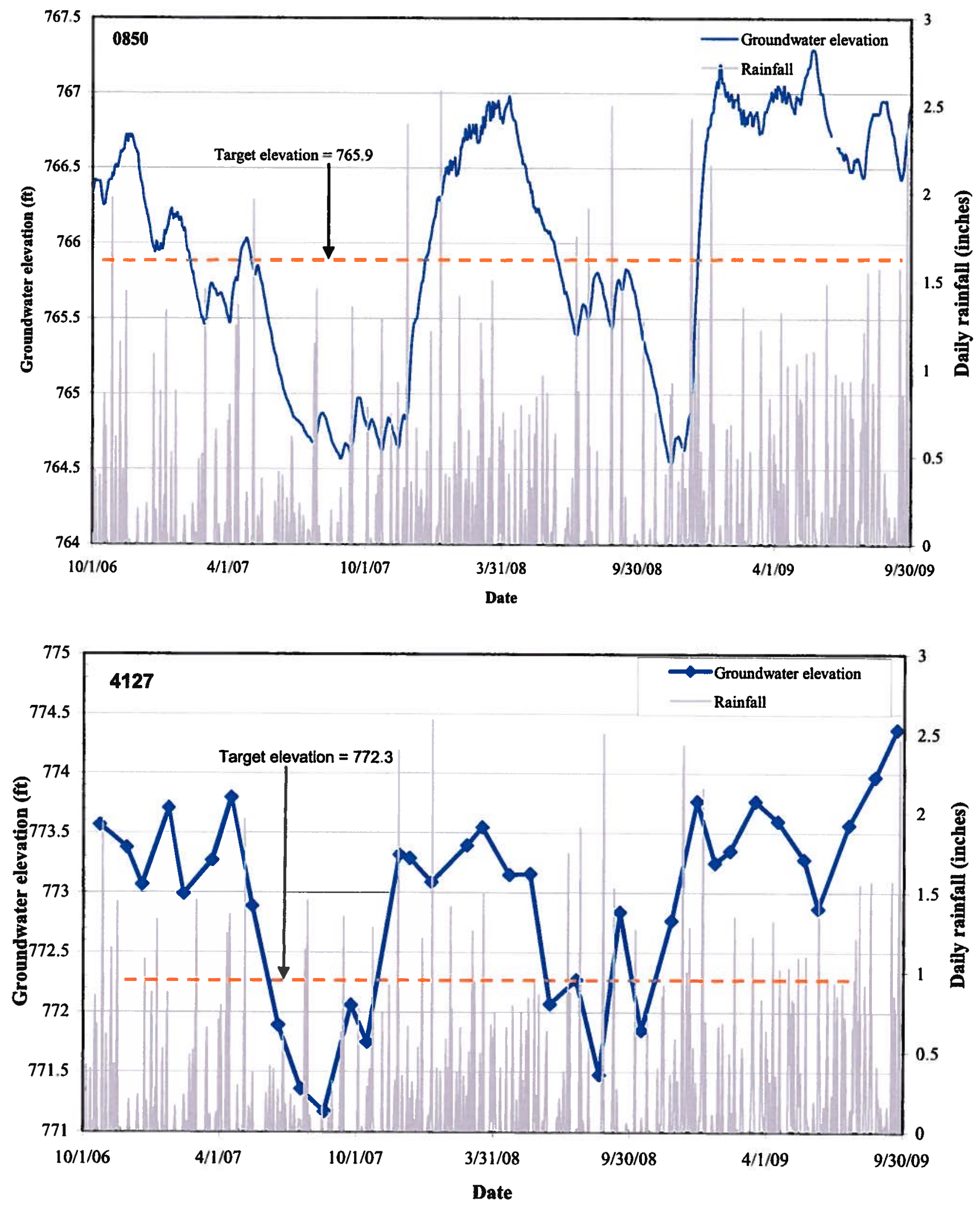

Figure B.10. Well hydrographs for wells 0850 and 4127. 

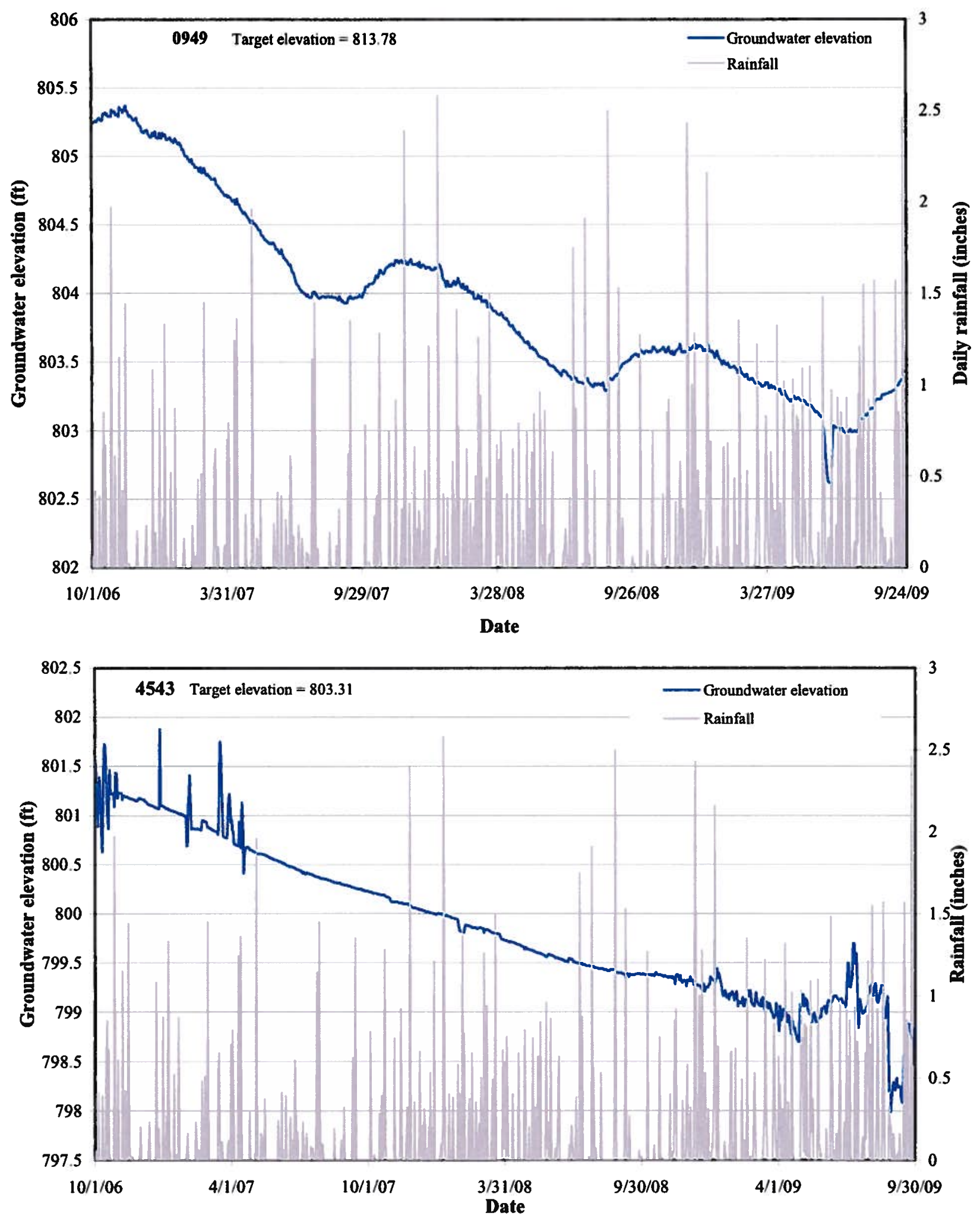

Figure B.11. Well hydrographs for wells 0949 and 4553. 

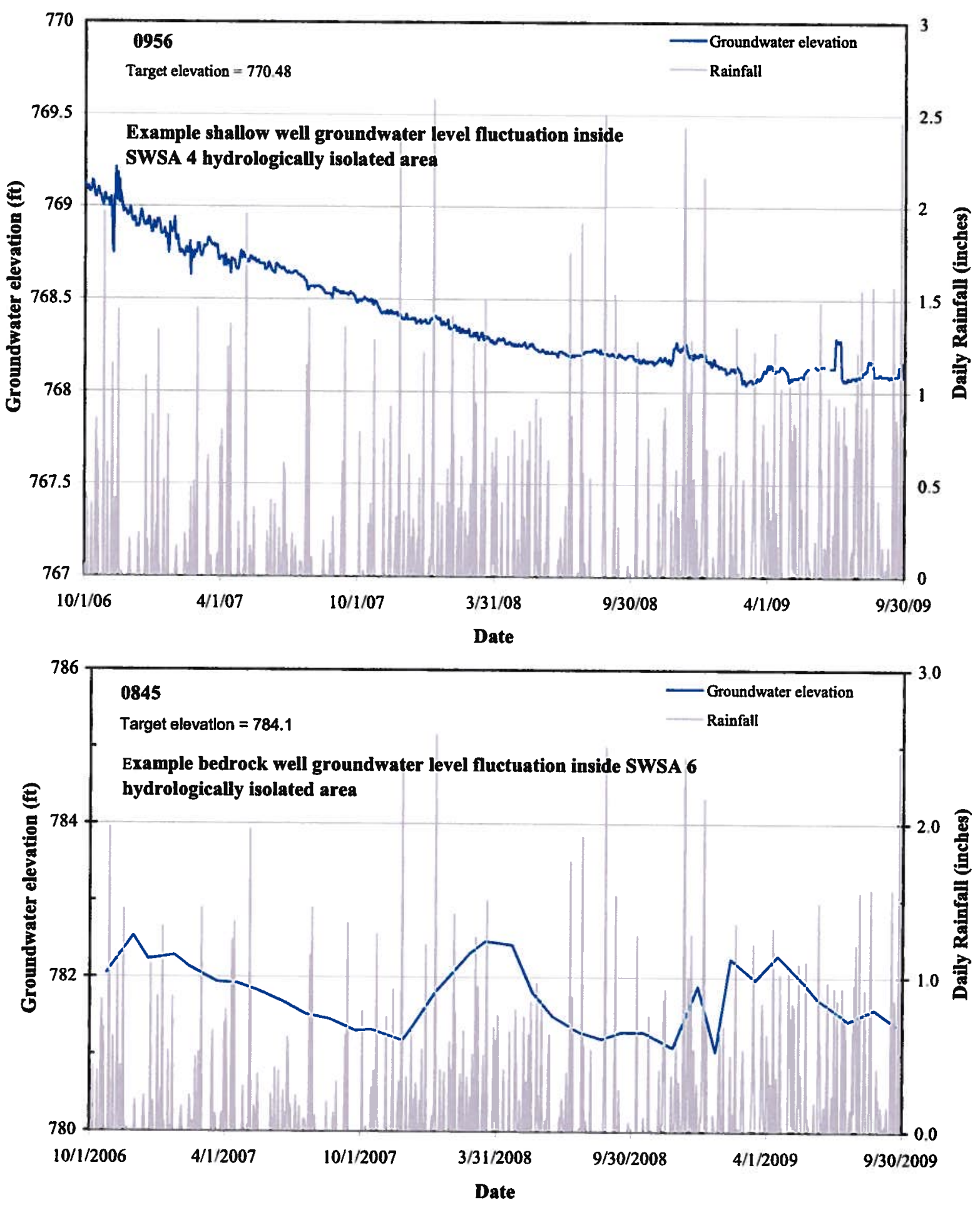

Figure B.12. Well hydrographs for well pair 0956 and well 0845. 

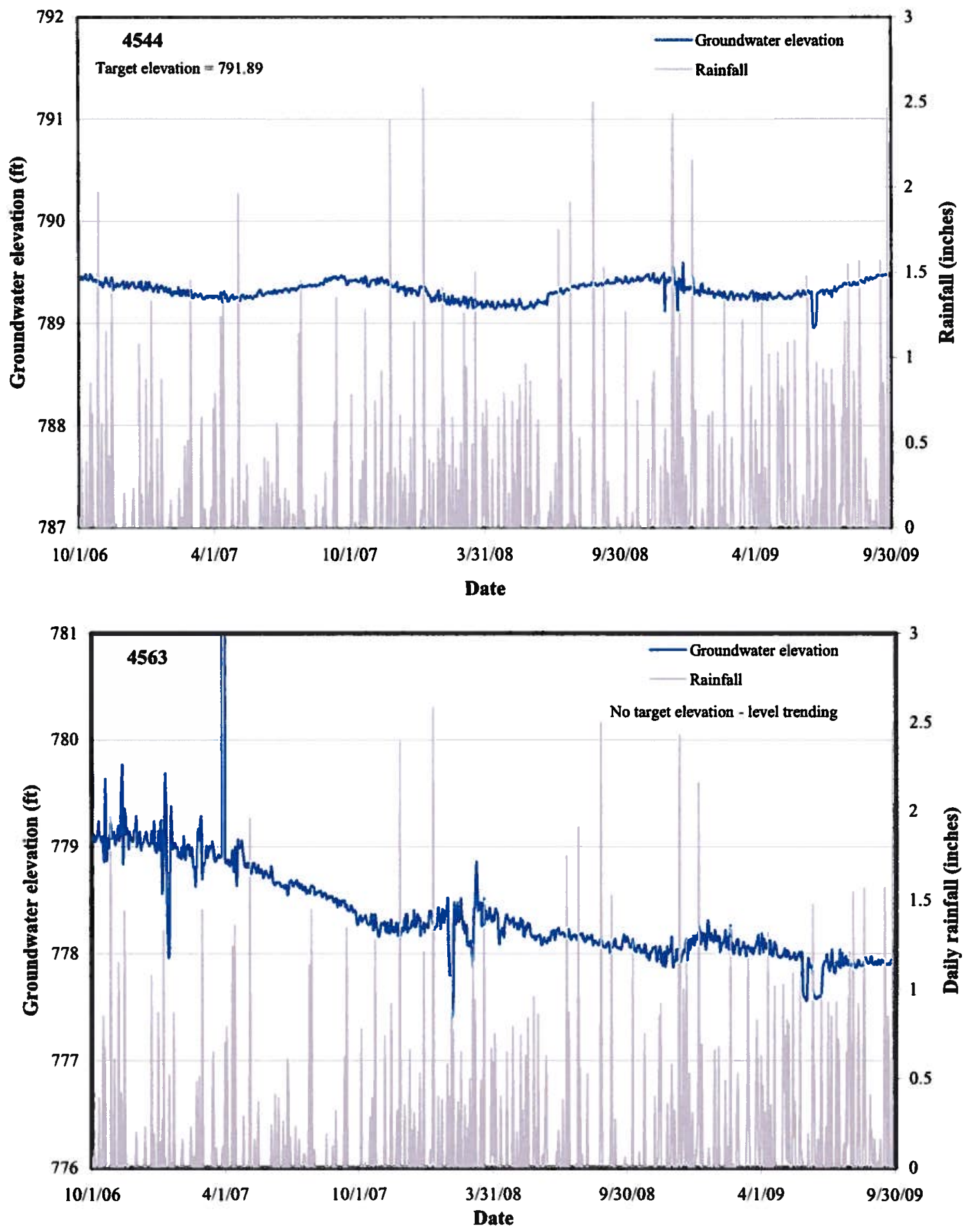

Figure B.13. Well hydrographs for wells 4544 and 4563. 

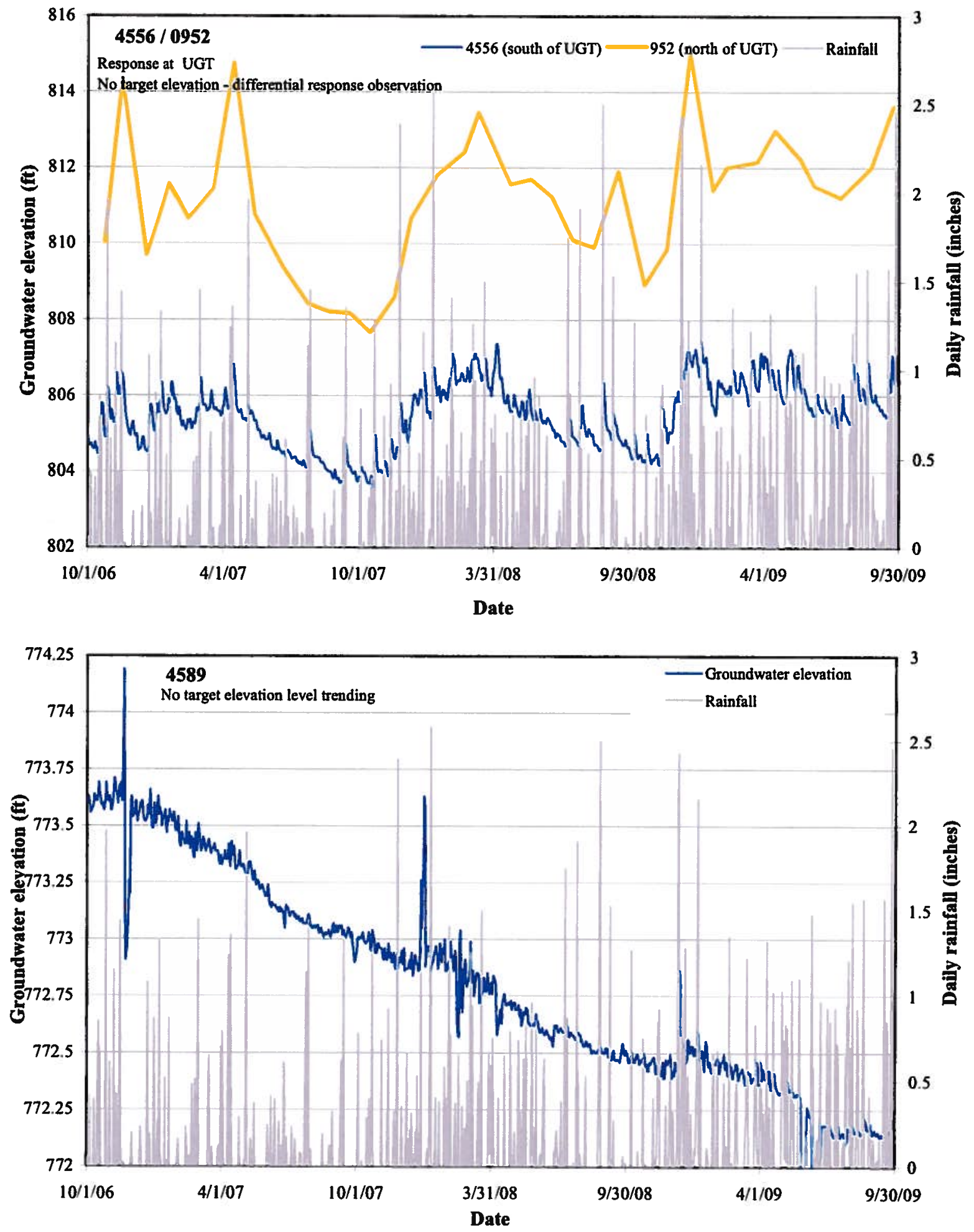

Figure B.14. Well hydrographs for wells $4556 / 0952$ and 4589 . 

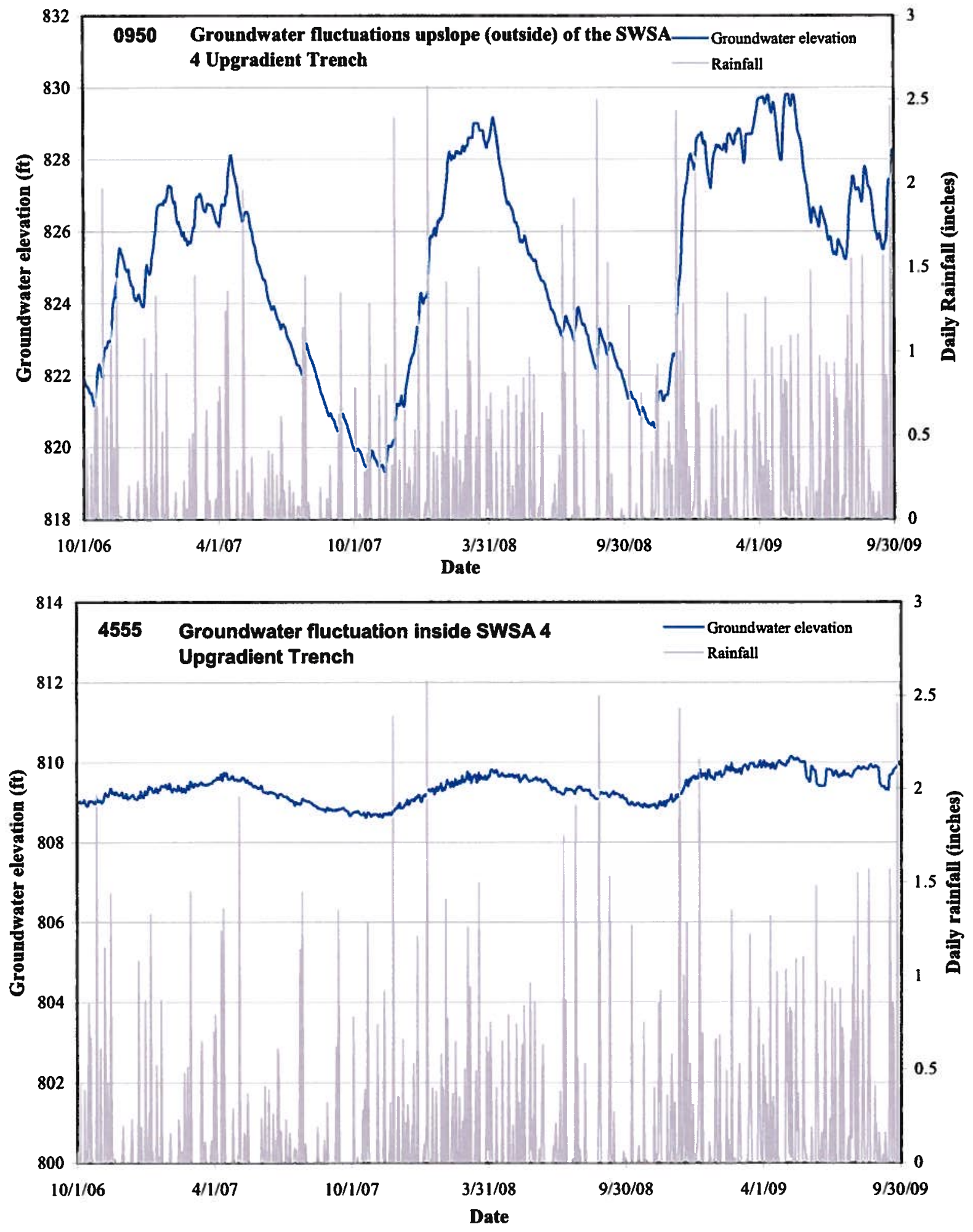

Figure B.15. Well hydrographs for wells 0950 and 4555. 

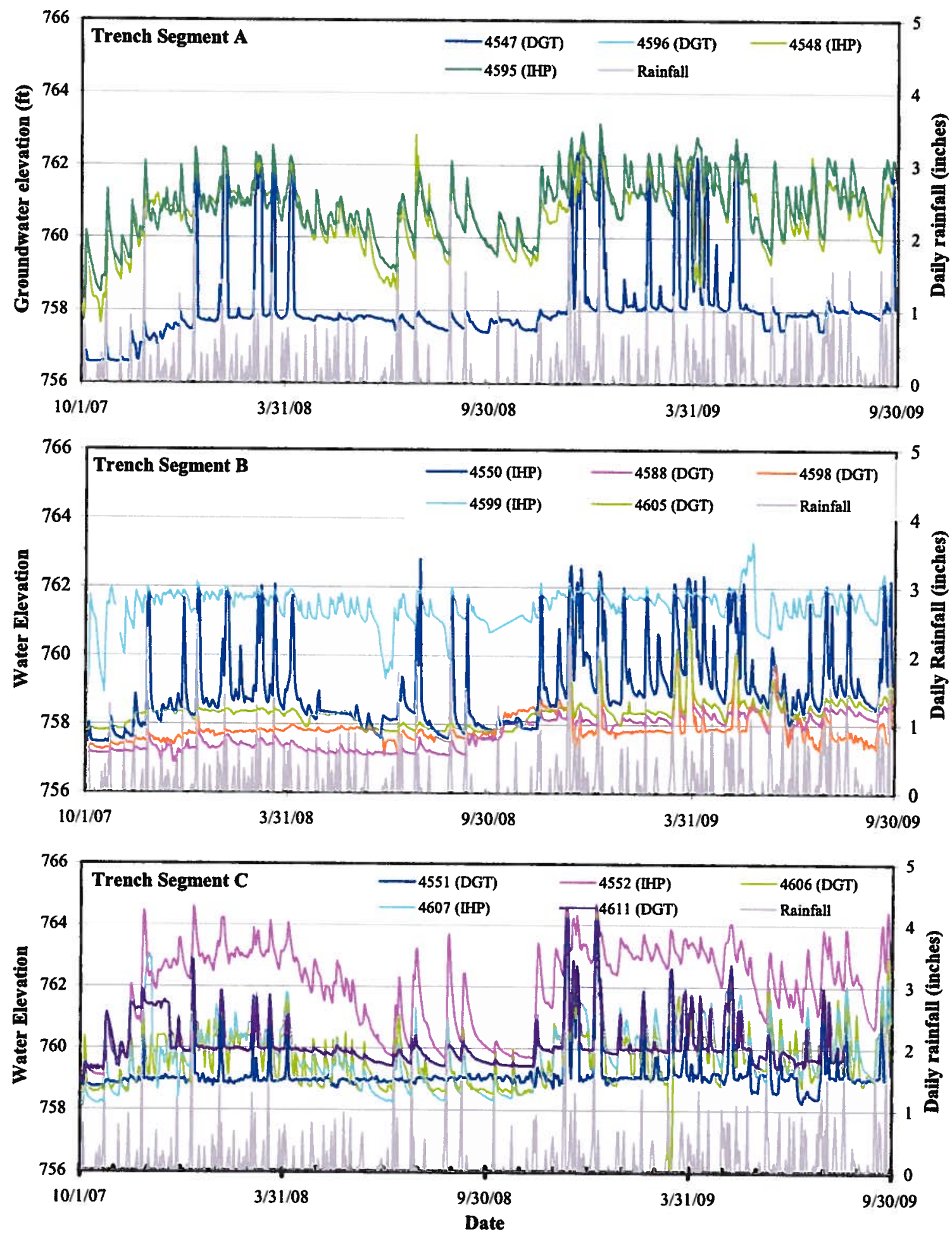

Figure B.16. Well hydrographs for wells at the SWSA 4 downgradient trench (FY 2009). 

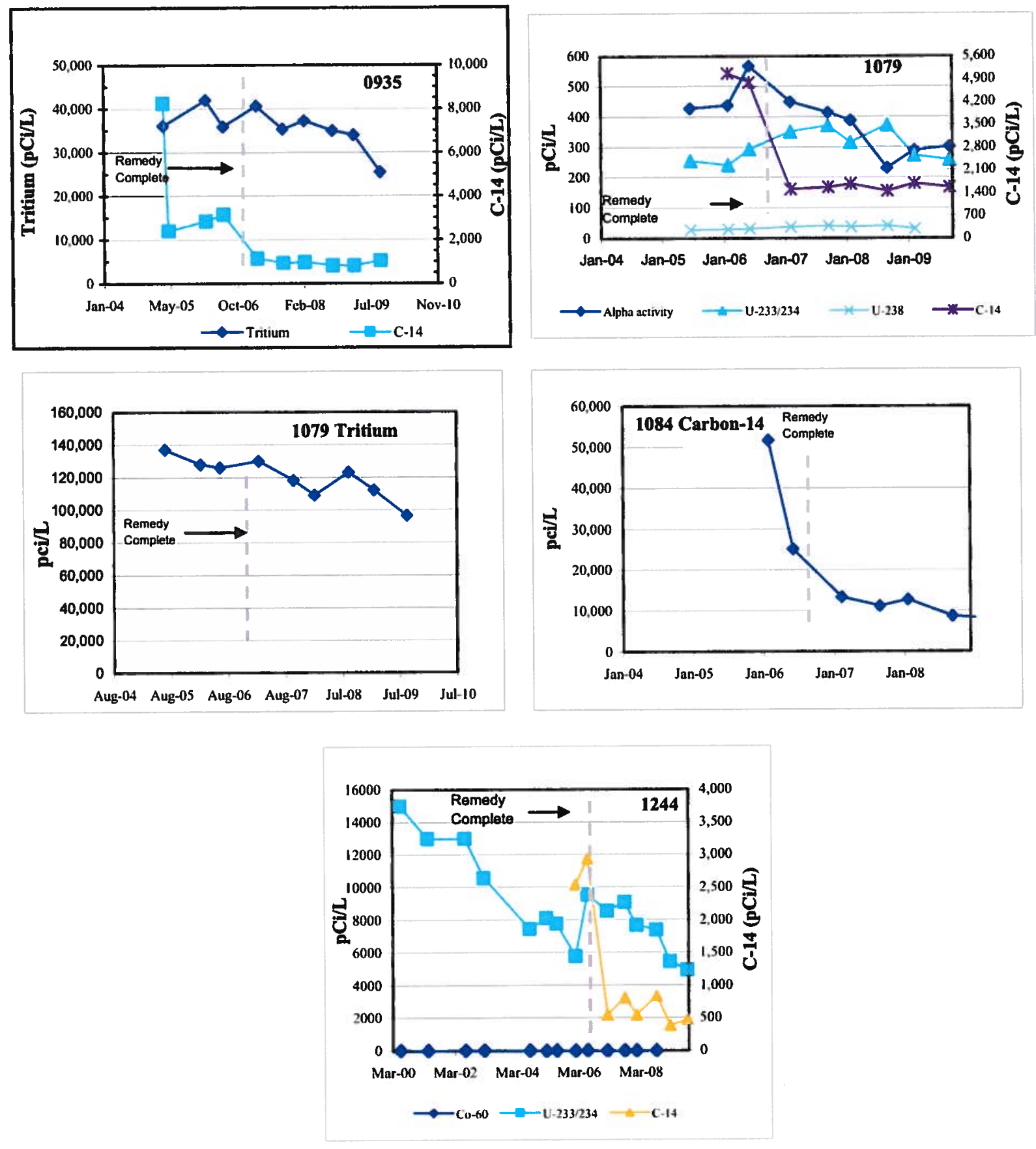

Figure B.17. Concentration trends for selected radionuclides at Pits and Trenches wells 0935, 1079, 1084, and 1244. 

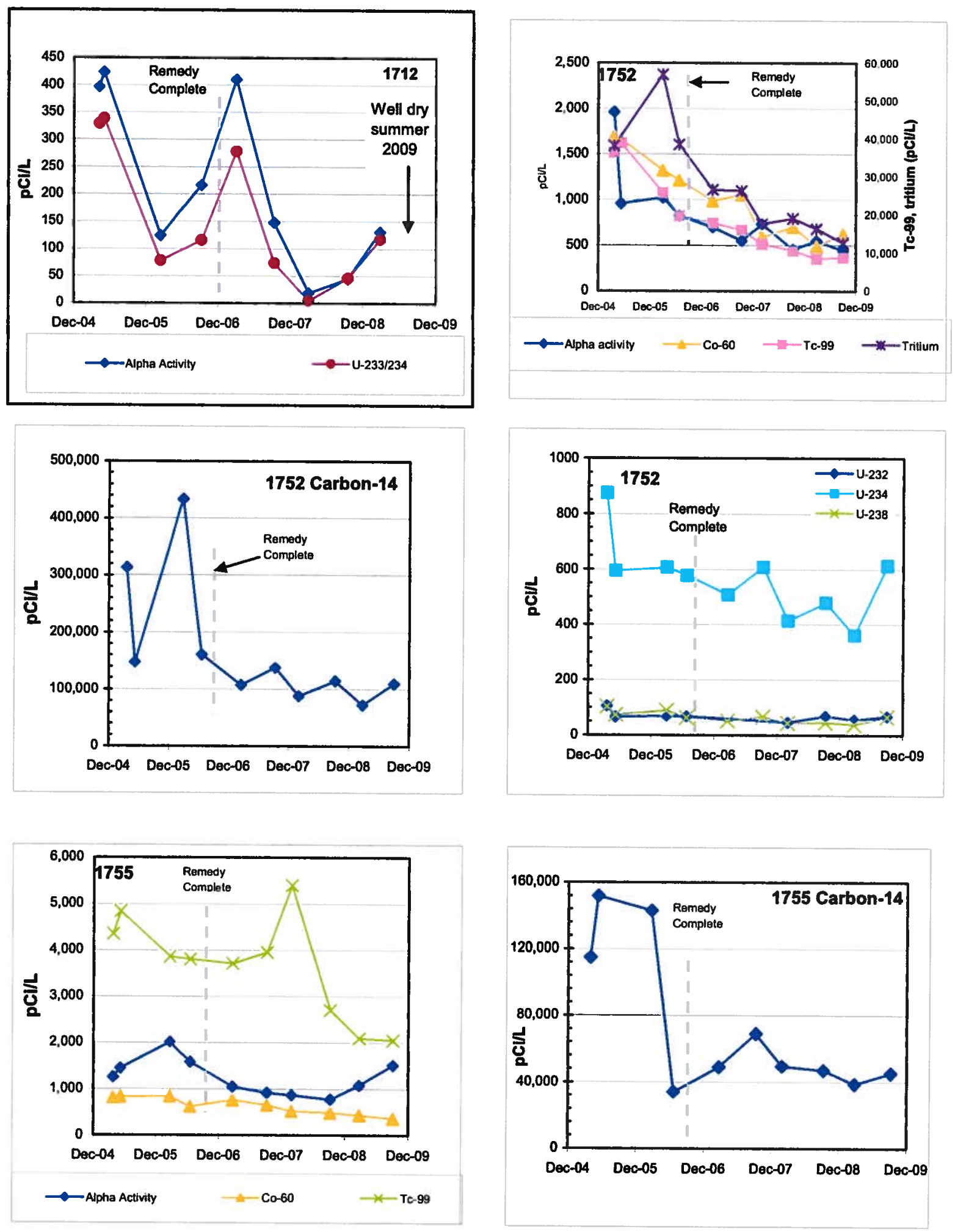

Figure B.18. Concentration histories for selected radionulicides at Pits and Trenches wells 1712, 1752, and 1755. 

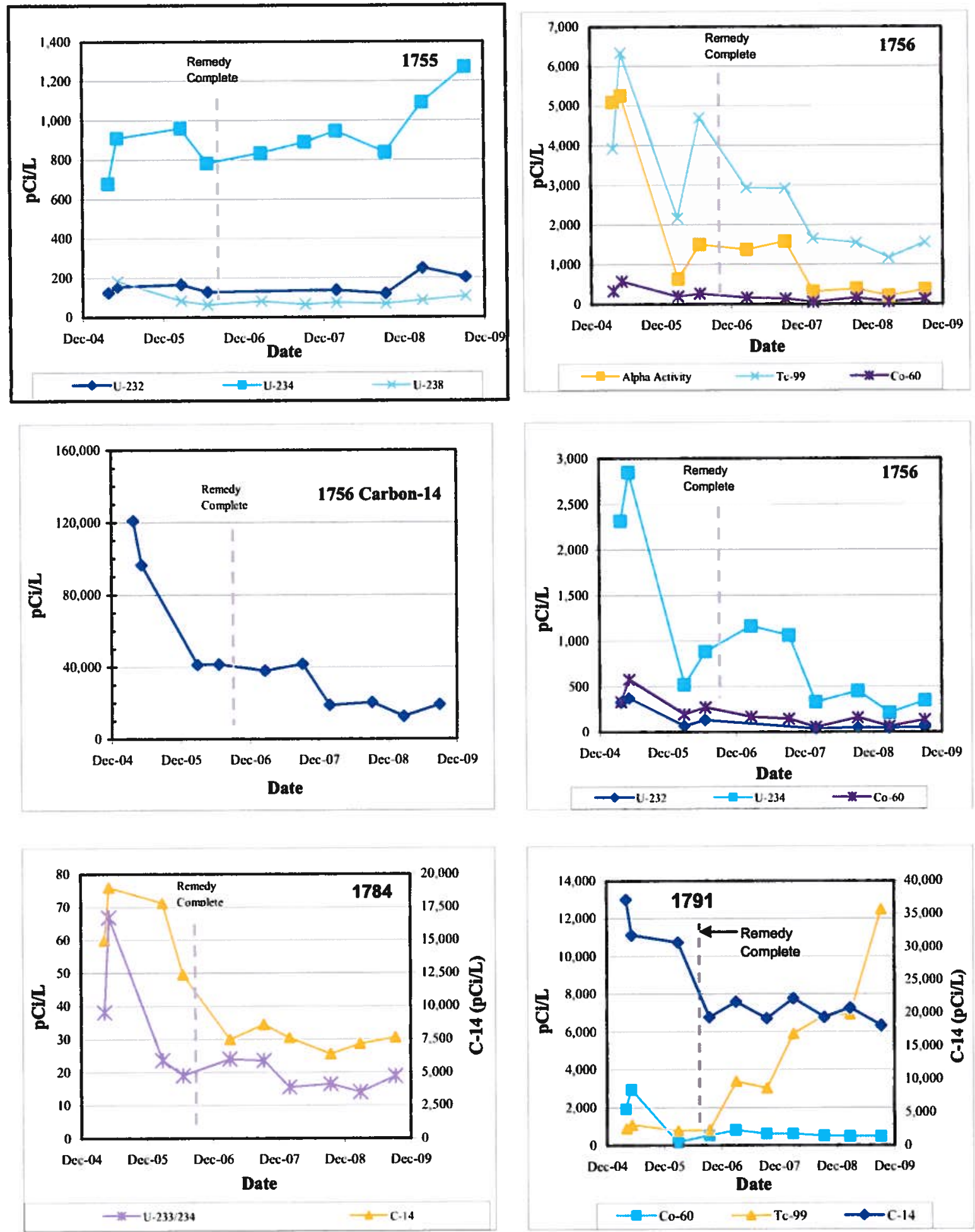

Figure B.19. Concentrations histories for selected radionuclides in Pits and Trenches wells 1755, 1756, 1784, and 1791. 

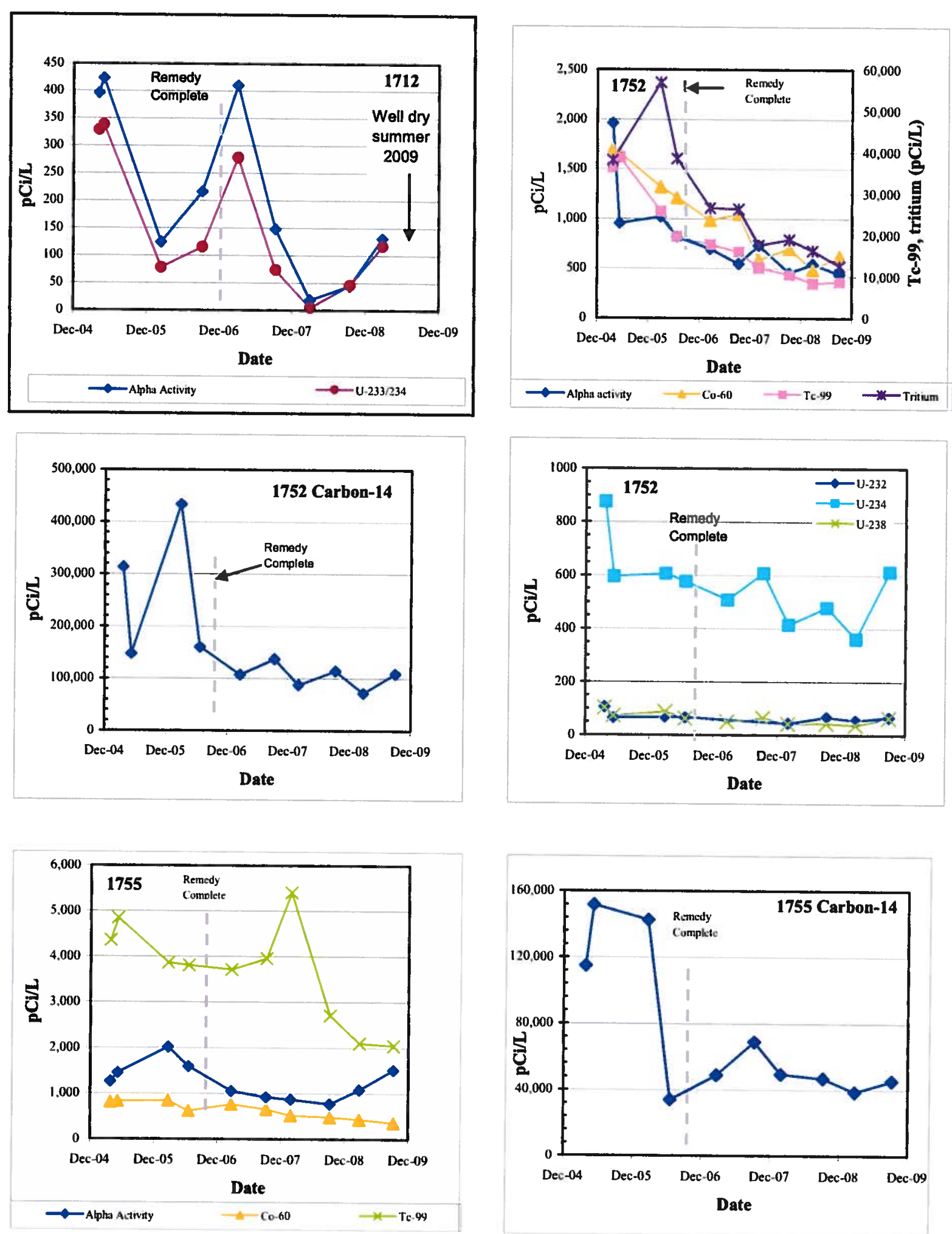

Figure B.20. Concentration histories for selected radionuclides in Pits and Trenches wells 4564, 4565, 4566, and 4587. 

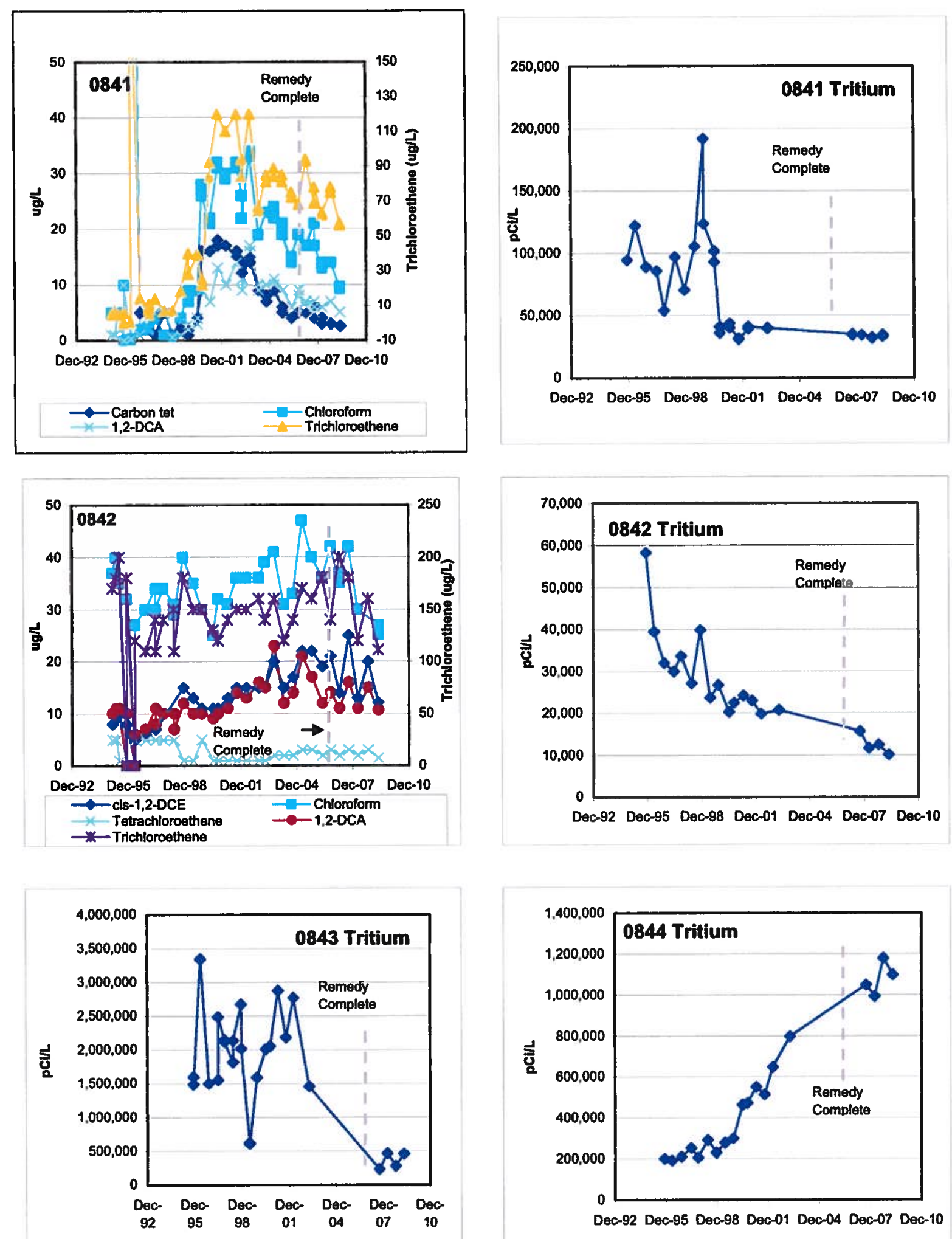

Figure B.21. Concentration trends for contaminants in SWSA 6 wells 0841, 0842, 0843, and 0844. 


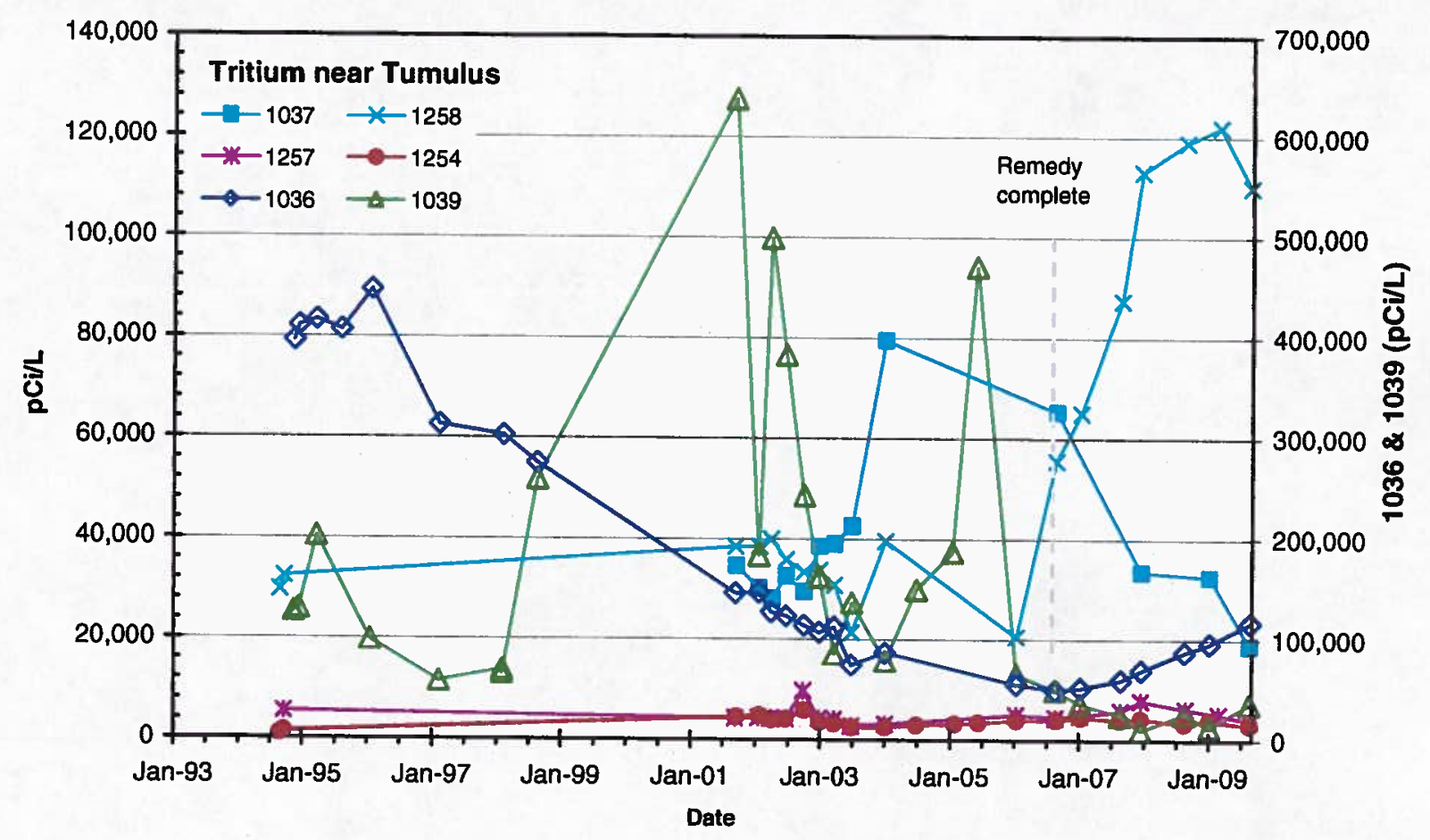

Figure B.22. Tritium trends in groundwater near the Tumulus facility. 


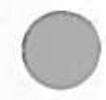

(

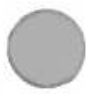




\section{RECORD OF DISTRIBUTION}

File-EMEF DMC-RC 


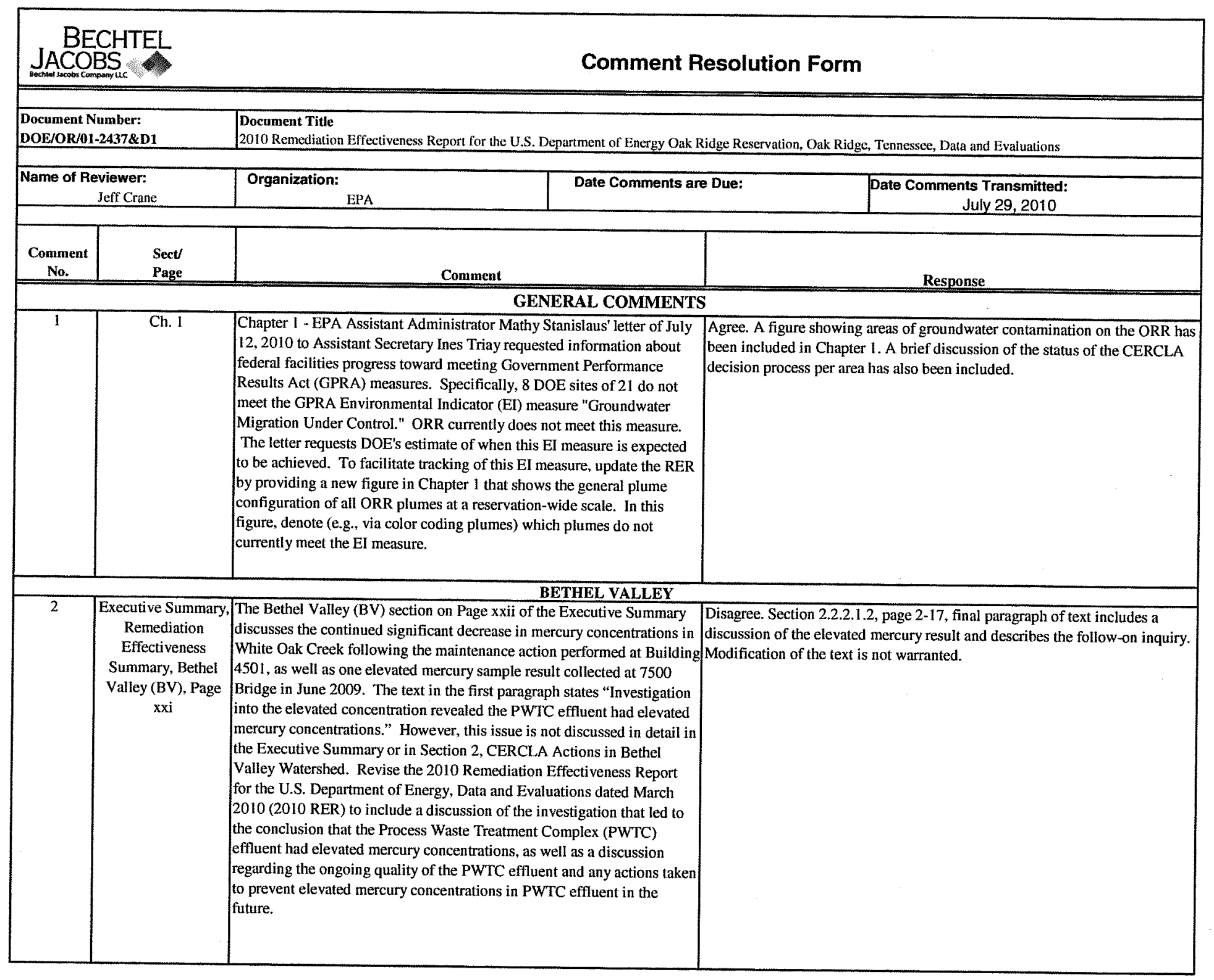




\begin{tabular}{|c|c|c|c|}
\hline $\begin{array}{c}\text { Comment } \\
\text { No. }\end{array}$ & $\begin{array}{l}\text { Sect/ } \\
\text { Page }\end{array}$ & Comment & Response \\
\hline $3 \mathrm{a}$ & \begin{tabular}{|c|} 
Sect. 2.3.1.3 \\
Performance \\
Summary, Page 2-37
\end{tabular} & $\begin{array}{l}\text { (a) Section 2.3.1.3 describes performance issues associated with the } \\
\text { Corehole } 8 \text { Plume collection system and provides recommendations for } \\
\text { responses. The recommendations as stated include "l) identification and } \\
\text { repair of potable water leaks in the vicinity of the contaminant source } \\
\text { areas and plumes which cause contaminant releases and overwhelm } \\
\text { collection systems, and 2) conduct an engineering evaluation of the } \\
\text { existing Corehole } 8 \text { Plume collection system and refurbish, as needed, to } \\
\text { ensure proper operation." Revise Section } 2.3 .1 .3 \text { and Table } 1.1,2010 \\
\text { summary of technical issues, recommendations, and follow-up actions, to } \\
\text { provide more detail regarding the proposed engineering evaluation } \\
\text { including specific analyses that will be performed on the Corehole } 8 \\
\text { Plume collection system. Alternatively, indicate that a scope of work } \\
\text { (i.e., work plan) for these actions will be submitted that will identify the } \\
\text { details of the proposed actions. }\end{array}$ & $\begin{array}{l}\text { Disagree. This RER reports monitoring and performance of remedies through } \\
\text { September } 2009 \text {. Subsequent to that time, DOE has initiated preparation of an } \\
\text { RDR/RAWP to enhance collection and treatment capabilties for the Core } \\
\text { Hole } 8 \text { plume. That process is ongoing in the ORNL. Core Team context with } \\
\text { preparation and review of the CERCLA document. Since all this activity is } \\
\text { FY } 2010 \text { progress, it will be reported in the } 2011 \text { RER. }\end{array}$ \\
\hline $3 b$ & $\begin{array}{l}\text { Exec. Sum.. Page } \\
\text { xxii }\end{array}$ & $\begin{array}{l}\text { (b) In addition, revise this section to address the firewater utility system } \\
\text { leaks that are discussed on Page xxii of the Executive Summary, or clarify } \\
\text { if these are the potable water leaks identified in Section 2.3.1.3. }\end{array}$ & $\begin{array}{l}\text { Agree. Text in both the Executive Summary and in Section 2.3.1.3 was } \\
\text { clarified to read fire water utility system. }\end{array}$ \\
\hline \multicolumn{4}{|c|}{ MELTON VALLEY } \\
\hline 4 & \begin{tabular}{|l|} 
Sect. 3.1.1, Status \\
and Updates, Page 3 \\
1
\end{tabular} & $\begin{array}{l}\text { Section } 3.1 .1 \text { describes the updates made to the } 2010 \text { RER for fiscal year } \\
2009 \text { but does not discuss the change in some toxicity factors for } \\
\text { radionuclides since the Interim Record of Decision (ROD) was approved. } \\
\text { As listed in Table 1.3, Summary of unresolved technical issues, } \\
\text { recommendations, and follow-up actions from the FYR, the } \\
\text { recommendation/follow-up action from the Five Year Review (FYR) is } \\
\text { "Toxicity factors and final cleanup goals will be evaluated as a part of the } \\
2011 \text { FYR and the Final ROD for MV." It is unclear why the changed } \\
\text { toxicity factors are not discussed in the RER for fiscal year 2009. Revise } \\
\text { the } 2010 \text { RER to include a discussion and evaluation based on the } \\
\text { changed toxicity factors for some radionuclides. Ensure the revision } \\
\text { indicates which radionuclides are impacted and includes documentation } \\
\text { that stakeholders have agreed to the proposed assessment period. }\end{array}$ & $\begin{array}{l}\text { Disagree. Evaluation of toxicity factors and evaluation of final cleanup goals, } \\
\text { as well as final protectiveness statements, are all components of the FYR. }\end{array}$ \\
\hline 5 & \begin{tabular}{|c|} 
Table 3.12 \\
Summary of MV \\
Watershed technical \\
issues and \\
recommendations, \\
Page 3-59
\end{tabular} & $\begin{array}{l}\text { Table } 3.12 \text { summarizes the ongoing technical issues and } \\
\text { recommendations but does not include the information presented in Table } \\
1.3 \text {, Summary of unresolved technical issues, recommendations, and } \\
\text { follow-up actions from the FYR. Table } 1.3 \text { indicates "There has been a } \\
\text { change in some toxicity factors for radionuclides since the Interim ROD } \\
\text { was approved" and "Toxicity factors and final cleanup goals will be } \\
\text { evaluated as part of the } 2011 \text { FYR and the Final ROD for MV." Revise } \\
\text { Table } 3.12 \text { to include this information and ensure that } 2011 \text { FYR actions } \\
\text { include full assessment of the affected toxicity factors and the resulting } \\
\text { impacts on overall risk. }\end{array}$ & $\begin{array}{l}\text { Disagree. Table } 1.3 \text { are issues from the last FYR and are not annual RER } \\
\text { issues. }\end{array}$ \\
\hline
\end{tabular}




\begin{tabular}{|c|c|c|c|}
\hline $\begin{array}{c}\text { Comment } \\
\text { No. }\end{array}$ & $\begin{array}{l}\text { Sect/ } \\
\text { Page } \\
\end{array}$ & Comment & Response \\
\hline \multicolumn{4}{|c|}{ BEAR CREEK VALLEY } \\
\hline 6 & \begin{tabular}{|l|} 
Sect. 4.2.2.2, Page 4 \\
25
\end{tabular} & $\begin{array}{l}\text { (a) The ROD goal to maintain clean groundwater in Zone } 1 \text { is at least } \\
\text { intermittently compromised as described in this RER. Start including } \\
\text { data tables/figures showing this intermittent compromise of the ROD } \\
\text { goal. Identify this matter as in issue in table 4.14. } \\
\text { (b) Does DOE intend to provide tables and figures in future RERs? }\end{array}$ & $\begin{array}{l}\text { (a) Agree. The intermittent nature of low-to-trace levels of contaminant } \\
\text { concentrations detected in Zone } 1 \text { groundwater has been listed as a Current } \\
\text { Issue in Table } 4.15 \text { (previously Table 4.14), as well as the summary Table } \\
\text { I.1. } \\
\text { (b) Tables and figures will be included in future RERs when results exceed } \\
\text { criteria, i.e., if the same situation exists in which the levels compromise the } \\
\text { ROD goal then tables and figures will be added to the document. Note that a } \\
\text { new table for nitrate concentrations was included in this year's (i.e., 2010) } \\
\text { RER. }\end{array}$ \\
\hline 7 & $\begin{array}{l}\text { Sect. 4.4, Table } \\
\text { 4.14, Page 4-43 }\end{array}$ & $\begin{array}{l}\text { The action/recommendation is an issue carried forward. Issues carried } \\
\text { forward from earlier RERs have not been acted upon or resolved to allow } \\
\text { documentation of closure. Provide a timeline and strategy acting/closure } \\
\text { on this issue. }\end{array}$ & $\begin{array}{l}\text { This specific issue requires EPA to make a monitoring determination. } \\
\text { Appendix I- } 12 \text { requires that monitoring changes are suggested in the RER and } \\
\text { followed up with letters to EPA and TDEC requesting approval of the change. }\end{array}$ \\
\hline 8 & $\begin{array}{l}\text { Sect. } 4.4, \text { Table } \\
4.14, \text { Page } 4-43\end{array}$ & $\begin{array}{l}\text { The riparian monitoring ( } 16 \text { ) has not been completed/resolved. The table } \\
\text { should correctly reflect this matter under "Issues Carried Forward." }\end{array}$ & $\begin{array}{l}\text { Agree. The riparian monitoring part of the BYBY issue ( } 1 \mathrm{~b} \text { ) has been listed } \\
\text { under Issues Carried Forward in Table } 4.15 \text { (previously Table 4.14), as well } \\
\text { as Table 1.1. }\end{array}$ \\
\hline \multicolumn{4}{|c|}{ CHESTNUT RIDGE } \\
\hline 9 & $\begin{array}{l}\text { Sect. 5.2.2, } \\
\text { Evaluation of } \\
\text { Performance } \\
\text { Monitoring Data - } \\
\text { FY 2009, Page 5-6 }\end{array}$ & $\begin{array}{l}\text { Section } 5.2 .2 \text { discusses the potential link between elevated beta activity } \\
\text { and natural occurring }{ }^{40} \mathrm{~K} \text { but does not justify the conclusion that elevated } \\
\text { beta activity is caused by }{ }^{40} \mathrm{~K} \text {. For example, the third paragraph on Page } 5 \\
6 \text { states "The calculated }{ }^{40} \mathrm{~K} \text { activities closely track (within } \sim 20 \mathrm{pCi} / \mathrm{L} \\
\text { except for a single outlier) the beta activity values indicating that } \\
\text { increased potassium concentrations that are detected under lower stress } \\
\text { sampling are responsible for the increase in beta activity. Analyses for } \\
\text { other beta-emitting radionuclides }\left({ }^{99} \mathrm{Tc},{ }^{90} \mathrm{Sr} \text { ) have not detected site- }\right. \\
\text { related contaminants other than low concentrations of }{ }^{90} \mathrm{Sr} \text {, which was not } \\
\text { detected in FY } 2009 . " \text { It is unclear how tracking }{ }^{40} \mathrm{~K} \text { activities within } 20 \\
\text { picoCuries per liter (pCi/L) establishes this trend, especially as this value } \\
\text { is approximately } 33 \text { percent (\%) of the gross beta results of } 59.1 \text { and } 64.3 \\
\text { pCi/L presented in Table } 5.3 \text {, Analytical results for performance indicator } \\
\text { constituents at the UNC Site, fiscal year } 2009 \text {. Revise the } 2010 \mathrm{RER} \text { to } \\
\text { provide further substantiation for the claims made regarding }{ }^{40} \mathrm{~K} \text { and eleva }\end{array}$ & $\begin{array}{l}\text { Agree. The discussion has been expanded and a figure has been added } \\
\text { showing the relationship between measured beta activity, computed beta } \\
\text { activity attributed to total potassium, and the residual beta activity. }\end{array}$ \\
\hline 10 & $\begin{array}{l}\text { Table 5.4, UNC Site } \\
\text { ground water }{ }^{90} \mathrm{Sr} \\
\text { results, FY } 2000 \\
\text { through FY 2009, } \\
\text { Page 5-7 }\end{array}$ & $\begin{array}{l}\text { Table } 5.4 \text { contains the characters " } \mathrm{U} \text { " and "J" but does not define the } \\
\text { terms. Revise Table } 5.4 \text { to include a note defining the terms " } U \text { " and "J". }\end{array}$ & Agree. A footnote to Table 5.4 was added to define the terms $J$ and $U$. \\
\hline
\end{tabular}




\begin{tabular}{|c|c|c|c|}
\hline $\begin{array}{c}\text { Comment } \\
\text { No. } \\
\end{array}$ & $\begin{array}{l}\text { Sect/ } \\
\text { Page } \\
\end{array}$ & Comment & Response \\
\hline \multicolumn{4}{|c|}{ UPPER EAST FORK POPLAR CREEK (UEFPC) } \\
\hline 11 & \begin{tabular}{|l|} 
Sect. 6.2.2.1.2, \\
Surface Water \\
Monitoring Results, \\
Page 6-11
\end{tabular} & $\begin{array}{l}\text { The fourth paragraph of Section } 6.2 .2 .1 .2 \text { briefly discusses metallic } \\
\text { mercury observed in a storm water catch basin but does not discuss the } \\
\text { potential sources of the metallic mercury or any potential actions that } \\
\text { could reduce or eliminate the collection of metallic mercury from this } \\
\text { catch basin. The fourth paragraph states "Metallic mercury continues to } \\
\text { be observed in a storm water catch basin (Manhole \#D3-418) in WEMA } \\
\text { southeast of Bldg. } 9201-4 \text {. An estimated I lb of mercury was recovered } \\
\text { from this catch basin by Y-12 Operations personnel on March 19,2009." } \\
\text { Revise Section } 6.2 .2 .1 .2 \text { to include a discussion of the possible source of } \\
\text { the metallic mercury, any potential actions that could reduce or eliminate } \\
\text { the flow of metallic mercury, and a summary of the historical quantities of } \\
\text { metallic mercury recovered from Manhole \#D3-418. }\end{array}$ & $\begin{array}{l}\text { Agree. Text in this section has been expanded to describe circumstances that } \\
\text { can cause mercury to accumulate in storm drains in Y-12. } \\
\text { f. }\end{array}$ \\
\hline \multicolumn{4}{|c|}{ EAST TENNESSEE TECHNOLOGY PARK (ETTP) } \\
\hline 12 & $\begin{array}{l}\text { Executive Summary, } \\
\text { ETTP, Page xxvi }\end{array}$ & $\begin{array}{l}\text { The ETTP section on Page xxvi of the Executive Summary presents a } \\
\text { confusing summary of the groundwater quality in wells UNW-064, UNW } \\
114, \text { and TMW-011. The first paragraph of this section states "An } \\
\text { evaluation of VOC concentrations in wells UNW 064, UNW-114, and } \\
\text { TMW-011 over the past several years indicates that generally VOC } \\
\text { concentrations in ground water continue to decline or remain relatively } \\
\text { stable with fluctuations related to climactic cycles. In these wells, current } \\
\text { VOC concentrations fluctuate near the respective maximum contaminant } \\
\text { level (MCL) levels." Revise this section to clearly indicate the current } \\
\text { groundwater quality, as it is unclear if the volatile organic compound } \\
\text { (VOC) concentrations in groundwater are declining, remaining stable, or } \\
\text { fluctuating at MCLs (i.e., no significant trend). }\end{array}$ & $\begin{array}{l}\text { Agree. The text in both the Executive Summary, as well as in Section 8.3.2.2, } \\
\text { has been revised for clarity. }\end{array}$ \\
\hline 13 & $\begin{array}{l}\text { Table 8-1, K-1407 } \\
\text { B/C Ponds RA, Page } \\
8-3\end{array}$ & $\begin{array}{l}\text { The K-1407 B/C Ponds were closed under RCRA with no CERCLA } \\
\text { evaluation of the pond beds. These ponds must undergo DVS } \\
\text { characterization, where applicable, as the Zone } 2 \text { ROD addresses sources } \\
\text { to GW from the soil zone, irrespective of depth. Although the ponds were } \\
\text { filled with clean soils the old pond beds were never sampled before } \\
\text { receiving the clean fill. One pond may be a good candidate for referral to } \\
\text { the GW investigation; however, one definitely is in the RA scope and has } \\
\text { had preliminary DVS investigations conducted. }\end{array}$ & $\begin{array}{l}\text { The CERCLA Record of Decsion for the K-1407-B/C Ponds at the Oak Ridge } \\
\text { K-25 Site, Oak Ridge, Tennessee (DOE/OR/02-1125\&D3) required the } \\
\text { placement of fill for shielding, institutional controls, and groundwater } \\
\text { monitoring. This decision was a final decision for ingestion of homegrown } \\
\text { produce and for direct exposure to ionizing radiation. Groundwater ingestion } \\
\text { was to be addressed in a subsequent action. Therefore, this action is } \\
\text { complete. The K-1407-B Holding Pond and the K-1407-C Retention Basin } \\
\text { are included in the Record of Decision for Soil, Buried Waste, and Subsurface } \\
\text { Structure Actions in Zone 2, East Tennessee Technology Park, Oak Ridge, } \\
\text { Tennessee (DOE/OR/O1-2161\&D2). The K-1407-C Retention Basin has } \\
\text { been evaluated as part of Exposure Unit (EU) Z2-29. The evaluation } \\
\text { recommends a remedial action, and this recommendation is documented in } \\
\text { the Fiscal Year 2009 Phased Construction Completion Report for Zone } 2 \\
\text { Exposure Units } 11,12,17,18,29, \text { and } 38 \text { at East Tennessee Technolog park, } \\
\text { Oak Ridge, Tennessee (DOE/OR/01-2415\&D2). } \\
\text { The remedial action has not been performed yet. The K-1407-C Retention } \\
\text { Basin is in EU Z2-35, but this EU has not been evaluated yet. As discussed at } \\
\text { the ETTP Remedial Action Core Team meeting on July } 28,2010 \text {, a footnote } \\
\text { will be added to the table indicating those sites with completed actions that } \\
\text { require subsequent CERCLA decisions. }\end{array}$ \\
\hline
\end{tabular}




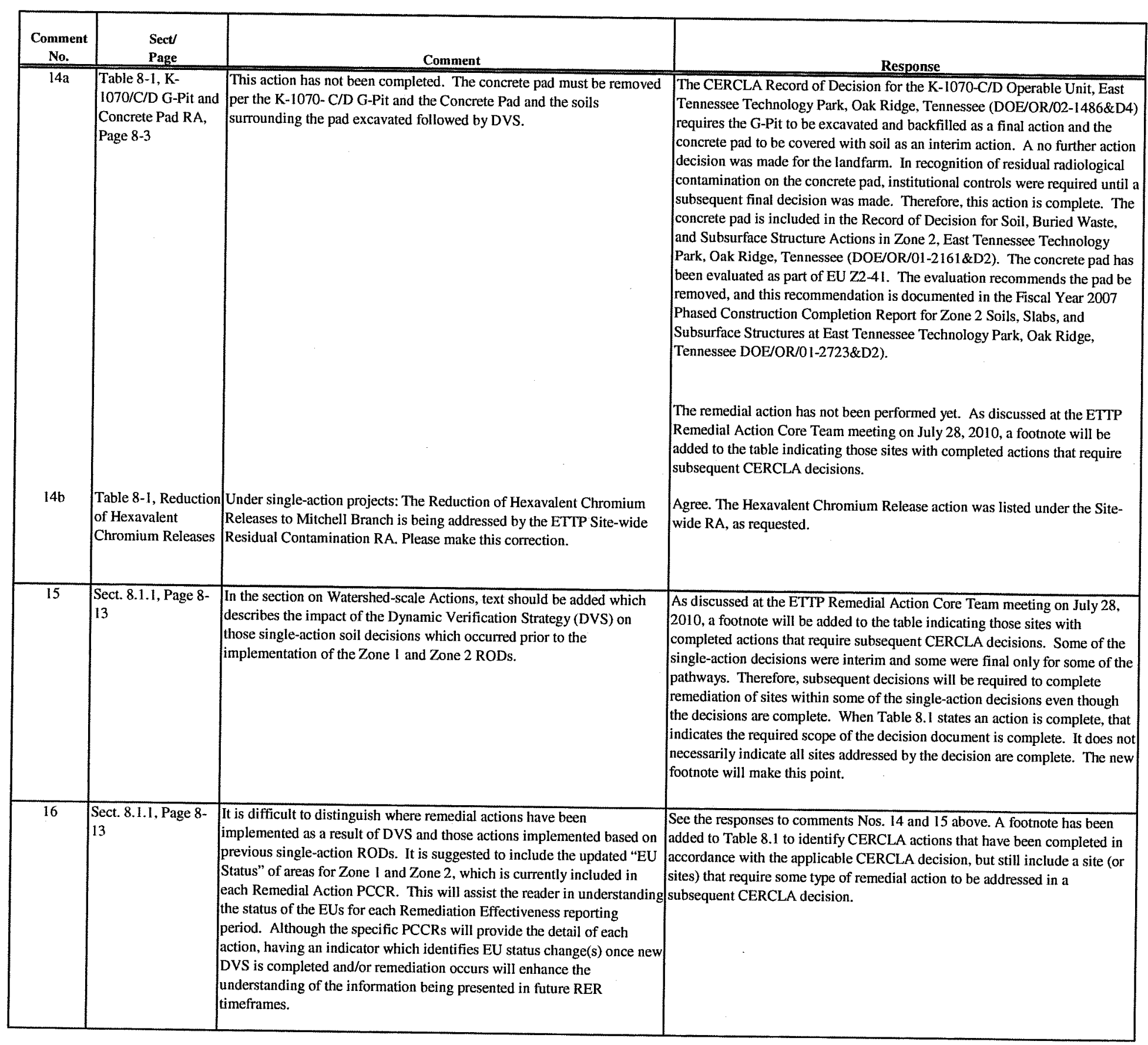




\begin{tabular}{|c|c|c|c|}
\hline $\begin{array}{c}\text { Comment } \\
\text { No. }\end{array}$ & $\begin{array}{l}\text { Sect/ } \\
\text { Page }\end{array}$ & Comment & Response \\
\hline 17 & $\begin{array}{l}\text { Sect. 8.1.1, Page 8- } \\
14\end{array}$ & $\begin{array}{l}\text { K-29, K-31, K-33: K- } 29 \text { is the only building of this three building } \\
\text { removal action. The text states the equipment from K-31 was removed. } \\
\text { However, the text does not state where the equipment is currently stored. } \\
\text { Please modify the text to reference the location. }\end{array}$ & $\begin{array}{l}\text { Disagree. The Action Memorandum called for equipment removal and } \\
\text { decontamination of the buildings. The equipment in all three buildings was } \\
\text { removed and eventually dispositioned to one of several disposal facilities } \\
\text { (e.g.. Envirocare of Utah, Nevada Test Site, Environmental Management } \\
\text { Waste Management Facility, etc.) or recycled (if shown not to be } \\
\text { contaminated). None of the equipment is currently stored. It is not feasible to } \\
\text { report the disposition of all equipment and waste streams from the } \\
\text { decontaminated buildings within the RER. Details of the disposition of all } \\
\text { waste streams from Building K-31 is reported in the Removal Action Report } \\
\text { for Equipment Removal and Building Decontamination for Buildings K-29, } \\
K-3 I \text {, and K-33, East Tennessee Technology Park. Oak ridge, Tennessee } \\
\text { (DOE/OR/01-2290\&D3), March 2007, as modified per addenda. }\end{array}$ \\
\hline 18 & $\begin{array}{l}\text { Sect. 8.1.1, Page 8- } \\
15\end{array}$ & $\begin{array}{l}\text { In the Group II, Phase } 3 \text { Remaining Facilities Demolition, K-1066-G yard } \\
\text { has been remediated. This should be referenced in the text, if action } \\
\text { occurred during the timeframe of this report. }\end{array}$ & $\begin{array}{l}\text { Disagree. The K-1066-G yard remediation consisted of removing one small } \\
\text { area }\left(<1 \mathrm{~m}^{2} \text { to a depth of } 3.5 \mathrm{ft}\right) \text { of mixed soil and gravel with surface } \\
\text { contamination of } 5410 \mathrm{cpm} \text {, which exceeded the action level of } 3000 \mathrm{cpm} \text {. } \\
\text { The RA was performed in October } 2009 \text {, which places the action in FY } 2010 \text {, } \\
\text { outside the time frame of this RER. Also, the action was conducted as part of } \\
\text { the Zone } 2 \text { ROD and is described in the Fiscal Year } 2010 \text { Phased } \\
\text { Construction Completion Report for EU Z2-32 in Zone 2, East Tennessee } \\
\text { Technology Park, Oak Ridge, Tennessee (DOE/OR/01-2452\&D1), which } \\
\text { was approved by the EPA and TDEC in March 2010. }\end{array}$ \\
\hline 19 & \begin{tabular}{|l|} 
Sect. 8.2.1.1, Page 8- \\
18, paragraph 2
\end{tabular} & $\begin{array}{l}\text { (a) There has been no formal proposal to change the current land use } \\
\text { depth or designation from protection of the industrial worker to } \\
\text { recreational has been approved. A risk assessment has been conducted } \\
\text { and the Duct Island/K-901-A Area Phased Construction Completion } \\
\text { Report has been submitted indicating a DOE preference to change the } \\
\text { current land use for the areas of Zone } 1 \text { within BORCE. This formal } \\
\text { change has not been completed nor has the public participation } \\
\text { requirement been activated. } \\
\text { (b) In addition, please modify the reference to K-901-A by removing the } \\
\text { "A" before Area. The K-901 Area is all inclusive and includes the area K- } \\
901 \text { Pond, which was equally divided north and south. The northern } \\
\text { portion of the K-901 Pond is included in the K-901 Area, where the } \\
\text { southern portion of the K-901 Pond is included in the Duct Island Area. } \\
\text { Please make this a global change when referring to the K-901 Area. }\end{array}$ & $\begin{array}{l}\text { (a) Comment noted. Please see response to Comment No. } 22 \text {. } \\
\text { (b) Agree. The text has been revised, as requested. }\end{array}$ \\
\hline 20 & \begin{tabular}{|l|} 
Sect. 8.2.1.1, Page 8- \\
19
\end{tabular} & $\begin{array}{l}\text { In the first paragraph, last line of the reference to the K-1007 Ponds Area } \\
\text { and Powerhouse North Area PCCR (before the bulleted items), please } \\
\text { add the word "Addendum." The K-1007 Ponds Area and Powerhouse } \\
\text { North Area PCCR were approved October 2, 2006. It is anticipated that } \\
\text { at least two (2) Addenda will he submitted to update the status of } \\
\text { exposure units is these areas. }\end{array}$ & Agree. The text has been revised, as requested. \\
\hline 21 & Table 8.4, Page 8-23 & $\begin{array}{l}\text { In Table 8.4, Column 3, the survey frequency for the K-770 Scrap Metal } \\
\text { Yard and soil should say "changed" versus "drained." }\end{array}$ & Agree. The text has been revised, as requested. \\
\hline
\end{tabular}




\begin{tabular}{|c|c|c|c|}
\hline $\begin{array}{c}\text { Comment } \\
\text { No. } \\
\end{array}$ & $\begin{array}{l}\text { Sect/ } \\
\text { Page } \\
\end{array}$ & Comment & Response \\
\hline 22 & $\begin{array}{l}\text { Sect. 8.2.1.2, Page 8- } \\
25\end{array}$ & $\begin{array}{l}\text { The text on this page should indicate that the land use designation is not } \\
\text { only inconsistent with the ROD and that portion of Zone } 1 \text { included in the } \\
\text { BORCE, but the recreational land use is not currently approved. This } \\
\text { change must formally go before the public for review and comment } \\
\text { followed by the required CERCLA process for modifying the land use } \\
\text { scenario. The text also needs to identify the public involvement } \\
\text { requirement that will be implemented associated with this intended land } \\
\text { use change. }\end{array}$ & $\begin{array}{l}\text { Section 8.2.1.2 states that "the end use identified in the ETTP Zone 1 ROD is } \\
\text { unrestricted industrial" and "recreational use was not designated." Therefore, } \\
\text { no change to Section 8.2.1.2 is necessary. } \\
\text { However, the recommendation in Table } 8.15 \text { in Section } 8.7 \text { (Table 1.1) has } \\
\text { been revised to indicate that the end use of this portion of Zone } 1 \text { will be } \\
\text { changed from industrial to recreational in an Explanation of Significant } \\
\text { Difference to the Zone } 1 \text { Interim ROD with the appropriate level of public } \\
\text { participation. The Addendum to the Phased Construction Completion Report } \\
\text { for the Duct Island Area and } K \text {-90I Area in Zone 1, East Tennessee } \\
\text { Technology Park, Oak Ridge, Tennessee (DOE/OR/0I-226I\&D2/A1/R1) } \\
\text { includes the risk assessment to support this change. }\end{array}$ \\
\hline 23 & \begin{tabular}{|l|} 
Table 8.15 \\
Summary of \\
technical issue and \\
recommendations, \\
Page 8-70
\end{tabular} & $\begin{array}{l}\text { Table } 8.15 \text { identified the new current issue: "The northern section of } \\
\text { ETTP Zone } 1 \text { has been identified as a conservation easement (BORCE). } \\
\text { The BORCE is utilized for recreational use: hiking, bicycling, and select } \\
\text { controlled deer hunts. The end use identified in the ETTP Zone 1 ROD is } \\
\text { unrestricted industrial, i.e., recreational use was not designated." The } \\
\text { recommended action presented in the table is "DOE acknowledges the } \\
\text { land use differences that exist between the BORCE use and that which is } \\
\text { in the Zone 1." While it is understood that DOE acknowledges the land } \\
\text { use differences, the recommended action does not present a strategy to } \\
\text { reconcile the two different land use designations in the } 2010 \text { RER. } \\
\text { Revise the } 2010 \text { RER to explain how each of the two different land use } \\
\text { designations will be managed simultaneously under the Comprehensive } \\
\text { Environmental Response, Compensation, and Liability Act of } 1980 \\
\text { (CERCLA). In addition, revise Section 8.2.1.2, Status of Requirements } \\
\text { for FY 2009, to discuss this issue. }\end{array}$ & See the response to Comment No. 22 . \\
\hline \multicolumn{4}{|c|}{$\begin{array}{l}\text { OTHER CERCLA SITES } \\
\end{array}$} \\
\hline 24 & $\begin{array}{l}\text { Sect. 9.1.I, Status of } \\
\text { Updates } \\
\text { (RESERVED), Page } \\
\text { 9-1 }\end{array}$ & $\begin{array}{l}\text { It is unclear why Section } 9.1 .1 \text { has been left blank instead of using this } \\
\text { section to summarize the status and present updates of CERCLA actions } \\
\text { at other sites. Revise the } 2010 \text { RER to include a current status and update } \\
\text { of the CERCLA actions at other sites. If the status has not changed from } \\
\text { the fiscal year } 2008 \text { data, revise the } 2010 \text { RER to indicate that is the case. }\end{array}$ & $\begin{array}{l}\text { Agree. The following has been added to the text: During FY } 2009, \text { no } \\
\text { additional CERCLA actions were implemented or completed at the WWSY or } \\
\text { at the ORAU SCF. Neither were there any FFA documents submitted or } \\
\text { approved for CERCLA actions located on the ORR but physically located } \\
\text { outside one of the five established watersheds. }\end{array}$ \\
\hline 25 & \begin{tabular}{|l|} 
Sect. 9.2.1.2, Status \\
of Requirements for \\
FY 2009, Page 9-1
\end{tabular} & $\begin{array}{l}\text { Section } 9.2 .1 .2 \text { summarizes annual maintenance activities such as } \\
\text { clearing fallen trees, repairing damaged fencing, and routine mowing. } \\
\text { However, this section does not describe the conditions observed during } \\
\text { the maintenance activities that indicate the status of the long-term } \\
\text { maintenance program. Revise Section } 9.2 .1 .2 \text { to include a summary of } \\
\text { the condition of the site, such as an estimate of the amount of fencing that } \\
\text { was in need of repair in fiscal year } 2009 \text {. Further, include documentation } \\
\text { that the repairs noted as being needed have been made. }\end{array}$ & $\begin{array}{l}\text { Disagree. Reporting the details of the conditions observed during routine } \\
\text { inspections and maintenance actions are not feasible in the annual RER. As } \\
\text { described in Section } 1.1 \text { of the RER, this information is collected and/or } \\
\text { compiled from various organization on the ORR by the WRRP. } \\
\text { Documentation is maintained for each site in the respective Project Document } \\
\text { Document Control Center (PDCC) and ultimately filed in the BJC Document } \\
\text { Management Center (DMC). The WRRP obtains copies of the relevant } \\
\text { documentation throughout the fiscal year to summarize the status of } \\
\text { compliance with the LTS requirements in the annual RER. Starting with FY } \\
2009 \text {, copies of this documentation will be provided annually to the CERCLA } \\
\text { Administrative Record and will be maintained for a period of three years. }\end{array}$ \\
\hline
\end{tabular}




\begin{tabular}{|c|c|c|c|}
\hline $\begin{array}{c}\text { Comment } \\
\text { No. }\end{array}$ & $\begin{array}{l}\text { Sect/ } \\
\text { Page }\end{array}$ & Comment & Response \\
\hline 26 & $\begin{array}{l}\text { Sect. 9.3.2, } \\
\text { Evaluation of } \\
\text { Performance } \\
\text { Monitoring Data- } \\
\text { FY 2009, Page } 9.4\end{array}$ & $\begin{array}{l}\text { Figure 9.3, VOC concentrations in wells GW-841 and GW-842 at SCF, } \\
\text { does not appear to include all fiscal year } 2009 \text { sampling data as indicated } \\
\text { and discussed in Section 9.3.2. Revise Section } 9.3 .2 \text { and Figure } 9.3 \text { to } \\
\text { ensure that all fiscal year 2009 sampling data are accurately and } \\
\text { consistently presented. }\end{array}$ & $\begin{array}{l}\text { Disagree. Monitoring is required at the SCF annually, usually in second } \\
\text { quarter (January through March) of the fiscal year. So, Figure } 9.3 \text { actually } \\
\text { does include all the data through the reporting period. However, the figure has } \\
\text { been revised to improve the readability of the axis labeling. }\end{array}$ \\
\hline \multicolumn{4}{|c|}{ CERCLA OFF-SITE ACTIONS } \\
\hline 27 & $\begin{array}{l}\text { Sect. 7.2.4.2, Status } \\
\text { of Requirements for } \\
\text { FY 2009, Page 7-11 }\end{array}$ & $\begin{array}{l}\text { Section 7.2.4.2 describes the process used to detect future residential use } \\
\text { of shallow groundwater as required by the Lower East Fork Poplar Creek } \\
\text { (LEFPC) ROD, which indicates that the U. S. Department of Energy } \\
\text { (DOE) will monitor to detect any future residential use of the shallow } \\
\text { groundwater. The text states "A survey to detect residential use of } \\
\text { shallow groundwater was performed in fiscal year 2007. A tist of } \\
\text { residential wells recorded in the Elverton, BV, and Windrock quadrangles } \\
\text { was obtained from the TDEC, Division of Water Supply. There are no } \\
\text { records of water wells in the area along LEFPC. No status change for } \\
\text { fiscal year } 2009 \text { was noted." It is unclear how a survey in fiscal year } \\
2007 \text { satisfies the ROD requirement in fiscal year } 2009 \text {. Revise Section } \\
7.2 .4 .2 \text { to further explain how a fiscal year } 2007 \text { survey satisfies the ROD } \\
\text { requirement given that shallow groundwater monitoring wells may have } \\
\text { been installed after completion of the fiscal year } 2007 \text { survey. }\end{array}$ & $\begin{array}{l}\text { Agree. In accordance with the LEFPC ROD (DOE/OR/02-1370\&D2), Section } \\
\text { 7.2.4.1 has been revised to read, "...DOE will periodically monitor to detect } \\
\text { any future residential use of the shallow groundwater." } \\
\text { To clarify that an additional survey was conducted in } 2009 \text { to verify the } \\
\text { results of the } 2007 \text { survey, Section } 7.2 .4 .2 \text { was revised to read, "A survey to } \\
\text { detect residential use of shallow groundwater was performed in FY } 2009 \text { to } \\
\text { verify survey results obtained in FY } 2007 \text {. A list of residential wells...No } \\
\text { status change for FY } 2009 \text { was noted." }\end{array}$ \\
\hline
\end{tabular}




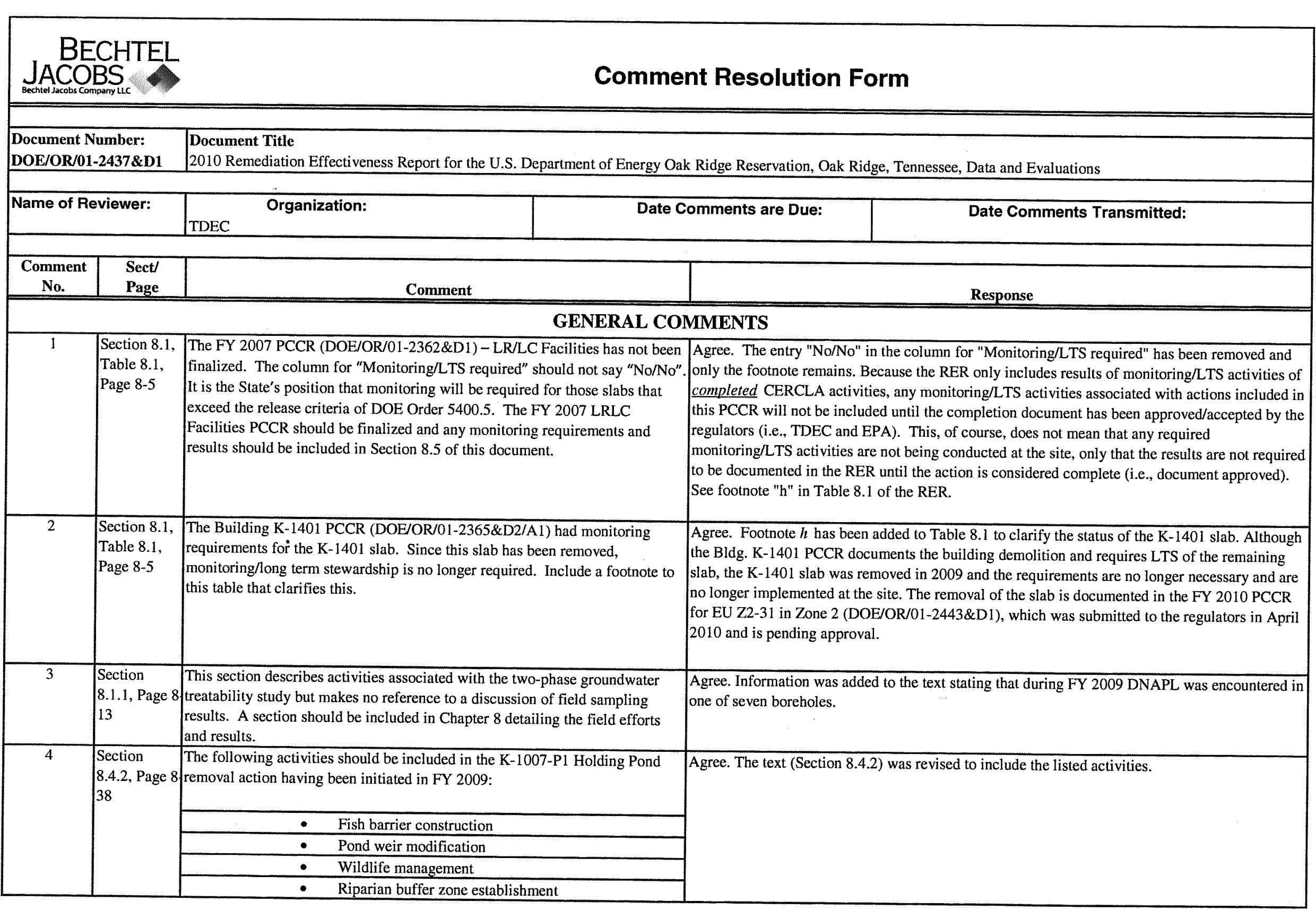




\begin{tabular}{|c|c|c|c|}
\hline $\begin{array}{c}\text { Comment } \\
\text { No. }\end{array}$ & $\begin{array}{l}\text { Sectl } \\
\text { Page }\end{array}$ & Comment & Response \\
\hline 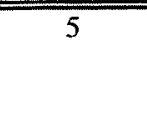 & $\begin{array}{l}\text { Section } \\
8.4 .2, \text { Page } 8 \\
38\end{array}$ & $\begin{array}{l}\text { The removal of undesirable fish from the P3 and P4 Holding Ponds should be } \\
\text { included as an activity completed in FY } 2009 \text {. Fish removal efforts were } \\
\text { conducted to support the K-1007-P1 Pond ecological enhancement }\end{array}$ & Agree. The text (Section 8.4.2) was revised to include the removal of the undesirable fish. \\
\hline 6 & $\begin{array}{l}\text { Section } \\
8.4 .2 .1, \text { Page } \\
8-38\end{array}$ & $\begin{array}{l}\text { Consider removing "Performance" from the title of this section. The second } \\
\text { phase of monitoring is called "performance monitoring" and may lead to } \\
\text { confusion as this section discusses both phases. }\end{array}$ & $\begin{array}{l}\text { The text has been revised to clarify the types (i.e., phases) of monitoring that are to be conducted } \\
\text { at the site. }\end{array}$ \\
\hline 7 & \begin{tabular}{l|} 
Section \\
8.4 .2 .1$, Page \\
$8-38$
\end{tabular} & $\begin{array}{l}\text { The first paragraph should indicate that operational monitoring will continue } \\
\text { until measured PCB levels in fish have diminished and pond water quality is } \\
\text { conducive to natural conditions. Also, a statement should be added indicating } \\
\text { that results from the operational monitoring phase will be reported in the } \\
\text { annual RER and 5-Year Review. }\end{array}$ & $\begin{array}{l}\text { Agree. More specific language as to the monitoring and reporting requirements has been added to } \\
\text { the text. }\end{array}$ \\
\hline 8 & \begin{tabular}{|l|} 
Section \\
8.4 .2 .1$, Page \\
$8-38$
\end{tabular} & $\begin{array}{l}\text { The second paragraph needs to identify the second phase of monitoring as } \\
\text { performance monitoring. Also, a statement should be added indicating that } \\
\text { results from the performance monitoring phase will be reported in the annual } \\
\text { RER and 5-Year Review. }\end{array}$ & $\begin{array}{l}\text { Agree. More specific language as to monitoring and reporting requirements has been added to the } \\
\text { report. }\end{array}$ \\
\hline$\overline{9}$ & \begin{tabular}{|l|} 
Section \\
8.4 .2 .2$, Page \\
$8-41$
\end{tabular} & $\begin{array}{l}\text { Strike "Performance" from the title of this section and rename it "Baseline". } \\
\text { As presented, the PCB results in largemouth bass represent preremediation } \\
\text { conditions. }\end{array}$ & Agree. The text was modified, as requested. \\
\hline 10 & \begin{tabular}{|l|} 
Section \\
8.4 .5 .2 \\
Figure 8.18, \\
Page 8-51
\end{tabular} & $\begin{array}{l}\text { The } x \text {-axis needs to be reconfigured. It is difficult to tell which data point } \\
\text { coincides with which sampling date and which sampling date to which tick } \\
\text { mark. There are far more data points than dates. }\end{array}$ & $\begin{array}{l}\text { Agree. The figure was reconfigured using a logarithmic scale to better depict the data, as well as } \\
\text { the sampling dates. }\end{array}$ \\
\hline 11 & $\begin{array}{l}\text { Section } \\
8.4 .2 .2, \text { Page } \\
8-52\end{array}$ & $\begin{array}{l}\text { The second to last sentence in the first full paragraph states that the maximum } \\
\text { value of total chromium at MIK } 0.71 / 0.79 \text { during FY } 2009 \text { was } 0.0058 \mathrm{mg} / \mathrm{L} \text {. } \\
\text { According to Table } 8.8 \text {, the maximum value was } 0.0101 \mathrm{mg} / \mathrm{L} \text {. }\end{array}$ & $\begin{array}{l}\text { Agree. The text (last sentence of } 2 \text { nd paragraph of Section } 8.4 .5 .2 .1 \text { ) was revised from } 0.0058 \\
\mathrm{mg} / \mathrm{L} \text { to } 0.0101 \mathrm{mg} / \mathrm{L} \text { to match the correct maximum value listed in Table } 8.8 \text {. }\end{array}$ \\
\hline 12 & $\begin{array}{l}\text { Section } 8.5 \\
\text { Table 8.9, } \\
\text { Page 8-54 }\end{array}$ & Footnote a should also include the K-1401 slab. & $\begin{array}{l}\text { Agree. The following information has been added to footnote } a \text { to Table } 8.9 \text { (see response to } \\
\text { Comment \#2): The PCCR for the Bldg. K-1401 demolition requires LTS of the remaining slab. } \\
\text { However, the slab was removed in 2009, making LTS no longer necessary. }\end{array}$ \\
\hline 13 & \begin{tabular}{|l|} 
Section 8.5 \\
Page $8-54$ \\
and \\
following
\end{tabular} & $\begin{array}{l}\text { Monitoring requirements identified in the FY } 2008 \text { PCCR (DOE/OR/01- } \\
2394 \& D 1 \text { ) - LR/LC Facilities should be included in Section } 8.5 \text { (Tables } 8.9 \text {, } \\
8.10 \text {, and 8.12). Monitoring results should also be included. }\end{array}$ & Agree. The information has been incorporated into the text where necessary. \\
\hline
\end{tabular}

